\title{
CONTRIBUIÇÃO DO COMPONENTE C5 DO SISTEMA COMPLEMENTO \\ EM MODELO EXPERIMENTAL MURINO DE \\ DOENÇA HEPÁTICA ALCOÓLICA
}

Tese apresentada ao Programa de Pós-Graduação em Imunologia do Instituto de Ciências Biomédicas da Universidade de São Paulo, para obtenção do Título de Doutor em Ciências. 


\section{CONTRIBUIÇÃO DO COMPONENTE C5 DO SISTEMA COMPLEMENTO \\ EM MODELO EXPERIMENTAL MURINO DE \\ DOENÇA HEPÁTICA ALCOÓLICA}

Tese apresentada ao Programa de Pós-Graduação em Imunologia do Instituto de Ciências Biomédicas da Universidade de São Paulo, para obtenção do Título de Doutor em Ciências.

Área de concentração: Imunologia

Orientadora: Prof ${ }^{\mathrm{a}} \mathrm{Dr}^{\mathrm{a}}$ Lourdes Isaac

Versão original 
DADOS DE CATALOGAÇÃO NA PUBLICAÇÃO (CIP)

Serviço de Biblioteca e Informação Biomédica do

Instituto de Ciências Biomédicas da Universidade de São Paulo

reprodução não autorizada pelo autor

Bavia, Lorena.

Contribuição do componente C5 do sistema complemento em modelo experimental murino de doença hepática alcóolica / Lorena Bavia. -- São Paulo, 2013.

Orientador: Profa. Dra. Lourdes Isaac.

Tese (Doutorado) - Universidade de São Paulo. Instituto de Ciências Biomédicas. Departamento de Imunologia. Área de concentração:

Imunologia. Linha de pesquisa: Sistema complemento.

Versão do título para o inglês: Contribution of murine component C5 in experimental alcoholic fatty liver disease.

1. Sistema complemento 2. Componente C5 3. Doença hepática alcóolica 4. Inflamação 5. Citocinas 6. Camundongo congênico I. Isaac, Profa. Dra. Lourdes II. Universidade de São Paulo. Instituto de Ciências Biomédicas. Programa de Pós-Graduação em Imunologia III. Título. 


\section{UNIVERSIDADE DE SÅO PAULO \\ INSTITUTO DE CIËNCIAS BIOMÉDICAS}

Candidato(a):

Título da Tese:

Orientador(a):

\section{Lorena Bavia.}

Contribuição do componente C5 do sistema complemento em modelo experimental murino de doença hepática alcóolica.

Profa. Dra. Lourdes Isaac.

A Comissão Julgadora dos trabal hos de Defesa da Tese de Doutorado, em sessäo

pública realizada a I I. considerou

\section{( )Aprovado(a)}

( ) Reprovado(a)

\begin{tabular}{|c|c|}
\hline Examinador(a): & Assinatura: \\
\hline & Nome: \\
\hline & Instituiçäa: ...... \\
\hline Examinador(a): & Assinatura: ................ \\
\hline & Nome: .............. \\
\hline & Instituiçäo: ...... \\
\hline Examinador(a): & 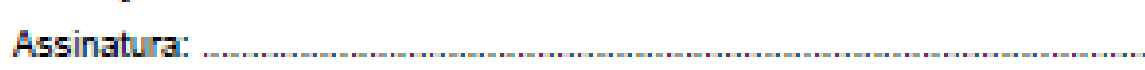 \\
\hline & Nome: $\ldots \ldots \ldots$ \\
\hline & Instituiçäo: \\
\hline Examinador(a): & Assinatura: ......... \\
\hline & Nome: .................. \\
\hline & Instituiçäo: ........ \\
\hline Presidente: & Assinatura: ................................. \\
\hline & Nome: \\
\hline & 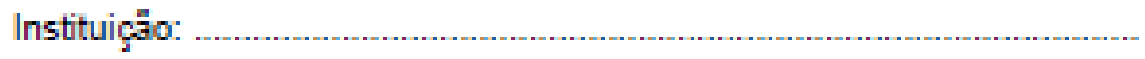 \\
\hline
\end{tabular}




\section{CERTIFICADO DA COMISSÃO DE ÉTICA}

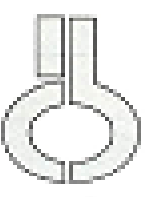

UNTVERSIDADE DE SÃO PALLO

INSTITUTO DE CIÉNCIAS BIOMEDICAS

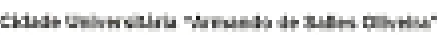

Parta. so-Arsa

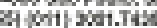

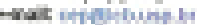

\section{Certificado}

Certificamos que o protocolo registrado sob $\mathrm{n}^{6} 057$ nas fls. 46 do twro 2 para uso de animais em experimentaçâ, sob a responsabilidade de Lourdes Isane Coordenador(a) đa Linha de pesçuisea "Expressâo gëndea dependente do componente CS em figado de camundongas com lessäo hepátlea tnduzlda

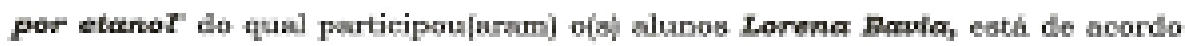
com $\infty$ Principios Éticas de Experimentaçảo Animal adotado pelo Colegio

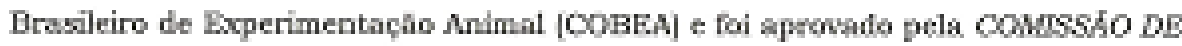
ETRCA EM EXPERMENTACAO ANMLLL (CEEA) em 31.03.2007.

Sso Paulo, 03 Ae setembro de 2007.

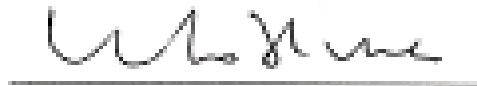

Prof. Dr. Wothan Tayares De Limea Coordenador CEEA - ICB/ USP

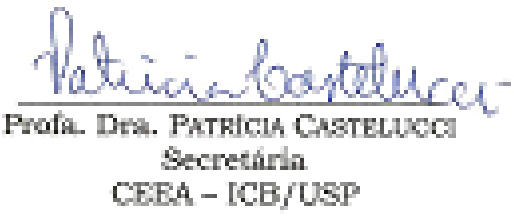




\section{RENOVAÇÃO DO CERTIFICADO DA COMISSÃO DE ÉTICA}

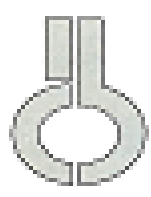

UNIVERSDADE DE SIÓ PAULO

IMSTITUTO DE CIẼMCLAS BIOMËDICAS

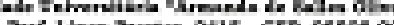

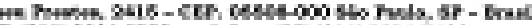

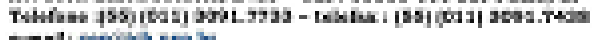

\section{Certificado}

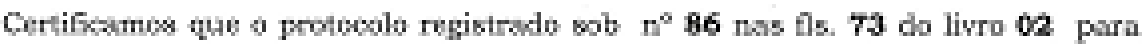

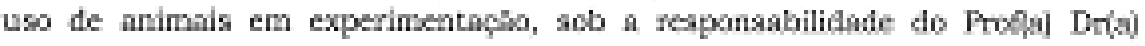

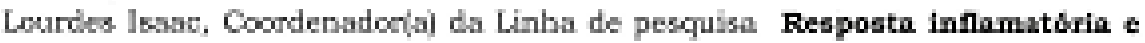
expresaho getuies dependeste do eomponente CS th lealo hepition do

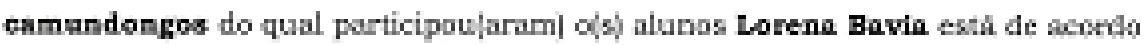

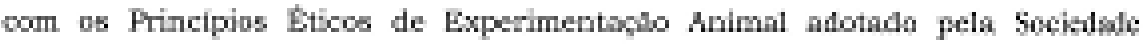

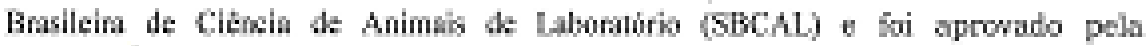

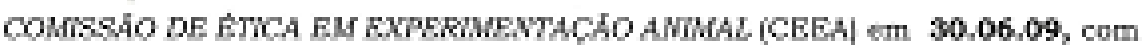
wilidode de st aros.

Swa Pak, ol de juTho de 2009.

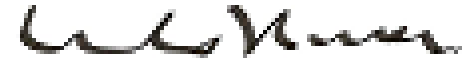

Prof Dr.Wonum Thuasa ar LM4 Copodenador CEFA - TC.3UEP

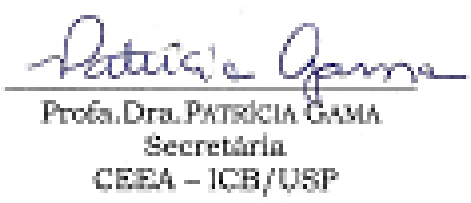


Dedico este trabalho aos meus queridos pais Sandra e Paulo pela dedicação, amor e exemplo.

Ao meu amado Rafael Carvalho Barreto pelo constante incentivo, companhia e admiração.

Meu companheiro de vida, de ciência e de bar. 


\section{AGRADECIMENTOS}

À Prof ${ }^{a}$. Dr ${ }^{a}$. Lourdes Isaac por ter me recebido em seu laboratório, pela confiança em mim depositada, pela paciência durante a minha formação, pela troca de experiências e por ter me disponibilizado todos os recursos necessários ao desenvolvimento desta tese. Em especial agradeço pela autonomia e independência concedidas, fatores importantíssimos na formação de um pesquisador.

Aos Professores do Departamento de Imunologia pelo conhecimento compartilhamento durante as aulas, conversas e discussões de corredores.

À Universidade de São Paulo, ao Instituto de Ciências Biomédicas, ao Departamento de Imunologia, ao Programa de Pós Graduação, a secretaria do Programa de Pós Graduação pela estrutura, formação e condições de trabalho.

À CAPES pela concessão da bolsa de estudos em um período deste doutorado.

À FAPESP pela concessão da bolsa de estudos e pelo apoio financeiro ao projeto de pesquisa.

À empresa BIOCLIN por ter cedido os kits para as determinações séricas de: ALT, AST, FA, albumina, colesterol total.

À Marlene Florido pela companhia, amizade e abraços revigorantes.

Ao Íris pelo auxílio durante os experimentos e pela companhia. Pelos finais de semana de trabalho tratando os camundongos e por continuar trabalhando com os camundongos congênicos.

Aos meus ex-colegas e colegas de laboratório: Zé, Renan, Mariane, Edimara, Karina, Mónica, Adriana, Tatiana, Leandro e Daniella pelas discussões, companhia e boas risadas.

À Dra ${ }^{\mathrm{a}}$. Silvia Massironi pelo auxílio durante o desenvolvimento dos camundongos congênicos. 
À equipe do Biotério de Isogênicos do Departamento de Imunologia, em especial Sueli e Roberto, pela paciência, cuidado e ajuda durante todos os períodos de tratamento dos camundongos e pelas ligações quando os animais resolviam entrar nos tubinhos.

Ao Prof. Dr. Venâncio Avancini Ferreira Alves e sua equipe, da Faculdade de Medicina USP, Departamento de Patologia Hepática pela avaliação cuidadosa das lâminas histopatológicas.

Ao Prof. Dr. Bruno Cogliati, da Faculdade de Medicina Veterinária e Zootecnia USP, Departamento de Patologia, pela avaliação e interpretação das lâminas histopatológicas, dicas e amizade.

Ao Prof. Dr. Paulo César Maiorka, da Faculdade de Medicina Veterinária e Zootecnia USP, Departamento de Patologia, pelo auxílio e avaliação das lâminas histopatológicas do modelo agudo de lesão hepática induzia pelo etanol e da padronização dos modelos de DHA e DHNA.

À Rosana Prisco pelo auxílio com todas as análises estatísticas e pelo café durante nossas reuniões e discussões.

Ao Paulo Albe, pela confecção das lâminas histológicas.

À Paula Aparecida de Araújo Santos pelo auxílio e prontidão na lavagem dos tantos tubos utilizados para tratar os camundongos.

À Marianna M. Koga minha querida amiga e parceira (parça) que fez meu último ano em São Paulo ficar mais divertido. As minhas amigas mais próximas: Inez, Giovana, Érika, Sheylla, Michele e Thiare pelo apoio e incentivo.

Aos meus colegas de departamento pelas discussões, pelas risadas e pelas festas.

Aos camundongos, preciosos e imprescindíveis ao desenvolvimento e conclusão desta tese. 
"It is true that Nature from time to time sheds a little of her mystery; sometimes one succeeds in picking up some of the petals which she strews in the wind"

Jules Bordet (1870-1961) 


\section{RESUMO}

BAVIA, L. Contribuição do componente C5 do sistema complemento em modelo experimental de doença hepática alcoólica. 2013. 248 f. Tese (Doutorado em Imunologia) Instituto de Ciências Biomédicas, Universidade de São Paulo, São Paulo, 2013.

A imunidade inata contribui efetivamente para o desenvolvimento da Doença Hepática Alcoólica (DHA). Dentre os componentes da imunidade inata, em um contexto inflamatório, a ativação do sistema complemento pode ser um importante fator ligado à patogenia desta doença. Modelos murinos de DHA mostraram evidências da contribuição de C3 para o acúmulo de triglicerídeos no fígado e também no tecido adiposo. Já a proteína C5 parece estar envolvida com a injúria e inflamação hepática após o consumo crônico de etanol. Portanto, tivemos como objetivos: a) investigar a contribuição do componente C5 no estabelecimento e manutenção da DHA aplicando as linhagens C57B1/6 (B6) e A/J, e a congênica B6 C5 deficiente (B6.A- $H c^{0}$ ); e, b) desenvolver duas linhagens congênicas para introduzir o gene $c 5$ mutante da linhagem A/J em fundo genético B6, e vice-versa. Para isso, camundongos B6 e A/J machos com 10 semanas de idade foram tratados com a dieta hiperlipídica de LiberDeCarli modificada contendo etanol, ou maltodextrina, ou apenas a dieta, por 6,8 e 10 semanas. Ao final de cada semana determinamos o número de leucócitos circulantes, coletamos material para análise histopatológica, determinamos a quantidade de triglicerídeos hepáticos, e quantificamos citocinas (TNF- $\alpha$, IL-6, IL-1 $\beta$, IL-12, IL-10) hepáticas por ELISA. Observamos que em ambas as linhagens que receberam etanol houve hepatomegalia acompanhada de acúmulo de triglicerídeos, e redução das citocinas IL-6 e IL-12 ao longo das semanas de tratamento. A linhagem A/J tratada com etanol apresentou aumento de leucócitos circulantes, de IL-10 e de NO hepáticos. Além disso, apresentou menor acúmulo de triglicerídeos hepáticos em relação à linhagem B6. A linhagem B6 tratada com etanol apresentou aumento de IL-1 $\beta$ e redução de IL-10 hepáticos. Dessa forma, a linhagem A/J sofreu mais danos inflamatórios que a B6, mas esteve mais protegida do acúmulo de triglicerídeos hepáticos. Uma vez validados por sequenciamento de nucleotídeos, ensaio hemolítico da Via Alternativa, imunodifusão dupla e por microssatélite, os camundongos B6. A- $\mathrm{Hc}^{0}$ e B6 foram tratados com as mesmas dietas anteriores por 10 semanas. Incluímos nas análises a concentração sérica de aspartato aminotransferases, fosfatase alcalina, albumina, glicose, triglicerídeos e colesterol. Coletamos materiais para análise histopatológica e ainda determinamos as quantidades de triglicerídeos e colesterol hepáticos. Por fim, quantificamos a concentração das citocinas (TNF- $\alpha$, IL-6, IL-1 $\beta$, IL-10, IL-12, IL-17, IFN- $\gamma$, TGF- $\beta$ ) e a produção de NO no tecido hepático. Observamos que o tratamento com etanol aumentou a concentração de IL-17 e IL-10 e reduziu IL-1 $\beta$ e TGF- $\beta$ hepáticas nos camundongos B6.A-Hc ${ }^{0}$ em relação aos B6. Encontramos também diferenças entre as linhagens, mas independente da dieta, onde os animais B6.A-Hc ${ }^{0}$ apresentaram maior concentração de todos os parâmetros séricos avaliados, exceto glicose. E ainda observamos na linhagem B6.A- $H c^{0}$ menor concentração hepática de IL-6, IL-12 e IFN- $\gamma$. Concluímos que o C5 favoreceu um ambiente hepático pró-inflamatório ao mesmo tempo que parece ser importante para o controle sérico das enzimas de função e síntese hepática, assim como do perfil lipídico no modelo de DHA.

Palavras-chave: Sistema complemento.Componente C5. Doença Hepática Alcoólica. Inflamação. Citocinas. Camundongos congênicos C5 deficientes e C5 suficientes. 


\begin{abstract}
BAVIA, L. Contribution of murine complement component $\mathbf{C} 5$ in experimental alcoholic fatty liver disease. 2013. $248 \mathrm{p}$. Ph. D. thesis (Immunology) - Instituto de Ciências Biomédicas, Universidade de São Paulo, São Paulo, 2013.
\end{abstract}

Innate immunity contributes effectively to the development of Alcoholic Liver Disease (ALD). The complement system activation may play an important role in the pathogenesis of this disease. Murine models of ALD have showed evidences of the C3 contribution to the accumulation of triglycerides in liver and in adipose tissue. On the other hand, C5 protein seems to be involved with inflammation and liver injury after chronic ethanol consumption. In this work we investigated the contribution of the $\mathrm{C} 5$ component in the establishment and maintenance of ALD employing C57B1/6 (B6) and A/J, and B6 C5 deficient congenic mice (B6.A- $\mathrm{Hc}^{0}$ ). We also developed two congenic strains introducing the mutant gene $c 5$ of $\mathrm{A} / \mathrm{J}$ in genetic background of B6 mice, and the other way around. Ten-week old B6 and A/J male mice were treated with modified Liber-DeCarli diet, containing or not, ethanol or maltodextrin. To determine the time of treatment which most highlights the differences among the strains, mice were treated daily for 6, 8 and 10 weeks. After this period, tissue samples were collected for histopathological analysis and we quantified the number of circulating leukocytes, the amount of hepatic triglycerides and the liver cytokines (TNF- $\alpha$, IL6 , IL-1 , IL-12, IL-10). We observed that in both strains treated with ethanol there was hepatomegaly, accumulation of triglycerides in the liver, and a reduction of IL-6 and IL-12. The A/J mice group had increased numbers of circulating leukocytes, and increased levels of IL-10 and NO in the liver. They also showed a reduction in liver triglycerides compared to B6 mice, which had increased IL-1 $\beta$ and reduced IL-10. Therefore, A/J strain presented more inflammatory liver damage than B6, but was more protected from hepatic triglyceride accumulation. The next step of this work was to study the congenic B6.A-Hc and B6 mice. Before starting the diet administration, these animals were validated by nucleotide sequencing, alternative pathway hemolytic assay, immunodiffusion and microsatellite. Then, the congenic B6.A-Hc and B6 mice were treated with the same diets above described for 10 weeks. The following parameters were analyzed: serum aspartate aminotransferase, alkaline phosphatase, albumin, glucose, triglycerides and cholesterol. We also collected tissue samples for histopathological analysis, determined the amounts of liver triglycerides, and quantified the concentration of liver cytokines (TNF- $\alpha$, IL-6, IL-1 $\beta$, IL-10, IL-12, IL-17, IFN- $\gamma$, TGF- $\beta$ ) and NO production. We observed that treatment with ethanol increased the concentration of IL-17 and IL-10 and reduced IL-1 $\beta$ and TGF- $\beta$ in the liver of B6. A- $H c^{0}$ mice compared to B6. We also found differences between the strains regardless the diet. B6.A- $H c^{0}$ mice presented higher concentrations of all serum parameters evaluated, with the exception of glucose. These animals also had a lower concentration of IL-6, IL-12 and IFN- $\gamma$ in the liver. We conclude that the $\mathrm{C} 5$ component contributes to liver inflammation. The presence of this molecule seems to be important for the control of liver homeostasis and serum lipid profile in the model of DHA.

Keywords: Complement system. Complement component C5. Alcoholic Fatty Liver Disease. Inflammation. Cytokines. Congenic mice C5 deficient and C5 sufficient. 


\section{LISTA DE ILUSTRAÇÕES}

Figura 1 - Ativação geral do sistema complemento.

$-29-$

Figura 2 - Controle e administração das diferentes dietas hiperlipídicas empregando tubo Falcon $50 \mathrm{~mL}$

Figura 3 - Representação esquemática do desenvolvimento de linhagens congênicas..

Figura 4 - Delineamento experimental do desenvolvimento, seleção e validação das linhagens congênicas B6.A-Hc e A.B6-Hc..

Figura 5 - Exemplos de cromatogramas obtidos a partir do sequenciamento de nucleotídeos para identificação e seleção genotípicas dos camundongos congênicos.

Figura 6 - Imunodifusão dupla dos soros de camundongos B6.A- $\mathrm{Hc}^{0}$ (B6 C5 deficientes) e A.B6-Hc (A/J C5 normal).

Figura 7 - Ensaio hemolítico da via alternativa do sistema complemento aplicando soro das linhagens: B6 (B6 C5 normal), B6.A- $\mathrm{Cc}^{0}$ (B6 C5 deficientes), A.B6-Hc (A/J C5 normal), A (A/J C5 deficiente).

Figura 8 - $\quad$ Marcadores genéticos amplificados para a análise de microssatélite..........

$-62-$

Figura 9 - Contagem absoluta e diferencial de leucócitos sanguíneos nas linhagens B6 e A/J 4 h após tratamento com $7 \mathrm{~g} / \mathrm{kg}$ de etanol.

Figura 10 - Determinação da concentração plasmática das enzimas associadas à função hepática $4 \mathrm{~h}$ após o tratamento das linhagens B6 e A/J com 7g/kg de etanol por gavagem.

Figura 11 - Análise histopatológica de tecido hepático dos camundongos B6 após tratamento agudo com etanol.

Figura 12 - Análise histopatológica de tecido hepático dos camundongos A/J após tratamento agudo com etanol...

Figura 13 - Determinação da concentração plasmática de IL-6 por ELISA em camundongos B6 e A/J $4 \mathrm{~h}$ após o tratamento com etanol (7 g/ $\mathrm{kg})$.

Figura 14 - Delineamento experimental para a padronização do modelo murino de injúria hepática crônica induzida por etanol.

Figura 15 - Ganho de peso total dos camundongos B6 e A/J após 6, 8 e 10 semanas de tratamento com as diferentes dietas hiperlipídicas.

Figura 16 - Razão do peso hepático pelo peso corporal dos camundongos B6 e A/J após 6,8 e 10 semanas de tratamento com as diferentes dietas hiperlipídicas.

Figura 17 - Quantificação da concentração de triglicerídeos hepáticos dos camundongos B6 e A/J..

Figura 18 - $\quad$ Análise histopatológica de fígado dos camundongos B6 tratados com as diferentes dietas hiperlipídicas por 6, 8 e 10 semanas.

Figura 19 - Análise histopatológica de fígado dos camundongos $\mathrm{A} / \mathrm{J}$ tratados com as diferentes dietas hiperlipídicas por 6, 8 e 10 semanas.

$-70-$

$-71-$

$-72-$

$-73-$

$-74-$

$-77-$

$-79-$

$-80-$

$-82-$

$-83-$

Figura 20 - Análise histopatológica de fígado dos camundongos B6 tratados com as $-86-$ diferentes dietas hiperlipídicas após 6, 8 e 10 semanas, coloração PAS.... 
Figura 21 - Análise histopatológica de fígado dos camundongos $\mathrm{A} / \mathrm{J}$ tratados com as diferentes dietas hiperlipídicas após 6, 8 e 10 semanas, coloração PAS....

Figura 22 - Análise histopatológica de fígado dos camundongos B6 tratados com as $-87-$ diferentes dietas hiperlipídicas após 6, 8 e 10 semanas, após coloração picrossírius.

Figura 23 - Análise histopatológica de fígado dos camundongos $\mathrm{A} / \mathrm{J}$ tratados com as diferentes dietas hiperlipídicas após 6, 8 e 10 semanas, após coloração picrossírius.

Figura 24 - Número de leucócitos totais periféricos após tratamento com as diferentes dietas hiperlipídicas por 6, 8 e 10 semanas de tratamento das linhagens B6 e A/J.

Figura 25 - Determinação da concentração das citocinas inflamatórias e NO em homogenato de tecido hepático após 6, 8 e 10 semanas de tratamento com diferentes dietas hiperlipídica nas linhagens B6 e A/J.

Figura 26 - Ganho de peso acumulado dos camundongos B6 e B6.A- $\mathrm{Hc}^{0}$ (C5 deficiente) durante as 10 semanas de tratamento com as diferentes dietas hiperlipídicas

Figura 27 - Ganho de peso total dos camundongos B6 e B6.A- $H c^{0}$ (C5 deficiente), após 10 semanas de tratamento com as diferentes dietas hiperlipídicas....

Figura 28 - Razão do peso hepático pelo peso corporal dos camundongos B6 e B6.A- $\mathrm{Hc}^{0}$ (C5 deficiente), após 10 semanas de tratamento com as diferentes dietas hiperlipídicas.

Figura 29 - Quantificação da concentração de triglicerídeos e colesterol extraídos do tecido hepático após 10 semanas de tratamento com as diferentes dietas hiperlipídicas, empregando as linhagens B6 e B6.A- $\mathrm{Hc}^{0}$ (C5 deficiente)..

Figura 30 - Parâmetros histopatológicos avaliados nos cortes de tecido hepático após 10 semanas de tratamento com as diferentes dietas hiperlipídicas, empregando as linhagens B6 e B6.A-Hc (C5 deficiente).

Figura 31 - Cortes representativos dos parâmetros histopatológicos avaliados em coloração HE após 10 semanas de tratamento com as diferentes dietas hiperlipídicas, empregando as linhagens B6 e B6.A- $\mathrm{Hc}^{0}$ (C5 deficiente)..

Figura 32 - Cortes representativos dos parâmetros histopatológicos avaliados em coloração picrossírius após 10 semanas de tratamento com as diferentes dietas hiperlipídicas, empregando as linhagens B6 e B6.A- $\mathrm{Hc}^{0}$ (C5 deficiente).

Figura 33 - Avaliação da função hepática e parâmetros fisiológicos dos camundongos B6 e B6.A-Hc (C5 deficiente), após 10 semanas de tratamento com diferentes dietas hiperlipídicas.

Figura34 - Contagem absoluta dos leucócitos circulantes dos camundongos B6 e B6.A-Hc ${ }^{0}$ (C5 deficiente), após 10 semanas de tratamento com as diferentes dietas hiperlipídicas.

Figura 35 - $\quad$ Determinação da concentração das citocinas TNF- $\alpha$, IL-1ß, IL-6, IL-17, IFN- $\gamma$, IL-12p(70), nos homogenatos de tecido hepático nas linhagens B6 e B6.A-Hc ${ }^{0}$ (C5 deficiente) após 10 semanas de tratamento com as diferentes dietas hiperlipídicas. 
Figura 36 - Determinação da concentração das citocinas anti-inflamatórias IL-10 e TGF- $\beta$ nos homogenatos de tecido hepático nas linhagens B6 e B6.A$\mathrm{Hc}^{0}$ (C5 deficiente) após 10 semanas de tratamento com as dietas hiperlipídicas.

Figura 37 - Determinação da formação de nitrito em homogenato de fígado após 10 $-121-$ semanas de tratamento com as diferentes dietas hiperlipídicas empregando as linhagens B6 e B6.A-Hc ${ }^{0}$ (C5 deficiente).

Figura 38 - Desenho esquemático ilustrando a estrutura do lóbulo hepático.

$-126-$

Figura A.1 - Delineamento experimental para a padronização do modelo de DHNA....

$-176-$

Figura A.2 - Ganho de peso acumulado semanalmente pelos camundongos das $-178-$ linhagens B6 e A/J durante 10 semanas de tratamento com as diferentes dietas hiperlipídicas

Figura A.3 - Ganho de peso total ao final dos três períodos de tratamento dos camundongos B6 e A/J com as diferentes dietas hiperlipídicas

Figura A.4 - Razão do peso hepático pelo peso corporal dos camundongos B6 e A/J após 6,8 e 10 semanas de tratamento com as diferentes dietas hiperlipídicas.

Figura A.5 - Quantificação da concentração de triglicerídeos hepáticos dos camundongos B6 e A/J após 6, 8 e 10 semanas de tratamento com as diferentes dietas hiperlipídicas.

Figura A.6 - Análises histopatológicas de fígado dos camundongos B6 tratados com as diferentes dietas hiperlipídicas por 6, 8 e 10 semanas.

Figura A.7 - Análises histopatológicas de fígado dos camundongos $\mathrm{A} / \mathrm{J}$ tratados com as diferentes dietas hiperlipídicas por 6, 8 e 10 semanas.

$-186-$

Figura A.8 - Análises histopatológicas de fígado dos camundongos B6 tratados com as diferentes dietas hiperlipídicas por 6, 8 e 10 semanas.

Figura A.9 - Análises histopatológicas de fígado dos camundongos $\mathrm{A} / \mathrm{J}$ tratados com as diferentes dietas hiperlipídicas por 6, 8 e 10 semanas.

Figura A.10 - Análises histopatológicas de fígado dos camundongos B6 tratados com as diferentes dietas hiperlipídicas por 6, 8 e 10 semanas.

Figura A.11 - Análises histopatológicas de fígado dos camundongos A/J tratados com as diferentes dietas hiperlipídicas por 6, 8 e 10 semanas.

Figura A.12 - Determinação da concentração de ALT plasmática nos camundongos das linhagens B6 e A/J após tratamento com as diferentes dietas hiperlipílicas durante 6,8 e 10 semanas.

Figura A.13 - Número de leucócitos totais periféricos após tratamento com as diferentes dietas hiperlipídicas por 6, 8 e 10 semanas de tratamento das linhagens B6 e A/J.

Figura A.14 - Determinação da concentração das citocinas inflamatórias e NO em homogenato de tecido hepático após 6,8 e 10 semanas de tratamento com diferentes dietas hiperlipídica nas linhagens B6 e A/J.

$-187-$

$-187-$

$-188-$

$-188-$

$-191-$

Figura A.15 - Ganho de peso acumulado dos camundongos B6 e B6.A-Hc ${ }^{0}$ (C5 deficientes) durante as 10 semanas de tratamento com as diferentes dietas hiperlipídicas.

Figura A.16 - Ganho de peso final dos camundongos B6 e B6.A- $H c^{0}$ (C5 deficientes) após 10 semanas de tratamento com as diferentes dietas hiperlipídicas.... 
Figura A.17 - Razão do peso do tecido adiposo epididimal pelo peso corporal dos camundongos B6 e B6.A-Hc ${ }^{0}$ (C5 deficientes) após 10 semanas de tratamento.

Figura A.18 - Acúmulo de gordura no tecido adiposo epididimal nos camundongos B6 e B6.A-Hc ${ }^{0}$ (C5 deficientes) e após 10 semanas de tratamento com as diferentes dietas hiperlipídica para indução da DHNA

Figura A.19 - Razão do peso hepático pelo peso corporal dos camundongos B6 e B6.A-Hc ${ }^{0}$ (C5 deficientes) após 10 semanas de tratamento.

$-209-$

Figura A.20 - Avaliação do depósito de lipídeo do tecido hepático após 10 semanas de tratamento com as diferentes dietas hiperlipídicas empregando camundongos das linhagens B6 e B6.A-Hc ${ }^{0}$ (C5 deficientes).

Figura A.21 - Análise estatística dos parâmetros histopatológicos avaliados nos cortes de tecido hepático após 10 semanas de tratamento com as diferentes dietas hiperlipídicas, empregando as linhagens B6 e B6.A- $\mathrm{Hc}^{0}$.

Figura A.22 - Cortes representativos dos parâmetros histopatológicos avaliados em coloração HE após 10 semanas de tratamento com as diferentes dietas hiperlipídicas, empregando as linhagens B6 e B6.A-Hc

Figura A.23 - Cortes representativos dos parâmetros histopatológicos avaliados em coloração picrossírius após 10 semanas de tratamento com as diferentes dietas hiperlipídicas, empregando as linhagens B6 e B6.A- $H c^{0}$.

Figura A.24 - Avaliação da função hepática e de parâmetros fisiológicos gerais dos camundongos da linhagem B6 e da linhagem congênica B6.A- $H c^{0}$ (C5 deficientes) após 10 semanas de tratamento com diferentes dietas hiperlipídicas.

Figura A.25 - Contagem absoluta dos leucócitos circulantes no sangue periférico dos camundongos B6 e B6.A-Hc ${ }^{0}$ (C5 deficientes) após 10 semanas de tratamento com as diferentes dietas hiperlipídicas.

Figura A.26 - Determinação das citocinas TNF- $\alpha$, IL-1ß, IL-6, IL-17, IFN- $\gamma$, IL$12 \mathrm{p}(70)$ nos homogenatos de tecido hepático nos camundongos das linhagens B6 e B6.A-Hc ${ }^{0}$ (C5 deficientes) após 10 semanas de tratamento com as diferentes dietas hiperlipídicas.

Figura A.27 - Determinação da concentração da citocina anti-inflamatória IL-10 e da produção de $\mathrm{NO}$ nos homogenatos de tecido hepático dos camundongos B6 (C5 normais) e B6.A-Hc ${ }^{0}$ (C5 deficientes) após 10 semanas de tratamento com as diferentes dietas hiperlipídicas

Figura C.1 - Ganho de peso acumulado semanalmente dos camundongos B6 e A/J durante 10 semanas de tratamento com as diferentes dietas hiperlipídicas.

Figura C.2 - Determinação da concentração de ALT plasmática nas linhagens B6 e $\mathrm{A} / \mathrm{J}$ após tratamento com as diferentes dietas hiperlipídicas durante 6,8 e 10 semanas.

$-219-$

Figura E.1 - $\quad \begin{aligned} & \text { Controle do consumo semanal das diferentes dietas hiperlipídicas pelos } \\ & \text { camundongos B6 e B6.A- } H c^{0} \text { durante as } 10 \text { semanas de tratamento.......... }\end{aligned}$

Figura E.1 - $\begin{aligned} & \text { Controle do consumo semanal das diferentes dietas hiperlipídicas pelos } \\ & \text { camundongos B6 e B6.A- } H c^{0} \text { durante as } 10 \text { semanas de tratamento.......... }\end{aligned}$ 


\section{LISTA DE TABELAS}

Tabela 1 - Sequência dos oligonucleotídeos para seleção dos animais congênicos..

Tabela 2 - Condições de realização da PCR a partir de DNA genômico extraído da cauda dos camundongos e da reação de sequenciamento do produto amplificado.

Tabela 3 - Identificação do cromossomo, locus, tamanho esperado do produto amplificado para as linhagens parentais e concentração de $\mathrm{MgCl}_{2}$

Tabela 5 - Composição da mistura de sais para a dieta hiperlipídica adaptada de "Lieber-DeCarli Rat Ethanol Diet Regular".

Tabela 6 - Composição da mistura de vitaminas da dieta hiperlipídica adaptada de "Lieber-DeCarli Rat Ethanol Diet Regular".

Tabela 7 - Número de camundongos utilizados por experimento durante a padronização do tempo de tratamento com as diferentes dietas para os modelos de DHA e DHNA.

Tabela 8 - Número de camundongos C57B1/6 e C57B1/6 C5 deficientes utilizados durante 10 semanas de tratamento com as diferentes dietas hiperlipídicas

Tabela 9 - Critérios histopatológicos do índice de atividade da Doença Hepática Alcoólica e da Doença Hepática Não Alcoólica.

Tabela 10 - Critérios histopatológicos para avaliação do estadiamento da fibrose hepática na esteatohepatite alcoólica e não alcoólica.

Tabela 11 - Resumo dos principais resultados obtidos com o modelo de injúria hepática aguda induzida pelo etanol.

Tabela 12 - Resumo dos principais resultados obtidos com a padronização da DHA

Tabela 13 - Resumo dos principais resultados obtidos com a aplicação do modelo de DHA

Tabela A.1 - Resumo dos principais resultados obtidos com a padronização da DHNA.

Tabela A.2 - Resumo dos principais resultados obtidos com a aplicação do modelo de DHNA nos camundongos B6 e B6.A-Hc ${ }^{0}$

Tabela D.1- Média e desvio padrão do peso dos órgãos e razão do peso do órgão pelo peso corporal final dos camundongos B6 e A/J após 6 semanas de tratamento com as diferentes dietas hiperlipídicas

Tabela D.2- Média e desvio padrão do peso dos órgãos e razão do peso do órgão pelo peso corporal final dos camundongos B6 e A/J após 8 semanas de tratamento com as diferentes dietas hiperlipídicas

Tabela D.3- Média e desvio padrão do peso dos órgãos e razão do peso do órgão pelo peso corporal final dos camundongos B6 e A/J após 10 semanas de tratamento com as diferentes dietas hiperlipídicas 
Tabela F.1- Média e desvio padrão do peso final dos órgãos e razão do peso final do órgão pelo peso corporal final dos camundongos B6 e B6.A- $\mathrm{Hc}^{0}$ após 10 semanas de tratamento com as diferentes dietas hiperlipídicas. 


\section{LISTA DE ABREVIATURAS E SIGLAS}

A:

aa:

A.B6-Hc:

ALT:

ANOVA:

AP50:

AST:

B6:

B6.A-Hc0:

C3aR:

C5aR:

C5L2:

$\mathrm{CCl}_{4}$ :

CD59:

cDNA:

Crry:

DAF:

$\mathrm{DH}$ :

DHA:

$\mathrm{DH}+\mathrm{E}$ :

$\mathrm{DH}+\mathrm{G}$ :

$\mathrm{DH}+\mathrm{M}$ :

DHNA:

DNA:

dNTP:

EDTA:

EHA:

ELISA:

ENA:

FA:

fB: adenosina

aminoácido

camundongo congênico A/J C5 normal

alanina aminotransferase

análise de vairância

ensaio hemolítico da via alternativa que compara valores obtidos para $50 \%$ de lise no soro

aspartato animotransferase

$\mathrm{C} 57 \mathrm{~B} 1 / 6$

camundongo congênico C57B1/6 C5 deficiente

receptor de $\mathrm{C} 3 \mathrm{a}$

receptor de C5a

receptor semelhante ao receptor de C5a

tetracloreto de carbono

do inglês complement regulatory protein

DNA complementar

do inglês complement receptor 1-related gene/protein y

do inglês decay-accelerating factor

dieta hiperlipídica

Doença Hepática Alcoólica

dieta hiperlipídica contendo etaanol

dieta hiperlipídica contendo glicose

dieta hiperlipídica contendo maltodextrina

Doença Hepática Não Alcoólica

ácido desoxirribonucléico

desoxirribonucleotídeo trifosfato

do inglês Ethylenediamine tetraacetic acid

esteatohepatite alcoólica

do inglês Enzyme Linked Immuno Sorbent Assay

esteatohepatite não alcoólica

fosfatase alcalina

fator B 


$\begin{array}{ll}\text { fD: } & \text { fator D } \\ \mathrm{fH}: & \text { fator } \mathrm{H} \\ \mathrm{g:} & \text { gramas }\end{array}$

GGT: $\quad$ gama glutamiltransferase

HE: hematoxilina e eosina

IFN- $\gamma$ : $\quad$ interferon $\gamma$

IL-1 $\beta$ : interleucina $1 \beta$

IL-10: $\quad$ interleucina 10

IL-6: $\quad$ interleucina 6

IL-17 interleucina 17

IL:12 interleucina 12

kDa: $\quad$ kilo Daltons

kb: $\quad$ kilo base

kg: $\quad$ kilograma

LPS: lipopolissacarídeo

MAC: $\quad$ complexo de ataque à membrana

MASP - 1/2/3: do inglês mannose-binding lectin associated serine protease - 1/2/3

MBL: $\quad$ do inglês mannose binding lectin

mg: $\quad$ miligrama

$\mathrm{mL}: \quad$ militro

MN: monocuclear

$\mathrm{NF}-\kappa \mathrm{B}: \quad$ fator nuclear $-\kappa \mathrm{B}$

NO: $\quad$ óxido nítrico

PAS: $\quad$ ácido periódico de Schiff

pb: $\quad$ pares de base

PBS: do inglês phosphate buffer saline

PCR: reação em cadeia da polimerase

PMN: polimorfonuclear

QTL: do inglês quantitative trait loci

RNA: ácido ribonucléico

RT-PCR: reação em cadeia da polimerase em tempo real

SDS: $\quad$ dodecil sulfato de sódio

SNP: do inglês single-nucleotide polymorphism

STAT-3: $\quad$ tradutor de sinal e ativador da transcrição -3 
$\mathrm{T}$ :

timina

TBE:

do inglês Tris-borate-EDTA

TE:

do inglês Tris-EDTA

TGF- $\beta$ :

do inglês transforming growth factor beta

TLR-4:

Tm:

receptor semelhante ao toll -4

TNF- $\alpha$ :

temperatura de anelamento dos primers

fator de necrose tumoral $-\alpha$ 


\section{SUMÁRIO}

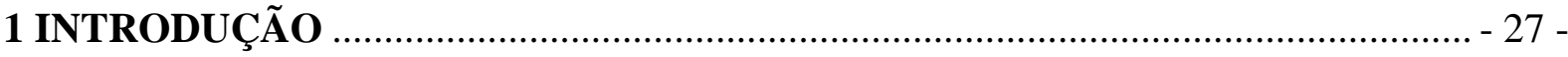

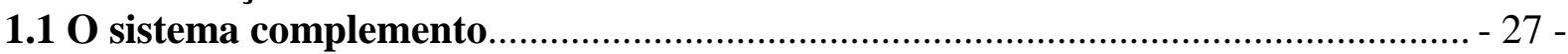

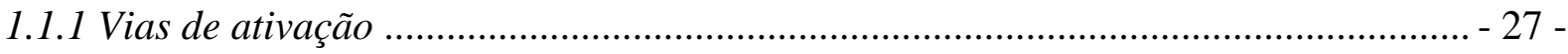

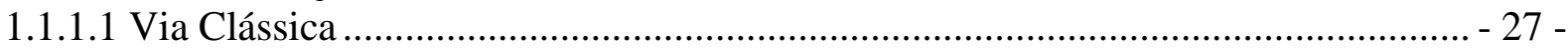

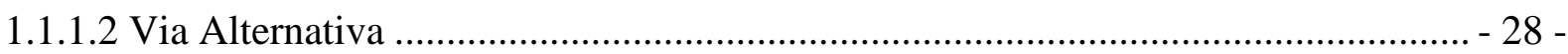

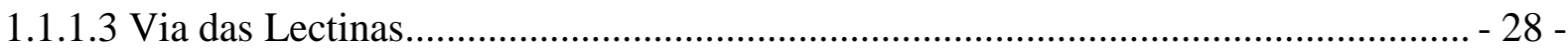

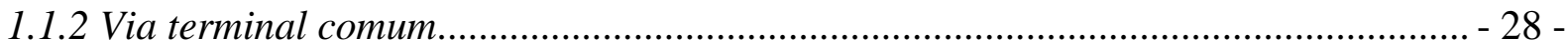

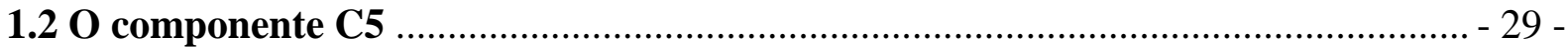

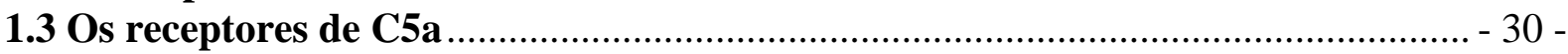

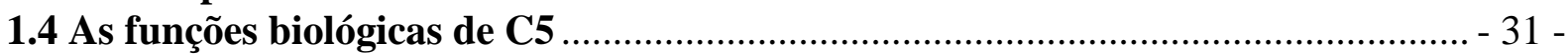

1.50 componente C5 e a regeneração hepática .................................................... - 33 -

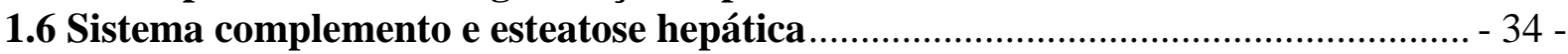

1.6.1 Sistema Complemento na DHA .............................................................................. - 35 -

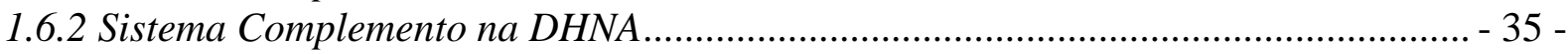

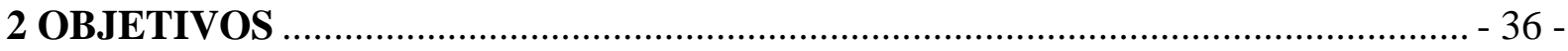

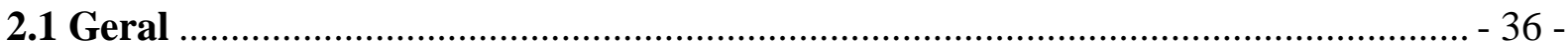

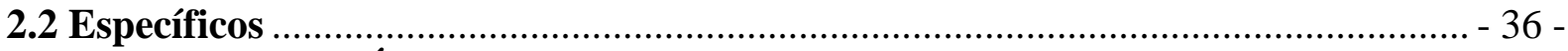

3 MATERIAIS E MÉTODOS ……............................................................ - 37 -

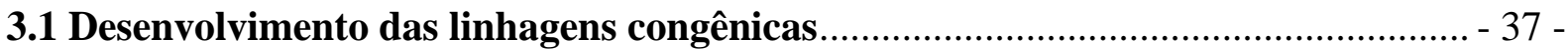

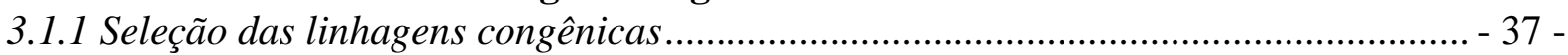

3.1.2 Validação das linhagens congênicas ........................................................................ - 39 -

3.1.2.1 Imunoprecipitação para verificação da proteína C5 no soro dos camundongos ..... - 39 -

3.1.2.2 Ensaio hemolítico para a Via Alternativa do Sistema Complemento para verificação da

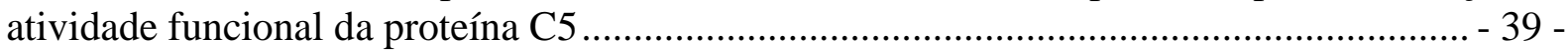

3.1.2.3 Análise por microssatélite para a confirmação do fundo genético das novas linhagens

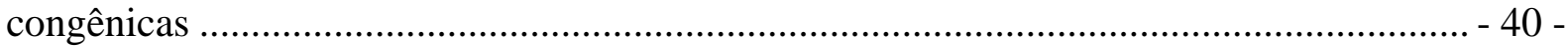

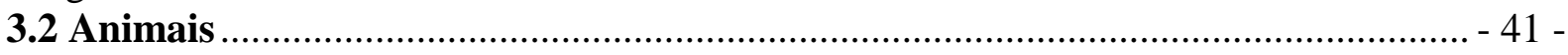

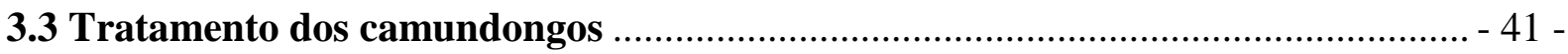

3.3.1 Modelo de administração aguda de etanol por gavagem .......................................... - 41 -

3.3.2 Modelo de administração crônica de etanol por meio de dieta hiperlipídica contendo etanol e modelo de administração crônica de glicose por meio de dieta hiperlipídica...... - 41 -

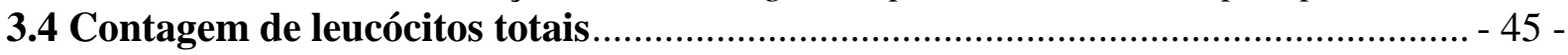

3.5 Ensaios bioquímicos ........................................................................................... - 46 -

3.5.1 Determinação dos parâmetros clínicos associados com a investigação de lesão

hepatocelular, função de síntese hepática e lesão de vias e fluxo biliar ................................ - 46 -

3.5.1.1 Determinação da atividade das enzimas ALT, AST e GGT................................... - 46 -

3.5.1.2 Determinação da concentração de albumina ......................................................... - 46 -

3.5.1.3 Determinação da enzima fosfatase alcalina.......................................................... - 47 -

3.5.2 Determinação de parâmetros clínicos gerais ............................................................... 47 -

3.5.2.1 Determinação da concentração de glicose e colesterol total .................................... - 47 -

3.5.2.2 Determinação da concentração de triglicerídeos .................................................. - 47 -

3.6 Homogenizaçã̃o hepática............................................................................... - 47 -

3.7 Determinação da concentração de proteínas totais no homogenato de fígado ...... - 48 -

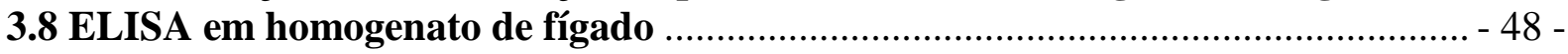

3.9 Dosagem de NO em homogenato de fígado ................................................... - 49 -

3.10 Extração de Lipídeos Hepáticos .......................................................................... - 49 -

3.11 Determinação da concentração de triglicerídeos e colesterol hepáticos ................ - 49 - 
3.12 Avaliação histopatológica …………………………………………………. - 50 -

3.13 Análise estatística ........................................................................................ - 51 -

4 CAPÍTULO 1 - DESENVOLVIMENTO, SELEÇÃO E VALIDAÇÃO DAS

LINHAGENS CONGÊNICAS ......................................................................... 53 -

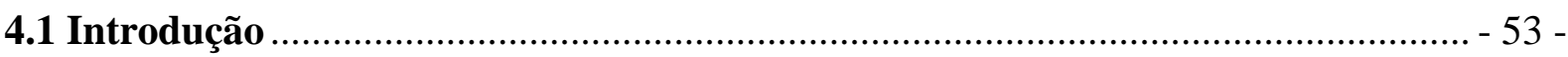

4.2 Estudos anteriores que já empregaram as linhagens congênicas B6 (C5 deficiente) e

A/J (C5 normal) ......................................................................................... - 54 -

4.3 Etapas do desenvolvimento de linhagens congênicas por retrocruzamento ……... - 55 -

4.4 Nomenclatura das linhagens congênicas ............................................................. - 57 -

4.5 Resultados do CAPÍTULO 1 ........................................................................ - 59 -

4.6 Discussão do CAPÍTULO 1 ............................................................................. 63 -

4.7 Conclusão do CAPÍTULO 1 ……....................................................................... 63 -

5 CAPÍTULO 2 - MODELO MURINO DE DOENÇA HEPÁTICA ALCOÓLICA.. - 64 -

5.1 Introdução

5.1.1 Características da Doença Hepática Alcoólica ……………………………………..... - 64 -

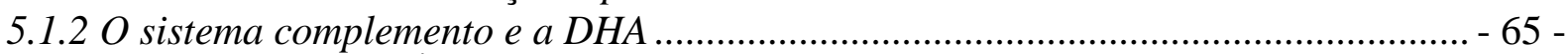

5.2 Resultados do CAPÍTULO 2 ………………………………………………….... - 69 -

5.2.1 Modelo de injúria hepática aguda induzida por etanol .............................................. - 69 -

5.2.1.1 Análise do perfil de leucócitos periféricos após tratamento dos camundongos B6 e A/J com etanol por gavagem........................................................................................ 69 -

5.2.1.2 Avaliação da função hepática pela determinação da concentração plasmática das enzimas ALT, AST e GGT........................................................................................ - 71 -

5.2.1.3 Análise histopatológica hepática das linhagens B6 e A/J após tratamento com etanol

5.2.1.4 Determinação das citocinas inflamatórias no plasma dos camundongos B6 e A/J

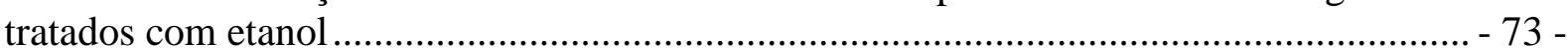
5.2.1.5 Conclusão geral do tópico "Modelo de injúria hepática aguda induzida por etanol" ......

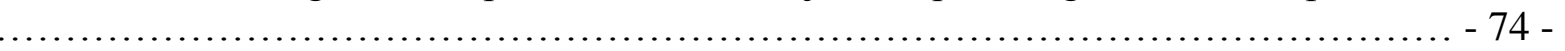

5.2.2 Padronização do modelo de injúria hepática crônica induzida por etanol (ou padronização da DHA) .......................................................................................... - 76 -

5.2.2.1 Avaliação dos parâmetros corporais ................................................................... - 78 -

5.2.2.2 Avaliação da função hepática e hematológica............................................................ - 89 -

5.3.2.3 Avaliação da resposta inflamatória no micro-ambiente hepático............................... - 91 -

5.2.2.4 Conclusão do tópico "Padronização do modelo de injúria hepática crônica induzida por etanol (ou padronização da DHA)" ......................................................................... - 100 5.2.3 Aplicação da linhagem congênica B6.A-Hc ${ }^{0}$ (C5 deficiente) no modelo de DHA ... - 101 -

5.2.3.1 Avaliação dos parâmetros corporais ..................................................................... - 101 -

5.2.3.2 Avaliação função hepática, bioquímica e hematológica ........................................... - 113 -

5.2.3.3 Avaliação da resposta inflamatória no micro-ambiente hepático............................ - 117 -

5.2.3.4 Conclusão do tópico "Aplicação da linhagem congênica B6.A-Hc no modelo de

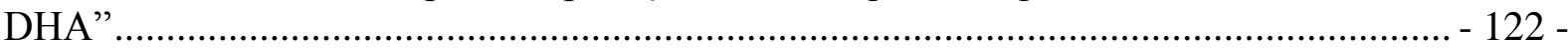

5.2.4 Resumo dos principais resultados obtidos em cada um dos tópicos avaliados no

CAPÍTULO 2

5.3 Discussão do CAPítULO 2

$-123-$

5.3.1 Discussão referente aos resultados da injúria hepática aguda induzida por etanol- 127 -

5.3.2 Discussão referente aos resultados da padronização do modelo de DHA em

camundongos $B 6$ e $A / J$

- 132 -

5.3.3 Discussão referente aos resultados da aplicação da linhagem congênica B6.A-Hc ${ }^{0}$ no modelo de DHA 
5.4.1 Conclusão do modelo de injúria hepática aguda induzida por etanol...................... - 145 -

5.4.2 Conclusões do modelo de injúria hepática crônica induzida pela DHA .................. - 145 -

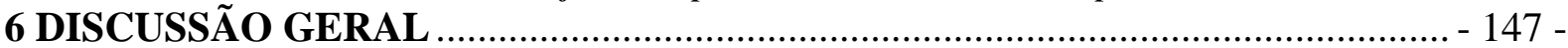

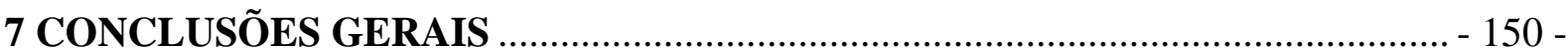

7.1 Desenvolvimento e validação de duas linhagens congênicas de camundongos B6.A-

$\mathrm{Hc}^{\mathbf{0}}$ (C5 deficiente) e A.B6-Hc (C5 normal) ............................................................ - 150 -

7.2 Modelo de injúria hepática aguda induzida por etanol ..................................... - 150 -

7.3 Padronização do modelo de DHA empregando as linhagens B6 e A/J ................ - 150 -

7.4 Aplicação da linhagem congênica B6.A-H $\boldsymbol{c}^{\boldsymbol{0}}$ no modelo de DHA .......................... - 151 -

7.4.1 Independentemente do tratamento os camundongos da linhagem B6.A-Hc ${ }^{0}$

apresentaram em relação aos camundongos linhagem B6 ............................................. - 151 -

7.4.2 Independentemente da linhagem, o tratamento com $D H+E$ promoveu ................... - 152 -

7.4.3 Diferenças entre as linhagens quando tratadas com $\mathrm{DH}+\mathrm{E}$................................... - 152 -

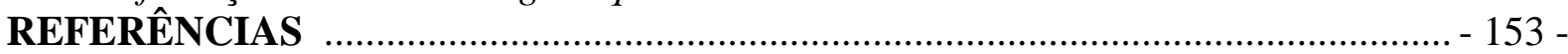

APÊNDICE A - MODELO MURINO DE DOENÇA HEPÁTICA NÃO-ALCOÓLICA

1 Introdução

1.1 Características da Doença Hepática Não-Alcoólica

1.2 Sistema Complemento na Doença Hepática Não-Alcoólica ......................................... - 168 -

1.3 Sistema Complemento e Obesidade ........................................................................... - 168 -

1.3.1 Trabalhos envolvendo o sistema complemento em pacientes obesos ....................... - 169 -

1.3.2 Trabalhos envolvendo o sistema complemento em culturas de adipócitos e macrófagos

...- 170 -

1.3.3 Trabalhos envolvendo o sistema complemento e modelos animais de obesidade ... - 171 -

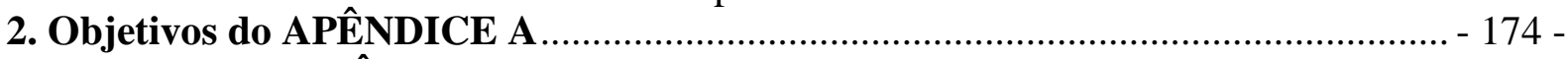

3 Resultados do APÊNDICE A ................................................................................. - 175 -

3.1 Padronização do modelo de injúria hepática crônica induzida por glicose (ou

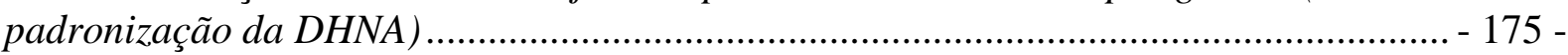

3.1.1 Avaliação dos parâmetros corporais ....................................................................... - 176 -

3.1.2 Avaliação da atividade hepática e perfil hematológico ............................................ - 189 -

3.1.3 Avaliação da resposta inflamatória no micro-ambiente hepático............................... - 193 -

3.1.4 Conclusão do tópico "Padronização do modelo de injúria hepática crônica induzida por glicose (ou padronização da DHNA)" "................................................................................. - 202 -

3.2 Aplicação da linhagem congênica B6.A-Hc ${ }^{0}$ no modelo de DHNA .............................. - 203 -

3.2.1 Avaliação dos parâmetros corporais ........................................................................ - 203 -

3.2.2 Avaliação função hepática, bioquímica e hematológica .......................................... - 216 -

3.2.3 Avaliação da resposta inflamatória no micro-ambiente hepático ............................... - 220 -

3.2.4 Conclusão do tópico "Aplicação da linhagem congênica B6.A- $H c^{0}$ no modelo de

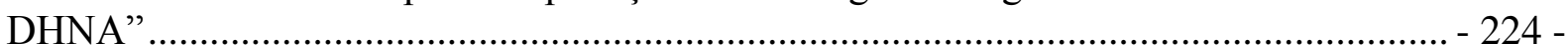

3.3 Resumo dos principais resultados obtidos em cada um dos tópicos avaliados no

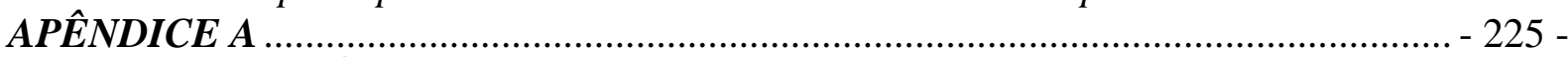

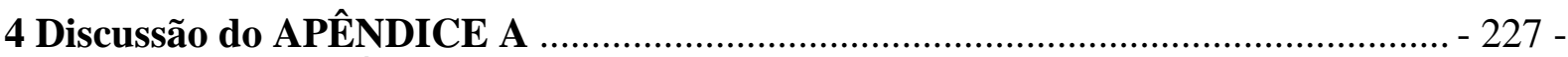

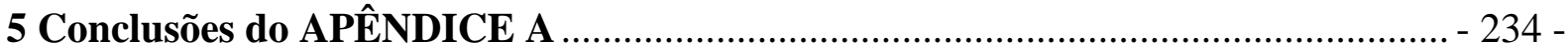

5.1 Conclusões sobre a padronização do modelo de DHNA empregando as linhagem B6 e A/J

5.2 Conclusões sobre a aplicação da linhagem congênica B6.A-Hc e B6 no modelo de

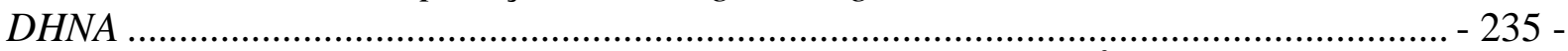

5.2.1 Independentemente do tratamento a linhagem B6.A-Hc apresentou em relação à

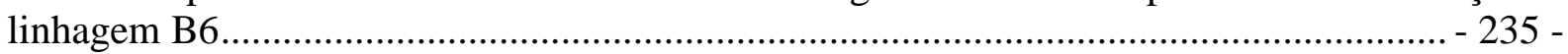


5.2.2 Independentemente da linhagem o tratamento com $\mathrm{DH}+\mathrm{G}$ por 10 semanas promoveu

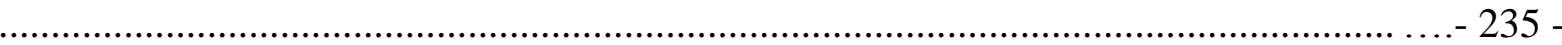

5.2.3 Diferenças entre as linhagens quando tratadas com $\mathrm{DH}+\mathrm{G}$.................................. - 236 APÊNDICE B - Análise da composição da Dieta Hiperlipídica ................................ - 237 APÊNDICE C - Ganho de peso acumulado semanalmente e dosagem da enzima ALT dos camundongos $\mathrm{B} 6$ e A/J durante as 10 semanas de tratamento no modelo de DHA

A P̂̂.NDICE D - Peso dos órgãos referentes às padronizaçones dos............................. 238

APENDICE D - Peso dos órgãos referentes às padronizações dos .......................... - 242 -

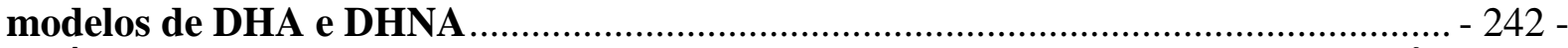

APÊNDICE E - Consumo semanal das dietas pelos camundongos B6 e B6.A-Hc ${ }^{0}$ durante as 10 semanas de tratamento com as diferentes dietas hiperlipídicas.......... - 245 APÊNDICE F - Peso dos órgãos referentes à aplicação dos camundongos ................ - 247 B6 e B6.A-H $c^{0}$ nos modelos de DHA e DHNA …................................................... - 247 -

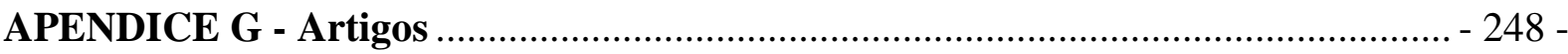




\section{SOBRE A APRESENTAÇÃO E A ORGANIZAÇÃO DA TESE}

Iniciaremos com uma INTRODUÇÃO geral, seguida pelos OBJETIVOS gerais e específicos que nortearam as nossas investigações e os MATERIAIS E MÉTODOS utilizados. Visando à organização textual dos resultados, esta tese está dividida em 2 capítulos. Onde, no CAPÍ́tUlO 1 abordaremos o desenvolvimento e caracterização de linhagens congênicas, as quais serão empregadas experimentalmente no capítulo e apêndices subsequientes. No CAPÍTULO 2 apresentaremos uma introdução detalhada sobre a (Doença Hepática Alcoólica) DHA e os principais trabalhos associados com sistema complemento, assim como os resultados obtidos com: (1) o modelo de injúria hepática aguda induzida pelo etanol, (2) a padronização do modelo desenvolvido para a reprodução da DHA em nos camundongos C57Bl/6 e A/J, (3) e aplicação do modelo de DHA em um dos camundongos congênicos desenvolvidos no CAPítUlo 1. Da mesma forma faremos também uma discussão para cada um dos tópicos descritos nos resultados e uma conclusão do capítulo.

Por fim, no APÊNDICE A além da introdução sobre a (Doença Hepática Não Alcoólica) DHNA também apresentaremos os resultados obtidos com: (1) a padronização do modelo desenvolvido para a reprodução da DHNA em nos camundongos C57B1/6 e A/J, (2) e aplicação do modelo de DHNA em um dos camundongos congênicos desenvolvidos no CAPÍTULO 1. Da mesma forma discutiremos cada um dos tópicos descritos nos resultados e a conclusão do APÊNDICE A. Optamos por esta divisão devido ao fato da tese ser demasiadamente longa e por termos utilizado os mesmos controles entre os modelos de DHA e DHNA. A metodologia empregada no APÊNDICE A foi a mesma que a do CAPÍTULO 2.

Portanto, cada capítulo contará com uma breve introdução pertinente ao assunto em questão, delineamento experimental assim como discussão e conclusões particulares. Ao final dos dois capítulos e do apêndice A discutiremos de maneira geral sobre os principais resultados encontrados. Por fim, faremos a DISCUSSÃO e CONCLUSÕES GERAIS da tese. 


\section{INTRODUÇÃO}

\subsection{O sistema complemento}

O sistema complemento é formado por 30 ou mais proteínas plasmáticas e de membrana. É um dos protagonistas centrais da imunidade inata, desempenhando importante papel na defesa contra a invasão de patógenos. Uma das relevantes funções do complemento é a opsonização de partículas ou microorganismos facilitando sua fagocitose e remoção. Ele também pode participar ativamente da resposta inflamatória por meio da produção de fatores quimiotáticos (C3a, C4a, C5a) que atraem células inflamatórias para o sítio de ativação (RICKLIN et al., 2010). O complemento pode ainda solubilizar e remover imunocomplexos evitando deposição e injúria tecidual (MILLER; NUSSENZWEIG, 1974), assim como ativar linfócitos B, estimulando-os para a síntese de imunoglobulinas (RICKLIN et al., 2010; WALPORT, 2001), além da lise de microorganismos pela formação do complexo de ataque à membrana (KONDOS et al., 2010).

\subsubsection{Vias de ativação}

\subsubsection{Via Clássica}

O início desta via depende principalmente da presença de imunocomplexos formados por anticorpos ligados especificamente a antígenos. O complexo protéico $\mathrm{C} 1$ é formado por uma molécula de $\mathrm{C} 1 \mathrm{q}$ e duas moléculas de $\mathrm{C} 1 \mathrm{r}$ e de $\mathrm{C} 1 \mathrm{~s}\left(\mathrm{C} 1 \mathrm{qC} 1 \mathrm{r}_{2} \mathrm{C} 1 \mathrm{~s}_{2}\right)$. $\mathrm{C} 1 \mathrm{q}$ inicia a ativação da via clássica ao ligar-se ao imunocomplexo, quando sofre uma mudança conformacional e passa a ativar $\mathrm{C} 1 \mathrm{r}$. Após este ser ativado, ele exibe atividade de serino-protease e ativa $\mathrm{C} 1 \mathrm{~s}$ que, por sua vez, também passa e exibir um sítio catalítico de serino-protease podendo clivar C4 e C2. C4 cliva-se em C4a e C4b, e a este último liga-se C2 que então sofre ação enzimática de $\mathrm{C} 1 \mathrm{~s}$ ativado, formando $\mathrm{C} 2 \mathrm{a}$ e $\mathrm{C} 2 \mathrm{~b}$. Os fragmentos $\mathrm{C} 4 \mathrm{~b} 2 \mathrm{a}$ formam a $\mathrm{C} 3$ convertase, responsável esta pela clivagem de C3 em C3a e C3b. Quando fragmentos C3b ligam-se ao complexo C4b2a [C4b2a3b $b_{n}$, forma-se então a C5 convertase (RICKLIN et al., 2010; WALPORT, 2001) (Figura 1). A ação desta enzima será abordada na página seguinte. 


\subsubsection{Via Alternativa}

A ativação desta via inicia-se a partir da hidrólise espontânea da ligação tiól-éster localizada na cadeia $\alpha$ do componente $\mathrm{C} 3$ gerando $\mathrm{C} 3\left(\mathrm{H}_{2} \mathrm{O}\right)$. Esta molécula exibe sítio reativo para a proteína plasmática fator $\mathrm{B}(\mathrm{fB})$, formando o complexo $\mathrm{C} 3\left(\mathrm{H}_{2} \mathrm{O}\right) \mathrm{B}$. Nesta condição, o $\mathrm{fB}$ pode ser clivado, pela enzima fator $\mathrm{D}(\mathrm{fD})$, em $\mathrm{Ba}$ e $\mathrm{Bb}$. $\mathrm{O}$ fragmento $\mathrm{Bb}$ permanece ligado ao $\mathrm{C} 3\left(\mathrm{H}_{2} \mathrm{O}\right) \mathrm{Bb}$, formando a primeira $\mathrm{C} 3$ convertase desta via, que agora apresenta atividade de serino-protease e cliva $\mathrm{C} 3$ em C3a e $\mathrm{C} 3 \mathrm{~b}$. $\mathrm{C} 3 \mathrm{~b}$, assim como $\mathrm{C} 3\left(\mathrm{H}_{2} \mathrm{O}\right)$, apresenta sítio para a ligação do $\mathrm{fB}$, o qual, uma vez ligado a $\mathrm{C} 3 \mathrm{~b}$, sofrerá clivagem pelo $\mathrm{fD}$, resultando no complexo $\mathrm{C} 3 \mathrm{bBb}$, a segunda $\mathrm{C} 3$ convertase desta via. Quando $\mathrm{C} 3$ se liga ao complexo $\mathrm{C} 3 \mathrm{bBb}$ forma $\mathrm{C} 3 \mathrm{bBb3} \mathrm{b}_{\mathrm{n}}$, o qual exerce atividade de C5 convertase (RICKLIN et al., 2010; WALPORT, 2001) (Figura 1).

\section{$\underline{1.1 .1 .3 ~ V i a ~ d a s ~ L e c t i n a s ~}$}

Esta via inicia-se a partir da ligação de açúcares como manose a lectinas, como a lectina ligadora de manose (mannose binding lectin - MBL). A MBL tem estrutura semelhante a C1q, mas se liga a resíduos de manose, $\mathrm{N}$-acetil-glicosamina, frutose, glicose, entre outros resíduos abundantes na superfície de microorganismos (TURNER, 2003). À MBL estão associadas três serino-proteases, mannose-binding lectin-associated serine protease-1 (MASP-1), MASP-2, MASP-3, que são ativadas quando a MBL se liga a açúcares. Essa ativação leva à clivagem de $\mathrm{C} 4$ e de $\mathrm{C} 2$, resultando na formação de $\mathrm{C} 3$ convertases e $\mathrm{C} 5$ convertases, semelhantes às convertases geradas na via clássica (RICKLIN et al., 2010; WALPORT, 2001) (Figura 1).

\subsubsection{Via terminal comum}

As C5 convertases formadas tanto pelas vias clássica/das lectinas (C4b2a3b) como pela via alternativa $(\mathrm{C} 3 \mathrm{bBb} 3 \mathrm{~b})$ clivam o componente $\mathrm{C} 5$ em $\mathrm{C} 5 \mathrm{a}$ e $\mathrm{C} 5 \mathrm{~b}$. O fragmento $\mathrm{C} 5 \mathrm{~b}$ adere à superfície celular e a ele o componente C6 se liga, formando o complexo C5b6. A este complexo incorpora-se também o componente $\mathrm{C} 7, \mathrm{C} 8$ e até 18 moléculas de $\mathrm{C} 9$, formando o complexo de ataque à membrana (MAC) C5b678(9) $)_{\mathrm{n}}$. O MAC se insere na célula como um canal transmembrânico, favorecendo o desequilíbrio iônico e aumento do volume intracelular levando ao rompimento da membrana celular (lise) (KONDOS et al., 2010) (Figura 1). 
Figura 1 - Ativação geral do sistema complemento.

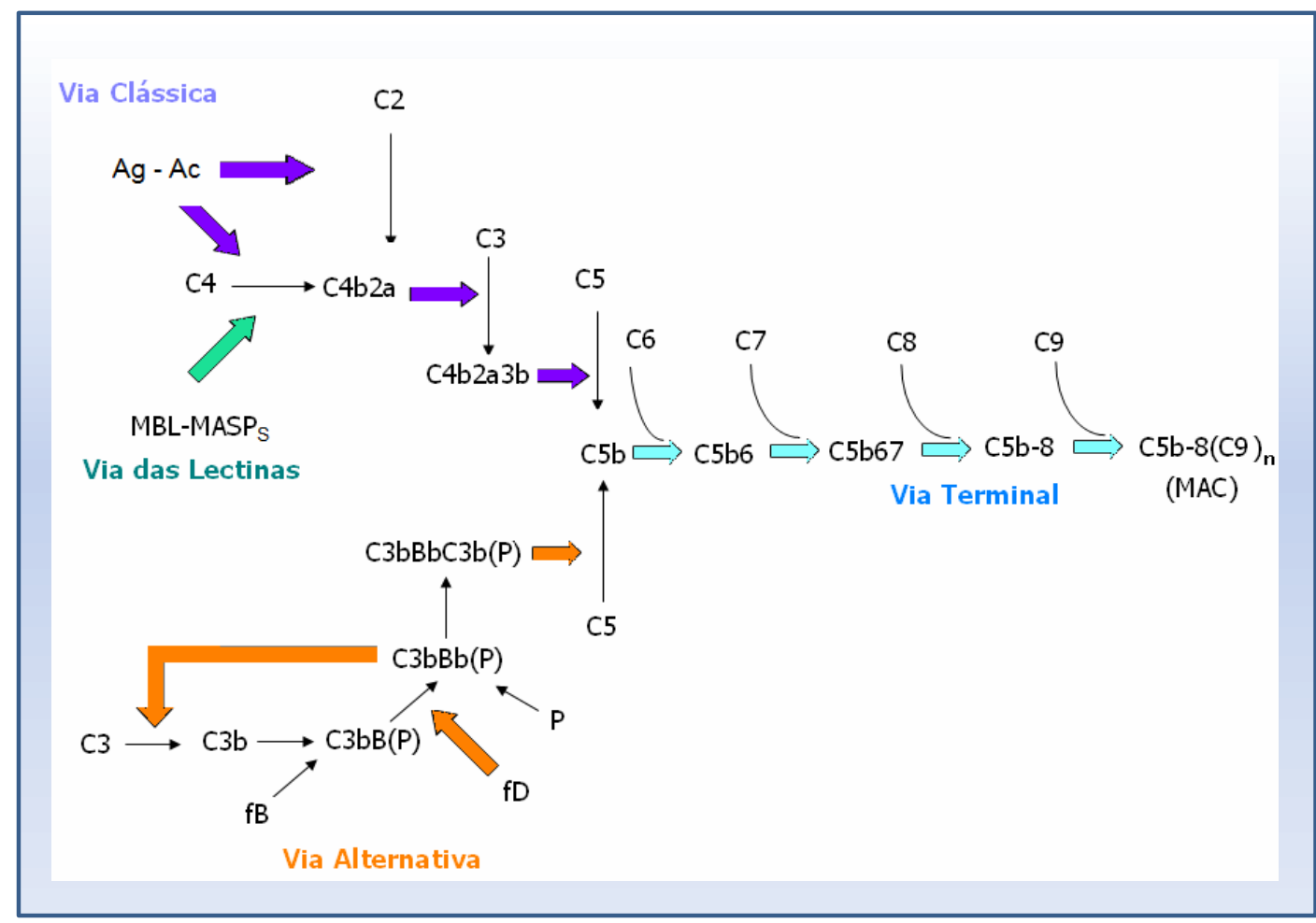

Ativação do Sistema de Complemento. As três vias culminam na Via terminal comum com a formação do Complexo de Ataque a Membrana (MAC), causando a lise da célula.

Fonte: Adaptado de Morgan e Harris (1999).

\subsection{O componente $\mathrm{C5}$}

O componente $\mathrm{C} 5$ pertencente à via terminal comum será o alvo de estudo em nosso trabalho. Sua biossíntese é realizada principalmente nos hepatócitos (MORGAN; GASQUE, 1997). No entanto, sítios secundários também sintetizam C5 como: pulmão, baço, intestino fetal, monócitos, macrófagos e células alveolares tipo II (WETSEL, 2000).

C5 é uma glicoproteína com 190 kDa que consiste de 2 cadeias polipeptídicas, cadeia $\alpha$ e cadeia $\beta$, com massa molecular de 155 e $75 \mathrm{kDa}$, respectivamente, as quais são ligadas entre si por ponte dissulfídica (TACK; MORRIS; PRAHL, 1979). É sintetizada inicialmente como uma única cadeia precursora, Pró-C5, de 1676 aminoácidos (aa) incluindo um peptídeo líder com 18 aa e uma sequência de ligação rica em arginina. O precursor de C5 (Pró-C5) é processado intracelularmente, originando as duas cadeias $\alpha$ e $\beta$, que se mantêm juntas por ligação dissulfídica e forças não-covalentes (WETSEL, 2000). Carney e colaboradores (1991) 
determinaram que o gene $c 5$ contém 41 éxons os quais abrangem uma região genômica de 79 $\mathrm{kb}$.

Por meio de estudo com células somáticas hibridadas com DNA complementar (cDNA) e por hibridação in situ, Jeremiah e colaboradores $(1987,1988)$ localizaram o gene $c 5$ humano no cromossomo 9q22-q34. No mesmo período, Wetsel e seu grupo (1987) também contribuíram para a análise molecular do gene $c 5$ humano na banda cromossômica 9q32-q34, com maior concentração na região 9q34.1 . D’Eustachio et al. (1986) estudando a localização cromossômica de genes que codificam os componentes do complemento $\mathrm{C} 5$ e fator $\mathrm{H}$ em camundongos, ratos e hamster chinês, encontraram que o gene estrutural c5 murino localizase no cromossomo 2. Wetsel, Fleischer, Haviland (1990) observaram que a deleção de dois pares de base (pb), uma timina e uma adenosina (TA), no éxon 7 próximo a extremidade 5' do gene $c 5$ (HAVILAND et al., 1991) era responsável pela deficiência de C5 em camundongos. A deleção de TA, afeta a sequência de leitura, gerando um códon de parada prematura (UGA) a quatro pares de base do local da deleção.

\subsection{Os receptores de C5a}

O fragmento C5a exerce a maioria de suas atividades biológicas através da ligação com seus receptores. O gene codificador para o receptor de $\mathrm{C} 5 \mathrm{a}(\mathrm{C} 5 \mathrm{aR})$ encontra-se no cromossomo 19q13.3 em humanos e no cromossomo 7 em camundongos e é encontrado em vários tipos celulares como eosinófilos, basófilos, neutrófilos, mastócitos, monócitos e macrófagos. A sua interação com C5a pode mediar a inflamação local e sistêmica (HAWLISCH et al., 2005) e também regular a liberação de citocinas e quimiocinas como IL1 $\beta$, IL-6, TNF- $\alpha$, IL-12 e IL-8 (EMBER; JAGELS; HUGLI, 1998). O receptor C5aR pertence à família dos receptores acoplados à proteína G (KLOS et al., 2009), já o receptor semelhante ao receptor de C5a (C5L2), descoberto em 2000 pelo grupo de Ohno foi considerado um receptor órfão putativo e não indutor de sinalização. O receptor C5L2 liga C5a, entretanto liga-se com maior afinidade ao fragmento de C5a que sofreu remoção da última arginina pela ação de uma N-carboxipeptidase (C5adesArg) (MATTHEUS; MUELLER-ORTIZ; WETSEL, 2004). Até o momento seu papel exato na resposta imune ainda é objeto de estudo (BAMBERG, et al., 2010). Existem trabalhos que mostram a expressão do receptor C5L2 em tecido adiposo e a ligação dos fragmentos C3a e C3adesArg a este receptor estimula a captura de glicose e a síntese de triglicerídeos pelo tecido adiposo. (CIANFLONE; XIA; CHEN, 2003; KALANT et al., 2005). Por outro lado, outros ligantes de C5L2 como C5a, C5adesArg 
e C4a não estimulam a síntese de lipídeos (GAO et al., 2005). Portanto, a real função deste receptor permanece ainda obscura.

\subsection{As funções biológicas de C5}

As funções biológicas de C5 dependem da atuação de C5a e C5b de receptores que interagem com o primeiro fragmento. Com a clivagem de $\mathrm{C} 5$ em $\mathrm{C} 5 \mathrm{a}$ e $\mathrm{C} 5 \mathrm{~b}$, o produto ativado do complemento, C5a, desempenha poderosas atividades biológicas que afetam a resposta inflamatória. O fragmento C5b é essencial para a formação do MAC, contribuindo para eliminação de células-alvo, como bactérias, fungos ou protozoários (KONDOS et al., 2010).

Assim como C3a, o fragmento C5a é uma anafilatoxina. C5a é um forte regulador da vasodilatação, aumentando a permeabilidade dos pequenos vasos e induzindo a contração da musculatura lisa. Em células como macrófagos, neutrófilos e eosinófilos, a ligação do fragmento $\mathrm{C} 5 \mathrm{a}$ em seu respectivo receptor, C5aR, pode estimular a explosão respiratória. Já em células como mastócitos e basófilos, C5a estimula a liberação de histamina. O fragmento C5a ainda é considerado um poderoso quimioatraente, recrutando células como: macrófagos, neutrófilos, linfócitos B ativados, linfócitos T, basófilos e mastócitos para o sítio inflamatório. Todas estas funções podem tanto contribuir para as funções imunes protetoras, quanto causar danos aos tecidos (GUO; WARD, 2005; KLOS et al., 2009).

Em adição às propriedades pró-inflamatórias do fragmento $\mathrm{C} 5 \mathrm{a}$, descritas acima, estudos recentes mostram que este fragmento também desempenha importante papel em outros contextos. Em 2000, Karp et al. empregando técnicas de microarranjo, polimorfismo de nucleotídeos (SNP) e Quantitative Trait Locus (QTL) identificaram o gene codificador de C5 como locus de susceptibilidade para o desenvolvimento da asma alérgica experimental. Addis-Lieser, Kohl, Chiaramonte (2005) estudaram o papel de C5 no desenvolvimento da fibrose pulmonar induzida por bleomicina. Estes autores observaram que durante a fase aguda C5 teve um papel protetor e anti-inflamatório, entretanto, durante o estágio crônico C5 contribuiu para o desenvolvimento de fibrose pulmonar. Estes dados sugerem o envolvimento de C5 tanto na inflamação quanto no reparo tecidual em modelos de fibrose induzido por bleomicina. Em modelos de fibrose hepática Hillebrandt et al. (2005) também empregaram a análise de QTL para identificar o locus que confere susceptibilidade à fibrose. O mesmo grupo também observou que C5 possui efeito fibrogênico tanto em modelos de fibrose murinos ou humanos. Complementando estes estudos sobre o papel fibrogênico do 
componente C5 em modelo de fibrose biliar induzido pela técnica de ligação do ducto biliar aplicando camundongos C5 suficientes e C5 deficientes observou-se que nos camundongos C5 deficientes a inflamação tornou-se atenuada concomitante a redução significativa de fibrose biliar (SCHMITT et al., 2012). Estes estudos evidenciam o componente C5 como um potencial alvo para intervenções terapêuticas para o controle do desenvolvimento de fibrose.

Em modelo de malária cerebral os camundongos C57Bl/6 (C5 suficientes) são susceptíveis à infecção, já os camundongos A/J (C5 deficientes) são resistentes. Para investigar se esta susceptibilidade estaria associada ao componente $\mathrm{C} 5$ ou ao fundo genético, Patel et al. (2008) geraram camundongos congênicos C57Bl/6 (C5 deficientes) e A/J (C5 suficientes) e submeteram estes animais à infecção com Plasmodium berghei. Interessantemente, estes autores encontraram que os animais A/J C5 suficientes tornaram-se susceptíveis ao desenvolvimento da malária cerebral. Estes resultados implicam que C5 contribuiu para a patogênese da malária cerebral independentemente do fundo genético da linhagem de camundongo empregada no modelo. Da mesma forma, camundongos C5 ou C5aR deficientes também foram resistentes em desenvolver sepsis, quando submetidos ao modelo experimental de punção e ligação do ceco (WARD, 2008).

Outro exemplo da ação de C5, em especial de C5a, é a regulação da imunidade adaptativa em contexto tumoral. A geração de C5a no microambiente tumoral aumenta o crescimento do tumor, suprimindo linfócitos $\mathrm{T} \mathrm{CD}^{+}$. Esta supressão está associada com o recrutamento de células supressoras mielóides para o sítio tumoral. C5a estimula as células supressoras a produzir espécies reativas de oxigênio e nitrogênio, as quais inibem a especificidade antigênica das células $\mathrm{TCD}^{+}$, que por sua vez deixam de atuar sobre as células tumorais permitindo o seu desenvolvimento (MARKIEWSKI et al., 2008).

Em modelo de artrite auto-imune, a ativação do sistema complemento e a geração dos seus produtos de ativação, como C5a, podem iniciar a diferenciação de células Th17 a partir de células TCD4 ${ }^{+}$. A expansão da subpopulação Th17 pode piorar o quadro de doenças autoimunes ou a própria resposta imunológica às infecções. O bloqueio do C5aR pode beneficiar o controle da inflamação e da progressão de doenças auto-imunes mediadas por Th17 (HASHIMOTO et al., 2010).

Além das funções citadas acima, os componentes do complemento, em especial C5, estão associados com a promoção de doenças neurodegenerativas em modelos animais. Empregando o modelo murino de Doença de Alzheimer, Fonseca et al. (2009) estudaram a contribuição de C5a e C5aR na patogênese e comportamento neste modelo de doença neurodegenerativa. Sabendo que C5a recruta e ativa células da microglia e astrócitos via 
C5aR, este autores administraram aos camundongos um peptídeo antagonista do C5aR. Após este tratamento, houve redução no quadro patológico desencadeado pela progressão da doença, melhora comportamental e cognitiva dos camundongos. Estes resultados sugerem que a inibição da função mediada por $\mathrm{C} 5 \mathrm{aR}$ pode interferir na neuroinflamação e neurodegeneração em modelos murinos de Doença de Alzheimer. Trabalhos empregando a administração de peptídeos antagonistas do $\mathrm{C} 5 \mathrm{aR}$ em doenças relacionadas ao sistema nervoso central (SNC) foram elegantemente discutidos na revisão de Woodruff e colaboradores (2010). Esta revisão mostrou que o uso de antagonistas para C5aR protegeu os camundongos em vários modelos de doenças degenerativas, injúrias agudas do SNC e infecções do SNC. Além disso, foi identificado que tanto o componente C5 quanto o seu receptor foram expressos durante o período de neurulação com expressão localizada na região cefálica do tubo neural. Em modelo de deficiência de ácido fólico durante o processo gestacional a remoção do gene C5aR ou após a administração de peptídeo antagonista ao C5aR em camundongos fêmeas prenhes houve má formação do tubo neural (DENNY et al., 2013). Assim sendo, além da promoção de doenças relacionadas aos SNC o componente C5 e C5aR também estão envolvidos com o desenvolvimento embrionário neurológicos em mamíferos.

Portanto, reunimos aqui algumas funções que envolvem o componente C5, que vão desde o seu papel clássico como anafilatoxina e como um componente pró-fibrogênico, até como um fator chave para o desenvolvimento de respostas inflamatórias severas em condições de malária cerebral e sepsis, ainda contribui para a progressão tumoral e para as doenças que acometem o SNC.

\subsection{O componente C5 e a regeneração hepática}

O fígado, além de ser um órgão fundamental para síntese e armazenamento de glicose, ele também é responsável pela síntese de colesterol, assim como pela lipogênese e metabolismo de proteínas. É o principal órgão desintoxicador do corpo, por meio do metabolismo de diversos fármacos e toxinas, e consequentemente, pela remoção dos produtos resultantes deste processo. O fígado, mesmo desempenhando estas inúmeras funções, também possui extraordinária capacidade regenerativa, regulando sua própria massa e crescimento (TAUB, 2004).

O componente C5 pode exacerbar a resposta inflamatória e conduzi-la a danos severos como citamos anteriormente. Mas, curiosamente, ele também pode desempenhar um papel 
claramente reparador. Interessantemente, outras nobres funções biológicas foram atribuídas a C5, sugerindo um envolvimento essencial na regeneração do fígado após injúria. Mastellos et al. (2001) mostraram que camundongos deficientes de C5 $\left(\mathrm{C}^{-1-}\right)$, quando submetidos a uma injúria por tetracloreto de carbono $\left(\mathrm{CCl}_{4}\right)$, exibem regeneração hepática anormal, sendo mais suscetíveis a danos tóxicos no fígado do que animais C5 suficientes $\left(\mathrm{C}^{+/+}\right)$. No entanto, quando camundongos $\mathrm{C}^{-/-}$foram reconstituídos com a proteína $\mathrm{C} 5$ murina purificada regeneraram o tecido hepático, semelhantemente ao observado em camundongos $\mathrm{C} 5$ normais. Com isso, sugere-se que o sistema complemento apresente importante desempenho na manutenção da homeostase hepática e na resposta fisiológica do fígado pós-injúria tóxica, provocada pelo emprego do $\mathrm{CCl}_{4}$. $\mathrm{O}$ grupo de Markiewski (2004) observou o mesmo processo patológico em camundongos $\mathrm{C}^{-/-}$. Desta forma, fica evidente o papel crítico dos componentes C5 e C3 para a recuperação hepática após dano tóxico.

Em modelo de hepatectomia parcial, Strey et al. (2003) demonstraram que os fragmentos C3a e C5a, assim como seus respectivos receptores (C3aR e C5aR), são essenciais para a regeneração do fígado, promovendo a proliferação dos hepatócitos. Neste processo regenerativo estariam identificados como reguladores cruciais as citocinas interleucina (IL)-6 e fator de necrose tumoral (TNF)- $\alpha$, bem como os fatores de transcrição: transdutor de sinal e ativador da transcrição 3 (STAT-3) e o fator nuclear $\kappa \mathrm{B}(\mathrm{NF}-\kappa \mathrm{B})$. Estes resultados foram novamente explorados e confirmados pelo grupo de Markiewski (2009), concluindo que os fragmentos C3a e C5a regulam a homeostase do fígado, em dependência de IL-6 e TNF- $\alpha$.

\subsection{Sistema complemento e esteatose hepática}

A ativação do sistema complemento de forma exacerbada no tecido hepático frente aos mais variados tipos de injúria, como acima citados, é correlacionada com a progressão de várias patologias crônicas (HILLEBRANDT et al., 2005). Dentre as patologias crônicas e "silenciosas" que podem ser influenciadas pela ativação do sistema complemento está a Doença Hepática Alcoólica (DHA) (PRITCHARD et al., 2007) e a Doença Hepática Não Alcoólica (DHNA) (RENSEN et al., 2009), doenças caracterizadas primariamente pela deposição de lipídeos nos hepatócitos (esteatose), seguida de inflamação e fibrose que podem progredir, sem possibilidade de regressão, para a cirrose (NAGATA; SUZUKI; SAKAGUCHI, 2008). 


\subsubsection{Sistema Complemento na DHA}

Apresentamos aqui um breve resumo dos principais trabalhos que investigaram o papel do sistema complemento na DHA, retomaremos este tema no CAPÍTULO 2. O primeiro estudo aplicando um modelo animal envolvendo a ativação do sistema complemento com a DHA foi realizado pelo grupo de Järveläinen, em 2002. Ratos foram tratados com uma dieta hiperlipídica contendo etanol por 4 a 6 semanas, e, após este período, observou-se deposição de C3 e esteatose no espaço porta hepático nos animais selvagens. Por outro lado, os ratos deficientes de C3 não apresentaram semelhante patologia.

Camundongos C3 deficientes também foram protegidos do depósito de gordura hepática após tratamento com dieta contendo etanol (BYKOV et al, 2006). Além disso, estudos onde camundongos C5 deficientes foram tratados com dieta hiperlipídica contendo etanol mostraram que estes animais apresentam menor produção de TNF- $\alpha$ e IL-6 hepáticos que os camundongos selvagens tratados com a mesma dieta, e camundongos CD59 deficientes apresentaram exacerbada esteatose hepática, assim como aumento de TNF- $\alpha$ e IL6 hepáticos (PRITCHARD et al., 2007).

\subsubsection{Sistema Complemento na DHNA}

Em 2009, Rensen e colaboradores descreveram pela primeira vez o depósito de produtos de ativação do sistema complemento em biópsias hepáticas de pacientes com DHNA e com a forma mais avançada da doença chamada Esteatohepatite Não Alcoólica (ENA). Empregando a técnica de imunohistoquímica foram encontrados em pacientes com DHNA depósito de C3 e MBL ao redor dos hepatócitos com acúmulo de gordura, infiltrado neutrofílico e aumento da expressão gênica da quimiocina IL-8 e da citocina IL-6 no tecido hepático. Consequentemente, todas estas características tornaram-se mais pronunciadas nos pacientes com ENA.

Até o presente momento não existem trabalhos que abordem o sistema complemento em modelo murino de DHNA. Este tema será apresentado com mais detalhes no APÊNDICE A. Estes resultados foram direcionados para o APÊENDICE A devido ao grande volume de resultados obtidos com o modelo de DHA. 


\section{OBJETIVOS}

\subsection{Geral}

Estudar a importância do componente C5 do sistema complemento in vivo na resposta inflamatória hepática de camundongos após injúria tecidual crônica induzida por etanol em modelos de DHA.

\subsection{Específicos}

* Desenvolver duas linhagens congênicas de camundongos C57B1/6 (C5 deficiente) e o A/J (C5 suficiente) e caracterizá-las quanto à presença e função da proteína C5, assim como avaliar integridade do fundo genético no qual o gene de c5 está inserido.

* Estabelecer um modelo de DHA, avaliando e identificando as alterações corporais e histopatológicas hepáticas observadas em pacientes ou modelos animais de DHA durante os diferentes tempos de tratamento (6, 8 e 10 semanas) empregando as linhagens C57Bl/6 e A/J.

* Analisar a resposta inflamatória principalmente pela determinação da concentração hepática das citocinas TNF- $\alpha$, IL-6, IL-1 $\beta$, IL-12, IL-10 e da produção de NO nos camundongos C57B1/6 e A/J, provocada pelo tratamento com etanol no modelo de DHA.

* Empregar uma das novas linhagens de camundongos congênicos (C57B1/6 C5 deficiente) no modelo de DHA estabelecido.

* Analisar a resposta inflamatória pela determinação da concentração hepática das citocinas TNF- $\alpha$, IL-6, IL-1 $\beta$, IL-12, INF- $\gamma$, IL-10 e TGF- $\beta$ e da produção de NO entre os camundongos C57Bl/6 (C5 suficiente) e C57Bl/6 (C5 deficiente) submetidos ao modelo de DHA. 


\section{MATERIAIS E MÉTODOS}

\subsection{Desenvolvimento das linhagens congênicas}

\subsubsection{Seleção das linhagens congênicas}

Empregamos como métodos para selecionar as linhagens congênicas, extração de DNA, a partir da cauda dos camundongos, reação em cadeia empregando DNA polimerase (PCR) e sequenciamento de nucleotídeos.

A extração de DNA foi realizada com aproximadamente $1 \mathrm{~cm}$ da ponta cauda dos camundongos de cada geração (desde a N2 até N10). Depois de cortado, o pedaço da cauda foi imediatamente congelado em nitrogênio líquido e armazenado a $-20{ }^{\circ} \mathrm{C}$ até o momento da extração. Para a extração de DNA o tecido foi descongelado no gelo e então macerado. Ao macerado foram adicionados $200 \mu \mathrm{L}$ da solução de lise $(50 \mathrm{mM}$ Tris $\mathrm{HCl}$ pH 8, $10 \mathrm{mM}$ EDTA pH 8, SDS 0,5\%, 1,5 mg / $\mathrm{mL}$ de proteinase $\mathrm{K}$ ) e incubados a $65^{\circ} \mathrm{C}$ por $2 \mathrm{~h}$. Após esta incubação, foram acrescentados $200 \mu \mathrm{L}$ da solução de lise sem proteinase $\mathrm{K}$. Uma vez digerido, a preparação foi centrifugada por $20 \mathrm{~min}, 13000 \mathrm{~g}$ à temperatura ambiente. $\mathrm{O}$ sobrenadante foi transferido para um tubo novo e precipitado com $840 \mu \mathrm{L}$ de etanol absoluto e acetato de sódio 3 M. Depois de centrifugado por $5 \mathrm{~min}, 2000 \mathrm{~g}$ em temperatura ambiente o DNA foi lavado com etanol 70\% e ressuspenso em $200 \mu \mathrm{L}$ de TE pH 8 (10 mM Tris- $\mathrm{HCl}$ pH 8, 1 mM EDTA). O DNA extraído foi quantificado após leitura da absorbância, empregandose o espectrofotômetro GeneQuant pro RNA/DNA calculator" (Biosciences Amersham, Inglaterra, Reino Unido).

Utilizamos o mesmo par de oligonucleotídeos (Tabela 1) tanto para a PCR quanto para a reação de sequenciamento, entretanto utilizados em diferentes concentrações (Tabela 2). Para a PCR empregamos o kit Ilusttra TM Taq DNA Polimerase (catálogo 27-0798-06, GE Healthcare Limited, Inglaterra, Reino Unido) e para a purificação dos fragmentos amplificados utilizamos o kit Ilusttra TM GFX TM PCR, DNA and Gel Band Purification (catálogo 28-9034-70, GE). A reação de sequenciamento foi realizada empregando o kit BigDyeTerminator v3.1 Cycle Sequencing (Applied Biosystems, Foster, Califórnia, Estados Unidos). Ambas as reações foram desenvolvidas segundo as especificações dos fabricantes. 
Tabela 1 - Sequência dos oligonucleotídeos para seleção dos animais congênicos.

\begin{tabular}{ccc}
\hline Identificação & Sentido 5' $\rightarrow$ 3' & Tm $\left({ }^{\mathbf{}} \mathbf{C}\right)$ \\
\hline MC5Fseq & GTC TAG GGC AAA ATT AGA AG & 56 \\
MC5Rseq & GAT CAG TTG GCT TCT TCA AG & 58 \\
\hline
\end{tabular}

Abreviatura:

Tm: Temperatura de melting (ou de hibridação com os oligonucleotídeos)

Tabela 2 - Condições de realização da PCR a partir de DNA genômico extraído da cauda dos camundongos e da reação de sequenciamento do produto amplificado.

\begin{tabular}{|c|c|c|c|}
\hline \multicolumn{2}{|l|}{ PCR } & \multicolumn{2}{|l|}{ Sequenciamento } \\
\hline Reagentes & $1 \mathbf{x}$ & Reagentes & $1 \mathbf{x}$ \\
\hline Tampão 10x & 5,0 & Tampão & 6,0 \\
\hline $\mathrm{MgCl}_{2} 25 \mathrm{mM}$ & 1,5 & MC5Fseq 3,2 picomoles/ $\mu L^{*}$ & 2,0 \\
\hline dNTP $10 \mathrm{mM}$ & 1,0 & $\mathrm{ou}$ & \\
\hline MC5Fseq $50 \mathrm{ng} / \mu \mathrm{L}$ & 1,0 & MC5Rseq 3,2 picomoles $/ \mu L^{*}$ & 2,0 \\
\hline MC5Rseq $50 \mathrm{ng} / \mu \mathrm{L}$ & 1,0 & DNA $100-300 \mathrm{ng} / \mu \mathrm{L}$ & 6,0 \\
\hline Taq $5 \mathrm{U} / \mu \mathrm{L}$ & 0,3 & Big Dye & 2,0 \\
\hline DNA $100 \mathrm{ng} / \mu \mathrm{L}$ & 1,0 & Água & 2,0 \\
\hline Água & 39,2 & & \\
\hline Volume final & $50 \mu \mathrm{L}$ & Volume final & $20 \mu \mathrm{L}$ \\
\hline
\end{tabular}

Nota: * Na reação de sequenciamento coloca-se apenas um dos oligonucleotídeos e são realizadas duas reações: uma reação no sentido $5^{\prime}-3^{\prime}$ e outra no sentido $3^{\prime}-5^{\prime}$.

Para a PCR empregamos o termociclador MJ Research Programmable Thermal Controller (modelo PTC-100, St. Bruno, Quebec, Canadá) e o seguinte programa: 1) $94{ }^{\circ} \mathrm{C}$ por $5 \mathrm{~min}, 2) 94^{\circ} \mathrm{C}$ por $\left.30 \mathrm{~s}, 3\right) 54^{\circ} \mathrm{C}$ por $\left.30 \mathrm{~s}, 4\right) 72{ }^{\circ} \mathrm{C}$ por $1 \mathrm{~min}, 39$ repetições dos passos 2 ao 4 e, por fim, $72{ }^{\circ} \mathrm{C}$ por $7 \mathrm{~min}$. Após cada amplificação, conferiu-se o tamanho do fragmento obtido após corrida eletroforética em gel de agarose 1\% em TBE (88 mM Tris Base, $88 \mathrm{mM}$ ácido bórico, $2 \mathrm{mM}$ EDTA pH 8). O fragmento amplificado foi purificado e a sua concentração foi quantificada no espectrofotômetro GeneQuant pro RNA/DNA calculator, e então diluído para a concentração específica para a reação de sequenciamento.

A reação de sequenciamento (Tabela 2) foi submetida ao seguinte programa: 1) $96{ }^{\circ} \mathrm{C}$ por $2 \mathrm{~min}$, 2) $96^{\circ} \mathrm{C}$ por $\left.45 \mathrm{~s}, 3\right) 50^{\circ} \mathrm{C}$ por $\left.30 \mathrm{~s}, 4\right) 60{ }^{\circ} \mathrm{C}$ por $4 \mathrm{~min}, 39$ repetições dos passos 2 ao 4 e, por fim, $60{ }^{\circ} \mathrm{C} 4$ min. Em seguida, as amostras foram precipitadas com $80 \mu \mathrm{L}$ de isopropanol $75 \%$ à temperatura ambiente por $15 \mathrm{~min}$, depois centrifugada por $20 \mathrm{~min}$ a 8000 
g. As amostras foram lavadas com $200 \mu \mathrm{L}$ de isopropanol $75 \%$ e centrifugadas por 5 min $8000 \mathrm{~g}$. Ao final o isopropanol foi descartado permitindo que as amostras secassem e armazenadas a $-20{ }^{\circ} \mathrm{C}$. As amostras foram ressuspensas em formamida antes da corrida eletroforética para o sequenciamento de nucleotídeos, no seqüenciador ABI PRISM 3100GeneticAnalyzer /HITACHI (Applied Biosystems Foster, Califórnia, Estados Unidos) localizado no Departamento de Bioquímica no Instituto de Química da USP. As sequências obtidas foram comparadas com os dados depositados no http://www.ncbi.nlm.nih.gov/entrez: NM 010406.1.

\subsubsection{Validação das linhagens congênicas}

\subsubsection{Imunoprecipitação para verificação da proteína C5 no soro dos camundongos}

Lâminas de vidro $(2,5 \mathrm{~cm}$ x 7,5 cm) foram revestidas com $1 \mathrm{~mL}$ de agarose $1 \%$ diluída

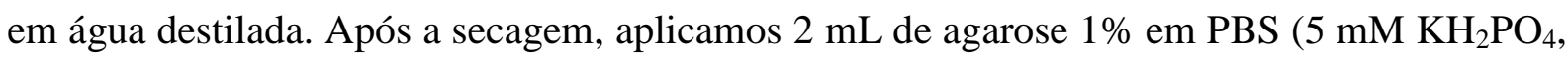
1,2 $\mathrm{mM} \mathrm{K}_{2} \mathrm{HPO}_{4}$ e $150 \mathrm{mM} \mathrm{NaCl} \mathrm{pH}$ 7). Em seguida, perfuramos orifícios na agarose para a aplicação da amostra e do anticorpo. $5 \mu \mathrm{L}$ do anticorpo anti-C5 de camundongo, produzido em nosso laboratório, foi aplicado no poço central e nos demais poços ao redor do poço central aplicamos $5 \mu \mathrm{L}$ da amostra pura. Incubamos as lâminas em câmara úmida a $4{ }^{\circ} \mathrm{C}$ por 48 h. Então, cobrimos as lâminas com solução salina tamponada (PBS 1x) a $4^{\circ} \mathrm{C}$ por $48 \mathrm{~h}$ para lavagem das mesmas. Envolvemos a lâmina com papel de filtro e deixamos na estufa para secar. Uma vez secas, coramos com corante para proteínas $(1,21 \mathrm{mM}$ Coomassie Brilliant Blue, 1,57 M ácido acético e 7,72 M etanol absoluto) por 20 min e retiramos o excesso com descorante (1,57 M ácido acético e 7,72 M etanol absoluto).

\subsubsection{Ensaio hemolítico para a Via Alternativa do Sistema Complemento para verificação da atividade funcional da proteína C5}

Para avaliação da via alternativa, empregamos hemácias de coelho em Alsever estéril. As hemácias foram lavadas três vezes em GVB EGTA $\mathrm{Mg}^{2+}$ (VBS: 0,72 $\mathrm{M} \mathrm{NaCl}, 4,8 \mathrm{mM}$ barbiturato de sódio, 12,5 mM ácido barbitúrico, $\mathrm{pH}$ 7,2. Para $1 \mathrm{~L}$ de GVB EGTA $\mathrm{Mg}^{2+}: 200$ $\mathrm{mL}$ de VBS, 0,2 g/L gelatina, 2mM EGTA pH 7,4, $1 \mathrm{mM} \mathrm{MgCl}_{2}$ ). Em seguida, tubos contendo as diluições: puro, 1:2; 1:4; 1:6 (em volume final de $25 \mu \mathrm{L}$ ) de soro de camundongo receberam $25 \mu \mathrm{L}$ da suspensão de hemácias a $1 \%$ em tampão GVB EGTA $\mathrm{Mg}^{2+}$. A reação foi 
incubada por 30 min a $37{ }^{\circ} \mathrm{C}$, seguida por centrifugação a $1200 \mathrm{~g}$ por 10 min a $25^{\circ} \mathrm{C}$. A absorbância do sobrenadante foi determinada pelo comprimento de $405 \mathrm{~nm}$. Comparamos os valores obtidos com o esperado para $100 \%$ de hemólise descontando-se o controle negativo $($ branco $): \%$ de Lise $=[($ D.O lida - D.O branco $) /($ D.O 100\% - D.O branco $)] \times 100$. Dessa forma calculamos o volume necessário de soro, para hemolisar 50\% das hemácias. AP50 é o volume de soro necessário para lisar 50\% das hemácias. Representamos os dados na forma de Unidades de Lise presentes em $1 \mathrm{~mL}$ de soro.

3.1.2.3 Análise por microssatélite para a confirmação do fundo genético das novas linhagens congênicas

Tabela 3 - Identificação do cromossomo, locus, tamanho esperado do produto amplificado para as linhagens parentais e concentração de $\mathrm{MgCl}_{2}$.

\begin{tabular}{ccccc}
\hline Cromossomo & Locus & C57Bl/6 $(\mathbf{p b})$ & A/J $\mathbf{p b})$ & $\mathbf{M g C l}_{\mathbf{2}} \mathbf{~ m M}$ \\
\hline 1 & D1 Mit 231 & 267 & 219 & 3,0 \\
2 & D2 Mit 92 & 148 & 200 & 1,5 \\
3 & D3 Mit 224 & 132 & 160 & 1,5 \\
4 & D4 Mit 12 & 198 & 168 & 1,5 \\
5 & D5 Mit 81 & 210 & 194 & 1,5 \\
6 & D6 Mit 8 & 164 & 190 & 1,5 \\
7 & D7 Mit 31 & 246 & 230 & 1,5 \\
8 & D8 Mit 121 & 250 & 222 & 1,5 \\
9 & D9 Mit 207 & 148 & 162 & 1,5 \\
10 & D10 Mit 83 & 251 & 275 & 1,5 \\
11 & D11 Mit 212 & 148 & 166 & 1,5 \\
12 & D12 Mit 19 & 346 & 324 & 1,5 \\
13 & D13 Mit 16 & 210 & 178 & 1,5 \\
14 & D14 Mit 141 & 141 & 125 & 3,0 \\
15 & D15 Mit 85 & 195 & 179 & 3,0 \\
16 & D16 Mit 131 & 144 & 174 & 1,5 \\
17 & D17 Mit 113 & 127 & 105 & 1,5 \\
18 & D18 Mit 149 & 136 & 114 & 1,5 \\
19 & D19 Mit 91 & 112 & 134 & 1,5 \\
X & DX Mit 119 & 154 & 168 & 3,0 \\
\hline
\end{tabular}

Após a extração de DNA procedemos com análise de microssatélites para 1 alelo de cada cromossomo. Seguimos o protocolo sugerido pelo fabricante Research Genetics Genome Center (MapPairs, Research Genetics, Huntsville, Alabama, Estados Unidos). Realizamos a análise para as quatro linhagens (C57B1/6 C5 normal e C5 deficiente, A/J C5 deficiente e C5 normal). Na Tabela 3 encontra-se a identificação do par de oligonucleotídeos usado para cada 
cromossomo, o tamanho do fragmento que será amplificado para cada uma das linhagens, assim como a concentração ótima de cloreto de magnésio empregada na reação.

\subsection{Animais}

Foram empregados camundongos isogênicos das linhagens C57Bl/6 e A/J machos, com 10 a 12 semanas de idade em todos os experimentos, oriundos do Biotério de Camundongos Isogênicos do Departamento de Imunologia, Instituto de Ciências Biomédicas da USP. Todos os protocolos e manipulação aqui descritos foram aprovados pelo Comitê de Ética em Experimentação do Animal ICB/USP. O número de camundongos utilizados para cada experimento encontra-se na legenda das figuras, entretanto ressaltamos que o n mínimo foi de 5 animais.

\subsection{Tratamento dos camundongos}

\subsubsection{Modelo de administração aguda de etanol por gavagem}

Dez camundongos da linhagem, C57B1/6 e A/J, receberam etanol 95\% (Merck. S.A., Rio de Janeiro, R.J., Brasil) 7 g / kg em solução a 32\% em água autoclavada por gavagem oral utilizando agulha de aço inoxidável de calibre 18. Este modelo de ingestão aguda é vastamente empregado por vários autores para indução de injúria hepática aguda mediada por etanol (CARSON; PRUETT, 1996; COLLIER; PRUETT, 2000; WEISS et al., 1996). A concentração de $7 \mathrm{~g} / \mathrm{kg}$ de etanol gera significativa alteração na concentração de alanina aminotransferase (ALT) no soro de animais tratados, quando comprados com o controle (CARSON; PRUETT, 1996). Dez animais de cada linhagem foram empregados como controles e receberam o equivalente em volume $7 \mathrm{~g} / \mathrm{kg}$ (da solução de etanol), diluído em água autoclavada.

3.3.2 Modelo de administração crônica de etanol por meio de dieta hiperlipídica contendo etanol e modelo de administração crônica de glicose por meio de dieta hiperlipídica

O modelo de administração experimental de etanol em longo prazo, para roedores e primatas, emprega uma dieta líquida, rica em lipídeos na qual é adicionada etanol (LIEBER; DE CARLI, 1982). Este modelo foi modificado por Bykov e colaboradores (2006) pela adição 
de ágar à composição da dieta. A adição de ágar confere à ração consistência semi-sólida, facilitando o manuseio, administração e controle de consumo. Portanto, resolvemos empregar uma fórmula semelhante à usada por Bykov e colaboradores (2006) (Tabela 4, 5 e 6), a qual foi encomendada à empresa Rhoster (Rhoster Indústria e Comércio LTDA, Araçoiaba da Serra, S.P., Brasil)

Tabela 4 - Composição da dieta hiperlipídica adaptada de "Lieber-DeCarli Rat Ethanol Diet Regular”.

\begin{tabular}{|cc}
\hline Ingredientes & gramas/litro de dieta \\
\hline Caseína & 41,4 \\
L-Cistina & 0,5 \\
DL-Metionina & 0,3 \\
Óleo de milho & 8,5 \\
Azeite de oliva & 28,4 \\
Óleo de Açafrão & 2,7 \\
Maltose Dextrina & 25,6 \\
Celulose & 10,0 \\
Mistura de sais & 8,75 \\
Mistura de vitaminas & 2,5 \\
Colina Bitartarato & 0,53 \\
Goma Guar & 3,0 \\
\hline
\end{tabular}

Nota: Esta dieta contém $1,0 \mathrm{kcal} / \mathrm{mL}$ dos quais $35 \%$ são derivados de gorduras, $11 \%$ são derivados de carboidratos, $18 \%$ são derivados de proteínas e $36 \%$ são derivados do etanol.

Instruções: Para cada 132,18 g da dieta foram adicionados (1) etanol $(67,3 \mathrm{~mL}$ de etanol $95 \%)$ e (2) quantidade suficiente para $1 \mathrm{~L}$ de água fria e misture por duas vezes de $60 \mathrm{~s} \mathrm{em} \mathrm{batedeira.}$

Fonte: Modificado de Lieber e De Carli (1982) e Bykov et al. (2006)

As proporções dos ingredientes foram baseadas na publicação de Bykov et al. (2006). Para cada 133 g de ração foram adicionados $1000 \mathrm{~mL}$ de água. Na metade do volume final de água dissolvemos o ágar $0,5 \%(\mathrm{~g} / \mathrm{v})$, que após resfriado foi adicionado à ração. O ágar e a ração foram misturados em liquidificador por $2 \mathrm{~min}$. Na sequência completamos o volume de água restante e acrescentamos etanol, misturados também em liquidificador. Como não conseguimos a Goma Xantana, a substituímos por Goma Guar na mesma proporção especificada pela dieta original. Segundo a empresa, a qual foi encomendada esta ração não há problemas em realizar esta substituição, pois a goma possui a finalidade de espessar a textura da ração sem induzir alterações químicas e calóricas. 
Tabela 5 - Composição da mistura de sais para a dieta hiperlipídica adaptada de "LieberDeCarli Rat Ethanol Diet Regular".

\begin{tabular}{cc}
\hline Ingredientes & gramas/kilograma de dieta \\
\hline Fosfato de Cálcio, dibásico & 500,00 \\
Cloreto de Sódio & 74,00 \\
Citrato de Potássio, monoidrato & 220,00 \\
Sulfato de Potássio & 52,00 \\
Óxido de Magnésio & 24,00 \\
Sulfato de Manganês, $\mathrm{H}_{2} \mathrm{O}$ & 4,6 \\
Sulfato de Ferro, $7 \mathrm{H}_{2} \mathrm{O}$ & 4,95 \\
Carbonato de Zinco & 1,6 \\
Carbonato de Cobre & 0,3 \\
Iodeto de Potássio & 0,01 \\
Selenita de Sódio & 0,01 \\
Sulfato de Potássio Cromo & 0,55 \\
Fluoreto de Sódio & 0,06 \\
Sucrose & 117,92 \\
\hline
\end{tabular}

Fonte: Modificado de Lieber e De Carli (1982) e Bykov et al. (2006)

Tabela 6 - Composição da mistura de vitaminas da dieta hiperlipídica adaptada de "LieberDeCarli Rat Ethanol Diet Regular".

\begin{tabular}{cc}
\hline Ingredientes & gramas/kilograma de dieta \\
\hline Tiamina HCl & 0,6 \\
Riboflavina & 0,6 \\
Piridoxina HCl & 0,7 \\
Niacina & 3,0 \\
Pantotenato de Cálcio & 1,6 \\
Ácido Fólico & 0,2 \\
Biotina & 0,02 \\
Vitamina B12 (0,1\%) & 10,00 \\
Acetato de Vitamina A (500,000 IU/g) & 4,8 \\
Vitamina D3 (400,000 IU/g) & 0,4 \\
Acetato de Vitamina E (500 IU/g) & 24,0 \\
Menadiona de Sódio Bissulfato & 0,08 \\
Ácido Amino Benzóico & 5,0 \\
Inositol & 10,00 \\
Dextrose & 939,0 \\
\hline
\end{tabular}

Fonte: Modificado de Lieber e De Carli (1982) e Bykov et al. (2006)

Segundo as especificações da análise laboratorial LabTron (APÊNDICE B), a dieta contém $32 \%$ de gordura, $27 \%$ de proteína bruta, $37 \%$ de carboidratos e $4 \%$ de umidade. 
Tabela 7 - Número de camundongos utilizados por experimento durante a padronização do tempo de tratamento com as diferentes dietas para os modelos de DHA.

\begin{tabular}{|c|c|c|c|c|c|c|}
\hline \multirow[b]{3}{*}{ Tratamento } & \multicolumn{6}{|c|}{ Duração do tratamento } \\
\hline & \multicolumn{2}{|c|}{6 semanas } & \multicolumn{2}{|c|}{8 semanas } & \multicolumn{2}{|c|}{10 semanas } \\
\hline & C57Bl/6 (n) & $\mathbf{A} / \mathbf{J}(\mathbf{n})$ & C57Bl/6 (n) & $\mathbf{A} / \mathbf{J}(\mathbf{n})$ & C57Bl/6 (n) & $\mathbf{A} / \mathbf{J}(\mathbf{n})$ \\
\hline $\mathrm{DH}$ & 6 & 6 & 7 & 7 & 6 & 6 \\
\hline $\mathrm{DH}+\mathrm{M}$ & 6 & 5 & 7 & 8 & 6 & 5 \\
\hline $\mathrm{DH}+\mathrm{E}$ & 5 & 6 & 8 & 8 & 7 & 6 \\
\hline
\end{tabular}

Abreviaturas: DH: Dieta hiperlipídica; DH+M: Dieta hiperlipídica contendo maltodextrina; DH+E: Dieta hiperlipídica contendo etanol.

Além dos grupos tratados com etanol (DH+E), trabalhamos também com os grupos maltodextrina ( $\mathrm{DH}+\mathrm{M}$, considerado como grupo controle equicalórico) e apenas dieta hiperlipídica (DH, considerado como grupo controle real), o número de animais utilizados por experimento durante a padronização do tempo da dieta encontra na Tabela 7.

Administramos a dieta aos animais, inicialmente sem etanol, ou glicose, ou maltodextrina e a cada dois dias, gradativamente, aumentamos a porcentagem de etanol (95\% Merck) a partir de 2\% até atingir 5,3\%. Empregamos o equivalente calórico em maltodextrina (77,1 g / L). Consideramos para os cálculos de equivalência calórica: 7 kcal / g para etanol e 4 $\mathrm{kcal} / \mathrm{g}$ para maltodextrina. Mantivemos dois a três animais por gaiola para melhor monitorar o consumo da ração, a qual foi pesada diariamente. Todas as gaiolas receberam dois tubos de ração nova por dia. Cada tubo era pesado antes de ser colocado nas gaiolas e retirado no dia seguinte. Desta maneira controlamos o consumo da ração diariamente. Enriquecemos o ambiente dos camundongos com pequenas caixas e rolos de papelão para estimular o desgaste dentário dos animais, uma vez que a ração é semi-sólida e não confere muita resistência (Figura 2).

Após estabelecer o período de 10 semanas como tempo ótimo de tratamento, tratamos os camundongos C57B1/6 e os congênicos C57B1/6 C5 deficientes com as diferentes dietas hiperlipídicas. O número de animais utilizados por experimento encontra-se na Tabela 8. 
Figura 2 - Controle e administração das diferentes dietas hiperlipídicas empregando tubo Falcon 50mL.
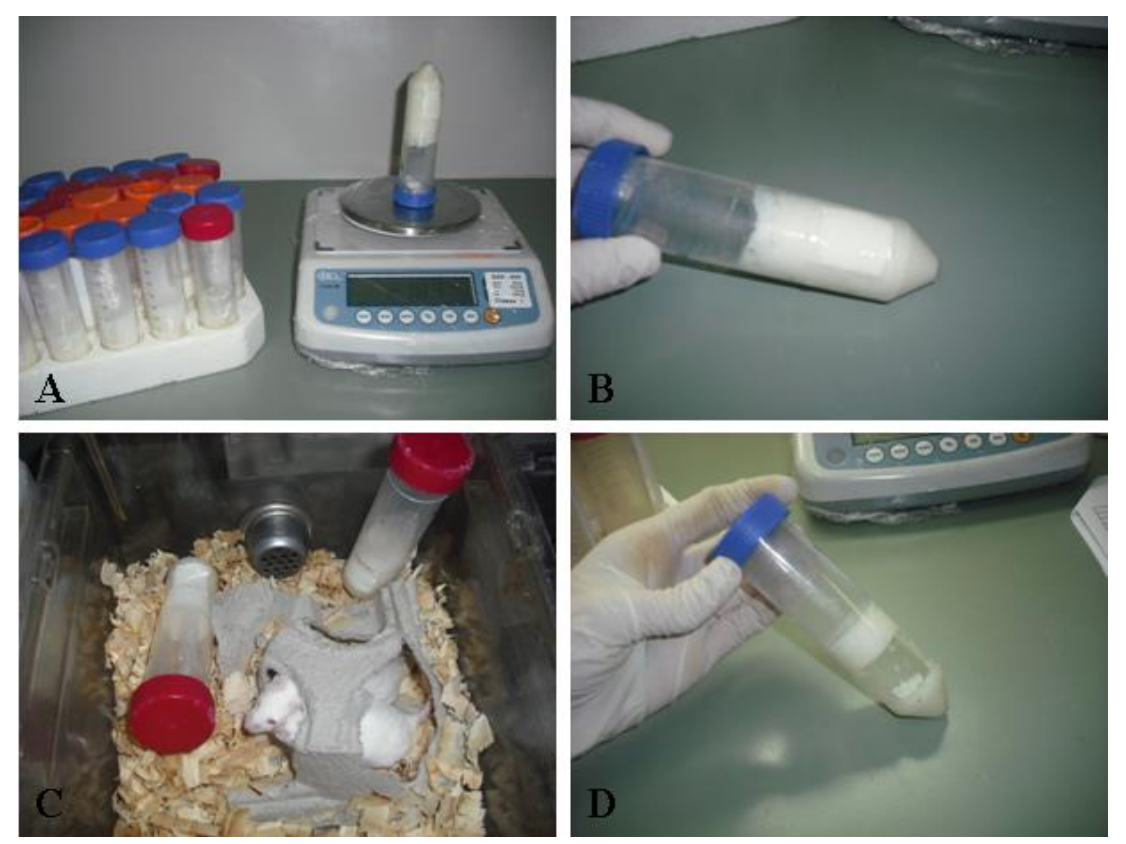

Controle do consumo das diferentes dietas hiperlipídicas pelos camundongos em (A) representamos a pesagem dos tubos, em (B) tubo contendo a dieta pré-consumo, em (C) enriquecimento ambiental e disposição dos tubos e em (D) tubo após-consumo.

Tabela 8 - Número de camundongos C57B1/6 e C57B1/6 C5 deficientes utilizados durante 10 semanas de tratamento com as diferentes dietas hiperlipídicas.

\begin{tabular}{ccc}
\hline & \multicolumn{2}{c}{ Linhagem } \\
\cline { 2 - 3 } Tratamento & C57B1/6 (n) & C57B1/6 C5 deficiente (n) \\
\hline DH & 6 & 8 \\
DH+M & 8 & 9 \\
DH+E & 7 & 11 \\
\hline
\end{tabular}

Abreviaturas: $\quad$ DH: Dieta hiperlipídica; DH+M: Dieta hiperlipídica contendo maltodextrina; DH+E: Dieta hiperlipídica contendo etanol.

\subsection{Contagem de leucócitos totais}

O sangue foi coletado pelo plexo ocular com capilar heparinizado após os animais serem anestesiados com ketamina $(125 \mathrm{mg} / \mathrm{kg})$ e xilazina $(12,5 \mathrm{mg} / \mathrm{kg})$. Cada microtubo que recebeu o sangue continha $20 \mu \mathrm{L}$ de EDTA $10 \%$ pH 8 para evitar a coagulação, pois apenas a heparina presente no capilar não foi suficiente para impedir a coagulação. O plasma 
foi obtido após centrifugação em $5000 \mathrm{~g}$ por $15 \mathrm{~min}$, a $4{ }^{\circ} \mathrm{C}$, aliquotado e estocado em congelador $-80{ }^{\circ} \mathrm{C}$ até análise. O número total de leucócitos foi obtido empregando-se câmara de Neubauer, utilizando o líquido de Türk (4,76 mM ácido acético, 6,25 $\mu \mathrm{M}$ azul de metileno) que lisa apenas as hemáceas e mantém as células nucleadas íntegras.

\subsection{Ensaios bioquímicos}

No modelo de administração de etanol por gavagem dosamos alanina aminotransferase (ALT), aspartato aminotransferase (AST) e gama glutamiltransferase (GGT). Na etapa de padronização dos modelos de DHA empregamos apenas a avaliação da ALT. Nos experimentos seguintes avaliamos também a concentração sérica dos seguintes parâmetros: AST, fosfatase alcalina, glicose, albumina, colesterol e triglicerídeos. Os animais tiveram os parâmetros acima avaliados após jejum de $12 \mathrm{~h}$. Considerando que os kits comerciais empregados eram para material humano, os protocolos foram adaptados para volumes menores (Biocontrol N ref K073, Bioclin Quibasa, Química Básica Ltda. Belo Horizonte, M.G., Brasil e Calibra H ref. K080, Labtest Diagnóstica S.A., Lagoa Santa, M.G., Brasil).

\subsubsection{Determinação dos parâmetros clínicos associados com a investigação de lesão hepatocelular, função de síntese hepática e lesão de vias e fluxo biliar}

\subsubsection{Determinação da atividade das enzimas ALT, AST e GGT}

Como parâmetro clínico de avaliação de lesão hepatocelular determinamos a concentração em U / L de ALT sérica/plasmática utilizamos o kit comercial ALT Bioclin ref. K035 (Bioclin Quibasa). O volume de soro/plasma empregado foi 12,5 $\mu \mathrm{L}$. Também como parâmetro clínico de avaliação de lesão hepatocelular determinamos a concentração em U / L de AST sérica/plasmática utilizamos o kit comercial AST Bioclin ref. K034 (Bioclin Quibasa). O volume de soro/plasma empregado foi $25 \mu \mathrm{L}$. Complementando estes parâmetros determinamos a concentração em U / L de GGT sérica utilizando o kit comercial GGT Bioclin ref. K080 (Bioclin Quibasa). O volume de soro empregado foi $25 \mu \mathrm{L}$.

\subsubsection{Determinação da concentração de albumina}


Determinamos a concentração sérica em g / dL de albumina para avaliação da função de síntese hepática. Empregamos o kit comercial Albumina Bioclin ref. K040 (Bioclin Quibasa). O volume de soro empregado foi $10 \mu \mathrm{L}$.

\subsubsection{Determinação da enzima fosfatase alcalina}

Como parâmetro clínico de avaliação da lesão das vias e fluxo biliar determinamos a concentração sérica de fosfatase alcalina em U / L. Empregamos o kit comercial Fosfatase Alcalina Bioclin ref. K019 (Bioclin Quibasa). O volume de soro empregado foi $10 \mu \mathrm{L}$.

\subsubsection{Determinação de parâmetros clínicos gerais}

Avaliamos também alguns parâmetros que podem estar alterados em pacientes com Doença Hepática Alcoólica e Doença Hepática Não Alcoólica, como: glicose, colesterol e triglicerídeos séricos.

\subsubsection{Determinação da concentração de glicose e colesterol total}

Determinamos a concentração sérica de glicose (em mg / dL) e colesterol (em mg / dL) empregando os kits comerciais Bioclin ref. K082 e Bioclin ref. K083 (Bioclin Quibasa), respectivamente. $\mathrm{O}$ volume de soro empregado foi $10 \mu \mathrm{L}$.

\subsubsection{Determinação da concentração de triglicerídeos}

Determinamos a concentração séria de triglicerídeos (em mg / dL) empregando o kit comercial Triglicérides Liquiform ref. K087 (Labtest Diagnóstica). O volume de soro empregado foi $10 \mu \mathrm{L}$.

\subsection{Homogenização hepática}

Após o sacrifício dos animais, um dos lóbulos hepáticos foi fixado em formalina e os demais lóbulos foram imediatamente congelados em nitrogênio líquido. Para a homogenização o tecido foi descongelado e pesado para então ser adicionado o volume adequado de tampão de lise: $50 \mathrm{mM}$ Tris- $\mathrm{HCl} \mathrm{pH} 7,4,1 \% \mathrm{NP}-40,0,25 \% \mathrm{C}_{24} \mathrm{H}_{39} \mathrm{NaO}_{4}, 150$ 
$\mathrm{mM} \mathrm{NaCl}, 1 \mathrm{mM}$ EDTA, cocktail inhibitor Complete Roche (Roche, Indianápolis, Indiana, Estados Unidos), 17,5 $\mu \mathrm{g} / \mathrm{mL}$ aprotinina, $5 \mu \mathrm{g} / \mathrm{mL}$ bestatina, $10 \mu \mathrm{g} / \mathrm{mL}$ leupeptina, $20 \mu \mathrm{g}$ / mL E-64, $1 \mathrm{mM} \mathrm{Na}_{3} \mathrm{VO}_{4}, 10 \mathrm{mM} \mathrm{Na} \mathrm{P}_{2} \mathrm{O}_{7}$. Empregamos 0,5 $\mathrm{mL}$ de tampão de lise para cada $0,1 \mathrm{~g}$ de tecido e homogenizamos com o auxílio de um potter de vidro.

\subsection{Determinação da concentração de proteínas totais no homogenato de fígado}

As amostras de homogenato de fígado foram diluídas 500 vezes para a determinação da concentração de proteínas totais e empregamos o reagente Bio-Rad Protein Assay Dye Reagent Concentrate (Bio-Rad S.A., Hercules, Califórnia, Estados Unidos), segundo as especificações do fabricante. Utilizamos 5 diluições da albumina de soro bovino como padrão dentro do intervalo de detecção $0,05 \mathrm{mg} / \mathrm{mL}$ a $0,5 \mathrm{mg} / \mathrm{mL}$, sugerido pelo fabricante. A leitura da absorbância foi realizada no espectrofotômetro Molecular Devices SpectraMax 190 (Estados Unidos) no comprimento de $595 \mathrm{~nm}$.

\subsection{ELISA em homogenato de fígado}

Empregamos kits comerciais da empresa BD para determinar a concentração das citocinas TNF- $\alpha$ (ELISA set para TNF- $\alpha$ de camundongo, BD OptEIA, Franklin Lakes, New Jersey, Estados Unidos), IL-1ß (ELISA set para IL-1ß de camundongo, BD OptEIA), IL-6 (ELISA set para IL-6 de camundongo, BD OptEIA), IL-10 (ELISA set para IL-10 de camundongo, BD OptEIA), IL-12p(40) (ELISA set para IL-12p(40) de camundongo, BD OptEIA), IL-12p(70) (ELISA set para IL-12p(70) de camundongo, BD OptEIA), INF- $\gamma$ (ELISA set para INF- $\gamma$ de camundongo, BD OptEIA), IL-17 (ELISA para IL-17A de camundongo, eBioscience, San Diego, Califórnia, Estados Unidos) e TGF- $\beta$ (ELISA para TGF- $\beta 1$ de humano e camundongo 2a. Geração, eBioscience) no homogenato de fígado. Para a determinação da concentração das citocinas plasmáticas utilizamos plasma puro e descongelado apenas no momento de uso. Entretanto, para a determinação das citocinas no tecido utilizamos três diluições a partir do homogenato, diluímos 1:50, 1:100 e 1:500. E para cada uma das diluições determinamos a concentração de proteínas totais. Desta forma normalizamos a quantidade de citocinas encontrada pela concentração de proteínas totais. A diluição escolhida foi 1:500. Apresentamos concentrações das citocinas plasmáticas em pg / $\mathrm{mL}$ e das citocinas hepáticas em pg / mg de proteína. 


\subsection{Dosagem de NO em homogenato de fígado}

Em uma placa de 96 poços utilizamos $100 \mu \mathrm{L}$ de homogenato de fígado puro para determinar indiretamente a quantidade de NO. A cada $100 \mu \mathrm{L}$ de homogenato foram adicionados $100 \mu \mathrm{L}$ de reagente de Griess: $44 \mu \mathrm{M} \mathrm{H}_{3} \mathrm{PO}_{2}, 58 \mathrm{mM}$ sulfanilamida $\left(\mathrm{C}_{6} \mathrm{H}_{8} \mathrm{~N}_{2} \mathrm{O}_{2} \mathrm{~S}\right)$, 0,38 mM N-1- naftilenodiamina dicloridrato $\left(\mathrm{C}_{10} \mathrm{H}_{7} \mathrm{NHCH}_{2} \mathrm{CH}_{2} \mathrm{NH}_{2} \cdot 2 \mathrm{HCl}\right)$. Pelo fato de cada amostra ter uma absorbância específica, incluímos um "branco" por amostra, para o qual empregamos $100 \mu \mathrm{L}$ de homogenato e $100 \mu \mathrm{L}$ de PBS 1x. Como "branco" da curva padrão utilizamos $100 \mu \mathrm{L}$ de tampão de lise e mesmo volume de reagente de Griess. Como curva padrão empregamos diferentes concentrações de $\mathrm{NaNO}_{2}(10,20,30$, 50 e $100 \mu \mathrm{M})$, volume final $200 \mu \mathrm{L}$. A placa foi protegida da luz e incubada por 10 min à temperatura ambiente, a absorbância foi lida em $540 \mathrm{~nm}$. Os resultados foram normalizados em relação à quantidade de proteína totais.

\subsection{Extração de Lipídeos Hepáticos}

A partir do macerado de fígado, descrito no item 6 , misturamos $0,5 \mathrm{~mL}$ deste para 0,5 $\mathrm{mL}$ da solução 1:1 de clorofórmio / metanol. Agitamos em vórtex por aproximadamente 10s e centrifugamos a $8000 \mathrm{~g}$ por $5 \mathrm{~min}$, à temperatura ambiente. Três fases (superior: fase aquosa, intermediária: resíduos insolúveis, inferior: fase orgânica) puderam ser observadas. Recolhemos a fase orgânica, lavando-a com 0,25 mL de $\mathrm{NaCl} 150 \mathrm{mM}$. Centrifugamos novamente a preparação, e coletamos a fase orgânica. A fase orgânica foi secada em estufa 37 ${ }^{\circ} \mathrm{C}$ por 16-18 h. Dissolvemos o extrato seco em $100 \mu \mathrm{L}$ da solução 1:28 de hidróxido de tetraetil-amônio / $95 \%$ etanol $60^{\circ} \mathrm{C}$ por $30 \mathrm{~min}$. Com a amostra ainda quente procedemos com a hidrólise ácida, adicionando $100 \mu \mathrm{L}$ de $\mathrm{HCl} 50 \mathrm{mM}$. O extrato foi armazenado em congelador $-80{ }^{\circ} \mathrm{C}$ até análise.

\subsection{Determinação da concentração de triglicerídeos e colesterol hepáticos}

Empregamos o mesmo kit comercial para a análise direta de triglicerídeos plasmáticos, Triglicérides Liquiform ref. K087 (Labtest Diagnóstica), para a dosagem do extrato de lipídeos hepáticos convertendo o valor de $\mathrm{mg} / \mathrm{dL}$ para $\mathrm{mg} / \mathrm{g}$ de fígado utilizado no macerado. Da mesma forma, empregamos o mesmo kit comercial utilizado para a determinação de colesterol sérico Bioclin ref. K083 (Bioclin Quibasa), empregamos $10 \mu \mathrm{L}$ 
para as cada dosagem, entretanto convertemos o valor obtido de $\mathrm{mg} / \mathrm{dL}$ pelo peso total em gramas de fígado utilizado para produzir o homogenato. Os dados foram apresentados nos gráficos como mg de triglicerídeos ou colesterol / grama de fígado.

\subsection{Avaliação histopatológica}

Imediatamente após a eutanásia dos animais, fragmentos do tecido hepático foram fixados em formol tamponado $(\mathrm{pH} \mathrm{7,2} \mathrm{-} \mathrm{7,4)} \mathrm{durante} 24 \mathrm{~h}$ e, posteriormente, processados e incluídos em parafina segundo os procedimentos padrões estabelecidos pelo Laboratório de Histologia do Departamento de Imunologia da USP. Cortes histológicos de $5 \mu \mathrm{m}$ foram corados em hematoxilina-eosina (HE) para avaliação histopatológica, por ácido-periódico Schiff (PAS) para avaliação do depósito de glicogênio, e por picrossírius para a evidenciação das fibras colágenas e estadiamento da fibrose.

Para análises histopatológicas nos modelos de injúria hepática aguda induzida por etanol e durante a padronização do modelo de injúria hepática crônica induzida por etanol contamos com o auxílio do Prof. Dr. Paulo César Maiorka, da Faculdade de Medicina Veterinária e Zootecnia da USP, Departamento de Patologia.

Já as análises histopatológicas referentes à aplicação da linhagem congênica C57Bl/6 C5 deficiente no modelo de DHA foram realizadas em colaboração com o grupo do Prof. Dr. Venâncio Avancini Ferreira Alves, da Faculdade de Medicina USP, Departamento de Patologia Hepática. Os cortes histopatológicos foram investigados às cegas por dois patologistas do grupo do Dr. Venâncio.

As lesões hepáticas foram graduadas de acordo com os critérios estabelecidos por Kleiner et al. (2005), com pequenas modificações, gerando o índice de atividade da DHA. Este índice inclui apenas características da lesão ativa, sendo definido pela soma dos graus de esteatose macro/microgoticular (0 a 3), inflamação lobular (0 a 3) e balonização (0 a 2). Dessa maneira, os valores do índice (DHA) variam entre 0 e 8 , sendo que DHA $\geq 5$ correlaciona-se com o diagnóstico de Esteatohepatite Alcoólica (EHA), enquanto DHA $<3$ não é considerado EHA. Por outro lado, animais com DNA entre 3 ou 4 podem ser considerados como prováveis portadores da EHA. O estadiamento ou "grau" da fibrose na esteatohepatite não alcoólica foi analisado nas lâminas coradas pelo picrossírius (0 a 4) e não faz parte do índice DHA. Nas Tabelas 9 e 10 estão descritos os critérios adotados para cada classificação e seus respectivos escores. Para o modelo da DHNA (apresentado APÊNDICE A) utilizamos o mesmo índice aplicado para o modelo da DHA. 
Tabela 9 - Critérios histopatológicos do índice de atividade da Doença Hepática Alcoólica.

\begin{tabular}{cc}
\hline Critérios histopatológicos & Classificação \\
\hline Balonização & Escore \\
Ausente & 0 \\
Poucas células balonizadas & 1 \\
Muitas células balonizadas & 2 \\
Esteatose Macro/Microgoticular & Escore \\
$<5 \%$ & 0 \\
$5-33 \%$ & 1 \\
$33-66 \%$ & 2 \\
$>66 \%$ & 3 \\
Inflamação Lobular & Escore \\
Ausência de focos & 0 \\
$<2$ focos por campo $(200 x)$ & 1 \\
$2-4$ focos por campo $(200 x)$ & 2 \\
$>4$ focos por campo $(200 x)$ & 3 \\
\hline
\end{tabular}

Fonte: Modificado de Kleiner et al. (2005)

Tabela 10 - Critérios histopatológicos para avaliação do estadiamento da fibrose hepática na esteatohepatite alcoólica.

\begin{tabular}{lc}
\hline Fibrose & Escore \\
\hline Ausente & 0 \\
Perissinusoidal ou periportal & 1 \\
\multicolumn{1}{c}{ Leve, zona 3, perissinusoidal } & $1 \mathrm{a}$ \\
\multicolumn{1}{r}{ Moderada, zona 3, perissinusoidal } & $1 \mathrm{~b}$ \\
$\quad$ Portal / Periportal & $1 \mathrm{c}$ \\
Perissinusoidal e Portal/Periportal & 2 \\
Fibrose em ponte & 3 \\
Cirrose & 4 \\
\hline
\end{tabular}

Fonte: Modificado de Kleiner et al. (2005)

\subsection{Análise estatística}

Para análise do tratamento agudo do etanol aplicamos o teste estatístico nãoparamétrico Mann-Whitney em cada linhagem para os dois tratamentos, comparando-os entre si. Apresentamos nossos dados em todos os gráficos como média e erro padrão. As diferenças significativas, quando presentes, foram representadas nas tabelas e nos gráficos. O nível de significância adotado foi $5 \%$.

Para os modelos crônicos de DHA analisamos estatisticamente o ganho de peso final, parâmetros bioquímicos e inflamatórios e para os critérios histopatológicos da porcentagem 
de esteatose e índice de atividade da DHA empregamos a análise paramétrica: análise de variância (ANOVA) com dois fatores, seguida por comparações múltiplas pelo método de Tukey. Apresentaremos nossos dados em todos os gráficos como média e erro padrão. O nível de significância adotado foi $5 \%$. As diferenças significativas, quando presentes, foram descritas no texto e representadas nos gráficos.

Para o ganho de peso acumulado semanalmente aplicamos a análise paramétrica: ANOVA com três fatores sendo medidas repetidas no fator semana, seguida por comparações múltiplas pelo método de Bonferroni. Apresentamos nos gráficos apenas as diferenças encontradas entre os tratamentos. As diferenças de ganho de peso encontradas entre as semanas foram descritas no texto. O nível de significância adotado foi $5 \%$.

Já os critérios histopatológicos como balonização, esteatose, inflamação lobular e fibrose foram analisados empregando-se o modelo Log-Linear. 


\section{CAPÍtUlo 1 - DESENVOLVIMENTO, SELEÇÃo E VALIDAÇÃo DAS LINHAGENS CONGÊNICAS}

\subsection{Introdução}

As linhagens isogênicas de camundongos C57Bl/6 (B6) e A/J são amplamente empregadas em estudos científicos, pois representam comportamentos distintos frente a diversos tipos de tratamentos e condições, tais como: alimentação (BURRAGE et al., 2007; FRAULOB et al., 2010; GALLOU-KABANI et al., 2007; KONDO et al., 2006), infecção (MULLICK et al., 2004; PATEL et al., 2008), metabolismo de drogas (GILL; BOYLE, 2008), fisiologia e comportamento (ALAISH, et al., 2005; KAYE; KUSY, 1995; POZZULO; SKAMENE; GERVAIS, 1993; RUSSEL; MEIER, 1966), entre outros. Nesta linha, um estudo genealógico de 102 linhagens diferentes mostrou que, dentro da árvore filogenética, as linhagens B6 e A/J são relativamente distantes entre si, portanto são classificadas e inseridas em grupos de origem filogenética distinta (PETKOV et al., 2004).

A linhagem isogênica B6 é empregada nos mais diversos modelos experimentais. Por ser uma linhagem muito estudada, de boa reprodutibilidade, ter a maior parte do seu genoma seqüenciado e ser usada como fundo genético para o desenvolvimento de inúmeros camundongos transgênicos, foi escolhida para ser a linhagem receptora do segmento gênico no qual está o gene $c 5$ deficiente proveniente da linhagem A/J. Quanto à proteína C5 do sistema complemento a linhagem B6 é considerada suficiente, mas existe uma variação na concentração plasmática desta proteína em relação ao sexo, classificada como dimorfismo sexual. Plasmas de machos e fêmeas da linhagem B6 quando submetidos à eletroforese apresentam padrões diferentes, sendo que fêmeas possuem apenas uma banda enquanto machos possuem duas bandas de C5. E quando fêmeas são tratadas com testosterona há o aparecimento de outra banda, a mesma observada nos machos, na corrida eletroforética (BABA; FUJITA; TAMURA, 1984).

A linhagem isogênica $\mathrm{A} / \mathrm{J}$ é espontaneamente C5 deficiente, pois possui uma deleção de 2 pb (TA), próxima à extremidade 5' do éxon 7 do gene $c 5$ (HAVILAND et al., 1991; WETSEL; FLEISCHER; HAVILAND, 1990), localizado no cromossomo 2 em camundongos (D’EUSTACHIO et al., 1986). A ausência destes 2 nucleotídeos gera um códon de parada prematura (UAG), localizado a 4 bases do local da deleção. 


\subsection{Estudos anteriores que já empregaram as linhagens congênicas B6 (C5 deficiente) e A/J (C5 normal)}

O desenvolvimento de linhagens congênicas entre B6 e A/J tem sido explorado sob os mais diversos aspectos biológicos, desde processos infecciosos (GERVAIS; DESFORGES; SKAMENE, 1989), composição celular da medula óssea (POZZULO; SKAMENE; GERVAIS, 1993) e atividades psico-motoras induzidas por drogas (GILL; BOYLE, 2008). Pacientes deficientes do componente C5 do sistema complemento exibem predisposição para severas infecções recorrentes especialmente por bactérias do gênero Neisseria, como meningite e gonorréia extragenital (WETSEL, 2000). Portanto, sendo a proteína C5 de crucial importância na resolução e proteção contra infecções, modelos animais de susceptibilidade às infecções empregando camundongos congênicos têm auxiliado na compreensão do papel da proteína C5 em contextos infecciosos.

Empregando a linhagem congênica A/J C5 suficiente, gerada a partir do cruzamento entre camundongos A/J e B6, em modelo de infecção por Listeria monocytogenes observouse que estes congênicos desenvolveram resistência à infecção e melhora na resposta inflamatória por macrófagos, quando comparados aos camundongos A/J naturalmente C5 deficientes (GERVAIS; DESFORGES; SKAMENE, 1989). Da mesma forma, camundongos da linhagem A/J são mais sensíveis e camundongos da linhagem B6 são relativamente resistentes à infecção por Candida albicans. No entanto, quando o gene $c 5$ deficiente é inserido em camundongos da linhagem B6, estes se tornam susceptíveis à infecção (MULLICK et al., 2004). Em modelo murino de malária cerebral (MC) por Plasmodium berghei todas as linhagens de camundongos C5 deficientes são resistentes e não desenvolvem MC. A transferência do gene $c 5$ deficiente para o fundo genético B6 confere resistência à MC aos camundongos infectados, já os camundongos $\mathrm{A} / \mathrm{J}$ que são resistentes à $\mathrm{MC}$ quando recebem o gene de $c 5$ normal passam a ser susceptíveis à infecção (PATEL et al., 2008). Estes estudos mostram a importância da proteína C5 seja na resolução ou promoção de processos infecciosos por bactérias, fungos ou protozoários, independentemente do fundo genético no qual ela esteja inserida.

Em condições de inflamação estéril a linhagem B6 responde com a migração de grande número de macrófagos para o peritôneo à aplicação intra-peritonial de tioglicolato, enquanto a linhagem A/J responde fracamente. Além disso, a linhagem A/J possui baixa celularidade na medula óssea, o que também contribui para a baixa inflamação peritonial após o estímulo por tioglicolato. Uma vez que, o gene $c 5$ normal é transferido para a linhagem $\mathrm{A} / \mathrm{J}$, 
a linhagem congênica A/J C5 normal passou a ter melhor resposta inflamatória e aumentou o número de células nucleadas na medula óssea e sua liberação para o sítio de inflamação (POZZULO; SKAMENE; GERVAIS, 1993). Ou seja, a presença de C5 também contribui para a celularidade da medula óssea.

\subsection{Etapas do desenvolvimento de linhagens congênicas por retrocruzamento}

Embora a construção de linhagens congênicas seja longa e trabalhosa, ela é possível. Para descrever as etapas de desenvolvimento das linhagens congênicas que serão aqui abordadas precisamos antes introduzir alguns termos. A primeira etapa no desenvolvimento de uma linhagem congênica é o cruzamento entre as duas linhagens isogênicas parentais $(\mathrm{P})$ B6 e A/J, consideradas não relacionadas entre si e que dará origem a uma geração denominada F1. O animal doador não precisa ser homozigoto para o locus de interesse, mas o receptor precisa. Na sequência há o cruzamento entre um animal da F1 (heterozigoto) e outro que será a linhagem receptora do alelo (Figura 3). Este cruzamento entre um animal F1 e um parental é chamado retrocruzamento (ou backcross). Os animais nascidos deste cruzamento darão origem à geração N2. Nesta geração, somente os animais que receberam o alelo doado (os heterozigotos) são selecionados para a próxima etapa de retrocruzamento. Estes retrocruzamentos foram repetidos por 10 gerações (N10) (SILVER, 1995).

A segunda etapa no desenvolvimento de uma linhagem congênica ocorre após a obtenção da geração N10, onde os irmãos heterozigotos são cruzados entre si, gerando filhotes homozigotos e heterozigotos para o gene de interesse (o qual segue a proporção da $1^{\text {a }}$ Lei Mendeliana 1:2:1). No nosso caso escolhemos os camundongos homozigotos B6 C5 deficientes e os camundongos homozigotos A/J C5 suficientes. Em termos matemáticos, depois de 10 gerações de retrocruzamentos a linhagem congênica apresentará aproximadamente 99,8\% de identidade com a linhagem receptora (SILVER, 1995). Ou seja, o segmento diferencial que contém o alelo representará a maior contribuição do genoma doador, encerrando o cruzamento.

Todas as etapas de retrocruzamento foram desenvolvidas sob auxílio da $\operatorname{Dr}^{\mathrm{a}}$ Silvia Maria Gomes Massironi, geneticista responsável pelo Biotério de Experimentação do Departamento de Imunologia do ICB - USP. Durante todo o processo, desde a N2 até a N10, os camundongos heterozigotos foram selecionados após sequenciamento de nucleotídeos da região do éxon 7 próxima da extremidade 5 ' do gene de $c 5$, onde se encontra localizada a mutação de interesse. Os animais congênicos desenvolvidos, tanto B6 C5 deficiente quanto 
A/J C5 normal, foram avaliados por sequenciamento de nucleotídeos para identificar e confirmar a presença ou não da mutação, imunoprecipitação para identificar a presença ou ausência da proteína C5 no soro dos camundongos, atividade hemolítica da Via Alternativa do sistema complemento para analisar a funcionalidade da proteína C5 e por microssatélite para o estudo de similaridade genética entre os congênicos e as linhagens parentais (Figura 4).

Figura 3 - Representação esquemática do desenvolvimento de linhagens congênicas.

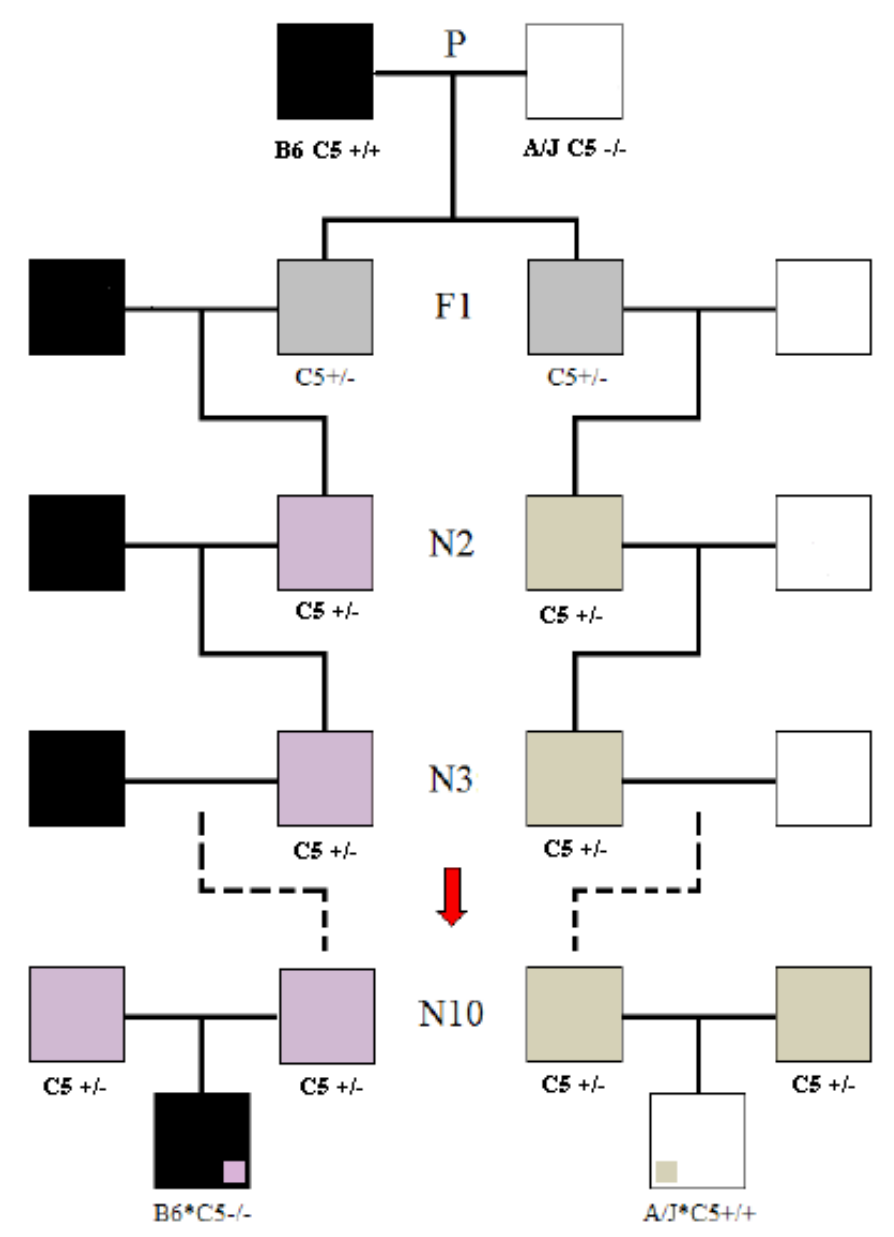

$\mathrm{P}$ refere-se aos camundongos parentais que darão origem a geração F1 que é composta integralmente por heterozigotos. A prole gerada pelo cruzamento da F1 com a linhagem B6 e pelo cruzamento da F1 com a linhagem A/J dará início à geração N2, a qual é avaliada quanto à presença de heterozigotos. Estes são selecionados para cruzar com camundongos B6 ou A/J, e sua prole dará origem à geração N3. Este processo ocorre até a geração N10, quando então os irmãos heterozigotos pré-selecionados são cruzados entre si e então dará origem a prole que irá conter os congênicos homozigotos para o gene em questão. Evidentemente, todas essas etapas ocorrem em paralelo entre as linhagens B6 e A/J, sendo que cada uma possui a sua própria geração de N2 a N10.

O desenvolvimento de uma linhagem congênica B6 C5 deficiente e uma linhagem A/J C5 normal são de importante valia na elucidação da real contribuição do fundo genético em 
condições onde a proteína C5 encontra-se ou não presente. Desta forma será possível identificar se determinadas respostas inflamatórias, que muitas vezes são divergentes entre as linhagens, são oriundas da função de C5 ou se é apenas uma sobreposição desta com o fundo genético no qual está inserida.

\subsection{Nomenclatura das linhagens congênicas}

Uma vez concluídas as etapas de desenvolvimento seguimos as orientações da "The Jackson Laboratory" (http://jaxmice.jax.org/support/nomenclature/tutorial.html) para efetuarmos a nomenclatura correta dos camundongos congênicos gerados. Segundo o Comitê Internacional de Padronização de Nomenclatura Genética para Camundongos a nomenclatura para a linhagem congênica é designada pela composição de um símbolo, o qual consiste da abreviatura do nome da linhagem receptora e da linhagem doadora separadas por um ponto (.), seguida por um hífen (-) e o símbolo em itálico do alelo diferencial introduzido a partir do doador. Portanto, os camundongos congênicos B6 C5 deficientes passarão a ser denominados de B6.A-Hc ${ }^{0}$, onde B6 é a abreviação do nome da linhagem receptora C57Bl/6, A é a abreviação do nome da linhagem doadora (A/J) e $H c^{0}$ é o nome do alelo (Hemolytic complement) onde está localizada a mutação de C5 encontrada na linhagem A/J. Da mesma forma, os camundongos congênicos A/J C5 normais passarão a ser denominados de A.B6-Hc. 
Figura 4 - Delineamento Experimental do desenvolvimento, seleção e valiação das linhagens congênicas B6.A-Hc e A.B6-Hc.

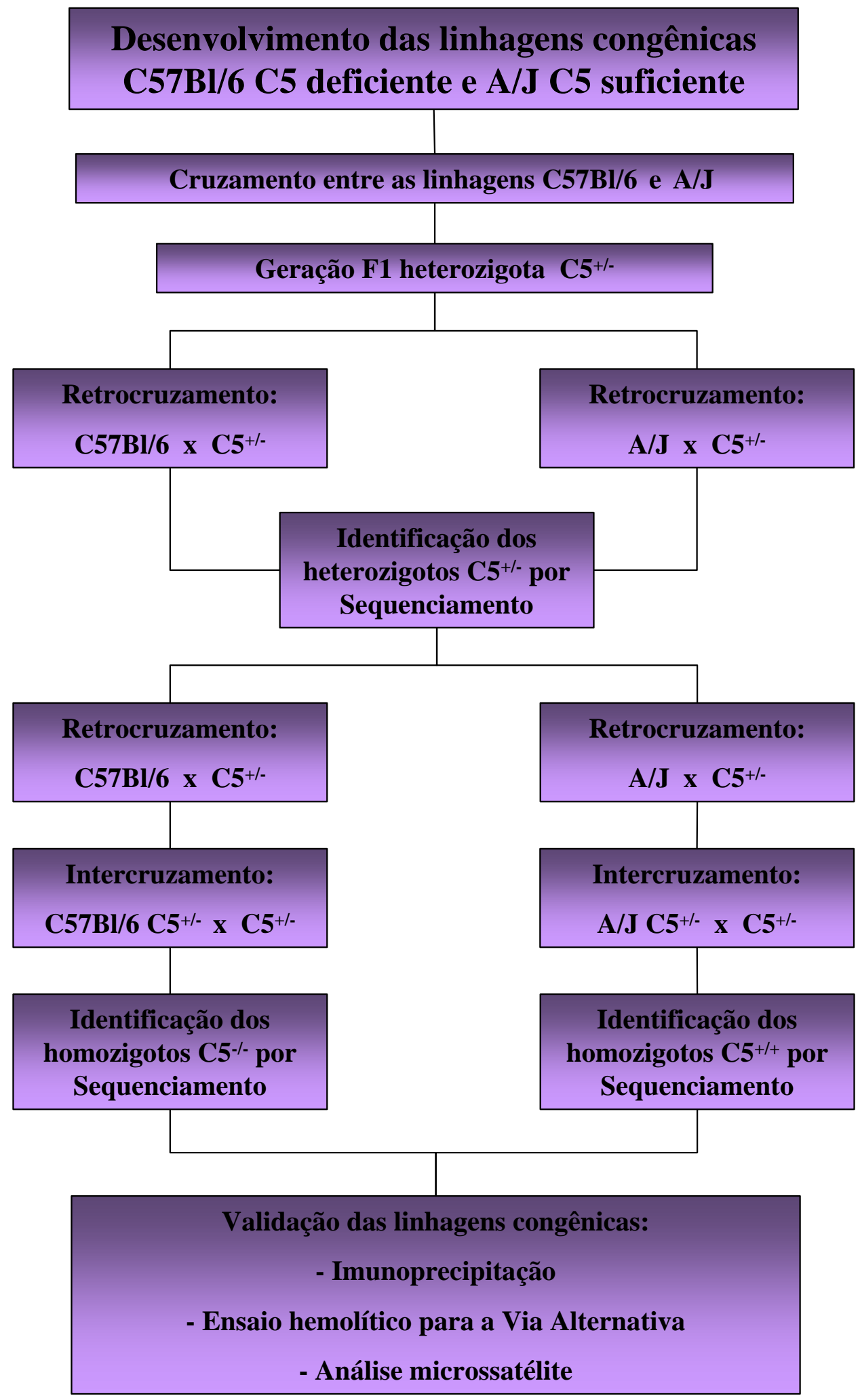




\subsection{Resultados do CAPÍtULO 1}

Amplificamos o fragmento correspondente ao segmento gênico de interesse composto por 316 pb por PCR a partir de DNA genômico extraído da cauda dos filhotes. A identificação dos animais contendo a deleção responsável pela deficiência de C5 apenas pôde ser feita após o sequenciamento dos produtos amplificados por PCR, onde identificamos os animais heterozigotos (Figura 5C) para a deleção a partir dos resultados obtidos com o sequenciamento de nucleotídeos (Figura 5).

Após a geração N10, tanto no fundo genético B6 como no fundo genético A/J, realizamos o intercruzamento, ou seja, o cruzamento entre os irmãos heterozigotos, visando obter pelo menos um casal homozigoto B6.A-Hc (B6 C5 deficiente) e um casal homozigoto A.B6-Hc (A/J C5 normal). Após a identificação destes homozigotos por sequenciamento de nucleotídeos, ambos os camundongos das linhagens congênicas desenvolvidas passaram por um processo de verificação da presença e a atividade da proteína C5 no soro, o qual incluiu imunodifusão dupla (OUTCHTERLONY, 1962) para a proteína C5 (Figura 6) e o ensaio hemolítico da via alternativa, respectivamente (Figura 7). E ainda realizamos a análise por microssatélites para confirmar se os congênicos mantiveram o fundo genético ao longo dos retrocruzamentos (Figura 8).

Por meio da imunodifusão dupla podemos detectar a presença ou ausência da proteína C5 no soro (Figura 6). Na imunodifusão dupla presente na Figura 6A foi possível observar a formação da linha de precipitação apenas na amostra de soro do camundongo B6 (C5 normal), nos demais soros de camundongos B6.A- $H c^{0}$ e A/J utilizados não observamos a formação da linha de precipitação. Já na Figura 6B observamos a presença da linha de precipitação em todos os soros A.B6-Hc e B6 (C5 normais), exceto no soro controle A/J C5 deficiente. Entretanto, com esta técnica afirmamos apenas se o camundongo avaliado é deficiente ou não para a presença da proteína C5 no soro, ou seja, é uma técnica qualitativa. Por meio da imunodifusão dupla não é possível afirmar se o camundongo que possui a formação da linha de precipitação é geneticamente heterozigoto ou homozigoto, portanto, devido a isso, todas as amostras de soro aqui apresentadas foram correlacionadas com os resultados obtidos a partir do sequenciamento de nucleotídeos, como demonstrado na Figura 5.

Com o ensaio hemolítico da via alternativa constatamos atividade hemolítica nos camundongos B6 C5 normal e A/J C5 normal. Embora a linhagem A/J C5 normal aparente maior atividade hemolítica que a linhagem B6 C5 normal não existe diferença significativa 
entre as mesmas (Figura 7). O ensaio foi realizado empregando todas as amostras ao mesmo tempo, sob as mesmas condições.

Após a confirmação funcional da proteína C5 validamos por microssatélite o fundo genético das linhagens congênicas desenvolvidas. Apresentamos aqui os resultados referentes a um marcador por cromossomo, mas ressaltamos que em colaboração com a $\operatorname{Dr}^{\mathrm{a}}$ Silvia Massironi outros marcadores estão sendo avaliados, totalizando 5 marcadores por cromossomo (Figura 8). Os tamanhos esperados para os fragmentos amplificados de cada linhagem e as condições ótimas de PCR encontram-se especificados na Tabela 3 descrita na seção MATERIAIS E MÉTODOS.

Figura 5 - Exemplos de cromatogramas obtidos a partir do sequenciamento de nucleotídeos para a identificação e seleção genotípica dos camundongos congênicos.

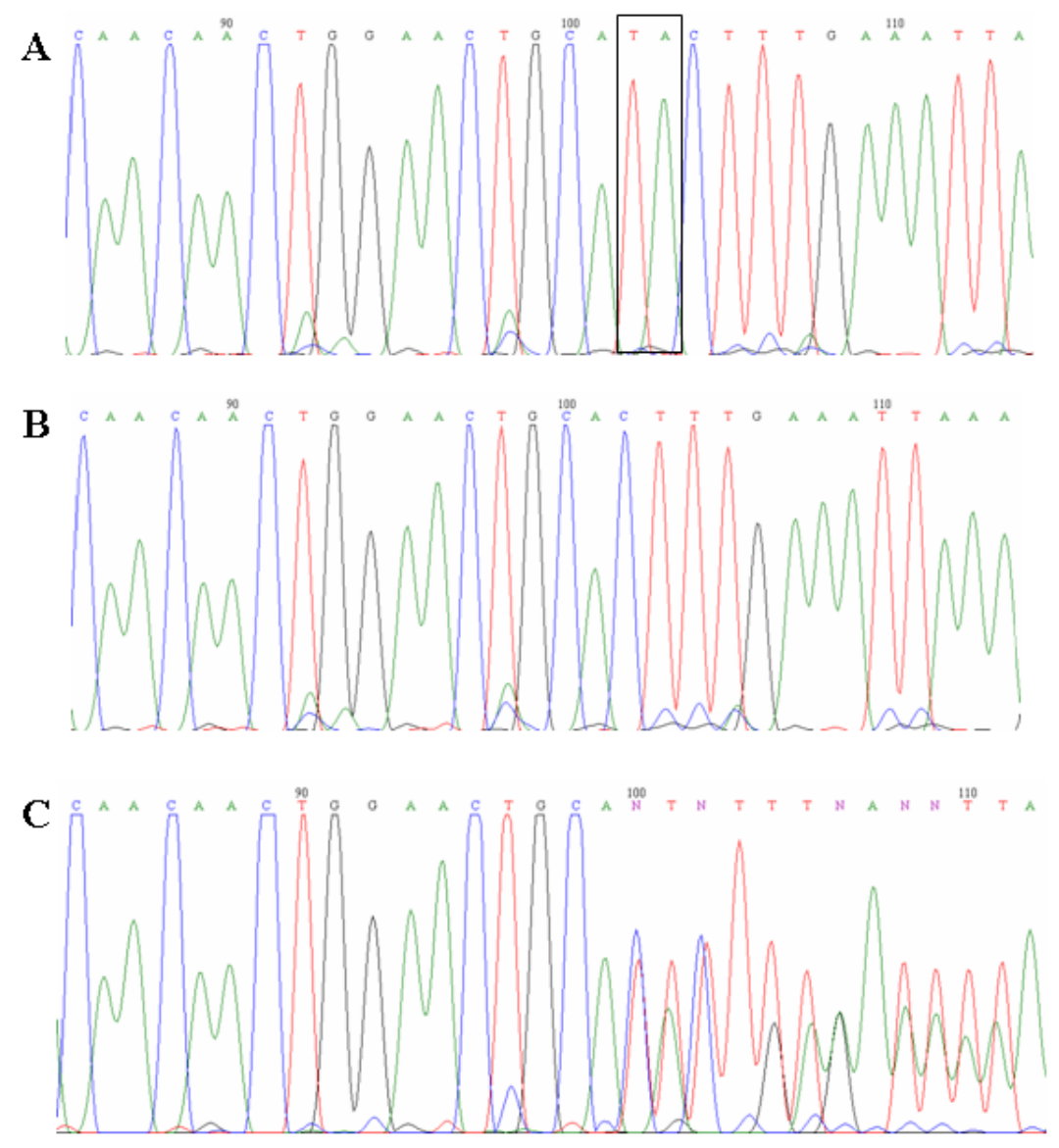

(A) Cromatograma a partir do sequenciamento de nucleotídeos de um camundongo homozigoto para o gene c5 normal, em (B) de um camundongo homozigoto para o gene $c 5$ deficiente e em (C) de um camundongo heterozigoto para o gene $c 5$. 
Figura 6 - Imunodifusão dupla dos soros de camundongos B6.A- $H c^{0}$ (B6 C5 deficientes) e A.B6-Hc (A/J C5 normal).

(A)

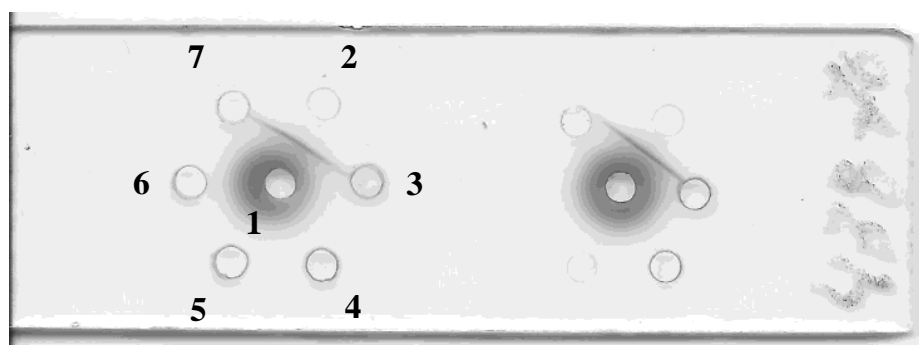

(B)

Repetição

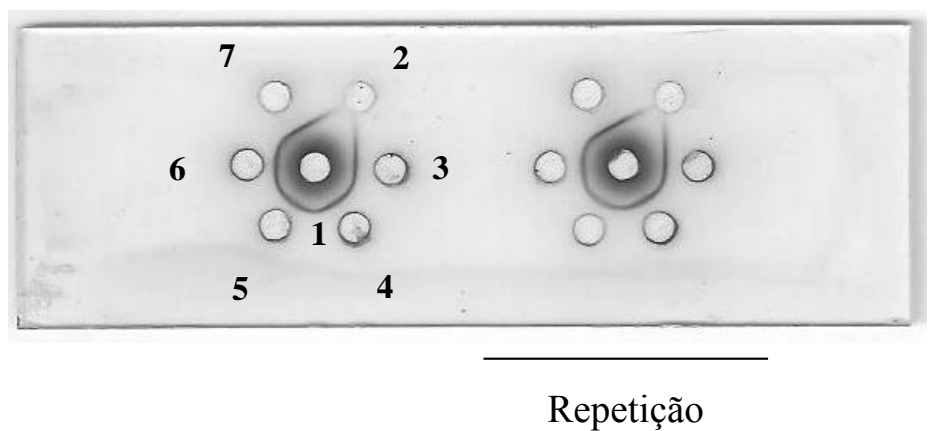

Em (A): 1- anticorpo anti-C5 murino feito em camundongo; 2- soro de camundongo B6 (controle C5 normal); 3 a 6- soro de camundongo B6 $\mathrm{C} 5$ deficiente (B6.A- $\mathrm{Cc}^{0}$ ); 7- soro de camundongo A/J (controle C5 deficiente). Em (B): 1- anticorpo anti-C5 murino feito em camundongo; 2- soro de camundongo $\mathrm{A} / \mathrm{J}$ (controle $\mathrm{C} 5$ deficiente) ; 3 a 6- soro de camundongos congênicos A.B6-Hc (C5 normais); 7- soro de camundongo B6 (controle C5 normal).

Figura 7 - Ensaio hemolítico da via alternativa do sistema complemento aplicando soro das linhagens.

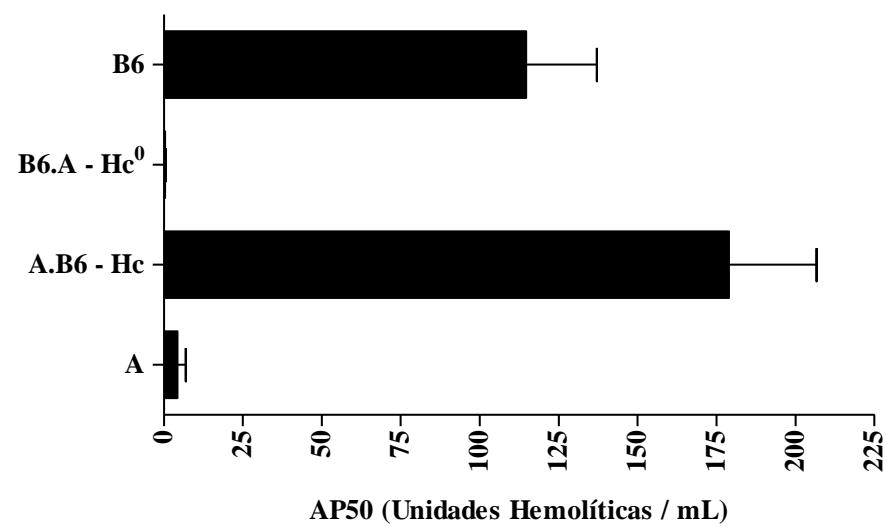

Empregamos soros de camundongos B6 (B6 C5 normal), B6.A-Hc (B6 C5 deficientes), A.B6-Hc (A/J C5 normal), A (A/J C5 deficiente). Empregamos 10 camundongos de cada linhagem para o ensaio. 
Figura 8 - Marcadores genéticos amplificados para a análise de microssatélite.

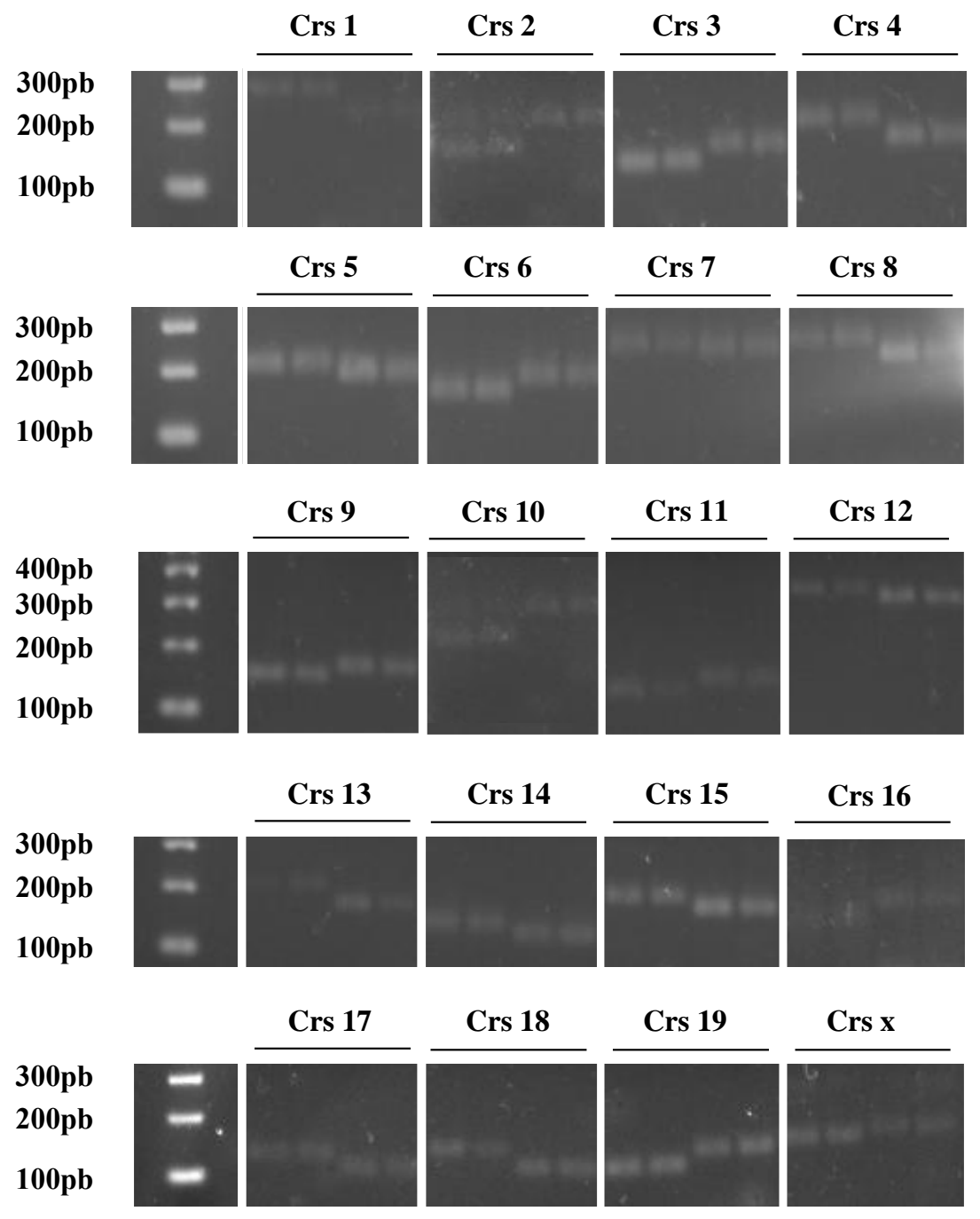

Para cada cromossomo empregamos uma mistura de DNAs genômicos pertencente a 7 animais da mesma linhagem. O marcador utilizado foi o de 100pb. Para todos os cromossomos manteve-se a mesma sequência de aplicação das amostras no gel: B6; B6.A- $H c^{0}$; A; A.B6-Hc. 


\subsection{Discussão do CAPÍTULO 1}

Como mencionamos anteriormente, o desenvolvimento destas linhagens não é uma tarefa trivial, mas também não é impossível. Iniciamos o desenvolvimento das linhagens em 2007 pelo método tradicional de retrocruzamento (SILVER, 1995).

Mesmo assim, este processo poderia ter sido acelerado se tivéssemos empregado protocolos de seleção assistida por marcadores genéticos, como a análise por microssatélites (WAKELAND et al., 1997) ou por mapeamento de polimorfismos de nucleotídeos (WONG, 2002). Nestes trabalhos, a técnica de seleção assistida por marcadores como microssatélites é empregada para acelerar o desenvolvimento, pois é possível identificar dentre os camundongos da prole quais são aqueles que, além de possuir o alelo de interesse, também possuem maior similaridade com fundo genético da linhagem no qual se quer inserir o novo alelo.

A geração destes camundongos congênicos abrirá novas linhas de pesquisa em nosso laboratório, além das pesquisas abordadas nesta tese, pois serão ferramentas importantes para o estudo do componente C5 em fundos genéticos que tendem a desenvolver um perfil de resposta Th1 e Th2, no caso das linhagens B6 e A/J, respectivamente (GORDON; TAYLOR, 2005; MILLS et al., 2000). Em conjunto aos trabalhos anteriores que desenvolveram e aplicaram as linhagens congênicas B6 C5 deficientes e A/J C5 normais nos mais diversos modelos experimentais, nossos animais congênicos também poderão contribuir para a elucidação do papel da proteína C5 nas patologias desenvolvidas pelo alcoolismo crônico.

\subsection{Conclusão do CAPÍTULO 1}

Desenvolvemos duas linhagens de camundongos congênicos por meio de métodos tradicionais, como retrocruzamento, PCR e sequenciamento de nucleotídeos, onde foi possível estabelecer duas linhagens congênicas B6.A-Hc ${ }^{0}$ e A.B6- $H c$ com 99,8\% de similaridade com as linhagens isogênicas parentais B6 e A/J, respectivamente. 


\section{CAPÍTULO 2 - MODELO MURINO DE DOENÇA HEPÁTICA ALCOÓLICA}

\subsection{Introdução}

\subsubsection{Características da Doença Hepática Alcoólica}

A Doença Hepática Alcoólica (DHA) é caracterizada por inflamação, necrose e apoptose de hepatócitos, esteatose, com eventual desenvolvimento de fibrose e cirrose hepática, quando há consumo crônico de etanol. A esteatose é o primeiro estágio de injúria hepática e ocorre em resposta à ingestão aguda ou crônica de etanol, seguida pela depleção da $\beta$-oxidação de ácidos graxos, aumento da síntese de triglicerídeos e mobilização de ácidos graxos extra-hepáticos (LIEBER, 2004). O acúmulo de lipídeos neutros nos hepatócitos leva à formação de esteatose macro- e micro-vesicular (TSUKAMOTO, 2005), sugerindo que a esteatose predispõe os hepatócitos a danos mais graves (NANJI; TSUKAMOTO; FRENCH, 1989).

Dados clínicos e experimentais reforçam a constatação que a imunidade inata desempenha um papel chave no desenvolvimento e progressão da DHA. Isto se deve à participação das células de Kupffer (macrófagos residentes do tecido hepático), aos receptores semelhantes ao Toll (TLR), e às citocinas pró-inflamatórias (NAGY, 2003). Diversos trabalhos mostraram que a ativação do TLR-4 por LPS em células de Kupffer promove estresse oxidativo e conseqüente acúmulo de lipídeo hepático, desenvolvimento de inflamação e necrose em modelos murinos de exposição crônica ao etanol (HINES; WHEELER, 2004). Além disso, tem sido mostrado que a ingestão crônica de etanol afeta a barreira do epitélio intestinal, facilitando a translocação de bactérias e endotoxinas (como o LPS) do lúmen gastro-intestinal para o tecido, chegando finalmente ao fígado onde ativam as células de Kupffer. Esta interação leva à produção de vários fatores como espécies reativas de oxigênio e citocinas. Em especial, a citocina pró-inflamatória TNF- $\alpha$ parece ser essencial para a injúria dos hepatócitos (NAGATA; SUZUKI; SAKAGUCHI, 2008). A citocina pró-inflamatória TNF- $\alpha$ foi uma das primeiras citocinas a ser detectada em soro de pacientes com hepatite alcoólica. Em modelos de DHA empregando camundongos knockout para o receptor para TNF- $\alpha$ (YIN et al., 1999) ou ratos que tiveram TNF- $\alpha$ neutralizado por anticorpos específicos apresentaram redução da injúria hepática (IIMURO et al., 1997).

Modelos experimentais desenvolvidos para induzir em camundongos as diversas patologias associadas à DHA em humanos tornaram-se ferramentas indispensáveis para o 
estudo dos mecanismos envolvidos com a patogênese da doença. Dietas modificadas para a inclusão de etanol em sua composição foram desenvolvidas e continuam sendo testadas há mais de 40 anos (LIEBER et al., 1963) e atualmente uma das mais empregadas é a dieta Lieber-DeCarli (1982). Esta dieta promove alterações nos parâmetros corporais de ratos e camundongos associados à evolução da DHA observados em humanos. Entre os parâmetros consideram-se: (a) dificuldade de ganho de peso (BYKOV et al., 2004; LIEBER; DE CARLI, 1982); (b) aumento da razão do peso hepático pelo peso corporal (BYKOV et al., 2004; LIEBER; DE CARLI, 1982); (c) aumento do depósito de triglicerídeos hepáticos (BYKOV et al., 2004; LIEBER; DE CARLI, 1982; SAUNDERS et al., 1984); e, (d) aumento da concentração hepática de TNF- $\alpha$ e NO (NAGY, 2003).

\subsubsection{O sistema complemento e a DHA}

Dentre os componentes da imunidade inata envolvidos com o desenvolvimento da DHA encontra-se o sistema complemento. Em 2002, Järveläinen e colaboradores investigaram se o sistema complemento mediaria a inflamação durante o desenvolvimento da DHA provocada pelo modelo no qual etanol é fornecido em conjunto com uma dieta hiperlipídica. Estes autores observaram a deposição dos componentes C3 e C8, mas não de C1, no fígado dos ratos tratados com etanol, além de identificar que as proteínas reguladoras do sistema complemento CD59 e Crry foram fracamente expressadas nos hepatócitos dos ratos tratados com etanol. Ou seja, após um consumo crônico de etanol (6 semanas), houve aumento da deposição dos componentes da via alternativa sobre os hepatócitos como consequência da ativação do sistema complemento. Esta deposição poderia estar relacionada à redução da expressão gênica das proteínas reguladoras subseqüente à administração de etanol.

Uma vez confirmada a ativação do sistema complemento no tecido hepático após a ingestão alcoólica, Bykov et al. (2004) investigaram se a ativação promoveria dano tecidual hepático ou desempenharia um papel homeostático em tecidos danificados pelo etanol. Empregando uma dieta rica em lipídeos e etanol, estes autores estudaram a importância do componente C6 e a participação da via terminal na prevenção ou promoção da resposta inflamatória mediada pelo sistema complemento em fígado de ratos no modelo de DHA. Os resultados indicaram que animais $\mathrm{C}^{+/+}$tratados com etanol apresentaram deposição de $\mathrm{C}$, C3, C8, e C9 no tecido hepático, o que não foi observado em animais $\mathrm{C6}^{-1-}$. Animais $\mathrm{C6}^{-1-}$ tratados com etanol exibiram maior concentração hepática da citocina TNF- $\alpha$ em relação à citocina IL-10, além de apresentarem marcantes alterações histopatológicas e aumento do 
peso hepático em relação aos animais C6 normais. Em outras palavras, a deficiência de C6 não protegeu os ratos quanto à resposta inflamatória induzida pelo etanol, portanto, deficiência na via terminal, em especial na ausência de C6, predispõe o tecido hepático à injúria promovendo uma resposta pró-inflamatória por citocinas como TNF- $\alpha$. Isto sugere que o sistema complemento em sua atividade normal talvez possa exercer importante função de reparo nas lesões hepáticas causadas por etanol e, desta forma, desempenhar uma função protetora quando o modelo de DHA é induzido em ratos.

O componente $\mathrm{C} 3$ é central para as três vias de ativação do sistema complemento e no contexto de resposta inflamatória pode acentuar a inflamação e causar sérios danos teciduais. Investigando a participação do componente C3 em modelo murino de DHA, Bykov e colaboradores (2006) observaram que nos camundongos C3 normais tratados com a dieta contendo etanol desenvolveram significativo grau de esteatose e o dobro da concentração de ALT observada para os camundongos controle. Por outro lado, os camundongos $\mathrm{C}^{-{ }^{--}}$tratados com etanol exibiram menor grau de esteatose, quando comparados com os camundongos controles e com os animais C3 normais tratados com etanol. Sendo assim, os camundongos $\mathrm{C}^{-1-}$ são protegidos quanto ao desenvolvimento de esteatose induzida por etanol, sugerindo que o componente $\mathrm{C} 3$ esteja envolvido com mecanismos relacionados ao acúmulo de gordura nos hepatócitos.

Complementando o estudo sobre o papel de C3 na DHA em modelo murino, Bykov e colaboradores (2007) analisaram parâmetros lipídicos e expressão gênica hepática empregando técnicas de microarranjo e reação em cadeia usando DNA polimerase em tempo real em camundongos $\mathrm{C}^{-/-}$que não desenvolveram esteatose após tratamento com etanol. Estes animais apresentaram marcada redução sérica do nível de colesterol, apolipoproteína AI, atividade da proteína de transferência de fosfolipídeos e também redução hepática dos níveis de RNAm de proteínas ligantes em ácidos graxos e da enzima $\beta$-oxidativa de ácidos graxos. Estes resultados sugerem uma importante relação entre a proteína C3 e os reguladores de metabolismo lipídico envolvidos com a esteatose induzida por álcool.

Ampliando a análise sobre a contribuição do sistema complemento na DHA, Pritchard e colaboradores (2007) estudaram o envolvimento de C3, C5 e decay-accelerating factor (DAF) no acúmulo de gordura no fígado induzido pelo etanol. Para isso, camundongos $\mathrm{C}^{-/-}$, $\mathrm{C}^{-/-}$e $\mathrm{DAF}^{-/-}$e seus respectivos controles normais foram tratados com uma dieta rica em gordura contendo ou não etanol por 6 semanas. O componente C3, como esperado, contribuiu primariamente para o acúmulo de triglicerídeos no fígado, enquanto o componente C5 esteve envolvido com o desenvolvimento da inflamação e injúria hepática. A ausência de DAF 
exacerbou todos estes eventos, sugerindo que a regulação da C3 convertase poderia atuar inibindo o acúmulo de gordura hepática induzida pelo etanol, e portanto sugere-se como um forte candidato a alvo terapêutico para a DHA.

Além de o sistema complemento ser importante para a perpetuação da resposta inflamatória em estágios mais avançados da DHA (6 semanas), Roychowdhury et al. (2009) sugeriram que o sistema complemento também seja necessário durante os estágios iniciais (4 d) da injúria hepática induzida pelo etanol, pois sua ativação é evidenciada pela deposição de C3b sobre os hepatócitos, após tratamento dos animais por 4 d com dieta rica em lipídeos contendo etanol. Os fragmentos C3a e C5a resultantes da ativação do complemento interagem com seus respectivos receptores presentes nas células de Kupffer estimulando a expressão de TNF- $\alpha$. Em um segundo estágio, após períodos mais longos de exposição ao etanol (4 a 6 semanas), as vias sinalizadoras dependentes de TLR-4 e o sistema complemento contribuem sinergicamente para o progresso da DHA.

Uma das principais características da injúria hepática induzida por etanol é a apoptose hepatocelular, onde o etanol predispõe os hepatócitos para apoptose tanto in vivo (HIGUCHI et al., 1996) como in vitro (PASTORINO; SHULGA; HOEK, 2003). Pelo fato de C1q se ligar a células apoptóticas e ativar a via clássica do sistema complemento, Cohen e colaboradores (2010) estudaram a contribuição desta proteína para a patogênese da injúria hepática induzida por etanol. Camundongos $\mathrm{C}_{1} \mathrm{q}^{-/-}$foram tratados por 4 ou 25 d com dieta hiperlipídica

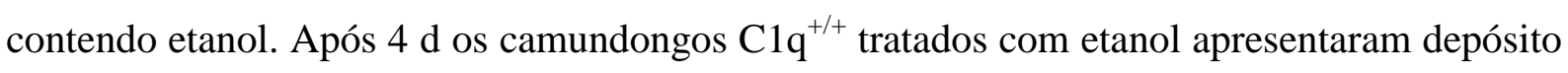
de produtos da ativação do complemento no fígado e aumento da citocinas TNF- $\alpha$ e IL-6, quando comparados com animais $\mathrm{C}_{1} \mathrm{q}^{-/-}$. Após $25 \mathrm{~d}$ recebendo etanol, os camundongos $\mathrm{C}_{1} \mathrm{q}^{+/+}$ desenvolveram esteatose, apoptose e parâmetros de injúria hepática como as enzimas ALT e AST aumentados, enquanto que nos animais $\mathrm{C}_{1} \mathrm{q}^{-/-}$todos estes marcadores de injúria mostraram-se atenuados. Este trabalho mostra que a proteína $\mathrm{C} 1 \mathrm{q}$ contribui para a patogênese da DHA.

Dado o abrangente consumo alcoólico pela população, é pertinente o emprego de modelos experimentais que estudem os efeitos do etanol sobre o fígado, assim como estudos detalhados sobre a contribuição dos componentes do complemento, para a patogênese de doenças hepáticas, tal como a DHA. Desta forma, o sistema complemento, em especial os componentes C3 e C5, parece ter importante participação no metabolismo de lipídeos e na modulação da resposta inflamatória envolvida com o estabelecimento e manutenção da DHA. Assim, nosso trabalho visa ao estudo do papel de C5 na indução da resposta inflamatória, em 
especial sobre a síntese de citocinas no tecido hepático em período longo de exposição ao etanol (10 semanas). 


\subsection{Resultados do CAPÍTULO 2}

Os resultados estão organizados em três tópicos principais: 1- Modelo de injúria hepática aguda induzida por etanol; 2- Padronização do modelo de injúria hepática crônica induzida por etanol (ou padronização da DHA), 3- Aplicação da linhagem congênica B6.A$H c^{0}$ no modelo de DHA. Convencionamos como denominação para os camundongos pertencentes à linhagem isogênica $\mathrm{C} 57 \mathrm{Bl} / 6$ apenas a abreviatura $\mathrm{B} 6$, a linhagem isogênica $\mathrm{A} / \mathrm{J}$ continuará como A/J, e para a linhagem congênica C57Bl/6 C5 deficiente será utilizada a nomenclatura B6.A-Hc ${ }^{0}$, conforme a descrição apresentada no CAPÍTULO 1.

\subsubsection{Modelo de injúria hepática aguda induzida por etanol}

Iniciamos nossas análises com o modelo de lesão hepática aguda induzida por etanol para identificar possíveis alterações na resposta inflamatória aguda entre as linhagens C57Bl/6 e $\mathrm{A} / \mathrm{J}$, uma vez que essas linhagens possuem comportamento inflamatório distinto frente às infecções (DOMÍNGUEZ-PUNARO et al., 2008) e injúrias químicas (ALAISH et al., 2005).

O modelo de tratamento alcoólico agudo é chamado binge drink, que significa beber muito em um curto espaço de tempo, este modelo foi estabelecido e caracterizado por Carson e Pruett (1996) para mimetizar em camundongos os efeitos agudos do consumo alcoólico humano. Tratamos ambas as linhagens com $7 \mathrm{~g} / \mathrm{kg}$ de etanol diluído a 32\% ou água estéril como controle. Essa dose equivale, por exemplo, ao consumo de três doses de vodka por uma pessoa pesando entre 50 e $60 \mathrm{~kg}$. Dessa maneira, a dose utilizada tenta reproduzir em camundongos o binge drink humano.

\subsubsection{Análise do perfil de leucócitos periféricos após tratamento dos camundongos B6 e A/J com etanol por gavagem}

Considerando estudos anteriores sobre o desenvolvimento e caracterização do modelo de binge drink aplicado a camundongos para avaliação do efeito do álcool sobre parâmetros inflamatórios (CARSON; PRUETT, 1996), escolhemos como ponto de análise da resposta inflamatória aguda o tempo de $4 \mathrm{~h}$ a partir da administração alcoólica aos camundongos. Aplicamos o teste estatístico não-paramétrico Mann Whitney para comparação entre os tratamentos. Não realizamos comparações entre as linhagens. 
Após a administração de $7 \mathrm{~g} / \mathrm{kg}$ de etanol por gavagem aos camundongos, avaliamos o perfil de leucócitos presentes no sangue periférico pela contagem total e diferencial destas células. Com esta análise, observamos diferença na média do número basal de leucócitos totais, onde, no grupo controle (tratado apenas com água estéril) da linhagem B6 encontramos $8 \times 10^{6}$ leucócitos / mL e da linhagem A/J 3,5 x 10 leucócitos / mL. Após o tratamento dos camundongos com etanol, observamos queda significativa no número absoluto de leucócitos circulantes em ambas as linhagens, quando comparadas com o grupo controle (Figura 9A). Quando investigamos a razão da porcentagem de leucócitos polimorfonucleares (PMN) e mononucleares $(\mathrm{MN})$, esta razão alterou-se significativamente apenas para a linhagem A/J quando tratada com etanol (Figura 9B), onde a porcentagem de PMNs aumentou de $40 \%$ para $60 \%$ comparando-se o grupo controle e tratado com etanol, respectivamente.

Figura 9 - Contagem absoluta e diferencial de leucócitos sanguíneos nas linhagens B6 e A/J 4 $\mathrm{h}$ após tratamento com $7 \mathrm{~g} / \mathrm{kg}$ de etanol por gavagem.
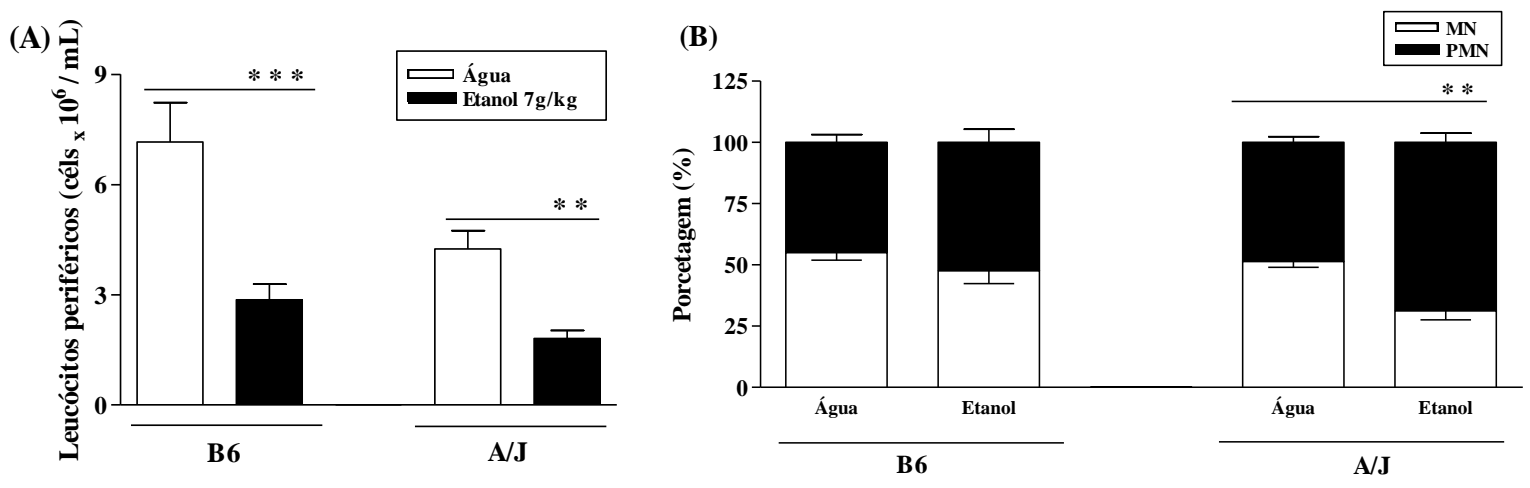

Em (A): número de leucócitos periféricos; (B): Porcentagem de leucócitos polimorfonucleares (PMN) e mononucleares $(\mathrm{MN})$. A barra branca representa os camundongos tratados com água e barra preta representa os camundongos tratados com etanol $(7 \mathrm{~g} / \mathrm{kg})$. Os resultados são representados como média e erro padrão $(\mathrm{n}=10$; $* * p<0,01 ; * * * p<0,001)$.

Estes resultados indicam que $4 \mathrm{~h}$ após o tratamento agudo com etanol, as linhagens B6 e A/J respondem de maneira similar com respeito ao número de leucócitos totais. Entretanto, apenas a linhagem A/J foi capaz de aumentar o número de células PMN em relação ao número de células MN (Figura 9). 
5.2.1.2 Avaliação da função hepática pela determinação da concentração plasmática das enzimas ALT, AST e GGT

Considerando que o aumento nos níveis plasmáticos de ALT, AST e GGT são indicativos de injúria hepática, analisamos a atividade destas enzimas no plasma de camundongos B6 e A/J tratados com etanol (Figura 10). Não encontramos diferença significativa nos níveis sérico da ALT (Figura 10A). Para a AST observamos aumento significativo apenas para a linhagem A/J, quando tratada com etanol e comparada ao grupo controle (Figura 10B). Da mesma forma, apenas a linhagem A/J apresentou aumento significativo da atividade de GGT, quando comparada ao grupo controle (Figura 10C). A linhagem B6 não apresentou alterações significativas para as enzimas AST e GGT, quando tratadas com etanol.

Figure 10 - Determinação da concentração plasmática das enzimas associadas à função hepática $4 \mathrm{~h}$ após o tratamento das linhagens B6 e A/J com etanol.
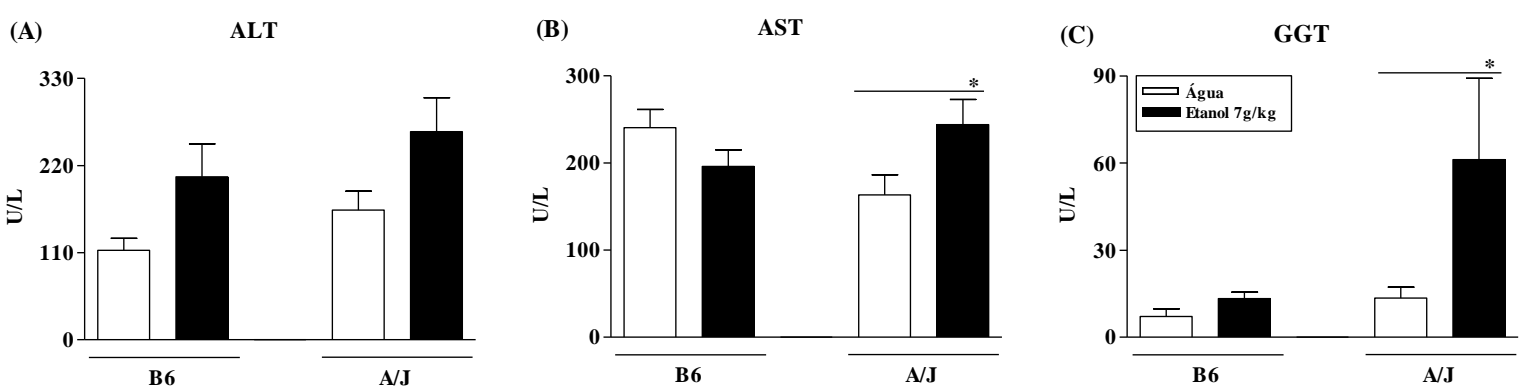

Determinação da atividade da ALT (A), AST (B) e GGT (C) no plasma dos camundongos tratados com etanol (7 $\mathrm{g} / \mathrm{kg}$ ) por gavagem. A barra branca representa os camundongos tratados com água e barra preta representa os camundongos tratados com etanol $(7 \mathrm{~g} / \mathrm{kg})$. Os resultados estão representados como média e erro padrão $(\mathrm{n}=$ $10 ; * p<0,05)$.

Portanto, considerando o perfil de enzimas associadas à integridade e função hepática, relacionadas a este modelo experimental, podemos sugerir que os camundongos da linhagem A/J foram mais sensíveis ao tratamento com etanol que os camundongos da linhagem B6 (Figura 10). 


\subsubsection{Análise histopatológica hepática das linhagens B6 e A/J após tratamento com etanol}

Para complementar a análise das enzimas hepáticas ALT, AST e GGT, avaliamos a arquitetura hepática por meio de cortes de fígado corados com hematoxilina e eosina (HE). Como esperado, não encontramos lesão nos grupos controles de ambas as linhagens (Figura 11A e 12A) tratados apenas com água. Após o tratamento com etanol, os camundongos B6 exibiram moderada vacuolização hepática ao redor da veia centro lobular (Figura 11B) e ainda observamos infiltrado de células MNs próximas ao ducto biliar (Figura 11C). No parênquima hepático, próximo a pequenas regiões necróticas, observamos agrupamentos leucocitários MNs (leucocitose) (Figura 11D), o qual pode ser interpretado com um foco de infiltrado celular ou um sítio de proliferação leucocitária.

Figura 11 - Análise histopatológica de tecido hepático dos camundongos B6 após tratamento agudo com etanol.
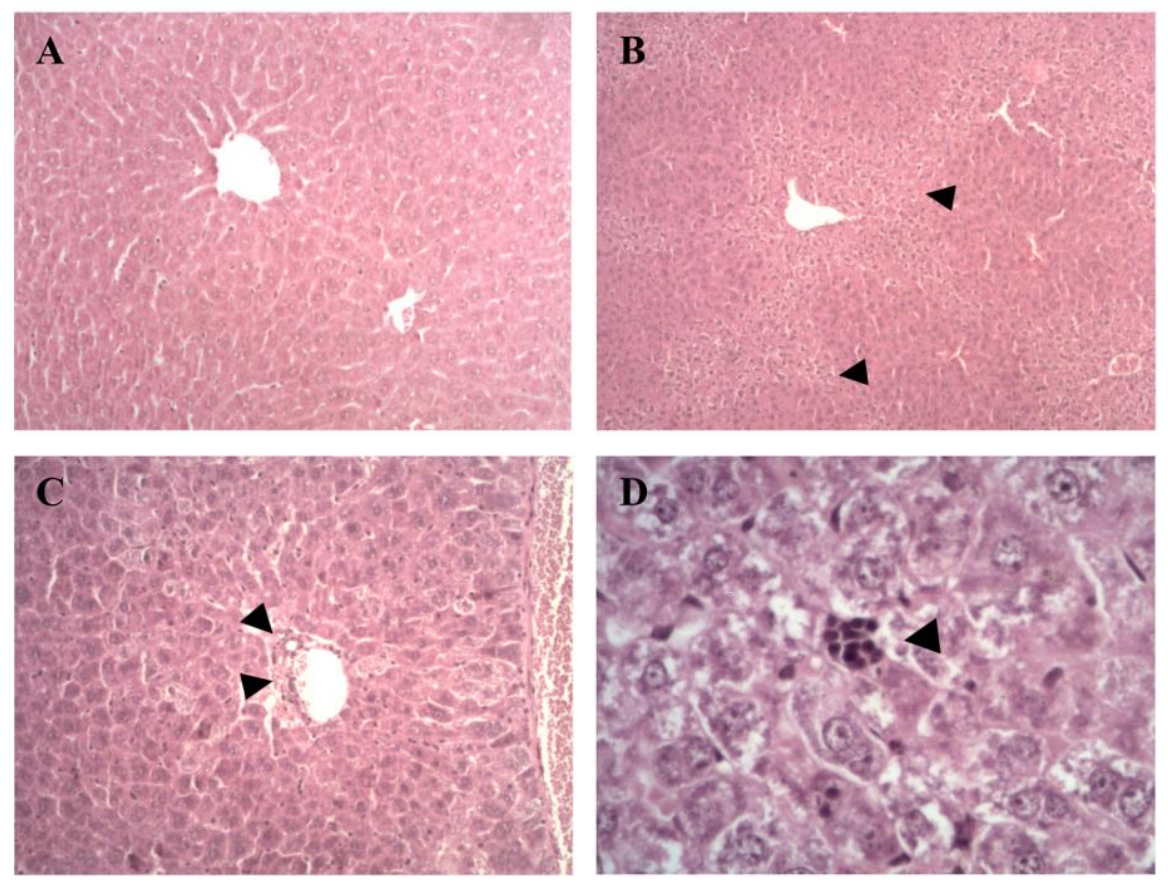

Os camundongos receberam $7 \mathrm{~g} / \mathrm{kg}$ de etanol por gavagem e após $4 \mathrm{~h}$ o tecido hepático foi fixado em formalina, preparados e corados com HE. O grupo tratado com água mostra arquitetura hepática intacta (A) e o grupo tratado com etanol está representado em B-D. As cabeças de setas indicam vacuolização ao redor da veia centrolobular (B), infiltrado de células mononucleares (C) e leucocitose (D). Aumentos: (A-C) 20x; (D) 100x.

A análise histopatológica hepática dos camundongos da linhagem A/J tratados com etanol mostrou intensa vacuolização e micro-esteatose ao redor da veia centrolobular (Figura 12A). Neste grupo também encontramos seções de necrose difusa distribuídas no parênquima 
(Figura 12B) com presença de células PMNs infiltradas (Figura 12C). E ainda, encontramos infiltrados de células MNs próximos aos ductos biliares e leucocitose no parênquima hepático (Figura 12D).

Figura 12 - Análise histopatológica de tecido hepático dos camundongos A/J após tratamento agudo com etanol.
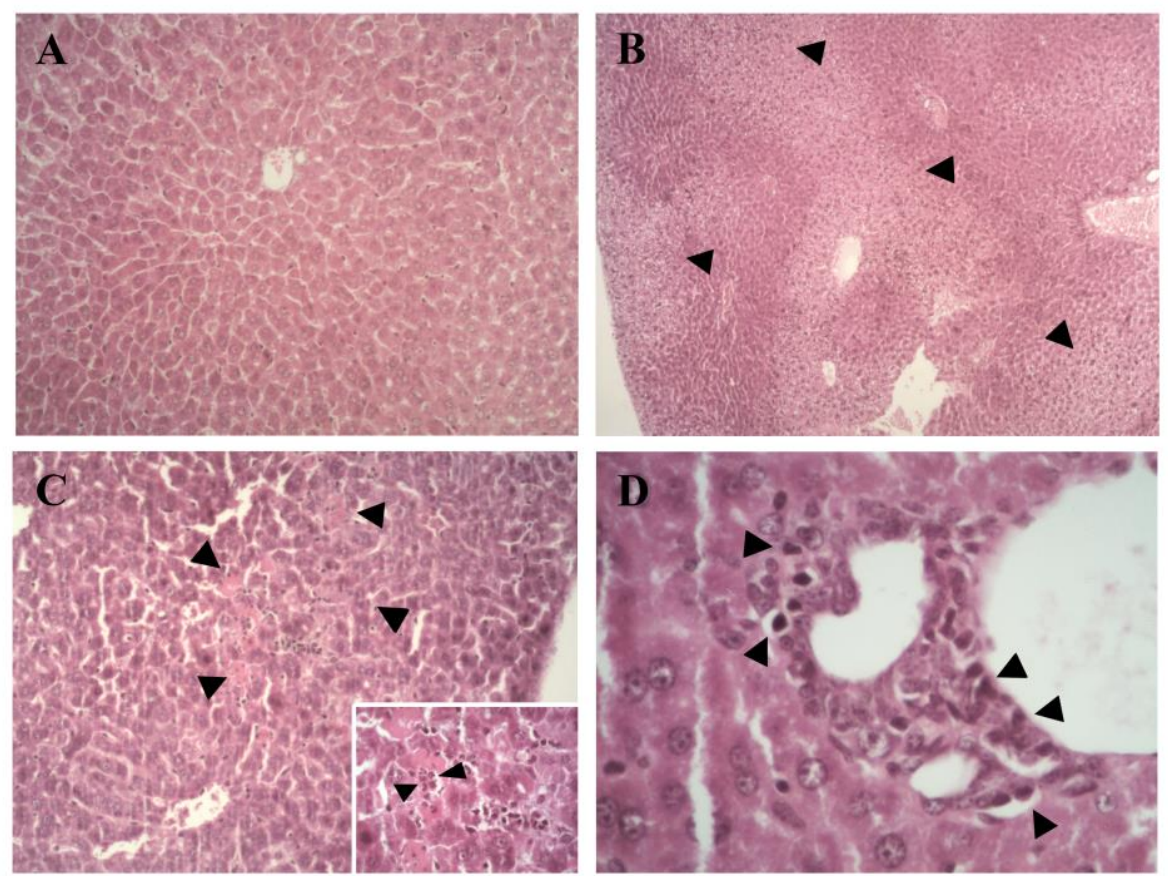

Os camundongos receberam $7 \mathrm{~g} / \mathrm{kg}$ de etanol por gavagem e após $4 \mathrm{~h}$ o tecido hepático foi fixado em formalina tamponada, preparados e corados com HE. O grupo tratado com água mostra arquitetura hepática intacta (A) e o grupo tratado com etanol está representados em B-D. As cabeças de setas indicam acentuada vacuolização ao redor da veia centrolobular (B), necrose difusa no parênquima (C). O detalhe apresentado em (C) mostra infiltrado de células PMNs. Na região dos ductos biliares as cabeças de setas apontam para o infiltrado de células mononucleares (D). Aumentos: (A-C) 20x, inserção em (C) 40x; (D) 100x.

Estes resultados indicam que a injúria hepática induzida por etanol foi mais pronunciada nos camundongos da linhagem A/J que nos da linhagem B6 (Figura 11 e 12).

5.2.1.4 Determinação das citocinas inflamatórias no plasma dos camundongos B6 e A/J $\underline{\text { tratados com etanol }}$

Sabendo-se que os camundongos B6 e A/J possuem diferentes características genéticas, fisiológicas e imunológicas decidimos avaliar a presença de citocinas inflamatórias no plasma destes animais, para inferir sobre a presença de um mecanismo inflamatório induzido por etanol. Estudos anteriores mostraram que o tratamento agudo com etanol causa 
depleção da resposta inflamatória (CARSON; PRUETT, 1996), isto também foi observado em nosso modelo, quando observamos queda do número de leucócitos circulantes e aumento da razão PMN / MN (Figura 10).

Dosamos no plasma dos camundongos tratados com etanol e nos controles a concentração das citocinas pro-inflamatórias TNF- $\alpha$, IL-1 $\beta$, IL-6 e anti-inflamatória IL-10. Neste modelo, apenas a produção de IL-6 mostrou-se afetada. Não encontramos mudanças induzidas por etanol nas concentrações das demais citocinas (dados não mostrados). Observamos aumento significativo da concentração plasmática da citocina IL-6 apenas nos camundongos A/J tratados com etanol (média e erro padrão: 97,46 \pm 61,93 pg / mL), quando comparados ao grupo controle (média e erro padrão: 25,4 \pm 19,1 pg / mL) (Figure 13).

Figura 13 - Determinação da concentração plasmática de IL-6 por ELISA em camundongos B6 e A/J $4 \mathrm{~h}$ após o tratamento com etanol (7 g / kg).

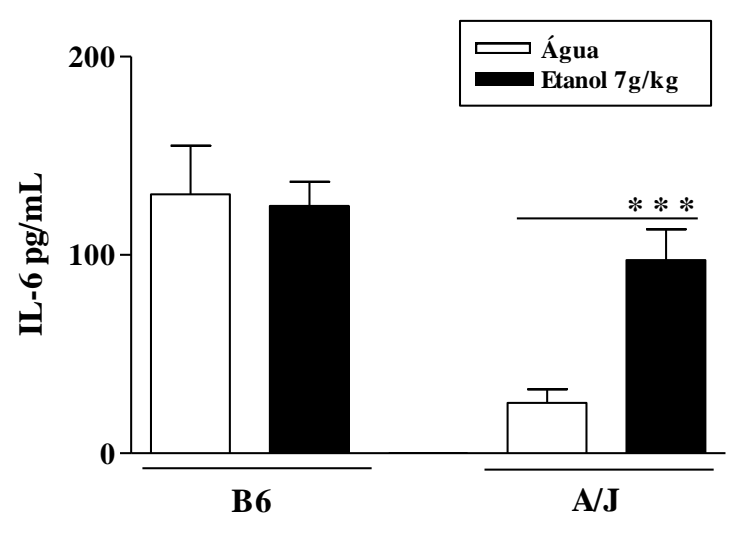

A barra branca representa os camundongos tratados com água e barra preta representa os camundongos tratados com etanol ( $7 \mathrm{~g} / \mathrm{kg})$. Os resultados estão representados como média e erro padrão $(\mathrm{n}=10$; *** $p<0.05)$.

O perfil de citocinas analisado indicou uma notável participação de IL-6 na resposta inflamatória induzida por etanol apenas em camundongos da linhagem A/J. Ou seja, os resultados acima sugerem que a linhagem A/J foi mais vulnerável ao tratamento alcoólico agudo do que a linhagem B6 (Figura 13).

5.2.1.5 Conclusão geral do tópico "Modelo de injúria hepática aguda induzida por etanol"

Embora o tratamento agudo com etanol induza uma depressão da resposta inflamatória e moderado dano hepático na linhagem B6, a linhagem A/J sofre maior dano hepático e marcante alteração da resposta inflamatória mostrando maior sensibilidade ao tratamento. Em 
outras palavras, o emprego das linhagens B6 e A/J é promissor na investigação de alterações na resposta inflamatória aguda induzida pelo etanol. 


\subsubsection{Padronização do modelo de injúria hepática crônica induzida por etanol (ou padronização da DHA)}

Empregamos camundongos da linhagem B6 e da linhagem A/J visando padronizar um modelo de DHA e investigar se neste contexto de tratamento crônico com etanol os camundongos da linhagem A/J continuariam sofrendo mais dano hepático que os camundongos da linhagem B6, conforme constatamos no modelo agudo de lesão hepática induzida por etanol.

Nesta etapa de padronização do modelo de DHA estabelecemos como meta tratar os camundongos da linhagem B6 e A/J com três dietas diferentes. Como grupo experimental empregamos uma dieta hiperlipídica contendo etanol $(\mathrm{DH}+\mathrm{E})$. Como controle equicalórico empregamos uma dieta hiperlipídica contendo maltodextina $(\mathrm{DH}+\mathrm{M})$, pois esta dieta possui a mesma equivalência calórica a dieta $\mathrm{DH}+\mathrm{E}$. Incluímos também como o controle real um grupo de animais tratados apenas com a dieta hiperlipídica (DH) para acompanharmos as alterações provocadas apenas pela dieta.

Uma vez estabelecidos os grupos de tratamentos, submetemos ambas as linhagens a estes tratamentos por 6,8 e 10 semanas com o objetivo de identificar o período ótimo de tratamento que evidenciaria as diferenças entre as linhagens. Para isso, avaliamos a presença de diferença significativa entre os tratamentos $(\mathrm{DH}+\mathrm{E}, \mathrm{DH}+\mathrm{M}$ e $\mathrm{DH})$, se estes tratamentos apresentariam diferenças de uma semana para a outra (6, 8 e 10 semanas) e o efeito de interação entre os tratamentos e as semanas, aplicando o teste estatístico de análise de variância para dois fatores (ANOVA). Esta análise é essencial para a interpretação conjunta de todos os dados. Por meio dela concluiremos sobre o estabelecimento e manutenção da doença, e escolheremos o tempo de tratamento ideal para aplicar nos estudos subseqüentes com a linhagem congênica B6.A-Hc ${ }^{0}$ (B6 C5 deficiente).

Portanto, consideramos para análise estatística e discussão que os camundongos tratados com $\mathrm{DH}$ e com $\mathrm{DH}+\mathrm{M}$ como grupos controles, onde $\mathrm{DH}$ é o controle real e $\mathrm{DH}+\mathrm{M}$ é o controle equicalórico, pois possui a mesma equivalência calórica que o tratamento com $\mathrm{DH}+\mathrm{E}$. Os resultados referentes à padronização do modelo de DHA serão apresentados respeitando a seguinte organização em seções: (1) avaliação dos parâmetros corporais; (2) avaliação da função hepática e hematológica; (3) avaliação da resposta inflamatória no microambiente hepático; (4) conclusão da padronização do modelo de injúria hepática crônica induzida por etanol (ou padronização da DHA), conforme esquematizado na Figura 14.

Ressaltaremos em itálico os pontos mais importantes de cada parâmetro avaliado. 
Figura 14 - Delineamento experimental para a padronização do modelo murino de injúria hepática crônica induzida por etanol (padronização da DHA).

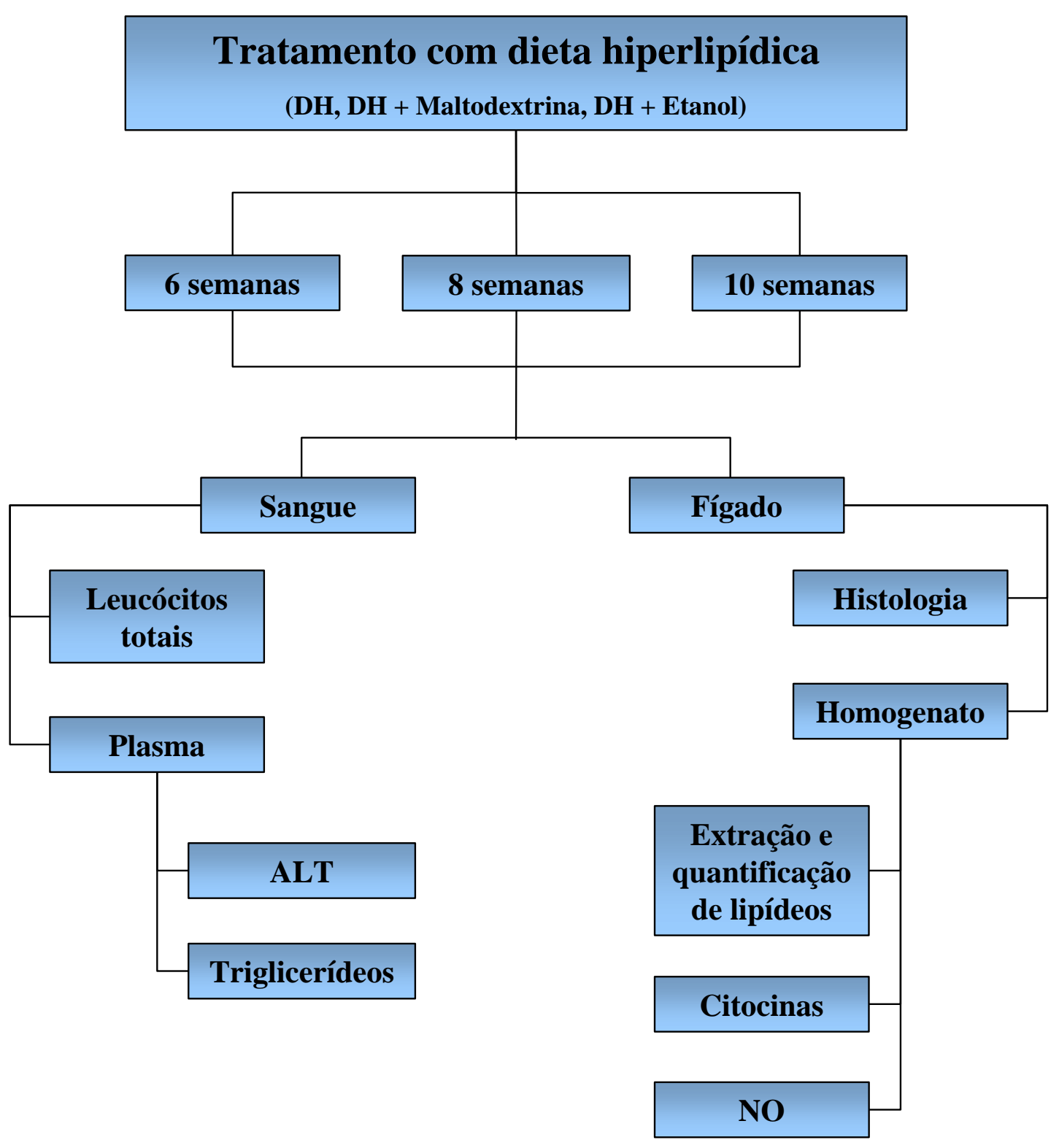

Tratamos os camundongos B6 e A/J com as dieferentes dietas hiperlipídica (DH) por 6, 8 ou 10 semanas. Após este período coletamos o sangue e o fígado dos animais para análise. 


\subsubsection{Avaliação dos parâmetros corporais}

Abordaremos nesta seção a análise dos seguintes parâmetros corporais: ganho de peso acumulado semanalmente, ganho de peso final, relação do peso hepático pelo peso corporal, quantificação do triglicerídeos hepáticos e análise histopatológica do fígado.

A análise do ganho de peso acumulado semanalmente foi realizada em separado para cada uma das linhagens apenas para o tempo de 10 semanas. Analisamos o ganho de peso para cada tratamento individualmente, comparando-os com os tratamentos (APÊNDICE C).

Durante o tratamento com $\mathrm{DH}+\mathrm{E}$ os camundongos da linhagem A/J ganharam menos peso, quando comparados com aqueles que receberam DH+M. Já os camundongos da linhagem $\mathrm{B} 6$ tratados com a $\mathrm{DH}+\mathrm{E}$ ganharam peso em relação àqueles tratados com DH. O tratamento com $\mathrm{DH}+\mathrm{E}$ compromete o ganho de peso principalmente nos camundongos da linhagem A/J (APÊNDICE C-Figura C.1).

Complementando a análise de ganho de peso acumulado, avaliamos o ganho de peso ao final de cada semana de tratamento. As análises mostram que existe efeito de interação entre tratamento e semana tanto para a linhagem B6 quanto para a linhagem A/J, com $p=0,007$ e $p<0,001$ respectivamente (Figura 15). Ou seja, o ganho de peso final foi influenciado pelo tratamento e semana concomitantemente. Para a linhagem B6, os camundongos tratados com $\mathrm{DH}$ e $\mathrm{DH}+\mathrm{M}$ ganharam significativamente mais peso de 6 para 8 semanas de tratamento, já os camundongos tratados com $\mathrm{DH}+\mathrm{E}$ ganharam de 6 para 10 semanas, $p<0,05$. No tempo de 10 semanas os camundongos tratados com $\mathrm{DH}+\mathrm{E}$ ganharam significativamente mais peso que os tratados com $\mathrm{DH}, p<0,05$ (Figura 15A).

Quanto à linhagem $\mathrm{A} / \mathrm{J}$, não encontramos diferença significativa entre os camundongos tratados com $\mathrm{DH}$ e $\mathrm{DH}+\mathrm{M}$ ao longo das semanas. Entretanto, os camundongos tratados com $\mathrm{DH}+\mathrm{E}$ ganharam peso de 6 para 8 e de 6 para 10 semanas, $p<0,05$. Com 6 semanas de tratamento os camundongos da linhagem $\mathrm{A} / \mathrm{J}$ que receberam $\mathrm{DH}+\mathrm{E}$ sofreram perda de peso, tanto em relação aos tratados com DH quanto em relação aos tratados com $\mathrm{DH}+\mathrm{M}, p<0,05$. Já com 8 semanas de tratamento os camundongos $\mathrm{A} / \mathrm{J}$ tratados com $\mathrm{DH}+\mathrm{E}$ apresentaram menor ganho de peso quando comparados aos tratados com $\mathrm{DH}+\mathrm{M}, p<0,05$ (Figura 15B). 
Figura 15 - Ganho de peso total dos camundongos B6 e A/J após 6, 8 e 10 semanas de tratamento com as diferentes dietas hiperlipídicas.

(A)

B6

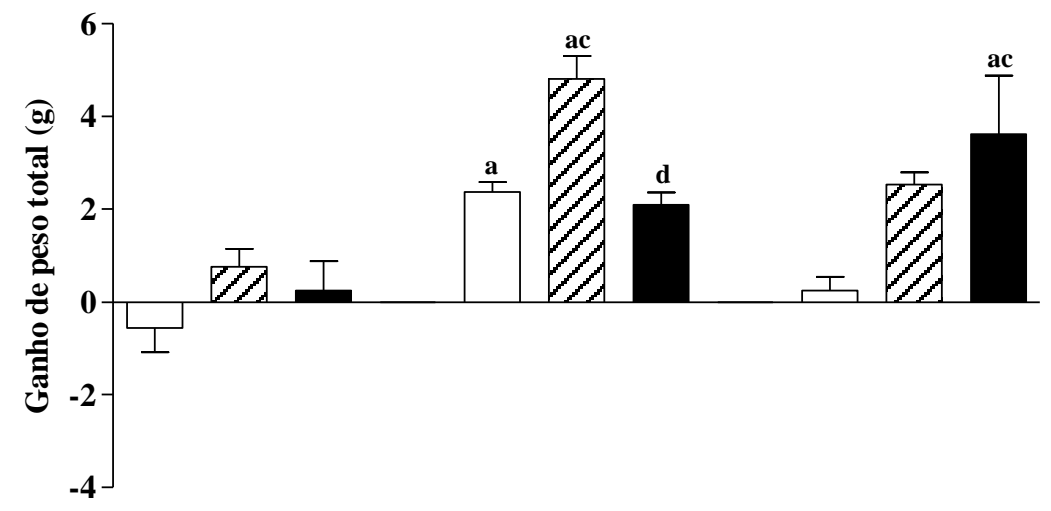

(B)

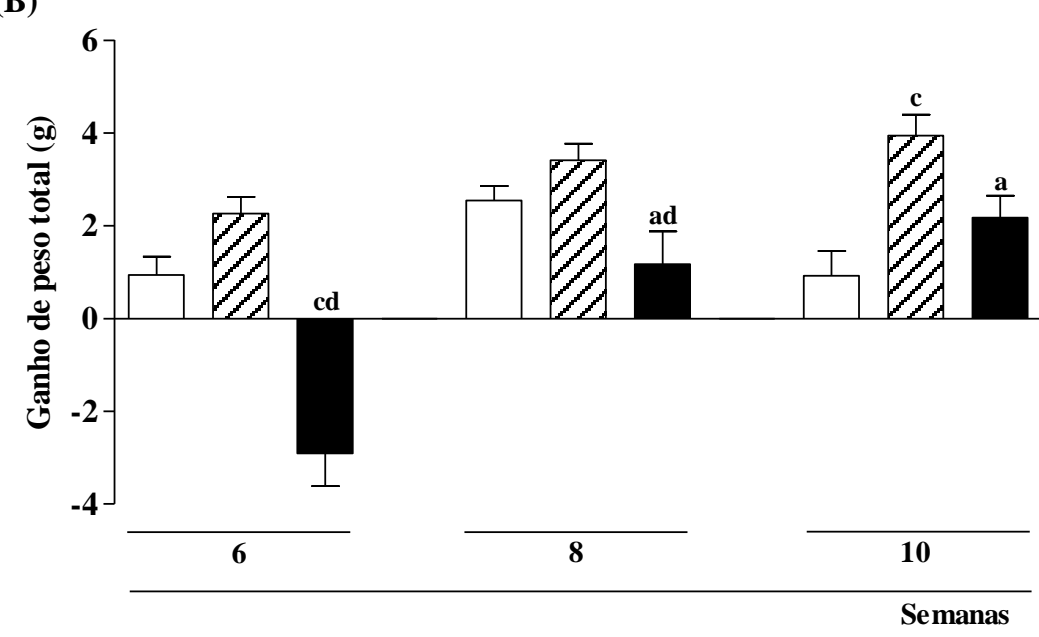

$\square \mathrm{DH} \quad \square \mathrm{DH}+\mathrm{M} \square \mathrm{DH}+\mathrm{E}$

Os resultados estão representados como média e erro padrão, $\mathrm{n} \geq 5$. As comparações correspondem: a vs. 6 semanas; b vs. 8 semanas; c vs. DH; d vs. DH+M. Siglas: DH - Dieta hiperlipídica; DH+M - Dieta hiperlipídica contendo maltodextrina; DH+E - Dieta hiperlipídica contendo etanol.

O aumento de volume hepático (hepatomegalia) é um indicador de doença hepática, consequentemente, uma das características marcantes da DHA é a elevada razão do peso hepático em relação ao peso final. Para a linhagem B6 nossas análises estatísticas identificaram efeito de interação entre tratamento e semana, $p=0,001$. Isto é, o tratamento foi influenciado pelo tempo, durante o qual foi administrado. Observamos redução significativa na razão peso hepático / peso corporal de 6 para 8 semanas após tratamento com $\mathrm{DH}+\mathrm{E}$, $p<0,05$. E ainda identificamos aumento significativo na razão peso hepático / peso corporal 
nos camundongos tratados em $\mathrm{DH}+\mathrm{E}$, quando comparados aos tratados com $\mathrm{DH}+\mathrm{M}, p<0,05$ (Figura 16A).

Quanto à linhagem A/J não detectamos efeito de interação entre tipo de dieta e tempo de tratamento, $p=0.129$. Também não foi detectada diferença significativa entre as semanas, $p=0,120$. Mas existe diferença significativa entre os tratamentos, $p<0,001$, onde os camundongos tratados com $\mathrm{DH}+\mathrm{E}$ apresentaram aumento significativo da razão peso hepático / peso corporal quando comparados aos camundongos tratados com $\mathrm{DH}+\mathrm{M}$ ou $\mathrm{DH}, p<0,05$ (Figura 16B).

Figura 16 - Razão do peso hepático pelo peso corporal dos camundongos B6 e A/J após 6, 8 e 10 semanas de tratamento com as diferentes dietas hiperlipídicas.

(A)

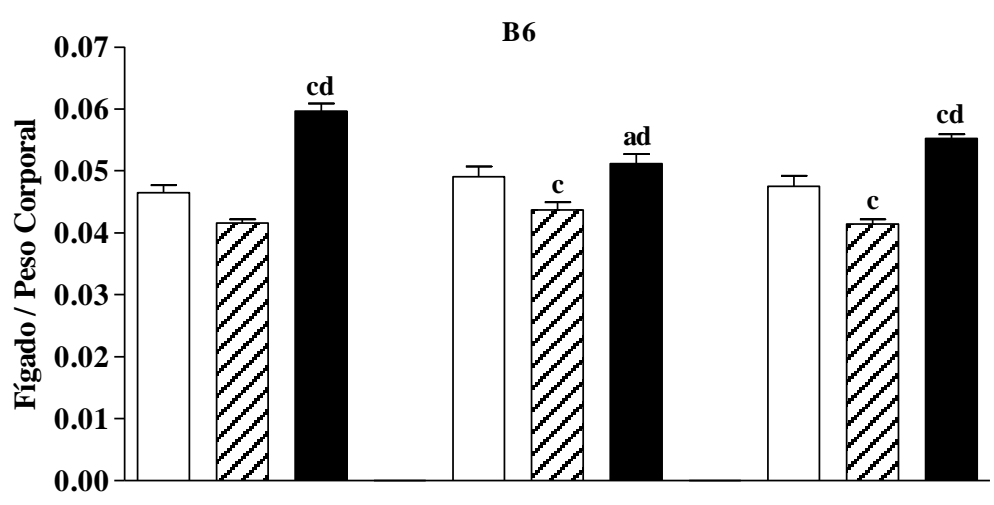

(B)

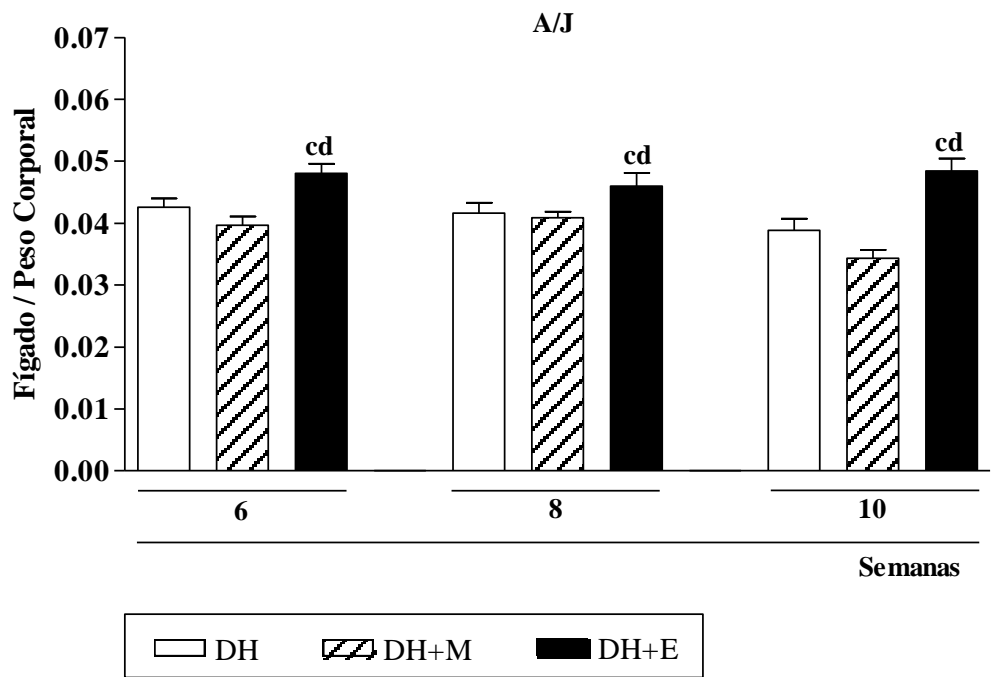

Os resultados estão representados como média e erro padrão, $\mathrm{n} \geq 5$. Em (A) apresentamos os resultados dos camundongos da linhagem B6 e em (B) da linhagem A/J. As comparações correspondem: a vs. 6 semanas; c vs. $\mathrm{DH}$; d vs. $\mathrm{DH}+\mathrm{M}, p<0,05$. Siglas: $\mathrm{DH}-$ Dieta hiperlipídica; DH+M - Dieta hiperlipídica contendo maltodextrina; DH+E - Dieta hiperlipídica contendo etanol. 
Ambas as linhagens apresentam aumento da razão do peso hepático pelo peso corporal após tratamento com $\mathrm{DH}+\mathrm{E}$ independente do tempo. Estes resultados são coerentes com as alterações observadas na DHA (Figura 16).

Além da análise do peso hepático, também avaliamos possíveis alterações nos pesos de outros órgãos como: baço, rins, estômago, coração. Pelo fato de termos encontrado alterações apenas no peso hepático, apresentaremos estes dados unicamente no APÊEDICE D.

Na DHA, a hepatomegalia geralmente é acompanhada pelo acúmulo de gordura no parênquima hepático, especialmente triglicerídeos, assim como edema e fibrose, características estas que contribuem para o aumento do volume e peso do órgão. Portanto, a extração, quantificação e identificação de lipídeos hepáticos é uma importante ferramenta na confirmação da eficiência do nosso modelo de DHA.

A partir de tecido hepático coletado ao final de cada semana de tratamento, extraímos a fração de lipídeos, quando determinamos a concentração de triglicerídeos por grama de tecido (Figura 17). Para a linhagem B6, segundo o teste estatístico aplicado, identificamos efeito de interação entre tratamento e semana, $p=0,001$. Encontramos aumento significativo de triglicerídeos hepáticos nos camundongos tratados com DH de 6 para 8 semanas, $p<0,05$. Ainda observamos que os camundongos tratados com $\mathrm{DH}+\mathrm{E}$ possuem significativamente mais triglicerídeos hepáticos que os camundongos tratados com DH, para os tempos de 6 e 10 semanas, $p<0,05$ (Figura 17A).

Quanto à linhagem $\mathrm{A} / \mathrm{J}$, não foi detectado efeito de interação entre tratamento e semana, $p=0,156$. Da mesma forma não foi detectada diferença significativa entre as semanas, $p=0,251$. Mas, houve diferença significativa entre os tratamentos, $p<0,001$, os camundongos $\mathrm{A} / \mathrm{J}$ tratados com $\mathrm{DH}+\mathrm{E}$ e $\mathrm{DH}+\mathrm{M}$ possuem significativamente maior acúmulo de triglicerídeos hepáticos que os camundongos tratados com $\mathrm{DH}$ independentemente do tempo de tratamento, $p<0,05$ (Figura 17B). É pertinente ressaltar que mesmo acumulando triglicerídeos hepáticos a linhagem $\mathrm{A} / \mathrm{J}$ apresenta, em média, menos triglicerídeos hepáticos que a linhagem B6.

Ambas as linhagens acumularam triglicerídeos hepáticos após tratamento com DH+E. Entretanto, os camundongos da linhagem A/J acumularam menos que os da linhagem B6 (Figura 17). 
Figura 17 - Quantificação da concentração de triglicerídeos hepáticos dos camundongos B6 e $\mathrm{A} / \mathrm{J}$.

(A)

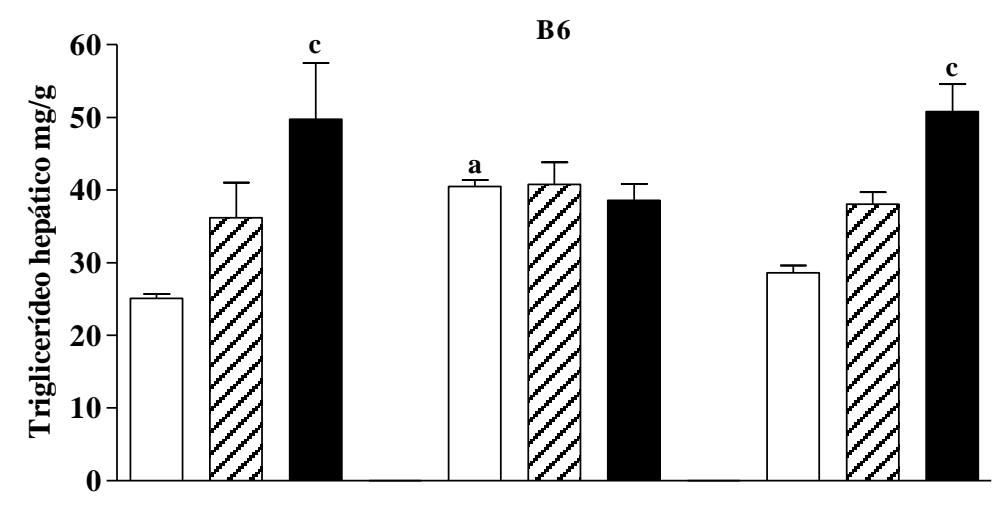

(B)

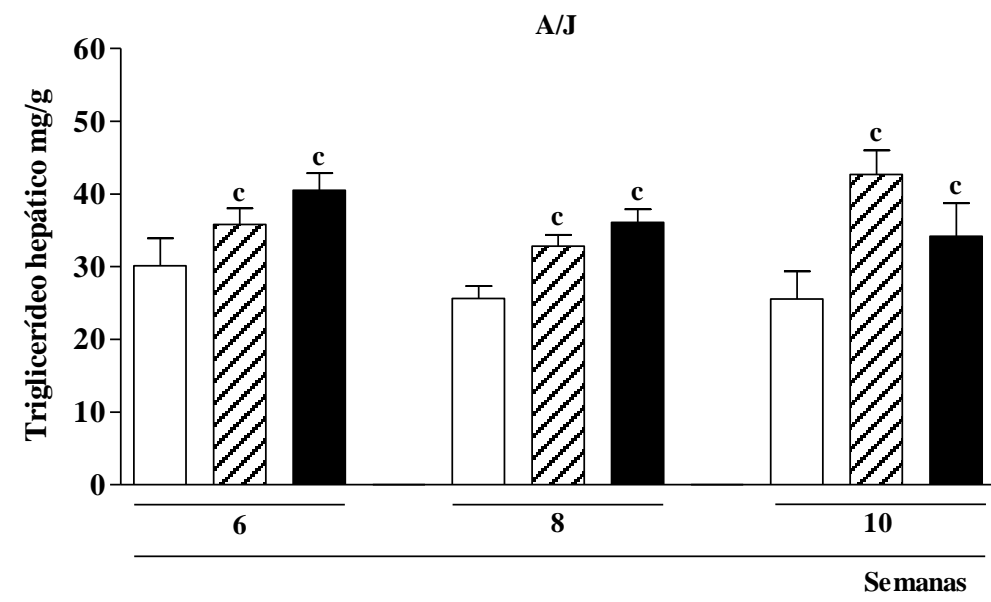

\section{$\square \mathrm{DH} \quad \square \mathrm{DH}+\mathrm{M} \quad \mathrm{DH}+\mathrm{E}$}

Em (A) apresentamos as concentrações de triglicerídeos hepático dos camundongos da linhagem B6 e em (B) apresentamos as concentrações dos camundongos da linhagem A/J após 6,8 e 10 semanas de tratamento com as diferentes dietas hiperlipídicas. Os resultados estão representados como média e erro padrão, $\mathrm{n} \geq 5$. As comparações correspondem: a vs. 6 semanas; $\mathbf{c} v s$. DH.

Siglas: DH - Dieta hiperlipídica; DH+M - Dieta hiperlipídica contendo maltodextrina; DH+E - Dieta hiperlipídica contendo etanol.

A seguir, apresentaremos as análises histopatológicas do fígado desses dois grupos de camundongos submetidos à DHA, onde o depósito de gordura no tecido hepático é uma característica marcante. Na Figura 18, apresentamos cortes histológicos de fígado da linhagem B6, corados com HE, após 6, 8 e 10 semanas de tratamento. Com 6 semanas de tratamento não houve alteração morfológica do fígado dos grupos DH e DH+M (Figura 18). Entretanto, observamos a presença de vesículas de lipídeos, patologicamente denominada 
esteatose, distribuídas na região intermediária entre o espaço porta hepático e a veia centro lobular no grupo que recebeu $\mathrm{DH}+\mathrm{E}$. Com 8 semanas de tratamento não houve alteração histológica nos grupos controles, porém encontramos vesículas, possivelmente lipídicas, nos grupos experimentais tratados com DH+E (Figura 18). Em ambos os grupos a distribuição destas vesículas encontra-se na região intermediária entre o espaço porta e a veia centro lobular. No grupo que recebeu $\mathrm{DH}+\mathrm{E}$ encontramos pequenos focos de infiltrado celular. Com 10 semanas de tratamento, os controles mantiveram a arquitetura hepática íntegra, no entanto podemos identificar no grupo controle tratado com $\mathrm{DH}+\mathrm{M}$ focos de infiltrado celular próximos aos vasos do espaço porta (Figura 18). No grupo que recebeu DH+E encontramos pequenos focos de infiltrado celular.

Figura 18 - Análise histopatológica de fígado dos camundongos B6 tratados com as diferentes dietas hiperlipídicas por 6, 8 e 10 semanas, após coloração HE.

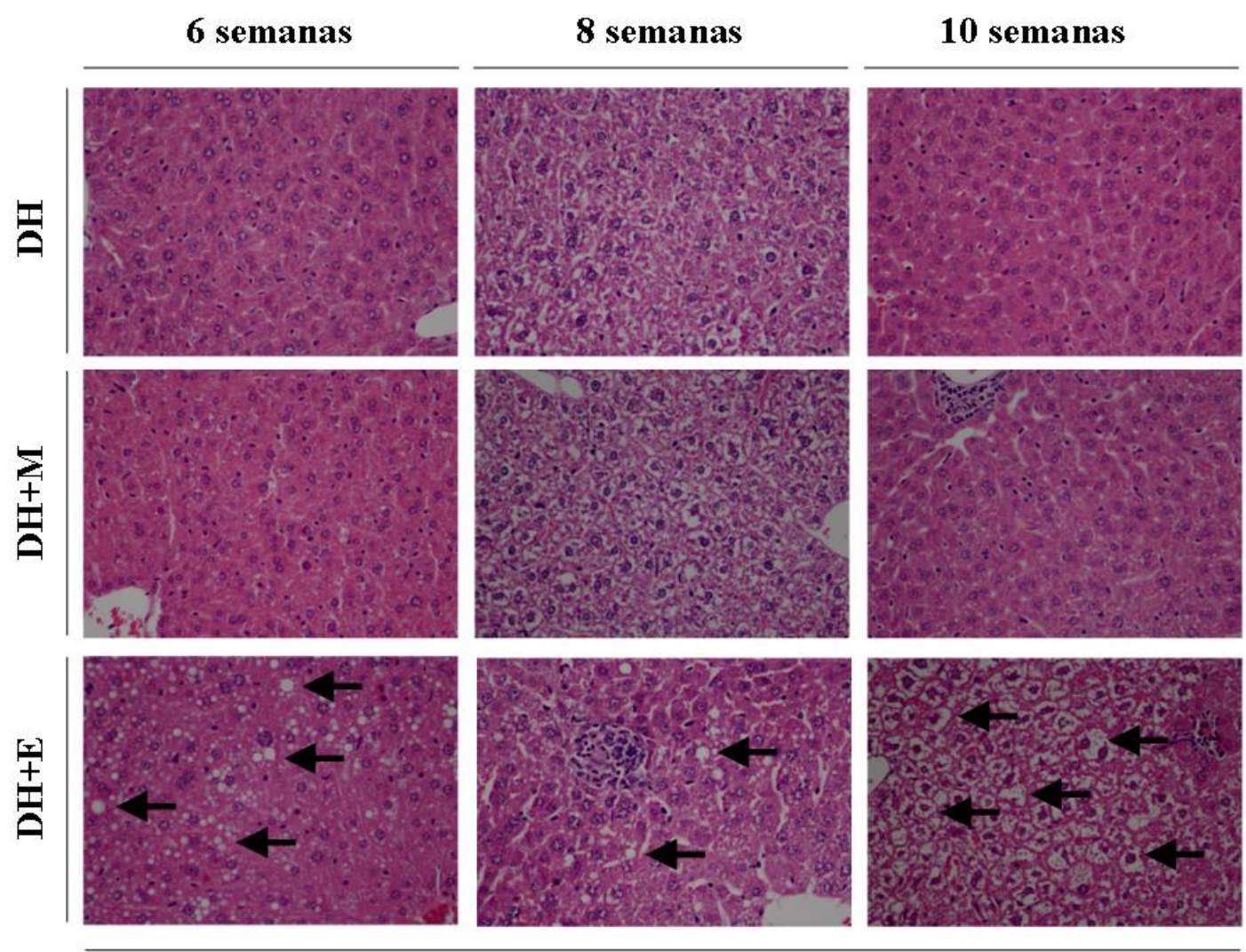

C57Bl/6

Coloração HE. As setas indicam vesículas presentes no interior dos hepatócitos nas condições de tratamento com etanol no tempo de 10 semanas. As setas apontam o depósito de gordura nos hepatócitos. Aumento 40x. Siglas: DH - Dieta hiperlipídica; DH+M - Dieta hiperlipídica contendo maltodextrina; DH+E - Dieta hiperlipídica contendo etanol. 
Confirmando os resultados obtidos com a razão peso hepático / peso corporal e determinação de triglicerídeos hepáticos para a linhagem B6, observamos a presença de vesículas lipídicas a partir da $6^{a}$ semana de tratamento quando tratada com DH+E. Estas vesículas se tornam mais freqüentes com o decorrer do tempo de tratamento, cobrindo cerca de $90 \%$ da área tecidual com 10 semanas (Figura 18).

Na Figura 19, apresentamos cortes histológicos de fígado da linhagem A/J, corados em HE, após 6, 8 e 10 semanas de tratamento. Os fígados dos camundongos A/J tratados com DH e DH+M não apresentaram alteração morfológica ou histológica após 6 semanas de tratamento (Figura 19), comportando-se da mesma forma que a linhagem B6. Entretanto, no grupo que recebeu $\mathrm{DH}+\mathrm{E}$ observamos a presença de menos vesículas distribuídas na região intermediária entre o espaço porta e a veia centro lobular, quando comparadas com a linhagem B6. Com 8 semanas de tratamento não houve alteração histológica nos grupos controles para a linhagem A/J (Figura 19). No grupo tratado com DH+E encontramos vesículas lipídicas na região intermediária entre o espaço porta e a veia centro lobular, mas em menor proporção em relação aos camundongos B6 tratados com DH+E. Por fim, os camundongos A/J tratados por 10 semanas com $\mathrm{DH}$ e $\mathrm{DH}+\mathrm{M}$ (Figura 19) mantiveram a arquitetura normal deste órgão. No grupo tratado com $\mathrm{DH}+\mathrm{E}$ observamos a presença de vesículas lipídicas na região intermediária do fígado, mas com menor diâmetro em relação às vesículas encontradas no fígado da linhagem B6. É possível que as diferenças de distribuição e diâmetro das vesículas lipídicas entre as linhagens sejam devidas ao metabolismo inato de cada uma.

Em suma, com relação aos camundongos da linhagem A/J tratados com $\mathrm{DH}+\mathrm{E}$ também observamos a presença de vesículas lipídicas desde a $6^{a}$ semana de tratamento, entretanto em menor proporção e diâmetro quando comparados aos camundongos da linhagem B6 tratada com DH+E (Figura 19).

Não encontramos diferenças no consumo da ração entre as linhagens. A média de consumo da ração para o grupo de animais B6 tratados com as diferentes dietas por 6, 8 e 10 semanas para a $\mathrm{DH}+\mathrm{E}$ foi $7,5 \mathrm{~g}$, para a $\mathrm{DH}+\mathrm{M}$ o consumo médio foi 8,2 $\mathrm{g}$ e para $\mathrm{DH}$ a média de consumo foi $9 \mathrm{~g}$ de ração semanal por camundongo. Para a linhagem A/J os valores são semelhantes aos da linhagem B6, onde os animais tratados com DH+E consumiram em média $8 \mathrm{~g}$ semanalmente por camundongo, quanto aos tratados com $\mathrm{DH}+\mathrm{M}$ o consumo médio foi 8 
g, já aqueles que receberam DH consumiram em média 8,7 g. De forma geral, os animais tratados apenas com DH consumiram 1,2 $\mathrm{g}$ a mais que os tratados com $\mathrm{DH}+\mathrm{M}$ ou $\mathrm{DH}+\mathrm{E}$.

Figura 19 - Análise histopatológica de fígado dos camundongos A/J tratados com as diferentes dietas hiperlipídicas por 6, 8 e 10 semanas, após coloração HE.

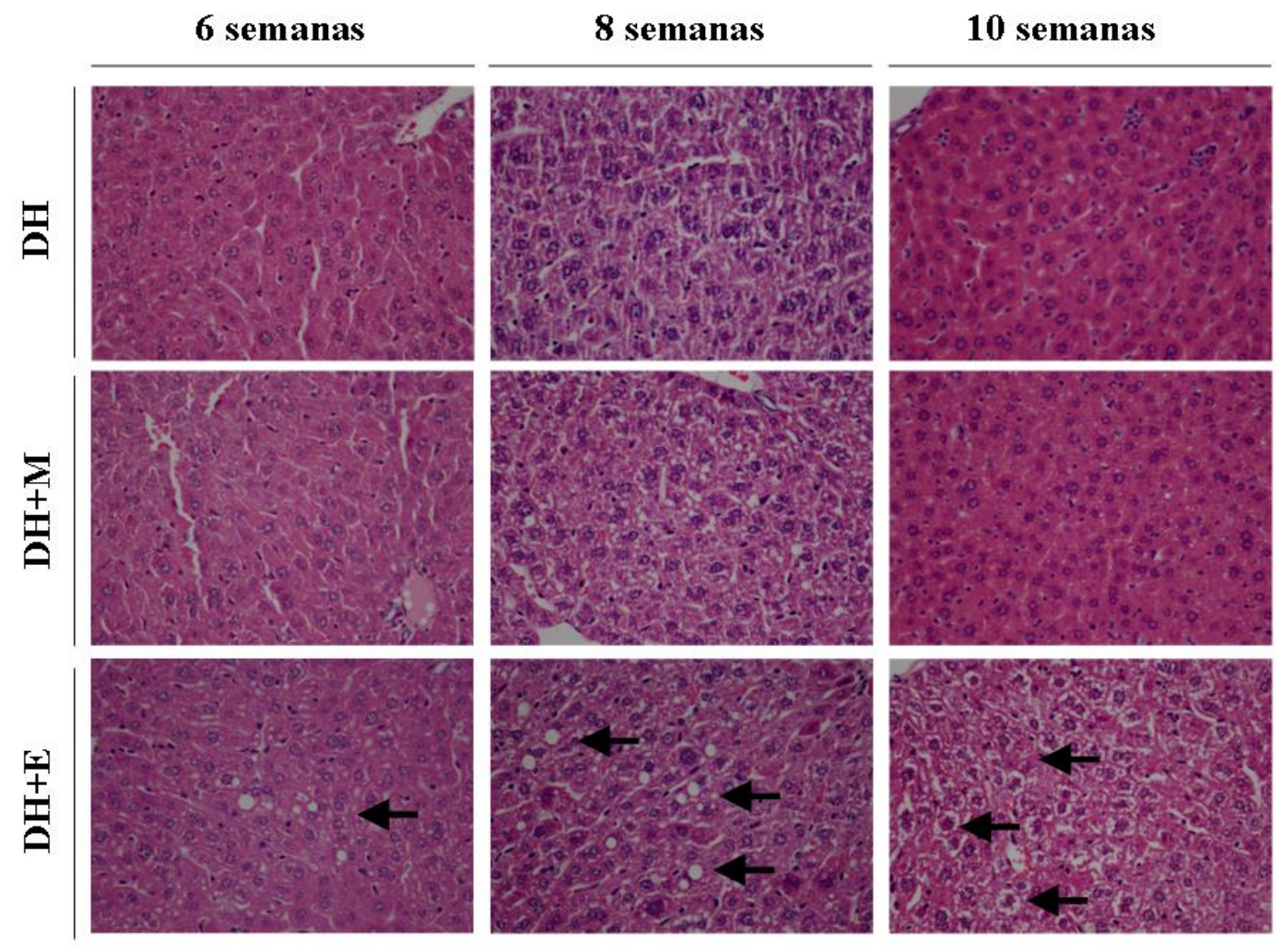

$\mathbf{A} / \mathbf{J}$

Coloração HE. Aumento 40x. As setas apontam o depósito de gordura nos hepatócitos.

Siglas: DH - Dieta hiperlipídica; DH+M - Dieta hiperlipídica contendo maltodextrina; DH+E - Dieta hiperlipídica contendo etanol.

Além da análise histopatológica empregando a coloração HE também analisamos os fígados após a coloração PAS, empregada para confirmar se as vesículas observadas por HE poderiam conter glicogênio (Figura 20 e 21).

Com esta coloração confirmamos a presença do depósito de glicogênio no citoplasma dos hepatócitos, e muitas vezes ao redor das vesículas mas não no interior das mesmas. Este padrão foi observado tanto nos fígados dos camundongos da linhagem B6 (Figura 20) quanto A/J (Figura 21), em todos os tratamentos. 
Figura 20 - Análise histopatológica de fígado dos camundongos B6 tratados com as diferentes dietas hiperlipídicas por 6, 8 e 10 semanas, após coloração PAS.

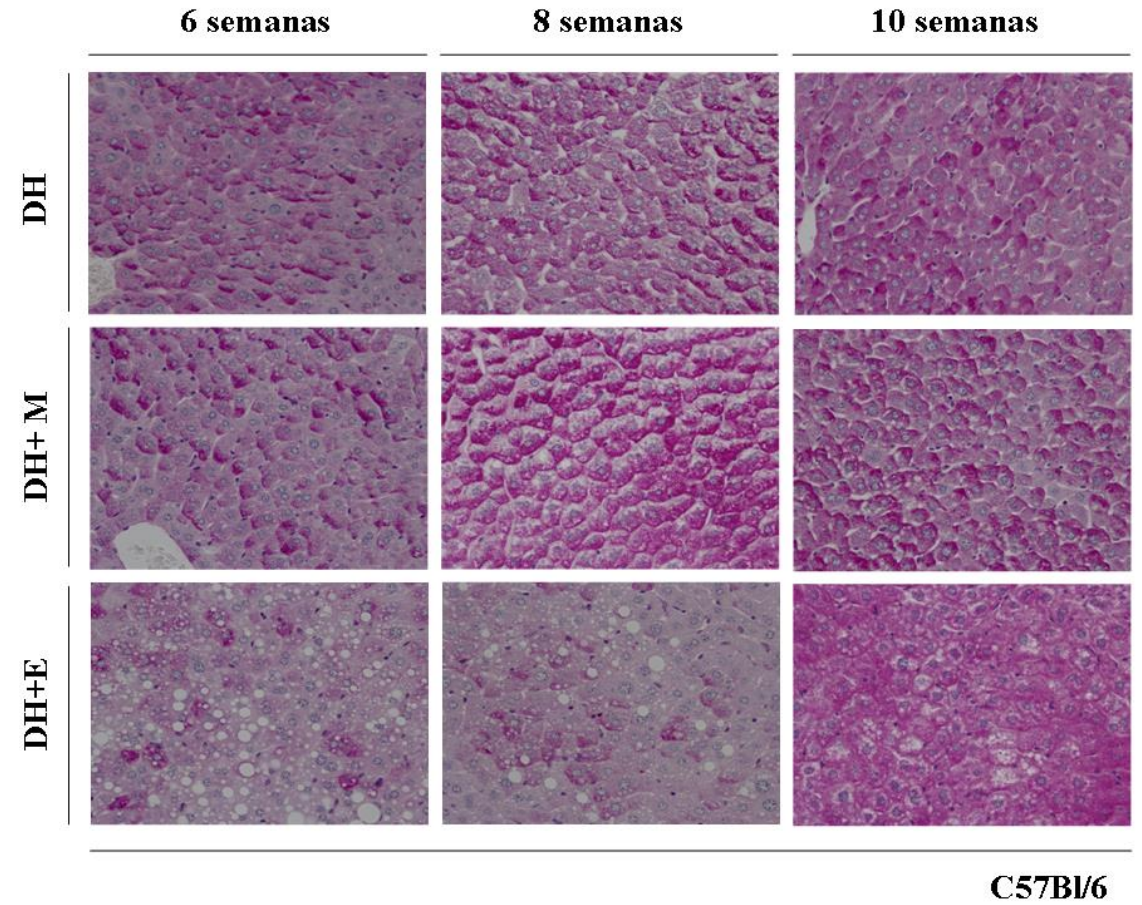

Siglas: DH - Dieta hiperlipídica; DH+M - Dieta hiperlipídica contendo maltodextrina; DH+E - Dieta hiperlipídica contendo etanol. Aumento 40x.

Figura 21 - Análise histopatológica de fígado dos camundongos A/J tratados com as diferentes dietas hiperlipídicas por 6, 8 e 10 semanas, após coloração PAS.

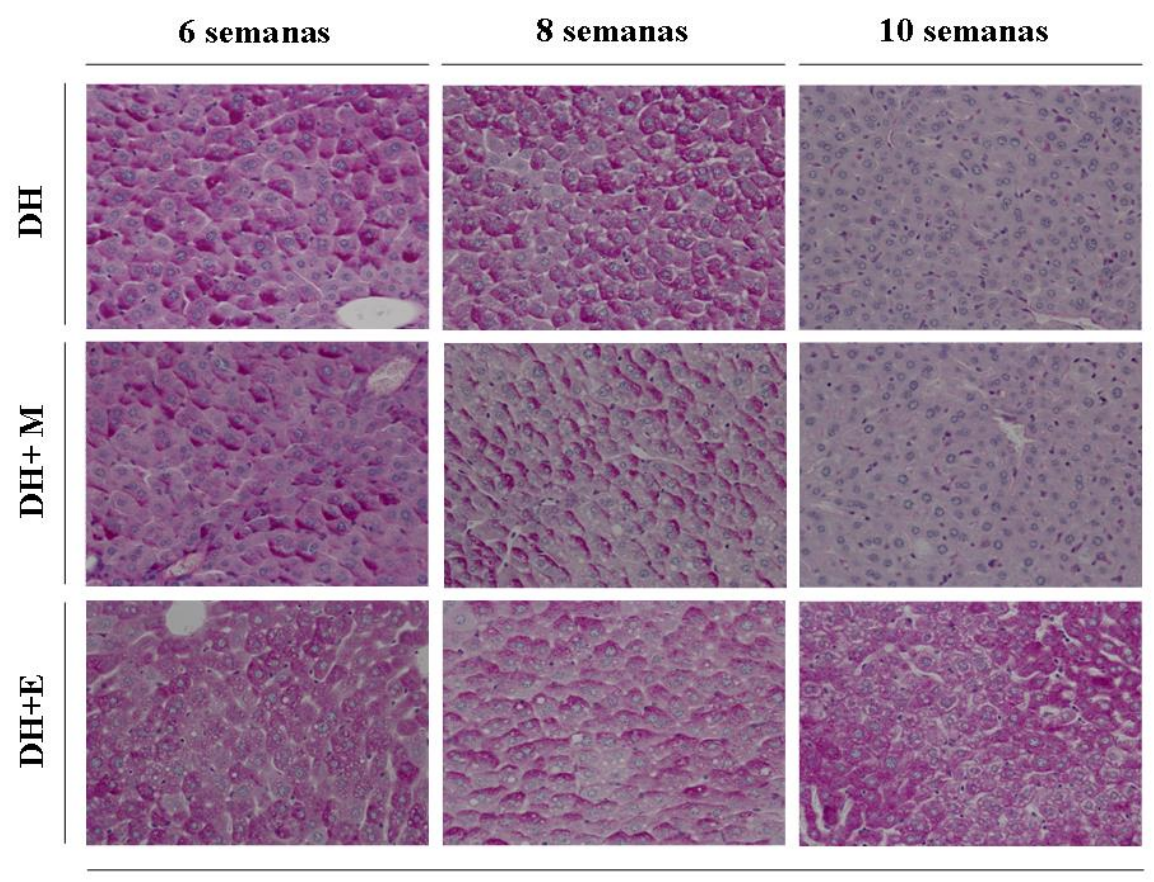

$\mathbf{A} / \mathbf{J}$

Siglas: DH - Dieta hiperlipídica; DH+M - Dieta hiperlipídica contendo maltodextrina; DH+E - Dieta hiperlipídica contendo etanol. Aumento 40x. 
Figura 22 - Análise histopatológica de fígado dos camundongos B6 tratados com as diferentes dietas hiperlipídicas após 6, 8 e 10 semanas, sob luz polarizada.

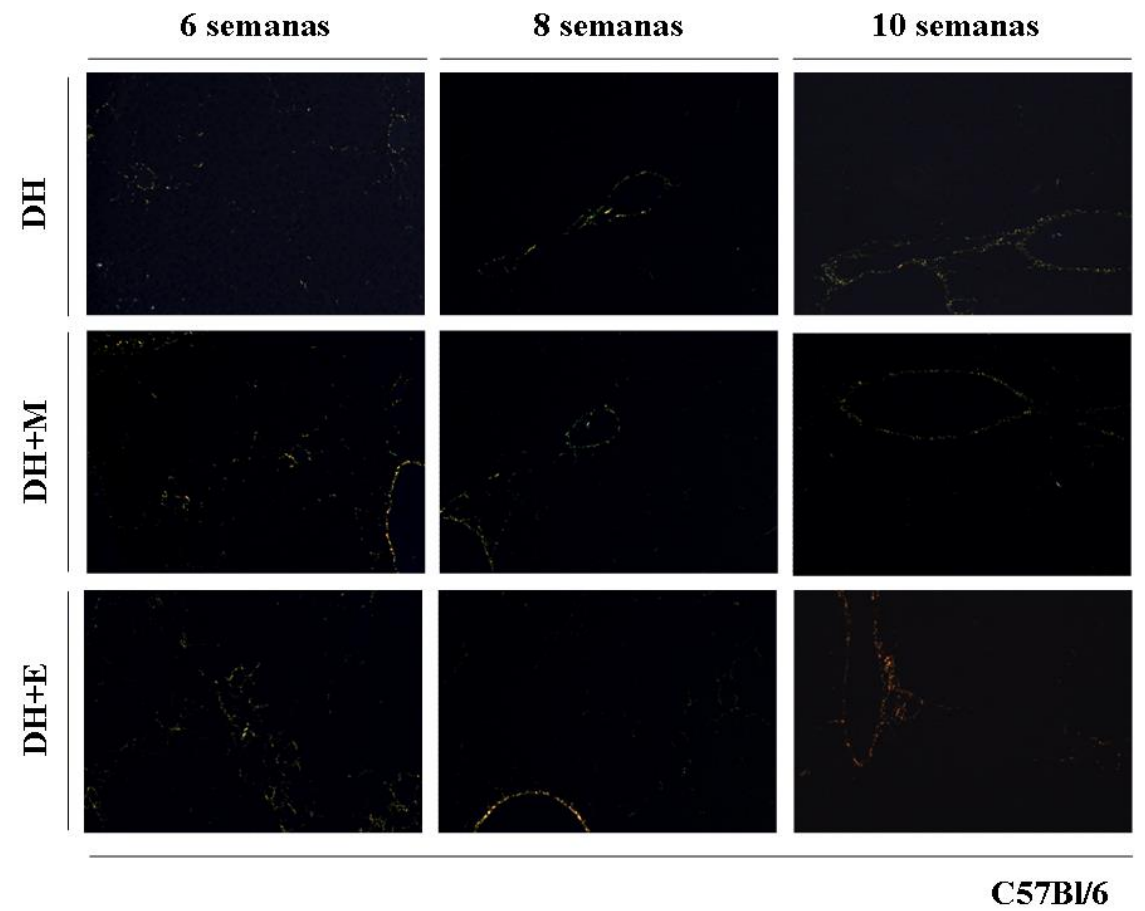

Siglas: DH - Dieta hiperlipídica; DH+M - Dieta hiperlipídica contendo maltodextrina; DH+E - Dieta hiperlipídica contendo etanol. Coloração picrossírius. Aumento 40x.

Figura 23 - Análise histopatológica de fígado dos camundongos A/J tratados com as diferentes dietas hiperlipídicas após 6, 8 e 10 semanas, sob luz polarizada.

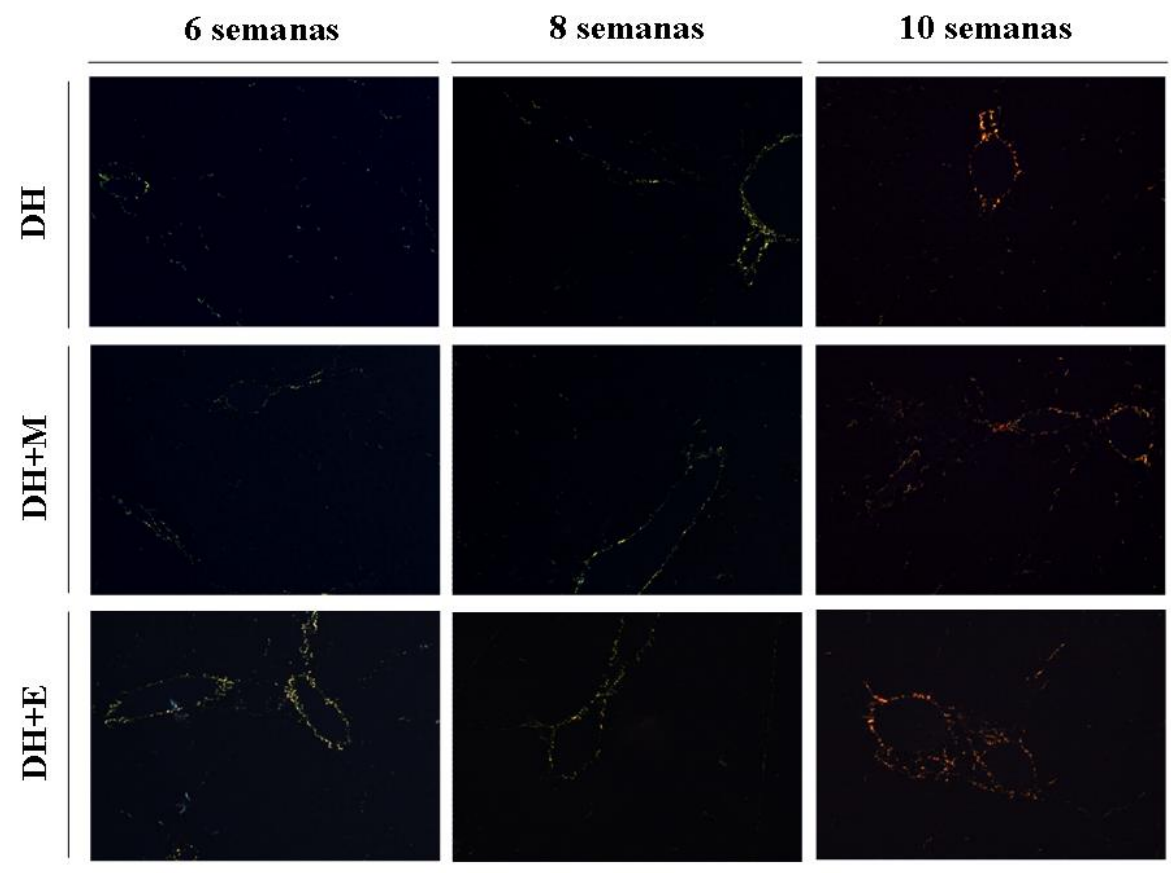

$\mathbf{A} / \mathbf{J}$

Siglas: DH - Dieta hiperlipídica; DH+M - Dieta hiperlipídica contendo maltodextrina; DH+E - Dieta hiperlipídica contendo etanol. Coloração picrossírius. Aumento 40x. 
Devido ao fato do alcoolismo crônico poder evoluir para cirrose e fibrose, buscamos identificar a presença de fibras de colágeno no tecido hepático das linhagens B6 e A/J após o tratamento com etanol. Os cortes histológicos de fígados corados pela técnica de picrossírius foram analisados em microscópio sob luz polarizada. Esta coloração é específica para fibras de colágeno. Com a luz polarizada é possível diferenciar as fibras de colágeno tipo I e tipo III. A primeira é uma fibra sintetizada constitutivamente e apresenta coloração verde / amarelada sob luz polarizada, já a segunda é sintetizada em condições de reparo tecidual e apresenta coloração avermelhada, quando atingida por luz polarizada. Para ambas as linhagens houve substituição gradativa de fibras de colágeno do tipo I pelo tipo III no fígado dos camundongos tratados ou não com etanol (Figura 22 e 23).

Conclusão da secão 5.2.2.1: $O$ período de 6 semanas foi crítico para ambas as linhagens tratadas com $\mathrm{DH}+\mathrm{E}$, entretanto os camundongos da linhagem A/J apresentaram maior dificuldade de ganho de peso ao final do tratamento em relação aos camundongos B6 também tratados com $\mathrm{DH}+\mathrm{E}$. $\mathrm{O}$ aumento da razão do peso hepático pelo peso corporal e o acúmulo de triglicerídeos no tecido hepático foi observado em ambas as linhagens quando tratadas com DH+E. Porém, neste último aspecto os camundongos da linhagem A/J apresentaram menor acúmulo em relação aos da $\mathrm{B} 6$ quando tratadas com $\mathrm{DH}+\mathrm{E}$. 


\subsubsection{Avaliação da função hepática e hematológica}

Pelo fato do fígado ser o órgão principalmente atingido em nosso modelo direcionamos nosso estudo para identificar outras possíveis alterações presentes neste órgão. Afim de confirmar se houve modificações funcionais oriundas da injúria hepática pelos diferentes tratamentos, determinamos a concentração plasmática da enzima ALT nestes camundongos, mas não identificamos diferenças significativas entre os tratamentos (APÊNDICE C - Figura C.2).

Mesmo sem encontrar variações significativas na concentração plasmática da ALT, buscamos também por alterações sistêmicas que poderiam estar relacionadas com a injúria sofrida por este órgão. Primeiramente analisamos o perfil leucocitário total no sangue periférico dos camundongos submetidos a cada um dos tratamentos (Figura 24), visando identificar possíveis modificações inflamatórias.

Com relação ao número absoluto de leucócitos para os camundongos da linhagem B6 não detectamos efeito de interação entre tratamento e semana, $p=0,623$. Também não encontramos diferença significativa entre os tratamentos, $p=0,080$, nem entre as semanas, $p=0,646$ (Figura 24A). Ou seja, não houve alteração no número absoluto de leucócitos periféricos para os camundongos da linhagem B6 submetidos aos diferentes tratamentos.

Quanto ao número de leucócitos circulantes para os camundongos da linhagem A/J tratados com as diferentes dietas encontramos efeito de interação entre tratamento e semana, $p<0,001$. Isto significa que o número de leucócitos se alterou dependentemente do tipo de dieta e do tempo de tratamento. Os camundongos A/J tratados com $\mathrm{DH}+\mathrm{E}$ apresentaram aumento significativo do número absoluto de leucócitos circulantes com o decorrer do tempo de tratamento, $p<0,05$. Por outro lado, aqueles que receberam $\mathrm{DH}+\mathrm{M}$ ou $\mathrm{DH}$ apresentaram redução significativa do número de leucócitos totais com o decorrer do tempo de tratamento, $p<0,05$. Comparando os tratamentos, os camundongos da linhagem $\mathrm{A} / \mathrm{J}$ tratados com $\mathrm{DH}+\mathrm{E}$ por 6 semanas apresentaram queda significativa no número de leucócitos totais em comparação aos camundongos tratados com DH+M e DH, $p<0,05$. Por outro lado, após 10 semanas de tratamento ocorreu uma inversão do comportamento leucocitário em relação a 6 semanas de tratamento, onde os camundongos tratados com $\mathrm{DH}+\mathrm{E}$ apresentaram aumento significativo no número de leucócitos totais em comparação aos camundongos tratados com $\mathrm{DH}+\mathrm{M}$ e DH, $p<0,05$ (Figura 24B). 
Figura 24 - Número de leucócitos totais periféricos após tratamento com as diferentes dietas hiperlipídicas por 6, 8 e 10 semanas de tratamento das linhagens B6 e A/J.

(A)

B6

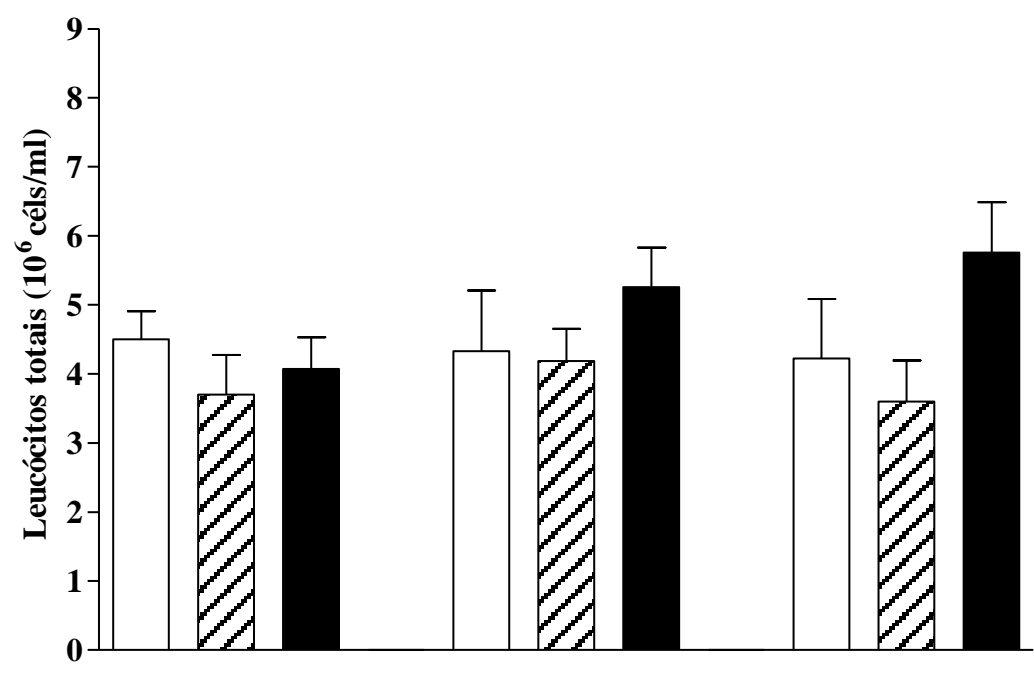

(B)
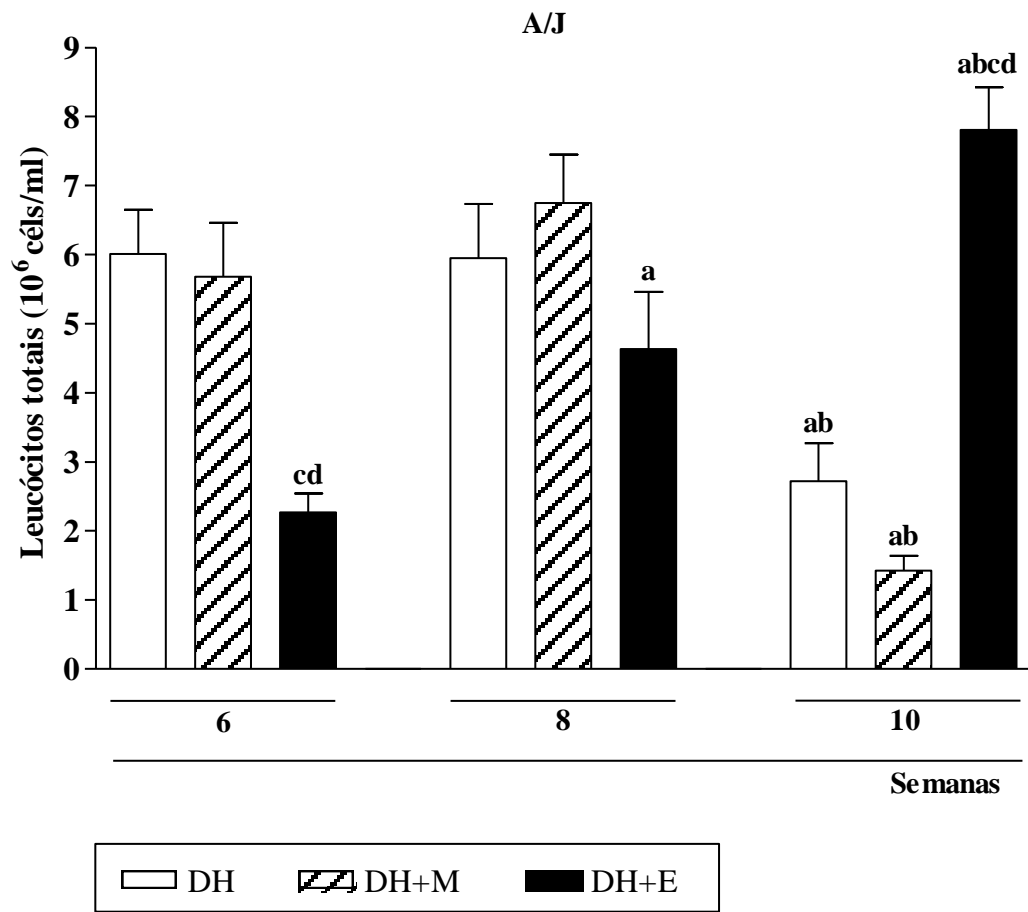

Em (A) apresentamos a contagem de leucócitos totais circulantes para os camundongos da linhagem B6 e em (B) da linhagem A/J. Os resultados estão representados como média e erro padrão, $\mathrm{n} \geq 5$. As comparações correspondem: a vs. 6 semanas; b vs. 8 semanas; c vs. DH; d vs. DH+M; $p<0,05$.

Siglas: DH - Dieta hiperlipídica; DH+M - Dieta hiperlipídica contendo maltodextrina; DH+E - Dieta hiperlipídica contendo etanol.

Durante os três períodos de tratamento apenas os camundongos da linhagem A/J apresentaram alterações no número de leucócitos circulantes para todos os tipos de tratamento. Em especial, quando tratados com $\mathrm{DH}+\mathrm{E}$ durante 10 semanas apresentaram 
aumento no número de leucócitos circulantes em comparação aos camundongos tratados com DH+M e DH (Figura 24).

Conclusão da secão 5.2.2.2: O tempo de tratamento em conjunto com a dieta $D H+E$ foi importante para alteração do número de leucócitos periféricos circulantes na linhagem A/J. Até o momento, a linhagem A/J mostrou-se mais sensível ao tratamento com $\mathrm{DH}+\mathrm{E}$, considerando a dificuldade de ganho de peso e as alterações leucocitárias, resultados estes que corroboram com os resultados obtidos com o tratamento agudo. Porém, a linhagem B6 sofreu mais dano hepático que a linhagem A/J, considerando-se o acúmulo de triglicerídeos no fígado.

\subsubsection{Avaliação da resposta inflamatória no micro-ambiente hepático.}

Como já mencionado na introdução deste capítulo a progressão da DHA segue um padrão caracterizado pelo acúmulo hepático de gordura (esteatose), seguido por inflamação, necrose e apoptose dos hepatócitos, nódulos regenerativos, fibrose e cirrose (NAGY, 2003). Modelos sobre o desenvolvimento da doença sugerem que o acúmulo de triglicerídeos nos hepatócitos seja lipotóxico e atue como um evento inicial no processo da doença estimulando a resposta inflamatória (KOTEISH; DIEHL, 2001). Por esta razão, fomos analisar outros parâmetros da resposta inflamatória quantificando por ELISA as concentrações das citocinas pró-inflamatórias: TNF- $\alpha$ (Figura 25A), IL-1 $\beta$ (Figura 25B), IL-6 (Figura 25C), IL-17 (Figura 25D), IL-12p40 e p70 (Figura 25E e F); e também da citocina anti-inflamatória IL10 (Figura 25G) produzidas no fígado. Por fim, mensuramos a produção de NO a partir do homogenato hepático (Figura 25H). Os resultados destas leituras foram posteriormente normalizados pela concentração de proteínas totais presentes nos homogenatos de fígado.

Dentre as citocinas pró-inflamatórias envolvidas com o mecanismo da DHA sugere-se que a citocina TNF- $\alpha$ atue como um fator chave (NAGATA; SUZUKI; SAKAGUCHI, 2008). Investigando a concentração hepática de TNF- $\alpha$ para a linhagem B6 não detectamos efeito de interação entre tratamento e semana, $p=0,607$. Também não detectamos diferença significativa entre os tratamentos com $p=0,086$. Entretanto, encontramos diferença significativa entre as semanas, $p=0,013$, onde independentemente do tratamento aplicado após 10 semanas de tratamento houve redução significativa da concentração de TNF- $\alpha$ em comparação ao tempo de 6 semanas de tratamento, $p<0,05$ (Figura 25A). 
Quanto à linhagem A/J constatamos a presença de efeito de interação entre tratamento e semana, $p=0,034$. A concentração de TNF- $\alpha$ se manteve a mesma ao longo das semanas de tratamento com $\mathrm{DH}+\mathrm{E}$, porém os camundongos que receberam $\mathrm{DH}$ ou $\mathrm{DH}+\mathrm{M}$ apresentaram redução significativa na concentração de TNF- $\alpha$ no homogenato hepático de 6 para 10 semanas de tratamento, $p<0,05$. Da mesma forma os camundongos que receberam $\mathrm{DH}+\mathrm{M}$ também apresentaram redução significativa na concentração de TNF- $\alpha$ no homogenato hepático de 8 para 10 semanas de tratamento, $p<0,05$. Após 10 semanas de tratamento com $\mathrm{DH}+\mathrm{E}$ observamos aumento significativo na concentração de TNF- $\alpha$ no homogenato hepático em comparação ao tratamento com $\mathrm{DH}+\mathrm{M}$ e com DH, $p<0,05$ (Figura 25A).

Desde a $6^{a}$ semana de tratamento observamos uma tendência no aumento da concentração da citocina TNF- $\alpha$ na linhagem A/J após o tratamento com DH+E. Após um período de 10 semanas detectamos significativamente este aumento, o qual pode ser um reflexo do micro-ambiente pró-inflamatório induzido pelo etanol. Por outro lado a linhagem B6 não apresentou variaçães marcantes quanto à concentração desta citocina.

IL-1ß é uma potente citocina pró-inflamatória, cuja concentração hepática está aumentada em pacientes com DHA (PETRASEK et al., 2012). Avaliando esta citocina para os camundongos da linhagem B6 encontramos efeito de interação entre tratamento e semana, $p<0,001$, onde os camundongos tratados com $\mathrm{DH}+\mathrm{E}$ apresentam redução significativa da concentração de IL-1ß de 6 e 8 para 10 semanas de tratamento, $p<0,05$. Ainda, após 10 semanas de tratamento identificamos redução significativa da concentração de IL-1ß dos camundongos tratados com $\mathrm{DH}+\mathrm{E}$ em comparação aos camundongos tratados com $\mathrm{DH}+\mathrm{M}$ e $\mathrm{DH}, p<0,05$ (Figura 25B).

Considerando os camundongos da linhagem A/J também identificamos efeito de interação entre tratamento e semana, $p<0,001$. Para esta linhagem observamos um comportamento diferente para os camundongos tratados com $\mathrm{DH}+\mathrm{E}$ com redução significativa da concentração de IL-1ß de 6 para 8 semanas e aumento significativo de 8 para 10 semanas de tratamento, $p<0,05$. Observamos no período de 8 semanas redução significativa da concentração de IL-1ß nos camundongos tratados com DH+E em comparação aos tratados com DH+M (Figura 25B).

Para os camundongos da linhagem B6 a concentração hepática da citocina IL-1ß sofreu redução durante os períodos de tratamento, isto é as concentraçães caíram de 6 e 8 
para 10 semanas. E também a concentração da citocina IL-1ß foi significativamente menor nos tratados com $\mathrm{DH}+\mathrm{E}$ que nos tratados com $\mathrm{DH}+\mathrm{M}$ ou $\mathrm{DH}$.

Avaliando a concentração da citocina IL-6 no homogenato hepático dos camundongos da linhagem B6 constatamos a ausência de efeito de interação entre tratamento e semana, $p=0,202$. Porém, encontramos diferença significativa entre os tratamentos e as semanas, $p=0,009$ e $p<0,001$ respectivamente. Observamos que a concentração de IL-6 hepática foi significativamente reduzida de 6 e 8 semanas para 10 semanas, $p<0,05$, para todos os tratamentos. Comparando os tratamentos identificamos que a concentração de IL-6 hepática foi significativamente maior nos camundongos tratados com $\mathrm{DH}+\mathrm{E}$ e $\mathrm{DH}+\mathrm{M}$ que nos tratados com DH para todas as semanas de tratamento, $p<0,05$ (Figura 25C).

Com relação aos camundongos da linhagem A/J não encontramos efeito de interação entre tratamento e semana, $p=0,102$. Porém, encontramos diferença significativa entre os tratamentos e entre as semanas, $p=0,028$ e $p<0,001$, respectivamente. Observamos que houve significativa redução na concentração de IL-6 no homogenato hepático ao longo das semanas de tratamento, $p<0,05$. Ainda identificamos que a concentração de IL-6 foi significativamente maior nos camundongos tratados com $\mathrm{DH}+\mathrm{E}$ que nos camundongos tratados com $\mathrm{DH}+\mathrm{M}$, independentemente do tempo de tratamento, $p<0,05$ (Figura 25C).

Identificamos um comportamento muito parecido entre as linhagens para a concentração da citocina IL-6 no tecido hepático. A concentração de IL-6 no fígado reduziu-se ao longo do tratamento, mas apenas os grupos tratados com $\mathrm{DH}+\mathrm{E}$ apresentaram aumento em relação aos controles. Isto indica que o consumo alcoólico induz o aumento de IL-6, porém esse aumento foi marcante nas primeiras semanas de tratamento, como observado com o tratamento agudo que elevou a concentração de IL-6 no plasma (Figura 13) e com o tratamento crônico de 6 semanas que elevou a concentração de IL-6 no fígado (Figura 25C).

Em pacientes com DHA a secreção de IL-17 no ambiente hepático, por células T infiltradas, contribui para o recrutamento de neutrófilos e manutenção do ambiente inflamatório (LEMMERS et al., 2009), pois esta citocina estimula células endoteliais e fibroblastos a secretarem citocinas como IL-6, IL-8, e também a prostaglandina E2. A análise estatística da concentração da citocina IL-17 no fígado dos camundongos da linhagem B6 mostrou que não existe efeito de interação entre tratamento e semana, $p=0,876$. Entretanto, 
identificamos diferença significativa entre as semanas de tratamento, $p<0,001$. A concentração da citocina IL-17 foi significativamente maior após 6 semanas do que após 8 ou 10 semanas de tratamento, $p<0,05$. Ou seja, houve redução da concentração de IL-17 ao longo das semanas de tratamento. Ainda, identificamos diferenças significativas entre as dietas, $p=0,002$, onde observamos redução significativa de IL-17 no homogenato hepático nos camundongos que receberam $\mathrm{DH}+\mathrm{E}$ em relação aos tratados com $\mathrm{DH}+\mathrm{M}$ e $\mathrm{DH}, p<0,05$ (Figura 25D).

Para a concentração hepática de IL-17 nos camundongos da linhagem A/J não detectamos efeito de interação entre tratamento e semana, $p=0,656$. Não encontramos diferença significativa entre os tratamentos, $p=0,078$, porém identificamos diferença significativa entre as semanas, $p<0,001$. A concentração de IL-17 foi significativamente maior após 6 semanas do que após 8 ou 10 semanas de tratamento, $p<0,05$ (Figura 25D).

Com o decorrer do período de tratamento a concentração hepática da citocina IL-17 reduziu-se em ambas as linhagens. Porém, além dessa redução com o decorrer do período de tratamento, apenas os camundongos da linhagem B6 tratados com DH+E tiveram a concentração da citocina $I L-17$ reduzida em relação àqueles tratados com $\mathrm{DH}+\mathrm{M}$ e $\mathrm{DH}$ (Figura 25D).

Continuando a análise das citocinas determinamos a concentração de IL-12. Dosamos a subunidade p40 e sua forma completa p70. A citocina IL-12 é secretada principalmente por células dendríticas sendo importante na defesa de patógenos intracelulares, indução da produção de IFN- $\gamma$ por células T e NK, co-estimulação a proliferação de linfócitos presentes no sangue periférico e indução da diferenciação para o perfil Th1 (TUNG et al., 2010).

Investigando a concentração hepática da subunidade p40 nos camundongos da linhagem B6 não encontramos efeito de interação entre tratamento e semana, $p=0,576$. Mas, identificamos diferença significativa entre as semanas de tratamento, $p<0,001$. Observamos que a concentração de IL-12p(40) no homogenato foi significativamente maior após 8 semanas de tratamento em comparação a 6 e 10 semanas de tratamento, $p<0,05$. E a concentração após 6 semanas de tratamento foi maior que após 10 semanas de tratamento, $p<0,05$. Identificamos também diferença significativa entre as dietas, $p=0,027$. Comparando os tratamentos observamos que os camundongos tratados com $\mathrm{DH}+\mathrm{E}$ apresentaram significativamente maior concentração hepática de IL-12p(40) que os tratados com DH, $p<0,05$ (Figura 25E). 
Quanto à concentração hepática de IL-12p(40) para os camundongos da linhagem A/J não identificamos efeito de interação entre tratamento e semana, $p=0,351$. Todavia, existe diferença significativa entre as semanas de tratamento, $p<0,001$. Com relação às semanas de tratamento observamos que a concentração hepática de IL-12p(40) compreende o seguinte intervalo $6>8>10$ semanas, $p<0,05$. Identificamos diferença significativa entre as dietas, $p=0,024$, onde os camundongos tratados com $\mathrm{DH}+\mathrm{E}$ apresentaram significativamente maior concentração hepática de IL-12p(40) que os tratados com DH, $p<0,05$ (Figura 25E).

Os resultados obtidos com as determinações da citocina IL-12p(70) são muito semelhantes aos descritos acima para IL-12p(40). Para os camundongos da linhagem B6 não detectamos efeito de interação entre tratamento e semana, $p=0,097$. Também não detectamos diferença significativa entre os tratamentos, $p=0,232$. Mas, encontramos diferença significativa entre as semanas de tratamento, $p<0,001$., onde observamos que a concentração de IL-12p(70) foi maior após $6>8>10$ semanas, $p<0,05$ (Figura 25F).

Com relação à concentração hepática da citocina IL-12p(70) para os camundongos da linhagem $\mathrm{A} / \mathrm{J}$ não detectamos efeito de interação entre tratamento e semana, $p=0,367$, não detectamos diferença significativa entre os tratamentos, $p=0,407$, mas encontramos diferença significativa entre as semanas de tratamento, $p<0,001$. A concentração de IL-12p(70) hepática foi significativamente maior após 6 e 8 semanas que após 10 semanas de tratamento, $p<0,05$ (Figura 25F).

A citocina IL-12, de forma geral, teve a sua concentração reduzida com as semanas de tratamento para as duas linhagens (Figura 25E e 25F). Entretanto, identificamos aumento significativo apenas na concentração da subunidade p40 nos camundongos tratados com $\mathrm{DH}+\mathrm{E}$ em relação aos tratados com $\mathrm{DH}$, tanto para a linhagem $\mathrm{B} 6$ quanto para a linhagem A/J (Figura $25 F)$.

Controlar e resolver de maneira apropriada um processo inflamatório é uma característica essencial. Falhas no término deste processo contribui para numerosas doenças inflamatórias crônicas, incluindo a DHA (VIDALI et al., 2008). Avaliando a concentração hepática da citocina anti-inflamatória IL-10 nos camundongos B6 encontramos efeito de interação entre tratamento e semana, $p<0,001$. Observamos que nos camundongos tratados com $\mathrm{DH}+\mathrm{E}$ houve aumento significativo da concentração hepática de IL-10 de 6 para 8 semanas e redução significativa de 8 para 10 semanas de tratamento, $p<0,05$. Para os camundongos tratados com $\mathrm{DH}+\mathrm{M}$ houve aumento significativo de 6 para 8 e de 6 para 10 
semanas, $p<0,05$. Entre os tratamentos $\mathrm{DH}+\mathrm{E}$ e $\mathrm{DH}+\mathrm{M}$ identificamos redução significativa da concentração hepática de IL-10 após 10 semanas de tratamento, $p<0,05$. E entre DH+E e DH, para os que receberam $\mathrm{DH}+\mathrm{E}$ identificamos aumento significativo da concentração hepática de IL-10 após 8 semanas de tratamento e redução significativa após 10 semanas de tratamento, $p<0,05$ (Figura 25G).

Tratando-se da concentração hepática de IL-10 para os camundongos da linhagem A/J também identificamos efeito de interação entre tratamento e semana, $p<0,001$. Observamos que nos camundongos tratados com $\mathrm{DH}+\mathrm{E}$ houve redução significativa da concentração hepática de IL-10 de 8 para 10 semanas e aumento significativo de 6 para 10 semanas de tratamento, $p<0,05$. Entre os tratamentos $\mathrm{DH}+\mathrm{E}$ e $\mathrm{DH}+\mathrm{M}$ identificamos redução significativa da concentração hepática de IL-10 após 8 semanas de tratamento, $p<0,05$, mas após 10 semanas de tratamento a concentração hepática de IL-10 aumentou significativamente, $p<0,05$. E entre os tratamentos $\mathrm{DH}+\mathrm{E}$ e $\mathrm{DH}$ identificamos após 10 semanas de tratamento aumento significativo na concentração hepática de IL-10, $p<0,05$ (Figura 25G).

A citocina anti-inflamatória IL-10 estabelece um ponto de diferença notável entre as linhagens. Os camundongos da linhagem B6 tratados com DH+E tiveram aumento significativo desta citocina após 8 semanas de tratamento e redução significativa de IL-10 após 10 semanas de tratamento. Já os camundongos da linhagem A/J apresentaram aumento significativo de IL-10 hepática apenas após 10 semanas de tratamento. Estes resultados sugerem uma modulação anti-inflamatória pela linhagem A/J dentro de um contexto pró-inflamatório induzido pelo consumo crônico do etanol e concomitante acúmulo de triglicerídeos hepáticos (Figura 25G).

Na sequência, perguntamo-nos quais seriam as células presentes no infiltrado celular encontrado nas análises histológicas e que poderiam contribuir para a resposta inflamatória no micro ambiente hepático. Para tentar responder estas perguntas dosamos a produção de óxido nítrico (NO), na forma de nitrito, presente no homogenato hepático. O NO é um mediador inflamatório relacionado à vaso dilatação, produzido principalmente por macrófagos e células endoteliais, que ocorre nas fases iniciais do processo inflamatório e com função microbicida. Avaliando a concentração de NO no homeganto hepático dos camundongos da linhagem B6 encontramos efeito de interação entre tratamento e semana, $p<0,001$. Dentre os camundongos que foram tratados com $\mathrm{DH}+\mathrm{E}$ observamos redução significativa de NO após 10 semanas de tratamento em relação a 6 e 8 semanas, $p<0,05$. Já os camundongos tratados com $\mathrm{DH}$ 
apresentaram aumento significativo de NO após 10 semanas de tratamento em relação aos camundongos tratados com a mesma dieta por 8 semanas, $p<0,05$. Entre os tratamentos, os camundongos tratados com DH+E tiveram redução significativa da concentração de $\mathrm{NO}$ em relação aos tratados com DH, $p<0,05$ (Figura 25H).

Quanto à concentração de NO para os camundongos da linhagem A/J tratados com as diferentes dietas também identificamos efeito de interação entre tratamento e semana, $p<0,001$. Dentre os camundongos que receberam $\mathrm{DH}+\mathrm{E}$ observamos redução significativa na produção de NO de 6 para 8 semanas de tratamento, $p<0,05$, e aumento significativo de 8 para 10 semanas de tratamento, $p<0,05$. Após 8 semanas de tratamento dos camundongos $\mathrm{A} / \mathrm{J}$ com $\mathrm{DH}+\mathrm{E}$ observamos redução significativa da produção de NO em relação àqueles tratados com $\mathrm{DH}+\mathrm{M}$ (Figura 25H).

Seria pertinente correlacionar e complementar estes resultados com a identificação de macrófagos e neutrófilos infiltrados no tecido hepático pela técnica de imunohistoquímica especifica para estas populações celulares. 
Figura 25 - Determinação da concentração das citocinas inflamatórias e NO em homogenato de tecido hepático após 6,8 e 10 semanas de tratamento com diferentes dietas hiperlipídicas nas linhagens B6 e A/J.

(A) TNF
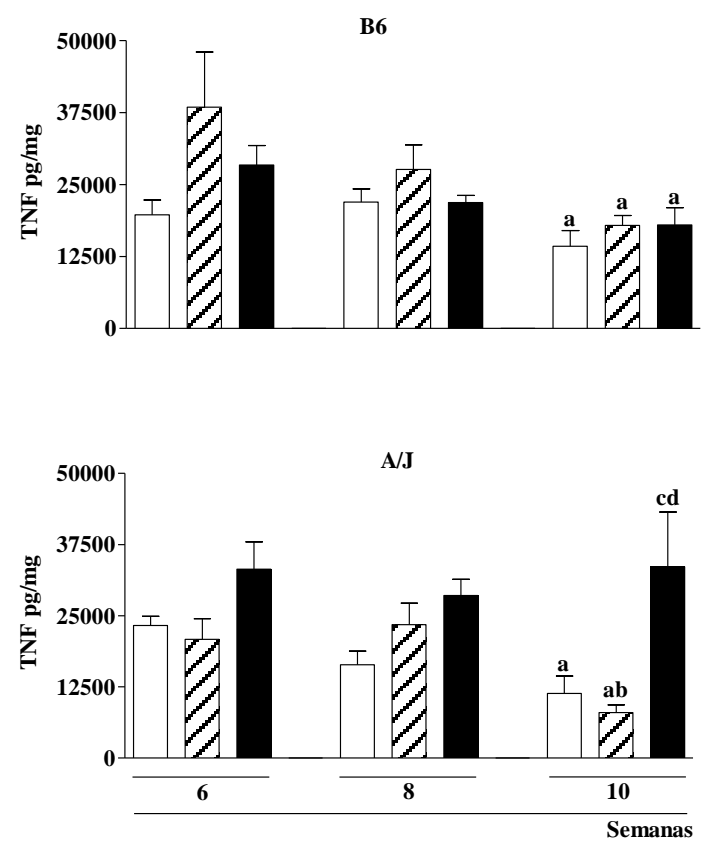

(C) IL-6
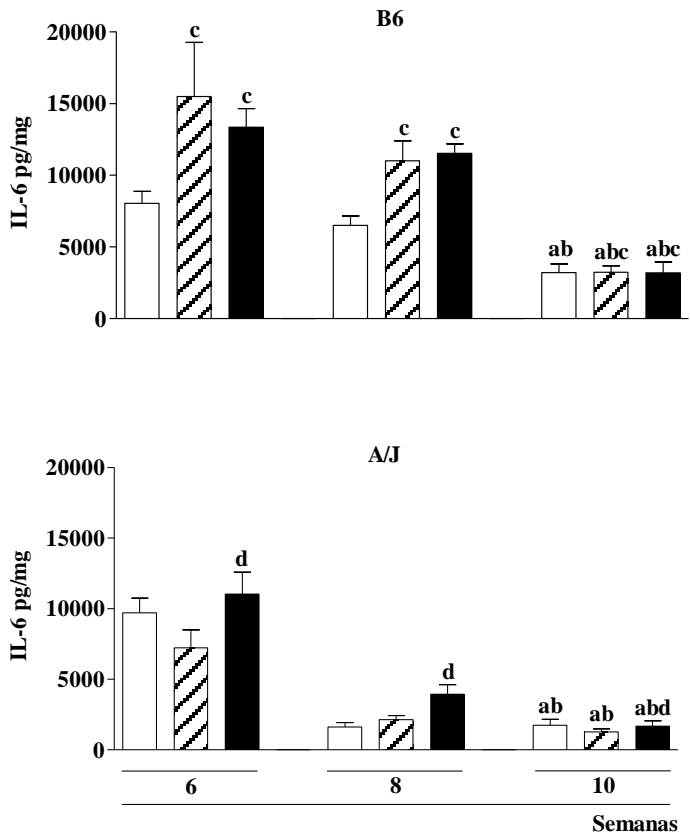

(B) IL-1 $\beta$
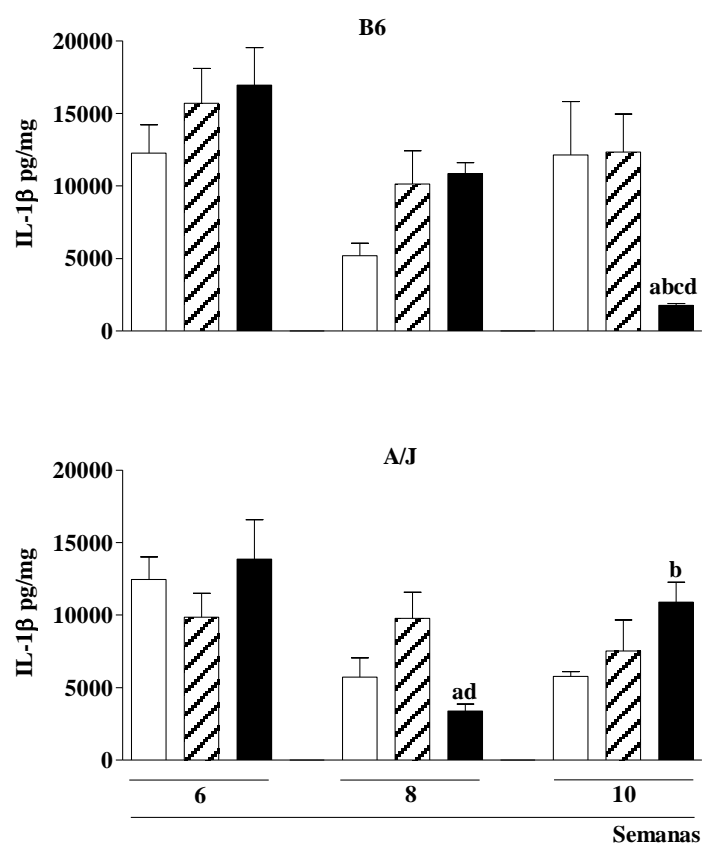

(D) IL-17
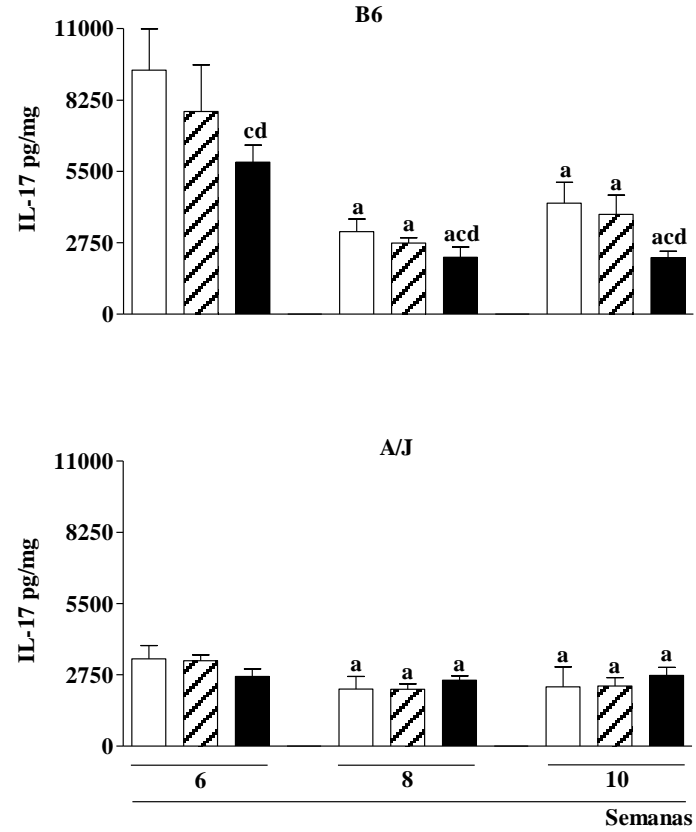

(Continua na próxima página) 
(E) IL-12p(40)
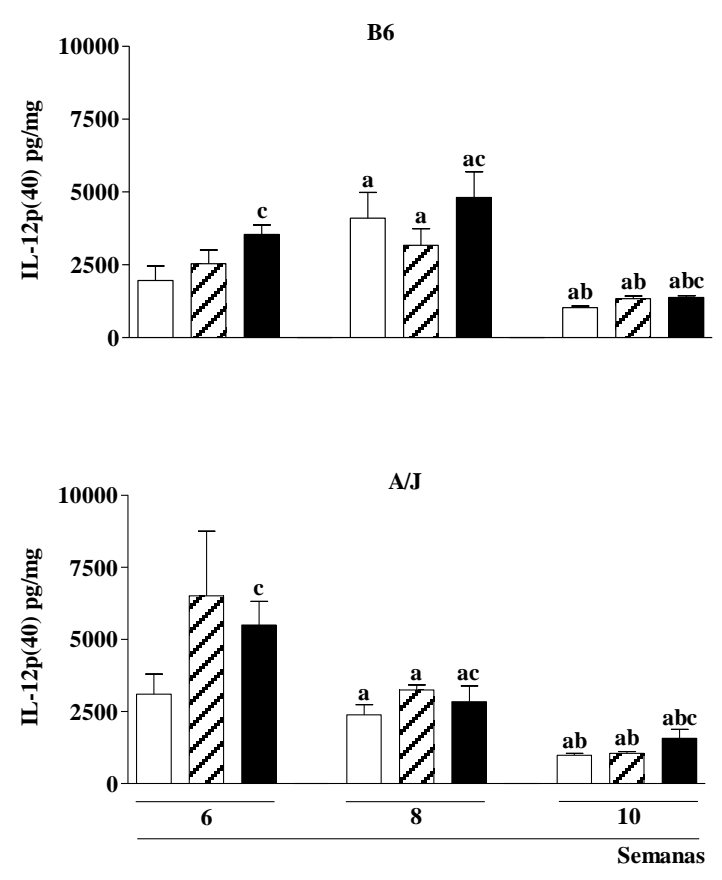

(G) IL-10
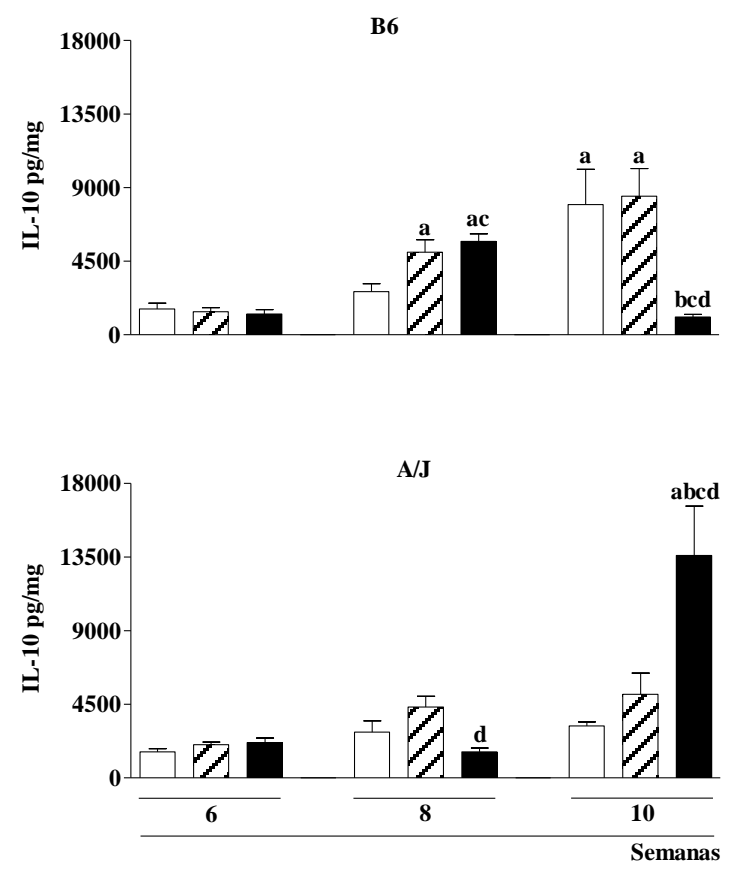

(F) IL-12p(70)
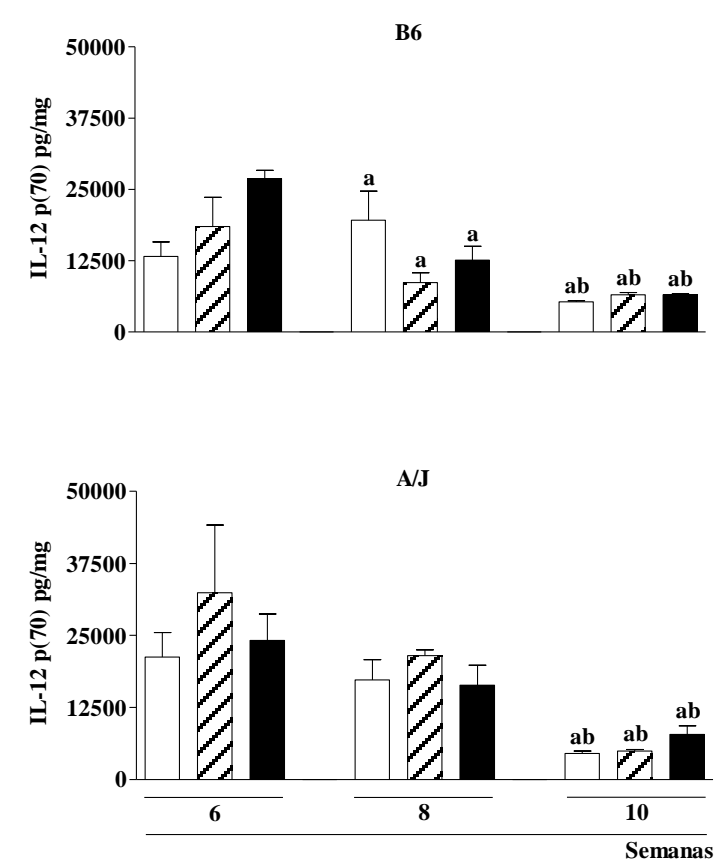

(H) NO
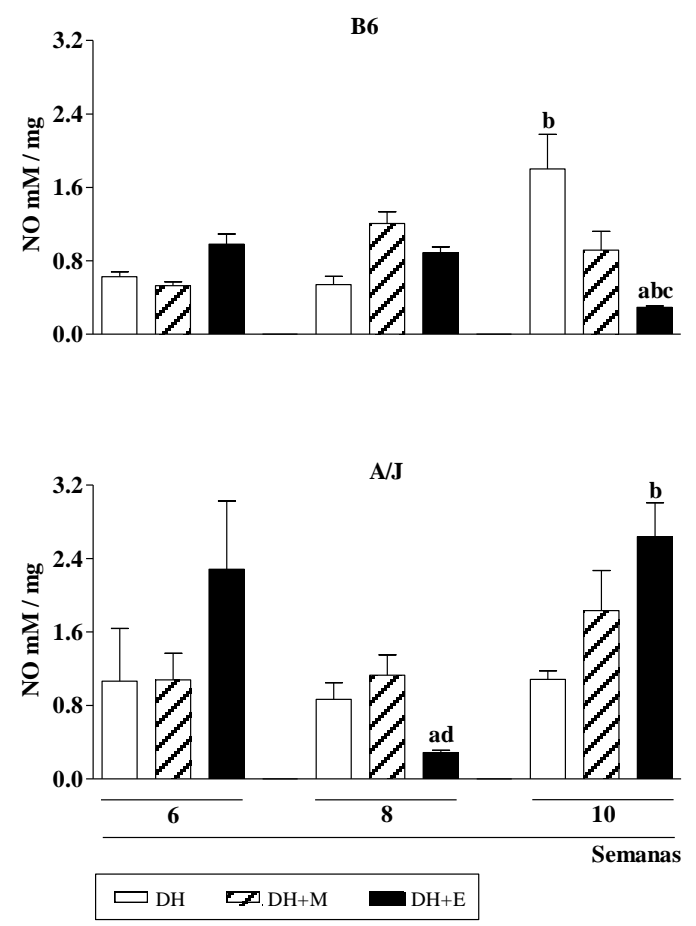

Em (A) representamos as concentrações da citocina TNF- $\alpha$, em (B) IL-1ß, em (C) Il-6, em (D) IL-17, em (E) IL12p(40), em (F) IL-12p(70), em (G) IL-10 e em (H) a produção de NO. Os resultados estão representados como média e erro padrão, $\mathrm{n} \geq 5$. As comparações correspondem: a vs. 6 semanas; b vs. 8 semanas; c vs. DH; d vs. $\mathrm{DH}+\mathrm{M}$.

Siglas: DH - Dieta hiperlipídica; DH+M - Dieta hiperlipídica contendo maltodextrina; DH+E - Dieta hiperlipídica contendo etanol. 
Conclusão da secão 5.2.2.3: Identificamos alguns padrões na produção de citocinas e de NO que são comuns, exclusivos ou opostos as linhagens B6 e A/J. Dentre os resultados comuns às duas linhagens esteve a concentração de IL-6 e IL-12p(40) que diminuiu significativamente durante as semanas de tratamento. E ainda, após 10 semanas de tratamento com $\mathrm{DH}+\mathrm{E}$ a concentração de IL-6 e IL-12p(40) aumentou em relação à $\mathrm{DH}$ para ambas as linhagens. Com relação aos resultados exclusivos para a linhagem B6 identificamos que a concentração da citocina IL-17 reduziu significativamente nos camundongos tratados com $\mathrm{DH}+\mathrm{E}$ em relação aos tratados com $\mathrm{DH}+\mathrm{M}$ e $\mathrm{DH}$ após 6,8 e 10 semanas. Já para a linhagem A/J a citocina TNF- $\alpha$ aumentou significativamente nos camundongos tratados com $\mathrm{DH}+\mathrm{E}$ em relação aos tratados com $\mathrm{DH}+\mathrm{M}$ e $\mathrm{DH}$ no final de 10 semanas. Quanto aos resultados opostos e que possivelmente sejam marcadores para evolução ou parada da doença sugerimos as citocinas IL-1ß e IL-10 e a produção de NO. Para estes parâmetros encontramos redução significativa para a linhagem B6 e aumento significativo para a linhagem $\mathrm{A} / \mathrm{J}$ após o tratamento de 10 semanas com $\mathrm{DH}+\mathrm{E}$ em relação à $\mathrm{DH}+\mathrm{M}$ e $\mathrm{DH}$.

5.2.2.4 Conclusão do tópico "Padronização do modelo de injúria hepática crônica induzida por etanol (ou padronização da DHA)"

Concluímos que 10 semanas foi período mais adequado de tratamento, com o qual evidenciamos as diferenças inflamatórias inerentes a cada linhagem. A aplicação deste período em associação a uma dieta hiperlipídica contendo etanol propiciou o desenvolvimento de alterações patológicas hepáticas observadas em pacientes com DHA, assim como a reprodução em nossos camundongos destas patologias. Dentre as alterações hepáticas ressaltamos: aumento da razão peso hepático / peso corporal, presença e acúmulo de triglicerídeos, promoção de um micro-ambiente pró-inflamatório e presença de fibrose.

Resta confirmar se tais patologias serão reprodutíveis e se as divergências entre as linhagens B6 e A/J são próprias do fundo genético ou se há uma participação da proteína C5 do sistema complemento. Portanto, para investigarmos o papel do componente C5 na DHA daremos sequência ao tópico 5.3.3, onde aplicaremos a linhagem congênica B6.A-Hc ${ }^{0}$ (B6 C5 deficiente) no modelo de DHA aqui padronizado tratando-as com $\mathrm{DH}+\mathrm{E}$ e os respectivos controles durante 10 semanas. 


\subsubsection{Aplicação da linhagem congênica B6.A-Hc ${ }^{0}$ (C5 deficiente) no modelo de DHA}

Desde o início deste projeto, o nosso objetivo foi empregar as linhagens congênicas que diferem apenas no locus $c 5$, para avaliar com clareza a real contribuição do componente C5 para a etiopatogenia da DHA. Entretanto, devido ao longo e demorado processo de desenvolvimento das linhagens congênicas, não conseguimos obter camundongos da linhagem congênica A.B6-Hc (A/J C5 normal) em número suficiente. Portanto, apresentaremos aqui apenas os resultados obtidos com o tratamento da linhagem isogênica B6 (C5 normal) e da linhagem congênica B6.A- $\mathrm{Hc}^{0}$ (C5 deficiente, como descrita e caracterizada no CAPÍtULO 1).

Após 10 semanas de tratamento avaliamos a presença ou não de diferença significativa entre as linhagens (B6 e B6.A- $H c^{0}$ ), quanto aos tratamentos e o efeito de interação entre linhagem e tratamento, aplicando o teste estatístico de análise de variância para dois fatores (ANOVA). O efeito de interação avalia o comportamento das linhagens frente aos tratamentos.

Consideramos para análise estatística e discussão que os camundongos tratados com $\mathrm{DH}$ e $\mathrm{DH}+\mathrm{M}$ como grupos controles, onde $\mathrm{DH}$ foi considerado como nosso controle real e $\mathrm{DH}+\mathrm{M}$ como controle equicalórico pois possui a mesma equivalência calórica que o tratamento dieta hiperlipídica contendo etanol (DH+E).E como grupo experimental DH+E.

Ressaltaremos em itálico os pontos mais importantes de cada parâmetro avaliado.

Tratamos os camundongos B6 e B6. A- $\mathrm{Hc}^{0}$ com DH, DH+M e DH+E por 10 semanas e na sequência avaliamos estatisticamente o ganho de peso, número absoluto de leucócitos circulantes, parâmetros de função hepática, citocinas, produção de NO e acúmulo de lipídeos no tecido hepático. Os resultados referentes a este tópico também serão apresentados respeitando a mesma organização apresentada anteriormente: (1) avaliação dos parâmetros corporais; (2) avaliação da função hepática, bioquímica e hematológica; (3) avaliação da resposta inflamatória no micro-ambiente hepático; e, (4) conclusão do tópico aplicação da linhagem congênica B6.A-Hc no modelo de DHA.

\subsubsection{Avaliação dos parâmetros corporais}

A partir do peso diário da dieta consumida calculamos a média semanal de consumo da ração (em gramas) por camundongo (gráfico disponível no APÊNDICE E). A média semanal de ganho de peso corporal para os camundongos da linhagem $\mathrm{B} 6$ tratados com $\mathrm{DH}+\mathrm{E}$ 
foi $13,9 \mathrm{~g}$, para aqueles tratados com $\mathrm{DH}+\mathrm{M}$ a média foi de $16,3 \mathrm{~g}$ e por fim o que receberam DH consumiram em média 18,1 g. Para a linhagem B6.A- $\mathrm{Hc}^{0}$ os resultados foram semelhantes, aqueles tratados com $\mathrm{DH}+\mathrm{E}$ consumiram em média 13,1 g, os que receberam $\mathrm{DH}+\mathrm{M}$ consumiram por volta de $16,6 \mathrm{~g}$ e os camundongos tratados com DH consumiram 16,5 g. Aparentemente, as linhagens consumiram valores semanais semelhantes (APÊENDICE E Figura E.1).

Além do consumo semanal da ração, acompanhamos o ganho de peso acumulado semanalmente (Figura 26) para investigar se as linhagens apresentariam comportamentos diferentes frente a cada tratamento. Observamos que ambas as linhagens apresentam o mesmo comportamento perante cada tratamento. Representamos nas Figuras 26A e 26B esta análise comparativa apenas entre os tratamentos.

Independentemente da linhagem, comparando os tratamentos observamos que os camundongos tratados com $\mathrm{DH}+\mathrm{E}$ e $\mathrm{DH}$ diferiram significativamente dos camundongos tratados com DH+M a partir da sexta semana de tratamento, quando estes acumularam mais peso em relação aos tratados com DH+E e DH. Essa diferença significativa entre os tratamentos manteve-se até a décima semana, $p<0,05$. Ressaltamos que os camundongos tratados com DH+E e DH não apresentaram diferença significativa de acúmulo de peso entre si (Figura 26A e 26B).

Ou seja, independentemente da linhagem expressar a proteína C5, ambas acumularam peso semelhantemente durante as 10 semanas de tratamento. E ainda, os camundongos tratados com $\mathrm{DH}+\mathrm{M}$ acumularam significativamente mais peso em relação aos tratados com $\mathrm{DH}+\mathrm{E}$ ou $\mathrm{DH}$ a partir da sexta semana de tratamento. Ou seja, ambas as linhagens, quando tratadas com $\mathrm{DH}+E$, apresentaram dificuldade de acúmulo de peso, sendo esta uma característica dependente apenas do fundo genético e do tratamento e não da presença de C5 (Figura $26 A$ e $26 B$ ). 
Figura 26 - Ganho de peso acumulado dos camundongos B6 e B6.A-Hc ${ }^{0}$ (C5 deficiente) durante as 10 semanas de tratamento com as diferentes dietas hiperlipídicas.

(A)

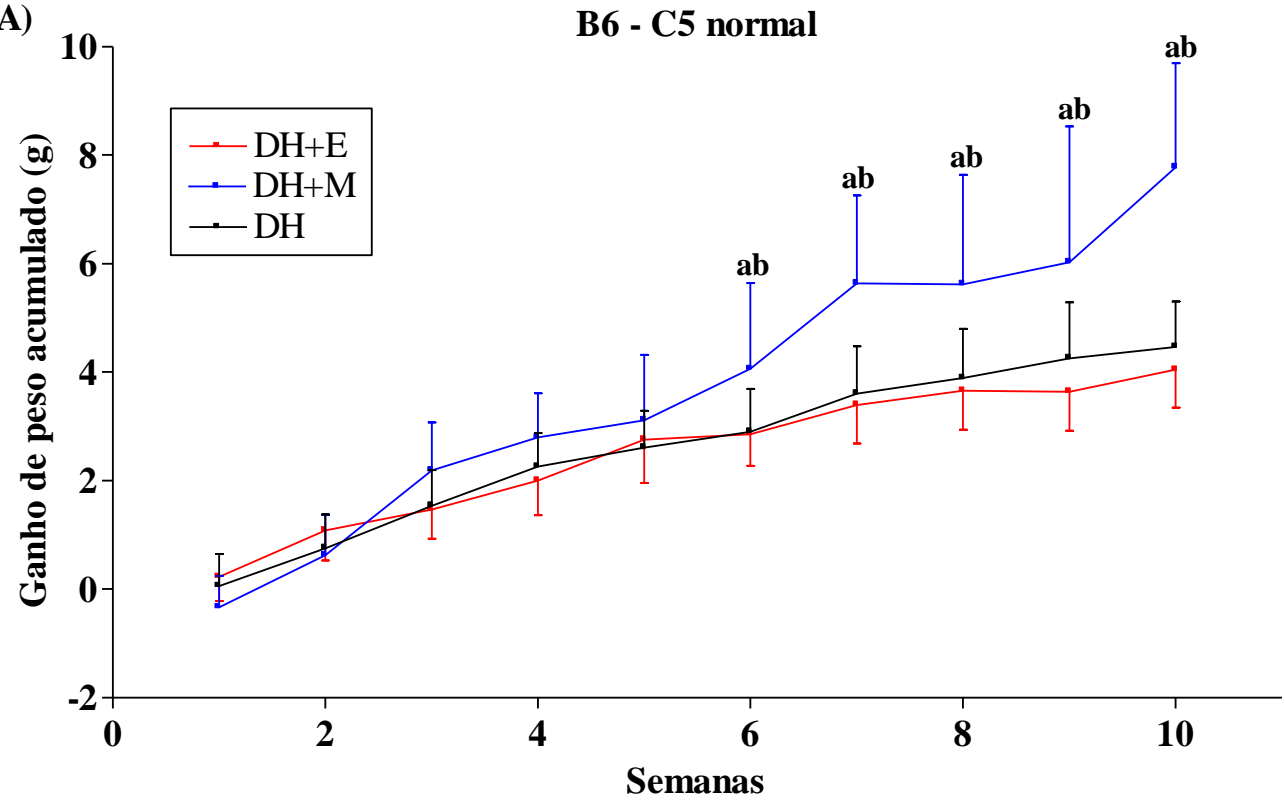

(B) B6.A-Hc ${ }^{0}$ - C5 deficiente

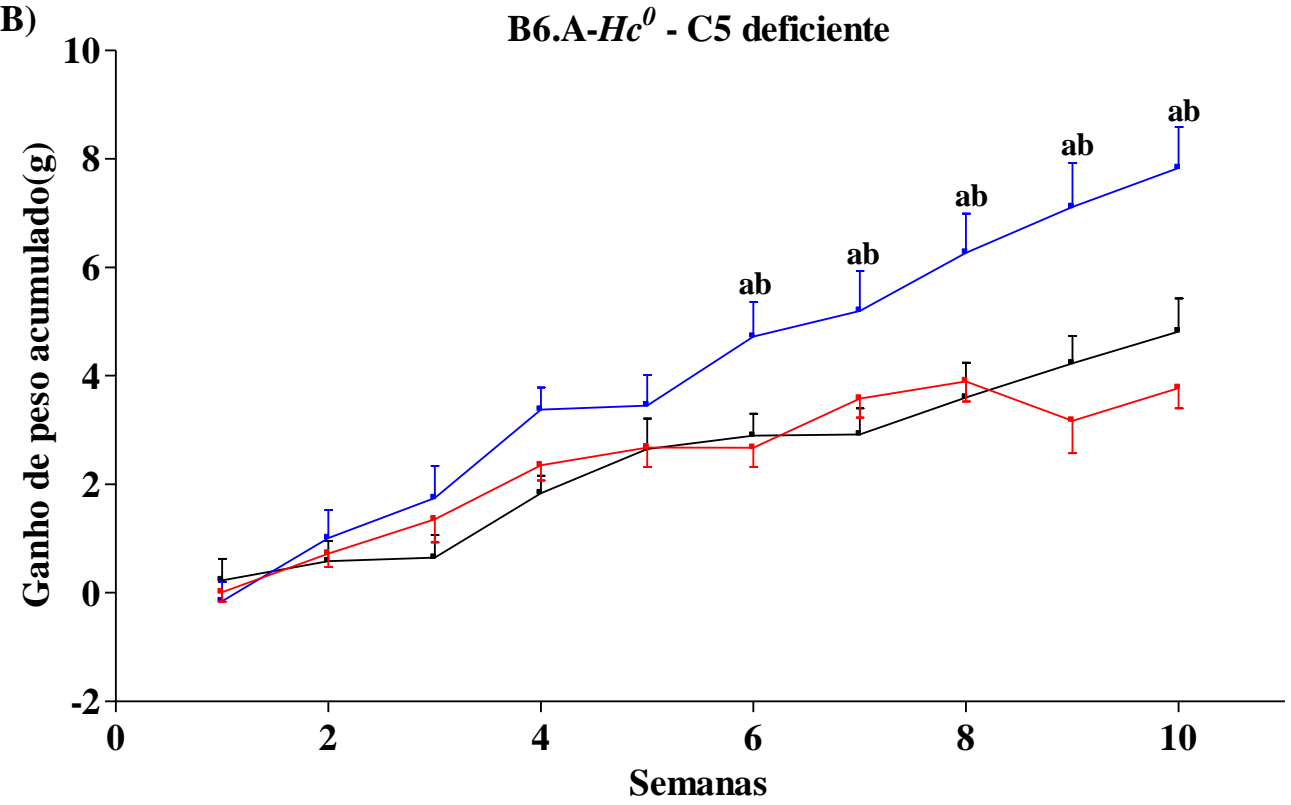

Em (A) estão os resultados para a linhagem B6 (C5 normal) e em (B) para a linhagem congênica B6.A-Hc ${ }^{0}$ (C5 deficiente). Representamos as diferenças entre os tratamentos na linha pertencente ao ganho de peso acumulado para o tratamento com dieta hiperlipídica contendo maltodextrina $(\mathrm{DH}+\mathrm{M})$ como: a vs. dieta hiperlipídica (DH) e b $v s$. dieta hiperlipídica contendo etanol $(\mathrm{DH}+\mathrm{E})$. Os resultados estão representados como média e erro padrão.Aplicamos para todos os tratamentos $n \geq 6$.

Na sequência investigamos se haveria diferenças avaliando apenas o ganho de peso no final das 10 semanas de tratamento. As análises sobre o ganho de peso final mostraram que não houve efeito de interação entre linhagem e tratamento, $p=0,903$, e que também não houve 
diferença significativa entre as linhagens, $p=0,927$. Entretanto, encontramos diferença significativa entre os tratamentos, $p<0,001$. Isto é, independentemente da linhagem, os camundongos tratados com $\mathrm{DH}+\mathrm{M}$ ganharam significativamente mais peso que os camundongos tratados com $\mathrm{DH}$ e $\mathrm{DH}+\mathrm{E}$ ao final das 10 semanas de tratamento, $p<0,05$ (Figura 27). Estes dados corroboram com os resultados apresentados na figura anterior.

$O$ ganho de peso ao final do tratamento foi semelhante para os camundongos B6 $e$ B6. $\mathrm{A}-\mathrm{Hc}^{0}$, isto mostra que o ganho de peso é realmente uma característica exclusiva do fundo genético B6 e do tratamento, independentemente da presença ou não proteína C5. Ambas as linhagem tratadas com $\mathrm{DH}+\mathrm{E}$ ou $\mathrm{DH}$ apresentaram dificuldade em ganhar peso (Figura 27).

Figura 27 - Ganho de peso total dos camundongos B6 e B6.A- $H c^{0}$ (C5 deficiente) após 10 semanas de tratamento com as diferentes dietas hiperlipídicas.

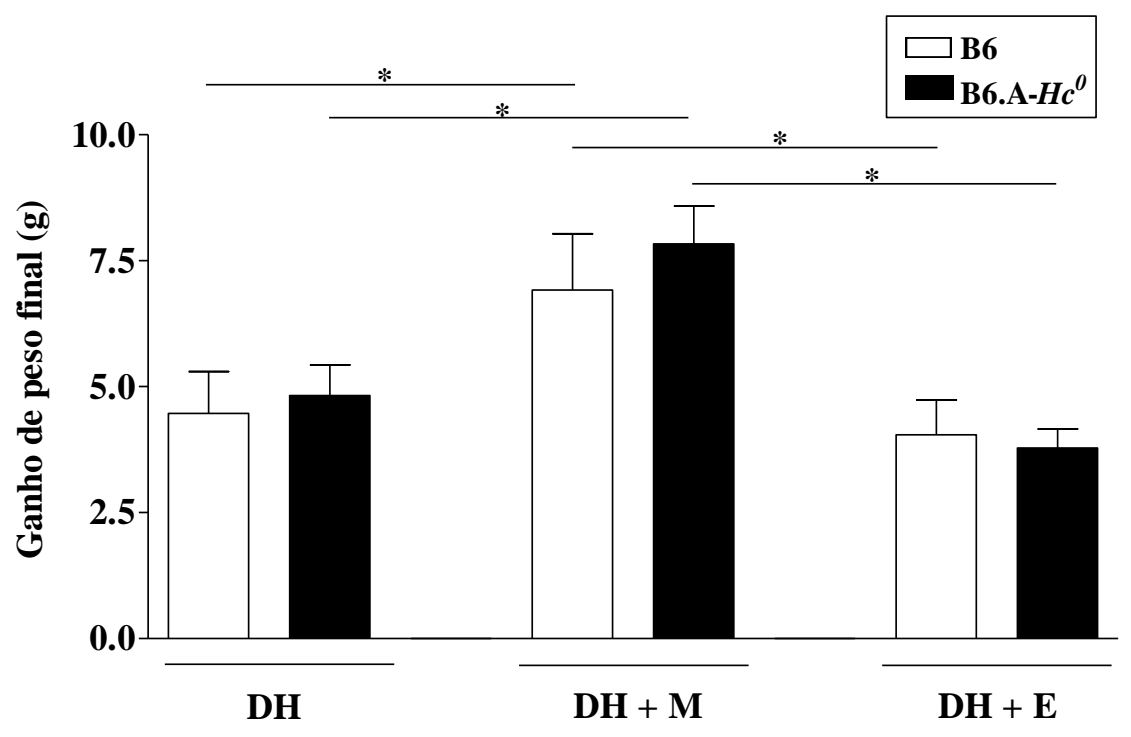

Os resultados estão representados como média e erro padrão. Empregamos pelo menos $n \geq 6$ camundongos de cada linhagem, e consideramos $* p<0,05$. Siglas presentes na figura representam: dieta hiperlipídica (DH); dieta hiperlipídica contendo maltodextrina (DH+M); dieta hiperlipídica contendo etanol (DH+E).

Uma vez investigado o ganho de peso, avaliamos a presença de hepatomegalia nos camundongos tratados com as diferentes dietas, uma característica marcante da DHA, como já mencionado anteriormente. Para analisar este parâmetro, utilizamos a razão do peso hepático em relação ao peso final de cada animal para seu tratamento específico. Nossos resultados 
(Figura 28) mostraram que as condições experimentais aplicadas induziram esta patologia, e que reproduzimos um dos parâmetros avaliados no tópico 5.3.2.

Avaliando a razão do peso hepático pelo peso corporal não constatamos efeito de interação entre linhagem e tratamento, $p=0,722$. Também não detectamos diferença significativa entre as linhagens, $p=0,078$, embora seja possível observar uma tendência nos camundongos da linhagem B6.A- $H c^{0}$ em ter menor razão do peso hepático / peso corporal em relação aos camundongos da linhagem B6. Entretanto, encontramos diferença significativa entre os tratamentos, $p<0,001$. Concluindo, ambas as linhagens tratadas com $\mathrm{DH}+\mathrm{E}$ apresentaram a razão peso hepático / peso corporal significativamente maior em relação àquelas tratadas com DH e DH+M, $p<0,05$. (Figura 28).

Figura 28- Razão do peso hepático pelo peso corporal dos camundongos B6 e B6.A- $\mathrm{Cc}^{0}$ (C5 deficiente), após 10 semanas de tratamento com as diferentes dietas hiperlipídicas.

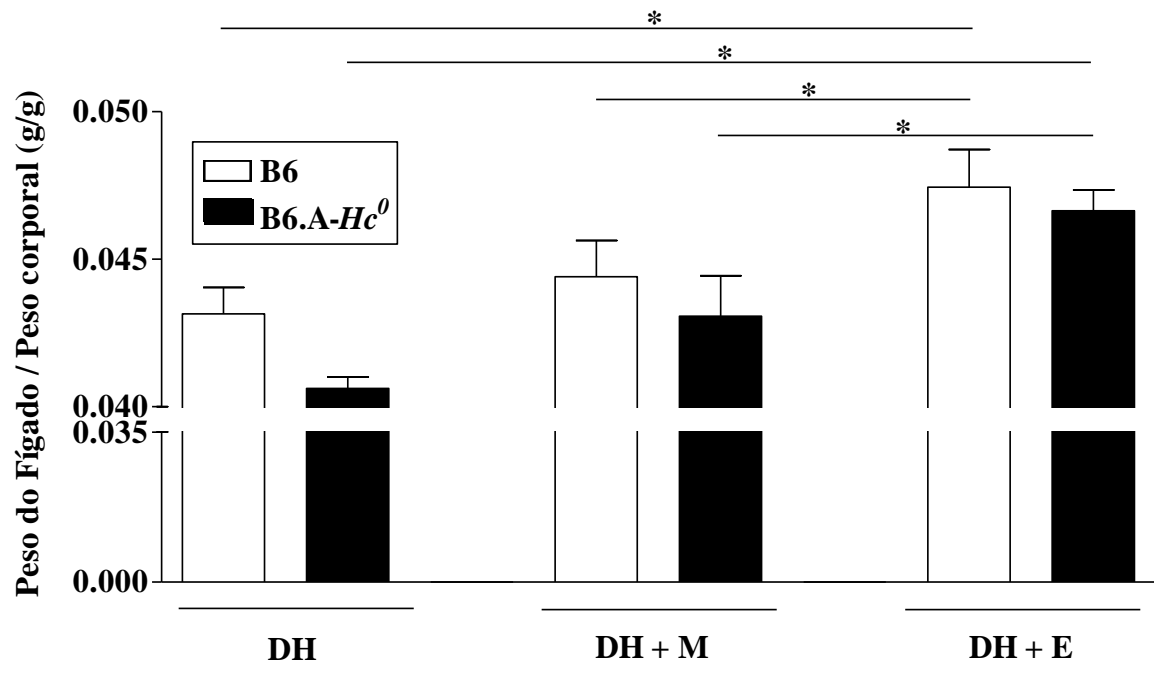

Os resultados estão representados como média e erro padrão. Empregamos pelo menos $\mathrm{n} \geq 6$ camundongos de cada linhagem, e consideramos $* p<0,05$. Siglas presentes na figura representam: dieta hiperlipídica (DH); dieta hiperlipídica contendo maltodextrina $(\mathrm{DH}+\mathrm{M})$; dieta hiperlipídica contendo etanol (DH+E).

O aumento na razão do peso hepático / peso corporal nos camundongos tratados com etanol confirmou que nosso modelo reproduziu características patológicas esperadas para o modelo de DHA. Com estes resultados concluímos que o fundo genético B6 é por si importante para explicar as alterações na razão do peso hepático / peso corporal (Figura 28). 
Investigamos também, mas não encontramos diferenças nos pesos de outros órgãos como: baço, rins e estômago. Estes dados estão apresentados em forma de tabela no APÊNDICE F.

Outra característica marcante da DHA é o acúmulo de lipídeos, em especial triglicerídeos, no parênquima hepático que contribui para o desenvolvimento da hepatomegalia. Após a extração de lipídeos totais a partir do homogenato do tecido hepático, quantificamos a presença de triglicerídeos (Figura 29A) e colesterol (Figura 29B) por grama de tecido hepático após 10 semanas de tratamento com as diferentes dietas.

Figura 29 - Quantificação da concentração de triglicerídeos e colesterol extraídos do tecido hepático após 10 semanas de tratamento com as diferentes dietas hiperlipídicas empregando as linhagens B6 e B6.A- $\mathrm{Hc}^{0}$ (C5 deficiente).
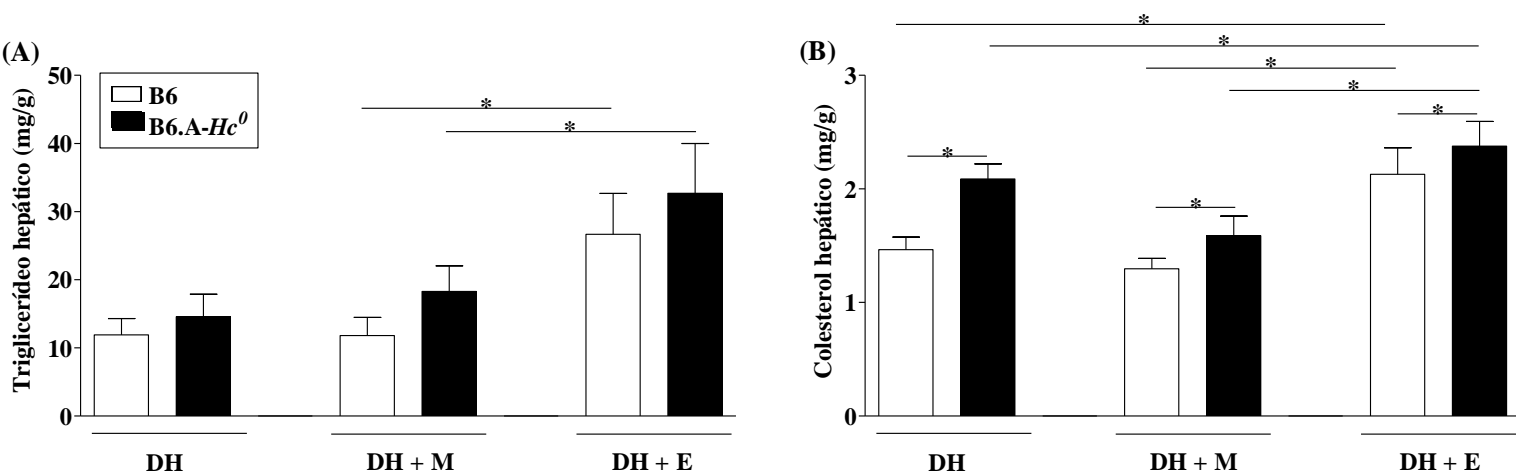

Em (A) apresentamos as dosagens do triglicerídeos e em (B) do colesterol total a partir dos lipídeos totais extraídos do homogenato hepático. Os resultados estão representados como média e erro padrão. Empregamos pelo menos $\mathrm{n} \geq 6$ camundongos de cada linhagem e consideramos como $* p<0,05$. As siglas presentes na figura: dieta hiperlipídica (DH); dieta hiperlipídica contendo maltodextrina $(\mathrm{DH}+\mathrm{M})$; dieta hiperlipídica contendo etanol (DH+E).

Quanto à concentração de triglicerídeos no tecido hepático, não identificamos efeito de interação entre linhagem e tratamento, $p=0,723$. Também não encontramos diferença significativa entre as linhagens, $p=0,075$. Todavia, encontramos diferença significativa entre os tratamentos, $p=0,046$. Independentemente da linhagem, os camundongos tratados com $\mathrm{DH}+\mathrm{E}$ apresentaram significativamente um maior depósito de triglicerídeos hepático que os camundongos tratados com DH+M, $p<0,05$ (Figura 29A).

Em relação à dosagem de colesterol hepático não detectamos efeito de interação entre linhagem e tratamento, $p=0,564$. Entretanto, observamos diferença significativa entre os tratamentos, $p<0,001$. Os camundongos tratados com $\mathrm{DH}+\mathrm{E}$ apresentaram significativamente maior depósito de colesterol hepático em relação aos camundongos tratados com DH+M ou 
$\mathrm{DH}, p<0,05$. Do mesmo modo, encontramos diferença significativa entre as linhagens, $p=0,014$, quando observamos que os camundongos da linhagem B6.A- $H c^{0}$ apresentaram significativamente mais colesterol hepático que os camundongos da linhagem $\mathrm{B} 6, p<0,05$ (Figura 29B). Ou seja, neste modelo, de alguma maneira ainda não esclarecida C5 contribui para a regulação do nível de colesterol no fígado.

A concentração hepática tanto de triglicerídeos quanto de colesterol foram significativamente maior nos camundongos tratados com $\mathrm{DH}+\mathrm{E}$ em relação àqueles tratados com $\mathrm{DH}+\mathrm{M}$ no caso de triglicerídeos, ou àqueles tratados com $\mathrm{DH}+\mathrm{M}$ ou $\mathrm{DH}$ para análise do colesterol. Observamos que a ausência da proteína C5 esteve associada ao aumento de colesterol hepático para todos os tratamentos (Figura 29).

Complementando os resultados apresentados nas Figuras 28 e 29, procedemos com análises histopatológicas do fígado de camundongos destas duas linhagens submetidas às diferentes dietas hiperlipídicas. Buscamos por alterações sobre os seguintes parâmetros patológicos: balonização, esteatose, porcentagem de esteatose, inflamação lobular e fibrose quando, após a avaliação dos parâmetros, calculamos o índice de atividade para DHA (escores e cálculo do índice de atividade estão detalhados em MATERIAIS E MÉTODOS).

Na Figura 30 apresentamos os resultados da avaliação histopatológica, e nas Figuras 31 e 32 apresentaremos secções representativas da análise dos parâmetros histopatológicos de tecido hepático em coloração HE e picrossírius, respectivamente.

A esteatose, como mencionado anteriormente, representa o acúmulo de triglicerídeos e colesterol dentro dos hepatócitos (SCHEUER; LEFTKOWITCH, 2000). Investigamos a presença de esteatose na histopatologia hepática pela distribuição tecidual, respeitando a porcentagem e os escores (segundo a descrição presente na Tabela 9 presente em MATERIAIS E MÉTODOS) estabelecidos por Kleiner et al. (2005). Avaliamos estatisticamente a porcentagem tecidual de esteatose aplicando o teste ANOVA para 2 fatores (linhagem e tratamento), e identificamos que não houve efeito de interação entre linhagem e tratamento, $p=0,210$, e nem diferença significativa entre as linhagens, $p=0,840$. Entretanto, identificamos diferença significativa entre os tratamentos, $p<0,001$, onde independentemente da linhagem dos camundongos o tratamento com $\mathrm{DH}+\mathrm{M}$ ou $\mathrm{DH}+\mathrm{E}$ induziu significativamente mais esteatose hepática que o tratamento apenas com $\mathrm{DH}, p<0,05$ (Figura 30A).

Os parâmetros esteatose, balonização, inflamação lobular e fibrose foram analisados empregando-se o modelo Log-Linear. Para o parâmetro esteatose identificamos que houve 
efeito de interação significativo entre tratamento e esteatose, com $p<0,001$. Observamos que para os tratamentos com $\mathrm{DH}+\mathrm{E}$ e com $\mathrm{DH}+\mathrm{M}$ a maior porcentagem das lâminas apresentaram escore 1 de esteatose, $61 \%$ e $47 \%$, e com escore 2 observamos $39 \%$ e $29 \%$ das lâminas, respectivamente. Já para o tratamento com DH a maior porcentagem das lâminas encontrou-se no escore 0 de esteatose, $71 \%$, e $29 \%$ das lâminas no escore 1 . Não identificamos diferença significativa entre as linhagens (Figura 30B).

As células possuem um mecanismo de regulação de entrada e saída de água, mas quando por algum motivo este mecanismo se torna prejudicado e um excesso de água acumula-se dentro da célula, esta é patologicamente caracterizada como balonizada, ou com degeneração hidrópica (SCHEUER; LEFTKOWITCH, 2000). Quanto à balonização dos hepatócitos identificamos a presença de efeito de interação significativo entre tratamento e balonização, $p<0,05$. Observamos que os camundongos tratados com $\mathrm{DH}+\mathrm{E}$ e $\mathrm{DH}+\mathrm{M}$ apresentaram $28 \%$ e $47 \%$, respectivamente, das lâminas com escore 1 de balonização, e 33\% e 41\%, respectivamente, das lâminas distribuídas no escore 2. Já os camundongos tratados com DH apresentaram 64\% no escore 0 e 22\% no escore 1 de balonização nas lâminas observadas. Não identificamos diferença significativa entre as linhagens (Figura 30C).

A inflamação lobular é dada pela presença de focos de infiltrado celular, ou seja células inflamatórias, no centro do lóbulo hepático (SCHEUER; LEFTKOWITCH, 2000). O método estatístico aplicado não identificou interações ou diferenças entre as linhagens e os tratamentos para o parâmetro inflamação (Figura 30D). Contudo, é possível observar que dentre os camundongos da linhagem B6 a distribuição de inflamação foi bastante semelhante entre os tratamentos $\mathrm{DH}, \mathrm{DH}+\mathrm{M}$ e $\mathrm{DH}+\mathrm{E}$. Já para os camundongos congênicos $\mathrm{B} 6 . \mathrm{A}-\mathrm{Hc}^{0} \mathrm{o}$ perfil gráfico tornou-se diferente com os tratamentos, mas o método estatístico não chegou a identificar nenhum efeito de interação significativo.

A fibrose hepática ocorre em resposta a um processo regenerativo após um dano ou uma injúria sofrido pelo fígado. Neste contexto há substituição dos hepatócitos agredidos ou mortos (necrose) por fibras de colágeno, com a finalidade de reparar o tecido lesado e, dependendo do tempo, intensidade e extensão da injúria, este fibrosamento pode ser reversível ou não. O resultado da sua progressão é formação de septos e perda da função da região fibrosada (SCHEUER; LEFTKOWITCH, 2000). O método estatístico aplicado também não identificou interações ou diferenças entre as linhagens e os tratamentos para o parâmetro fibrose (Figura 30E). 
Figura 30 - Parâmetros histopatológicos avaliados nos cortes de tecido hepático após 10 semanas de tratamento com as diferentes dietas hiperlipídicas, empregando as linhagens B6 e B6.A-Hc (C5 deficiente).
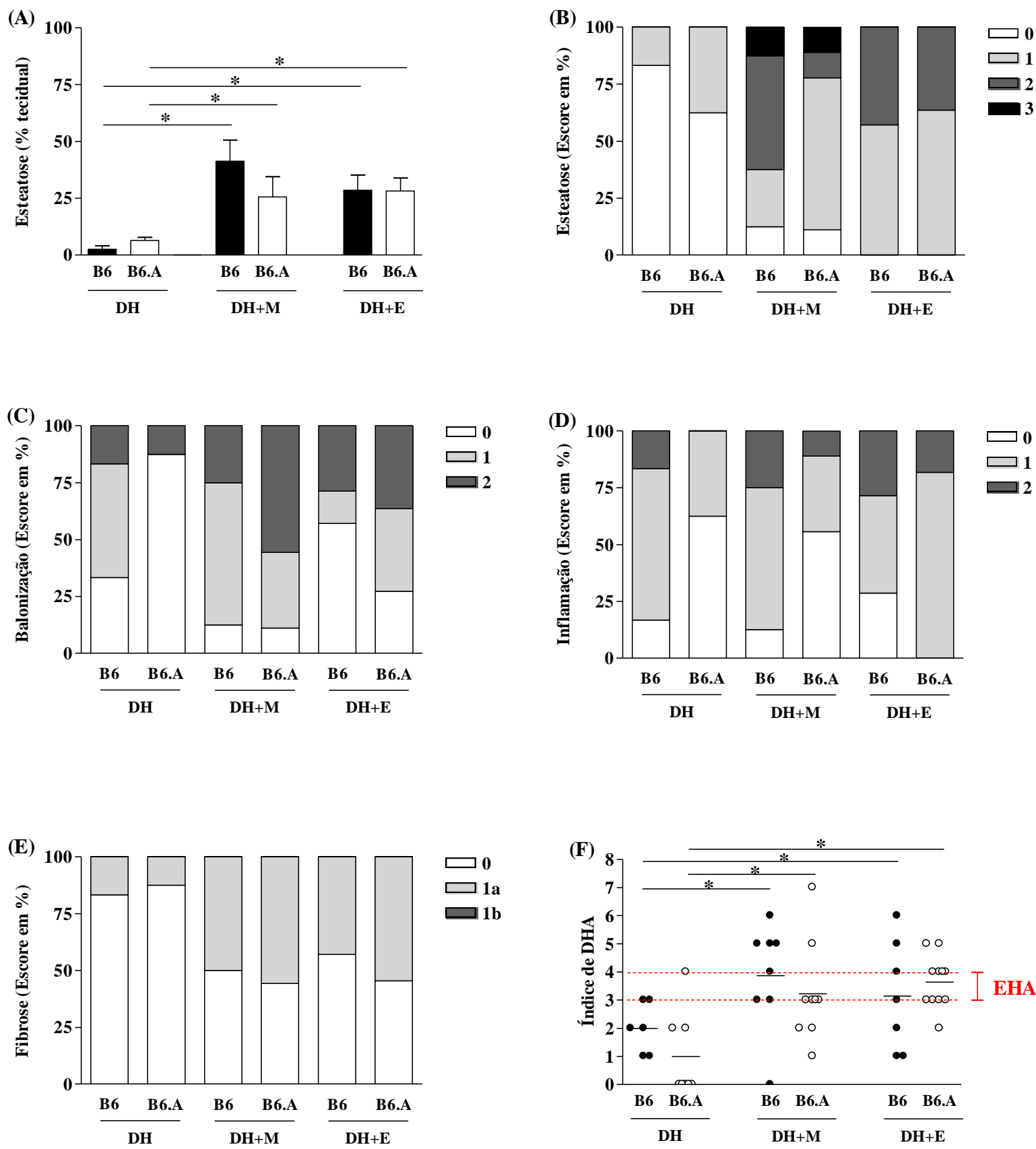

Avaliamos no tecido hepático a distribuição de esteatose (A e B), balonização (C), inflamação (D) e fibrose (E). De (B) a (E) os números 0, 1, 1a, 1b, 2, e 3 presentes nas figuras representam os escores empregados na avaliação histopatológica como descritas nas Tabelas 9 e 10 presentes em MATERIAIS E MÉTODOS. Em (F) apresentamos o índice de DHA, dentro do qual identificamos os camundongos que apresentam a forma mais avançada da DHA, a EHA, onde a barra representa a média do grupo. Os resultados estão representados como média e erro padrão. Siglas DH: dieta hiperlipídica; DH+M: dieta hiperlipídica contendo maltodextrina; DH+E: dieta hiperlipídica contendo etanol; EHA: esteatohepatite alcoólica, B6.A: B6.A- $H c^{0}, \mathrm{n} \geq 6,{ }^{*} p<0,05$. 
Conforme descrito em MATERIAIS E MÉTODOS as lesões hepáticas foram graduadas de acordo com os critérios estabelecidos por Kleiner et al. (2005), com pequenas modificações, gerando o índice de atividade da DHA, o qual avaliamos estatisticamente pela metodologia ANOVA para 2 fatores. Não identificamos efeito de interação entre linhagem e tratamento, nem entre as linhagens. Entretanto, encontramos diferença significativa entre os tratamentos, $p=0,001$, quando, independentemente da linhagem, os camundongos tratados com $\mathrm{DH}+\mathrm{M}$ ou $\mathrm{DH}+\mathrm{E}$ apresentaram significativamente maior índice de atividade da DHA que aqueles que receberam DH. Segundo os valores do índice, estes grupos também apresentaram as médias de 3,2 e 3,8 para os camundongos B6 tratados com DH+E e DH+M, respectivamente. Já os camundongos B6.A- $H c^{0}$ tratados com $\mathrm{DH}+\mathrm{E}$ e $\mathrm{DH}+\mathrm{M}$ apresentaram as médias 3,6 e 3,2, respectivamente, as quais estão dentro da faixa que inclui os índices de atividade da DHA entre 3 e 4, e portanto foram diagnosticados com EHA (Figura 30F).

Avaliando os parâmetros histopatológicos, identificamos que, os parâmetros esteatose e balonização estiveram significativamente aumentados nos camundongos tratados com $\mathrm{DH}+\mathrm{E}$ e $\mathrm{DH}+\mathrm{M}$ em relação aos camundongos tratados com apenas $\mathrm{DH}$. $\mathrm{O}$ índice de DHA mostrou também que os camundongos tratados com $\mathrm{DH}+\mathrm{E}$ e $\mathrm{DH}+\mathrm{M}$ apresentaram a forma mais severa da doença, a EHA (Figura 30). Em suma, independente da linhagem os tratamentos $\mathrm{DH}+\mathrm{E}$ e $\mathrm{DH}+\mathrm{M}$ induziram danos hepáticos consideráveis em relação ao tratamento $\mathrm{DH}$ (Figura 30). A presença de C5 não interferiu no desenvolvimento de esteatose e balonização e nem tampouco no grau de cicatrização tecidual.

$\mathrm{Na}$ Figura 31 apresentamos os cortes histológicos corados em HE que são representativos dos grupos avaliados. Ressaltamos a presença de esteatose em ambas as linhagens tratadas com $\mathrm{DH}+\mathrm{E}$ e $\mathrm{DH}+\mathrm{M}$ nas regiões intermediárias entre o espaço porta hepático e a veia centro lobular. Embora seja possível observar maior área esteatótica nos camundongos da linhagem B6 tratados com $\mathrm{DH}+\mathrm{E}$ em relação aos camundongos congênicos B6.A- $H c^{0}$, não houve diferença significativa entre as linhagens.

Na Figura 32 apresentamos os cortes histológicos avaliados empregando coloração picrossírius que são representativos dos grupos avaliados. Ressaltamos a presença de depósito de fibras de colágeno próxima aos vasos que compõe a região do espaço porta e da região centro lobular e no parênquima hepático em menor proporção. Embora seja possível observar o depósito de colágeno entre as regiões dos vasos nos camundongos de ambas as linhagens 
tratadas com $\mathrm{DH}+\mathrm{E}$ e $\mathrm{DH}+\mathrm{M}$ em relação aos camundongos tratados apenas com $\mathrm{DH}$, não identificamos diferença estatística. A quantificação de fibrose foi apresentada na Figura 30E.

Conforme a avaliação histopatológica apresentada na Figura 30 as imagens histológicas apresentadas nas Figuras 31 e 32 comprovam que independente da presença de C5 não houve interferência no desenvolvimento de esteatose nem na fibrose tecidual, respectivamente.

É possível que o controle equicalórico $\mathrm{DH}+\mathrm{M}$ não seja um controle ideal a longo prazo, pois segundo os parâmetros histopatológicos: esteatose, balonização e inflamação esta dieta leva ao desenvolvimento dos mesmos sintomas esperados para o modelo de DHA (e DHNA aborada no APÊNDICE A). De qualquer forma, mostramos com estes resultados que o consumo crônico de maltodextrina em conjunto com uma dieta hiperlipídica também favoreceu o desenvolvimento de esteatose e inflamação hepática.

Conclusão da secão 5.2.3.1: O tratamento com $\mathrm{DH}+\mathrm{E}$ prejudicou o ganho de peso (Figura 27), aumentou a razão entre o peso hepático e peso corporal (Figura 28) e induziu o acúmulo de triglicerídeos e colesterol hepático (Figura 29) para ambas as linhagens. Corroborando estes resultados a análise histopatológica mostrou que o tratamento com $\mathrm{DH}+\mathrm{E}$ de esteatose, o tratamento com $\mathrm{DH}+\mathrm{M}$ induziu $90 \%$ de esteatose, já o tratamento com DH foi o que menos induziu esteatose (28,5\%) entre os scores 1 a 3 para ambas as linhagens (Figura 30B). Identificamos que as linhagens B6 e B6.A-Hc ${ }^{0}$ diferiram significativamente quanto ao depósito de colesterol hepático, onde a linhagem C5 deficiente além de ter o depósito de colesterol hepático aumentado pelo tratamento com $\mathrm{DH}+\mathrm{E}$ ela também apresentou mais colesterol hepático que os camundongos da linhagem B6 (Figura 29). 
Figura 31 - Cortes representativos dos parâmetros histopatológicos avaliados em coloração HE após 10 semanas de tratamento com as diferentes dietas hiperlipídicas, empregando as linhagens B6 e B6.A- $\mathrm{Cc}^{0}$ (C5 deficiente).
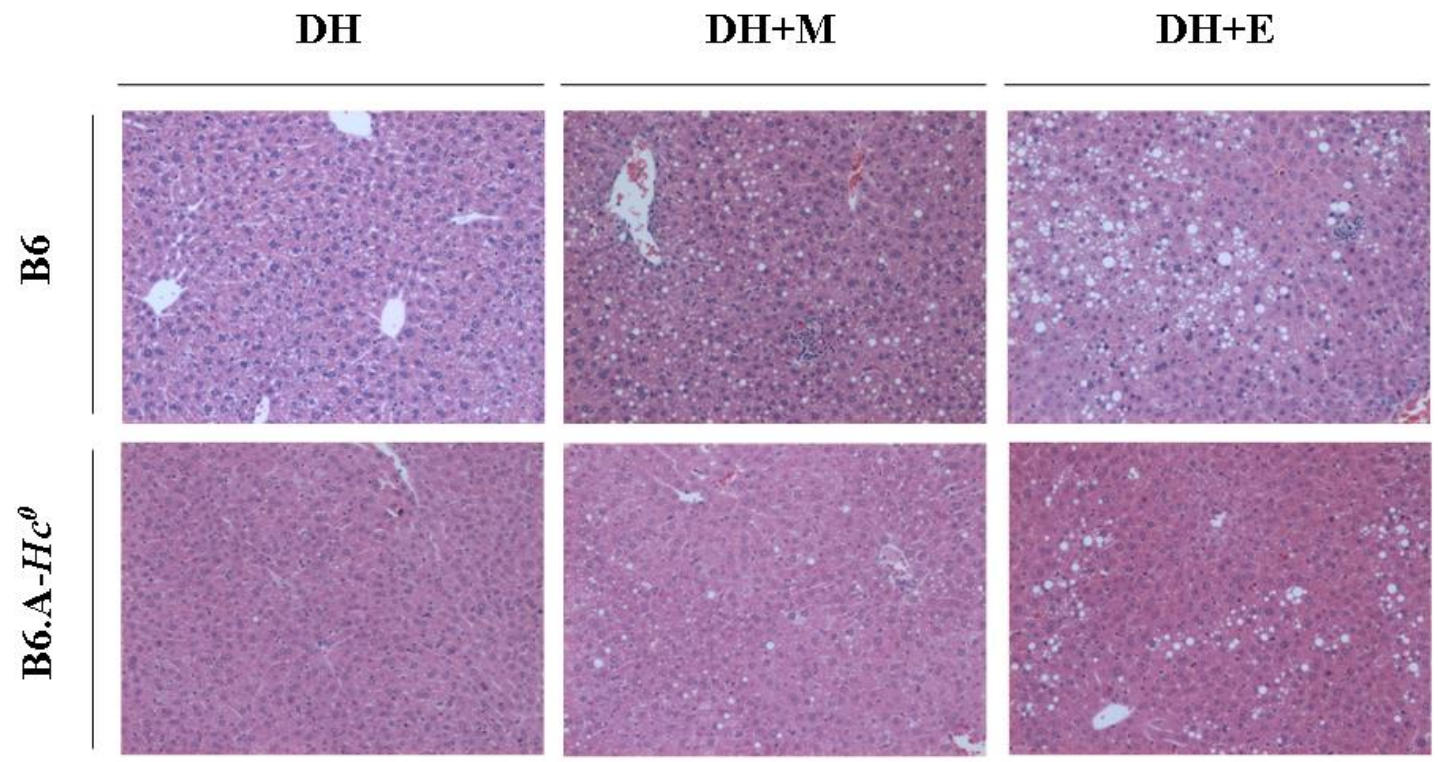

As siglas presentes na figuras indicam a dieta administrada aos camundongos B6 e B6.A-Hc ${ }^{0}$ onde DH: dieta hiperlipídica; DH+M: dieta hiperlipídica contendo maltodextrina; DH+E: dieta hiperlipídica contendo etanol. Aumento 10x.

Figura 32 - Cortes representativos dos parâmetros histopatológicos avaliados em coloração picrossírius após 10 semanas de tratamento com as diferentes dietas hiperlipídicas, empregando as linhagens B6 e B6.A- $\mathrm{Hc}^{0}$ (C5 deficiente).

\section{DH}
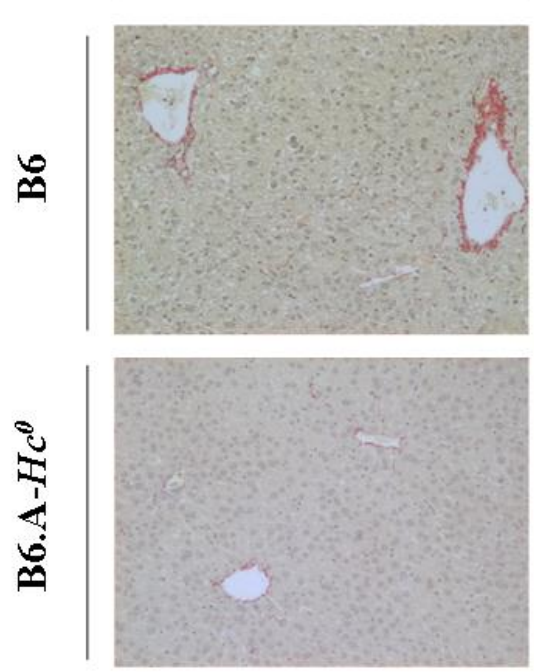

$\mathbf{D H}+\mathbf{M}$
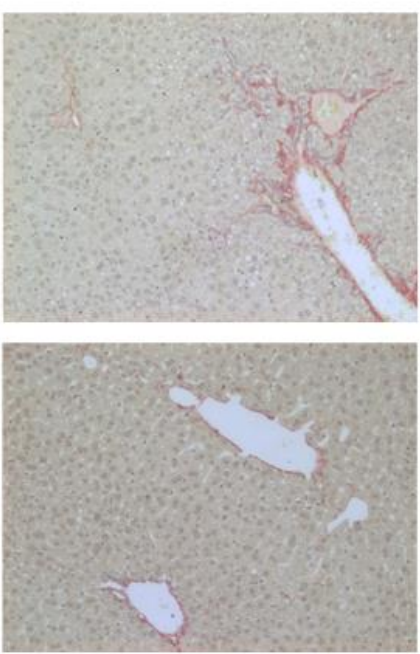

$\mathbf{D H}+\mathbf{E}$
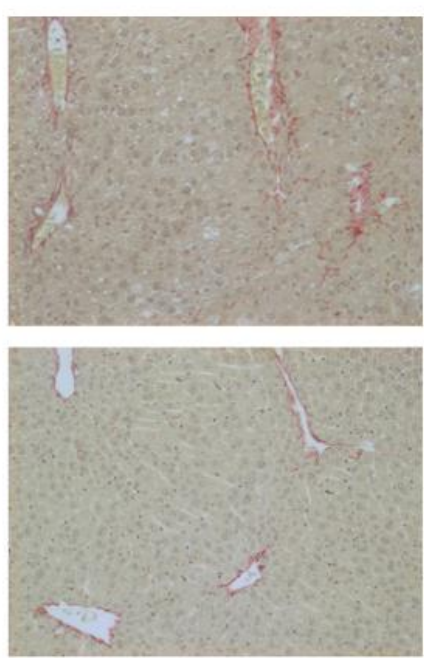

As siglas presentes na figuras indicam a dieta administrada aos camundongos B6 e B6.A-Hc onde DH: dieta hiperlipídica; DH+M: dieta hiperlipídica contendo maltodextrina; $\mathrm{DH}+\mathrm{E}$ : dieta hiperlipídica contendo etanol. Aumento 10x. 


\subsubsection{Avaliação função hepática, bioquímica e hematológica}

Todos os parâmetros histopatológicos observados não devem ser interpretados individualmente, devem ser correlacionados com avaliações clínicas de lesão e síntese hepática. Portanto, com o intuito de aprofundar nossas análises sobre os danos hepáticos induzidos pelo consumo crônico do etanol e buscar por possíveis diferenças relacionadas à presença ou não da proteína C5, investigamos a integridade da atividade hepática, manutenção sérica dos níveis de glicose e perfil lipídico nos camundongos B6 e B6.A-Hc ${ }^{0}$ tratados com as diferentes dietas hiperlipídicas.

A função hepática foi avaliada bioquimicamente, considerando-se os seguintes parâmetros: (a) presença de lesão hepatocelular, considerando-se os níveis séricos de ALT e AST; (b) presença de lesão das vias biliares e fluxo biliar, pela concentração sérica de fosfatase alcalina (FA); e (c) alterações na síntese hepática, avaliando-se a concentração de albumina circulante no soro (Figura 33).

Dentre os parâmetros que identificam lesão hepatocelular, não encontramos diferença significativa para ALT. Na sequência investigamos a concentração sérica da enzima AST e segundo o teste estatístico aplicado não houve efeito de interação entre linhagem e tratamento, $p=0,664$. Também não identificamos diferença significativa entre os tratamentos, $p=0,343$. No entanto, identificamos diferença significativa entre as linhagens, $p=0,015$. Ou seja, nos camundongos da linhagem congênica B6.A- $H c^{0}$ a concentração de AST sérica foi significativamente maior que nos camundongos da linhagem B6 independentemente da dieta dada aos camundongos (Figura 33A).

Resultados semelhantes à AST foram observados quanto aos níveis séricos de FA. Não encontramos efeito de interação entre linhagem e tratamento, $p=0,197$, nem diferença significativa entre os tratamentos, $p=0,068$. Porém, encontramos diferença significativa entre as linhagens, $p=0,019$. Onde, os camundongos da linhagem B6.A- $H c^{0}$ apresentaram significativamente maior concentração de FA sérica em relação aos da linhagem B6 independentemente do tratamento (Figura 33B).

A albumina sérica é um importante transportador tanto de proteínas como de ácidos graxos (triglicerídeos e fosfolipídeos) e compreende 50\% das proteínas do soro. Investigando sua concentração sérica não identificamos efeito de interação entre linhagem e tratamento, $p=0,220$, nem diferença significativa entre os tratamentos, $p=0,723$. Não obstante, identificamos diferença significativa entre as linhagens, $p<0,001$. Em outras palavras, os camundongos da linhagem B6.A- $H c^{0}$ apresentaram significativamente maior concentração de 
albumina sérica em relação aos da linhagem B6 independentemente do tratamento aplicado (Figura 33C).

Considerando os parâmetros de função hepática investigados, os camundongos da linhagem congênica B6.A-Hc apresentaram aumento nas concentrações de AST, FA $e$ albumina em relação às concentrações obtidas para os da linhagem $B 6$, independentemente do tratamento dado aos camundongos. Em outras palavras, espontaneamente a linhagem C5 deficiente possivelmente mostrou-se mais sensível a danos hepáticos (Figura 33A e 33B) e com alta atividade sintética (Figura 33C). Ou esta seja uma característica da ausência da proteína C5 no fundo genético B6 independente da presença de dano hepático, a qual componha o perfil de atividade hepática característico desta nova linhagem congênica desenvolvida.

Alterações na concentração sérica de glicose pode ser um reflexo da perda função tamponante exercida pela mesma sobre o soro / plasma. Espera-se que a concentração de glicose seja constante, pois variações podem ser cruciais para a atividade de vários órgãos e desencadear síndromes metabólicas. Buscando identificar alterações séricas nas concentrações de glicose nossas análises não detectaram efeito de interação entre linhagem e tratamento, $p=0,433$, nem diferença significativa entre os tratamentos, $p=0,880$. Contudo, identificamos diferença significativa entre as linhagens, $p<0,001$, ou seja, os camundongos da linhagem B6. A- $H c^{0}$ tiveram significativamente menor concentração de glicose sérica que os da linhagem B6 independente da dieta que os camundongos receberam (Figura 33D).

Finalmente, investigando a concentração de lipídeos séricos, quantificamos triglicerídeos e colesterol total circulantes. Segundo a análise estatística aplicada para a concentração sérica de triglicerídeos não observamos efeito de interação entre linhagem e tratamento, $p=0,136$. Também não observamos diferença significativa entre os tratamentos, $p=0,611$, mas, identificamos diferença significativa entre as linhagens, $p=0,012$. Portanto, os camundongos da linhagem B6.A-Hc ${ }^{0}$ deficiente apresentaram significativamente maior concentração de triglicerídeos séricos que os camundongos da linhagem B6 independente do tratamento dado (Figura 33E). 
Figura 33 - Avaliação da função hepática e parâmetros fisiológicos dos camundongos B6 e B6.A-Hc (C5 deficiente), após 10 semanas de tratamento com diferentes dietas hiperlipídicas.

(A)

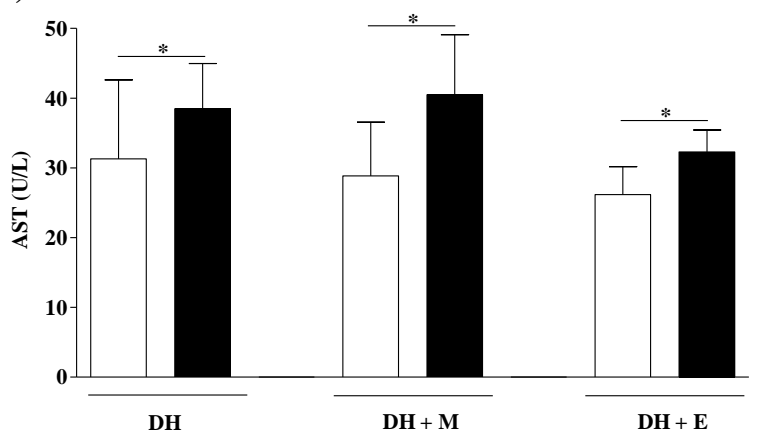

(C)

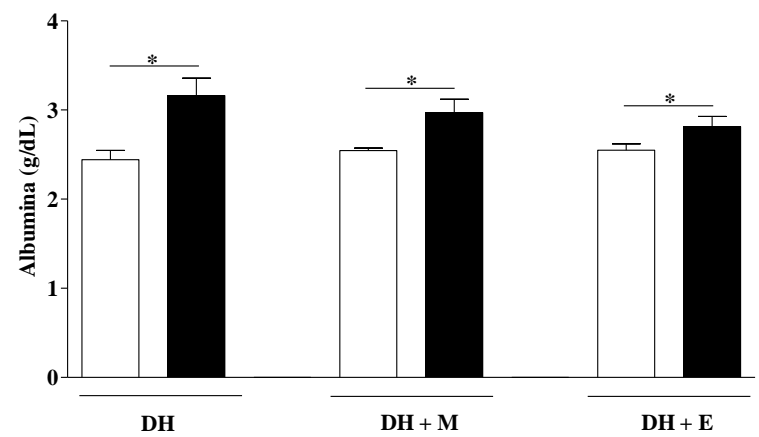

(E)

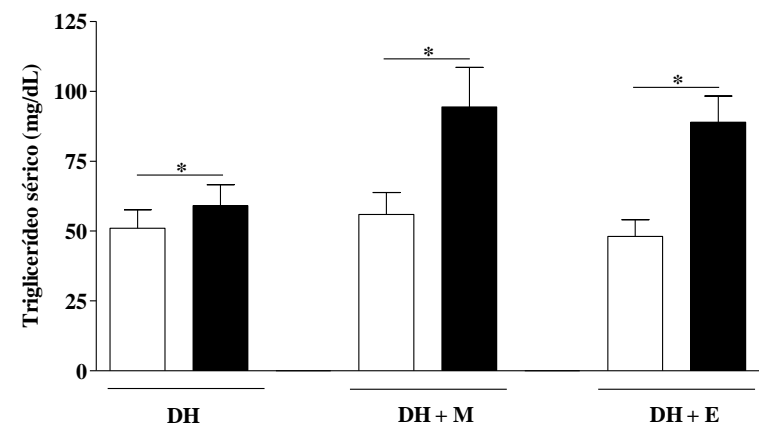

(B)

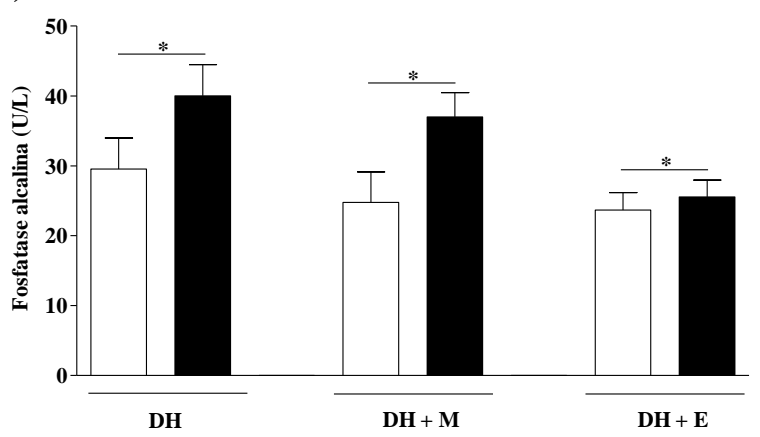

(D)

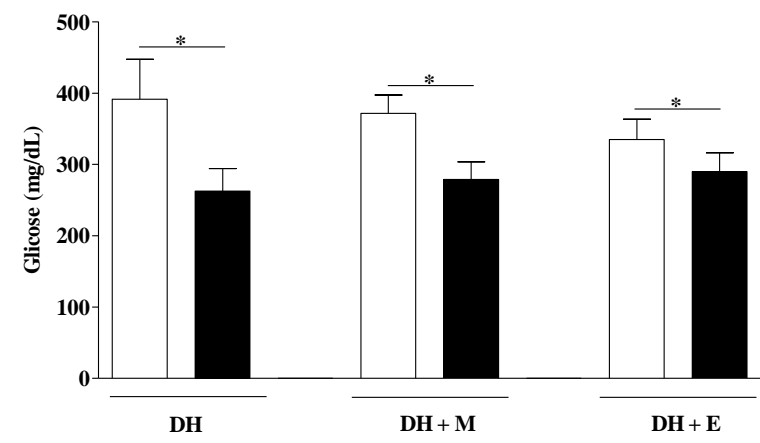

(F)

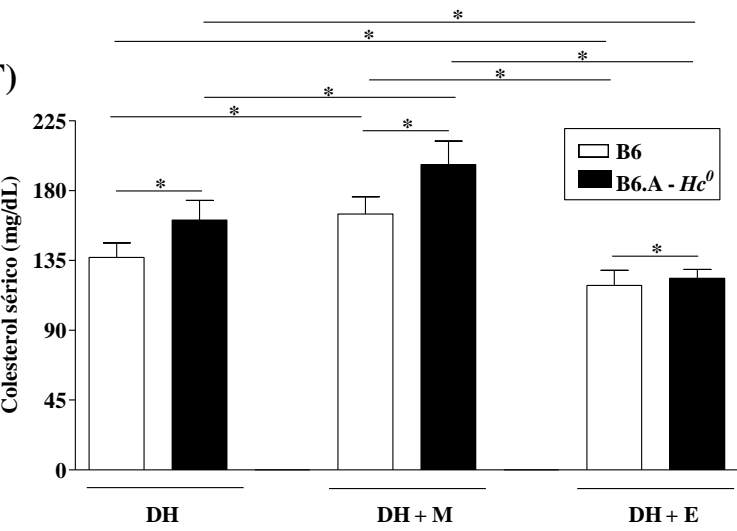

Os resultados estão representados como média e erro padrão. Empregamos pelo menos $\mathrm{n} \geq 6$ camundongos de cada linhagem e consideramos como $* p<0,05$. As siglas presentes na figura: dieta hiperlipídica (DH); dieta hiperlipídica contendo maltodextrina $(\mathrm{DH}+\mathrm{M})$; dieta hiperlipídica contendo etanol (DH+E).

Quanto aos níveis séricos de colesterol não detectamos efeito de interação entre linhagem e tratamento, $p=0,415$. No entanto, identificamos a existência de diferença 
significativa entre os tratamentos, $p<0,001$, onde o grupo tratado com DH diferiu do grupo tratado $\mathrm{DH}+\mathrm{M}$ e $\mathrm{DH}+\mathrm{E}(p<0,05)$. Além disso, o grupo tratado com $\mathrm{DH}+\mathrm{M}$ diferiu do grupo $\mathrm{DH}+\mathrm{E}(p<0,05)$. Ou seja, os camundongos tratados com $\mathrm{DH}+\mathrm{E}$ tiveram significativamente menos colesterol sérico que os tratados com $\mathrm{DH}+\mathrm{M}$ ou DH. Também identificamos diferença significativa entre as linhagens, $p=0,038$, onde os camundongos da linhagem B6.A- $H c^{0}$ apresentaram significativamente maior concentração de colesterol sérico que os da linhagem B6 independentemente do tratamento. (Figura 33F).

Tanto a concentração da glicose, quanto de triglicerídeos séricos não se alteraram com o tratamento, no entanto, a primeira mostrou-se reduzida e a segunda aumentada nos camundongos congênicos C5 deficientes. Estas características bioquímicas possivelmente estiveram relacionadas com a ausência da proteína C5 no fundo genético B6. Quanto à concentração sérica de colesterol observamos claramente que esta se reduziu após o tratamento com a $\mathrm{DH}+\mathrm{E}$ em relação aos tratamentos com $\mathrm{DH}+\mathrm{M}$ ou $\mathrm{DH}$ para ambas as linhagens (Figura 33D, 33E e 33F).

Durante a padronização do modelo de DHA apresentada no tópico anterior observamos aumento nos leucócitos circulantes na linhagem A/J (C5 deficiente) após 10 semanas de tratamento com DH+E. Por ser um parâmetro divergente entre as linhagens B6 e A/J, optamos por avaliá-lo considerando a ausência de C5 no fundo genético B6 (Figura 34). Analisando o valor absoluto de leucócitos totais presentes no sangue periférico, não encontramos efeito de interação entre linhagem e tratamento, $p=0,182$, nem diferença significativa entre os tratamentos, $p=0,884$. No entanto, encontramos diferença significativa entre as linhagens, $p=0,003$. Concluindo, os camundongos da linhagem B6.A-Hc ${ }^{0}$ apresentaram maior número de leucócitos circulantes em relação aos da linhagem B6 independentemente do tratamento administrado aos camundongos (Figura 34). Este comportamento foi o oposto do observado para a linhagem A/J.

Avaliamos o número absoluto de leucócitos totais nos camundongos B6 (n=5) e nos congênicos B6 C5 deficientes $(\mathrm{n}=9)$ com 8 semanas de idade sob a dieta regular sem manipulação e obtivemos média de 4,57 leucócitos x 106/ mL e 4,69 x 10 leucócitos / mL, respectivamente. Aparentemente a dieta hiperlipídica promoveu aumento no número de leucócitos totais circulantes para ambas as linhagens, mas em especial a linhagem B6.A-Hc ${ }^{0}$ foi mais afetada. 
Figura 34 - Contagem absoluta dos leucócitos circulantes dos camundongos B6 e B6.A-Hc ${ }^{0}$ (C5 deficiente), após 10 semanas de tratamento com as diferentes dietas hiperlipídicas.

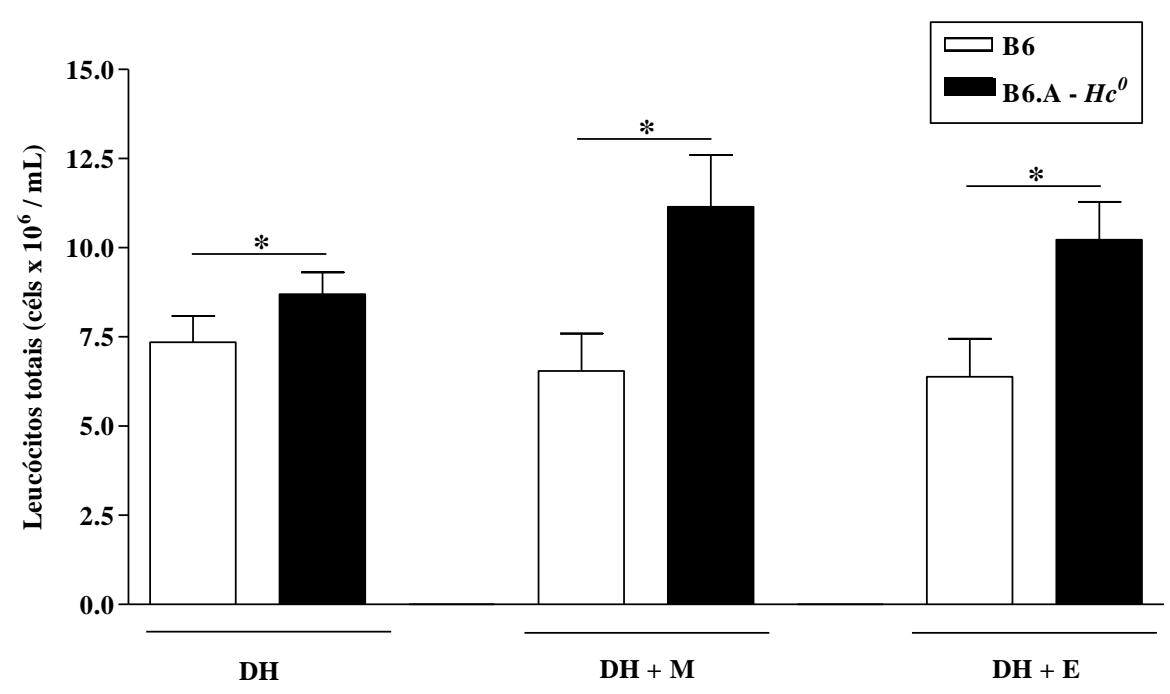

Os resultados estão representados como média e erro padrão. Empregamos pelo menos $\mathrm{n} \geq 6$ camundongos de cada linhagem e consideramos como $* p<0,05$. As siglas presentes na figura: dieta hiperlipídica (DH); dieta hiperlipídica contendo maltodextrina $(\mathrm{DH}+\mathrm{M})$; dieta hiperlipídica contendo etanol (DH+E).

Conclusão da secão 5.2.3.2: A ausência da proteína C5 afetou consideravelmente os níveis séricos de todos os parâmetros avaliados nesta seção. Desta forma, seria interessante investigar estes parâmetros: ALT, AST, FA, albumina, glicose, triglicerídeos, colesterol e leucócitos totais em camundongos sob dieta regular (por exemplo, dieta padrão NUVITAL) para afirmarmos categoricamente se as diferenças observadas são inerentes à ausência de C5 ou simplesmente uma consequência da ausência de C5 frente o metabolismo de uma dieta hiperlipídica.

\subsubsection{Avaliação da resposta inflamatória no micro-ambiente hepático}

A partir do homogenato hepático quantificamos as seguintes citocinas próinflamatórias: TNF- $\alpha$, IL-1ß, IL-6, IL-17, IFN- $\gamma$, IL-12p(70) (Figura 35); e as citocinas antiinflamatórias: IL-10 e TGF-ß (Figura 36). Além disso, também determinamos nitrito, o qual é uma inferência sobre a síntese de NO (Figura 37). Todas as dosagens foram normalizadas pela concentração de proteínas totais presente no homogeneizado.

Avaliando a concentração hepática da citocina TNF- $\alpha$ não identificamos efeito de interação entre linhagem e tratamento, $p=0,501$, nem diferença significativa entre as linhagens, $p=0,730$. Contudo, existe diferença significativa entre os tratamentos, $p=0,008$. 
Independentemente da linhagem, os camundongos tratados com $\mathrm{DH}+\mathrm{E}$ apresentaram aumento significativo na concentração de TNF- $\alpha$ hepático em relação aos tratados com DH apenas (Figura 35A).

Para a concentração da citocina IL-1ß no homogenato hepático detectamos efeito de interação entre linhagem e tratamento, $p=0,035$. Onde os camundongos B6 e B6.A- $H c^{0}$ tratados com $\mathrm{DH}+\mathrm{E}$ apresentaram diferença significativa, $p<0,05$. Ou seja, o tratamento com DH+E levou ao aumento significativo da concentração hepática de IL-1ß nos camundongos B6 e a redução significativa da concentração de IL-1ß nos camundongos B6.A- $H c^{0}$ (Figura 35B). Este foi o primeiro resultado divergente entre as linhagens e sugere que a proteína C5 é importante para a produção de IL-1ß no micro-ambiente hepático, neste modelo murino de DHA.

Quanto à concentração hepática da citocina IL-6 não encontramos efeito de interação entre linhagem e tratamento, $p=0,794$, e também não encontramos diferença significativa entre os tratamentos, $p=0,858$. Porém, encontramos diferença significativa entre as linhagens, $p=0,013$. Portanto, os camundongos da linhagem B6.A-Hc ${ }^{0}$ tiveram menor concentração de IL-6 hepática que os camundongos da linhagem B6 independentemente do tratamento (Figura 35C).

Da mesma forma que observamos para a citocina IL-1ß, a análise estatística para concentração hepática do citocina IL-17 apresentou efeito de interação entre linhagem e tratamento, $p=0,007$, onde, as linhagens diferiram significativamente entre si quando tratadas apenas com DH, $p<0,05$. E ainda, os camundongos da linhagem B6.A- $H c^{0}$ apresentaram aumento significativo de IL-17 após o tratamento com DH+E em relação ao tratamento DH. $\mathrm{Ou}$ seja, para a linhagem B6.A-Hc o tratamento com etanol promoveu o aumento significativo da citocina inflamatória IL-17 no ambiente hepático (Figura 35E). Enquanto a concentração de IL-17 se manteve a mesma após as diferentes dietas hiperlipídicas para os camundongos da linhagem B6, a ausência da proteína C5 no micro-ambiente hepático levou ao aumento da produção de IL-17 após o tratamento dos camundongos com DH+E.

Investigando a concentração da citocina IFN- $\gamma$ no tecido hepático não identificamos efeito de interação entre linhagem e tratamento, $p=0,690$, nem diferença significativa entre os tratamentos, $p=0,922$. Entretanto, identificamos diferença significativa entre as linhagens, $p=0,012$, onde os camundongos da linhagem B6.A- $\mathrm{Hc}^{0}$ apresentaram menor concentração de IFN- $\gamma$ hepática em relação aos da linhagem B6 independentemente do tratamento (Figura 35F). 
Finalizando a análise das citocinas pró-inflamatórias, não observamos efeito de interação entre linhagem e tratamento, $p=0,844$, nem diferença significativa entre os tratamentos, $p=0,096$. Mas, observamos diferença significativa entre as linhagens, $p=0,027$, onde os camundongos da linhagem B6.A- $\mathrm{Hc}^{0}$ apresentaram menor concentração hepática de IL-12p70 em relação aos camundongos da linhagem B6 independentemente do tratamento (Figura 35G).

Figura 35 - Determinação da concentração das citocinas nos homogenatos de tecido hepático nas linhagens B6 e B6.A- $\mathrm{Hc}^{0}$ (C5 deficiente) após 10 semanas de tratamento com as diferentes dietas hiperlipídicas.

(A)

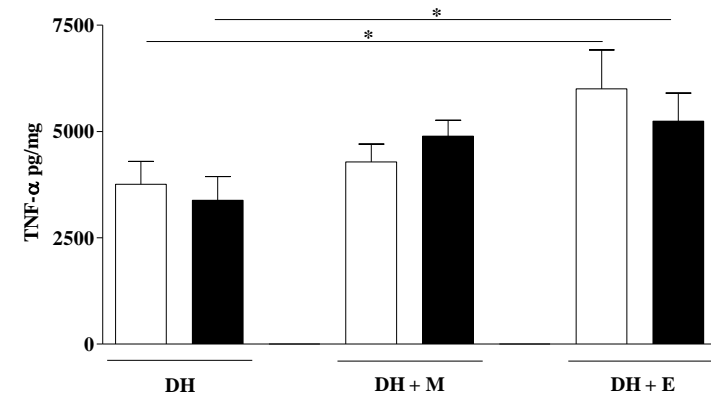

(C)

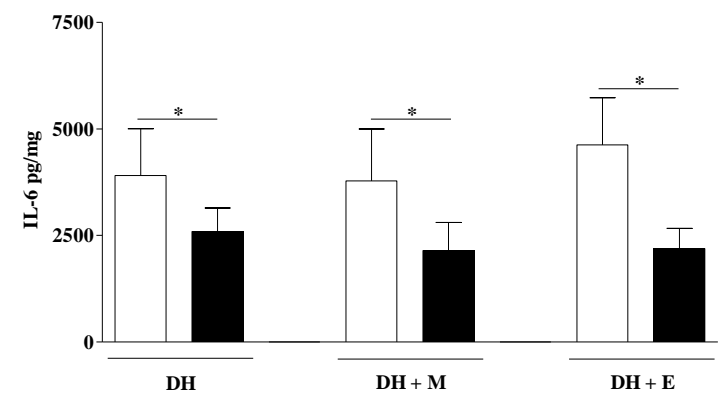

(E)

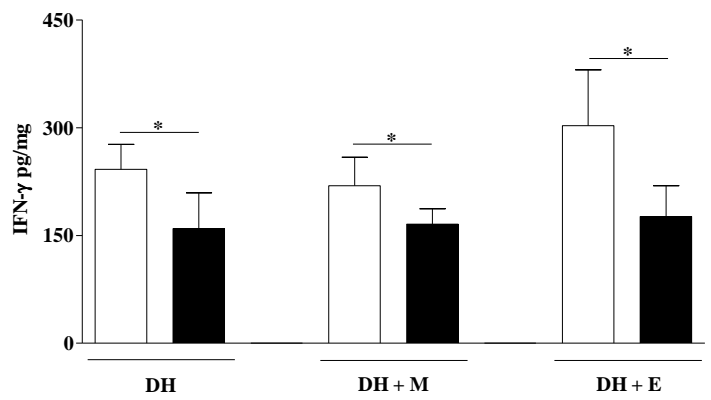

(B)

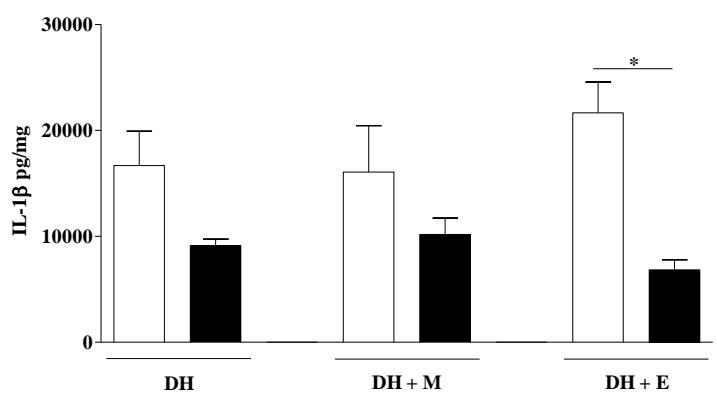

(D)

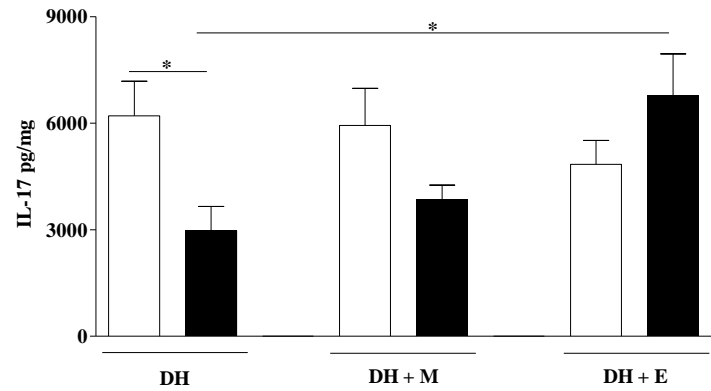

(F)

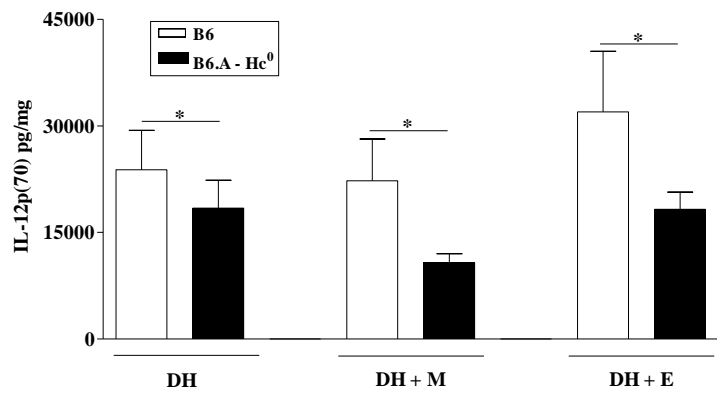

Em (A) representamos as concentrações da citocina TNF- $\alpha$, em (B) IL-1ß, em (C) IL-6, em (D) IL-17, em (E) IFN- $\gamma$ e em (F) IL-12p(70). Os resultados estão representados como média e erro padrão. Empregamos pelo menos $\mathrm{n} \geq 6$ camundongos de cada linhagem e consideramos como $* p<0,05$. As siglas presentes na figura: dieta hiperlipídica $(\mathrm{DH})$; dieta hiperlipídica contendo maltodextrina $(\mathrm{DH}+\mathrm{M})$; dieta hiperlipídica contendo etanol $(\mathrm{DH}+\mathrm{E})$. 
Dentre as citocinas pró-inflamatórias identificamos apenas duas, IL-1ß e IL-17, que apresentaram comportamentos distintos induzidos pela $\mathrm{DH}+\mathrm{E}$ entre as duas linhagens empregadas neste estudo. A primeira teve sua concentração reduzida e a segunda teve sua concentração aumentada, isto mostra que a ausência da proteína pode contribuir na modulação da resposta-inflamatória seja suprimindo ou estimulando-a. Já as citocinas IL6, IFN-y e IL-12p(70) tiveram suas concentrações reduzidas nos animais C5 deficientes, mostrando que a ausência da proteína C5 reduziu a concentração desta citocinas em um micro-ambiente hepático pró-inflamatório induzido pela exposição crônica ao álcool.

Analisando as citocinas anti-inflamatórias IL-10 e TGF-ß encontramos efeito de interação entre linhagem e tratamento para ambas citocina, $p=0,020$ e $p=0,034$ respectivamente (Figura 36A e B). Para a citocina IL-10 as linhagens diferiram significativamente entre si quando tratadas apenas com $\mathrm{DH}, p<0,05$. Portanto, os camundongos da linhagem B6.A- $H c^{0}$ apresentaram aumento significativo de IL-10 após os tratamentos com DH+M e DH+E quando comparados a DH apenas (Figura 36A). E para os camundongos da linhagem B6 a concentração de IL-10 se manteve constante independente do tratamento.

Quanto à concentração da citocina TGF- $\beta$, as linhagens diferiram significativamente entre si quando tratadas com $\mathrm{DH}+\mathrm{E}, p<0,05$. Além disso, fígados dos camundongos da linhagem B6.A- $H c^{0}$ apresentaram redução significativa de TGF- 3 após os tratamentos com $\mathrm{DH}+\mathrm{M}$ e $\mathrm{DH}+\mathrm{E}$, quando comparados a DH apenas. Para os camundongos da linhagem B6 tratados com DH+E a concentração de TGF-ß aumentou significativamente em relação aos camundongos congênicos B6.A- $\mathrm{Hc}^{0}$ (Figura 36B).

Investigando a concentração hepática das citocinas anti-inflamatórias IL-10 e TGFß podemos concluir que a ausência da proteína C5 afetou a concentração de ambas as citocinas. Com relação à citocina IL-10 observamos nos camundongos B6.A-Hc ${ }^{0}$ aumento da sua concentração frente aos tratamentos com $\mathrm{DH}+\mathrm{M}$ e $\mathrm{DH}+\mathrm{E}$, alcançando os níveis observados para os camundongos B6. Já a citocina TGF-ß teve sua concentração reduzida nos camundongos B6.A-Hc ${ }^{0}$ e aumentada nos B6, isto mostra que a ausência de C5 contribuiu para a redução na concentração de TGF- $\beta$ (Figura 36). 
Figura 36 - Determinação da concentração das citocinas anti-inflamatórias IL-10 e TGF- 3 nos homogenatos de tecido hepático nas linhagens B6 e B6.A-Hc ${ }^{0}$ (C5 deficiente) após 10 semanas de tratamento com as diferentes dietas hiperlipídicas.

(A)

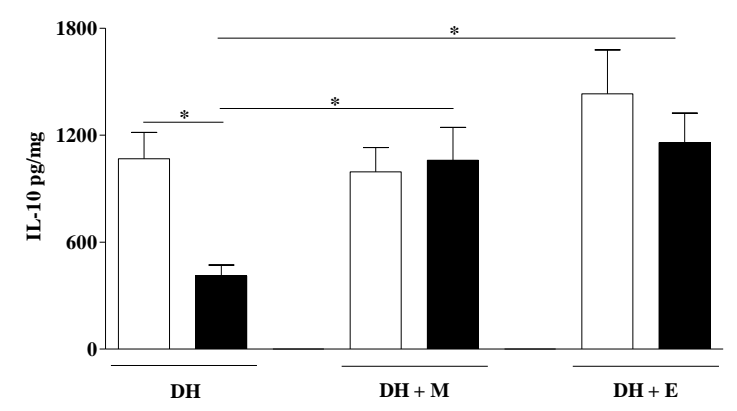

(B)

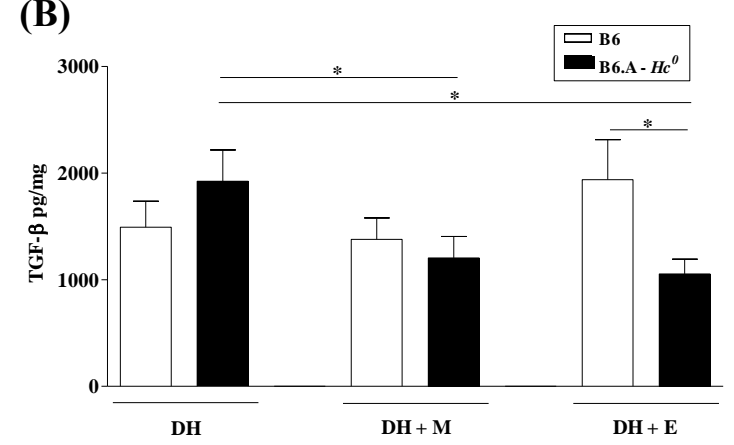

Em (A) apresentamos da determinação da concentração hepática de IL-10 e em (B) de TGF- $\beta$. Os resultados estão representados como média e erro padrão. Empregamos pelo menos $\mathrm{n} \geq 6$ camundongos de cada linhagem e consideramos como $* p<0,05$. As siglas presentes na figura: dieta hiperlipídica (DH); dieta hiperlipídica contendo maltodextrina $(\mathrm{DH}+\mathrm{M})$; dieta hiperlipídica contendo etanol $(\mathrm{DH}+\mathrm{E})$.

Quanto à concentração de NO no homogenato hepático não foi detectado efeito de interação entre linhagem e tratamento, $p=0,209$, nem diferença significativa entre as linhagens, $p=0,799$. Porém, encontramos diferença significativa entre os tratamentos, $p=0,028$. Concluindo, ambas as linhagens apresentaram aumento significativo de NO hepático quando tratadas com DH+E em relação ao tratamento DH+M (Figura 37).

Figura 37 - Determinação da formação de nitrito em homogenato de fígado após 10 semanas de tratamento com as diferentes dietas hiperlipídicas empregando as linhagens B6 e B6.A-Hc ${ }^{0}$ (C5 deficiente).

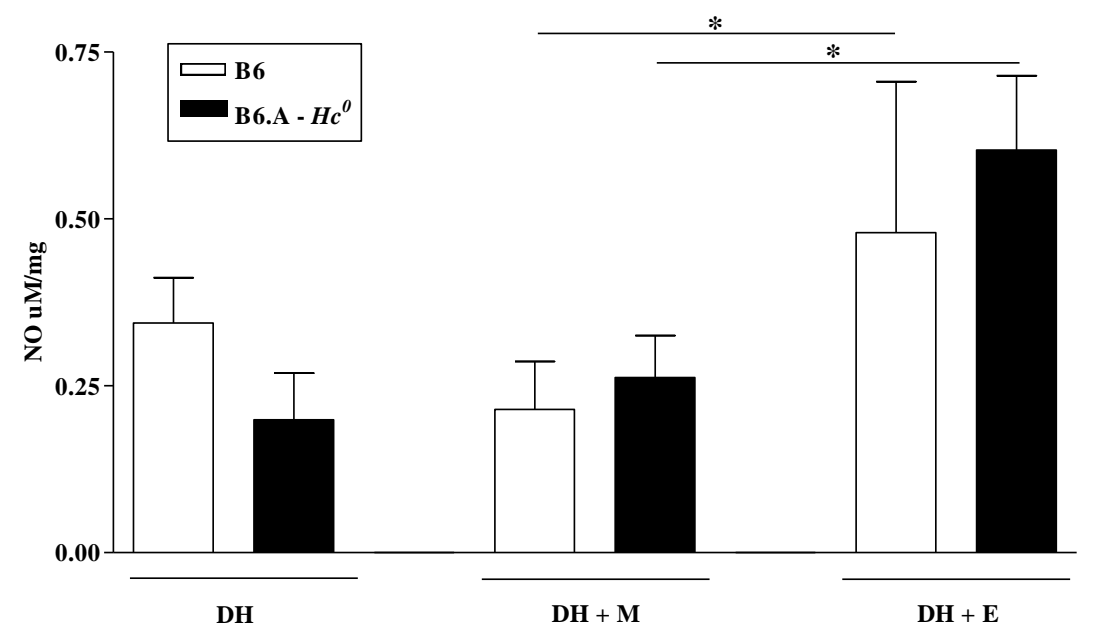

Os resultados estão representados como média e erro padrão. Empregamos pelo menos $\mathrm{n} \geq 6$ camundongos de cada linhagem e consideramos como $* p<0,05$. As siglas presentes na figura: dieta hiperlipídica (DH); dieta hiperlipídica contendo maltodextrina $(\mathrm{DH}+\mathrm{M})$; dieta hiperlipídica contendo etanol $(\mathrm{DH}+\mathrm{E})$. 
Independentemente da linhagem, ou da presença ou não de C5, o tratamento com a DH+E aumentou a produção de NO por células localizadas no tecido hepático, possivelmente macrófagos (Figura 37).

5.2.3.4 Conclusão do tópico "Aplicação da linhagem congênica B6.A- $H c^{0}$ no modelo de DHA"

A aplicação da linhagem congênica B6.A-Hc ${ }^{0}$ no modelo de DHA evidenciou características aparentemente dependentes da ausência da proteína C5. Parâmetros relacionados à fisiologia e bioquímica hepática como AST, FA, albumina, colesterol e triglicerídeos séricos foram maiores na linhagem C5 deficiente. Por outro lado, a ausência de C5 no fundo genético B6 promoveu um micro-ambiente hepático com menor inflamação, quando comparado à linhagem B6 C5 normal. Dentre as principais diferenças encontradas, constatamos redução da concentração de IL-1ß e TGF-ß e o aumento de IL-10 e IL-17 na linhagem B6.A- $H c^{0}$ após o tratamento com DH+E. 
5.2.4 Resumo dos principais resultados obtidos em cada um dos tópicos avaliados no CAPÍTULO 2

Nas tabelas a seguir encontram-se resumidos os resultados mais importantes obtidos com o modelo de injúria hepática aguda (Tabela 11), padronização da DHA (Tabela 12) e aplicação da linhagem congênica B6.A- $H c^{0}$ (Tabela 13).

Os dados apresentados na Tabela 11 são resultados referentes ao tratamento agudo das linhagens B6 e A/J com etanol em relação à água (vs. água). Não abordaremos aqui a avaliação histopatológica, pois estes resultados serão citados, abordados e correlacionados com os parâmetros descritos na Tabela 11 de forma detalhada na discussão.

Tabela 11 - Resumo dos principais resultados obtidos com o modelo de injúria hepática aguda induzida pelo etanol.

\begin{tabular}{lcc}
\hline & \multicolumn{2}{c}{ Linhagens } \\
\cline { 2 - 3 } Parâmetros / Tratamento & B6 & A/J \\
Leucócitos totais periféricos & Etanol 7 g/kg vs. Água & Etanol 7g / kg vs. Água \\
Razão PMN / MN & $\downarrow$ & $\downarrow$ \\
AST plasmática & & $\uparrow$ \\
GGT plasmática & & $\uparrow$ \\
IL-6 plasmática & & $\uparrow$ \\
\hline
\end{tabular}

Camundongos da linhagem B6 e A/J receberam $7 \mathrm{~g} / \mathrm{kg}$ de etanol a $32 \%$ por gavagem foram comparados aos camundongos do grupo controle receberam água autoclavada ( $v s$. água). Empregamos $\mathrm{n}=10$ para cada grupo.

Abreviaturas: vs.: versus; PMN: polimorfonuclear; MN: mononuclear; AST: aspartato amino transferase; GGT: gama glutamil transferase.

Na Tabela 12 resumiremos os resultados obtidos a partir da padronização da DHA onde empregamos as linhagens isogênicas B6 e A/J, as quais foram submetidas a três tempos de tratamento. Os resultados apresentados são referentes aos tratamentos com $\mathrm{DH}+\mathrm{E}$ em comparação aos controles DH+M (controle equicalórico) e DH (controle real). 
Tabela 12 - Resumo dos principais resultados obtidos com a padronização da DHA. Camundongos das linhagens isogênicas B6 e A/J foram tratados com diferentes dietas hiperlipídicas durante 6,8 e 10 semanas.

\begin{tabular}{|c|c|c|c|c|c|c|}
\hline Período de tratamento & \multicolumn{2}{|c|}{6 semanas } & \multicolumn{2}{|c|}{8 semanas } & \multicolumn{2}{|c|}{10 semanas } \\
\hline Parâmetro / Linhagem & B6 & $\mathbf{A} / \mathbf{J}$ & B6 & $\mathbf{A} / \mathbf{J}$ & B6 & $\mathbf{A} / \mathbf{J}$ \\
\hline Ganho de peso final & & $\begin{array}{c}\downarrow v s . \mathrm{DH}+\mathrm{M} \\
\downarrow \downarrow v s . \mathrm{DH}\end{array}$ & $\downarrow v s . \mathrm{DH}+\mathrm{M}$ & $\downarrow v s . \mathrm{DH}+\mathrm{M}$ & $\uparrow v s . \mathrm{DH}$ & \\
\hline $\begin{array}{l}\text { Razão peso hepático / peso } \\
\text { corporal }\end{array}$ & $\begin{array}{c}\uparrow v s . \mathrm{DH}+\mathrm{M} \\
\uparrow v s . \mathrm{DH}\end{array}$ & $\begin{array}{c}\uparrow v s . \mathrm{DH}+\mathrm{M} \\
\uparrow v s . \mathrm{DH}\end{array}$ & $\uparrow v s . \mathrm{DH}+\mathrm{M}$ & $\begin{array}{c}\uparrow v s . \mathrm{DH}+\mathrm{M} \\
\uparrow v s . \mathrm{DH}\end{array}$ & $\begin{array}{c}\uparrow v s . \mathrm{DH}+\mathrm{M} \\
\uparrow v s . \mathrm{DH}\end{array}$ & $\begin{array}{c}\uparrow v s . \mathrm{DH}+\mathrm{M} \\
\uparrow v s . \mathrm{DH}\end{array}$ \\
\hline Depósito de triglicerídeos hepático & $\uparrow v s . \mathrm{DH}$ & $\begin{array}{c}\uparrow v s . \mathrm{DH}+\mathrm{M} \\
\uparrow v s . \mathrm{DH}\end{array}$ & & $\begin{array}{c}\uparrow v s . \mathrm{DH}+\mathrm{M} \\
\uparrow v s . \mathrm{DH}\end{array}$ & $\uparrow v s . \mathrm{DH}$ & $\begin{array}{c}\uparrow v s . \mathrm{DH}+\mathrm{M} \\
\uparrow v s . \mathrm{DH}\end{array}$ \\
\hline Leucócitos totais periféricos & & $\begin{array}{c}\downarrow v s . \mathrm{DH}+\mathrm{M} \\
\downarrow \downarrow v s . \mathrm{DH}\end{array}$ & & & & $\begin{array}{c}\uparrow v s . \mathrm{DH}+\mathrm{M} \\
\uparrow v s . \mathrm{DH}\end{array}$ \\
\hline$T N F-\alpha$ & & $\begin{array}{c}\uparrow v s . \mathrm{DH}+\mathrm{M} \\
\uparrow v s . \mathrm{DH}\end{array}$ & & & & \\
\hline$I L-1 \beta$ & & & & $\downarrow v s . \mathrm{DH}$ & $\begin{array}{c}\downarrow v s . \mathrm{DH}+\mathrm{M} \\
\downarrow \downarrow v s . \mathrm{DH}\end{array}$ & \\
\hline$I L-6$ & $\uparrow v s . \mathrm{DH}$ & $\uparrow v s . \mathrm{DH}+\mathrm{M}$ & $\uparrow v s . \mathrm{DH}$ & $\uparrow v s . \mathrm{DH}+\mathrm{M}$ & $\uparrow v s . \mathrm{DH}$ & $\uparrow v s . \mathrm{DH}+\mathrm{M}$ \\
\hline$I L-17$ & $\begin{array}{l}\downarrow v s . \mathrm{DH}+\mathrm{M} \\
\quad \downarrow v s . \mathrm{DH}\end{array}$ & & $\begin{array}{l}\downarrow v s . \mathrm{DH}+\mathrm{M} \\
\downarrow \downarrow v s . \mathrm{DH}\end{array}$ & & $\begin{array}{l}\downarrow v s . \mathrm{DH}+\mathrm{M} \\
\quad \downarrow v s . \mathrm{DH}\end{array}$ & \\
\hline$I L-12 p 40$ & $\uparrow v s . \mathrm{DH}$ & $\uparrow v s . \mathrm{DH}$ & $\uparrow v s . \mathrm{DH}$ & $\uparrow v s . \mathrm{DH}$ & $\uparrow v s . \mathrm{DH}$ & $\uparrow v s . \mathrm{DH}$ \\
\hline$I L-10$ & & & $\uparrow v s . \mathrm{DH}$ & $\downarrow v s . \mathrm{DH}+\mathrm{M}$ & $\downarrow v s . \mathrm{DH}$ & $\uparrow v s . \mathrm{DH}$ \\
\hline NO & & & & $\downarrow v s . \mathrm{DH}+\mathrm{M}$ & $\downarrow v s . \mathrm{DH}$ & \\
\hline
\end{tabular}

Representamos os resultados obtidos após o tratamento com $\mathrm{DH}+\mathrm{E}$ em comparação aos controles DH+M (vs. $\mathrm{DH}+\mathrm{M})$ ou DH (vs. DH). As setas indicam aumento e redução significativa dos parâmetros em questão.

Abreviaturas: vs.: versus; DH: Dieta hiperlipídica (controle real); DH+M: Dieta hiperlipídica contendo maltodextrina (controle equicalórico); DH+E: Dieta hiperlipídica contendo etanol $(5,3 \%)$.

Por fim, na Tabela 13 apresentaremos os resultados obtidos tratando a linhagem isogênica B6 e a linhagem congênica B6.A- $H c^{0}$ por 10 semanas com a DH+E em comparação aos controles DH+M (controle equicalórico) e DH (controle real). Ressaltamos em azul os principais parâmetros divergentes entre as linhagens B6 e B6.A- $\mathrm{Hc}^{0}$ associados ao tratamento com etanol. E ressaltamos em verde enfatizaremos diferenças entre as linhagens que não foram associadas ao tratamento. Por fim, em vermelho os parâmetros comuns à linhagem $\mathrm{A} / \mathrm{J}$ e a linhagem B6. A- $\mathrm{Hc}^{0}$ mas que divergiram da linhagem B6 associados ao tratamento com etanol. 
Tabela 13 - Resumo dos principais resultados obtidos com a aplicação do modelo de DHA. Camundongos da linhagem isogênica B6 e congênica B6.A- $\mathrm{Cc}^{0}$ (C5 deficiente)

\begin{tabular}{|c|c|c|c|}
\hline \multirow[b]{2}{*}{ Parâmetros } & \multicolumn{2}{|c|}{ Comparação entre DH+E vs DH+M ou DH } & \multirow{2}{*}{$\begin{array}{c}\text { Comparação entre as } \\
\text { linhagens }\end{array}$} \\
\hline & B6 & B6.A $-H^{0}$ & \\
\hline Ganho de peso final & $\downarrow v s . \mathrm{DH}+\mathrm{M}$ & $\downarrow$ vs. $\mathrm{DH}+\mathrm{M}$ & \\
\hline $\begin{array}{l}\text { Razão peso hepático / peso } \\
\text { corporal }\end{array}$ & $\begin{array}{c}\uparrow v s . \mathrm{DH}+\mathrm{M} \\
\uparrow v s . \mathrm{DH}\end{array}$ & $\begin{array}{c}\uparrow v s . \mathrm{DH}+\mathrm{M} \\
\uparrow v s . \mathrm{DH}\end{array}$ & \\
\hline Depósito de triglicerídeos hepático & $\uparrow v s . \mathrm{DH}+\mathrm{M}$ & $\uparrow$ vs. $\mathrm{DH}+\mathrm{M}$ & \\
\hline Depósito de colesterol hepático & $\begin{array}{c}\uparrow v s . \mathrm{DH}+\mathrm{M} \\
\uparrow v s . \mathrm{DH}\end{array}$ & $\begin{array}{c}\uparrow v s . \mathrm{DH}+\mathrm{M} \\
\uparrow v s . \mathrm{DH}\end{array}$ & B6 $<$ B6.A-H $c^{0}$ \\
\hline$A S T-F A-A l b u m i n a ~ s e ́ r i c a$ & & & В6 $<$ B6.A-Hc ${ }^{0}$ \\
\hline Glicose sérica & & & B6>B6.A-Hc ${ }^{0}$ \\
\hline Triglicerídeos sérico & & & B6 $<$ B6.A-Hc ${ }^{0}$ \\
\hline Colesterol sérico & $\begin{array}{c}\downarrow v s . \mathrm{DH}+\mathrm{M} \\
\downarrow v s . \mathrm{DH}\end{array}$ & $\begin{array}{c}\downarrow v s . \mathrm{DH}+\mathrm{M} \\
\downarrow v s . \mathrm{DH}\end{array}$ & $\mathrm{B} 6<\mathrm{B} 6 . \mathrm{A}-\mathrm{H} c^{0}$ \\
\hline Leucócitos totais periféricos & & & В6 $<$ B6.A-H $c^{0}$ \\
\hline TNF- $\alpha$ hepático & $\uparrow v s . \mathrm{DH}$ & $\uparrow v s . \mathrm{DH}$ & \\
\hline IL-1ß hepático & & & B6>B6.A-Hc ${ }^{0}(D H+E)^{\dagger} *$ \\
\hline IL-6 hepático & & & $\mathrm{B} 6>\mathrm{B} 6 . \mathrm{A}-H c^{0}$ \\
\hline IL-17 hepático & & $\uparrow v s . \mathrm{DH}$ & B6>B6.A-Hc $(D H)^{\dagger} *$ \\
\hline IFN- $\gamma$ hepático & & & B6>B6.A-Hc ${ }^{0}$ \\
\hline IL-12p70 hepático & & & $\mathrm{B} 6>\mathrm{B} 6 . \mathrm{A}-H c^{0}$ \\
\hline IL-10 hepático & & $\uparrow v s . \mathrm{DH}$ & B6>B6.A-Hc ${ }^{0}(\mathrm{DH})^{t *}$ \\
\hline TGF- $\beta$ hepático & & $\downarrow v s . \mathrm{DH}$ & B6>B6.A-Hc ${ }^{0}(D H+E)^{\dagger} *$ \\
\hline NO hepático & $\uparrow v s . \mathrm{DH}+\mathrm{M}$ & $\uparrow v s . \mathrm{DH}+\mathrm{M}$ & \\
\hline
\end{tabular}

Camundongos de ambas as linhagens foram tratados por 10 semanas com as diferentes dietas hiperlipídicas. A Tabela resume os resultados obtidos com o tratamento dos camundongos com DH+E e comparados aos controles $\mathrm{DH}+\mathrm{M}$ (vs. $\mathrm{DH}+\mathrm{M})$ ou $\mathrm{DH}$ (vs. DH). As setas indicam aumento e redução significativa dos parâmetros em questão e o símbolo * indica a presença de efeito de interação entre linhagem e tratamento.

Abreviaturas: vs.: versus ou em relação a; DH: Dieta hiperlipídica (controle real); DH+M: Dieta hiperlipídica contendo maltodextrina (controle equicalórico); DH+E: Dieta hiperlipídica contendo etanol $(5,3 \%) ;(\mathrm{DH}+\mathrm{E})^{\dagger}$ : diferença entre as linhagens apenas com o tratamento $\mathrm{DH}+\mathrm{E} ;(\mathrm{DH})^{\dagger}$ : diferença entre as linhagens apenas com o tratamento DH.

Realces coloridos: Azul: divergências entre as linhagens B6 e B6.A-Hc associados ao tratamento DH+E; Verde: diferenças entre as linhagens B6 e B6.A- $\mathrm{Hc}^{0}$ não associadas ao tratamento; Vermelho: parâmetro comum às linhagens $\mathrm{A} / \mathrm{J}$ (referente à Tabela 12) e B6.A-Hc 


\subsection{Discussão do CAPÍTULO 2}

Antes de iniciarmos nossa discussão sobre as injúrias hepáticas observadas nas linhagens A/J, B6 e B6.A-Hc apresentaremos uma breve descrição sobre a estrutura e fisiologia básica do tecido hepático (Figura 38).

Figura 38 - Desenho esquemático ilustrando a estrutura do lóbulo hepático.

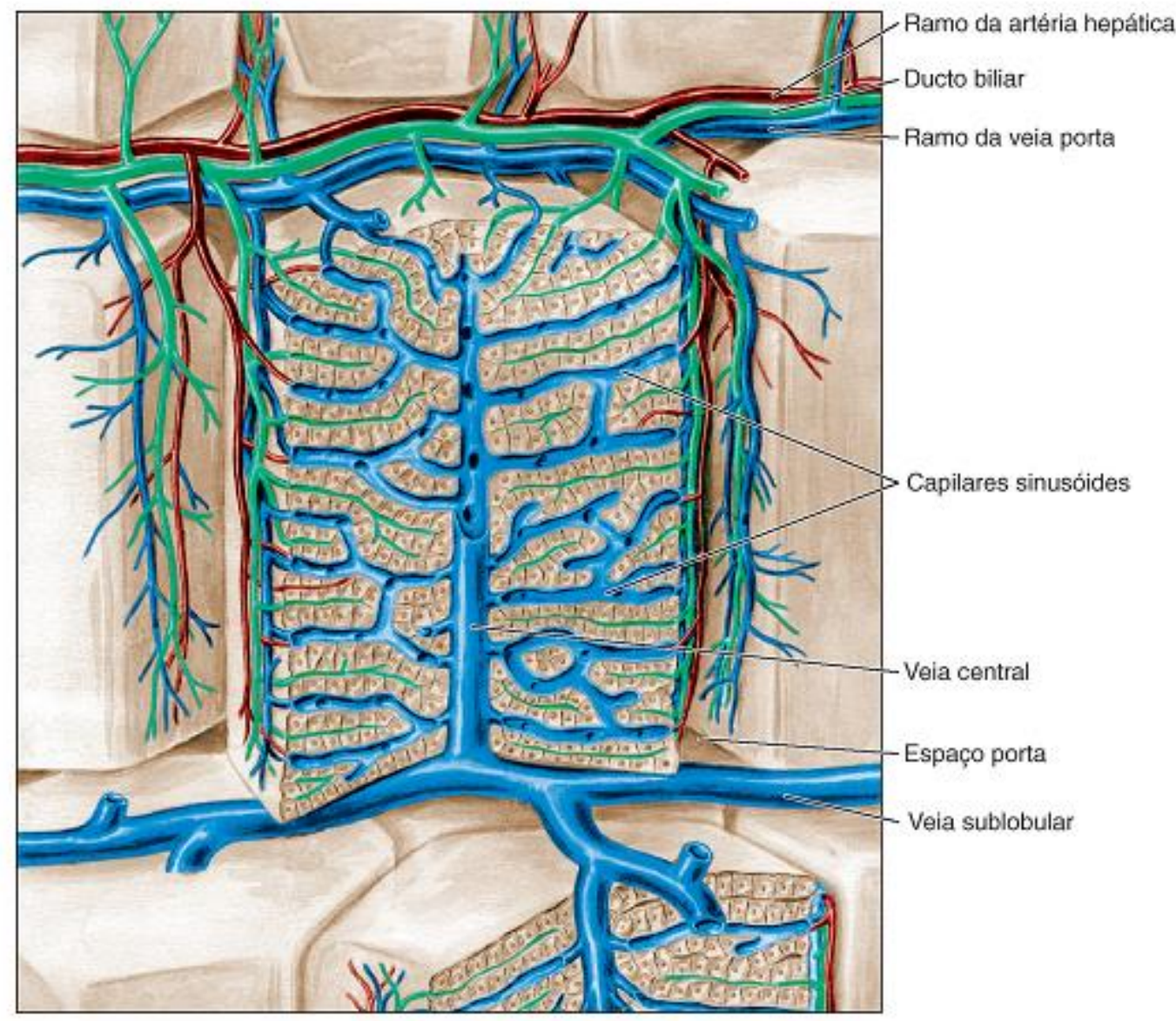

O lóbulo hepático é circundado pelos espaços portas, os quais são compostos por arteríolas, vênulas e ductos biliares. E no centro do lóbulo está a veia central que em conjunto a veia sublobular é responsável pela drenagem do sangue para fora do lóbulo.

Fonte: Junqueira e Carneiro (2008)

O tecido hepático tem como componente estrutural básico os hepatócitos, os quais são organizados em placas interconectadas dando forma a unidades estruturais chamadas lóbulos hepáticos. Contornando a periferia dos lóbulos hepáticos estão distribuídos ductos biliares, vasos linfáticos, nervos e vasos sanguíneos que em seu conjunto formam a região portal (ou espaço porta) e é através do espaço porta que ocorre a entrada sanguínea do fígado. O sangue que chega ao fígado é $75 \%$ oriundo do trato gastro intestinal, pâncreas e baço altamente rico 
em nutrientes, mas pobre em oxigênio. O restante do sangue é procedente da artéria hepática, pobre em nutriente mas rico em oxigênio. Os nutrientes provenientes do sangue atravessam as paredes endoteliais dos vasos e entram em contato com os hepatócitos, favorecendo a troca de nutrientes e eliminação de metabólitos celulares. O lóbulo hepático é permeado por capilares sinusóides, que convergem até a veia centro lobular, a qual é auxiliada pela veia sublobular na remoção do sangue do lóbulo hepático. A veia sublobular funde-se às veias hepáticas que desembocam na veia cava (Figura 38). Em condições de abuso crônico de etanol ou sob condições dietéticas inadequadas o principal local hepático que apresentará alterações como esteatose e inflamação é a região entre o espaço porta e a veia centro lobular, o chamado espaço ou região intermediária (TAUB, 2004).

\subsubsection{Discussão referente aos resultados da injúria hepática aguda induzida por etanol}

Na primeira parte deste trabalho, avaliamos a importância do fundo genético na resposta inflamatória aguda no modelo de binge drinking, empregando as linhagens isogênicas B6 e A/J mimetizando em camundongos a ingestão excessiva de álcool por adultos humanos, o que equivale ao consumo de 3 doses de vodka por um adulto pesando entre 50 a $60 \mathrm{~kg}$. Além de serem amplamente utilizadas em pesquisas e serem bem caracterizadas quanto ao fundo genético, estas linhagens diferem quanto ao perfil de resposta inflamatória provocada por microorganismos ou metabolização de fármacos, polarizando a resposta imunológica para perfil Th1 em camundongos B6 (MILLS et al., 2000) e para perfil Th2 em camundongos da linhagem A/J (CASPI, 2002).

A linhagem A/J carrega uma deleção de 2 pb próxima à região 5' no final do éxon 7 do gene $c 5$ do sistema complemento, a qual leva à ausência da expressão da proteína C5 por esta linhagem (WETSEL; FLEISCHER; HAVILAND, 1990). Além desta mutação espontânea, os macrófagos da linhagem A/J não são capazes de expressar a proteína inibidora de apoptose neuronal (NAIP) 5, a qual é normalmente expressa por macrófagos oriundos da linhagem B6 (WRIGHT et al., 2003). Em camundongos, a NAIP 5 está associada com o desenvolvimento de doenças inflamatórias ou aumento da susceptibilidade às infecções bacterianas (INOHARA; NUÑEZ, 2003).

E ainda, dentre as diferenças entre as linhagens, em situações de consumo voluntário de etanol os camundongos da linhagem A/J apresentaram baixo consumo de etanol, cerca de 2 $\mathrm{g} / \mathrm{kg}$, quando comparados aos camundongos da linhagem B6 que ingeriram voluntariamente 15 - $16 \mathrm{~g} / \mathrm{kg}$ de etanol dentro de um período de $24 \mathrm{~h}$ (YONEYAMA et al., 2008). 
Com o objetivo de investigar o comportamento da resposta inflamatória induzida pelo etanol entre as linhagens tratamos os camundongos B6 e A/J com $7 \mathrm{~g} / \mathrm{kg}$ de etanol por gavagem e as principais diferenças obtidas estão descritas resumidamente na Tabela 11. Após $4 \mathrm{~h}$ de tratamento com etanol, observamos redução significativa do número de leucócitos no sangue periférico em ambas as linhagens em comparação com animais do grupo controle que receberam apenas água (Figura 9A). Em humanos o consumo de etanol afeta o compartimento hematológico devido à presença de produtos do metabolismo do etanol na medula óssea (LIEBER, 1982), entretanto, não podemos afirmar se um período de $4 \mathrm{~h}$ é suficiente para influenciar a multiplicação e liberação de células pela medula óssea dos camundongos. Devido a isso levantamos algumas hipóteses que poderiam talvez explicar a redução no número de leucócitos observada nos camundongos B6 e A/J tratados com etanol: (a) migração de células PMN e / ou MN para o fígado; (b) o etanol poderia danificar a migração leucocitária (SAEED et al., 2004); (c) o fornecimento natural de células da medula óssea para o sangue periférico por ser afetado por este tratamento (ZHANG et al., 2009); (d) os leucócitos poderiam migrar para outros órgãos como estômago ou pulmão (ANDRADE et al., 2006); (e) o etanol poderia induzir a morte celular dos leucócitos (BOÉ et al., 2010). Estas hipóteses serão discutidas nos parágrafos seguintes.

A diferença observada no número basal de leucócitos totais entre os camundongos controles B6 e A/J já foi descrita anteriormente por Pozzulo, Skamene, Gervais (1993), quando observaram que os camundongos $\mathrm{A} / \mathrm{J}$ possuem metade do número de células precursoras na medula óssea que os camundongos B6. É possível especular também que a ausência de C5 na linhagem A/J contribua para este baixo número de células, uma vez que camundongos A/J geneticamente modificados para se tornarem C5 normais apresentaram mais células nucleadas migrando da medula óssea após estímulo inflamatório. Além disso, a linhagem A/J também possui defeito na resposta mediada pelo receptor de IL-3, o qual contribui para a expansão de células hematopoéticas que são diretamente dependentes de IL-3 (ICHIHARA et al., 1995). Finalmente, a intoxicação pelo álcool pode inibir a divisão e diferenciação celular de células tronco hematopoéticas (ZHANG et al., 2009) ou ainda os produtos metabólicos do etanol podem induzir necrose ou apoptose nos leucócitos levando à sua redução na circulação sanguínea (BOÉ et al., 2010).

Apenas a linhagem A/J mostrou aumento na proporção de células PMN no sangue após o tratamento com etanol (Figura 9B). É possível que o etanol tenha comprometido a migração desta população celular, uma vez que o consumo agudo e crônico de etanol pode interferir nas atividades de monócitos/macrófagos e neutrófilos (MOLINA et al., 2010). Uma 
das consequências do consumo de etanol é a redução na expressão de moléculas de adesão presentes nas células edoteliais, tal como a molécula CD18, a qual é necessária para a migração de neutrófilos para o sítio inflamatório (MACGREGOR, 1996). Além disso, o recrutamento de células PMN para o tecido pode ser suprimido em animais tratados com etanol (ZHANG; BAGBY; HAPPEL, 2002). Uma outra explicação possível seria que, as células $\mathrm{MN}$ dos camundondos da linhagem $\mathrm{A} / \mathrm{J}$ tratados com etanol migraram para o fígado e ficaram retidas neste local, e por isso observamos o aumento de células PMN no sangue. Nesta linhagem observamos a presença de infiltrado leucocitário composto tanto por células PMN quanto por MN no tecido hepático (Figura 12D). Já os camundongos B6 tratados com etanol não apresentaram infiltrados de células PMN no tecido hepático de forma tão robusta quanto à linhagem A/J (Figura 11D). É possível especular que as células PMN da linhagem B6 tenham migrado para outros órgãos que também sofreram danos devido ao etanol, tal como o estômago, pois a consecutiva exposição ao etanol induz gastrite concomitantemente a uma resposta inflamatória no estômago caracterizada por infiltrados celulares de MN e PMN (ANDRADE et al., 2006). Por fim, um elegante experimento o qual também aplicou o modelo de binge drink em camundongos mostrou que a administração aguda de etanol aumenta o número de linfócitos $\mathrm{T}\left(\mathrm{CD}^{+}\right.$e $\left.\mathrm{CD}^{+}\right)$e reduz o número de linfócitos $\mathrm{B}$ e células matadoras naturais (NK) no baço (WU et al., 1994). Considerando os nossos resultados esta poderia ser uma explicação plausível, onde os leucócitos ficariam retidos no baço, e consequentemente, a razão de células PMN / MN aumentaria após o tratamento com etanol.

Em doenças hepáticas alcoólicas o aumento da atividade das enzimas ALT e AST em amostras de sangue geralmente refletem dano e destruição de tecidos ricos em aminotransferases (CARSON; PRUETT, 1996; NYBLOM et al., 2004). Observamos em nosso modelo experimental de binge drinking aumento significativo da atividade de enzima AST somente na linhagem A/J, quando tratada com etanol (Figura 10B). Como marcador de doenças hepáticas, a AST é menos específica que a ALT, pois também é encontrada em vários outros tecidos como: músculo cardíaco, rins, pulmão, intestino e cérebro (BOONE et al., 2005; REJ , 1985). Portanto, a AST também pode ser, até certo ponto, informativa sobre a integridade e condições fisiológicas sistêmicas (BOONE et al., 2005). Finalmente, observamos aumento significativo da atividade da GGT apenas no plasma de camundongos A/J tratados com etanol (Figura 10B). GGT primariamente é encontrada no fígado, músculo cardíaco e rins (LAMY et al., 1974). No fígado esta enzima encontra-se regularmente presente em altas concentrações na região centrolobular dos hepatócitos (LEONARD et al., 1984) e a elevação da sua concentração no plasma em humanos é diretamente proporcional à 
quantidade de etanol consumida (WHITFIELD, 2001). A elevação desta enzima nos camundongos A/J está em concordância com a elevação plasmática da enzima AST (Figuras 10A e 10B) confirmando o efeito do etanol sobre a linhagem $A / J$ e sua susceptibilidade ao dano hepático mediado pelo tratamento alcoólico. O aumento da concentração plasmática de AST e GGT pode ser considerado como um marcador diferencial para dano hepático induzido por etanol em modelo de binge drink entre os camundongos da linhagem B6 e A/J. Contudo, mais experimentos são necessários para apoiar essa hipótese.

A necrose observada na linhagem A/J (Figura 12C) pode estar correlacionada com o aumento da concentração plasmática das enzimas AST e GGT (Figura 10A e 10B) após o tratamento com etanol. As análises histopatológicas identificaram diferenças nos padrões de lesão hepática entre os camundongos B6 e A/J, sendo que, neste modelo de binge drink, a linhagem A/J foi mais sensível que a linhagem B6 em desenvolver necrose e conseqüente infiltração de leucócitos PMN no tecido hepático. Diferenças entre as linhagens B6 e A/J também foram observadas em modelo de injúria colestática causado pela ligação do ducto biliar, neste modelo os camundongos da linhagem A/J apresentaram sobrevida maior que os camundongos da linhagem B6 (ALAISH et al., 2005). Da mesma forma foi observada maior mortalidade dos camundongos da linhagem B6 que nos camundongos da linhagem A/J empregando o modelo murino de sepsis por ligação e puntura do ceco (STEWART et al., 2002), confirmando a influência do fundo genético para o desenvolvimento de cada condição patológica.

Finalmente, demonstramos que a concentração de IL-6 plasmática aumentou significativamente na linhagem A/J 4 h após o tratamento com etanol, em média aumentou de $20 \mathrm{pg} / \mathrm{mL}$ para $100 \mathrm{pg} / \mathrm{mL}$, já a linhagem B6 manteve a média de $120 \mathrm{pg} / \mathrm{mL}$ tanto para o grupo controle quanto para o grupo tratado com etanol (Figura 13). Este aumento pode ser um mecanismo protetor inerente à linhagem A/J para inibir a apoptose mediada pelo etanol (HONG et al., 2002; MCCLAIN et al., 2004; PRUETT; FAN, 2009) ou um efeito da resposta inflamatória induzida pelo etanol nos camundongos A/J. Observamos também uma tendência de aumento da concentração plasmática de IL-10 nos camundongos A/J tratados com etanol (média e erro padrão: $39.17 \pm 32.36 \mathrm{pg} / \mathrm{mL}$ ), mas não encontramos diferença significativa. Possivelmente a detecção de citocinas no plasma não seja uma abordagem adequada para o modelo que empregamos. A produção de citocinas durante o consumo alcoólico é tempo-, tecido- e estímulo-dependente (MCCLAIN et al., 2004; PRUETT; PRUETT, 2006), pois quando camundongos B6C3F1 ( $\mathrm{F} 1$ do cruzamento entre $\mathrm{B} 6$ e $\mathrm{C} 3 \mathrm{H}$ ) foram tratados com etanol sob o modelo de binge drinking, nenhuma mudança nos níveis séricos de IL-6 (controles 
apresentaram concentração em torno de $100 \mathrm{pg} / \mathrm{mL}$ e tratados com etanol apresentaram concentração média de 50 pg / mL), IL-10 (controles apresentaram concentração em torno de $17 \mathrm{pg} / \mathrm{mL}$ e tratados com etanol apresentaram concentração média de 12 pg / mL) e IL-12 foram observadas após $6 \mathrm{~h}$ de tratamento, resultados consideravelmente próximos aos que obtivemos após $4 \mathrm{~h}$ de tratamento. Mas, quando estes animais foram simultaneamente infectados com E. coli e tratados com etanol, a concentração sérica de IL-10 aumentou e a concentração de IL-6 diminuiu após 17 h de tratamento (PRUETT et al., 2004). Por outro lado, camundongos da linhagem B6 tratados por 4 dias com a dieta Lieber-DE CARLI contendo $2 \%$ de etanol exibiram aumento significativo de TNF- $\alpha$, IL-6 e INF- $\gamma$ no tecido hepático. E quando camundongos sem os receptores para os fragmentos C3a ou C5a foram submetidos ao mesmo tratamento não apresentaram aumento de TNF- $\alpha$ (ROYCHOWDHURY et al., 2009). A citocina TNF- $\alpha$ é a principal citocina necessária para a manutenção do micro-ambiente inflamatório na doença hepática alcoólica (ZHOU et al., 2003). Com isso, o fígado passa a ser o local ideal para a determinação da concentração de citocinas, sejam elas pró-inflamatórias ou anti-inflamatórias, frente ao tratamento agudo ou crônico com etanol.

Concluindo, os resultados apresentados revelam diferenças consideráveis na resposta inflamatória aguda mediada pelo etanol entre os camundongos B6 e A/J que estão resumidas na Tabela 11. Mesmo que ambas as linhagem tenham apresentado redução no número de leucócitos totais circulantes após o tratamento com etanol, apenas a linhagem A/J apresentou aumento na razão PMN / MN. Observamos também concomitante aumento das enzimas AST e GGT com a citocina pró-inflamatória IL-6 apenas nos camundongos da linhagem A/J tratados com etanol. Portanto, os resultados sugerem que no modelo de binge drinking os camundongos $\mathrm{A} / \mathrm{J}$ sofrem mais danos hepáticos que os camundongos B6 devido à resposta inflamatória promovida pelo etanol. 


\subsubsection{Discussão referente aos resultados da padronização do modelo de DHA em camundongos B6 e A/J}

A análise estatística do ganho de peso acumulado foi realizada apenas com os dados obtidos após 10 semanas de tratamento por compreender o período semanal total testado. Portanto, após 10 semanas acompanhando o ganho de peso acumulado observamos que os camundongos da linhagem A/J apresentaram dificuldade de ganho de peso quando tratados com a $\mathrm{DH}+\mathrm{E}$ em comparação aos tratados com $\mathrm{DH}+\mathrm{M}$. Neste contexto de tratamento, a linhagem A/J apresentou comprometimento do ganho de peso acumulado semanalmente (Apêndice C - Figura C.1) e ganho de peso final (Figura 15). Entretanto, os camundongos da linhagem B6 tratados com $\mathrm{DH}+\mathrm{E}$ apresentaram ganho de peso significativo em relação aos tratados com DH. Estes dados mostraram que a dieta contendo etanol afetou o ganho de peso acumulado para a linhagem $\mathrm{A} / \mathrm{J}$, seja ele acumulado semanalmente ou o ganho de peso total obtido ao final do tratamento, como esperado perante a uma dieta contendo etanol e em concordância com os trabalhos anteriores (BYKOV et al., 2004; LIEBER; DE CARLI, 1982).

O aumento da razão do peso hepático pelo peso corporal ocorre, principalmente, em consequência ao acúmulo de triglicerídeos nos hepatócitos, o qual é induzido pelo consumo alcoólico em conjunto com a dieta hiperlipídica (BYKOV et al., 2004; LIEBER; DE CARLI, 1982). Observamos que para ambas as linhagens tratadas com $\mathrm{DH}+\mathrm{E}$ houve o aumento significativo tanto da razão do peso hepático pelo peso corporal quanto aumento do acúmulo de triglicerídeos hepáticos, em comparação aos animais tratados com DH (Figuras 16 e 17). A partir da extração de lipídeos totais quantificamos a concentração de triglicerídeos presentes no extrato, nossos resultados para a linhagem B6 tratada com $\mathrm{DH}+\mathrm{E}$ foi em média $50 \mathrm{mg} / \mathrm{g}$ de tecido, o mesmo valor obtido de triglicerídeos no modelo de Lieber-DeCarli (1982) em tecido hepático de ratos. Já a linhagem A/J mostrou-se mais resistente ao acúmulo de triglicerídeos hepáticos apresentando a concentração média de $35 \mathrm{mg} / \mathrm{kg}$. Entretanto, esta confirmação apenas pôde ser efetivamente validada pela análise histopatológica do tecido hepático empregando as colorações HE e PAS (Figuras 18, 19, 20 e 21), onde foi possível observar a presença de micro- e macro esteatose (vesículas lipídicas) hepática nos camundongos de ambas as linhagens quando tratados com $\mathrm{DH}+\mathrm{E}$ por 10 semanas. A coloração PAS foi de grande valia pois confirmou que o conteúdo das vesículas lipídicas realmente continha triglicerídeos e não glicogênio, este último esteve depositado ao redor das vesículas lipídicas (Figuras 20 e 21). 
Portanto, o modelo padronizado induziu nas linhagens B6 e A/J os padrões corporais observados analogamente em pacientes e em outros modelos animais de DHA. Na sequência, analisamos os comportamentos das linhagens em relação aos diversos parâmetros inflamatórios presentes no micro ambiente hepático. A partir daqui evidenciaremos as diferenças inflamatórias entre as linhagens e correlacionaremos essas alterações com a progressão patológica da DHA ao longo das semanas de tratamento.

Dentre os parâmetros inflamatórios analisados que apresentam comportamento comum às linhagens estão as citocinas IL-6 e IL-12. Observamos aumento significativo para ambas as citocinas após o tratamento com $\mathrm{DH}+\mathrm{E}$ em relação ao tratamento com $\mathrm{DH}+\mathrm{M}$ ou $\mathrm{DH}$. Além disso, identificamos por meio das análises estatísticas entre os tempos de tratamento que as concentrações de IL-6 e IL-12 mesmo sendo maiores nos camundongos tratados com DH+E foram reduzidas ao longo das semanas de tratamento, especialmente quando comparadas de 6 para 10 semanas, (Figura 25C, 25E, 25F). Dessa forma, o tratamento com etanol aumenta a concentração hepática de IL-6, mas com o passar do tempo essa concentração reduz gradativamente no grupo dos animais tratados com etanol. Semelhante conclusão pode ser afirmada para a citocina IL-12.

A citocina IL-6 desempenha duas funções dentro do contexto inflamatório, a primeira delas é mediada pelo estímulo da síntese de citocinas pró-inflamatórias por macrófagos, a segunda tem ação hepato-protetora, contribuindo para a recuperação da necrose hepática associada à inflamação (MENG et al., 2012). A citocina IL-6 protege contra a injúria hepática induzida pelo álcool sinalizando via signal transducer and activator of transcription 3 (STAT3) e subseqüente indução de vários genes hepato-protetores nos hepatócitos (GAO, 2012; MILLER el al., 2011). Camundongos deficientes de IL-6, quando tratados cronicamente com etanol, apresentam aumento significativo no acúmulo de gordura hepática, peroxidação lipídica, dano ao DNA mitocondrial e sensibilização dos hepatócitos à apoptose induzida por TNF- $\alpha$. Quando os camundongos receberam IL-6 recombinante, ocorreu a reversão deste quadro (EL-ASSAL et al., 2004; MENG et al., 2012). Em todas as semanas de tratamento a concentração de IL-6 esteve aumentada nos camundongos que receberam etanol, entretanto essa concentração reduziu-se com o passar das semanas, em concordância com os estudos sobre o caráter protetor de IL-6, o qual atua principalmente nas fases iniciais do desenvolvimento da DHA (MILLER et al., 2011).

Não existem trabalhos sobre as concentrações hepáticas de IL-12 em modelos murinos de DHA. No entanto, o nível sérico de IL-12 foi avaliado em pacientes com DHA, quando se observou uma correlação com os diferentes estágios da doença, e pacientes com hepatite 
alcoólica tiveram maior concentração sérica de IL-12 que os pacientes que apresentaram cirrose alcoólica, estes ainda apresentaram maior concentração que os pacientes com esteatose alcoólica. Todos estes pacientes apresentaram maior concentração de IL-12 que o grupo controle (TUNG et al., 2010). Nossos resultados mostraram um comportamento oposto para a concentração de IL-12 hepática, mesmo o grupo tratado com DH+E possuindo concentração menor que os tratados com $\mathrm{DH}+\mathrm{M}$ ou DH, a concentração de IL-12 decresceu gradativamente de 6 para 10 semanas de tratamento (Figura 25E e 25F). De certa forma também encontramos uma relação entre a concentração de IL-12 hepática e a progressão da DHA em modelo murino, com o tempo e o tratamento houve a promoção da severidade patológica da DHA e redução significativa da concentração de IL-12.

Encontramos também que a concentração hepática de IL-10 e a produção de NO após 10 semanas de tratamento são parâmetros com comportamento oposto entre as linhagens B6 e A/J. E analisando tanto a citocina IL-10 como a produção de NO para ambas as linhagens detectamos efeito de interação entre os tratamentos e o tempo. Quanto a citocina antiinflamatória IL-10 para a linhagem B6 identificamos que a concentração desta citocina reduziu após o tratamento com $\mathrm{DH}+\mathrm{E}$ em relação ao tratamento com $\mathrm{DH}+\mathrm{M}$ ou $\mathrm{DH}$. E ainda, identificamos que dentre os camundongos $\mathrm{B} 6$ tratados com $\mathrm{DH}+\mathrm{E}$ a citocina IL-10 reduziu de 8 para 10 semanas de tratamento. Já para a linhagem A/J o tratamento com $\mathrm{DH}+\mathrm{E}$ promoveu o aumento da concentração de IL-10 em relação aos camundongos tratados com DH+M ou DH, além disso a concentração de IL-10 aumentou entre os camundongos A/J tratados com DH+E de 6 para 10 semanas (Figura 25G). A produção de NO no tecido hepático dos camundongos tratados com $\mathrm{DH}+\mathrm{E}$ também tem comportamento divergente, sendo que para a linhagem B6 houve redução significativa de 6 e 8 para 10 semanas e identificamos que para a linhagem A/J houve aumento significativo de 8 para 10 semanas de tratamento (Figura 25H).

A citocina IL-10 possui um potente papel anti-nflamatório por meio do bloqueio da produção de TNF- $\alpha$, IL-1ß e IL-6. Camundongos knockout para IL-10 tratados com dieta contendo etanol apresentaram inflamação hepática e sistêmica em comparação aos selvagens. Mas surpreendentemente, embora a inflamação tenha sido aumentada os camundongos ausentes de IL-10 apresentaram redução no acúmulo de triglicerídeos hepáticos e baixos níveis séricos de AST / ALT após o tratamento com etanol em comparação aos selvagens. É possível que nos camundongos knockout para IL-10 a elevação de IL-6 e sua sinalização via STAT3 no fígado tenha melhorado a esteatose e os danos hepatocelulares (MILLER et al., 2011). 
Macrófagos ativados por LPS ou citocinas Th1 são responsáveis pela liberação de moléculas com atividades pró-inflamatória ou citotóxica. Dentre as moléculas produzidas que estão associadas a dano tecidual estão às espécies reativas de oxigênio (ROS) e nitrogênio (RNS), além de proteases e mediadores lipídicos. Dentre as ROS estão: ânion superóxido, NO, peróxido de hidrogênio que são principalmente geradas por reações catalíticas durante a respiração mitocondrial. Em baixas concentrações e sob condições fisiológicas as ROS e RNS funcionam como moléculas reguladoras da sinalização celular importantes na manutenção da homeostase tecidual, mas, quando geradas em excesso, causam dano tecidual. Lipídios, proteínas e DNA são alvos freqüentes que sofrem modificações pela da ação das ROS, estas modificações provocam alterações funcionais, necrose e apoptose (LASKIN et al., 2011). O álcool aumenta a produção de ROS por vários mecanismos, dentre eles pelo metabolismo mediado pela cadeia de transporte eletrônico mitocondrial e pelo citocromo P450-2E1, o que já é suficiente para gerar injúria e necrose celular. No nosso modelo a linhagem A/J acumulou acentuadamente triglicerídeos nos hepatócitos após 8 e 10 semanas de tratamento com etanol. Curiosamente, a produção de NO acompanhou o acúmulo de triglicerídeos, portanto seria interessante investigar uma possível modulação anti-inflamatória na linhagem A/J. Já a linhagem B6 teve a produção de NO reduzida após 10 semanas e aumento da distribuição de esteatose hepática.

Exclusivamente à linhagem B6 observamos que a concentração hepática da citocina IL-1ß reduziu-se ao longo das semanas nos camundongos tratados com $\mathrm{DH}+\mathrm{E}$ e após 10 semanas a concentração desta citocinas foi menor que a dos camundongos tratados com $\mathrm{DH}+\mathrm{M}$ e DH (Figura 25B). O mesmo comportamento foi observado para a citocina IL-17 quanto à redução da concentração ao longo do tempo de tratamento com $\mathrm{DH}+\mathrm{E}$, mas identificamos para todos os tempos de tratamento que a concentração de IL-17 foi menor nos tratados com DH+E que nos tratados com DH+M ou DH (Figura 25D).

Além dos receptores extracelulares do tipo Toll existem outros receptores para patógenos ou produtos originários da desregulação metabólica que são conhecidos como receptores semelhantes ao NOD (NLRs). Alguns destes NLRs formam complexos intracelulares chamados inflamassomas que são responsáveis pela sensibilização celular por produtos microbianos e por estresse metabólico promovendo a ativação proteolítica das citocinas pro-inflamatórias como IL-1ß e IL-18 (MARTINON; MAYOR; TSCHOPP, 2009). A sinalização via receptor de IL-1ß (IL-1R) é necessária para o desenvolvimento da esteatose, inflamação e injúria hepática induzida pelo etanol. O aumento de IL-1ß ocorre em resposta à atividade da caspase-1 e ativação do inflamassoma. O papel patogênico de IL-1ß na DHA 
ocorre por conta da ativação do inflamassoma nas células Kupffer (PETRASEK et al., 2012). Nossos resultados mostram que a concentração de IL-1ß foi alta após 6 e 8 semanas de tratamento com $\mathrm{DH}+\mathrm{E}$, mas sua concentração reduz significativamente com 10 semanas. Possivelmente a redução da concentração de IL-1 ocorreu como um mecanismo interno para conter a progressão do esteatose.

A citocina IL-17 também é pró-inflamatória com função muito parecida da citocina TNF- $\alpha$, porém mais fraca. Ela pode atuar sinergicamente com outras citocinas, como TNF- $\alpha$, e ativar via NF-kB e induzir a produção de IL-8, uma quimiocina responsável por atrair neutrófilos até o sítio inflamatório (MENG et al., 2012). Em soro de pacientes com DHA foram encontrados altos níveis de IL-17, sendo os monócitos e células T presentes no sangue e neutrófilos e células $\mathrm{T}$ infiltradas no fígado as principais fontes desta citocina. Nestes pacientes pôde ser identificada uma correlação entre a secreção de IL-17 pelas células infiltradas e a severidade da fibrose hepática (LEMMERS et al., 2009). De forma inversa ao observado em pacientes os camundongos B6 apresentaram redução da concentração hepática desta citocina.

Por fim, exclusivamente à linhagem $\mathrm{A} / \mathrm{J}$ encontramos variação quanto ao número de leucócitos totais e quanto à concentração da citocina TNF- $\alpha$, onde nestes parâmetros detectamos efeito de interação entre tratamento e tempo (semanas) apenas para a linhagem $\mathrm{A} / \mathrm{J}$. A linhagem $\mathrm{A} / \mathrm{J}$ tratada com $\mathrm{DH}+\mathrm{E}$ teve o número de leucócitos circulantes reduzido com 6 semanas de tratamento e após 10 semanas o número de leucócitos aumentou significativamente tanto em relação aos controles DH+M e DH quanto de 6 para 10 semanas (Figura 24B). Já para a citocina pró-inflamatória TNF- $\alpha$ houve aumento da concentração nos camundongos tratados com $\mathrm{DH}+\mathrm{E}$ em relação aos tratados com $\mathrm{DH}+\mathrm{M}$ e $\mathrm{DH}$ após 10 semanas de tratamento, (Figura 25B). Portanto, ficou evidente que para a linhagem A/J a interação entre o tratamento com $\mathrm{DH}+\mathrm{E}$ e o período de 10 semanas afetou o aumento do número de leucócitos e tornou proeminente a diferença na concentração de TNF- $\alpha$ no micro ambiente hepático em relação aos controles $\mathrm{DH}+\mathrm{M}$ e $\mathrm{DH}$.

A citocina TNF- $\alpha$ está intimamente associada ao estabelecimento e progressão da DHA tanto para pacientes quanto em modelos animais, pois altos níveis séricos desta proteína foram encontrados em pacientes com DHA (MENG et al., 2012) e em camundongos tratados com DH+E a produção de TNF- $\alpha$ é induzida nos períodos iniciais da doença e é fortemente relacionada ao desenvolvimento de injúria hepática (ROYCHOWDHURY et al., 2009). Observamos aumento de TNF- $\alpha$ apenas na linhagem A/J tratada com DH+E por 10 semanas, 
quanto à linhagem B6 não encontramos diferença entre os tratamentos, mas é possível observar uma tendência no aumento da concentração desta citocina nos tratados com DH+E.

Avaliando o conjunto de parâmetros corporais e inflamatórios é possível dizer que a linhagem B6 possui mais depósito de lipídeo hepático e não apresentou dificuldade de ganho de peso. E neste contexto, evidenciado pelo tempo de 10 semanas, houve uma aparente depleção da resposta inflamatória induzida pela DH+E com redução de IL-1ß, IL-17, IL-10, NO e ao mesmo tempo encontramos aumento de IL-6 e IL-12. É importante lembrar que mesmo IL-6 e IL-12 estando aumentadas suas concentrações decaem com o passar das semanas. Essa depleção na resposta inflamatória observada após 10 semanas pode ser uma consequência do aumento de IL-10 produzido após 8 semanas de tratamento, ou o resultado de um mecanismo compensatório desenvolvido pela linhagem para conter a resposta inflamatória uma vez que o tecido hepático estava cerca de 80 a 90\% comprometido com o depósito de lipídeos, e consequentemente estava com a sua função parcialmente comprometida.

Por outro lado a linhagem A/J apresentou menos depósito de lipídeo hepático e dificuldade de ganho de peso. Mas neste contexto de DHA no período de 10 semanas identificamos uma marcante resposta inflamatória induzida pelo tratamento com $\mathrm{DH}+\mathrm{E}$ com aumento característico de TNF- $\alpha$, IL-6, IL-12, IL-10 e NO. Consequentemente, é possível que a citocina IL-10 segure os danos induzidos pela citocina TNF- $\alpha$ e IL-6 também contribua na proteção destes danos por meio de sua função hepato-protetora. Pois, se a linhagem A/J mesmo em meio a este contexto pró-inflamatório esteve protegida do acúmulo de lipídeos e da lesão induzida etanol possivelmente foi pelo papel hepato-protetor oriundo da interação IL6/STAT3 e IL-10/STAT3 que atenuaram a resposta inflamatória pela expressão de genes antiapoptóticos, anti-oxidantes, proteínas pró-oncogênicas que são responsáveis por várias funções hepáticas (MILLER et al., 2011). Ou seja, na linhagem A/J identificamos uma possível inter-relação IL-6/IL-10/STAT3 a qual melhora e protege contra a injúria hepática induzida pelo etanol. E ainda, estes resultados corroboram com os dados presentes na literatura e são coerentes com modelos apresentados para descrever a função hepato-protetora de IL-6.

Portanto, quando submetidas ao tratamento crônico contendo etanol, as linhagens A/J e B6 continuam apresentando parâmetros inflamatórios divergentes, quando a linhagem A/J apresentou um perfil pró-inflamatório e a linhagem B6 apresentou um perfil de depleção inflamatória. Possivelmente em consequência ao avançado dano hepático que os camundongos da linhagem B6 estariam tentando responder ao dano induzido pelo etanol e 
modulando a resposta inflamatória via IL-6. Estes resultados em conjunto aos dados observados com o tratamento agudo de etanol sustentam nossa afirmação de que as linhagens A/J e B6 continuam divergindo entre si quanto à resposta inflamatória induzida pelo etanol, sendo que a primeira continua exibindo uma acentuada resposta pró-inflamatória, enquanto a linhagem B6 mostrou-se tendenciosa a um perfil anti-inflamatório. E ainda, segundo o modelo crônico de tratamento com etanol a linhagem A/J é mais resistente ao acúmulo de lipídeo hepático enquanto a linhagem B6 é mais sensível, possivelmente um reflexo da resposta inflamatória presente no micro-ambiente hepático.

Concluindo, nosso modelo crônico de DHA não apenas induziu as características corporais como conseguiu reproduzir na linhagem A/J a ação hepato-protetora sinérgica de IL-6 e IL-10. Com isso, nos perguntamos se a ausência da proteína C5 em fundo genético B6 promoveria esta resposta inflamatória de caráter protetor, uma vez que a proteína C5 é conhecida por seu potente papel pró-inflamatório. 
5.3.3 Discussão referente aos resultados da aplicação da linhagem congênica B6.A-Hc ${ }^{0}$ no modelo de DHA

Na Tabela 13 estão reunidos os principais resultados obtidos com os diferentes tratamentos aos quais as linhagens B6 e B6.A- $H c^{0}$ foram submetidas. Nela é possível identificar 4 divisões:

(I) parâmetros observados em humanos com DHA e nos modelos murinos de DHA, os quais foram reproduzidos igualmente entre os camundongos B6 e B6.A- $H c^{0}$ : dificuldade de ganho de peso, aumento da razão do peso hepático pelo peso corporal, aumento do depósito de triglicerídeos e de colesterol hepático, aumento da citocina pró-inflamatória TNF- $\alpha$ e da produção de NO no tecido hepático;

(II) parâmetros divergentes entre as linhagens e que são dependentes da interação entre C5 e o tratamento com DH+E: colesterol sérico e hepático, IL-1ß, IL-17, IL-10 e TGF$\beta$

(III) parâmetros divergentes entre as linhagens e que são apenas dependentes de C5 e que não estão associados ao tratamento com as diferentes dietas: colesterol hepático, AST, FA, albumina, glicose, triglicerídeos e colesterol total séricos, citocinas IL-6, IFN- $\gamma$ e IL$12 \mathrm{p}(70)$;

(IV) parâmetro influenciado pela ausência de C5 comum entre linhagem A/J e a linhagem B6.A- $H c^{0}$ : o aumento da citocina anti-inflamatória IL-10 após o tratamento com etanol.

Com base nesta classificação entre os resultados conduziremos nossa discussão e evidenciaremos os pontos mais importantes.

Conforme avaliado durante a padronização do modelo de DHA também realizamos o acompanhamento do ganho de peso semanal, avaliamos a presença do aumento da razão do peso hepático pelo peso corporal e acúmulo de triglicerídeos hepáticos como parâmetros centrais de confirmação da funcionalidade do modelo (BYKOV et al, 2004; HINES; WHEELER, 2004; LIEBER; DE CARLI, 1982). Após 10 semanas acompanhando o ganho de peso acumulado semanalmente observamos que tanto os camundongos da linhagem B6 quanto os camundongos congênicos B6.A- $\mathrm{Hc}^{0}$ apresentaram dificuldade de ganho de peso quando tratados com a DH+E em comparação aos tratados com DH+M. Este comprometimento também foi observado avaliando-se o ganho de peso total final (Figuras 26 e 27). Quanto ao ganho de peso, seja ele acumulado ou final, ambas as linhagens apresentaram o mesmo comportamento mostrando que a dieta contendo etanol afetou 
significativamente o peso das linhagens de forma coerente aos dados observados durante a padronização do nosso modelo e aos trabalhos anteriores que também aplicaram a dieta hiperlipídica em camundongos (BYKOV et al., 2004; 2006).

Uma das consequências do consumo de etanol a longo prazo é o aumento da razão do peso hepático pelo peso corporal induzido pelo acúmulo / depósito de lipídeos nos hepatócitos (BYKOV et al., 2004; PRITCHARD et al., 2007). Observamos que para ambas as linhagens tratadas com $\mathrm{DH}+\mathrm{E}$ houve o aumento significativo da razão do peso hepático pelo peso corporal em comparação os camundongos tratados com DH+M ou DH (Figura 28). Confirmando mais uma vez a eficiência do nosso modelo. A partir do processamento do tecido hepático dos camundongos B6 e B6.A- $H c^{0}$ realizamos a extração de lipídeos totais e quantificamos especificamente a concentração de triglicerídeos e de colesterol total, presentes no extrato (Figura 29). Ambas as linhagens tratadas com DH+E apresentaram a concentração média de $35 \mathrm{mg} / \mathrm{g}$ em comparação ao tratamento DH+M, cuja média esteve entre 15 e $20 \mathrm{mg}$ I g (Figura 29A). Interessantemente, observamos aumento na concentração de colesterol após o tratamento com $\mathrm{DH}+\mathrm{E}$ para ambas as linhagens quando comparadas aos controles $\mathrm{DH}+\mathrm{M}$ e DH. Entretanto, a linhagem C5 deficiente, B6.A- $\mathrm{Hc}^{0}$, apresentou significativamente mais colesterol hepático que a linhagem B6 independentemente do tratamento aplicado, ou seja, possivelmente esta é uma característica da linhagem congênica gerada (Figura 29B). Da mesma forma é possível identificar uma tendência nos camundongos B6. A- $H c^{0}$ em apresentar mais depósito de triglicerídeos hepáticos que os camundongos B6.

Em continuidade a avaliação dos parâmetros corporais, investigamos de forma mais aprofundada características histopatológicas associadas à injúria hepática induzida pelo etanol. A avaliação histopatológica foi realizada pela observação das lâminas histopatológicas às cegas por dois hepato-patologistas e o escore obtido para cada grupo de tratamento foi submetido à análise estatística. As análises indicaram efeito de interação entre tratamento e esteatose, assim como entre tratamento e balonização. Ou seja, identificamos que os tratamentos $\mathrm{DH}+\mathrm{E}$ e $\mathrm{DH}+\mathrm{M}$ induzem escores mais agressivos que os induzidos pelo tratamento com apenas DH. E ainda avaliando o índice de atividade da DHA identificamos que os tratamentos com DH+E e DH+M induzem, em média, a forma mais severa da doença, a EHA (Figuras 30 e 31). Não identificamos estatisticamente diferenças entre as linhagens, mas observando as lâminas histológicas qualitativamente podemos inferir que os camundongos B6.A-Hc ${ }^{0}$ (C5 deficientes) aparentemente são mais protegidos do desenvolvimento de esteatose tanto para o tratamento com $\mathrm{DH}+\mathrm{E}$ quanto para $\mathrm{DH}+\mathrm{M}$. 
Uma vez que o tecido hepático foi afetado pelo tratamento com $\mathrm{DH}+\mathrm{E}$, buscamos por evidências da injúria hepática que pudessem ser detectadas no soro dos camundongos B6 e B6.A- $\mathrm{Hc}^{0}$ tratados. Identificamos que apenas a concentração sérica do colesterol foi alterada pelo tratamento $\mathrm{DH}+\mathrm{E}$. Ambas as linhagens tratadas com $\mathrm{DH}+\mathrm{E}$ apresentaram redução significativa da concentração sérica de colesterol total em comparação aos camundongos tratados com DH+M e DH. E ainda observamos diferenças entre as linhagens, onde os camundongos congênicos C5 deficientes apresentaram maior concentração de colesterol que os camundongos B6 tratados com DH+E (Figura 34F). Esta redução do colesterol sérico também foi observada em camundongos B6 normais e B6 C3 deficientes tratados por 6 semanas com dieta hiperlipídica contendo etanol, independentemente do genótipo (BYKOV, et al., 2007a). Portanto a redução sérica do colesterol após o tratamento crônico com etanol é uma característica do fundo genético B6, mas nossos resultados mostraram que mesmo assim a ausência de C5 reduz a ainda mais a concentração de sérica de colesterol nos camundongos mesmo quando tratados apenas com DH (dieta controle).

Surpreendentemente, após investigar alguns parâmetros de integridade, função e síntese hepática também identificamos diferenças entre as linhagens independentemente do tratamento. As concentrações séricas de AST, FA, albumina, triglicerídeos e colesterol são significativamente maiores na linhagem B6.A- $H c^{0}$, já a concentração sérica da glicose é significativamente menor na linhagem B6.A- $\mathrm{Cc}^{0}$ que na linhagem B6 (Figura 34A - F). Curiosamente também observamos que a linhagem B6.A- $H c^{0}$ possui significativamente maior número de leucócitos circulantes que linhagem B6 (Figura 34). Estes resultados fazem parte do conjunto de parâmetros que são distintos entre as linhagens e que independem do tratamento aplicado.

O aumento de AST, FA e albumina séricos são reflexos de perturbação da função e atividade hepática, pois o primeiro retrata rompimento da integridade do hepatócito e também de outros tecidos como o tecido cardíaco, pulmonar e renal (BOONE et al., 2005). Já a FA revela lesões nas vias biliares e fluxo biliar e a albumina indica alterações na síntese hepática. Portanto, é possível sugerir que a linhagem C5 deficiente apresente mais dano hepático que a linhagem C5 normal em condições de dietas hiperlipídicas. Estas diferenças entre as linhagens são curiosas, entretanto não podemos afirmar que sejam diferenças inerentes às linhagens, pois o ideal seria avaliar este mesmo perfil bioquímico em condições normais, onde as linhagens não estejam se alimentando de uma dieta hiperlipídica. Estamos realizando estas dosagens em camundongos adultos com idade de 8 semanas tratados com a dieta padrão para 
então podermos afirmar se é uma característica dependente ou não da dieta hiperlipídica e dependente ou não de C5.

Dentre as diferenças entre as linhagens que também não foram associadas ao tratamento identificamos que as concentrações hepáticas das citocinas IL-6, IFN- $\gamma$ e IL$12 \mathrm{p}(70)$ foram menores nos C5 deficientes e maiores no C5 normais. Com relação ao aumento da produção de citocinas pró-inflamatórias relacionadas à injúria hepatocelular durante a exposição ao etanol analisamos a concentração hepática de TNF- $\alpha$, IL-6 e IFN- $\gamma$. Observamos que apenas a citocina TNF- $\alpha$ aumentou após o tratamento com DH+E para ambas as linhagens e a concentração hepática das citocinas IL-6 e IFN- $\gamma$ estiveram aumentadas nos camundongos B6 e reduzidas nos camundongos $\mathrm{C} 5$ deficientes, B6.A- $H c^{0}$ (Figura 35A, 35C, 35E). Camundongos B.10.D2/0SnJ (C5 deficiente) e B.10.D2/nSnJ (C5 normal) quando tratados com etanol por 4 semanas exibiram resultados semelhantes aos observados em nossos animais, onde a concentração de citocinas hepáticas TNF- $\alpha$, IL-6 e IFN- $\gamma$ estiveram diminuídas nos C5 deficientes (PRITCHARD et al., 2007).

Também com perfil pro-inflamatório investigamos a concentração hepática das citocinas IL-1ß e IL-17 e com perfil anti-inflamatório investigamos as citocinas IL-10 e TGFß. Estas citocinas apresentaram comportamento divergente entre as linhagens associadas ao tratamento com DH+E, e portanto, segundo a classificação dada no início desta discussão elas foram classificadas como diferenças oriundas da interação entre a presença ou não de C5 e o tratamento com etanol (Figura 35 e 36).

Avaliando o conjunto de parâmetros corporais e inflamatórios é possível dizer que a linhagem B6 apresentou concomitante ao aumento da razão do peso hepático pelo peso corporal, depósito de triglicerídeos hepático e aumento das concentrações das citocinas hepáticas TNF- $\alpha$, IL-1ß, TGF- $\beta$, e da produção de NO, e redução de IL-17. Houve uma tendência no aumento de IL-6 e IL-12, mas não foi confirmada estatisticamente. Para a linhagem B6.A- $H c^{0}$ também encontramos aumento da razão do peso hepático pelo peso corporal, depósito de triglicerídeos hepático e aumento da concentração das citocinas hepáticas TNF- $\alpha$, IL-17, IL-10 e da produção de NO. Houve também redução significativa das concentrações de IL-1ß, TGF-ß.

Especulando-se um pouco sobre o mecanismo inflamatório envolvendo ou não C5 e as diferenças bioquímicas encontradas entre as linhagens B6 e B6.A- $H c^{0}$ tratadas com as diferentes dietas hiperlipídicas é possível sugerir que ausência de C5 contribuiu para o aumento de vários parâmetros bioquímicos, dentre eles AST e FA e albumina que estão associados à lesão hepatocelular, vias biliares e síntese hepática. Isto é, a ausência de C5 pode 
deixar o fígado previamente mais susceptível à lesão pois nos camundongos B6.A-Hc ${ }^{0}$ os valores séricos de AST, FA e albumina são maiores que nos C5 normais independentemente do tratamento. E devido a isso, os camundongos B6.A-Hc ${ }^{0}$ passam a ter um micro-ambiente hepático inerentemente anti-inflamatório com finalidade protetora à integridade hepática, antes mesmo de receber qualquer tratamento indutor de lesão. E quando há a indução de lesão pela $\mathrm{DH}+\mathrm{E}$ o micro-ambiente hepático que já se encontra sob uma condição anti-inflamatória acaba protegendo o fígado de uma lesão pró-inflamatória mais severa como a observada nos camundongos B6. Outro fator importante a ser observado é que os camundongos B6.A-Hc ${ }^{0}$ possuem maior depósito de colesterol hepático e maior concentração sérica de colesterol, sugerindo que esse acúmulo de colesterol hepático e sérico podem também contribuir para o aumento dos valores séricos de AST, FA e albumina. O colesterol hepático e o extra-hepático contribuem para formação de sais biliares o que poderia estar gerando um estresse nos ductos biliares e consequentemente lesões, portanto é possível detectar o aumento sérico da FA. Ao mesmo tempo, os camundongos B6.A- $\mathrm{Hc}^{0}$ podem apresentar problemas na captura de triglicerídeos pelo tecido adiposo e pelo tecido muscular, e dessa forma aumenta a quantidade sérica de triglicerídeos que chega ao fígado podendo gerar estresse e lesão dos hepatócitos devido ao seu acúmulo, e então aumentando a concentração de AST. Entretanto essa enzima não é exclusivamente associada ao tecido hepático, então possivelmente outros órgãos como os tecidos musculares, pulmonares e renais podem sofrer lesão (BOONE et al., 2005).

É possível ainda que a menor concentração de glicose sérica observada nos camundongos congênicos B6. A- $H c^{0}$ em relação aos B6 esteja relacionada ao aumento de triglicerídeos séricos observados nos animais congênicos B6.A- $H c^{0}$, uma vez que a glicose é utilizada para a síntese de triglicerídeos tanto pelos hepatócitos quanto para os adipócitos. Estas células expressam o receptor C5L2, que em adipócitos por meio da ligação com o fragmento C3desArg estimula a síntese de triglicerídeos e a captura de glicose (MACLAREN et al., 2008).

Portanto, a deficiência de C5 nos camundongos congênicos B6.A-Hc ${ }^{0}$ tornou-os mais sensíveis a danos hepáticos, o que promoveu como consequência um micro-ambiente antiinflamatório. E o tratamento com uma $\mathrm{DH}+\mathrm{E}$ que deveria induzir uma resposta inflamatória passa a ser controlado ou atenuado desde o seu início e como consequência houve menor inflamação, houve menor lesão e sutilmente menos acúmulo de gordura. Talvez aplicando a linhagem congênica A.B6-Hc no modelo de DHA traga resultados que complementem essa hipótese. 
No momento estamos testando todos os parâmetros bioquímicos aqui avaliados nas linhagens B6, B6.A-Hc ${ }^{0}$, A/J e A.B6-Hc sob condições fisiológicas e sob dieta padrão (NUVITAL) para investigar se a ausência de C5 realmente pode estar relacionada aos altos valores séricos de AST, FA, albumina, colesterol, triglicérides e ao baixo valor de glicose sérico. Uma vez concluídos estes ensaios eles irão completar a validação das linhagens congênicas apresentada no CAPÍTULO 1. 


\subsection{Conclusões do CAPÍTULO 2}

\subsubsection{Conclusão do modelo de injúria hepática aguda induzida por etanol (binge drink)}

* Os camundongos da linhagem A/J em relação aos camundongos B6 foram mais sensíveis aos danos hepáticos induzidos pelo tratamento agudo com etanol. Os camundongos A/J apresentaram necrose hepática acompanhada de infiltrado celular PMN e MN além de aumento sérico de IL-6.

\subsubsection{Conclusões do modelo de injúria hepática crônica induzida pela DHA}

* Dentre os tempos testados para o modelo de DHA identificamos que 10 semanas foi o período ótimo para induzir alterações inflamatórias entre os camundongos das linhagens B6 e A/J tratadas cronicamente com etanol. Ainda identificamos que os camundongos da linhagem A/J apresentaram um perfil pró-inflamatório protetor em relação aos da linhagem B6.

* Padronizamos um modelo de DHA para camundongos que induziu as principais patologias observadas nos pacientes com DHA e nos modelos animais presentes na literatura, dentre elas: dificuldade de ganho de peso, aumento da ração do peso hepático pelo peso corporal, acúmulo de gordura no tecido hepático, presença de infiltrado celular no tecid0 hepático.

* O modelo de DHA durante o período de 10 semanas de tratamento induziu nos camundongos da linhagem B6 e nos camundongos congênicos B6.A- $H c^{0}$ as alterações corporais clássicas para a DHA: dificuldade de ganho de peso, aumento da razão do peso hepático pelo peso corporal, acúmulo de gordura no tecido hepático, presença de infiltrado celular no tecido hepático, aumento da concentração hepática de TNF- $\alpha$ e da produção de NO por macrófagos presentes no fígado.

* Os camundongos B6.A- $H c^{0}$ não apresentaram um perfil pró-inflamatório como a linhagem A/J. Contudo, em relação aos camundongos B6 os camundongos B6.A- $\mathrm{Hc}^{0}$ apresentaram um perfil anti-inflamatório com caráter protetor principalmente pelo aumento significativo de IL-10 e redução significativa de IL-1ß e TGF-ß durante o tratamento com etanol. Além disso, identificamos algumas diferenças marcantes entre as linhagens quanto às: (I) Análises bioquímicas: 
a) os camundongos B6.A- $H c^{0}$ apresentaram aumento sérico de AST, FA, albumina, triglicerídeos e colesterol (independentemente do tratamento);

b) os camundongos B6.A- $\mathrm{Hc}^{0}$ apresentaram redução de glicemia (independentemente do tratamento);

c) os camundongos B6.A-Hc apresentaram aumento de leucócitos totais periféricos (independentemente do tratamento);

(II) Análises histopatológicas:

a) a porcentagem de esteatose hepática e o índice de atividade da EHA apresentaram diferenças significativas entre os tratamentos (independentemente da linhagem);

b) os escores para balonização e esteatose hepática apresentaram efeito de interação entre tratamento e balonização (independentemente da linhagem);

(III) Análises inflamatórias (citocinas hepáticas):

a) os camundongos B6.A- $H c^{0}$ apresentaram menor concentração hepática de IL-6, IFN $\gamma$, IL12 (independentemente do tratamento);

b) apenas os camundongos B6.A- $H c^{0}$ apresentaram redução na concentração hepática de IL13 e TGF-ß (dependentemente do tratamento com DH+E);

c) apenas os camundongos B6.A- $H c^{0}$ apresentaram aumento de IL-10 após tratamento com etanol (dependentemente do tratamento com $\mathrm{DH}+\mathrm{E}$ ).

* Independente do tipo da dieta, observamos que a presença da proteína C5 favoreceu um micro-ambiente hepático pró-inflamatório devido a maior concentração de IL-6, IL-12, IFN- $\gamma$ nos camundongos B6 em relação aos congênicos B6.A- $H c^{0}$. Entretanto, o tratamento dos camundongos B6 com a DH+E promoveu: hepatomegalia, acúmulo de triglicerídeos e colesterol hepáticos, redução da concentração sérica de colesterol, e aumento nas concentrações hepática de TNF- $\alpha$, IL-1 $\beta$ e NO. Quanto aos camundongos congênicos B6.A$H c^{0}$ tratados com DH+E observamos: hepatomegalia, acúmulo de triglicerídeos e colesterol hepáticos, redução da concentração sérica de colesterol, e aumento nas concentrações hepática de TNF- $\alpha$, IL-17, IL-10 e NO e redução de IL-1 $\beta$ e TGF- $\beta$. Curiosamente, identificamos que as linhagens divergiram completamente quanto às concentrações séricas de AST, FA, albumina, triglicerídeos, colesterol e glicose sugerindo que o componente C5 também participe da manutenção da homeostase hepática. 


\section{DISCUSSÃO GERAL}

Desenvolvemos os camundongos congênicos B6.A-Hc ${ }^{0}$ e A.B6- $H c$ com o objetivo de estudar em um mesmo fundo genético a presença ou não da proteína C5 e ainda avaliar se perante fundos genéticos diferentes o papel da proteína C5 seria o mesmo entre as linhagens ou seria influenciado pelo fundo genético. Lamentavelmente, não conseguimos empregar a tempo a linhagem congênica A.B6-Hc nos nossos estudos de DHA (e de DHNA APÊNDICE A). Mesmo assim, conseguimos explorar a importância da proteína C5 no fundo genético B6 comparando com a linhagem congênica B6.A- $H c^{0}$ no modelo de DHA (e de DHNA - APENNDICE A).

Tanto a DHA e como a DHNA compartilham características patológicas e inflamatórias comuns. Nagata, Suzuki, Sakaguchi (2008) propuseram a existência de mecanismos patogênicos em comum no desenvolvimento da esteatose hepática causada ou não pelo etanol, como por exemplo, o importante papel das endotoxinas derivadas do tratogastrointestinal, a imunidade inata pela ativação das células de Kupffer via TRL-4 e também pela ativação do sistema complemento, além do estresse oxidativo gerado no tecido hepático como consequência do acúmulo de triglicerídeos. Além de mecanismos relacionados com a imunidade inata, a ativação da imunidade adquirida também favorecem a imunopatogênese das DHA e DHNA (VALENTI; FRACANZANI; FARGION, 2009).

Nossas análises identificaram que dentre as características comuns aos modelos animais de DHA e DHNA e em humanos apenas o aumento da concentração hepática de TNF- $\alpha$ e da produção de NO foram observados nos camundongos B6 e B6.A-Hc ${ }^{0}$ tratados com $\mathrm{DH}+\mathrm{E}$ ou $\mathrm{DH}+\mathrm{G}$ em relação aos camundongos tratados com DH (Figuras 35, 37, A.26 e A.27) e o aumento da síntese hepática da citocina anti-inflamatória IL-10 apenas nos camundongos B6.A- $\mathrm{Hc}^{0}$ também tratados com $\mathrm{DH}+\mathrm{E}$ ou $\mathrm{DH}+\mathrm{G}$ em relação aos controles (Figuras 36 e A.27). Pelo fato de termos empregado os mesmos controles para a comparação com os tratamentos $\mathrm{DH}+\mathrm{E}$ e $\mathrm{DH}+\mathrm{G}$, podemos considerar que, dentre os parâmetros avaliados, o aumento hepático da concentração de TNF- $\alpha$ e da produção de NO são componentes comuns ao desenvolvimento imunopatológico dos nossos modelos de DHA e DHNA, independente da presença da proteína C5. Já o aumento da concentração de IL-10 foi uma resposta observada apenas nos camundongos B6. A- $\mathrm{Hc}^{0}$ (deficientes para $\mathrm{C} 5$ ), mostrando que em ambos os modelos a ausência da proteína C5 elevou a produção de IL-10, e consequentemente, pode ter atenuado o papel pró-inflamatório de C5. 
Dentre as funções biológicas do componente C5, em especial do produto de sua clivagem a anafilatoxina C5a e seu receptor, destacam-se a sua alta capacidade quimioatraente e a sua indução de citocinas pró-inflamatórias (GUO; WARD, 2005). Neste trabalho investigamos um painel bastante abrangente de citocinas e observamos que nos camundongos C5 deficientes, B6.A-Hc ${ }^{0}$, independentemente de qualquer tratamento houve redução da concentração hepática das citocinas: IL-1 $\beta$, IL-6, IL-12, IFN- $\gamma$, TGF- $\beta$ mostrando a importância de C5 para a expressão destas citocinas pró-inflamatórias (Figuras 25, 35, A.14 e A.26). Durante o desenvolvimento da esteatose hepática ocorre aumento na produção de TNF- $\alpha$, IL-1 $\beta$, IL-6 e IL-12 (VALENTI; FRACANZANI; FARGION, 2009), entretanto, não identificamos diferenças nas concentrações dessas citocinas após 10 semanas sob tratamento com as diferentes dietas (exceto TNF- $\alpha$ ). Durante as análises cinéticas da padronização dos modelos de DHA (Figura 25) e DHNA (Figura A.14), observamos redução significativa da concentração das citocinas citadas acima, ao longo das semanas de tratamento, e confirmamos estes resultados após 10 semanas de tratamento dos camundongos B6 e B6.A-Hc ${ }^{0}$, quando também não houve diferenças entre os tratamentos.

Além de modular a produção de citocinas, curiosamente, observamos que a ausência de C5, independentemente do tratamento, aumentou a concentração sérica de AST, FA, albumina, triglicerídeos, colesterol total e reduziu a concentração da glicose (Figuras 33 e A.24). O tratamento dos camundongos de ambas as linhagens com DH+E reduziu a concentração sérica de colesterol total em relação aos tratados com DH+M e DH (Figura 33F). Camundongos da linhagem B6 normais e C3 deficientes quando tratados por 6 semanas com DH+E também apresentaram redução significativa do colesterol sérico, independente do genótipo (BYKOV et al., 2007a). Portanto, a redução observada na concentração de colesterol sérico após o tratamento com etanol em ambas as linhagens pode ser uma característica do modelo, pois nos baseamos na mesma dieta de Bykov et al (2004). Além disso, o tratamento dos animais com a dieta $\mathrm{DH}+\mathrm{G}$ levou a redução da concentração sérica de FA e ao aumento sérico de glicose apenas nos B6.A-Hc ${ }^{0}$ em relação aos tratados com DH (Figura A.24B e A.24D). O aumento sérico da FA está correlacionado especialmente com a progressão de doenças hepáticas e problemas no trato biliar, mas a redução sérica de FA pode ser observada no hipotireoidismo, retardo de crescimento nas crianças, hipofosfatasia (erro metabólico inato) ou desnutrição grave (Bioclin). É possível que nossos camundongos B6.A- $H c^{0}$ estejam sofrendo mais com desfunções metabólicas no nosso modelo de DHNA esta seja uma diferença característica entre as linhagens. Já a glicose sérica, também esteve aumentada apenas nos B6. A- $\mathrm{Hc}^{0}$ podendo também ser um marcador da linhagem. A hiperglicemia ocorre 
em vários tipos de diabetes mellitus, onde também estão presentes lesões renais e aterosclerose.

O período de 10 semanas de tratamento induz um estágio intermediário da DHNA, possivelmente se estendessemos esse período para 12 semanas, talvez evidenciaríamo alterações mais pronunciadas. Segundo o modelo proposto por Nagata; Suzuki; Sakaguchi (2008), a progressão da DHNA para ENA envolve duas etapas: a primeira ocorre pelo acúmulo de gordura corporal, resistência à insulina, obesidade e hiperlipidemia e consequentemente o desenvolvimento de esteatose e inflamação moderada que sensibilizaram o fígado para a segunda etapa que inclui a injúria hepática dada pelo aumento de TNF- $\alpha$ originado pelo estímulo de endotoxinas derivadas do trato gastro-intestinal, e aumento do estresse oxidativo (aumento de NO).

Em conclusão, desenvolvemos dois modelos de doença hepática (DHA e DHNA) e aplicamos nestes modelos pelo menos uma das linhagens congênicas que nos propusemos a desenvolver. Como esperado, os camundongos C5 normais apresentaram concentrações hepática de IL-6, IFN $\gamma$ e IL-12 mais altas que os camundongos C5 deficientes. Entretanto, os camundongos C5 deficientes apresentaram concentrações séricas aumentadas de AST, FA, albumina, triglicerídeos e colesterol em relação aos camundongos C5 normais. Além de promover a resposta inflamatória hepática, a proteína C5 possivelmente desempenha um papel importante na homeostase hepática e manutenção dos parâmetros séricos observados sob alimentação com uma dieta hiperlipídica. Portanto, as linhagens B6 e B6.A-Hc ${ }^{0}$ compartilharam e divergiram tanto em características fisiológicas quanto inflamatórias, possibilitando os mais diversos tipos de estudos. 


\section{CONCLUSÕES GERAIS}

\subsection{Desenvolvimento e validação de duas linhagens congênicas de camundongos B6.A- $\mathrm{Hc}^{0}$ (C5 deficiente) e A.B6-Hc (C5 normal)}

* As linhagens congênicas B6.A- $H c^{0}$ e A.B6-Hc foram desenvolvidas, avaliadas e validadas quanto ao genótipo, presença ou não de C5, atividade hemolítica de C5 quando presente e quanto ao fundo genético. Para isso realizamos pelo menos 10 retrocruzamentos.

\subsection{Modelo de injúria hepática aguda induzida por etanol}

* Houve redução do número de leucócitos totais em ambas as linhagens tratadas com etanol. Entretanto, apenas a linhagem A/J apresentou aumento no número de leucócitos PMN;

* Apenas os camundongos da linhagem A/J apresentaram aumento sérico significativo das enzimas associadas à função e integridade hepática AST, GGT e da citocina próinflamatória IL-6

\subsection{Padronização do modelo de DHA empregando as linhagens B6 e A/J}

Testamos 6, 8 e 10 semanas de tratamento. Realizamos a análise estatística destes resultados empregando ANOVA para dois fatores (tempo em semanas e parâmetros). Ou seja, analisamos o comportamento cinético (6,8 e 10 semanas) dos parâmetros investigados para cada linhagem. O tempo de tratamento que evidenciou as diferenças entre as linhagens B6 e A/J foi 10 semanas. Dentre as principais conclusões obtidas estão:

* A linhagem A/J quando tratada com DH+E apresentou aumento significativo do número de leucócitos circulantes com o decorrer das semanas de tratamento;

* A razão entre o peso do fígado / peso corporal foi significativamente maior para os animais tratados com $\mathrm{DH}+\mathrm{E}$ em todos os tempos avaliados e para as duas linhagens;

* O depósito de triglicerídeos hepáticos foi significativamente maior para os animais tratados com $\mathrm{DH}+\mathrm{E}$ em todos os tempos e para as duas linhagens; 
* A concentração da citocina hepática IL-6 decresceu significativamente no decorrer das semanas de tratamento com $\mathrm{DH}+\mathrm{E}$, tanto para a linhagem B6 quanto para A/J

* A concentração da citocina hepática IL-10 aumentou significativamente no decorrer das semanas de tratamento com $\mathrm{DH}+\mathrm{E}$ apenas para a linhagem $\mathrm{A} / \mathrm{J}$;

* A concentração da citocina hepática IL-12 decresceu significativamente no decorrer das semanas de tratamento com $\mathrm{DH}+\mathrm{E}$, tanto para a linhagem B6 quanto para A/J;

* A produção de NO hepática aumentou significativamente no decorrer das semanas de tratamento com $\mathrm{DH}+\mathrm{E}$ apenas para a linhagem $\mathrm{A} / \mathrm{J}$. E decresceu no decorrer das semanas de tratamento com DH+E para a linhagem B6;

* A histopatologia hepática mostrou elevado depósito de lipídeos hepáticos na linhagem B6 em relação à linhagem A/J quando tratadas com DH+E. Esse depósito intensificou-se com o aumento do tempo de tratamento.

De maneira geral concluímos com estes tratamentos que a linhagem A/J é mais protegida de desenvolver dano hepático que a linhagem B6 quando tratadas com etanol. É possível que esta característica foi promovida pela resposta inflamatória observada na linhagem, onde a ausência de C5 possivelmente foi um dos fatores que contribuíram para a proteção.

\subsection{Aplicação da linhagem congênica $\mathrm{B6} . \mathrm{A}-\mathrm{Hc}^{0}$ no modelo de DHA}

7.4.1 Independentemente do tratamento os camundongos da linhagem B6.A-Hc ${ }^{0}$ apresentaram em relação aos camundongos linhagem B6

* Houve aumento no número de leucócitos e na concentração de AST, FA, albumina, triglicerídeos, colesterol sérico e hepático;

* Houve menor glicemia e menores concentrações de IL-6, IL-12p70, IFN- $\gamma$. 
7.4.2 Independentemente da linhagem, o tratamento com DH+E promoveu

* Houve aumento das concentrações de TNF- $\alpha$, na produção de NO, acúmulo de triglicerídeos e colesterol hepático;

* Houve redução dos níveis de colesterol sérico.

7.4.3 Diferenças entre as linhagens quando tratadas com $\mathrm{DH}+\mathrm{E}$

* Observamos aumento da concentração de IL-1 $\beta$ hepática na linhagem B6 e redução de IL-1 $\beta$ na B6.A- $H c^{0}$;

* Observamos aumento de IL-17 hepática na linhagem B6.A- $H c^{0}$;

* Observamos aumento da concentração de IL-10 hepática na linhagem B6.A- $H c^{0}$,

* Observamos aumento da concentração de TGF- $\beta$ hepático na linhagem B6 e redução de TGF- $\beta$ na B6.A- $H c^{0}$.

* A proteína C5 além de suas funções pró-inflamatórias, possivelmente, desempenha um papel importante na homeostase hepática e na manutenção dos parâmetros séricos aqui avaliados sob um contexto de dieta hiperlipídica: AST, FA, albumina, triglicerídeos, colesterol e glicose. 


\section{REFERÊNCIAS *}

ADDIS-LIESER, E.; KOHL, J.; CHIARAMONTE, M. G. Opposing regulatory roles of complement factor 5 in the development of bleomycin-induced pulmonary fibrosis. The Journal of Immunology, v. 175, p. 1894-1902, 2005.

ALAISH, S. M.; TORRES, M.; FERLITO, M; SUN, C. C.; DE MAIO, A. The severity of cholestatic injury is modulated by the genetic background. Shock, v. 24, n. 5, p. 412-416, 2005 .

ANDRADE, M. C.; MENESES, J. S.; CASSALI, G. D.; MARTINS-FILHO, O. A.; CARA, D. C.; FARIA, A. M. C. Alcohol-induced gastritis prevents oral tolerance induction mice. Clinical and Experimental Immunology, v. 146, p. 321-322, 2006.

BABA, A.; FUJITA, T.; TAMURA, N. Sexual dimorphism of the fifth component of mouse complement. The Journal of Experimental Medicine, v. 160, n. 2, p. 411-419, 1984.

BHAVE, S. V.; HOFFMAN, P. L.; LASSEN, N.; VASILIOU, V.; SABA, L.; DEITRICH, R. A.; TABAKOFF, B. Gene array profiles of alcohol and aldehyde metabolizing enzymes in brains of C57B1/6 e DBA/2 mice. Alcoholism: Clinical and Experimental Research, v. 30, n. 10, p. 1659-1669, 2006.

BOÉ, D. M.; RICHENS, T. R.; HORSTMANN, S. A.; BURNHAM, E. L.; JANSSEN, W. J.; HENSON, P. M.; MOSS, M.; VANDIVIER, R. W. Acute and chronic alcohol exposure impairs the phagocytosis of apoptotic cells and enhances the pulmonary inflammatory response. Alcoholism: Clinical and Experimental Research, v. 34, n. 10, p. 1723-1732, 2010.

BOONE, L.; MEYER, D. P.; CUSICK, P.; ENNULAT, D.; BOLLIGER, A. P.; EVERDS, N.; MEADOR, V.; ELLIOTT, G.; HONOR, D.; BOUNOUS, D.; JORDAN, H. Selection and interpretation of clinical pathology indicators of hepatic injury in pre clinical studies, Veterinary Clinical Pathology, v. 34, n. 3, p. 182-188, 2005.

BURRAGE, L. C.; BASKIN-HILL, A. E.; SINASAC, D. S.; SINGER, J. B.; CRONIGER, C. M.; KIRBY, A.; KULBOKAS, E. J.; DALY, M. J.; LANDER, E. S.; BROMAN, K. W.; NADEAU, J. H. Genetic resistance to diet-induced obesity in chromosome substitution strains of mice. Mammalian Genome, v. 21, n. 3, p. 115-129, 2010.

BYKOV, I.; JUNNIKKALA, S.; PEKNA, M.; LINDROS, K. O.; MERI, S. Effect of chronic ethanol consumption on the expression of complement components and acute phase proteins in liver. Clinical Immunology, v. 124, n. 2, p. 213-220, 2007.

BYKOV, I.; JAUHIAINEN, M.; OLKKONEN, V. M.; SAARIKOSKI, S. T.; EHNHOLM, C.; JUNNIKKALA, S.; VAKEVA, A.; LINDROS, K. O.; MERI, S. Hepatic gene expression and lipid parameters in complement $\mathrm{C} 3(-/-)$ mice that do not develop ethanol-induced steatosis. Journal of Hepatology, v. 46, n. 5, p. 907-914, 2007.

\footnotetext{
"De acordo com:

ASSOCIAÇÃO BRASILEIRA DE NORMAS TÉCNICAS. NBR 6023: informação e documentação: referências: elaboração. Rio de Janeiro, 2002.
} 
BYKOV, I.; JUNNIKKALA, S.; PENKA, M; LINDROS, K. O.; MERI, S. Complement C3 contributes to ethanol-induced liver statosis in mice. Annals of Medicine, n. 38, p. 280-286, 2006.

BYKOV, I.; VÄKEVÄ, A.; JÄRVELÄINEN, H.; MERI, S.; LINDROS, K. O. Protective function of complement against alcohol-induced rat liver damage. International Immunopharmacology, n. 4, p. 1445-1454, 2004.

CAIN, S. A.; MONK, P. N. The orphan receptor C5L2 has high affinity binding sites for complement fragments C5a and C5a des-Arg(74). The Journal of Biological Chemistry, v. 277, n. 9, p. 7165-7169, 2002.

CARSON, E. J.; PRUETT, S. B. Development and characterization of a binge drinking model in mice for evaluation of the immunological effects of ethanol. Alcholism: Clinical and Experimental Research, v. 20, n. 1, p. 132-138, 1996.

CASPI, R. R. Th1 and Th2 responses in pathogenesis and regulation of experimental autoimmune uveoretinitis. International Reviews of Immunology, v. 21, n. 2, p. 197-208, 2002.

CHIANG, D. J.; PRITCHARD, M. T.; NAGY, L. E. Obesity, diabetes mellitus, and liver fibrosis. The American Journal of Physiology-Gastrointestinal and Liver Physiology, v. 300, n. 5, p. 697-702, 2011.

CIANFLONE, K.; XIA, Z.; CHEN, L. Y. Critical review of acylation-stimulating protein physiology in humans and rodents. Biochimica et Biophysica Acta, v. 1609, p. 127-143, 2003.

COHEN, J. I.; ROYCHOWDHURY, S.; MCMULLEN, M.; STAVITSKY, A.; NAGY, L. E. Complement and alcoholic liver disease: role of C1q in the pathogenesis of ethanol-induced liver injury in mice. Gastroenterology, v. 139, p. 664-667, 2010.

COLLIER, S. D.; PRUETT, S. B. Mechanisms of suppression of poly I:C-induced activation of NK cells by ethanol. Alcohol, v. 21, n. 1, p. 87-95, 2000.

CSAK, T.; GANZ, M.; PESPISA, J.; KODYS, K.; DOLGANIUC, A.; SZABO, G. Fatty acid and endotoxin activate inflammasomes in mouse hepatocytes that release danger signals to stimulate immune cells. Hepatology, v. 54, n. 1, p. 133-144, 2011.

D’EUSTACHIO, P.; KRISTENSEN, T.; WETSEL, R. A.; RIBLET, R. J.; TAYLOR, B. A.; TACK, B. F. Cromosomal location of the genes encoding complement components C5 and factor $\mathrm{H}$ in the mouse. The Journal of Immunology, v. 137, n. 12, p. 3990-3995, 1986.

DAS, S. K.; BALAKRISHNAN, V. Role of cytokines in the pathogenesis of non-alcoholic Fatty liver disease. Indian Journal of Clinical Biochemistry, v. 26, n. 2, p. 202-209, 2011.

DENNY, K. J.; COULTHARD, L. G.; JEANES, A.; LISGO, S.; SIMMONS, D. G.; CALLAWAY, L. K.; WLODARCZYK, B.; FINNELL, R. H.; WOODRUFF, T. M.; TAYLOR, S. M. C5a Receptor signaling prevents folate eficiency-induced neural tube defects in mice. The Journal of Immunology, v. 190, n. 7, p. 3493-3499, 2013. 
DIXON, L. J.; FLASK, C. A.; PAPOUCHADO, B. G.; FELDSTEIN, A. E.; NAGY, L. E. Caspase-1 as a central regulator of high fat diet-induced non-alcoholic steatohepatitis. PLoS One, v. 8, n. 2, p. E56100, 2013.

DOMÍNGUEZ-PUNARO, M. L.; SEGURA, M.; RADZIOCH, D.; RIVEST, S.; GOTTSCHALK, M. Comparison of the susceptibilities of C57BL/6 and A/J mouse strains to Streptococcus suis serotype 2 infection. Infection and Immunity, v. 76, n. 9, p. 3901-3910, 2008.

EL-ASSAL, O.; HONG, F.; KIM, W. H.; RADAEVA, S.; GAO, B. IL-6-deficient mice are susceptible to ethanol-induced hepatic steatosis: IL-6 protects against ethanol-induced oxidative stress and mitochondrial permeability transition in the liver. Cellular and Molecular Immunology, v. 1, n. 3, p. 205-211, 2004.

EMBER, J. A.; JAGELS, M. A.; HUGLI, T. E. Characterization of complement anaphylatoxins e their biological responses. In: VOLANAKIS, J. E.; FRANK, M.M. The human complement system in health e disease. New York: Marcel Dekker Inc., 1998. p. 241-284.

FISETTE, A.; MUNKONDA, M. N.; OIKONOMOPOULOU, K.; PAGLIALUNGA, S.; LAMBRIS, J. D.; CIANFLONE, K. C5L2 receptor disruption enhances the development of diet-induced insulin resistance in mice. Immunobiology, v. 218, n. 1, p. 127-133, 2013.

FONSECA, M. I.; AGER, R. R.; CHU, S. H.; YAZAN, O.; SANDERSON, S. D.; LA FERLA, F. M.; TAYLOR, S. M.; WOODRUFF, T. M.; TENNER, A. J. Treatment with a $\mathrm{C} 5 \mathrm{aR}$ antagonist decreases pathology and enhances behavioral performance in murine models of Alzheimer's disease. The Journal of Immunology, v. 183, p. 1375-1383, 2009.

FRAULOB, J. C.; OGG-DIAMANTINO, R.; FERNANDES-SANTOS, C.; AGUILA, M. B.; MANDARIM-DE-LACERDA, C. A. A mouse model of metabolic syndrome: insulin resistance, fatty liver and non-alcoholic fatty pancreas disease (NAFPD) in C57BL/6 mice fed a high fat diet. Journal of Clinical Biochemistry and Nutrition, v. 46, n. 3, p. 212-223, 2010.

GALLOU-KABANI, C.; VIGÉ, A.; GROSS, M. S.; RABÈS, J. P.; BOILEAU, C.; LARUEACHAGIOTIS, C.; TOMÉ, D.; JAIS, J. P.; JUNIEN, C. C57BL/6J and A/J mice fed a highfat diet delineate components of metabolic syndrome. Obesity, v. 15, n. 8, p. 1996-2005, 2007.

GAO, B. Hepatoprotective and anti-inflammatory cytokines in alcoholic liver disease. Journal of Gastroenterology and Hepatology, v. 27, n. 2, p. 89-93, 2012.

GAO, H.; NEFF, F. A.; GUO, R.; SPEYER, C. L.; SARMA, J. V.; TOMLINS, S.; MAN, Y.; RIEDEMANN, N. C.; HOESEL, L. M. Evidence for a functional role of the second C5a receptor C5L2. The FASEB Journal, 2005.

GAUVREAU, D.; ROY, C.; TOM, F. Q.; LU, H.; MIEGUEU, P.; RICHARD, D.; SONG, W. C.; STOVER, C.; CIANFLONE, K. A new effector of lipid metabolism: complement factor properdin. Molecular Immunology, v. 51, n. 1, p. 73-81, 2012. 
GERVAIS, F.; DESFORGES, C.; SKAMENE, E. The C5-sufficient A/J congenic mouse strain. Inflammatory response and resistance to Listeria monocytogenes. The Journal of Immunology, v. 142, n. 6, p. 2057-2060, 1989.

GILL, K. J.; BOYLE, A. E. Genetic influences on drug-induced psychomotor activation in mice. Genes, Brain and Behavior, v. 7, n. 8, p. 859-868, 2008.

GORDON, S.; TAYLOR, P. R. Monocyte and macrophage heterogeneity. Nature Reviews Immunology, v. 5, n. 12, p. 953-964, 2005.

GUO, R. F.; WARD, P. A role of C5a in inflammatory responses. Annual Review of Immunology, v 23, p. 821-852, 2005.

GUSTOT, T.; LEMMERS, A.; MORENO, C.; NAGY, N.; QUERTINMONT, E.; NICAISE, C.; FRANCHIMONT, E.; LOUIS, H.; DEVIERE, J.; LEMOINE, O. Differential liver sensitization to toll-like receptor pathways in mice with alcoholic fatty liver, Hepatology, v.43, p. 989-1000, 2006.

HASHIMOTO, M.; HIROTA, K.; YOSHITOMI, H.; MAEDA, S.; TERADAIRA, S.; AKIZUKI, S.; PRIETO-MARTIN, P.; NOMURA, T.; SAKAGUCHI, N.; KÖHL, J.; HEYMAN, B.; TAKAHASHI, M.; FUJITA, T.; MIMORI, T.; SAKAGUCHI, S. Complement drives Th17 cell differentiation and triggers autoimmune arthritis. The Journal of Experimental Medicine, v. 207, n.6, p. 1135-1143, 2010.

HAVILAND, D. L.; HAVILAND, J. C.; FLEISCHER, D. T.; WETSEL, R. A. Structure of the murine fifth complement component (C5) gene. A large, highly interrupted gene with a variant donor splice site and organizational homology with the third and fourth complement component genes. The Journal of Biological Chemistry, v. 266, n. 18, p. 11818-11825, 1991.

HAWLISCH, H.; BELKAID, Y.; BAELDER, R.; HILDEMAN, D.; GERARD, C.; KÖHL, J. C5anegatively regulates Toll-like receptor 4-induced immune responses. Immunity, v. 22, p. 415-426, 2005.

HEIJNEN, B. H. M.; STRAATSBURG, I. H.; PADILLA, N. D.; VAN MIERLO, G. J.; HACK, C. E.; VAN GULIK, T. M. Inhibition of classical complement activation attenuates liver ischaemia and reperfusion injury in a rat model. Clinical and Experimental Immunology, n. 143, p. 15-23, 2005.

HERNÁNDEZ-MIJARES, A.; JARABO-BUENO, M. M.; LÓPEZ-RUIZ， A.; SOLÁIZQUIERDO, E.; MORILLAS-ARIÑO, C.; MARTÍNEZ-TRIGUERO, M. L. Levels of C3 in patients with severe, morbid and extreme obesity: its relationship to insulin resistance and different cardiovascular risk factors. International Journal of Obesity, v. 31, n. 6, p. 927932, 2007.

HIGUCHI, H.; KUROSE, I.; KATO, S.; MIURA, S.; ISHII, H. Ethanol-induced apoptosis and oxidative stress in hepatocytes. Alcoholism: Clinical and Experimental Research, v. 20, n. 9, p. 340A-346A, 1996. 
HILLEBRANDT, S.; WASMUTH, H. E.; WEISKIRCHEN, R.; HELLERBRAND, C.; KEPPELER, H. Complement factor 5 is a quantitative trait gene that modifies liver fibrogenesis in mice and humans. Nature Genetics, v. 37, n. 8, p. 835-843, 2005.

HINES, I. N.; WHEELER, M. D. Recent advances in alcoholic liver disease III. Role of the innate immune response in alcoholic hepatitis. American Journal of Physiology: Gastrointestinal and Liver Physiology, v. 287, n. 2, p. 310-314, 2004.

HONG, F.; KIM, W. H.; TIAN, Z.; JARUGA, B.; ISHAC, E.; SHEN, X.; GAO, B. Elevated interleukin-6 during ethanol consumption acts as a potential endogenous protective cytokine against ethanol-induced apoptosis in the liver: involvement of induction of Bcl-2 and $\mathrm{Bcl}-\mathrm{x}(\mathrm{L})$ proteins. Oncogene, v. 21, n. 1, p. 32-43, 2002.

ICHIHARA, M.; HARA, T.; TAKAGI, M.; CHO, L. C.; GORMAN, D. M.; MIYAJIMA, A. Impaired interleukin-3 (IL-3) response of the A/J mice is caused by a branch point deletion in the IL-3 receptor alpha subunit gene. The EMBO Journal, v. 14, p. 939-950, 1995.

IIMURO, Y.; GALlUCCI, R. M.; LUSTER, M. I.; KONO, H.; THURMAN, R. G. Antibodies to tumor necrosis factor alfa attenuate hepatic necrosis and inflammation caused by chronic exposure to ethanol in the rat. Hepatology, v. 26, n. 6, p. 1530-1537, 1997.

INOHARA, N.; NUÑEZ, G. NODs: intracellular proteins involved in inflammation and apoptosis. Nature Reviews Immunology, v. 3, n. 5, p. 371-382, 2003.

JÄRVELÄINEN, H. A.; VÄKEVÄ, A.; LINDROS, K. O.; MERI, S. Activation of complement components and reduced regulator expressão in alcohol-induced liver injury in the rat. Clinical Immunology, v. 105, n. 1, p. 57-63, 2002.

JEREMIAH, S. J.; WEST, L. F.; DAVIS, M. B.; POVEY, S.; CARRITT, B.; FEY, G. Assignment of human complement component C5 to chromosome 9. (Abstract) Cytogenetics and Cell Genetics, v. 46, p. 634, 1987.

JEREMIAH, S. J.; WEST, L. F.; DAVIS, M.; POVEY, S.; CARRITT, B.; FEY, G. H. The assignment of the human gene coding for complement C5 to chromosome 9q22-9q33. Annals of Human Genetics, v. 52, p. 111-116, 1988.

KALANT, D.; MACLAREN, R.; CUI, W.; SAMANTA, R.; MONK, P. N.; LAPORTE, S. A.; CIANFLONE, K. C5L2 is a functional receptor for acylation-stimulating protein. The Journal of Biological Chemistry, v. 280, n. 25, p. 23936-23944, 2005.

KALANT, D.; CAIN, S. A.; MASLOWSKA, M.; SNIDERMAN, A. D.; CIANFLONE, K.; MONK, P. N. The Chemoattractant Receptor-like Protein C5L2 Binds the C3a desArg77/Acylation-stimulating Protein. The Journal of Biological Chemistry, v. 278, n. 13, 28, p. 11123-11129, 2003.

KARP, C. L.; GRUPE, A.; SCHADT, E.; EWART, S. L.; KEANE-MOORE, M. Identification of complement factor 5 as a susceptibility locus for experimental allergic asthma. Nature Immunology, v. 1, n. 3, 2000. 
KAYE, M.; KUSY, R. P. Genetic lineage, bone mass, and physical activity in mice. Bone, v. 17, n. 2, p. 131-135, 1995.

KLEINER, D. E.; BRUNT, E. M.; VAN NATTA, M.; BEHLING, C.; CONTOS, M. J.; CUMMINGS, O. W.; FERRELL, L. D.; LIU, Y. C.; TORBENSON, M. S.; UNALP-ARIDA, A.; YEH, M.; MCCULLOUGH, A. J.; SANYAL, A. J. Nonalcoholic Steatohepatitis Clinical Research Network. Design and validation of a histological scoring system for nonalcoholic fatty liver disease. Hepatology, v. 41, n. 6, p. 1313-1321, 2005.

KLOS, A.; TENNER, A. J.; JOHSWISH, K.; AGER, R. R.; REIS, E. S.; KÖHL, J. The role of the anaphylatoxins in health and disease. Molecular Immunology, v. 46, n. 14, p. 2753 2766, 2009.

KONDO, H.; MINEGISHI, Y.; KOMINE, Y.; MORI, T.; MATSUMOTO, I.; ABE, K. Differential regulation of intestinal lipid metabolism-related genes in obesity-resistant $\mathrm{A} / \mathrm{J}$ vs. obesity-prone C57B1/6 mice. American Journal of Physiological and Endocrinological Metabolism, v. 291, p. 1092-1099, 2006.

KONDOS, S. C.; HATFALUDI, T.; VOSKOBOINIK, I.; TRAPANI, J. A.; LAW, R. H.; WHISSTOCK, J. C.; DUNSTONE, M. A.; KOTEISH, A.; DIEHL, A. M. Animal models of steatosis, Seminars in Liver Disease, v. 21, p. 89-104, 2001.

KRAWCZYK, M.; BONFRATE, L.; PORTINCASA, P. Nonalcoholic fatty liver disease. Best Practice and Research Clinical Gastroenterology, v. 24. p. 695-708, 2010.

LAMY, J.; BAGLIN, M. C.; FERRANT, J. P.; WEILL, J. Decrease in serum gammaglutamyltranspeptidase following abstention from alcohol. Clinica Chimica Acta, v. 56, n. 2, p. 169-173, 1974.

LASKIN, D. L.; SUNIL, V. R.; GARDNER, C. R.; LASKIN, J. D. Macrophages and tissue injury: agents of defense or destruction? The Annual Review of Pharmacology and Toxicology, v. 51, p. 267-288, 2011.

LEE, H.; WHITFELD, P. L.; MACKAY, C. R. Receptors for complement C5a. The importance of C5aR and the enigmatic role of C5L2. Immunology and Cell Biology, v. 86, n. 2, p. 153-160, 2008.

LEMMERS, A.; MORENO, C.; GUSTOT, T.; MARÉCHAL, R.; DEGRÉ, D.; DEMETTER, P.; DE NADAI, P.; GEERTS, A.; QUERTINMONT, E.; VERCRUYSSE, V.; LE MOINE, O.; DEVIÈRE, J. The interleukin-17 pathway is involved in human alcoholic liver disease. Hepatology, v. 49, n. 2, p. 646-657, 2009.

LIEBER, C. S. Alcoholic fatty liver: its pathogenesis and mechanism of progression to inflammation and fibrosis, Alcohol, v. 34, p. 9-19, 2004.

LIEBER, C. S.; DECARLI, L. M. The feeding of alcohol in liquid diets: two decades of applications and 1982 update. Alcoholism: Clinical and Experimental Research, v. 6, n. 4, p. 523-531, 1982. 
LIEBER, C. S.; JONES, D. P.; MENDELSON, J.; DECARLI, L. M. Fatty liver, hyperlipemia and hyperuricemia produced by prolonged alcohol consumption despite adequate dietary intake. Trans Ass Amer Physicians, v. 76, p. 289-300, 1963.

LIM, J.; IYER, A.; SUEN, J. Y.; SEOW, V.; REID, R. C.; BROWN, L.; FAIRLIE, D. P. $\mathrm{C} 5 \mathrm{aR}$ and $\mathrm{C} 3 \mathrm{aR}$ antagonists each inhibit diet-induced obesity, metabolic dysfunction, and adipocyte and macrophage signaling. FASEB Journal, v. 27, n. 2, p. 822-831, 2013.

MACGREGOR, R. R. Alcohol and imunne defense. Journal of the American Medical Association, v. 256, p. 1474-1479, 1986.

MALIK, T. H.; CORTINI, A.; CARASSITI, D.; BOYLE, J. J.; HASKARD, D. O.; BOTTO, $M$. The alternative pathway is critical for pathogenic complement activation in endotoxin- and diet-induced atherosclerosis in low-density lipoprotein receptor-deficient mice. Circulation, v. 122, n. 19, p. 1948-1956, 2010.

MARKIEWSKI, M. M.; DE ANGELIS, R. A.: STREY, C. W.; FOUKAS, P. G.; GERARD, C.; GERARD, N.; WETSEL, R. A.; LAMBRIS, J. D. The regulation of liver cell survival by complement. The Journal of Immunology, v. 182, p. 5412-5418, 2009.

MARKIEWSKI, M. M.; DE ANGELIS, R. A.; BENENCIA, F.; RICKLIN-LICHTSTEINER, S. K.; KOUTOULAKI, A.; GERARD, C.; COUKOS, G.; LAMBRIS, J. D. Modulation of the antitumor immune response by complement. Nature Immunology, v. 9, n. 11, p. 1225-1234, 2008.

MARKIEWSKI, M. M.; MASTELLOS, D.; TUDORAN, R.; DE ANGELIS, R. A. C3a and C3b Activation Products of the Third Component of Complement (C3) Are Critical for Normal Liver Recovery after Toxic Injury. The Journal of Immunology, v. 173, p. 747-754, 2004.

MARTINON, F.; MAYOR, A.; TSCHOPP, J. The inflammasomes: guardians of the body. The Annual Review of Immunology, v. 27, p. 229-265, 2009.

MASTELLOS, D.; PAPADIMITRIOU, J. C., FRANCHINI, S.; TSONIS, P.; LAMBRIS, J. D. A novel role of complement: mice deficient in the fifth component of complement (C5) exhibit impaired liver regeneration. The Journal of Immunology, v. 166, p. 2479-2486, 2001.

MATTEONI, C. A.; YOUNOSSI, Z. M.; GRAMLICH, T.; BOPARAI, N.; LIU, Y. C.; MCCULLOUGH, A. J. Nonalcoholic fatty liver disease: a spectrum of clinical and pathological severity, Gastroenterology, v. 116, n. 6, p. 1413-1439, 1999.

MATTHEWS, K. W.; MUELLER-ORTIZ, S. L.; WETSEL, R. A. Carboxypeptidase N: a pleiotropic regulator of inflammation. Molecular Immunology, v. 40, n. 11, p. 785-793, 2004.

MCCLAIN, C. J.; SONG, Z.; BARVE, S. S.; HILL, D. B.; DEACIUC, I. Recent advances in alcoholic liver disease IV. Dysregulated cytokine metabolism in alcoholic liver disease. American Journal of Physiology-Gastrointestinal and Liver Physiology, v. 287, p. 497$502,2004$. 
MENG, F.; WANG, K.; AOYAMA, T.; GRIVENNIKOV, S. I.; PAIK, Y.; SCHOLTEN, D.; CONG, M.; IWAISAKO, K.; LIU, X.; ZHANG, M.; OSTERREICHER, C. H.; STICKEL, F.; LEY, K.; BRENNER, D. A.; KISSELEVA, T. Interleukin-17 signaling in inflammatory, Kupffer cells, and hepatic stellate cells exacerbates liver fibrosis in mice. Gastroenterology, v. 143, n. 3, p. 765-776, 2012.

MIELE, L.; MARRONE, G.; LAURITANO, C.; CEFALO, C.; GASBARRINI, A.; DAY, C.; GRIECO, A. Gut-liver axis and microbiota in NAFLD: insight pathophysiology for novel therapeutic target. Current Pharmaceutical Design, 2013. In press.

MILLER, A. M.; WANG, H.; BERTOLA, A.; PARK, O.; HORIGUCHI, N.; KI, S. H.; YIN, S.; LAFDIL, F.; GAO, B. Inflammation-associated interleukin-6/signal transducer and activator of transcription 3 activation ameliorates alcoholic and nonalcoholic fatty liver diseases in interleukin-10-deficient mice. Hepatology, v. 54, n. 3, p. 846-856, 2011.

MILLER, G. W.; NUSSENZWEIG, V. Complement as a regulator of interactions between immune complexes and cell membranes. Journal of Immunology, v. 113, n. 2, p. 464-469, 1974.

MILLS, C. D.; KINCAID, K.; ALT, J. M.; HEILMAN, M. J.; HILL, A. M. M-1/M-2 macrophages and the Th1/Th2 paradigm. The Journal of Immunology, v. 164, n. 12, p. 6166-6173, 2000.

MOLINA, P. E.; HAPPEL, K. I.; ZHANG, P.; KOLLS, J. K.; NELSON, S. Focus on: alcohol and the immune system. Alcohol Research \& Health, v. 33, n. 1-2, p. 97-108, 2010.

MORGAN, B. P.; HARRIS, C. L. 1999. Complement regulatory proteins. Academic Press.

MORENO-NAVARRETE， J. M.; MARTÍNEZ-BARRICARTE， R.; CATALÁN, V.; SABATER, M.; GÓMEZ-AMBROSI, J.; ORTEGA, F. J.; RICART, W.; BLÜHER, M. FRÜHBECK, G.; RODRÍGUEZ DE CORDOBA, S.; FERNÁNDEZ-REAL， J. M. Complement factor $\mathrm{H}$ is expressed in adipose tissue in association with insulin resistance. Diabetes, v. 59, n. 1, p. 200-209, 2010.

MORGAN, B. P.; GASQUE, P. Extrahepatic complement biosynthesis: where, when and why? Clinical and Experimental Immunology, n. 107, p. 1-7, 1997.

MORIO, L. A.; CHIU, H.; SPROWLES, K. A.; LASKIN, D. L. Funcional heterogeneity of rat hepatic and alveolar macrophages: effects of chronic ethanol administration. Journal of Leukocyte Biology, v. 68, p. 614-620, 2000.

MULLICK, A.; ELIAS, M.; PICARD, S.; BOURGET, L.; JOVCEVSKI, O.; GAUTHIER, S.; TUITE, A.; HARAKIDAS, P.; BIHUN, C.; MASSIE, B.; GROS, P. Dysregulated inflammatory response to Candida albicans in a C5-deficient mouse strain. Infection and Immunity, v. 72, n. 10, p. 5868-5876, 2004.

MUNKONDA, M. N.; LAPOINTE, M.; MIEGUEU, P.; ROY, C.; GAUVREAU, D.; RICHARD, D.; CIANFLONE, K. Recombinant acylation stimulating protein administration to $\mathrm{C} 3-/-$ mice increases insulin resistance via adipocyte inflammatory mechanisms. PLoS One, n. 14, p. 1058-1066, 2012. 
NAGATA, K.; SUZUKI, H.; SAKAGUCHI, S. Common pathogenic mechanism in development progression of liver injury caused by non-alcoholic or alcoholic steatohepatitis, The Journal of Toxicological Sciences, v. 32, n. 5, p. 453-468, 2008.

NAGY, L. E. Recent insights into the role of the innate immune system in the development of alcoholic liver disease. Experimental Biology and Medicine, v. 228, p. 882-890, 2003.

NANJI, A.; TSUKAMOTO, H.; FRENCH, S. W. Relationship between fatty liver and subsequent development of necrosis, inflammation and fibrosis in experimental alcoholic liver disease. Experimental and Molecular Pathology, v. 51, n. 2, p. 141-148, 1989.

NEFF, S.; NEFF, T. A.; KUNKEL, S. L.; HOGABOAM, C. M. Alterations in cytokine /chemokine expression during organ-to-organ communication established via acetaminopheninduced toxicity. Experimental and Molecular Pathology, v. 75, p. 187-193, 2003.

NYBLOM, H.; BERGGREN, U.; BALLDIN, J.; OLSSON, R. High ast / alt ratio may indicate advanced alcoholic liver disease rather than heavy drinking. Alcohol, v. 39, n. 4, p. 336-339, 2004.

O’SHEA, J. J.; MURRAY, P. J. Cytokine signaling modules in inflammatory responses. Immunity, v. 28, p. 477-487, 2008.

OBERBACH, A.; BLÜHER, M.; WIRTH, H.; TILL, H.; KOVACS, P.; KULLNICK, Y.; SCHLICHTING, N.; TOMM, J. M.; ROLLE-KAMPCZYK, U.; MURUGAIYAN, J.; BINDER, H.; DIETRICH, A.; VON BERGEN, M. Combined proteomic and metabolomic profiling of serum reveals association of the complement system with obesity and identifies novel markers of body fat mass changes. Journal of Proteome Research, v. 10, n. 10, p. 4769-4788, 2011.

OHNO, M.; HIRATA, T.; ENOMOTO, M.; ARAKI, T.; ISHIMARU, H.; TAKAHASHI, T. A. A putative chemoattractant receptor, C5L2, is expressed in granulocyte and immature dendritic cells, but not in mature dendritic cells. Molecular Immunology, v. 37, p. 407-412, 2000.

OUCHTERLONY, Ö. Diffusion-in-gel methods for immunological analysis II. In: KALLOS, P.; WAKSMAN, B. H. Progress in allergy. Basel: Karger, 1962. p. 30-154.

PAGLIALUNGA, S.; FISETTE, A.; YAN, Y.; DESHAIES, Y.; BROUILLETTE, J. F.; PEKNA, M.; CIANFLONE, K. Acylation-stimulating protein deficiency and altered adipose tissue in alternative complement pathway knockout mice. American Journal of Physiology Endocrinology and Metabolism, v. 294, n. 3, p. E521-529, 2008.

PASTORINO, J. G.; SHULGA, N.; HOEK, J. B. TNF-a-induced cell death in ethanolexposed cells depends on p38 MAPK signaling but is independent of Bid and caspase- 8 . The American Journal of Physiology - Gastrointestinal and Liver Physiology, v. 285, p. G503-516, 2003.

PATEL, S. N.; BERGHOUT, J.; LOVEGROVE, F. E.; AYI, K.; CONROY, A.; SERGHIDES, L.; C5 deficiency and C5a or C5aR blockade protects against cerebral malaria. The Journal of Experimental Medicine, v. 205, n. 5, p. 1133-1143. 2008. 
PETKOV, P. M.; DING, Y.; CASSELL, M. A.; ZHANG, W.; WAGNER, G.; SARGENT, E. E.; ASQUITH, S., CREW, V., JOHNSON, K. A.; ROBINSON, P.; SCOTT, V. E.; WILES, M. V. An efficient SNP system for mouse genome scanning and elucidating strain relationships. Genome Research, v. 14, n. 9, p. 1806-1811, 2004.

PETRASEK, J.; BALA, S.; CSAK, T.; LIPPAI, D.; KODYS, K.; MENASHY, V.; BARRIEAU, M.; MIN, S. Y.; KURT-JONES, E. A.; SZABO, G. IL-1 receptor antagonist ameliorates inflammasome-dependent alcoholic steatohepatitis in mice. The Journal of Clinical Investigation, v. 122, n. 10, p. 3476-3489, 2012.

POURSHARIFI, P.; LAPOINTE, M.; PÉTRIN, D.; DEVOST, D.; GAUVREAU, D.; HÉBERT, T. E.; CIANFLONE, K. C5L2 and C5aR interaction in adipocytes and macrophages: insights into adipoimmunology. Cellular Signalling, v. 25, n. 4, p. 910-918, 2013.

POZZULO, G. N.; SKAMENE, E.; GERVAIS, F. Bone marrow cell response following induction of acute inflammation in different strains of mice. Inflammation, v. 17, n. 6, p. 677-685, 1993.

PRITCHARD, M. T.; MCMULLEN, M. R.; STAVITSKY, A. B.; COHEN, J. I.; LIN, F.; MEDOF, M. E.; NAGY, L. E. Differential contributions of C3, C5 and decay accelerating factor to ethanol-induced fatty liver in mice. Gastroenterology, v.132, n.3, p. 1117-1126, 2007.

PRUETT, S. B.; FAN, R. Ethanol inhibits LPS-induced signaling and modulates cytokine production in peritoneal macrophages in vivo in a model for binge drinking. BMC Immunology, v. 18, p. 10-49, 2009.

RECINOS, A.; CARR, B. K.; BARTOS, D. B.; BOLDOGH, I.; CARMICAL, J. R.; BELALCAZAR, L. M.; BRASIER, A.R. Liver gene expression associated with diet and lesion development in atherosclerosis-prone mice: induction of components of alternative complement pathway. Physiological Genomics, v. 19, n. 1, p. 131-142, 2004.

RENSEN, S. S.; SLAATS, Y.; DRIESSEN, A.; PEUTZ-KOOTSTRA, K. J.; NIJHUIS, J.; Activation of the complement systemin human non alcoholic fatty liver disease. Hepatology, v. 50, p. 1809-1817, 2009.

RICKLIN, D.; HAJISHENGALLIS, G.; YANG, K.; LAMBRIS, J. D. Complement: a key system for immune surveillance and homeostasis. Nature Immunology, v. 11, p. 785-797, 2010.

ROY, C.; PAGLIALUNGA, S.; FISETTE, A.; SCHRAUWEN, P.; MOONEN-KORNIPS, E.; ST-ONGE, J.; HESSELINK, M. K.; RICHARD, D.; JOANISSE, D. R,; CIANFLONE, K. Shift in metabolic fuel in acylation-stimulating protein-deficient mice following a high-fat diet. American Journal of Physiology - Endocrinology and Metabolism, v. 294, n. 6, E1051-1059, 2008.

ROYCHOWDHURY, S.; MCMULLEN, M. R.; PRITCHARD, M. T.; HISE, A, G.; ROOIJEN, N. VAN. An early complement-dependent and TLR-4-independent phase in the 
pathogenesis of etanol-induced liver injury in mice. Hepatology, v. 49, n. 3, p. 1326-1334, 2009.

RUSSELL, E. S.; MEIER, H. Constitutional diseases. In: laboratory mouse. 2nd ed. New York: Dover, 1966. p. 571-587.

Biology of the

SACKMANN-SALA, L.; BERRYMAN, D. E.; MUNN, R. D.; LUBBERS, E. R.; KOPCHICK, J. J. Heterogeneity among white adipose tissue depots in male C57BL/6J mice. Obesity, v. 20, n. 1, p. 101-111, 2012.

SAEED, R. W.; VARMA, S.; PENG, T.; TRACEY, K. J.; SHERRY, B.; METZ, C. N. Ethanol blocks leukocyte recruitment and endothelial cell activation in vivo and in vitro. The Journal of Immunology, v. 173, p. 6376-6383, 2004.

SAUNDERS, J. B.; WODAK, A. D.; WILLIAMS, R. What determines susceptibility to liver damage from alcohol?: discussion paper. Journal of the Royal Society of Medicine, v. 77, n. 3, p. 204-216, 1984.

SCHEUER, P. J.; LEFKOWITCH, J. H. Drugs and toxins. In: SCHEUER, P. J.; LEFKOWITCH, J. H. (Ed.). Liver biopsy interpretation. London: WB Saunders, 2000. p. 134-150.

SCHMITT, J.; RODERFELD, M.; SABRANE, K.; ZHANG, P.; TIAN, Y., MERTENS, J. C.; FREI, P.; STIEGER, B.; WEBER, A.; MÜllHAUPT, B., ROEB, E., GEIER, A. Complement factor C5 deficiency significantly delays the progression of biliary fibrosis in bile duct-ligated mice. Biochemical and Biophysical Research Communications, v. 418, n. 3, p. 445-450, 2012.

SELLERS, R. N.; MORTON, D.; MICHAEL, B.; ROOME, N.; JOHNSON, J. K; YANO, B. L.; PERRY, R.; SCHAFER, K. Society of toxicologic pathology position paper: organ weight recommendations for toxicology studies. Toxicologic Pathology, v. 35, p.751-755, 2007.

SERVAIS, G.; WALMAGH, J.; DUCHATEAU, J. Simple quantitative haemolytic microassay for determination of complement alternative pathway activation (AP50). Journal of Immunological Methods, v. 140, p. 93-100. 1991.

SHOELSON, S. E.; HERRERO, L.; NAAZ, A. Obesity, inflammation, and insulin resistance. Gastroenterology, v. 132, n. 6, p. 2169-2180, 2007.

SHOELSON, S. E.; LEE, J.; GOLDFINE, A. B. Inflammation and insulin resistance. Journal of Clinical Investigation, v. 116, p. 1793-1801, 2006.

SILVER, L. M. Laboratory mice. In: Mouse genetic: concepts and applications. New York: Oxford, 1995. Cap. 3, p. 32-57.

STEWART, D.; FULTON, W. B.; WILSON, C.; MONITTO, C. L.; PAIDAS, C. N.; REEVES, R. H.; DE MAIO, A. Genetic contribution to the septic response in a mouse model. Shock, v. 18, n. 4, p. 342-347, 2002. 
STIENSTRA, R.; SAUDALE, F.; DUVAL, C.; KESHTKAR, S.; GROENER, J.E.M.; VAN ROOIJEN, N. Kupffer cells promote hepatic steatosis via interleukin-1 $\beta$ dependent suppression of peroxisome proliferator-activated receptor activity. Hepatology, v. 51, p. 511$522,2010$.

STREY, C. W.; MARKIEWSKI, M.; MASTELLOS, R. T.; SPRUCE, L. A.; GREENBAUM, L. E.; LAMBRIS, J. D. The proinflammatory mediators C3a and C5a are essential for liver regeneration. The Journal of Experimental Medicine, v. 198, n. 6, p. 913-923, 2003.

SURWIT, R. S.; SELDIN, M. F.; KUHN, C. M.; COCHRANE, C.; FEINGLOS, M. N. Control of expression of insulin resistance and hyperglycemia by different genetic factors in diabetic C57BL/6J mice. Diabetes, v. 40, p. 82-87,1991.

TACK, B. F.; MORRIS, S. C.; PRAHL, J. W. Fifth component of human complement: purification from plasma and polypeptide chain structure. Biochemistry, v.18, p.1490-1497, 1979.

TANG, Y.; BIAN, Z.; ZHAO, L.; LIU, Y.; LIANG, S.; WANG, Q.; HAN, X.; PENG, Y.; CHEN, X.; SHEN, L.; QIU, D.; LI, Z.; MA, X. Interleukin-17 exacerbates hepatic steatosis and inflammation in non-alcoholic fatty liver disease. Clinical \& Experimental Immunology, v. 166, n. 2, p. 281-290, 2011.

TAUB, R. Liver Regeneration: from myth to mechanism. Nature Reviews, v. 5, p. 836-847, 2004.

TOM, F. Q.; GAUVREAU, D.; LAPOINTE, M.; LU, H.; POURSHARIFI, P.; LUO, X. P.; CIANFLONE, K. Differential chemoattractant response in adipocytes and macrophages to the action of acylation stimulating protein.. The European Journal of Cell Biology, v. 92, n. 2, p. 61-69, 2013.

TSUKAMOTO, H. Fat paradox in liver disease. The Keio Journal of Medicine, v. 54, n. 4, p.190-192. 2005.

TUNG, K. H.; HUANG, Y. S.; YANG, K. C.; PERNG, C. L.; LIN, H. C.; LEE, S. D. Serum interleukin-12 levels in alcoholic liver disease. Journal of the Chinese Medical Association, v. 73, n. 2, p. 67-71, 2010.

TURNER, M. W. The role of mannose-binding lectin in health and disease. Molecular Immunology, v.40, p. 423-429, 2003.

VALENTI, L.; FRACANZANI, A. L.; FARGION, S. The immunopathogenesis of alcoholic and nonalcoholic steatohepatitis: two triggers for one disease? Seminars in Immunopathology, v. 31, n. 3, p. 359-369, 2009.

VAN GREEVENBROEK, M. M; GHOSH, S.; VAN DER KALLEN, C. J.; BROUWERS, M. C.; SCHALKWIJK, C. G.; STEHOUWER, C. D. Up-regulation of the complement system in subcutaneous adipocytes from nonobese, hypertriglyceridemic subjects is associated with adipocyte insulin resistance. The Journal of Clinical Endocrinology \& Metabolism, v. 97, n. 12, p. 4742-4752, 2012. 
VIDALI, M.; HIETALA, J.; OCCHINO, G.; IVALDI, A.; SUTTI, S.; ALBANO, E.; NIEMELÄ, O. Immune responses against oxidative stress-derived antigens are associated with increased circulating tumor necrosis factor-a in heavy drinkers. Free Radical Biology \& Medicine, v. 45, p. 306-311, 2008.

WAKELAND, E.; MOREL, L.; ACHEY, K.; YUI, M.; LONGMATE, J. Speed congenics: a classic technique in the fast lane (relatively speaking). Immunology Today, v. 18, n. 10, p. 472-477, 1997.

WALPORT, M. J. Complement (First of Two Parts). New England Journal of Medicine, v. 344, n. 14, p. 1058-1066, 2001.

WALPORT, M. J. Complement (Second of Two Parts). New England Journal of Medicine, v. 344, n. 14, p. 1140-1144, 2001.

WARD, P. Role of the complement in experimental sepsis. Journal of Leukocyte Biology, v. 83, p. 467-470, 2008.

WEISS, P. A.; COLLIER, S. D.; PRUETT, S. B. Role of glucocorticoids in ethanol-induced decreases in expression of MHC class II molecules on B cells and selective decreases in spleen cell number. Toxicology and Applied Pharmacology, v. 139, n. 1, p. 153-162, 1996.

WETSEL, R. A. C5. In: MORLEY, B. J.; WALPORT, M. J. (Org.). The complement: facts book. London: Academic Press, 2000. p. 104-109.

WETSEL, R. A.; LEMONS, R. S.; LE BEAU, M. M.; BARNUM, S. R.; NOACK, D.; TACK, B. F. Molecular analysis of human complement component C5: localization of the structural gene to chromosome 9. Biochemistry, v.27, p. 1474-1482, 1987.

WETSEL, R. A.; FLEISCHER, D. T.; HAVILAND, D. L. Deficiency of the murine fifth complement component (C5): a 2-base pair gene deletion in a 5-prime-exon. Journal of Biological Chemistry, v. 265, p. 2435-2440, 1990.

WHITFIELD, J. B. Gamma glutamyl transferase. Critical Reviews in Clinical Laboratory Sciences, v. 38, n. 4, p. 263-355, 2001.

WONG, G. T. Speed congenics: applications for transgenic and knock-out mouse strain. Neuropeptides, v. 36, p. 230-236, 2002.

WOODRUFF, T. M.; AGER, R. R.; TENNER, A. J.; NOAKES, P. G.; TAYLOR, S. M. The role of the complement system and the activation fragment $\mathrm{C} 5 \mathrm{a}$ in the central nervous system. NeuroMolecular Medicine, v. 12, n. 2, p. 179-192, 2010.

WRIGHT, E. K.; GOODART, S. A.; GROWNEY, J. D.; HADINOTO, V.; ENDRIZZI, M. G.; LONG, E. M.; SADIGH, K.; ABNEY, A. L; BERNSTEIN-HANLEY, I.; DIETRICH, W. F. Naip5 affects host susceptibility to the intracellular pathogen Legionella pneumophila. Current Biology, v. 13, n. 1, p. 27-36, 2003.

XIA, Z.; CIANFLONE, K.; Acylation-stimulating protein precursor proteins in adipose tissue in human obesity. Metabolism, v. 52, n. 10, p. 1360-1366, 2003. 
YIN, H.; KIM, M.; KIM, J.; KONG, G.; KANG, K.; KIM, H.;YOON, B.; LEE, M.; LEE, B. Differential gene expression and lipid metabolism in fatty liver induced by acute ethanol treatment in mice. Toxicology and Applied Pharmacology, v. 223, p. 225-233, 2007.

YONEYAMA, N.; CRABBE, J. C.; FORD, M. M.; MURILLO, A.; FINN, D. A. Voluntary ethanol consumption in 22 inbred mouse strains. Alcohol, v. 42, n. 3, p. 149-160, 2008.

ZHANG, J.; WRIGHT, W.; BERNLOHR, D. A.; CUSHMAN, S. W.; CHEN, X. Alterations of the classic pathway of complement in adipose tissue of obesity and insulin resistance. American Journal of Physiology - Endocrinology and Metabolism, v. 292, n. 5, p. 14331440, 2007.

ZHANG, P.; BAGBY, G. J.; HAPPEL, K. I. Pulmonary host defenses and alcohol. Frontiers in Bioscience, v. 7, p. 1314-1330, 2002.

ZHANG, P.; WELSH, D. A.; SIGGINS, R. W.; BAGBY, G. J.; RAASCH, C. E.; HAPPEL, K. I.; NELSON, S. Acute alcohol intoxication inhibits the lineage- c-kit+ Sca-1+ cell response to Escherichia coli bacteremia. The Journal of Immunology, v. 182, n. 3, p. 15681576, 2009. 


\section{APÊNDICE A - MODELO MURINO DE DOENÇA HEPÁTICA NÃO-ALCOÓLICA}

\section{Introdução}

\subsection{Características da Doença Hepática Não-Alcoólica}

A Doença Hepática Não-Alcoólica (DHNA) possui características histopatológicas semelhantes àquelas encontradas na DHA, porém é diagnosticada na ausência ou na presença de baixo consumo alcoólico. A DHNA compreende amplo espectro histopatológico desde acúmulo de gordura nos hepatócitos sem concomitante inflamação nem fibrose até o estabelecimento de esteatose hepática com necrose e inflamação (esteatohepatite) que pode ou não estar associada com fibrose e cirrose. A esteatose hepática pode progredir para a forma mais severa da doença chamada esteatohepatite não alcoólica (ENA), presente em $20 \%$ das pessoas obesas e 60\% das pessoas com obesidade mórbida (MATTEONI et al., 1999).

A DHNA é considerada uma manifestação hepática da síndrome metabólica, a qual inclui anormalidades como resistência à insulina, obesidade visceral, deslipidemia, diabetes, hipertensão, entre outras. A patogênese da DHNA não é completamente entendida, entretanto a resistência à insulina e a produção de citocinas inflamatórias são mecanismos chaves que levam à esteatose hepática. Os eventos iniciais são: excesso de peso, obesidade, aumento da adiposidade visceral com produção de TNF- $\alpha$, IL-6 e IL-1ß (também conhecidas por adipocinas), alterações hormonais (leptina e resistina) e estresse oxidativo. A microflora intestinal também contribui para a etiopatogênese desta doença pela liberação de endotoxinas para a circulação sanguínea e pela produção de etanol endógeno (KRAWCZYK et al., 2010). Evidências experimentais que suportam o modelo de indução da síndrome metabólica correlacionada à microbiota intestinal, pela translocação bacteriana ou de LPS do intestino para a corrente sanguínea, e a esteatose hepática tornam-se cada vez mais freqüentes. Sabe-se que a alteração da permeabilidade intestinal induzida pelo consumo de uma dieta hiperlipídica pode favorecer a passagem de derivados microbianos do lúmem intestinal para a circulação sanguínea causando um estado de inflamação sistêmica, o qual é característico da síndrome metabólica. E estas interações entre permeabilidade intestinal induzida pela dieta e bactérias presentes no lúmem estão envolvidas com a patogênese e evolução da DHNA. Portanto, a modulação da microbiota e controle da inflamação podem ser ferramentas promissoras para abordagens terapêuticas da DHNA (MIELE et al., 2013). 
Além das adipocinas estarem intimamente ligadas à manutenção da inflamação sistêmica, um elegante trabalho do grupo de Dixon (2013) mostrou a importância do inflamassoma para a injúria e para inflamação hepática induzidas pela dieta hipercalórica. Camundongos B6 sem o gene codificador para caspase-1, quando submetidos a uma dieta hiperlipídica por 12 semanas apresentaram menor depósito de triglicerídeos hepáticos e plasmáticos, menor concentração de TNF- $\alpha$, da proteína quimioatraente de monócitos (MCP) -1 e de fibrose no tecido hepático em relação aos camundongos B6 normais. Ou seja, o controle da inflamação favoreceu a proteção contra o desenvolvimento de lesão e acúmulo de gordura no tecido hepático.

\subsection{Sistema Complemento na Doença Hepática Não-Alcoólica}

Em 2009, Rensen e colaboradores descreveram pela primeira vez o depósito de produtos de ativação do sistema complemento em biópsias de fígado coletadas de pacientes tanto com DHNA quanto com a sua forma mais avançada, a ENA. Empregando a técnica de imunohistoquímica foi observado depósito de C3 e MBL ao redor dos hepatócitos com acúmulo de gordura e também infiltrado neutrofílico no tecido hepático nos pacientes com DHNA. Por PCR quantitativo estes autores constataram o aumento na expressão da quimiocina IL-8 e da citocina IL-6 no tecido hepático. Consequentemente, todas estas características tornaram-se mais pronunciadas nos pacientes com ENA.

Até o presente momento não existem trabalhos que abordem especificamente o sistema complemento em modelo murino de DHNA.

\subsection{Sistema Complemento e Obesidade}

Nem sempre pessoas obesas apresentam DHNA, mas a maior proporção das pessoas que desenvolvem DHNA sofre também por excesso de peso. Segundo o trabalho de Rensen e colaboradores (2009), pacientes com quadro de esteatose hepática apresentaram índice de massa corporal (IMC) em torno de 46, pacientes com esteatose hepática e ENA apresentaram IMC por volta de 48 e os pacientes saudáveis permaneceram com 29 de IMC. Ou seja, conforme houve a progressão e a severidade da doença ocorreu o aumento do IMC. Portanto, reunimos aqui alguns trabalhos associando os componentes do sistema complemento em análises realizadas com amostras de pacientes obesos e em modelos murinos de obesidade. 
Em grande maioria os trabalhos investigam a relação entre o sistema complemento e o tecido adiposo.

\subsubsection{Trabalhos envolvendo o sistema complemento em pacientes obesos}

Avaliando a concentração sérica de C3 em pacientes com obesidade severa, mórbida ou extrema, Hernández-Mijares e colaboradores (2007) identificaram uma correlação entre o aumento de C3 sérico com a progressão da obesidade, seja ela de severa para mórbida ou de severa para extrema. Além isso, identificaram uma correlação positiva entre o aumento da concentração de C3 sérica com o aumento do IMC e a resistência a insulina.

A análise combinada do perfil proteômico e metabolômico em soro de pacientes obesos revelou associações entre os componentes do sistema complemento com a progressão da obesidade e ainda identificou marcadores de mudanças de massa gorda corporal. A análise identificou o fragmento C3b como um dos marcadores desta associação, além da clusterina (apolipotproteína J; proteína reguladora da via terminal do sistema complemento) e proteína ligante de vitamina D. Este estudo também confirmou marcadores séricos previamente descobertos associados com as mudanças de massa gorda corporal, dentre eles estiveram o componente C3 e a proteína amilóide P do soro (OBERBACH et al., 2011).

A via alternativa do sistema complemento é apontada como um elo entre a obesidade e desordens metabólicas, pois estudando a expressão de $\mathrm{C} 3, \mathrm{fB}$ e adipsina (fD) no tecido adiposo de pacientes obesos, Xia e Cianflone (2003) identificaram uma correlação positiva para o aumento de C3 e de fD concomitante com o aumento do IMC em pacientes obesos. Concluindo, C3 e fD podem contribuir para o desenvolvimento do tecido adiposo visceral. Nesta mesma linha, estudando a correlação da expressão gênica de fH e fB circulantes e no tecido adiposo de pacientes com obesidade e resistência à insulina, o grupo de MorenoNavarrete (2010) encontrou que as concentrações tanto de fH quanto de fB também estavam associadas positivamente com o aumento de IMC, da circunferência abdominal, dos triglicerídeos circulantes e dos parâmetros inflamatórios sistêmicos.

Observou-se também aumento da regulação do sistema complemento nos adipócitos subcutâneos de pacientes não obesos, mas com hipertrigliceridemia associada com a resistência à insulina. Mais uma vez a expressão gênica do sistema complemento esteve associada com o aumento de triglicerídeos e da circunferência abdominal nos pacientes obesos usados como controles, mas nos pacientes não obesos que foram tratados farmacologicamente para hipertrigliceridemia houve redução desta patologia mas não afetou a 
expressão do sistema complemento. Estes resultados mostraram um aumento da regulação do sistema complemento nos adipócitos subcutâneos sob condições de estresse metabólico mesmo em pacientes sem obesidade excessiva. Ou seja, o aumento da regulação do sistema complemento pode influenciar a piora do processo patológico devido à promoção da migração de macrófagos para o tecido adiposo e pela indução de resistência à insulina dos adipócitos (VAN GREEVENBROEK et al., 2012)

\subsubsection{Trabalhos envolvendo o sistema complemento em culturas de adipócitos e macrófagos}

A síntese de triglicerídeos pelo tecido adiposo é estimulada por meio da ativação do receptor C5L2 pelo seu ligante da alta afinidade a proteína estimuladora de acilação (ASP do inglês acylation stimulating protein) também conhecida como C3adesArg (KALANT et al., 2005). O fragmento C3a, produto da clivagem de C3 em C3a e C3b, é gerado pela ativação das três vias do sistema complemento e pode ser clivado pela carboxipeptidase $\mathrm{N}$ ou R, a qual remove a arginina da região carboxi terminal de C3a gerando C3adesArg que reduz entre 10100 vezes seu papel pró-inflamatório que C3a (MATTHEWS; MUELLER-ORTIZ; WETSEL, 2004). O receptor C5L2 também pode ligar moderadamente outros produtos resultantes da ativação do sistema complemento como C3a, C5a e C5adesArg (CAIN; MONK, 2002) e devido a esta plasticidade é explorado como um potencial receptor "isca" para os fragmentos quimioatraentes de forma a regular a resposta inflamatória (LEE; WHITFELD; MACKAY 2008).

Sabendo que a obesidade está associada à inflamação e é caracterizada pelo infiltrado de macrófagos no tecido adiposo, Poursharifi e colaboradores (2013) investigaram a interação de C3desArg e C5a com os receptores C5L2 e C5aR presentes em linhagens de adipócitos e macrófagos. Por meio de microscopia confocal estes autores identificaram que o tratamento da cultura de adipócitos com C3adesArg ou C5a induziu a internalização dos receptores C5L2 e C5aR, seguida pela co-localização dos receptores na região peri-nuclear. Este mesmo tratamento realizado com a cultura de macrófagos induziu pouca co-localização quando tratado com C5a. De maneira geral, este trabalho mostra que os mecanismos envolvidos com a resposta diferencial da ativação dos receptores C5L2-C5aR é dependente do tipo celular e podem auxiliar na compreensão do processo inflamatório na obesidade. Seguindo a mesma linha de estudo, Tom e colaboradores (2013) também trataram culturas de adipócitos e macrófagos com concentrações fisiológicas de C3adesArg, pois em condições de obesidade, resistência à insulina e síndrome metabólica ocorre aumento da concentração de C3adesArg 
circulante. Na cultura de adipócitos tratados com C3adesArg houve secreção da citocina MCP-1 e a quimiocina derivada de queratinócito (KC), já os macrófagos tratados com C3adesArg não secretaram MCP-1. Quando os adipócitos e os macrófagos foram cocultivados houve secreção de MCP-1 e de adiponectina, e na presença de C3adesArg houve aumento desta secreção. Portanto, o fragmento C3adesArg estimulou a síntese de citocinas inflamatórias pelos adipócitos o que possivelmente promoveu a infiltração de macrófragos e a inflamação para o tecido adiposo em obesos.

\subsubsection{Trabalhos envolvendo o sistema complemento e modelos animais de obesidade}

Complementando os trabalhos anteriores realizados in vitro, o emprego de camundongos deficientes para os receptores C5L2 ou C5aR ou C3aR, para o componente C3, ou ainda tratando os animais com antagonistas para estes receptores, foram empregados em diversos estudos e confirmaram muitos dos resultados descritos acima em modelos in vivo. Camundongos deficientes para o receptor C5L2 sob uma dieta de baixo teor de gordura apresentaram comportamento hiperfágicos e mantiveram o mesmo peso corporal e do tecido adiposo que um camundongo normal. Contudo, sob uma dieta hiperlipídica, apresentam aumento do tamanho dos adipócitos, atraso na remoção de triglicerídeos circulantes no período pós-prandial (após as refeições) e aumento na oxidação de ácidos graxos nos tecidos musculares esqueléticos e cardíacos. Ou seja, os camundongos sem o receptor C5L2 sob uma dieta hiperlipídica e em resposta ao baixo armazenamento de triglicerídeos no tecido adiposo desenvolveram um mecanismo compensatório de aumento na oxidação de ácidos graxos em tecidos musculares (PAGLIALUNGA et al., 2007). Estes mesmos camundongos sob uma dieta indutora de diabetes desenvolveram sensibilidade à insulina, aumentaram a captura de glicose pelo fígado ao mesmo tempo em que apresentaram redução de glicose pelo tecido adiposo e tecido muscular esquelético, e ainda houve aumento do conteúdo lipídico pelo fígado e pelo tecido muscular. Além disso, os camundongos deficientes para o receptor C5L2 também apresentaram aumento plasmático das citocinas IL-6, MIP-1 e KC (FISETTE et al., 2013). Por fim, ratos tratados com uma dieta rica em carboidrato e em gordura desenvolveram obesidade, adiposidade visceral, inflamação no tecido adiposo, intolerância à glicose e aumento de $\mathrm{C} 3 \mathrm{a}$ no plasma. Porém, quando submetidos à mesma dieta e tratados concomitantemente com antagonistas para os receptores C5aR e C3aR houve a atenuação de todos estes parâmetros além da redução de adipocinas pró-inflamatórias e modificações na expressão de genes inflamatórios no tecido adiposo (LIM et al., 2013). 
Camundongos deficientes para o componente C3 tratados com uma dieta hiperlipídica removeram triglicerídeos em condição pós-prandial mais tardiamente, e apresentaram hiperfagia acompanhada por aumento do gasto energético (ROY et al., 2008). Todavia, quando reconstituídos com C3adesArg recombinante e sob a mesma dieta hiperlipídica tornaram-se resistentes à insulina e aumento da resposta inflamatória pela elevação da secreção das citocinas pró-inflamatórias Rantes, KC, MCP-1, IL-6 e G-CSF pelo tecido adiposo (MUNKONDA et al., 2012). Estes resultados sugeriram que o aumento de C3adesArg no plasma em associação com a obesidade pode ser um fator adicional no desenvolvimento da síndrome metabólica, da resistência à insulina e da diabetes.

Abordando o papel da via alternativa na obesidade e síndrome metabólica Paglialunga e colaboradores (2007) trataram camundongos deficientes de fB, fD e C3 com dieta hiperlipídica e observaram que tanto os $\mathrm{fB}$ quanto os C3 deficientes retardaram a remoção de triglicerídeos circulantes no período pós-prandial e também a remoção de ácidos graxos não estereficados do plasma. Ambos os camundongos deficientes para fB e fD não produzem C3adesArg, além dos próprios deficientes de C3. Portanto, a ausência de C3adesArg, mas não de C3, dirigiu o fenótipo metabólico, ou seja a deficiência ou a redução da concentração de C3adesArg esteve associada com a promoção de um estado anti-adipogênico e pode servir como um alvo para o controle da estocagem de gordura. Complementando o estudo sobre os componentes da via alternativa, Gauvreau e colaboradores (2012) investigaram o papel da properdina no metabolismo lipídico. Camundongos deficientes para a properdina sob tratamento com uma dieta hiperlipídica ganharam peso, reduziram o gasto energético e a remoção de lipídeos da circulação após as refeições.

Os componentes da via alternativa são bastante explorados em modelos de obesidade, entretanto, pouco foi investigado sobre a interação dos componentes da via clássica com o tecido adiposo. O grupo de Zhang (2007) buscando pela presença de alterações na expressão gênica dos componentes da via clássica no tecido adiposo identificou aumento da expressão de C1q e decorina (proteoglicado de matriz extra celular que liga-se com C1q como inibidor) no tecido adiposo epididimal de camundongos obesos (ob/ob), ratos obesos (Zucker) e em camundongos que se tornaram obesos por indução dietética. Os componentes C1r e C1s também tiveram suas expressões aumentadas em adipócitos de humanos resistentes à insulina. Ou seja, estes resultados mostram uma ativação excessiva da via clássica na obesidade.

Em resumo, mencionamos aqui um conjunto de proteínas do sistema complemento como: fB, fD, fH, C3, C3adesArg, C1q, C1s, C3aR, C5L2, C5aR que infuenciam o 
metabolismo lipídico, o armazenamento de energia e resistência à insulina suportanto uma complexa relação entre o sistema complemento e o tecido adiposo.

Estudos relacionados à injúria aterosclerótica também correlacionaram o envolvimento dos componentes da via alternativa com a progressão da doença. Avaliando a expressão gênica hepática em camundongos tratados com uma dieta hiperlipídica para indução de aterosclerose observou-se aumento da expressão gênica dos componentes $\mathrm{C} 3$, properdina e fD da via alternativa no tecido hepático. E a proteína C3 foi identificada nas lesões aórticas por imunohistoquímica (RECINOS et al., 2004). Posteriormente, aplicando camundongos deficientes de $\mathrm{fB}$ cruzados com camundongos deficientes para receptor de LDL foi demonstrado que sob uma dieta hiperlipídica indutora de aterosclerose a via alternativa foi ativada por LPS ou pela própria dieta hiperlipídica, sugerindo que a ativação da via alternativa possui um papel pró-aterogênico (MALIK et al., 2010).

Trabalhos envolvendo a DHNA mostram a importância do sistema complemento na manutenção da inflamação do micro-ambiente hepático. A compreensão desta modulação pode auxiliar na investigação da etiopatogenia destas doenças e compreender melhor o papel do sistema complemento na injúria hepática. Este será o primeiro trabalho envolvendo a proteína C5 e a identificar a contribuição da via terminal do sistema complemento em modelo de DHNA em camundongos. 


\section{Objetivos do APÊNDICE A}

* Estabelecer um modelo de DHNA, avaliando e identificando as alterações corporais e histopatológicas hepáticas observadas em pacientes ou modelos animais de DHNA durante diferentes tempos de tratamento (6, 8 e 10 semanas) empregando as linhagens C57B1/6 e A/J.

* Analisar a resposta inflamatória principalmente pela determinação da concentração hepática das citocinas TNF- $\alpha$, IL-6, IL-1 $\beta$, IL-12, IL-10 e da produção de NO nos camundongos C57Bl/6 e A/J, provocada pelo tratamento com glicose no modelo de DHNA.

* Empregar uma das novas linhagens de camundongos congênicos (C57B1/6 C5 deficiente) no modelo de DHNA estabelecido.

* Analisar a resposta inflamatória pela determinação da concentração hepática das citocinas TNF- $\alpha$, IL-6, IL-1 $\beta$, IL-12, INF- $\gamma$, IL-10 e TGF- $\beta$ e da produção de NO entre os camundongos C57B1/6 (C5 suficiente) e C57Bl/6 (C5 deficiente) submetidos ao modelo de DHNA. 


\section{Resultados do APÊNDICE A}

Os resultados estão organizados em dois tópicos principais: 1- Padronização do modelo de injúria hepática crônica induzida por glicose (ou padronização da DHNA), 2Aplicação da linhagem congênica B6.A-Hc ${ }^{0}$ no modelo de DHNA. Para este capítulo também convencionamos como denominação para os camundongos pertencentes à linhagem isogênica $\mathrm{C} 57 \mathrm{~B} 1 / 6$ apenas B6, a linhagem isogênica $\mathrm{A} / \mathrm{J}$ continuará como $\mathrm{A} / \mathrm{J}$, e a para linhagem congênica C57B1/6 C5 deficiente será utilizada a nomenclatura B6.A-Hc ${ }^{0}$, conforme descrito no CAPÍtulo 1.

\subsection{Padronização do modelo de injúria hepática crônica induzida por glicose (ou padronização da DHNA)}

Camundongos B6 e A/J foram empregados durante a padronização do modelo de DHNA com o objetivo de induzir dano hepático pelo tratamento crônico com a glicose em associação a uma dieta hiperlipídica e identificar diferenças fisiológicas e inflamatórias entre as linhagens.

Consideramos para análise e discussão que os animais tratados com dieta hiperlipídica (DH) e dieta hiperlipídica contendo maltodextina ( $\mathrm{DH}+\mathrm{M})$ como grupos controles, onde $\mathrm{DH}$ é o nosso controle real e $\mathrm{DH}+\mathrm{M}$ é o controle equicalórico, pois possui a mesma equivalência calórica que o tratamento dieta hiperlipídica contendo glicose $(\mathrm{DH}+\mathrm{G})$. Os dados referentes às dietas DH e DH+M já foram apresentados no CAPÍTULO 2 e foram os mesmso utilizados para as análises comparativas com a $\mathrm{DH}+\mathrm{G}$. Para avaliar as diferenças estatísticas entre os tempos de tratamento e as diferentes dietas, e o efeito de interação entre eles, aplicamos o teste ANOVA para 2 fatores. Ressaltaremos em itálico os pontos mais importantes de cada parâmetro avaliado.

Os resultados referentes à padronização do modelo de DHNA serão distribuídos nas seguintes seções: (1) Avaliação dos parâmetros corporais; (2) Avaliação da atividade hepática e perfil hematológico; (3) Avaliação da resposta inflamatória no micro-ambiente hepático; (4) Conclusão do tópico padronização do modelo de injúria hepática crônica induzida por glicose. Na Figura A.1 apresentamos um delineamento experimental sobre a padronização do modelo de DHNA. 
Figura A.1 - Delineamento experimental para a padronização do modelo de DHNA empregando camundongos $\mathrm{B} 6$ e $\mathrm{A} / \mathrm{J}$ tratados com as diferentes dietas hiperlipídicas.

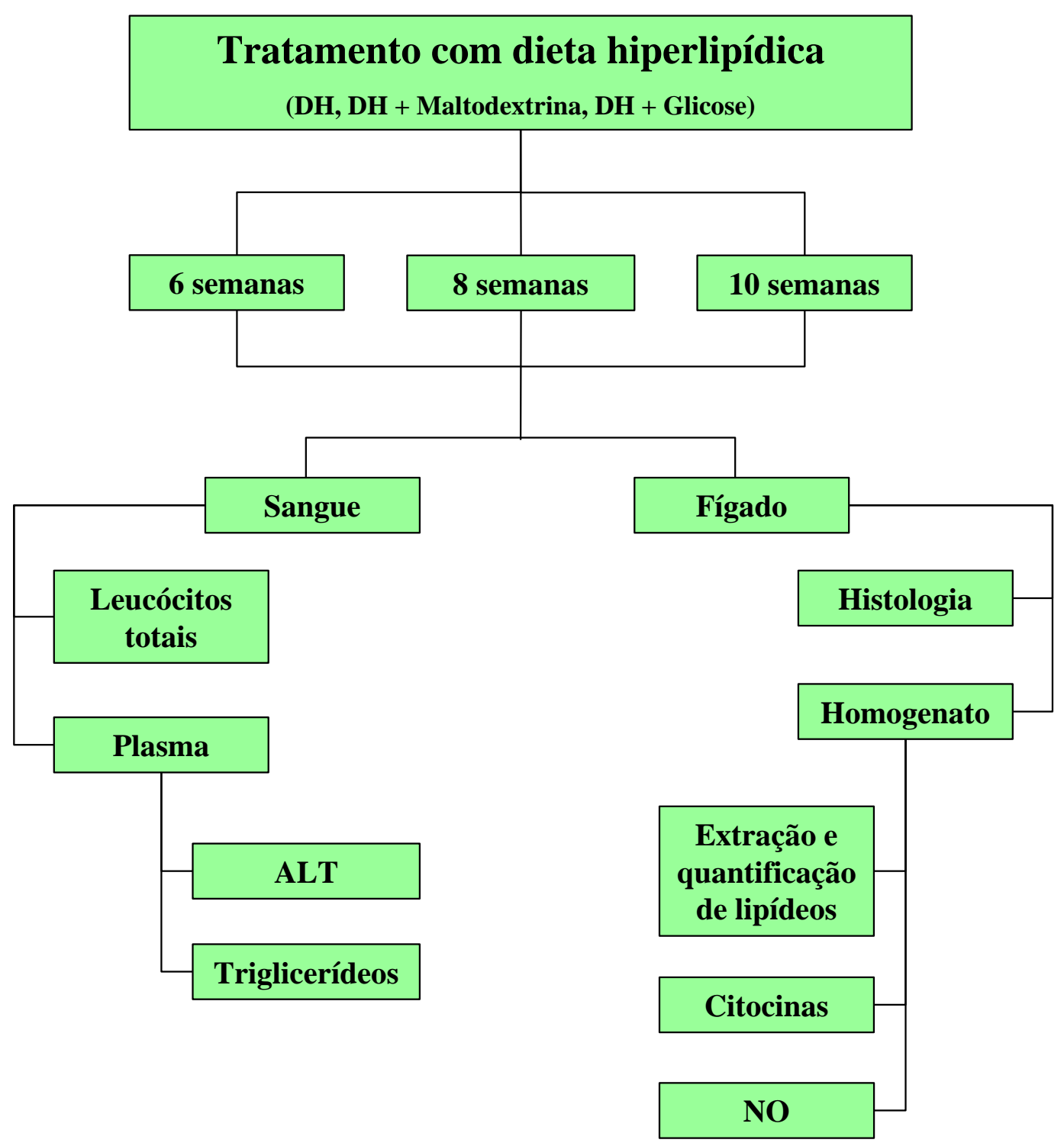

Os camundongos das linhagens B6 e A/J foram tratados durante 6, 8 ou 10 semanas com dieta hiperlipídica (DH), $\mathrm{DH}$ contendo maltodextrina $(\mathrm{DH}+\mathrm{M})$ ou $\mathrm{DH}$ contendo glicose $(\mathrm{DH}+\mathrm{G})$. Coletamos sangue e fígado para análise.

Siglas: alanina aminotransferase (ALT) e óxido nítrico (NO).

\subsubsection{Avaliação dos parâmetros corporais}

Avaliamos nesta seção o ganho de peso acumulado semanalmente (ou acúmulo de peso semanal), ganho de peso final, razão do peso hepático pelo peso corporal, quantificação do depósito de triglicerídeos hepáticos e análise histopatológica hepática. 
A análise do acúmulo de peso semanal foi realizada separadamente para cada uma das linhagens empregando apenas o tempo de 10 semanas. Analisamos o acúmulo de peso para cada tratamento individualmente e em seguida comparando-os aos diferentes tratamentos,

Avaliando o acúmulo de peso semanal para cada tratamento individualmente observamos que os camundongos da linhagem B6 quando tratados com $\mathrm{DH}+\mathrm{G}$ acumularam peso significativamente a partir da terceira semana de tratamento, o qual se manteve significativo até a quinta semana, $p<0,05$. A partir da sexta semana até o final do tratamento não houve acúmulo significativo de peso, houve apenas a manutenção do peso adquirido até a quinta semana. Nos camundongos B6 tratados com DH+M observamos que o acúmulo de peso foi significativo a partir da oitava semana de tratamento, mantendo-se constante até a décima semana, $p<0,05$. Já para os camundongos tratados com DH não observamos acúmulo significativo de peso durante as semanas de tratamento.

Comparando os tratamentos $\mathrm{DH}+\mathrm{G}, \mathrm{DH}+\mathrm{M}$ e $\mathrm{DH}$ entre si, observamos que os camundongos B6 tratados com $\mathrm{DH}+\mathrm{G}$ acumularam significativamente mais peso que os animais tratados com DH+M ou DH durante todas as semanas de tratamento, $p<0,05$. Os camundongos tratados com $\mathrm{DH}+\mathrm{M}$ apresentaram acúmulo de peso significativamente maior que o grupo tratado com DH somente na décima semana de tratamento, $p<0,05$ (Figura A.2).

Os camundongos da linhagem A/J apresentaram comportamentos diferentes dos camundongos da linhagem B6 quanto ao acúmulo de peso semanal perante os diferentes tratamentos. Avaliando o acúmulo de peso semanal para cada tratamento individualmente observamos que nos camundongos $\mathrm{A} / \mathrm{J}$ quando tratados com $\mathrm{DH}+\mathrm{G}$ acumularam peso significativamente na sétima semana de tratamento, o qual se manteve constante até a décima semana, $p<0,05$. Para os camundongos tratados com $\mathrm{DH}+\mathrm{M}$ observamos que houve acúmulo significativo de peso a partir da segunda semana de tratamento, o qual se manteve significativo até a quarta semana, $p<0,05$. A partir da quinta semana até o final do tratamento não houve acúmulo de peso significativo. Quanto aos camundongos tratados com DH não houve acúmulo de peso semanal significativo.

Comparando os tratamentos observamos que os camundongos $\mathrm{A} / \mathrm{J}$ tratados com $\mathrm{DH}+\mathrm{G}$ acumularam significativamente mais peso em relação àqueles tratados com $\mathrm{DH}$ durante todas as semanas avaliadas, $p<0,05$. A partir da quarta semana os camundongos tratados com $\mathrm{DH}+\mathrm{M}$ acumularam significativamente mais peso que os camundongos tratados com $\mathrm{DH}, p<0,05$. O tratamento com $\mathrm{DH}+\mathrm{G}$ levou ao maior ganho de peso acumulado na primeira semana de tratamento em relação ao tratamento com $\mathrm{DH}+\mathrm{M}, p<0,05$. A partir da segunda até a sétima semana não observamos diferença significativa de acúmulo de peso entre 
ambos os grupos, entretanto, na oitava e nona semana de tratamento os camundongos que receberam $\mathrm{DH}+\mathrm{M}$ superaram significativamente o acúmulo de peso semanal em relação aos camundongos tratados com $\mathrm{DH}+\mathrm{G}, \mathrm{p}<0,05$ (Figura A.2).

Figura A.2 - Ganho de peso acumulado semanalmente pelos camundongos das linhagens B6 e A/J durante 10 semanas de tratamento com as diferentes dietas hiperlipídicas.

(A)

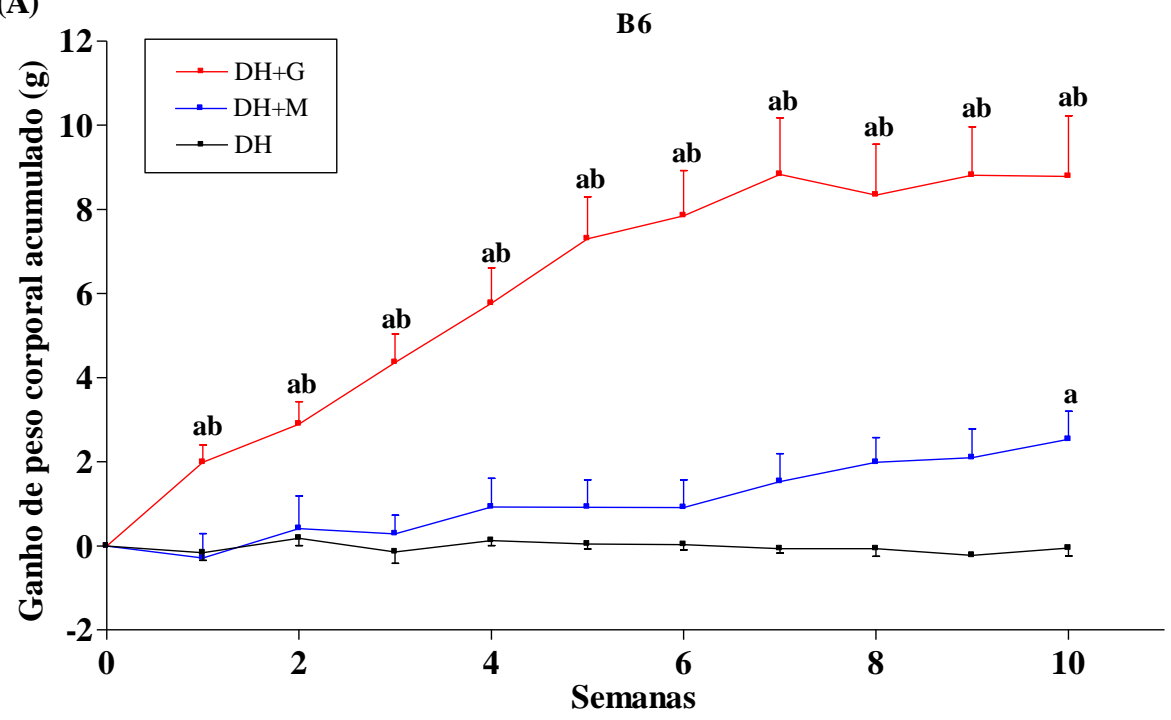

(B)

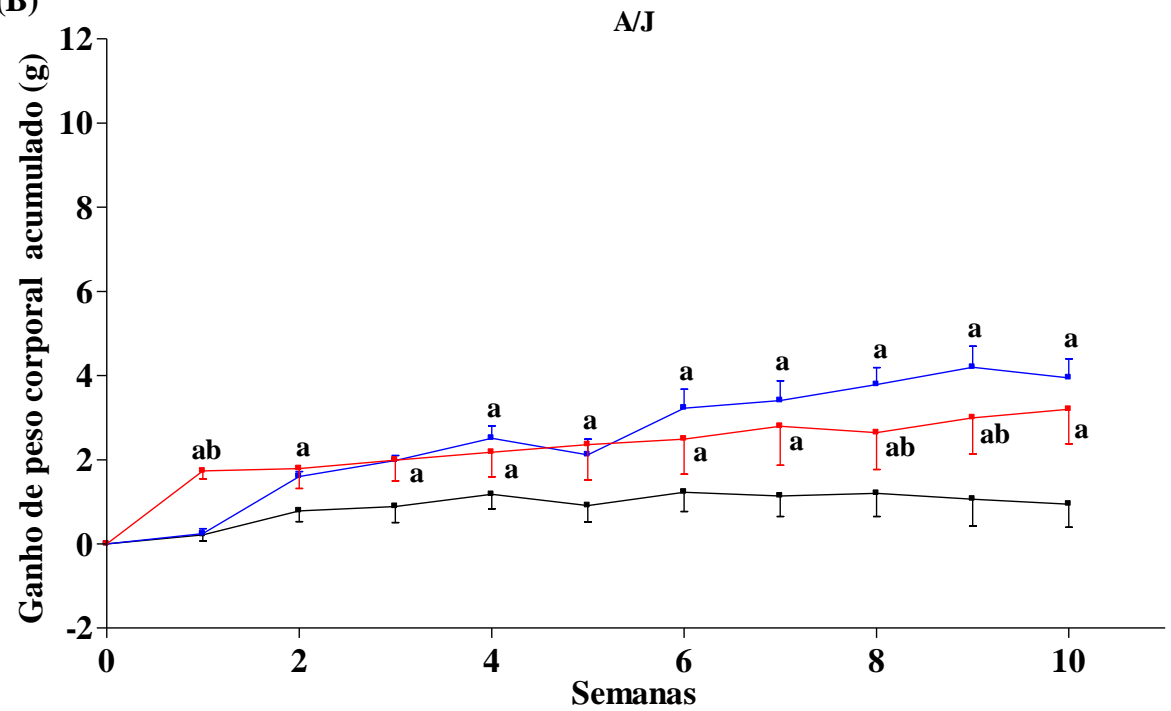

Representaremos nos gráficos de acúmulo de peso semanal apenas as comparações entre os tratamentos. Os resultados estão representados como média e erro padrão, $\mathrm{n} \geq 5$. As comparações correspondem: a $v s$. DH e b $v s$. $\mathrm{DH}+\mathrm{M}, p<0,05$. Em (A) apresentamos o ganho de peso acumulado para os camundongos da linhagem B6 e em (B) da linhagem $\mathrm{A} / \mathrm{J}$ tratados com as diferentes dietas hiperlipidicas tratados durante 10 semanas.

Siglas: DH - Dieta hiperlipídica; DH+M - Dieta hiperlipídica contendo maltodextrina; DH+G - Dieta hiperlipídica contendo glicose. 
Durante o tratamento com $\mathrm{DH}+\mathrm{G}$ os camundongos da linhagem $\mathrm{A} / \mathrm{J}$ acumularam significativamente menos peso quando comparados com aqueles que receberam $\mathrm{DH}+\mathrm{M}$. Aparentemente a linhagem A/J foi resistente ao acúmulo de peso induzido pela glicose. Já os camundongos $\mathrm{B} 6$ tratados com a $\mathrm{DH}+\mathrm{G}$ acumularam peso consideravelmente em relação àqueles tratados com $\mathrm{DH}+\mathrm{M}$ ou $\mathrm{DH}$. As linhagens $\mathrm{B} 6$ e A/J apresentaram comportamentos divergentes quanto ao acúmulo de peso semanal após o tratamento com DH+G (Figura A.2).

Associado a análise de ganho de peso acumulado avaliamos também o ganho de peso ao final de cada semana de tratamento. As análises estatísticas identificaram efeito de interação significativo entre tratamento e semana tanto para os camundongos da linhagem B6 quanto para os da linhagem A/J, com $p<0,001$ e $p=0,005$, respectivamente (Figura A.3). Para a linhagem B6, os camundongos tratados com $\mathrm{DH}+\mathrm{M}$ ganharam peso significativamente de 6 para 8 semanas de tratamento, já os camundongos tratados com $\mathrm{DH}+\mathrm{G}$ ganharam peso significativamente de 6 para 10 semanas e de 8 para 10 semanas, $p<0,05$. Após 8 semanas os camundongos tratados com $\mathrm{DH}+\mathrm{G}$ ganharam menos peso que aqueles tratados com $\mathrm{DH}+\mathrm{M}$, mas após 10 semanas de tratamento houve inversão deste comportamento onde os camundongos tratados com $\mathrm{DH}+\mathrm{G}$ ganharam significativamente mais peso que os tratados com DH+M, $p<0,05$. Além disso, após 10 semanas, aqueles camundongos tratados com $\mathrm{DH}+\mathrm{G}$ apresentaram aumento significativo de peso em relação aos tratados com $\mathrm{DH}, p<0,05$. Por fim, dentre os camundongos tratados com DH+M e DH encontramos que os animais tratados com $\mathrm{DH}+\mathrm{M}$ ganharam significativamente mais peso que os tratados com $\mathrm{DH}$ tanto após 8 quanto após 10 semanas de tratamento, $p<0,05$ (Figura A.3A).

Quanto à linhagem $\mathrm{A} / \mathrm{J}$, não encontramos diferença significativa entre os tratamentos ao longo das semanas. Entretanto, os camundongos tratados com DH+G ganharam significativamente mais peso em relação aos tratados com DH após 10 semanas de tratamento, $p<0,05$. Neste mesmo período identificamos também diferenças entre os controles, onde os camundongos tratados com $\mathrm{DH}+\mathrm{M}$ ganham significativamente mais peso que os tratados com DH, $p<0,05$ (Figura A.3B).

Os camundongos da linhagem A/J apresentaram menor ganho de peso total ao final dos três tempos de tratamento em relação aos camundongos da linhagem B6, mostrando-se resistentes à indução do ganho de peso pelo consumo de uma dieta hiperlipídica contendo glicose (Figura A.3). 
Figura A.3 - Ganho de peso total ao final dos três períodos de tratamento dos camundongos da linhagem B6 e A/J com as diferentes dietas hiperlipídicas.

(A)

B6

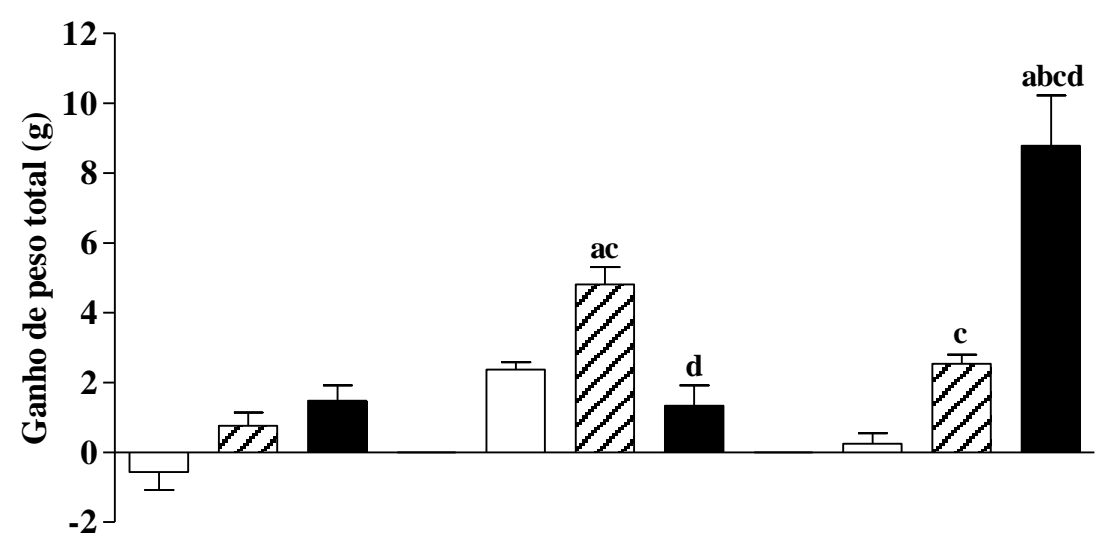

(B)

$\mathbf{A} / \mathbf{J}$

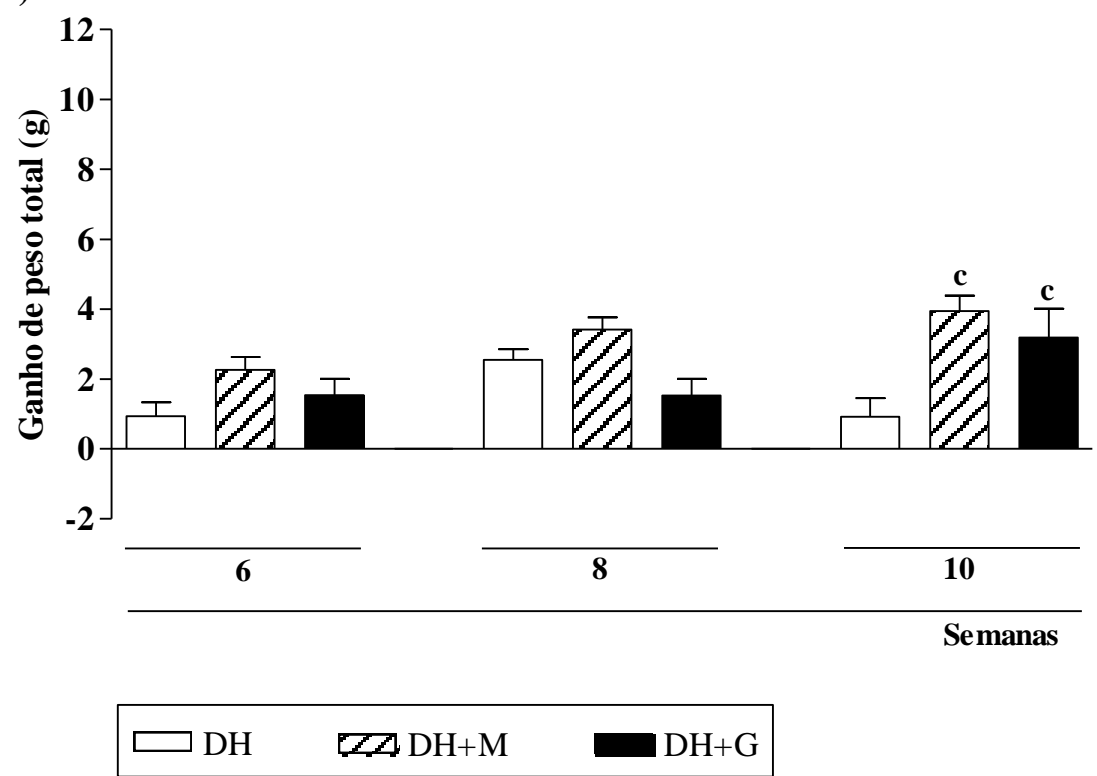

Em (A) peso final dos camundongos B6 e dos A/J (B) após 6, 8 e 10 semanas de tratamento com as diferentes dietas hiperlipídicas. Os resultados estão representados como média e erro padrão, $\mathrm{n} \geq 5$. As comparações correspondem: a vs. 6 semanas; b vs. 8 semanas; c vs. DH; d vs. DH+M, $p<0,05$. Siglas: DH - Dieta hiperlipídica; DH+M - Dieta hiperlipídica contendo maltodextrina; DH+G - Dieta hiperlipídica contendo glicose.

A hepatomegalia também ocorre na DHNA (KRAWCZYK et al., 2010) concomitante a elevação do peso corporal o que dificulta a detecção da elevação da razão do peso hepático em relação ao peso final de forma tão clara quanto à observada na DHA. Mesmo assim avaliamos a alteração da razão acima citada e para os camundongos da linhagem B6 identificamos efeito de interação significativo entre tratamento e semana, $p=0,032$, onde após de 10 semanas de tratamento encontramos aumento significativo da razão do peso hepático / 
peso corporal nos animais tratados $\mathrm{DH}+\mathrm{G}$ em relação aos tratados com $\mathrm{DH}+\mathrm{M}, p<0,05$ (Figura A.4A).

Quanto aos camundongos da linhagem A/J não identificamos efeito de interação entre tratamento e semana, $p=0,083$, nem diferença significativa entre as semanas, $p=0,081$. Mas, encontramos diferença significativa entre os tratamentos, $p=0,014$. Independentemente do tempo de tratamento, os camundongos $\mathrm{A} / \mathrm{J}$ tratados com $\mathrm{DH}+\mathrm{G}$ apresentaram redução significativa da razão peso hepático / peso corporal em relação àqueles tratados com DH, $p<0,05$ (Figura A.4B).

Figura A.4 - Razão do peso hepático pelo peso corporal dos camundongos B6 e A/J após 6, 8 e 10 semanas de tratamento com as diferentes dietas hiperlipídicas.
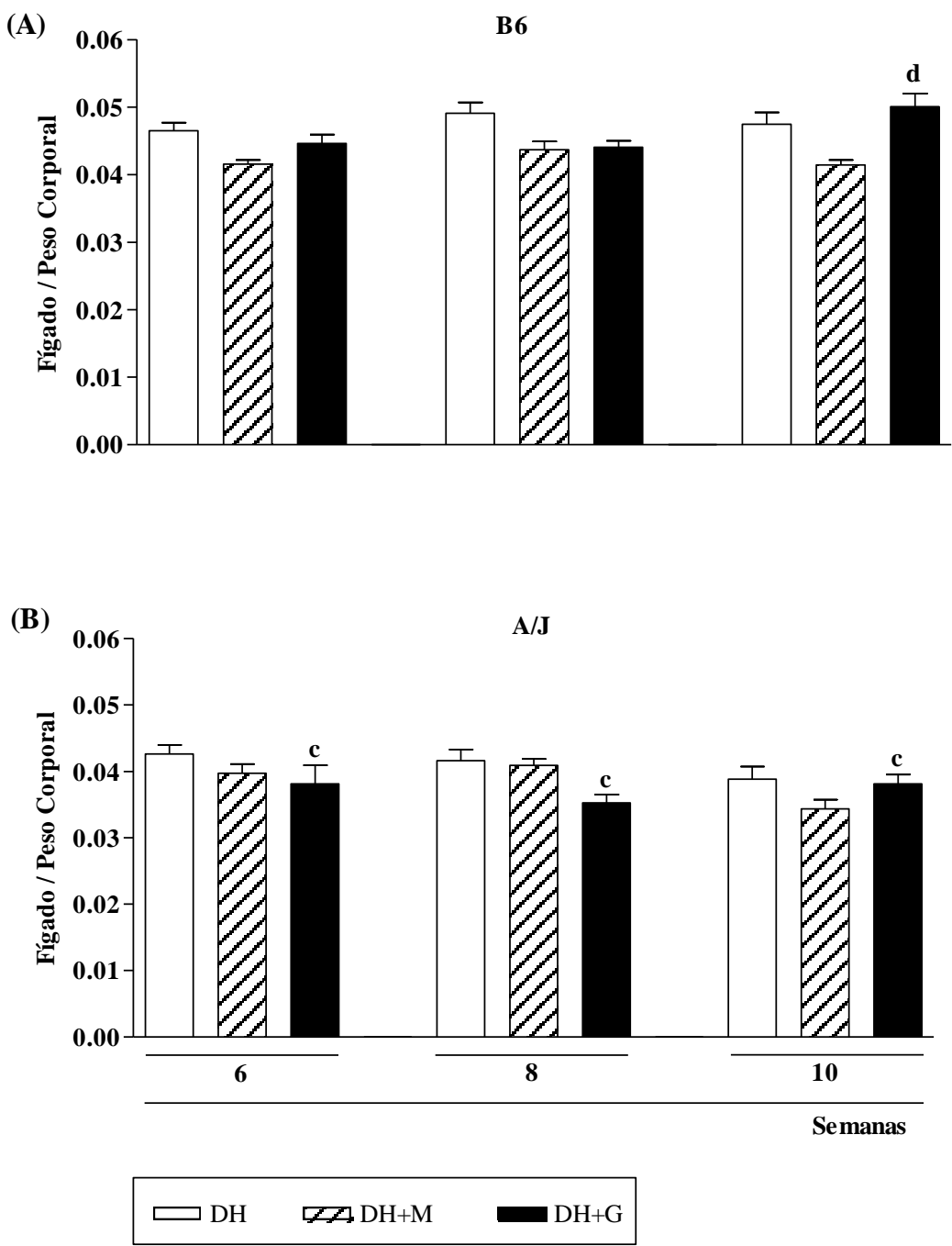

Em (A) peso final dos camundongos B6 e dos A/J (B) após 6, 8 e 10 semanas de tratamento com as diferentes dietas hiperlipídicas. Os resultados estão representados como média e erro padrão, $\mathrm{n} \geq 5$. As comparações correspondem: c vs. DH; d vs. DH+M, $p<0,05$. Siglas: DH - Dieta hiperlipídica; DH+M - Dieta hiperlipídica contendo maltodextrina; $\mathrm{DH}+\mathrm{G}-$ Dieta hiperlipídica contendo glicose. 
Prosseguindo com a análise do peso hepático também avaliamos possíveis alterações nos pesos de outros órgãos como: baço, rins, estômago, coração. Estes dados estão apresentados no APÊNDICE D. Cabe aqui citar que não encontramos diferenças nos pesos dos demais órgãos que sejam dignas de nota.

A DHNA é assinalada pelo acúmulo de gordura nos hepatócitos, em sua maior composição encontra-se o depósito de triglicerídeos e colesterol (KRAWCZYK et al., 2010). Portanto, a extração, quantificação e identificação de lipídeos hepáticos também é uma importante ferramenta na confirmação da eficiência do modelo de DHNA que padronizamos.

Após a eutanásia dos camundongos coletamos todo o tecido hepático, que foi direcionado para a confecção de lâminas histológicas e um homogenato, o qual foi utilizado para realizarmos a extração de lipídeos totais, as determinações das citocinas e produção de NO. Nas amostras, das quais extraímos lipídeos totais determinamos a concentração de triglicerídeos por grama de tecido (Figura A.5).

Avaliando estatisticamente o depósito de triglicerídeos hepáticos para os camundongos da linhagem B6, identificamos efeito de interação significativo entre tratamento e semana, $p<0,001$. Encontramos aumento significativo de triglicerídeos hepáticos nos camundongos tratados com $\mathrm{DH}+\mathrm{G}$ de 6 e 8 para 10 semanas, $p<0,05$. E ainda observamos que os camundongos tratados com $\mathrm{DH}+\mathrm{G}$ apresentaram significativamente mais triglicerídeos hepáticos que os camundongos tratados com DH+M ou DH após 10 semanas de dieta, $p<0,05$ (Figura A.5A).

Com relação à dosagem de triglicerídeos hepáticos nos camundongos da linhagem A/J, detectamos indicação de efeito de interação entre tratamento e semana, $p=0,053$. Onde observamos aumento significativo de depósito de triglicerídeos hepáticos de 6 para 8 semanas de tratamento nos camundongos tratados com $\mathrm{DH}+\mathrm{G}, p<0,05$. Após 10 semanas de tratamento identificamos aumento significativo no depósito de triglicerídeos nos camundongos tratados com $\mathrm{DH}+\mathrm{M}$ em relação aos tratados apenas com $\mathrm{DH}, p<0,05$ (Figura A.5B).

Complementando os resultados obtidos com o ganho de peso final, os camundongos da linhagem A/J também apresentaram menor razão do peso hepático / peso corporal e menor acúmulo de triglicerídeos hepáticos após 10 semanas de tratamento com $\mathrm{DH}+\mathrm{G}$. Já os camundongos da linhagem B6 foram mais susceptiveis ao ganho de peso e ao acúmulo de triglicerídeos hepáticos após 10 semanas de tratamento com $\mathrm{DH}+\mathrm{G}$ (Figuras A.3, A.4 e A.5). 
Figura A.5 - Quantificação da concentração de triglicerídeos hepáticos dos camundongos B6 e A/J após 6, 8 e 10 semanas de tratamento com as diferentes dietas hiperlipídicas.

(A)

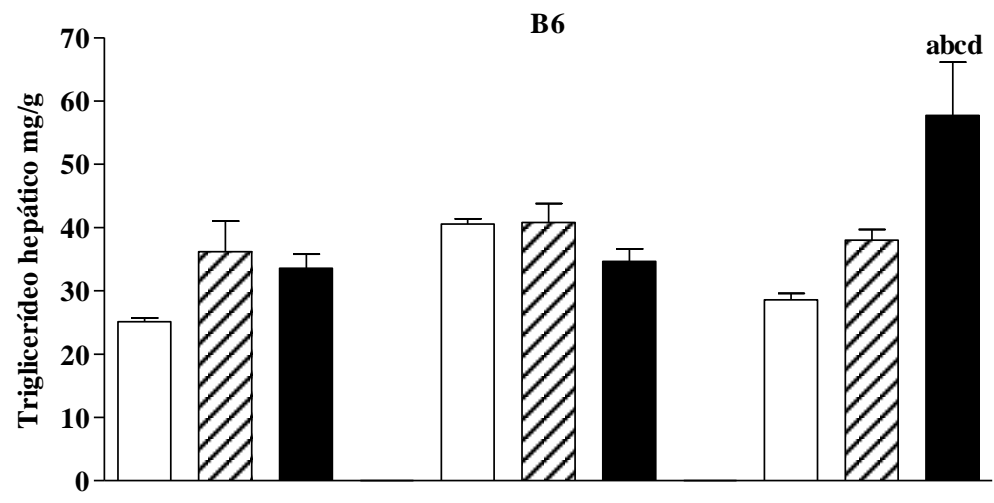

(B)

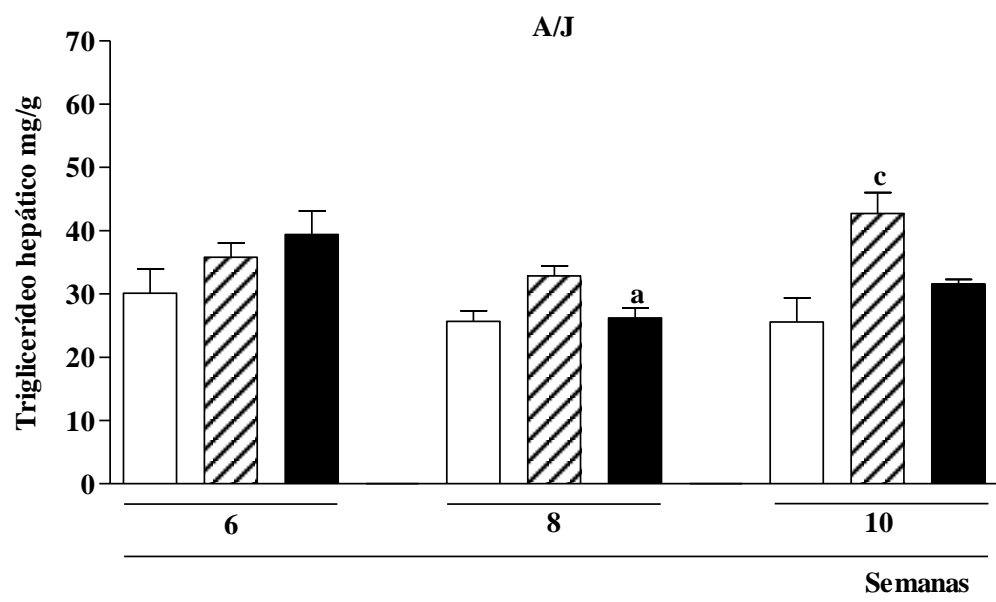

$\square \mathrm{DH} \quad \square \not \mathrm{DH}+\mathrm{M} \quad \mathrm{DH}+\mathrm{G}$

Em (A) dosagem de triglicerídeos hepáticos dos camundongos da linhagem B6 e dos A/J (B) após 6, 8 e 10 semanas de tratamento com as diferentes dietas hiperlipídicas. Os resultados estão representados como média e erro padrão, $\mathrm{n} \geq 5$. As comparações correspondem: c vs. DH; d vs. DH+M, $p<0,05$. Siglas: DH - Dieta hiperlipídica; DH+M - Dieta hiperlipídica contendo maltodextrina; $\mathrm{DH}+\mathrm{G}$ - Dieta hiperlipídica contendo glicose.

Além de confirmar a presença do acúmulo de gordura e auxiliar na diferenciação da DHNA de outras doenças hepáticas, a investigação histopatológica permite avaliar também a presença de hepatite e o quanto a doença está avançada. Portanto, apresentaremos as imagens representativas de cada grupo obtidas a partir das lâminas histológicas confeccionadas para cada tempo e tratamento. Como mencionado nos parágrafos anteriores o depósito de gordura no tecido hepático também é uma característica marcante da DHNA e por meio da histopatologia conseguimos visualizar seu depósito no fígado. 
Na Figura A.6, apresentamos cortes histológicos de fígado dos camundongos da linhagem B6, corados com HE, após 6, 8 e 10 semanas de tratamento. Com 6 semanas de tratamento não houve alteração morfológica do fígado para nenhum dos grupos. Com 8 semanas de tratamento não houve alteração histológica nos grupos tratados com DH+M e DH, porém encontramos algumas vesículas lipídicas nos hepatócitos dos camundongos tratados com $\mathrm{DH}+\mathrm{G}$. A distribuição destas vesículas encontrou-se na região intermediária entre o espaço porta e a veia centro lobular. Ainda nos animais tratados com $\mathrm{DH}+\mathrm{G}$ encontramos pequenos focos de infiltrado celular. Com 10 semanas de tratamento, os controles $(\mathrm{DH}+\mathrm{M}$ e DH) mantiveram a arquitetura hepática íntegra, no entanto identificamos nos tratados com $\mathrm{DH}+\mathrm{M}$ focos de infiltrado celular próximos aos vasos do espaço porta. Por fim, naqueles que receberam $\mathrm{DH}+\mathrm{G}$ encontramos pequenos focos de infiltrado celular e extensa esteatose macro- e micro-vesicular (Figura A.6).

Figura A.6 - Análises histopatológicas de fígado dos camundongos B6 tratados com as diferentes dietas hiperlipídicas por 6, 8 e 10 semanas.

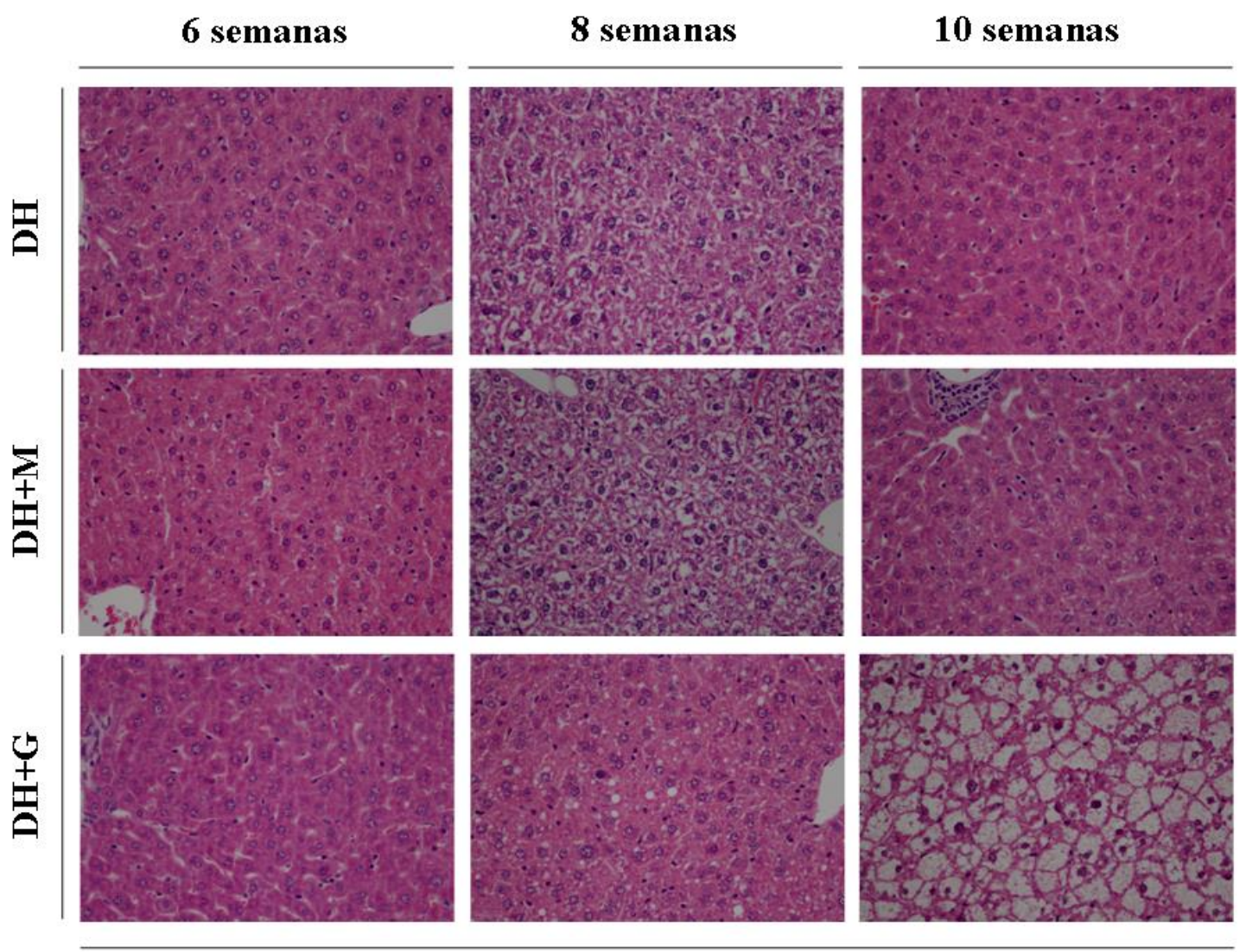

C57Bl/6

Coloração HE. Aumento 40x. As siglas na figura representam as diferentes dietas: DH - Dieta hiperlipídica; $\mathrm{DH}+\mathrm{M}$ - Dieta hiperlipídica contendo maltodextrina; $\mathrm{DH}+\mathrm{G}-$ Dieta hiperlipídica contendo glicose. 
Confirmando os resultados obtidos com a determinação de triglicerídeos hepáticos para a linhagem B6, quando tratada com $\mathrm{DH}+\mathrm{G}$, observamos a presença de vesículas lipídicas a partir da $8^{a}$ semana de tratamento. Estas se tornaram cada vez mais freqüentes com o decorrer do tempo de tratamento, cobrindo ampla área tecidual com 10 semanas de tratamento (Figura A.6).

$\mathrm{Na}$ Figura A.7, apresentamos cortes histológicos de fígado da linhagem A/J, corados em HE, após 6, 8 e 10 semanas de tratamento. Os fígados dos camundongos A/J tratados com as diferentes dietas: $\mathrm{DH}, \mathrm{DH}+\mathrm{M}$ e $\mathrm{DH}+\mathrm{G}$ não apresentaram alteração morfológica ou histológica após 6 semanas de tratamento, comportando-se da mesma forma que os da linhagem B6. Com 8 semanas de tratamento também não houve alteração histológica nos camundongos para nenhum tratamento. Por fim, os camundongos A/J tratados por 10 semanas com $\mathrm{DH}$ e $\mathrm{DH}+\mathrm{M}$ mantiveram a arquitetura normal deste órgão. No grupo de animais tratados com $\mathrm{DH}+\mathrm{G}$ observamos baixa freqüência de vesículas lipídicas na região intermediária do fígado e distribuição exacerbada de infiltrados celulares próximos aos vasos (Figura A.7).

Em suma, com relação aos camundongos da linhagem $\mathrm{A} / \mathrm{J}$ tratados com $\mathrm{DH}+\mathrm{G}$ observamos raras vesículas lipídicas e distribuição exacerbada de infiltrados celulares após a $10^{a}$ semana de tratamento, um comportamento completamente divergente quando comparados aos camundongos da linhagem B6 tratados com $\mathrm{DH}+\mathrm{G}$, os quais apresentaram grande depósito lipídico e pouco infiltrado celular (Figura A.6 e A.7).

Estas diferenças quanto à distribuição e diâmetro das vesículas lipídicas entre as linhagens podem estar associadas ao metabolismo de cada uma, sendo uma característica específica da linhagem. Não encontramos diferenças quanto ao consumo da ração entre as linhagens. Acompanhamos o consumo da ração diariamente, e no final de cada semana calculamos a média de consumo diário e por sua vez a média de consumo semanal. A partir dessa média semanal calculamos a média geral para as 10 semanas de tratamento, portanto a média de consumo da ração para o grupo de camundongos da linhagem B6 tratados com as diferentes dietas por 6,8 e 10 semanas para a $\mathrm{DH}+\mathrm{G}$ o consumo médio foi de 7,3 g, para a $\mathrm{DH}+\mathrm{M}$ o consumo médio foi de 8,2 $\mathrm{g}$ e para DH a média de consumo foi de $9 \mathrm{~g}$ de ração semanal por camundongo. Para os camundongos da linhagem $\mathrm{A} / \mathrm{J}$ os valores são sutilmente menores que os valores observados para os camundongos da linhagem B6 onde os animais 
tratados com $\mathrm{DH}+\mathrm{G}$ consumiram por volta de $6,8 \mathrm{~g}$ semanalmente por camundongo, quanto aos tratados com $\mathrm{DH}+\mathrm{M}$ o consumo médio foi de 7,8 g, já aqueles que receberam $\mathrm{DH}$ consumiram cerca de $8,7 \mathrm{~g}$ de ração.

Figura A.7 - Análises histopatológicas de fígado dos camundongos A/J tratados com as diferentes dietas hiperlipídicas por 6, 8 e 10 semanas.

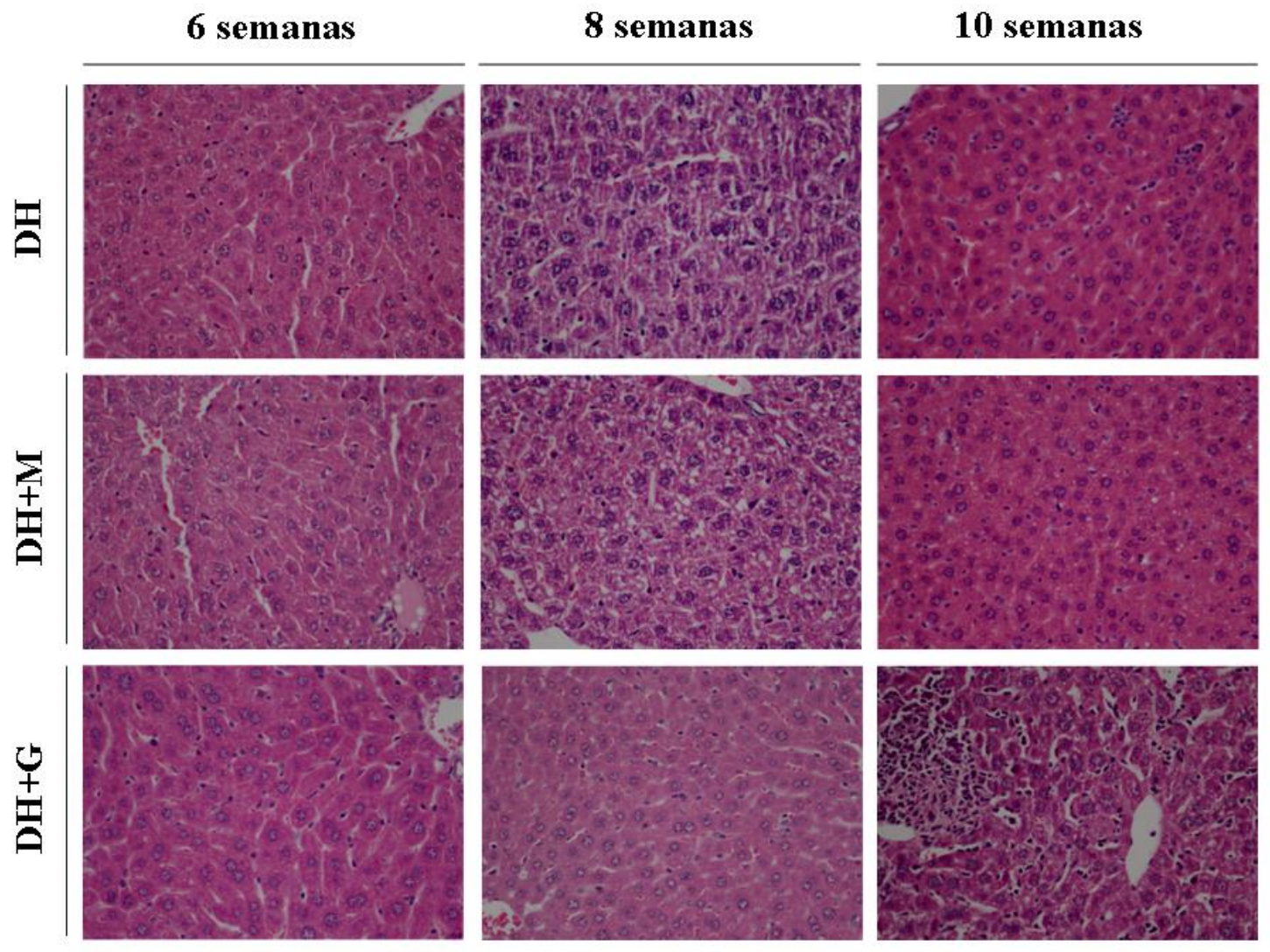

$\mathbf{A} / \mathbf{J}$

Coloração HE. Aumento 40x. As siglas na figura representam as diferentes dietas: DH - Dieta hiperlipídica; $\mathrm{DH}+\mathrm{M}$ - Dieta hiperlipídica contendo maltodextrina; $\mathrm{DH}+\mathrm{G}$ - Dieta hiperlipídica contendo glicose.

Com a coloração PAS verificamos que não houve depósito de glicogênio no interior das vesículas encontradas no tecido hepático dos camundongos das linhagens B6 e A/J (Figuras A.8 e A.9). Desta forma podemos inferir que o conteúdo destas vesículas possivelmente sejam lipídeos. Outra abordagem realizada para também confirmar o conteúdo destas vesículas foi a extração de lipídeos hepáticos totais, pela metodologia que emprega metanol:clorofórmio. A partir dos lipídeos extraídos dosamos a quantidade de triglicerídeos nestas amostras como já apresentado na Figura A.5. 
Figura A.8 - Cortes histológicos de fígado dos camundongos B6 tratados com as diferentes dietas hiperlipídicas por 6,8 e 10 semanas.

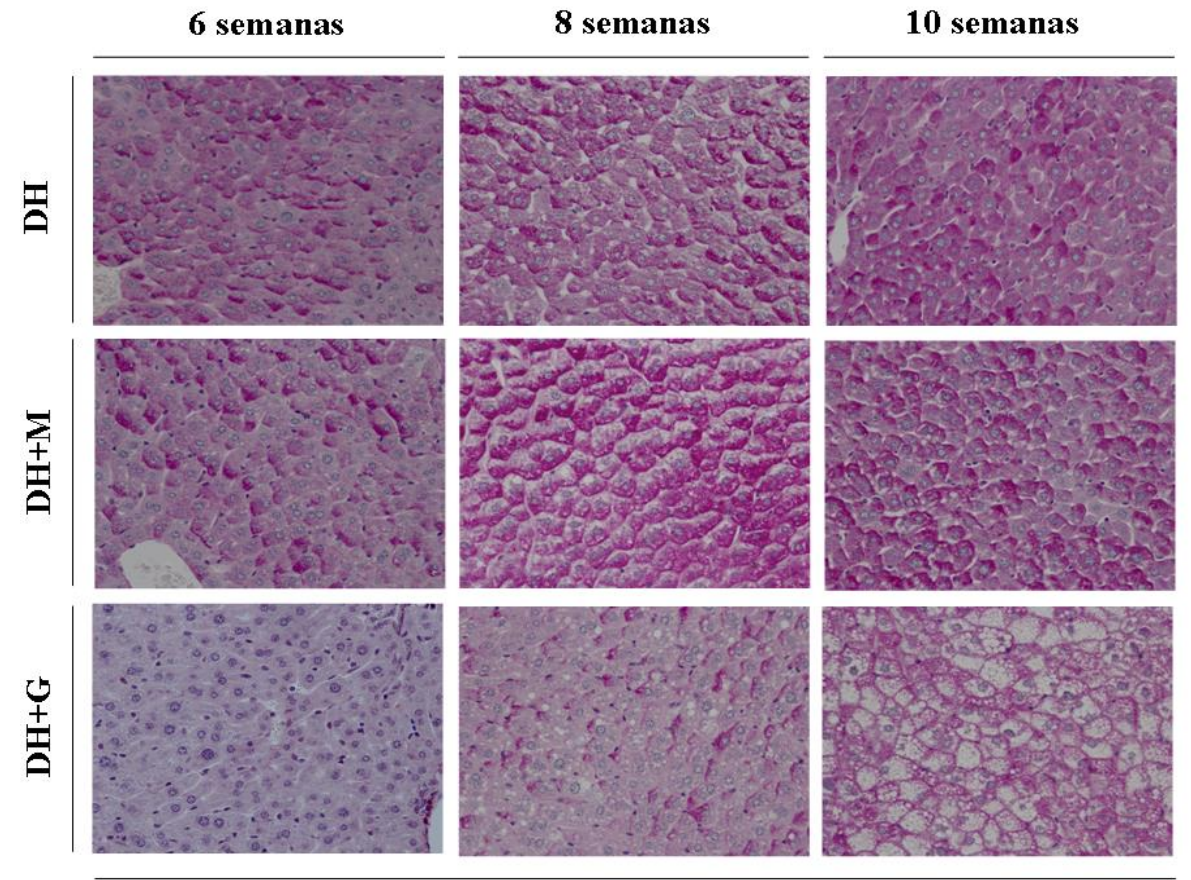

$\mathrm{C57B1/6}$

Coloração PAS. Aumento 40x. As siglas na figura representam as diferentes dietas: DH - Dieta hiperlipídica; $\mathrm{DH}+\mathrm{M}$ - Dieta hiperlipídica contendo maltodextrina; $\mathrm{DH}+\mathrm{G}$ - Dieta hiperlipídica contendo glicose.

Figura A.9 - Cortes histológicos de fígado dos camundongos A/J tratados com as diferentes dietas hiperlipídicas por 6, 8 e 10 semanas.

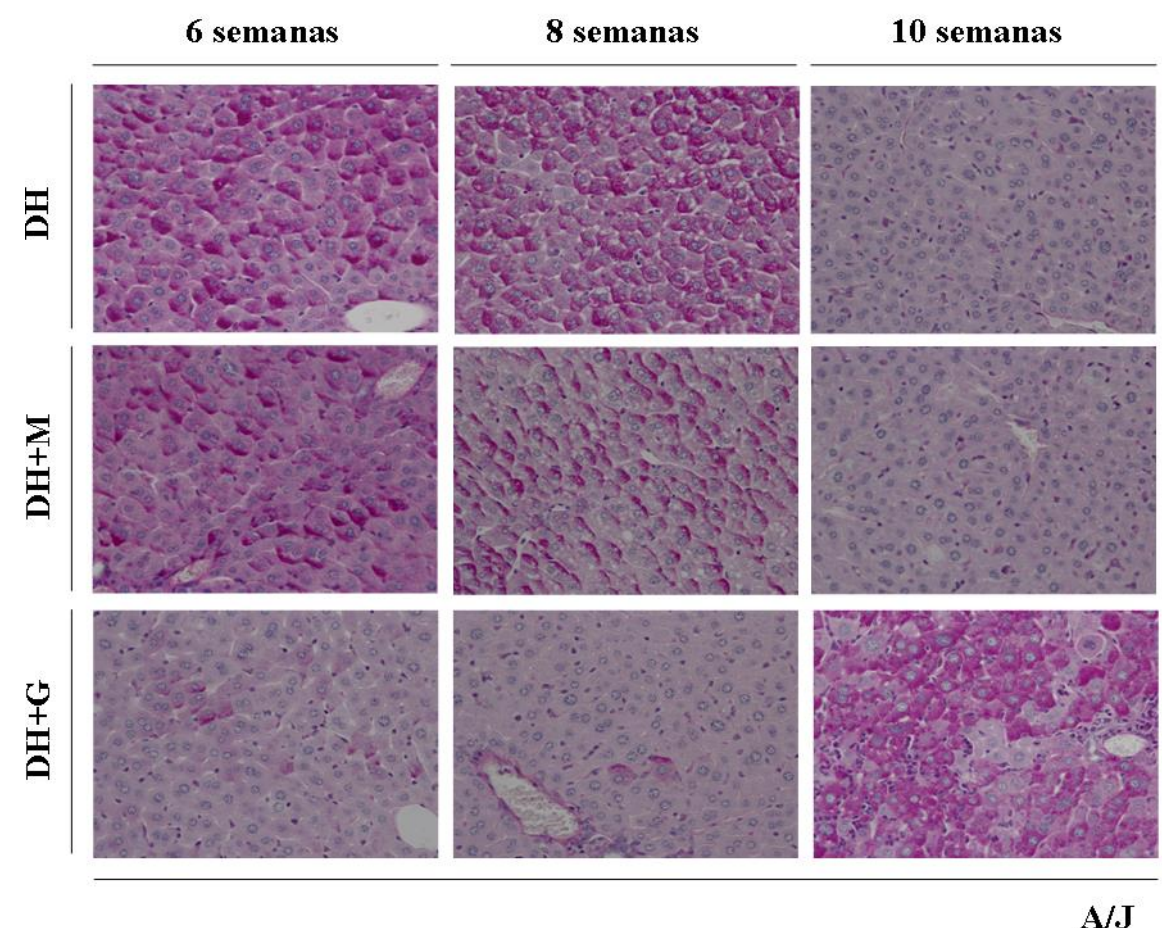

Coloração PAS. Aumento 40x. As siglas na figura representam as diferentes dietas: DH - Dieta hiperlipídica; $\mathrm{DH}+\mathrm{M}$ - Dieta hiperlipídica contendo maltodextrina; $\mathrm{DH}+\mathrm{G}-$ Dieta hiperlipídica contendo glicose. 
Figura A.10 - Cortes histológicos de fígado dos camundongos B6 tratados com as diferentes dietas hiperlipídicas por 6,8 e 10 semanas.

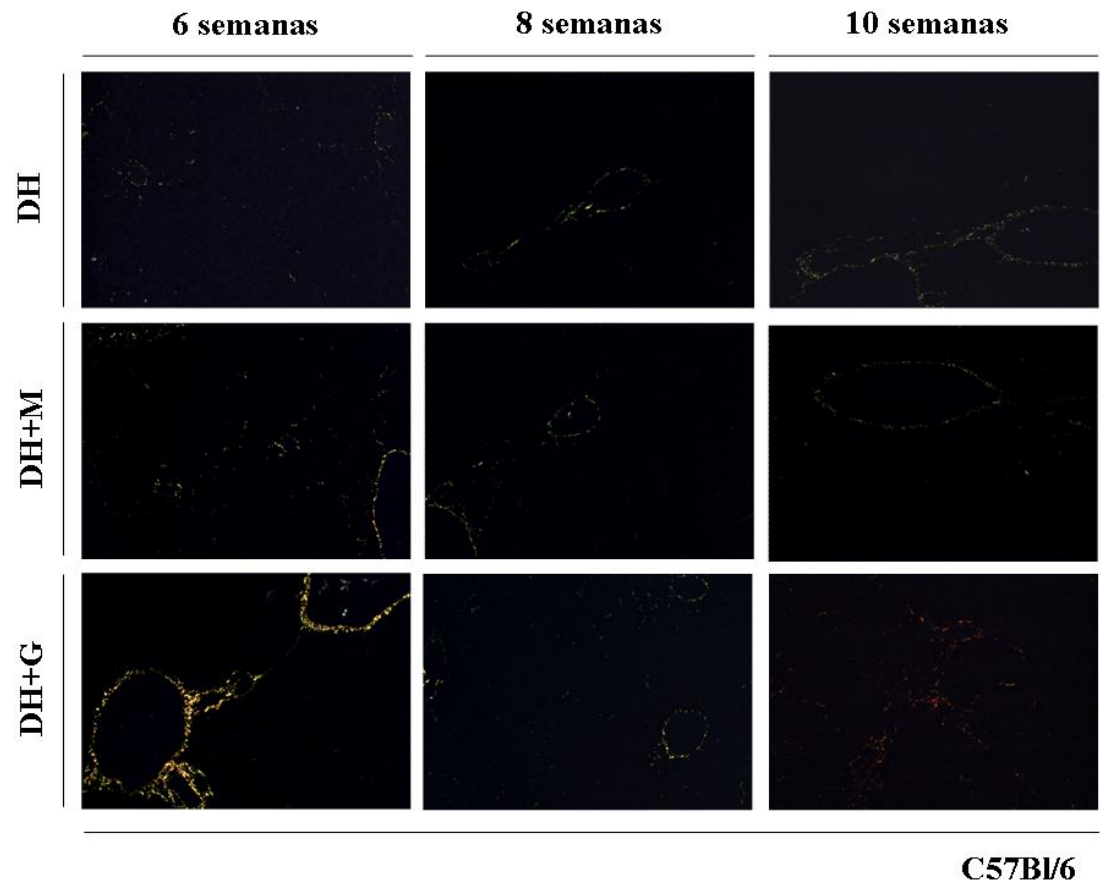

Coloração Picrossirius red sob luz polarizada. Aumento 40x. As siglas na figura representam as diferentes dietas: DH (Dieta hiperlipídica); DH+M (DH contendo maltodextrina); DH+G (DH contendo glicose).

Figura A.11 - Cortes histológicos de fígado dos camundongos A/J tratados com as diferentes dietas hiperlipídicas por 6,8 e 10 semanas.

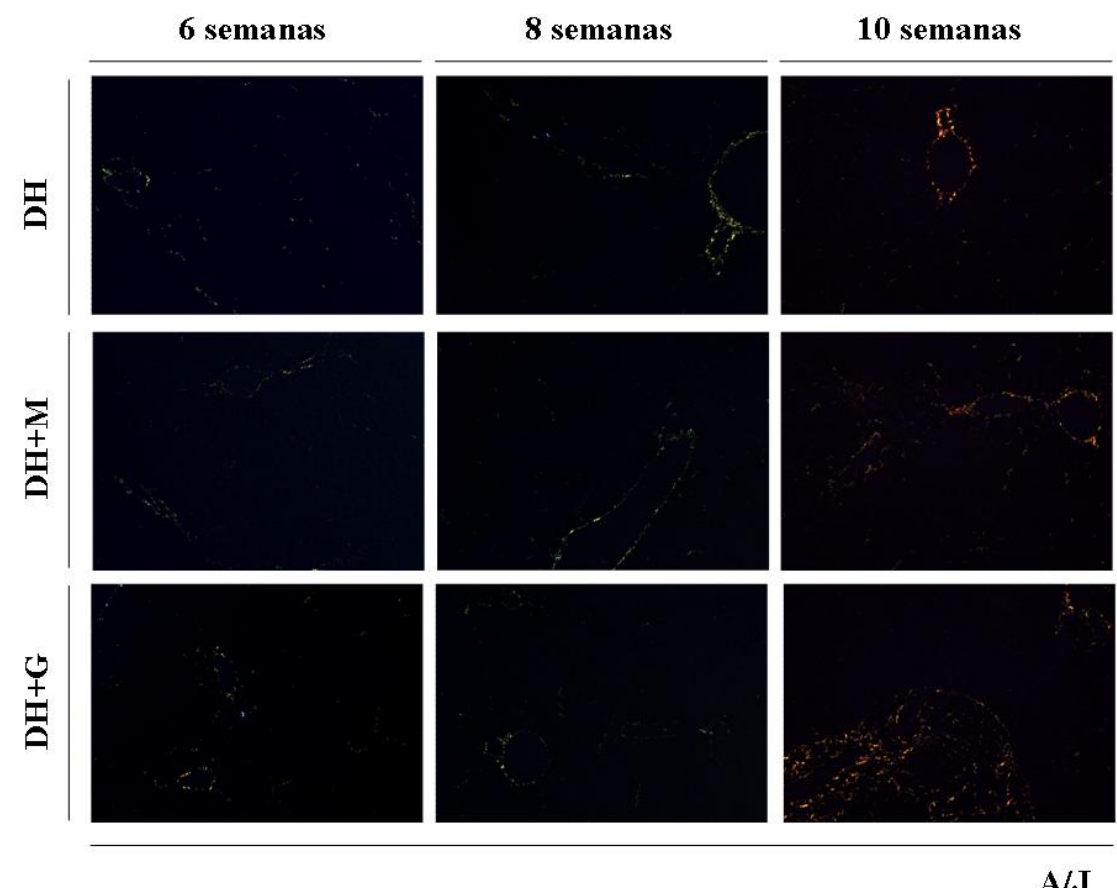

Coloração Picrossirius red sob luz polarizada Aumento 40x. As siglas na figura representam as diferentes dietas: $\mathrm{DH}$ (Dieta hiperlipídica); DH+M (DH contendo maltodextrina); $\mathrm{DH}+\mathrm{G}$ (DH contendo glicose). 
B6 e A/J após o tratamento com $\mathrm{DH}+\mathrm{G}$ visando encontrar fibrose (Figura A.10 e 1.11). Os cortes histológicos hepáticos corados pela técnica de picrossírius foram analisados em microscópio com luz polarizada. Esta coloração é específica para fibras de colágeno e aplicando a luz polarizada é possível diferenciar as fibras de colágeno tipo I e tipo III. A primeira é uma fibra sintetizada constitutivamente e apresenta coloração verde / amarelada sob luz polarizada, já a segunda fibra é sintetizada em condições de reparo tecidual e apresenta coloração avermelhada quando submetida à avaliação por luz polarizada.

Podemos constatar que houve discreto depósito de fibras de colágeno nos grupos controles tanto para os camundongos da linhagem B6 quanto para os da linhagem A/J nos tempos de tratamento 6, 8 e 10 semanas. Para ambas as linhagens houve a substituição gradativa das fibras de colágeno do tipo I para o tipo III para os camundongos tratados com $\mathrm{DH}+\mathrm{G}$ ao longo das semanas de tratamento, entretanto as fibras de colágeno do tipo III foram mais evidentes após o tratamento por 10 semanas com DH+G (Figura A.10 e A.11).

Conclusão da secão 3.1.1: Tanto os camundongos da linhagem B6 quanto os da A/J ganharam peso após 10 semanas de tratamento com $D H+G$. Entretanto, o aumento da relação peso do fígado pelo peso corporal foi observado apenas para os camundongos da linhagem $\mathrm{B} 6$ tratados com $\mathrm{DH}+\mathrm{G}$ por 10 semanas e a redução foi observada apenas para os camundongos da linhagem A/J tratados com $D H+G$ para todos os tempos de tratamento. A linhagem B6 teve aumento do depósito de triglicerídeos hepático após 10 semanas de tratamento com $\mathrm{DH}+\mathrm{G}$ enquanto a linhagem A/J manteve a concentração de triglicerídeos hepáticos constante. Estes resultados foram confirmados pela histopatologia hepática a qual mostrou extensa esteatose para a linhagem B6 com pouco infiltrado celular e mínima esteatose na linhagem A/J e excessivo infiltrado celular para os camundongos tratados com DH+G. Acompanhando a esteatose hepática nos camundongos B6 e o infiltrado celular hepático nos camundongos A/J identificamos depósito de fibras de colágeno do tipo III após 10 semanas de tratamento em ambas as linhagens.

\subsubsection{Avaliação da atividade hepática e perfil hematológico}

Dado que o fígado é o órgão alvo do nosso modelo e por exibir substanciais alterações como depósito de lipídeos, infiltrados celulares e aumento de tamanho hepático após o tratamento com $\mathrm{DH}+\mathrm{G}$, direcionamos nossas análises para identificar no plasma a presença de alterações ou lesões resultantes de danos presentes neste órgão. Frente à injúria 
tecidual hepática, muitas vezes ocorre o rompimentos dos hepatócitos e consequentemente liberação do conteúdo citoplasmático. Dentre os componentes liberados estão as enzimas relacionadas ao metabolismo de proteínas, por exemplo a ALT e a AST, que podem alcançar a circulação sanguínea e serem dosadas. Nem sempre a análise da concentração da ALT é informativa em condições de DHNA, mesmo assim realizamos a determinação da sua concentração no plasma dos camundongos tratados com as diferentes dietas.

Com relação à concentração plasmática de ALT para os camundongos da linhagem B6 identificamos efeito de interação significativo entre tratamento e semana, $p=0,009$. Os camundongos B6 tratados com DH apresentaram aumento significativo da concentração de ALT plasmática de 6 para 8 semanas, $p<0,05$, e queda significativa de 8 para 10 semanas, $p<0,05$. Já os camundongos tratados com $\mathrm{DH}+\mathrm{M}$ apresentaram redução significativa de apenas 8 para 10 semanas, $p<0,05$. (Figura A.12A).

Com relação aos camundongos da linhagem A/J, não detectamos efeito de interação entre tratamento e semana, $p=0,784$. Também não detectamos diferença significativa entre os tratamentos, $p=0,0796$, mas identificamos diferença significativa entre as semanas, $p<0,001$. Independente do tipo de dieta que os camundongos $\mathrm{A} / \mathrm{J}$ receberam houve aumento da concentração plasmática de ALT de 6 para 8 e de 6 para 10 semanas de tratamento (Figura A.12B). É possível que dieta hiperlipídica, de maneira geral, esteja promovendo o aumento em pelo menos $50 \%$ da concentração plasmática de ALT.

Ainda buscamos por alterações sistêmicas que poderiam estar relacionadas à inflamação este órgão, para isso analisamos o perfil leucocitário total no sangue periférico de cada um dos tratamentos (Figura A.13) visando identificar possíveis alterações. Com relação ao número absoluto de leucócitos para os camundongos da linhagem B6 não detectamos efeito de interação entre tratamento e semana, $p=0,089$, também não encontramos diferença significativa entre os tratamentos, $p=0,523$, nem entre as semanas, $p=0,381$ (Figura A.13A).

Quanto ao número de leucócitos circulantes para os camundongos da linhagem A/J encontramos efeito de interação entre tratamento e semana, $p<0,001$. Isto significa que o número de leucócitos se alterou dependentemente do tratamento e do tempo (semana) de tratamento. Os camundongos $\mathrm{A} / \mathrm{J}$ tratados com $\mathrm{DH}+\mathrm{M}$ e $\mathrm{DH}$ apresentaram redução significativa do número absoluto de leucócitos circulantes de 6 e 8 para 10 semanas de tratamento, $p<0,05$. Comparando os tratamentos, os camundongos da linhagem $\mathrm{A} / \mathrm{J}$ tratados com $\mathrm{DH}+\mathrm{G}$ por 6 semanas apresentaram queda significativa no número de leucócitos totais em comparação aos camundongos tratados com DH+M e DH, $p<0,05$. Por outro lado, após 10 semanas de tratamento ocorreu uma inversão do comportamento leucocitário em relação a 6 
semanas de tratamento, onde os camundongos tratados com $\mathrm{DH}+\mathrm{G}$ apresentaram aumento significativo no número de leucócitos totais em comparação aos camundongos tratados com $\mathrm{DH}+\mathrm{M}$ e DH, $p<0,05$ (Figura A.13B).

Figura A.12 - Determinação da concentração de ALT plasmática nos camundongos das linhagens B6 e A/J após tratamento com as diferentes dietas hiperlipílicas durante 6,8 e 10 semanas.
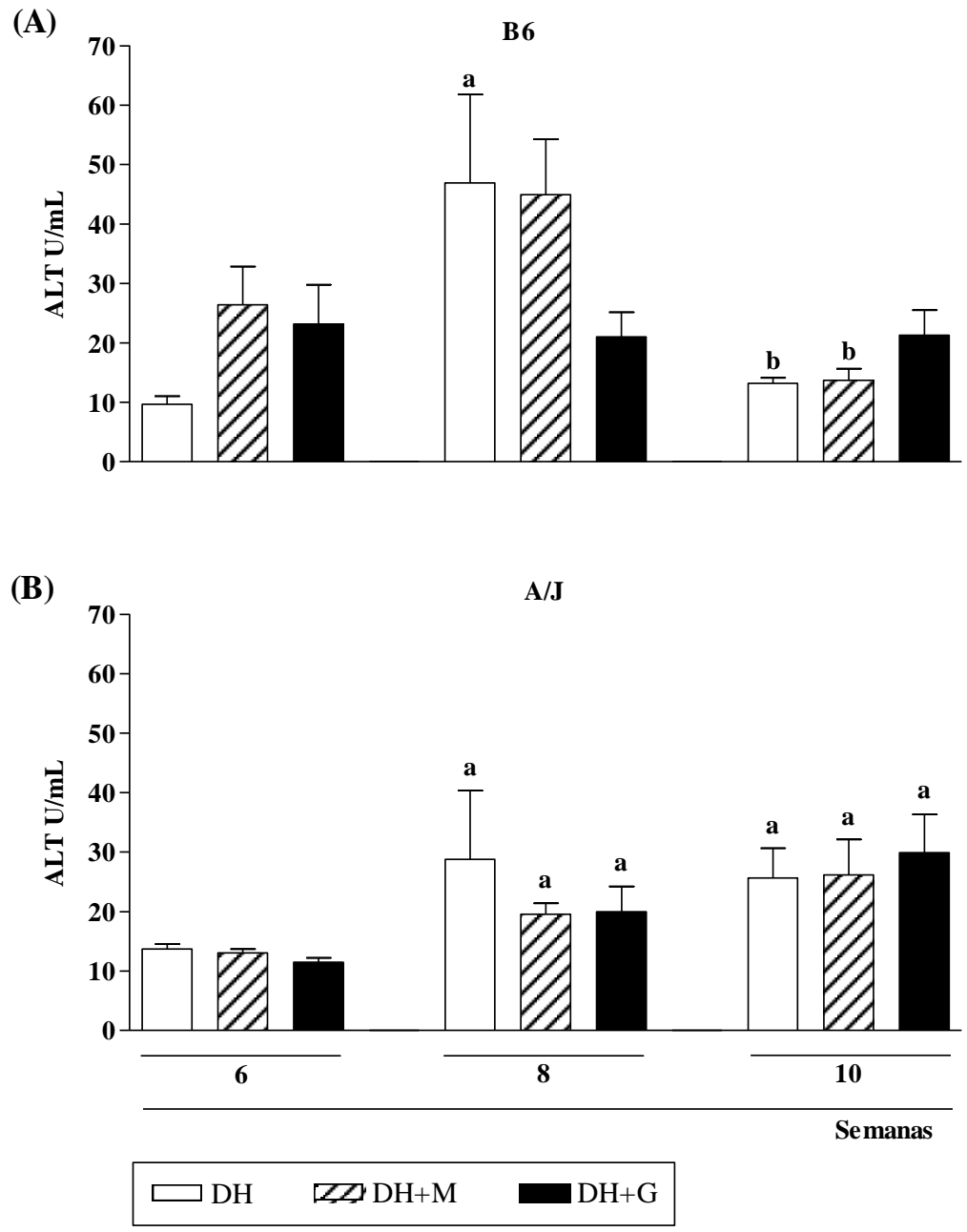

Apresentamos as concentrações plasmáticas de AST dos camundongos das linhagens B6 (A) e A/J (B) obtidas após os tratamentos dos animais com as diferentes dietas sob os diferentes tempos de tratamentos. Os resultados estão representados como média e erro padrão, e para cada grupo aplicamos $n \geq 5$. As comparações correspondem: a vs. 6 semanas; b vs. 8 semanas; c vs. DH; d vs. DH+M. Siglas: DH - Dieta hiperlipídica; $\mathrm{DH}+\mathrm{M}$ - Dieta hiperlipídica contendo maltodextrina; $\mathrm{DH}+\mathrm{G}-$ Dieta hiperlipídica contendo glicose. 
Figura A.13 - Número de leucócitos totais periféricos após tratamento com as diferentes dietas hiperlipídicas por 6, 8 e 10 semanas de tratamento das linhagens B6 e $\mathrm{A} / \mathrm{J}$.

(A)

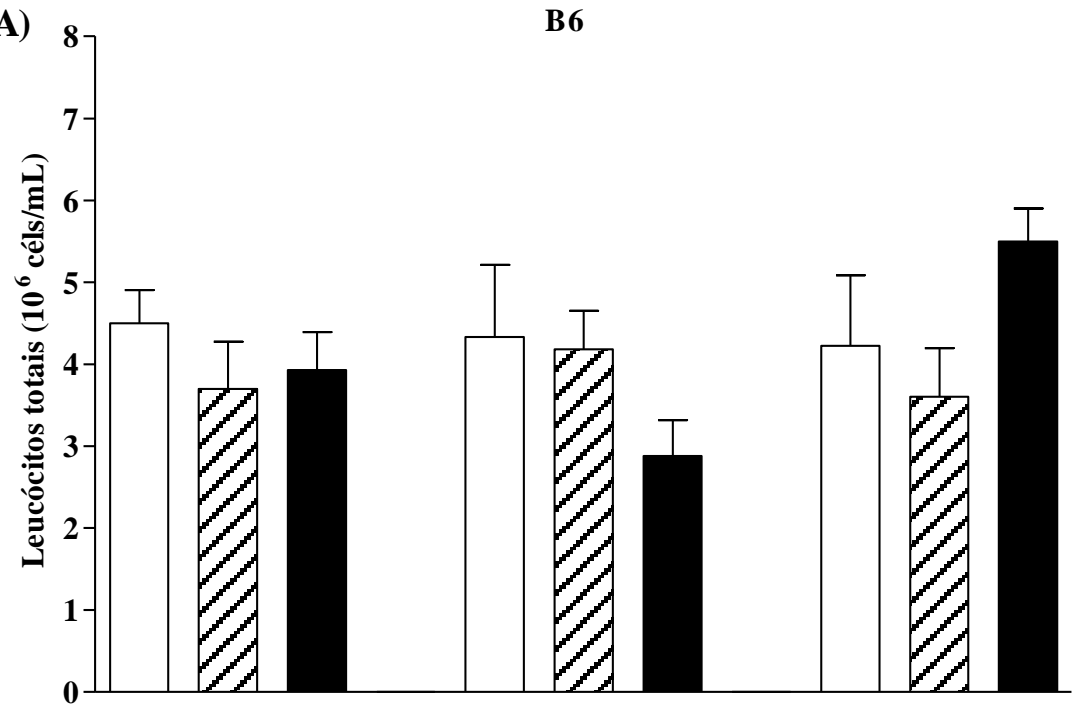

(B)

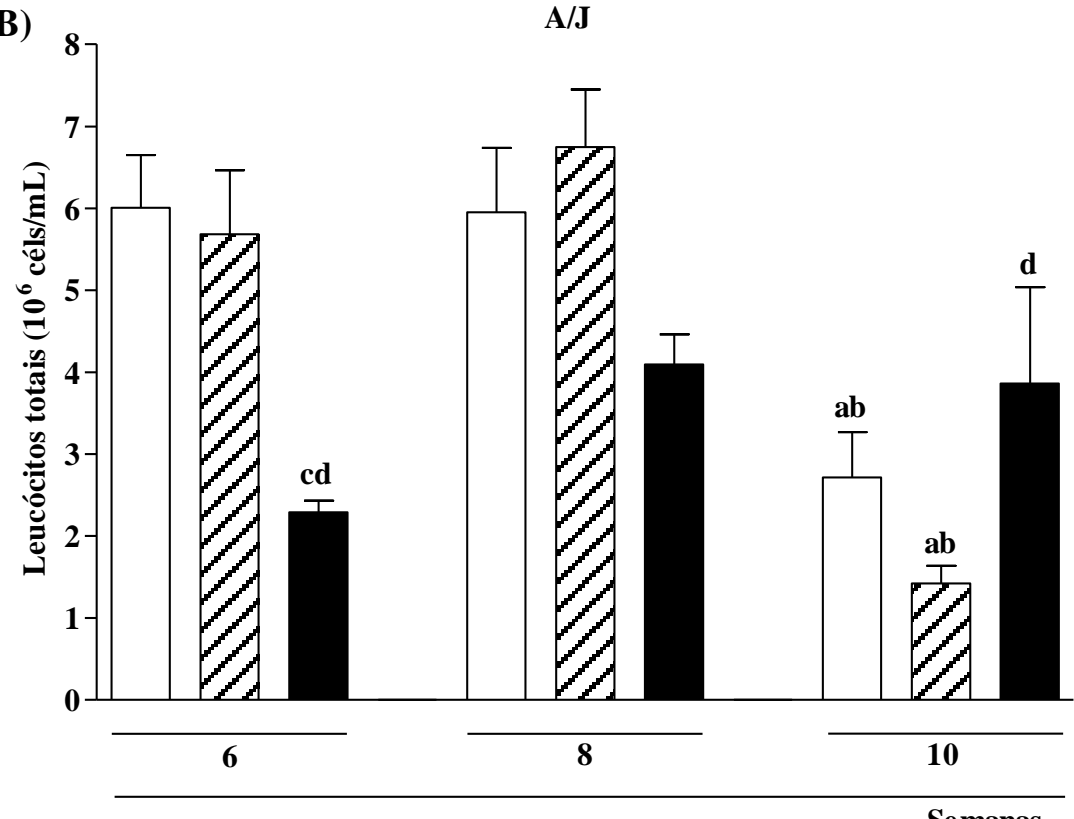

\section{$\square \mathrm{DH} \quad \square \mathrm{DH}+\mathrm{M} \square \mathrm{DH}+\mathrm{G}$}

Apresentamos as contagens de leucócitos sanguíneos dos camundongos das linhagens B6 (A) e A/J (B) obtidas após os tratamentos dos animais com as diferentes dietas sob os diferentes tempos de tratamentos. Os resultados estão representados como média e erro padrão, $\mathrm{n} \geq 5$. As comparações correspondem: a vs. 6 semanas; $\mathbf{b}$ vs. 8 semanas; c vs. DH; d vs. DH+M. Siglas: DH - Dieta hiperlipídica; DH+M - Dieta hiperlipídica contendo maltodextrina; $\mathrm{DH}+\mathrm{G}-$ Dieta hiperlipídica contendo glicose. 
Durante os três períodos de tratamento apenas os camundongos da linhagem A/J apresentaram alterações no número de leucócitos circulantes para todos os tipos de tratamento. Após 6 semanas de tratamento com $\mathrm{DH}+\mathrm{G}$ houve redução do número de leucócitos circulantes em relação ao número de leucócitos dos camundongos tratados com DH+M e DH. E após 10 semanas de tratamento houve a redução da população leucocitária dos camundongos tratados com $\mathrm{DH}+\mathrm{M}$ e $\mathrm{DH}$ e aumento dos leucócitos nos camundongos tratados com DH+G (Figura A.13).

Conclusão da secão 3.1.2: Os camundongos da linhagem A/J apresentaram aumento na concentração plasmática de ALT independentemente do tratamento após 8 e 10 semanas. Além disso, o número de leucócitos circulantes no sangue dos camundongos da linhagem A/J sofreu alteração tanto com os diferentes tratamentos quanto com o tempo em que foram tratados. Nos camundongos $\mathrm{A} / \mathrm{J}$ tratados com $\mathrm{DH}+\mathrm{G}$ houve redução significativa do número de leucócitos circulantes após 6 semanas de tratamento e após 10 semanas de tratamento houve aumento significativo do número de leucócitos totais nos camundongos tratados com $\mathrm{DH}+\mathrm{G}$ pois ao mesmo tempo identificamos uma redução significativa nos camundongos tratados com $\mathrm{DH}+\mathrm{M}$ e $\mathrm{DH}$.

\subsubsection{Avaliação da resposta inflamatória no micro-ambiente hepático}

Buscando identificar os mecanismos inflamatórios envolvidos nas diferenças observadas entre as linhagens B6 e A/J, investigamos o perfil de citocinas no tecido hepático após os diferentes tempos de tratamento (Figura A.14). Determinamos por ELISA as concentrações das citocinas pró-inflamatórias: TNF- $\alpha$ (Figura A.14A), IL-1 $\beta$ (Figura A.14B), IL-6 (Figura A.14C), IL-17 (Figura A.14D), IL-12p40 e p70 (Figura A.14E e 52F); e também da citocina anti-inflamatória IL-10 (Figura A.14G). Por fim, mensuramos a produção de NO a partir do homogenato hepático (Figura A.14H), Os resultados destas leituras foram normalizados pela concentração de proteínas totais presentes nos homogenatos de fígado.

Dentre as citocinas pró-inflamatórias envolvidas com o estabelecimento da DHNA sugere-se a citocina TNF- $\alpha$ como um fator chave (NAGATA; SUZUKI; SAKAGUCHI, 2008). Portanto, investigando a concentração hepática desta citocina para os camundongos da linhagem B6 detectamos efeito de interação significativo entre tratamento e semana, $p=0,002$. Avaliando a concentração de TNF- $\alpha$ cineticamente ao longo das semanas observamos que os 
camundongos tratados com $\mathrm{DH}+\mathrm{G}$ apresentaram aumento significativo da concentração hepática de TNF- $\alpha$ de 6 para 8 semanas, $p<0,05$. Mas, comparando os tratamentos detectamos que este aumento só foi possível pois após 6 semanas de tratamento houve queda significativa da concentração de TNF- $\alpha$ nos camundongos tratados com $\mathrm{DH}+\mathrm{G}$ em relação aos tratados com DH+M, $p<0,05$ (Figura A.14A). Ou seja, o tratamento dos camundongos B6 com $\mathrm{DH}+\mathrm{G}$ aumentou a concentração de TNF- $\alpha 6$ para 8 semanas, e esta se manteve até a $10^{\mathrm{a}}$ semana.

Quanto à concentração hepática de TNF- $\alpha$ para os camundongos da linhagem A/J também constatamos a presença de efeito de interação entre tratamento e semana, $p=0,030$. A concentração de TNF- $\alpha$ se alterou ao longo das semanas de tratamento onde houve queda significativa na sua concentração 6 e 8 para 10 semanas após os tratamentos $\mathrm{DH}+\mathrm{M}$ e $\mathrm{DH}+\mathrm{G}$, $p<0,05$. Da mesma forma, os camundongos que receberam DH apresentaram redução significativa na concentração de TNF- $\alpha$ no homogenato hepático de 6 para 10 semanas de tratamento, $p<0,05$. Avaliando as diferenças entre os tratamentos observamos que após 8 semanas de tratamento com $\mathrm{DH}+\mathrm{G}$ houve aumento significativo na concentração de TNF- $\alpha$ hepática em comparação ao tratamento com DH, $p<0,05$ (Figura A.14A).

A concentração hepática da citocina TNF- $\alpha$ para os camundongos da linhagem B6 tratados com $\mathrm{DH}+\mathrm{G}$ mostrou-se reduzida em relação ao tratamento com $\mathrm{DH}+\mathrm{M}$ após o período de 6 semanas. Após 8 semanas identificamos que a concentração de TNF-a nos camundongos tratados com $D H+G$ aumentou em relação à $6^{a}$ semana alcançando a concentração dos controles DH+M e DH. Para os camundongos da linhagem A/J tratados com $\mathrm{DH}+\mathrm{G}$ identificamos redução da concentração de TNF-a ao longo das semanas de forma independe do tratamento (Figura A.14A).

Durante a progressão da DHNA, especialmente em condições de EHNA, ocorre a ativação do inflamassoma no citoplasma dos hepatócitos por sinais endógenos e exógenos e consequentemente há liberação de IL-1ß, a qual além de ser uma potente citocina próinflamatória também está relacionada ao aumento do depósito de triglicerídeos hepáticos (CSAK et al., 2011; DIXON et al., 2013). Dessa forma, seria pertinente determinar a concentração desta citocina nos homogenatos hepáticos dos camundongos submetidos ao modelo de DHNA que estamos desenvolvendo. Para os camundongos da linhagem B6 não encontramos efeito de interação entre tratamento e semana, $p=0,170$. Não identificamos 
diferença significativa entre as semanas, $p=0,140$, nem diferença significativa entre os tratamentos, $p=0,397$ (Figura A.14B).

Quanto à concentração hepática da citocina IL-1ß para os camundongos da linhagem A/J também não identificamos efeito de interação entre tratamento e semana, $p=0,255$. Porém, identificamos diferença significativa entre os tratamentos e entre as semanas, $p=0,008$ e $p=0,005$, respectivamente. Observamos para todos os períodos aumento significativo da concentração de IL-1ß nos camundongos tratados com $\mathrm{DH}+\mathrm{G}$ em comparação aos tratados com $\mathrm{DH}+\mathrm{M}$ ou $\mathrm{DH}, p<0,05$. E ainda, para esta linhagem observamos redução significativa da concentração de IL-1ß de 6 para 10 semanas de tratamento, $p<0,05$, para todas as dietas administradas. (Figura A.14B).

Identificamos um marcante aumento da citocina IL-1ß apenas nos camundongos da linhagem $\mathrm{A} / \mathrm{J}$ tratados com $\mathrm{DH}+\mathrm{G}$ em relação aos controles $\mathrm{DH}+\mathrm{M}$ e $\mathrm{DH}$. É possível que o aumento desta citocina para a linhagem A/J exerceu um papel protetor contra o depósito de triglicerídeos hepáticos (Figura A.14B).

Avaliando a concentração hepática da citocina IL-6 nos camundongos da linhagem B6 constatamos a presença de efeito de interação significativo entre tratamento e semana, $p<0,001$. Observamos que para os camundongos tratados com $\mathrm{DH}+\mathrm{G}$ a concentração de IL-6 hepática aumentou significativamente de 6 para 8 semanas, $p<0,05$, e reduziu significativamente de 8 para 10 semanas, $p<0,05$. E para os camundongos tratados com $\mathrm{DH}+\mathrm{M}$ ou DH a redução da concentração de IL-6 foi significativa de 6 e 8 semanas para 10 semanas, $p<0,05$. Por fim, comparando os tratamentos identificamos que após 6 semanas a concentração de IL-6 hepática foi significativamente menor nos camundongos tratados com $\mathrm{DH}+\mathrm{G}$ em relação aos tratados com $\mathrm{DH}+\mathrm{M}, p<0,05$. Já após 8 semanas de tratamentos identificamos que nos tratados com $\mathrm{DH}+\mathrm{G}$ a concentração de IL-6 esteve aumentada em relação aos tratados com $\mathrm{DH}, p<0,05$ (Figura A.14C).

Com relação à linhagem $\mathrm{A} / \mathrm{J}$ encontramos efeito de interação significativo entre tratamento e semana, $p=0,009$. Observamos que houve significativa redução na concentração de IL-6 no homogenato hepático dos camundongos tratados com $\mathrm{DH}+\mathrm{G}$ ao longo das semanas de tratamento, isto é, de 6 e 8 semanas para 10 semanas de tratamento, $p<0,05$. Da mesma forma observamos que para os tratados com $\mathrm{DH}+\mathrm{M}$ ou $\mathrm{DH}$ houve redução significativa de IL-6 de 6 para 8 e de 6 para 10 semanas, $p<0,05$. Por fim, comparando os tratamentos identificamos que a concentração de IL-6 foi significativamente maior nos 
animais tratados com $\mathrm{DH}+\mathrm{G}$ que nos camundongos tratados com $\mathrm{DH}$ após 8 de tratamento, $p<0,05$ (Figura A.14C).

O perfil da citocina IL-6 foi bastante semelhante entre ambas as linhagens, o tratamento com $D H+G$ por 8 semanas induziu o aumento da concentração de IL-6 em relação ao tratamento com DH. Identificamos também que dentre todos os tratamentos a concentração desta citocina reduziu significativamente com o decorrer das semanas de tratamento (Figura A.14C).

A citocina IL-17 acentua a esteatose e inflamação durante o desenvolvimento da DHNA (TANG et al., 2011), sendo uma importante citocina a ser investigada nos diferentes tempos de tratamento. A análise da concentração hepática desta citocina dentre os camundongos da linhagem B6 mostrou que não houve efeito de interação entre tratamento e semana, $p=0,255$. Entretanto, identificamos diferença significativa entre os tratamentos e entre as semanas, $p=0,008$ e $p<0,005$, respectivamente. A concentração da citocina IL-17 foi significativamente maior após 6 semanas do que após 8 ou 10 semanas de tratamento, $p<0,05$. E ainda identificamos aumento significativo de 8 para 10 semanas de tratamento, $p<0,05$. Dentre os tratamentos observamos redução significativa de IL-17 no homogenato hepático nos camundongos que receberam $\mathrm{DH}+\mathrm{G}$ em relação aos tratados $\mathrm{DH}, p<0,05$ (Figura A.14D).

Quanto aos camundongos da linhagem A/J não detectamos efeito de interação entre tratamento e semana, $p=0,143$. Não encontramos diferença significativa entre os tratamentos, $p=0,107$, nem identificamos diferença significativa entre as semanas, $p=0,635$. A concentração de IL-17 não se alterou nem com o tratamento nem com o passar do tempo para os camundongos da linhagem A/J (Figura A.14D).

A concentração hepática da citocina IL-17 nos camundongos B6 esteve significativamente mais baixa nos tratados com $\mathrm{DH}+\mathrm{G}$ que nos tratados com $\mathrm{DH}$ para os tempos testados. De forma geral a concentração desta citocina reduziu-se de 6 para 8 semanas mas aumentou de 8 para 10 semanas (Figura A.14D).

Continuando a análise das citocinas determinamos a concentração de IL-12. Dosamos a subunidade p40 e sua forma completa p70. A citocina IL-12 é secretada principalmente por células dendríticas sendo importante na defesa de patógenos intracelulares, indução da 
produção de IFN- $\gamma$ por linfócitos $\mathrm{T}$ e NK, co-estimulação a proliferação de linfócitos presentes no sangue periférico e ainda participa da indução da diferenciação de linfócito T para o perfil Th1. Além disso, as células de Kupffer também sintetizam IL-8, IL-12 e IFN- $\gamma$, as quais contribuem para o recrutamento e ativação de granulócitos para o tecido hepático em condições severas da DHNA (VALENTI; FRACANZANI; FARGION, 2009).

Investigando a concentração da subunidade p40 da citocina IL-12 no tecido hepático dos camundongos da linhagem B6 não encontramos efeito de interação entre tratamento e semana, $p=0,287$. Não identificamos diferença significativa entre os tratamentos, mas identificamos diferença significativa entre as semanas de tratamento, $p=0,199$ e $p<0,001$, respectivamente. Observamos que a concentração de IL-12p(40) no homogenato foi significativamente maior após 6 e 8 semanas de tratamento em comparação a 10 semanas de tratamento, $p<0,05$. (Figura A.14E).

Quanto à concentração hepática de IL-12p(40) para os camundongos da linhagem A/J não identificamos efeito de interação entre tratamento e semana, $p=0,190$. Todavia encontramos diferença significativa entre os tratamentos e entre as semanas, $p=0,029$ e $p<0,001$, respectivamente. Com relação ao tempo de tratamento observamos que a concentração hepática de IL-12p(40) compreendeu o seguinte intervalo de concentração $6>8$ $>10$ semanas independente do tratamento, $p<0,05$. E os camundongos tratados com $\mathrm{DH}+\mathrm{M}$ apresentaram significativamente maior concentração que os tratados com DH, $p<0,05$ (Figura A.14E). O tratamento com $D H+G$ parece não alterou a concentração de IL-12p(40) durante as semanas.

Os resultados obtidos com as determinações da concentração hepáticas de IL-12p(70) são muito semelhantes aos descritos acima para IL-12p(40). Para os camundongos B6 não detectamos efeito de interação entre tratamento e semana, $p=0,115$. Também não detectamos diferença significativa entre os tratamentos, $p=0,351$, mas encontramos diferença significativa entre as semanas, $p<0,001$. Observamos que a concentração de IL-12p(70) foi maior após 6 em relação a 10 e 8 sem relação a 10 semanas de tratamento, $p<0,05$, independentemente da dieta aplicadas aos camundongos (Figura A.14F).

Com relação à linhagem A/J não detectamos efeito de interação entre tratamento e semana, $p=0,699$, não detectamos diferença significativa entre os tratamentos, $p=0,236$, mas encontramos diferença significativa entre as semanas, $p<0,001$. Ou seja, independentemente da dieta dada aos camundongos a concentração de IL-12p(70) hepática foi significativamente maior após 6 e 8 semanas que após 10 semanas de tratamento, $p<0,05$ (Figura A.14F). 
Tanto para os camundongos B6 quanto para os $A / J$ a concentração da citocina $I L$ 12 do micro-ambiente hepático, de forma geral, teve a sua concentração reduzida de 6 e 8 para 10 semanas de tratamento independentemente do tratamento que os camundongos receberam (Figura A.14E e A.14F). Ou seja, houve redução significativa da concentração de IL-12 com o período em que os camundongos foram tratados.

Avaliamos também a concentração hepática da citocina anti-inflamatória IL-10 nos camundongos B6 e encontramos efeito de interação significativo entre tratamento e semana, $p=0,004$. Observamos que nos camundongos tratados com $\mathrm{DH}+\mathrm{G}$ e $\mathrm{DH}+\mathrm{M}$ houve aumento significativo da concentração hepática de IL-10 de 6 para 8 e 10 semanas de tratamento, $p<0,05$. Já nos tratados apenas com DH houve aumento significativo de 6 e 8 para 10 semanas de tratamento, $p<0,05$. Entre os tratamentos identificamos aumento significativo da concentração hepática de IL-10 nos tratados com DH+G após 8 semanas de tratamento em relação aos tratados apenas com DH, $p<0,05$. (Figura A.14G).

Avaliando a concentração hepática de IL-10 para os camundongos da linhagem A/J também identificamos efeito de interação significativo entre tratamento e semana, $p=0,032$. Observamos que nos camundongos tratados com $\mathrm{DH}+\mathrm{G}$ houve aumento significativo da concentração hepática de IL-10 de 6 e 8 para 10 semanas de tratamento, $p<0,05$. Entre os tratamentos observamos aumento significativo da concentração hepática de IL-10 nos camundongos tratados com $\mathrm{DH}+\mathrm{G}$ em relação aos tratados com DH tanto após 8 quanto após 10 semanas de tratamento, $p<0,05$ (Figura A.14G).

Nos camundongos B6 tratados com DH+G a concentração hepática de IL-10 aumentou de 6 para 8 semanas e manteve-se a mesma concentração até a $10^{a}$ semana. Nos camundongos A/J tratados com $\mathrm{DH}+\mathrm{G}$ a concentração de IL-10 aumentou de 6 para 8 e de 6 para 10 semanas em comparação aos camundongos tratados com DH (Figura A.14G).

Finalizando nossas análises, perguntamo-nos como estaria a produção de óxido nítrico (NO) no micro ambiente hepático, uma vez que observamos a presença de infiltrados celulares e intensiva resposta inflamatória no fígado dos animais tratados com etanol. O NO é um mediador inflamatório relacionado à vasodilatação, produzido principalmente por macrófagos e células endoteliais, que ocorre nas fases iniciais do processo inflamatório e com função microbicida. 
Avaliando a produção de NO no tecido hepático para os camundongos da linhagem B6 encontramos efeito de interação entre tratamento e semana, $p=0,002$. Dentre os tratados com DH houve aumento significativo de NO após 10 semanas de tratamento em relação aos camundongos tratados com a mesma ração por 6 e 8 semanas, $p<0,05$. Os camundongos tratados com $\mathrm{DH}+\mathrm{G}$ ou $\mathrm{DH}+\mathrm{M}$ não apresentaram alterações significativas (Figura A.14H).

Quanto à linhagem $\mathrm{A} / \mathrm{J}$ não identificamos efeito de interação entre tratamento e semana, $p=0,492$. Também não identificamos diferença significativa entre os tratamentos, $p=0,219$. Mas, detectamos diferença significativa durante o tempo de tratamento, $p=0,003$. Após 10 semanas de tratamento dos camundongos A/J observamos aumento significativo da produção de NO em relação àqueles tratados com as diferentes dietas por 6 e 8 semanas, $p<0,05$ (Figura A.14H).

Por meio da dosagem de NO sugerimos a participação de macrófagos no tecido hepático para ambas as linhagens e identificamos que para os camundongos da linhagem A/J, independentemente do tratamento, a produção de NO aumentou significativamente de 6 e 8 para 10 semanas, e este aumento acompanhou o aumento da concentração da citocina IL-10 (Figura A.14H). Possivelmente a população de macrófagos presente no tecido hepático dos camundongos A/J (Figura A.7) pode ter contribuído para síntese de IL10 (Figura A.14H).

Conclusão da secão 3.1.3: Identificamos alguns padrões na produção de citocinas e NO que são comuns, exclusivos ou opostos as linhagens B6 e A/J. Dentre os resultados comuns às duas linhagens encontramos que a concentração de IL-6 e IL-12p(40) diminuiu significativamente durante as semanas de tratamento. Com relação aos resultados exclusivos para a linhagem B6 identificamos que a concentração da citocina IL-17 reduziu significativamente nos camundongos tratados com $\mathrm{DH}+\mathrm{G}$ em relação aos tratados com $\mathrm{DH}$ após 6, 8 e 10 semanas. Já para a linhagem A/J a concentração da citocina IL-1ß aumentou significativamente nos camundongos tratados com $\mathrm{DH}+\mathrm{G}$ em relação aos tratados com $\mathrm{DH}+\mathrm{M}$ e $\mathrm{DH}$ em todos os períodos de tratamento. Exclusivo aos camundongos da linhagem A/J também identificamos aumento da produção de NO de 6 e 8 para 10 semanas para todos os tratamentos. Quanto aos resultados opostos encontramos que a concentração da citocina anti-inflamatória IL-10 aumentou significativamente de 6 para 8 semanas para os camundongos de ambas as linhagens após o tratamento com DH+G. Mesmo assim, a concentração de IL-10 manteve-se constante de 8 para 10 semanas 
nos camundongos da linhagem B6 enquanto que nos camundongos da linhagem $\mathrm{A} / J$ esta concentração continuou aumentando tanto em relação as semanas anteriores quanto em relação aos tratamentos $\mathrm{DH}+\mathrm{M}$ e DH (Figura A.14).

Figura A.14 - Determinação da concentração das citocinas inflamatórias e NO em homogenato de tecido hepático após 6,8 e 10 semanas de tratamento com diferentes dietas hiperlipídica nas linhagens B6 e A/J.

(A) TNF- $\alpha$
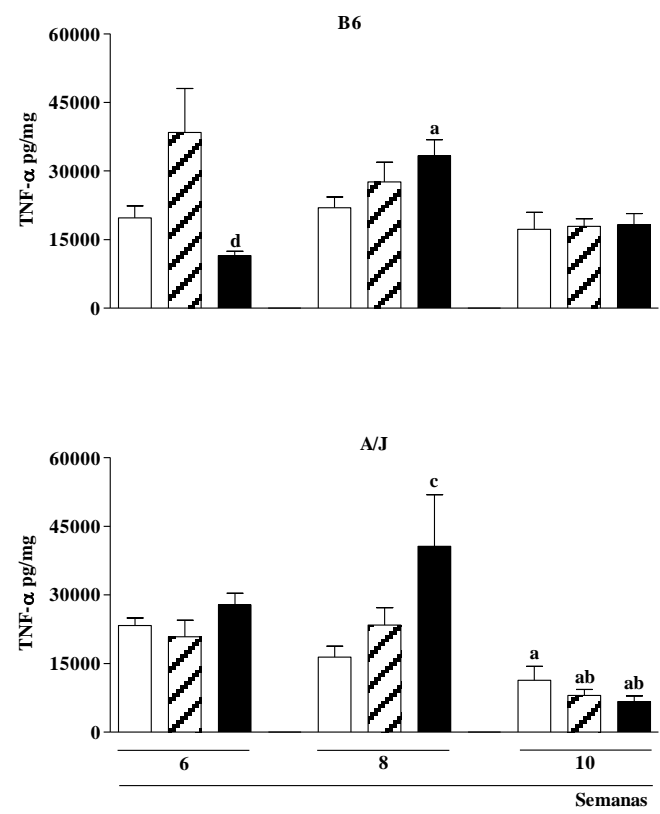

(C) IL-6
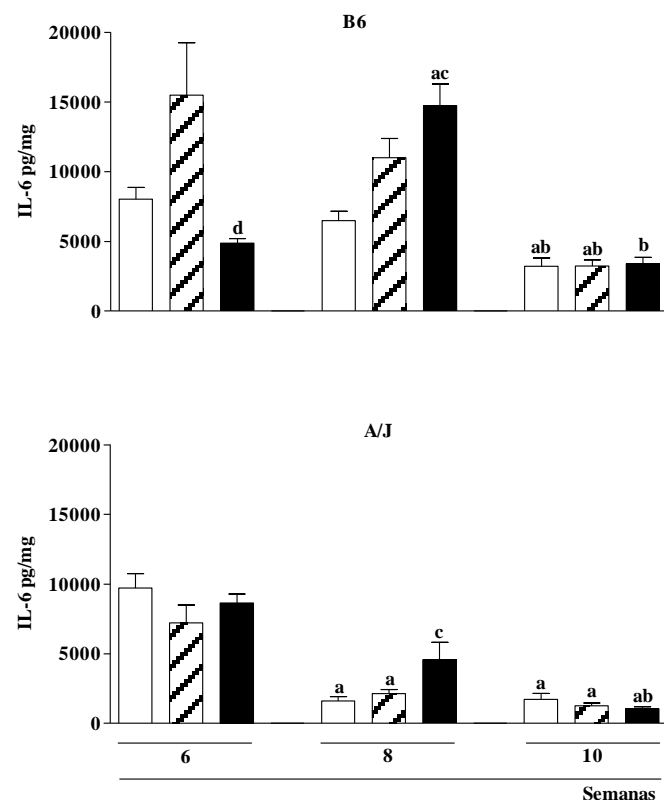

(B) IL-1 $\beta$
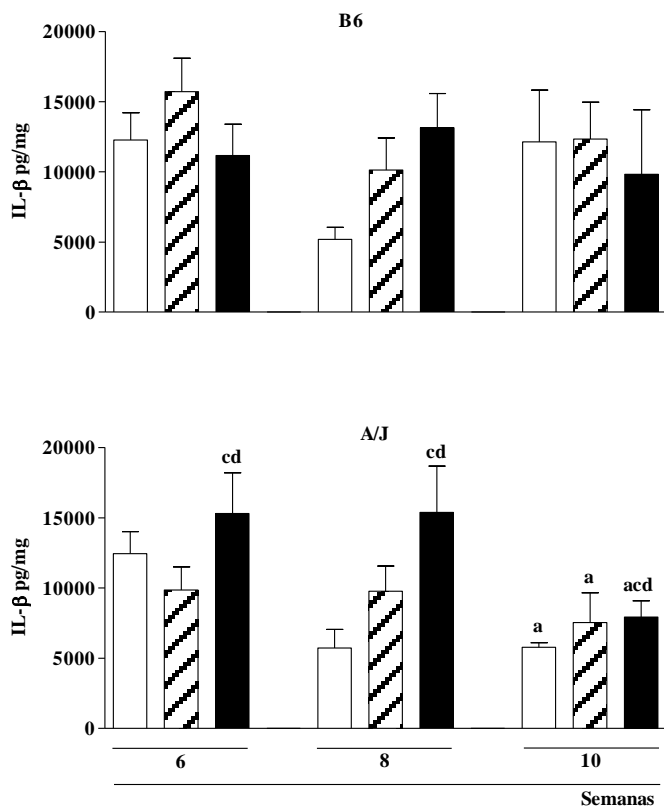

(D) IL-17
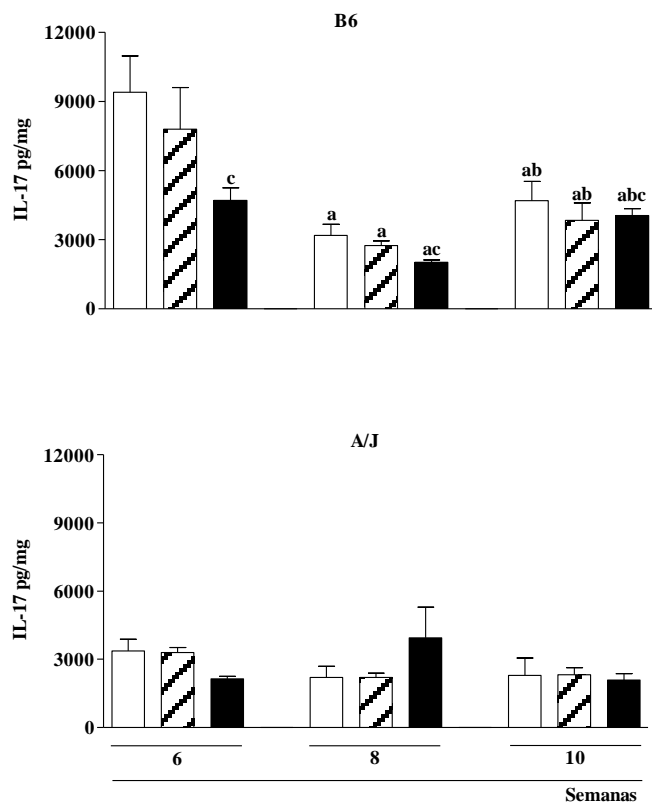

(Continua na próxima página) 
(E) IL-12p(40)
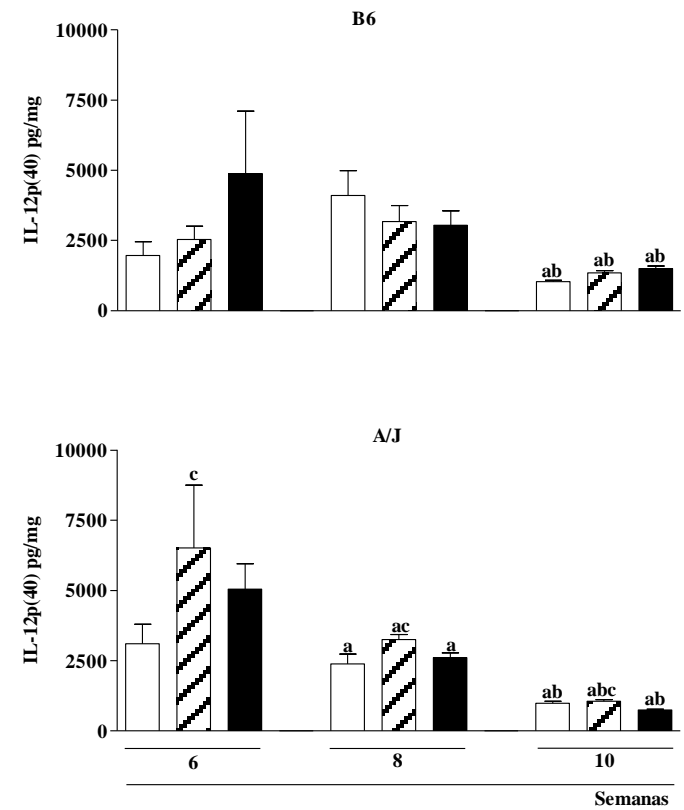

(G) IL-10
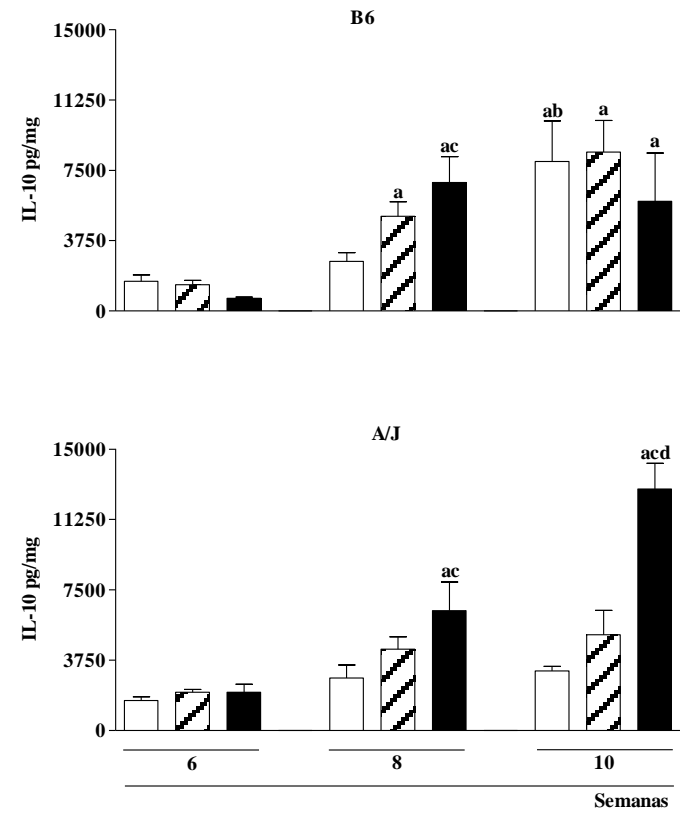

(F) IL-12p(70)
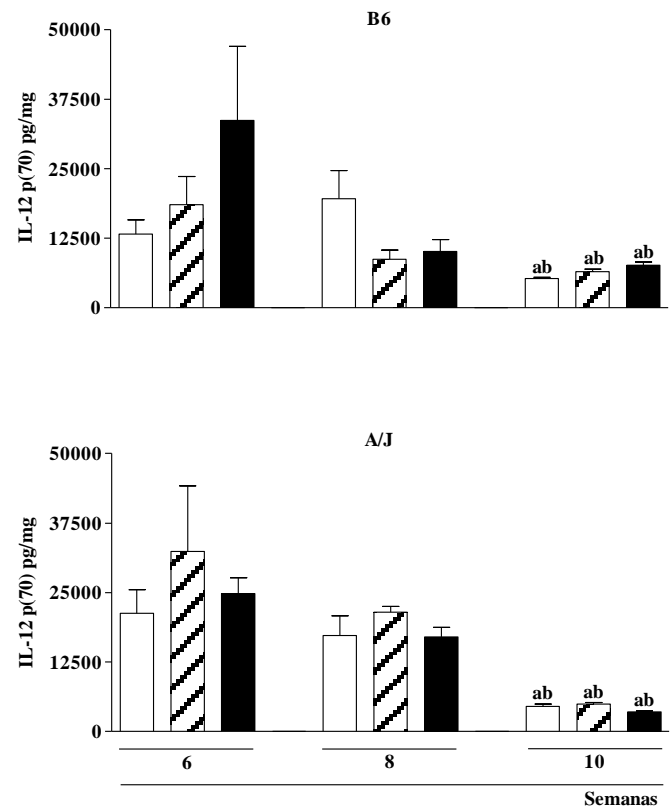

(H) NO
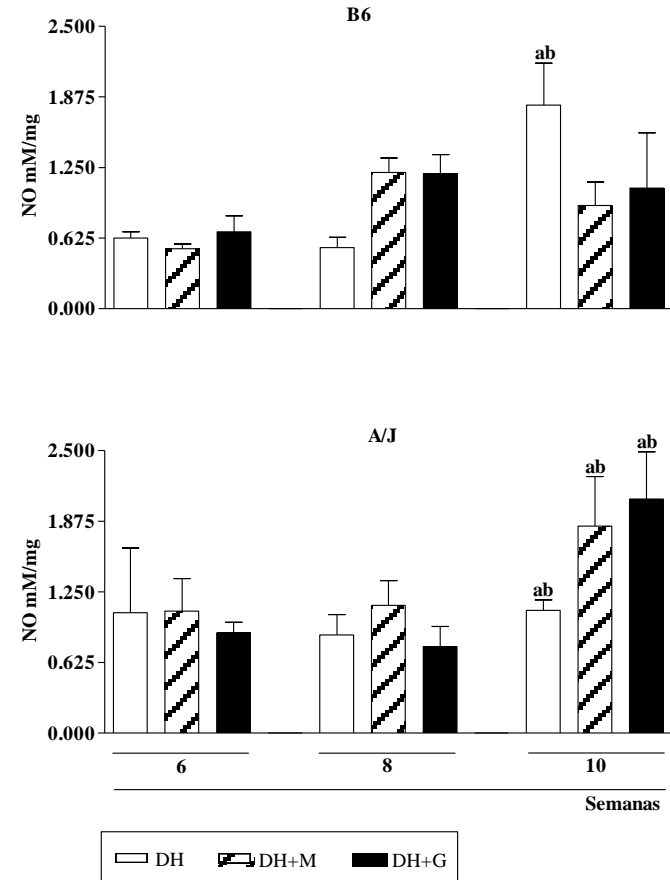

Os resultados estão representados como média e erro padrão, $\mathrm{n} \geq 5$. As comparações correspondem: a vs. 6 semanas; b vs. 8 semanas; c vs. DH; d vs. DH+M, $p<0,05$. Siglas: DH - Dieta hiperlipídica; DH+M - Dieta hiperlipídica contendo maltodextrina; $\mathrm{DH}+\mathrm{G}$ - Dieta hiperlipídica contendo glicose. 
3.1.4 Conclusão do tópico "Padronização do modelo de injúria hepática crônica induzida por glicose (ou padronização da DHNA)"

Concluímos que 10 semanas foi período de tratamento que induziu a lesão esperada e com o qual evidenciamos as diferenças inflamatórias inerentes a cada linhagem. A aplicação deste período em associação a uma dieta hiperlipídica contendo glicose propiciou o desenvolvimento de alterações patológicas hepáticas comuns aos pacientes com DHNA, assim como a reprodução destas patologias em pelo menos um de nossos camundongos congênicos. Dentre as alterações hepáticas induzidas pelo consumo da $\mathrm{DH}+\mathrm{G}$ ressaltamos: aumento da razão peso hepático / peso corporal para os camundongos da linhagem B6 e redução desta razão nos camundongos $\mathrm{A} / \mathrm{J}$, presença e acúmulo de triglicerídeos hepáticos com maior proporção nos camundongos B6 (cerca de $60 \mathrm{mg} / \mathrm{g}$ ) e menor acúmulo nos A/J (30 mg / g), aumento e redução no número de leucócitos circulantes apenas nos camundongos A/J, promoção de um micro-ambiente pró-inflamatório e presença de fibrose para ambas as a linhagens mas em especial para os camundongos B6.

Resta confirmar se tais patologias serão reprodutíveis e se as divergências entre as linhagens B6 e A/J são próprias do fundo genético ou se há uma participação da proteína C5 do sistema complemento na manutenção do ambiente inflamatório visto que a linhagem A/J mostrou-se bastante resistente ao desenvolvimento do quadro. Portanto, para investigarmos o papel do componente C5 no desenvolvimento e manutenção da DHNA daremos sequência ao tópico 3.2, onde aplicaremos os camundongos da linhagem congênica B6.A-Hc ${ }^{0}$ (C5 deficiente) no modelo de DHNA aqui padronizado tratando-os com $\mathrm{DH}+\mathrm{G}$ e os respectivos controles durante 10 semanas. Investigaremos também, de maneira mais aprofundada, a função e atividade hepática assim como o aumento do tecido adiposo epididimal e os lipídeos circulantes no sangue. 


\subsection{Aplicação da linhagem congênica B6.A-Hc ${ }^{0}$ no modelo de DHNA}

Da mesma forma que apresentamos no CAPÍTULO 2, desde o início deste projeto, o nosso objetivo foi empregar as linhagens congênicas que diferem apenas no locus $c 5$, para avaliar com clareza a real contribuição do componente C5 para a etiopatogenia da DNHA. Portanto, apresentaremos aqui apenas os resultados obtidos com o tratamento da linhagem isogênica B6 (C5 normal) e da linhagem congênica B6.A-Hc ${ }^{0}$ (C5 deficiente, como descrita e caracterizada no CAPÍTULO 1).

Após 10 semanas de tratamento, avaliamos a possível presença ou não de diferença significativa entre as linhagens (B6 e B6.A- $H c^{0}$ ), quanto aos tratamentos e o efeito de interação entre linhagem e tratamento, aplicando o teste estatístico de análise de variância para dois fatores (ANOVA). O efeito de interação avalia o comportamento das linhagens frente aos tratamentos. Tratamos os camundongos B6 e B6.A- $\mathrm{Hc}^{0}$ com $\mathrm{DH}, \mathrm{DH}+\mathrm{M}$ e $\mathrm{DH}+\mathrm{G}$ por 10 semanas e consideramos para análise estatística e discussão que os camundongos tratados com DH e DH+M como grupos controles, onde DH é o controle real e DH+M é o controle equicalórico com mesma equivalência calórica que o tratamento dieta hiperlipídica contendo glicose $(\mathrm{DH}+\mathrm{G})$.

\subsubsection{Avaliação dos parâmetros corporais}

Nesta seção abordaremos a avaliação dos parâmetros corporais referentes às linhagens B6 e B6.A-Hc dentre as quais estão: acúmulo de peso semanal, ganho de peso final, razão do peso do tecido adiposo pelo peso corporal, razão do peso hepático pelo peso corporal, quantificação de triglicerídeos e colesterol total no tecido hepático e análise histopatológica hepática.

Antes de iniciarmos as análises sobre os parâmetros corporais acompanhamos o consumo das diferentes dietas diariamente pesando o tubo contendo a dieta antes de colocá-lo na caixa e no dia seguinte após retirá-lo da caixa (Figura 2 - MATERIAIS E MÉTODOS). Todos os tubos utilizados foram previamente identificados e a partir do peso diário da dieta consumida calculamos a média semanal de consumo da ração (em gramas) por camundongo (gráfico disponível no APÊNDICE E). A média semanal para os camundongos da linhagem B6 tratados com $\mathrm{DH}+\mathrm{G}$ foi $14,1 \mathrm{~g}$, para aqueles tratados com $\mathrm{DH}+\mathrm{M}$ a média foi $16,3 \mathrm{~g}$ e por fim os que receberam DH consumiram 18,1 g. Para os camundongos da linhagem congênica B6. $\mathrm{A}-\mathrm{Hc}^{0}$ os resultados foram semelhantes, aqueles tratados com $\mathrm{DH}+\mathrm{G}$ consumiram em 
média 14,5 g, os que receberam DH+M consumiram 16,6 g e os camundongos tratados com DH consumiram 16,5 g. Aparentemente, as linhagens consumiram valores semanais semelhantes. Além do consumo da ração acompanhamos o acúmulo de peso semanalmente (Figura A.15) para investigar se as linhagens apresentariam comportamentos diferentes frente a cada tratamento. As linhagens B6 e B6.A- $H c^{0}$ apresentam o mesmo comportamento frente a cada um dos tratamentos e para simplificar a exposição dos dados representamos nas Figuras A.15A e A.15B apenas a análise comparativa entre os tratamentos.

Avaliando o acúmulo de peso semanalmente para cada tratamento observamos que em ambas as linhagens tratadas com $\mathrm{DH}+\mathrm{G}$ o acúmulo de peso foi significativo desde a terceira até a décima semana de tratamento, $p<0,05$. Nos camundongos tratados com DH+M observamos acúmulo significativo de peso a partir da terceira semana que se manteve constante até a décima semana, $p<0,05$. Nos camundongos tratados com DH foi observado acúmulo de peso significativo desde a quarta até a sexta semana de tratamento, $p<0,05$, a partir da qual não houve mais acúmulo de peso significativo.

Independentemente da linhagem, comparando os tratamentos observamos que os camundongos tratados com $\mathrm{DH}+\mathrm{G}$ acumularam significativamente mais peso que aqueles tratados com DH+M ou DH a partir da quinta e terceira semana de tratamento, respectivamente. Esse maior acúmulo de peso induzido pelo tratamento com $\mathrm{DH}+\mathrm{G}$ mantevese significativo em relação aos tratamentos $\mathrm{DH}+\mathrm{M}$ e $\mathrm{DH}$ até a décima semana, $p<0,05$. Também encontramos diferenças entre os controles, pois os camundongos tratados com $\mathrm{DH}+\mathrm{M}$ ou DH diferiram significativamente entre si a partir da sexta semana, onde aqueles tratados com $\mathrm{DH}+\mathrm{M}$ acumularam significativamente mais peso que os tratados com $\mathrm{DH}$, $p<0,05$ (Figuras A.15A e A.15B).

Independentemente da presença ou ausência da proteína C5, ambas as linhagens se comportaram igualmente quanto ao acúmulo de peso durante as 10 semanas de tratamento. E ainda, os camundongos de ambas as linhagens, quando tratados com $\mathrm{DH}+G$, acumularam significativamente mais peso em relação aos tratados com $\mathrm{DH}+\mathrm{M}$ a partir da quinta e em relação aos tratados com $\mathrm{DH}$ a partir da terceira semana de tratamento. Ou seja, ambas as linhagem, quando tratadas com $\mathrm{DH}+\mathrm{G}$ apresentaram maior de acúmulo de peso, sendo esta uma característica dependente apenas do fundo genético e do tratamento (Figura A.15A e A.15B). 
Figura A.15 - Ganho de peso acumulado dos camundongos B6 e B6.A-Hc ${ }^{0}$ (C5 deficientes) durante as 10 semanas de tratamento com as diferentes dietas hiperlipídicas.
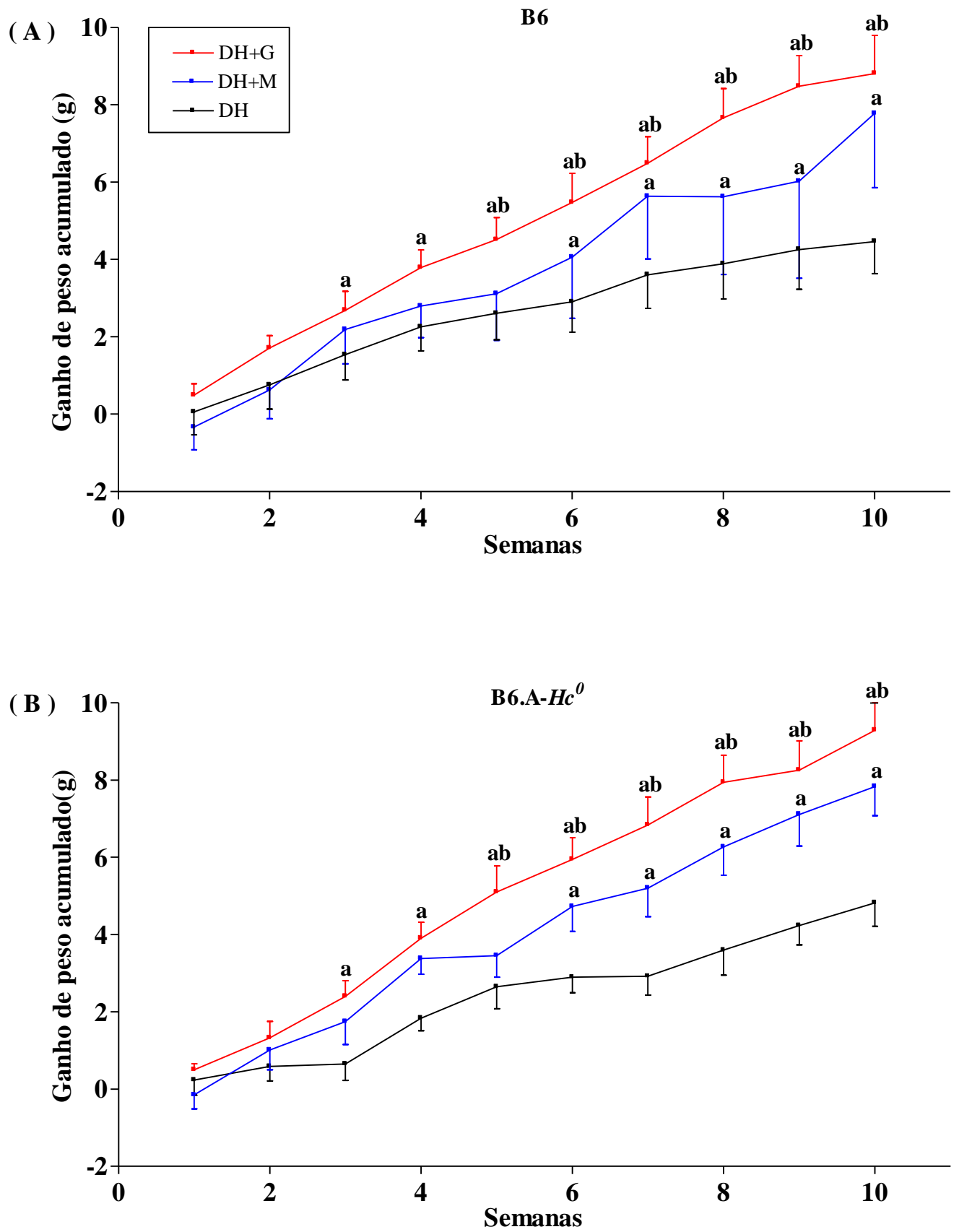

Em (A) estão os resultados para a linhagem B6 (C5 normal) e em (B) para a linhagem congênica B6.A-Hc ${ }^{0}$ (C5 deficiente). Representamos as diferenças entre os tratamentos na linha pertencente ao ganho de peso acumulado para o tratamento com dieta hiperlipídica contendo maltodextrina (DH+M) como: a vs. dieta hiperlipídica (DH) e b vs. dieta hiperlipídica contendo glicose $(\mathrm{DH}+\mathrm{G})$. Os resultados estão representados como média e erro padrão.Aplicamos para todos os tratamentos $n \geq 6$. 
Analisando estatisticamente o ganho de peso total ao final das 10 semanas de tratamento para os camundongos B6 e B6.A- $H c^{0}$ não identificamos efeito de interação entre linhagem e tratamento, $p=0,960$. Também não encontramos diferença significativa entre as linhagens, $p=0,651$. Porém, encontramos diferença significativa entre os tratamentos, $p<0,001$. Ambas as linhagens tratadas com DH ganharam significativamente menos peso que aos animais dos tratamentos $\mathrm{DH}+\mathrm{M}$ e $\mathrm{DH}+\mathrm{G}, p<0,05$ (Figura A.16).

Figura A.16 - Ganho de peso final dos camundongos B6 e B6.A- $H c^{0}$ (C5 deficientes) após 10 semanas de tratamento com as diferentes dietas hiperlipídicas.

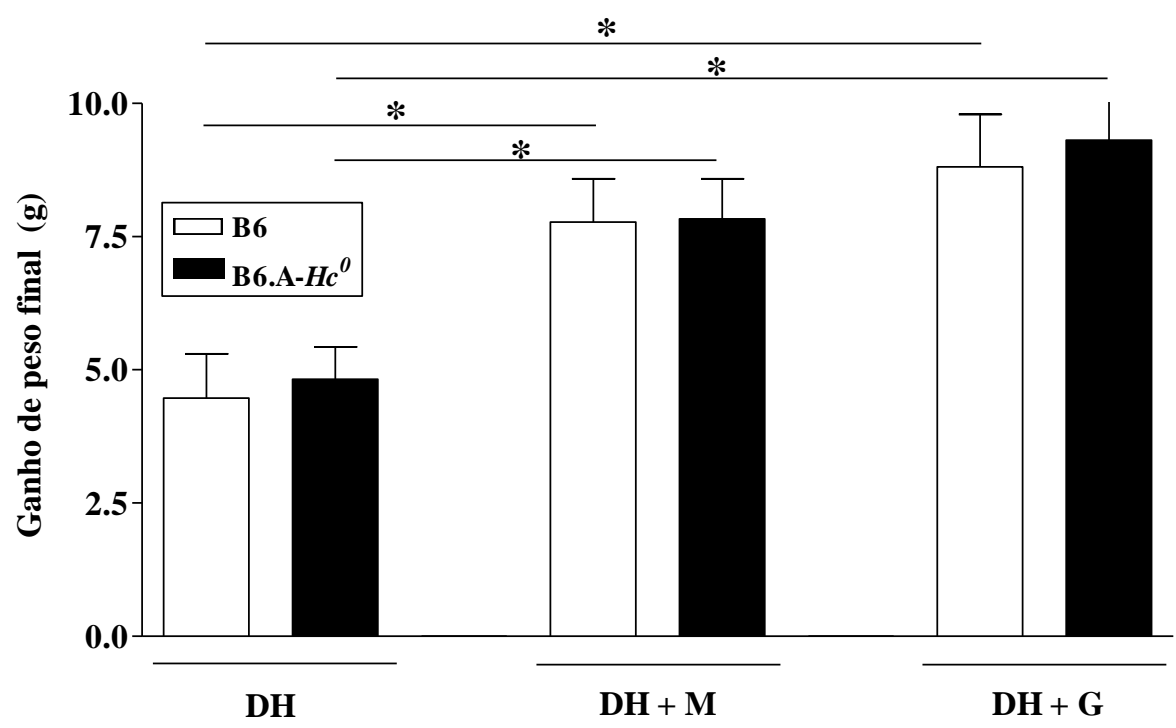

Os resultados estão representados como média e erro padrão. Empregamos pelo menos $\mathrm{n} \geq 6$ camundongos de cada linhagem, e consideramos $* p<0,05$. Siglas presentes na figura representam: dieta hiperlipídica (DH); dieta hiperlipídica contendo maltodextrina $(\mathrm{DH}+\mathrm{M})$; dieta hiperlipídica contendo glicose $(\mathrm{DH}+\mathrm{G})$.

$O$ ganho de peso ao final do tratamento foi o mesmo para os camundongos $B 6 \boldsymbol{e}$ B6.A-Hc ${ }^{0}$, mostrando que o ganho de peso é realmente uma característica induzida pelo fundo genético B6 e pelo do tratamento, independentemente da presença ou não proteína C5. Ambas as linhagens quando tratadas com $D H+G$ ou $D H+M$ ganharam significativamente mais peso que quando tratadas com apenas DH (Figura A.16).

Durante a DHNA é comum ocorrer o acúmulo de gordura hepática e extra-hepática nos tecido adiposo distribuídos por todo o corpo, por isso investigamos também a razão do peso do tecido adiposo epididimal pelo peso corporal final. Escolhemos o tecido adiposo epididimal, pois dentre os tecidos adiposos intra-abdominais este apresentou aumento de tamanho considerável após as 10 semanas de tratamento e também devido a sua facilidade de 
remoção. No tecido adiposo epididimal que ocorre alto metabolismo de glicose e lipídeos, e além de possuir baixo conteúdo protéico é nele, principalmente, onde estão situados os maiores adipócitos (SACKMANN-SALA et al., 2012). Este tecido, após remoção, foi pesado e congelado imediatamente em gelo seco e armazenado a $-80^{\circ} \mathrm{C}$ para futuramente investigarmos a presença de citocina pró- e anti-inflamatórias, a produção de NO e a presença de infiltrados celulares por meio da análise histopatológica.

Avaliando estatisticamente a razão do peso do tecido adiposo epididimal pelo peso corporal final nos camundongos B6 e B6.A- $H c^{0}$ não encontramos efeito de interação entre linhagem e tratamento, $p=0,962$, nem diferença estatística entre as linhagens, $p=0,639$. Todavia, encontramos diferença significativa entre os tratamentos, $p=0,004$. Observamos que dentre os camundongos de ambas as linhagens houve aumento da razão peso tecido adiposo / peso corporal naqueles tratados com $\mathrm{DH}+\mathrm{G}$ e $\mathrm{DH}+\mathrm{M}$ em relação aos que receberam apenas DH, $p<0,05$ (Figura A.17).

Figura A.17 - Razão do peso do tecido adiposo epididimal pelo peso corporal dos camundongos B6 e B6.A-Hc ${ }^{0}$ (C5 deficientes) após 10 semanas de tratamento.

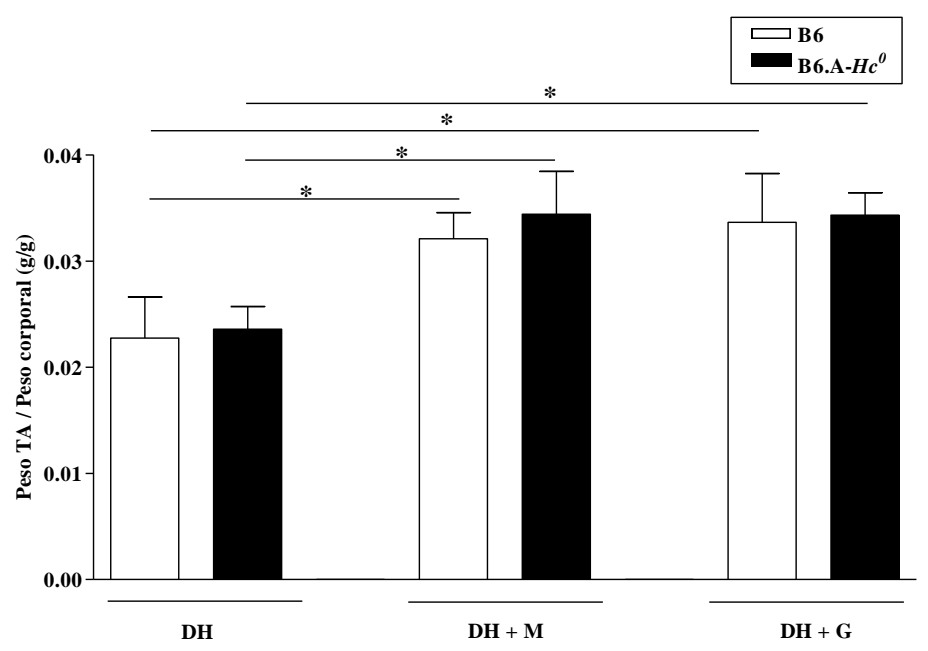

Os resultados estão representados como média e erro padrão. Empregamos pelo menos $\mathrm{n} \geq 6$ camundongos de cada linhagem, e consideramos $* p<0,05$. Siglas presentes na figura representam: dieta hiperlipídica (DH); dieta hiperlipídica contendo maltodextrina $(\mathrm{DH}+\mathrm{M})$; dieta hiperlipídica contendo glicose $(\mathrm{DH}+\mathrm{G})$.

Confirmando os dados apresentados acima podemos observar na Figura A.18 que o tratamento de ambas as linhagens com $\mathrm{DH}+\mathrm{G}$ e $\mathrm{DH}+\mathrm{M}$ levaram ao acúmulo de gordura abdominal e visceral, quando comparados aos tratados com DH. Mesmo não identificando diferença estatística entre as linhagens quanto à avaliação abordada na Figura A.17 observamos que a linhagem congênica B6.A- $\mathrm{Hc}^{0}$ apresentou sutilmente mais gordura 
abdominal que a linhagem B6. O peso médio do tecido adiposo epididimal encontrado para os camundongos B6.A- $\mathrm{Hc}^{0}$ segundo os tratamentos com DH foi $0,67 \mathrm{~g}$, para DH+M foi $1,19 \mathrm{~g}$ e para $\mathrm{DH}+\mathrm{G}$ foi $1,18 \mathrm{~g}$. E para os camundongos da linhagem $\mathrm{B} 6$ o peso médio do tecido adiposo para $\mathrm{DH}$ foi $0,69 \mathrm{~g}, \mathrm{DH}+\mathrm{M}$ foi $1,11 \mathrm{~g}$ e para os que receberam $\mathrm{DH}+\mathrm{G}$ foi $1,10 \mathrm{~g}$ (APÊNDICE F).

Figura A.18 - Acúmulo de gordura no tecido adiposo epididimal nos camundongos B6 e B6.A-Hc ${ }^{0}$ (C5 deficientes) e após 10 semanas de tratamento com as diferentes dietas hiperlipídica para indução da DHNA.
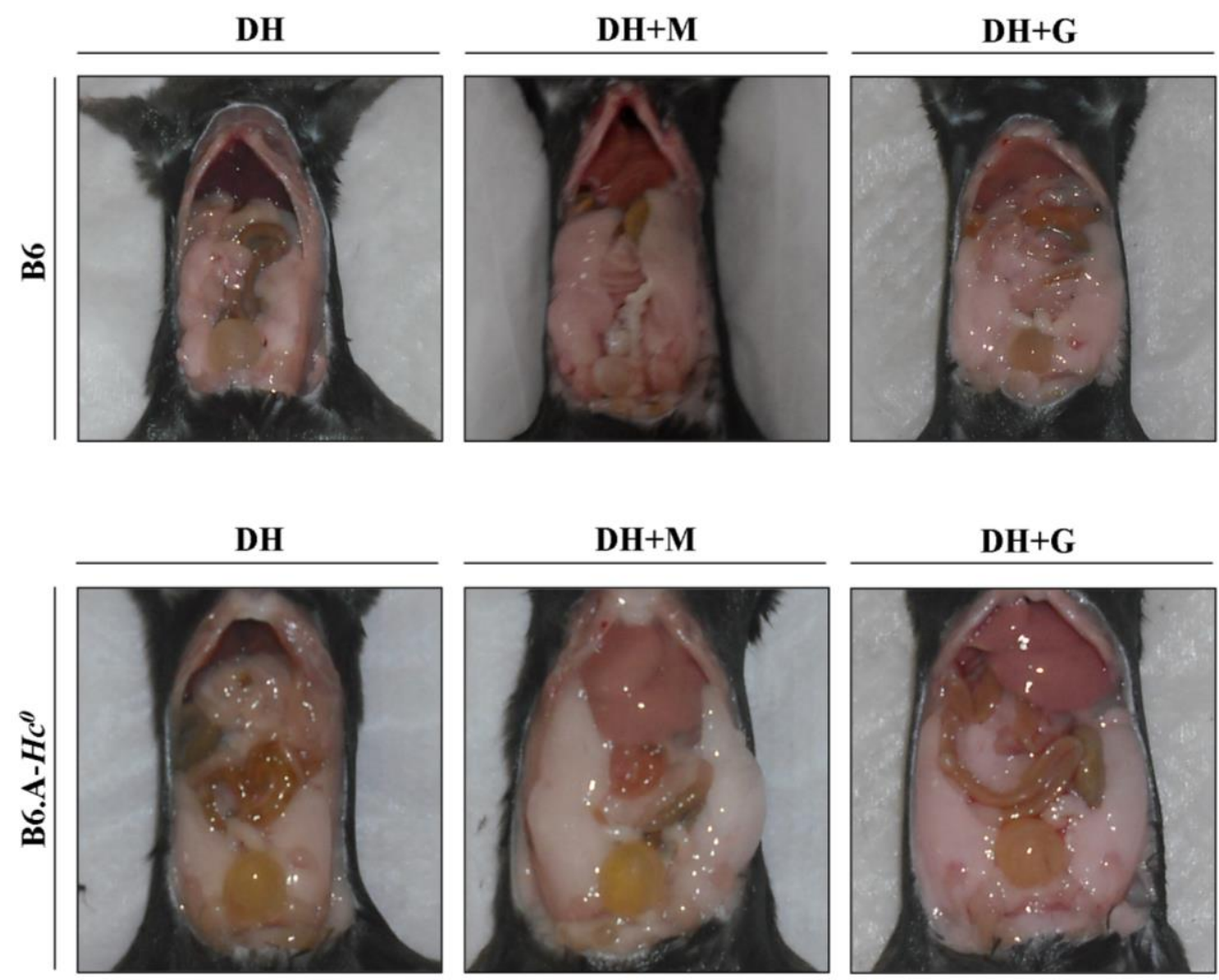

Foto representativa do grupo onde empregamos pelo menos $\mathrm{n} \geq 6$ camundongos de cada linhagem. Siglas presentes na figura representam: dieta hiperlipídica $(\mathrm{DH})$; dieta hiperlipídica contendo maltodextrina $(\mathrm{DH}+\mathrm{M})$; dieta hiperlipídica contendo glicose $(\mathrm{DH}+\mathrm{G})$.

O aumento na razão do peso tecido adiposo / peso corporal e o aumento do acúmulo de gordura abdominal em ambas as linhagens tratadas com glicose confirmou que nosso modelo induziu uma das características esperadas para a DHNA. Com estes resultados concluímos que a presença ou não de C5 no fundo genético B6 foi indiferente tanto para provocar alterações na razão do peso tecido adiposo / peso corporal como para aumentar o acúmulo de gordura abdominal (Figura A.17 e A.18). 
Em condições de DHNA espera-se encontrar além da gordura abdominal acúmulo de gordura hepática (NAGATA; SUZUKI; SAKAGUCHI, 2008). Para investigar possíveis alterações no tecido hepático entre as linhagens avaliamos a razão do peso hepático pelo peso corporal (Figura A.19) e avaliamos também o depósito de triglicerídeos e colesterol total por grama de tecido hepático (Figura A.20).

Avaliando a razão do peso hepático pelo peso corporal encontramos efeito de interação entre linhagem e tratamento, $p=0,033$. Onde, após o tratamento com $\mathrm{DH}+\mathrm{G}$ os camundongos B6.A- $\mathrm{Hc}^{0}$ apresentaram aumento significativo da razão peso hepático / peso corporal em comparação aos camundongos B6, $p<0,05$. Avaliando a presença de diferença entre os tratamentos para os camundongos da linhagem B6 encontramos que aqueles tratados com $\mathrm{DH}+\mathrm{G}$ apresentaram significativamente menor razão do peso hepático / peso corporal que os tratados com $\mathrm{DH}+\mathrm{M}, \mathrm{p}<0,05$ (Figura A.19).

Figura A.19 - Razão do peso hepático pelo peso corporal dos camundongos B6 e B6.A-Hc ${ }^{0}$ (C5 deficientes) após 10 semanas de tratamento.

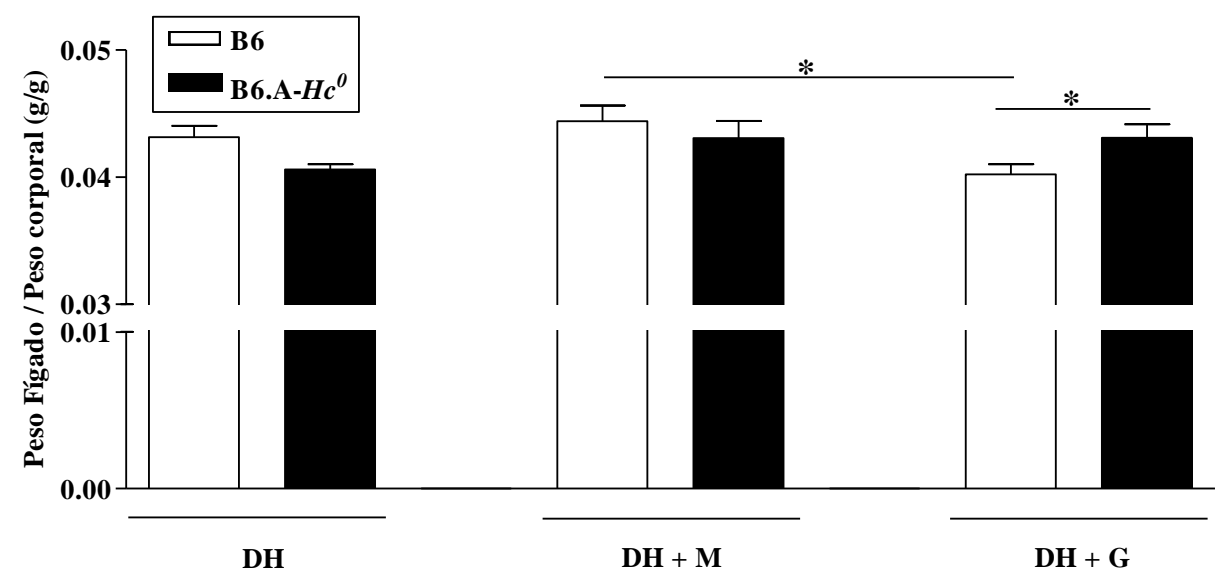

Os resultados estão representados como média e erro padrão. Empregamos pelo menos $\mathrm{n} \geq 6$ camundongos de cada linhagem, e consideramos $* p<0,05$. Siglas presentes na figura representam: dieta hiperlipídica (DH); dieta hiperlipídica contendo maltodextrina $(\mathrm{DH}+\mathrm{M})$; dieta hiperlipídica contendo glicose $(\mathrm{DH}+\mathrm{G})$.

Houve redução significativa na razão do peso hepático / peso corporal para os camundongos B6 tratados com $\mathrm{DH}+\mathrm{G}$ em comparação aos camundongos tratados com DH+M. Essa redução também foi significativa em relação aos camundongos B6.A-Hco tratados com $\mathrm{DH}+\mathrm{G}$. Com estes resultados podemos inferir que a presença de C5 no fundo genético B6 contribuiu para a redução na razão do peso hepático / peso corporal dos camundongos B6 tratados com DH+G (Figura A.19). 
Com o tecido hepático total confeccionamos um homogenato a partir do qual uma parte foi direcionada para a extração de lipídeos totais, e neste extrato quantificamos a presença de triglicerídeos (Figura A.20A) e colesterol total (Figura A.20B) por grama de fígado após 10 semanas de tratamento com $\mathrm{DH}+\mathrm{G}$ ou $\mathrm{DH}+\mathrm{M}$ ou $\mathrm{DH}$.

A análise para a concentração de triglicerídeos hepáticos mostrou que não houve efeito de interação entre linhagem e tratamento, $p=0,926$. Também não encontramos diferença significativa entre os tratamentos, $p=0,684$. Entretanto, encontramos diferença significativa entre as linhagens, $p=0,024$. Para os camundongos da linhagem B6.A- $H c^{0}$ (C5 deficiente) o depósito de triglicerídeos hepático foi significativamente maior que para os camundongos da linhagem B6 (C5 normal), $p<0,05$, independentemente do tratamento (Figura A.20A).

Quanto à determinação da concentração de colesterol hepático detectamos efeito de interação entre linhagem e tratamento, $p=0,048$. Os camundongos da linhagem B6.A- $H c^{0}$ apresentaram significativamente maior depósito de colesterol hepático que os camundongos da linhagem B6 quando tratados com DH, $p<0,05$ (Figura A.20B).

Figura A.20 - Avaliação do depósito de lipídeo do tecido hepático após 10 semanas de tratamento com as diferentes dietas hiperlipídicas empregando camundongos das linhagens B6 e B6.A-Hc ${ }^{0}$ (C5 deficientes).

(A)

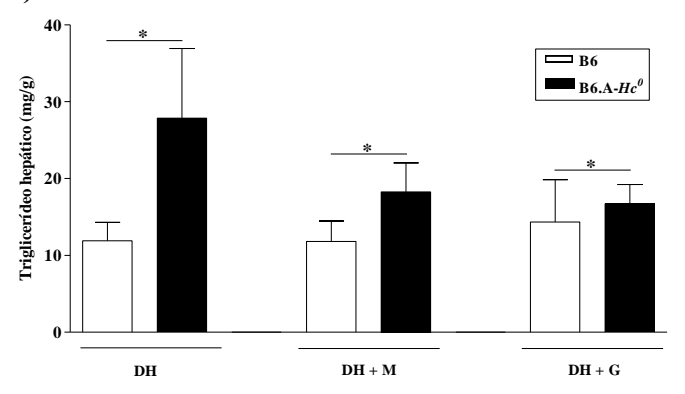

(B)

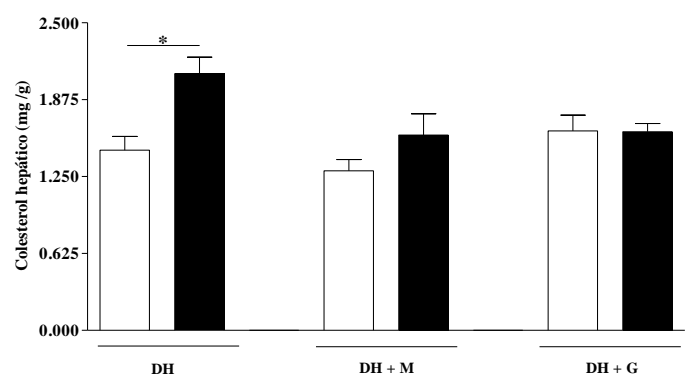

A quantificação de triglicerídeos (A) e colesterol (B) foram normalizadas por grama de tecido hepático total. Os resultados estão representados como média e erro padrão. Para todos os tratamentos aplicamos $n \geq 6$ onde * $p<0,05$. Siglas: dieta hiperlipídica (DH); dieta hiperlipídica contendo maltodextrina ( $\mathrm{DH}+\mathrm{M})$; dieta hiperlipídica contendo glicose $(\mathrm{DH}+\mathrm{G})$.

Curiosamente o depósito hepático de triglicerídeos esteve aumentado nos camundongos C5 deficientes para todos os tratamentos (Figura A.20A). Até o momento podemos dizer que os camundongos B6 quando tratados com glicose apresentaram menor razão do peso hepático / peso corporal e menor concentração de triglicerídeos hepáticos em relação aos B6.A-Hc ${ }^{0}$. 
Com base nos resultados apresentados nas Figuras A.19 e A.20 ainda são necessárias as análises histopatológicas para concluirmos sobre o depósito lipídico e processo inflamatório no tecido hepático decorrido após o tratamento dos camundongos com $\mathrm{DH}+\mathrm{G}$ por 10 semanas.

Na Figura A.21 apresentamos os resultados da avaliação histopatológica. E nas Figuras A.22 e A.23 apresentaremos secções representativas da análise dos parâmetros histopatológicos do tecido hepático em coloração HE e picrossírius, respectivamente.

O acúmulo de lipídeos neutros dentro dos hepatócitos é denominado patologicamente como esteatose (SCHEUER; LEFTKOWITCH, 2000). Investigamos a presença de esteatose nos cortes histopatológicos hepáticos pela distribuição tecidual respeitando a porcentagem e os escores estabelecidos por Kleiner et al. (2005). Portanto, primeiro avaliamos estatisticamente a porcentagem tecidual de esteatose aplicando o teste ANOVA para 2 fatores (linhagem e tratamento) e identificamos que não houve efeito de interação significativo entre linhagem e tratamento, $p=0,196$, e nem diferença significativa entre as linhagens, $p=0,506$. Entretanto, identificamos diferença significativa entre os tratamentos, $p<0,001$, onde independentemente da linhagem dos camundongos os tratamentos com $\mathrm{DH}+\mathrm{M}$ e $\mathrm{DH}+\mathrm{G}$ induziram significativamente maior porcentagem de esteatose hepática do que o tratamento apenas com DH, $p<0,05$ (Figura A.21A).

Para avaliar estatisticamente dados categóricos como os escores de esteatose ( 0 a 3), balonização (0 a 2), inflamação lobular (0 a 3) e fibrose ( 0 a 4) aplicamos o modelo LogLinear, pois não dados categóricos, e portanto não seguem uma distribuição normal. Analisando o parâmetro esteatose identificamos que houve efeito de interação significativo entre tratamento e esteatose, com $p=0,001$. Observamos que para os tratamentos com $\mathrm{DH}+\mathrm{G}$ e com DH+M a maior porcentagem das lâminas apresentaram escore 1 de esteatose, $60 \%$ e $47 \%$, e com escore 2 observamos $39 \%$ e $29 \%$ das lâminas, respectivamente. Entretanto, para o tratamento com DH a maior porcentagem das lâminas encontrou-se no escore 0 de esteatose, $71 \%$, e $29 \%$ das lâminas no escore 1 . Não identificamos diferença significativa entre as linhagens (Figura A.21B).

Falhas no mecanismo de controle osmótico celular podem levar ao alto influxo de água para dentro da célula, o qual patologicamente é classificado como degeneração hidrópica, ou balonização (SCHEUER; LEFTKOWITCH, 2000). Portanto avaliando à balonização dos hepatócitos dos camundongos B6 e B6.A- $\mathrm{Hc}^{0}$ identificamos a presença de efeito de interação significativo entre tratamento e balonização, $p<0,05$, onde os camundongos de ambas as linhagens quando tratados com $\mathrm{DH}+\mathrm{G}$ e $\mathrm{DH}+\mathrm{M}$ apresentaram 
cerca de $50 \%$ e $47 \%$, respectivamente, de balonização distribuídos entre o escore 1 . E $30 \% 3$ $41 \%$, respectivamente, das lâminas apresentaram escore 2 de balonização. Já os tratados com DH apresentaram 64\% e 22\% das lâminas distribuídas entre os escores 0 e 1, respectivamente (Figura A.21C).

A inflamação lobular é dada pela presença de focos de infiltrado celular, ou seja células inflamatórias, no centro do lóbulo hepático (SCHEUER; LEFTKOWITCH, 2000). Identificamos efeito de interação significativo entre linhagem e inflamação lobular. (Figura A.21D). Por meio da análise foi possível observar que dentre os camundongos da linhagem B6 a distribuição das lâminas quanto à inflamação lobular foi $9 \%$ no escore $0,73 \%$ no escore 1 e $18 \%$ no escore 2. Já para os camundongos congênicos B6.A- $\mathrm{Hc}^{0}$ encontramos $42 \%$ das lâminas no escore 0,48\% distribuídas no escore 1 e $10 \%$ distribuídas no escore 2. Ou seja, as linhagens diferem quanto à inflamação, sendo que os camundongos B6 apresentaram maior inflamação lobular que os camundongos congênicos B6.A-Hc ${ }^{0}$ independentemente do tratamento.

A fibrose hepática ocorre em resposta a um processo regenerativo após um dano ou uma injúria sofrido pelo fígado. Neste contexto ocorre a substituição dos hepatócitos agredidos ou mortos (necrose) por fibras de colágeno com a finalidade de reparar o tecido lesado e dependendo do tempo, intensidade e extensão da injúria ela poder ser reversível ou não. O resultado da sua progressão é formação de septos e perda da função da região fibrosada (SCHEUER; LEFTKOWITCH, 2000). O método estatístico aplicado também não identificou interações ou diferenças significativas entre as linhagens e os tratamentos para o parâmetro fibrose (Figura A.21E).

Conforme descrito em MATERIAIS E MÉTODOS as lesões hepáticas foram graduadas de acordo com os critérios estabelecidos por Kleiner et al. (2005), com pequenas modificações, gerando o índice de atividade da doença hepática não-alcoólica (ou DHNA), mesma análise empregada no modelo de DHA. Este índice incluiu apenas características da lesão ativa, sendo definido pela soma dos graus de esteatose macro/microgoticular ( 0 a 3$)$, inflamação lobular ( 0 a 3) e balonização (0 a 2). Dessa maneira, os valores do índice de atividade da DHNA variaram entre 0 e 8 , sendo que para humanos um índice de atividade da DHNA $\geq 5$ correlaciona-se com o diagnóstico de esteatohepatite não-alcoólica (ENA), uma forma mais severa da doença. Por outro lado, animais com índice de atividade da DHNA $\geq 3$ ou 4 foram considerados como prováveis portadores da ENA. Avaliamos o índice de atividade da DHNA estatisticamente pela metodologia ANOVA para 2 fatores. Não identificamos efeito de interação entre linhagem e tratamento, $p=0,467$, nem entre as 
linhagens, $\mathrm{p}=0,253$. Mas encontramos diferença significativa entre os tratamentos, $p<0,001$, onde independentemente da linhagem os camundongos tratados com $\mathrm{DH}+\mathrm{M}$ ou $\mathrm{DH}+\mathrm{G}$ apresentaram significativamente maior índice de atividade da DHNA que os que receberam DH. Segundo os valores do índice, estes grupos também apresentaram a média dos camundongos dentro da faixa que inclui os índices de atividade da DHNA entre 3 e 4, e portanto foram diagnosticados com ENA (Figura A.21F).

Avaliando os parâmetros histopatológicos identificamos que independentemente da linhagem, esteatose, balonização e o índice de atividade da DHNA estiveram significativamente aumentadas nos camundongos tratados com $\mathrm{DH}+\mathrm{G}$ e $\mathrm{DH}+\mathrm{M}$ em relação aos camundongos tratados com apenas $\mathrm{DH}$. Dependentemente das linhagens encontramos que os camundongos B6.A-Hc inflamaram menos que os camundongos B6 (Figura A.21).

Na Figura A.22 apresentamos os cortes histológicos corados em HE que são representativos dos grupos avaliados. Ressaltamos a presença de esteatose em ambas as linhagens tratadas com $\mathrm{DH}+\mathrm{G}$ e $\mathrm{DH}+\mathrm{M}$ nas regiões intermediárias entre o espaço porta hepático e a veia centro lobular. Embora seja possível observar maior área esteatótica nos camundongos da linhagem B6 tratados com $\mathrm{DH}+\mathrm{G}$ em relação aos camundongos congênicos B6.A-Hc $c^{0}$, não houve diferença significativa entre as linhagens. Houve apenas efeito de interação entre tratamento e esteatose. Na Figura A.23 apresentamos os cortes histológicos avaliados em coloração picrossírius que são representativos dos grupos de tratamento. Ressaltamos a presença de depósito de fibras de colágeno próxima aos vasos que compõe a região do espaço porta e da região centro lobular e também no parênquima hepático em menor proporção. Embora seja possível observar o depósito de colágeno entre as regiões dos vasos nos camundongos de ambas as linhagens tratadas com $\mathrm{DH}+\mathrm{G}$ e $\mathrm{DH}+\mathrm{M}$ em relação aos camundongos tratados apenas com $\mathrm{DH}$, não identificamos diferença estatística. A quantificação de fibrose foi apresentada na Figura A.21E.

É possível que o controle equicalórico $\mathrm{DH}+\mathrm{M}$ não seja um controle ideal a longo prazo, pois segundo os parâmetros histopatológicos: esteatose, balonização e inflamação esta dieta leva ao desenvolvimento dos mesmos sintomas esperados para o modelo de DHA (abordado no CAPÍTULO 2) e DHNA. De qualquer forma, mostramos com estes resultados que o consumo crônico de maltodextrina em conjunto a uma dieta hiperlipídica favoreceu o desenvolvimento de esteatose e inflamação hepática. 
Figura A.21 - Análise estatística dos parâmetros histopatológicos avaliados nos cortes de tecido hepático após 10 semanas de tratamento com as diferentes dietas hiperlipídicas, empregando as linhagens B6 e B6.A- $\mathrm{Hc}^{0 .}$ (C5 deficiente).
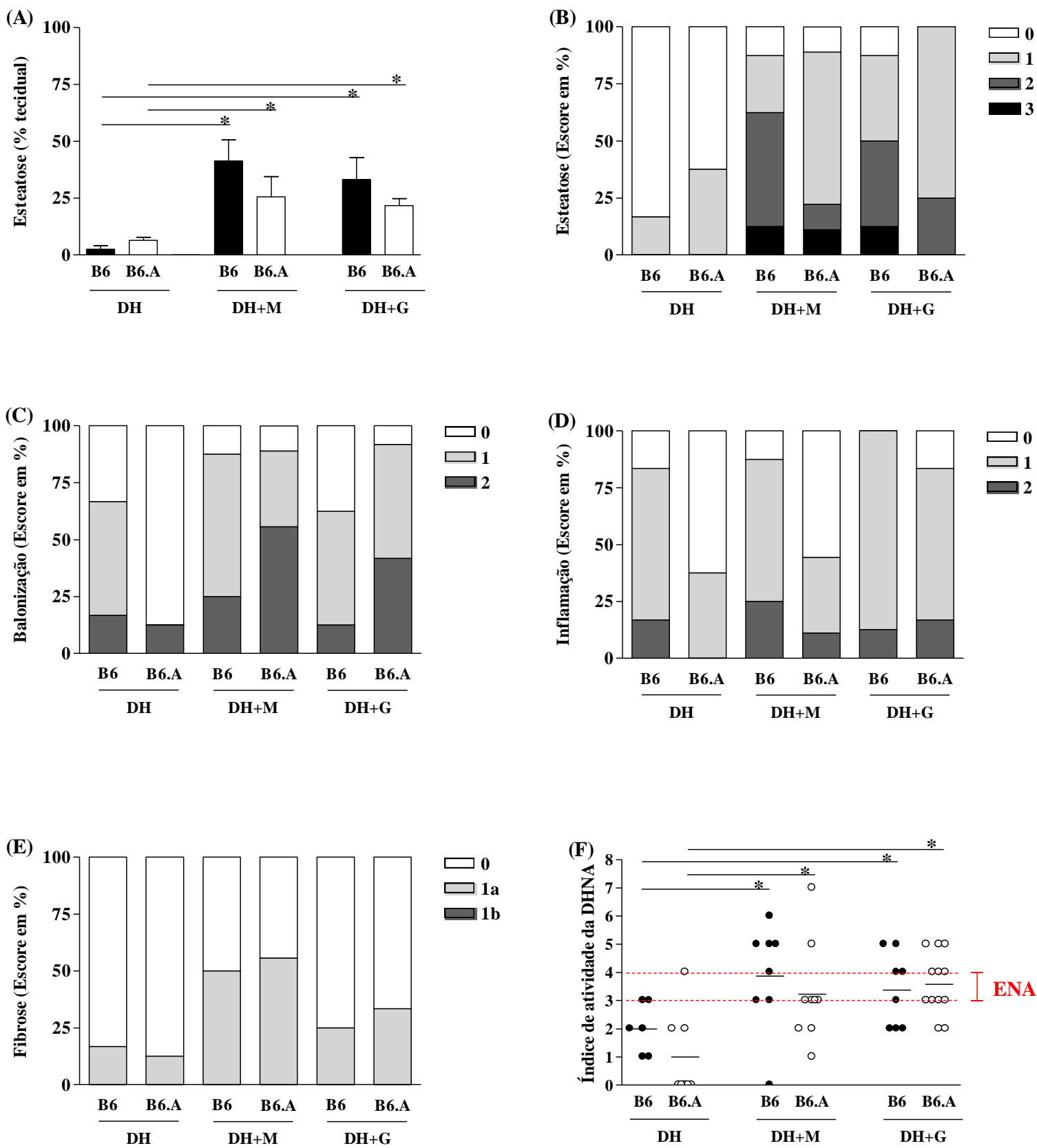

Avaliamos no tecido hepático a distribuição de esteatose (A e B), balonização (C), inflamação (D) e fibrose (E). De (B) a (E) os números 0, 1, 1a, 1b, 2, e 3 presentes nas figuras representam os escores empregados na avaliação histopatológica como descritas nas Tabelas 9 e 10 presentes em MATERIAIS E MÉTODOS. Em (F) apresentamos o índice de DHA, dentro do qual identificamos os camundongos que apresentam a forma mais avançada da DHA, a EHA, onde a barra representa a média do grupo. Os resultados estão representados como média e erro padrão. Siglas DH: dieta hiperlipídica; $\mathrm{DH}+\mathrm{M}$ : dieta hiperlipídica contendo maltodextrina; $\mathrm{DH}+\mathrm{G}$ : dieta hiperlipídica contendo glicose; DHNA: Doença hepática Não Alcoólica. ENA: esteatohepatite nãoalcoólica, B6.A: B6.A-Hc ${ }^{0}, \mathrm{n} \geq 6,{ }^{*} p<0,05$. 
Figura A.22 - Cortes representativos dos parâmetros histopatológicos avaliados em coloração HE após 10 semanas de tratamento com as diferentes dietas hiperlipídicas, empregando as linhagens B6 e B6.A- $\mathrm{Cc}^{0}$ (C5 deficiente).
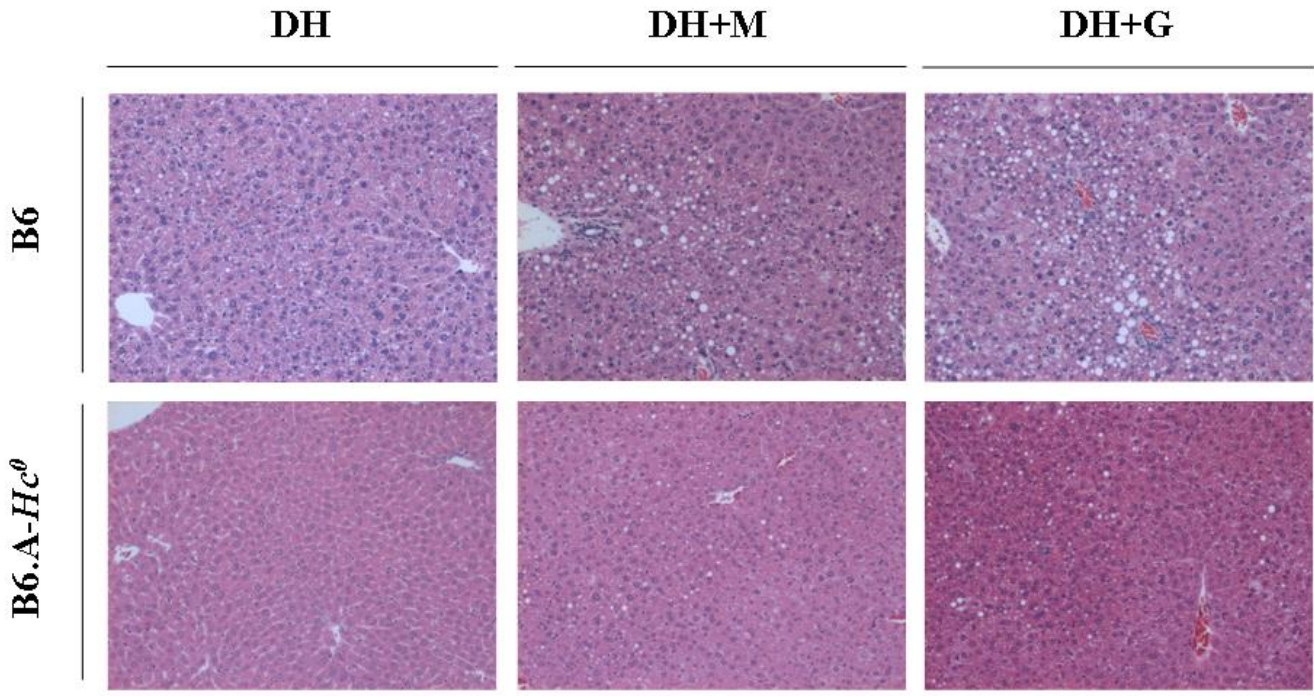

As siglas presentes na figuras indicam a dieta administrada aos camundongos B6 e B6.A- $\mathrm{Hc}^{0}$ onde DH: dieta hiperlipídica; $\mathrm{DH}+\mathrm{M}$ : dieta hiperlipídica contendo maltodextrina; $\mathrm{DH}+\mathrm{G}$ : dieta hiperlipídica contendo glicose. Aumento 10x.

Figura A.23 - Cortes representativos dos parâmetros histopatológicos avaliados em coloração picrossírius após 10 semanas de tratamento com as diferentes dietas hiperlipídicas, empregando as linhagens B6 e B6.A- $\mathrm{Hc}^{0}$ (C5 deficiente).
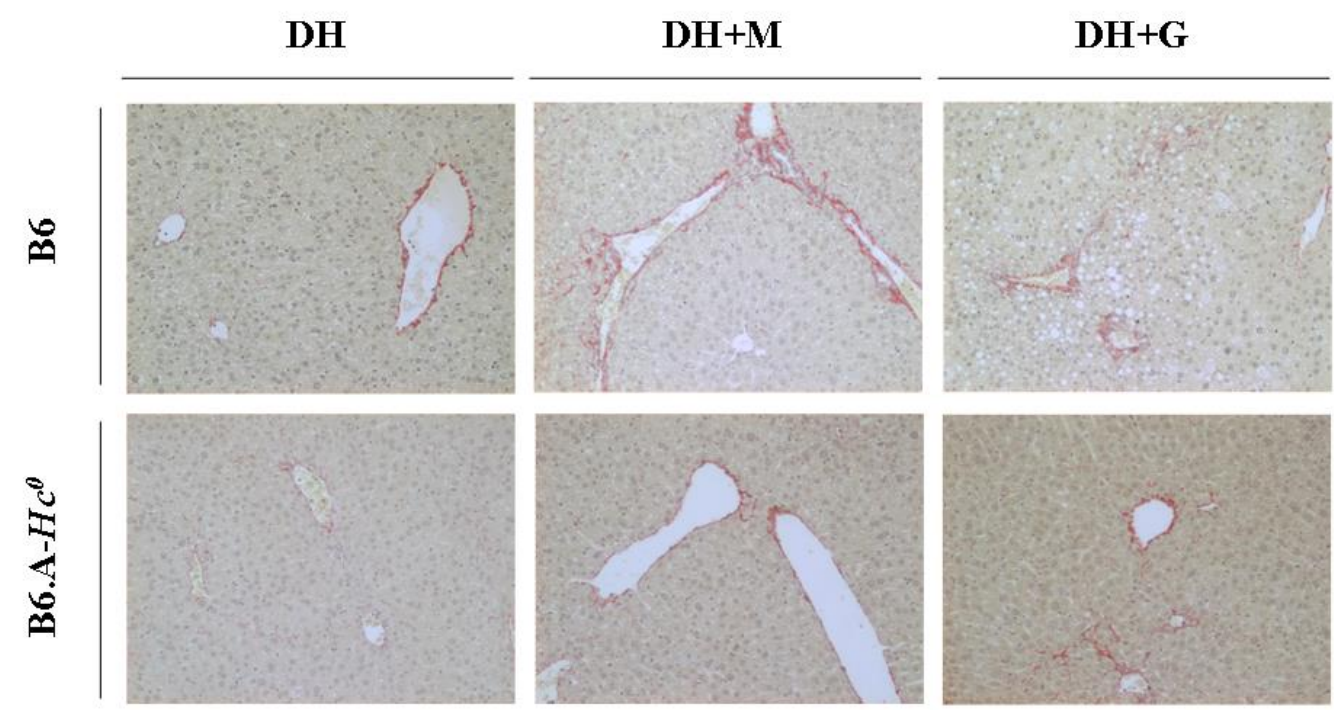

As siglas presentes na figuras indicam a dieta administrada aos camundongos $\mathrm{B} 6$ e B6.A- $\mathrm{Hc}^{0}$ onde DH: dieta hiperlipídica; DH+M: dieta hiperlipídica contendo maltodextrina; DH+G: dieta hiperlipídica contendo glicose. Aumento 10x. 
Conclusão da seç̃ão 3.2.1: O tratamento com $D H+G$ promoveu o ganho de peso (Figura A.15 e A.16) e induziu o aumento da razão do peso do tecido adiposo / peso corporal (Figura A.17) para ambas as linhagens, reduziu a razão entre o peso hepático pelo peso corporal nos camundongos da linhagem B6 (Figura A.19). Complementando estes resultados a análise histopatológica mostrou que para ambas as linhagens o tratamento com $\mathrm{DH}+\mathrm{G}$ ou $\mathrm{DH}+\mathrm{M}$ induziu maior proporção de esteatose, balonização, e índice de atividade de DHNA em relação ao tratamento com apenas DH (Figura A.21F). Identificamos que as linhagens $\mathrm{B6}$ e B6.A-Hc diferiram significativamente quanto ao depósito de triglicérides e colesterol hepático, onde a linhagem C5 deficiente apresentou maior concentração destes lipídeos que os camundongos da linhagem B6, independentemente do tratamento (Figura A.20). Por fim, as linhagens também diferiram, quanto à distribuição de inflamação lobular, sendo menor nos camundongos B6.A-Hc ${ }^{0}$ (Figura A.21D).

\subsubsection{Avaliação função hepática, bioquímica e hematológica}

A função hepática foi avaliada bioquimicamente, considerando-se os seguintes parâmetros: (a) presença de lesão hepatocelular pela quantificação dos níveis séricos de alanina aminotransferase (ALT) e aspartato aminostransferase (AST); (b) presença de lesão das vias biliares e fluxo biliar, pela concentração sérica de fosfatase alcalina (FA); e, (c) alterações de síntese hepática, avaliando-se a concentração de albumina circulante (Figura A.24).

Dentre os parâmetros que identificam lesão hepatocelular, não encontramos diferença significativa para a concentração sérica da ALT. Já para a concentração sérica da AST não detectamos efeito de interação entre linhagem e tratamento, $p=0,994$, também não encontramos diferença significativa entre os tratamentos, $p=0,995$. No entanto, encontramos diferença significativa entre as linhagens, $p=0,040$. Os camundongos da linhagem B6.A- $H c^{0}$ apresentaram maior concentração sérica de AST que os camundongos da linhagem B6 independentemente do tratamento aplicado aos animais (Figura A.24A).

Não observamos efeito de interação entre linhagem e tratamento no que diz respeito à análise da concentração sérica de FA. Entretanto, detectamos uma indicação de efeito de interação entre linhagem e tratamento, $p=0,052$. A indicação aponta para uma possível diferença entre os tratamentos aplicados nos camundongos da linhagem B6.A- $\mathrm{C}^{0}$, onde a 
concentração sérica de FA sérica tende a reduzir nos tratados com $\mathrm{DH}+\mathrm{G}$ em relação aos tratados com DH+M e DH, $p=0,052$. (Figura A.24B).

Quanto à concentração sérica de albumina, também não observamos efeito de interação entre linhagem e tratamento, $p=0,370$. Também, não houve diferença significativa entre os tratamentos, $p=0,578$, mas, identificamos diferença significativa entre as linhagens, $p<0,001$. Os camundongos da linhagem B6.A- $H c^{0}$ apresentaram maior concentração de albumina sérica que os camundongos da linhagem B6 independentemente do tratamento (Figura A.24C).

Considerando os parâmetros de função hepática, a linhagem congênica B6.A-Hc ${ }^{0}$ (C5 deficiente) apresentou aumento nas concentrações de AST e albumina em relação à linhagem B6, independentemente do tratamento. Mas, com relação à concentração sérica de FA o tratamento dos camundongos B6.A-Hco com $\mathrm{DH}+\mathrm{G}$ influenciou a redução na concentração de $\mathrm{FA}$ em relação àqueles que receberam $\mathrm{DH}+\mathrm{M}$ ou apenas $\mathrm{DH}$. Estas alterações serão melhor exploradas na discussão (Figuras A.24 A-C).

Visando identificar alteração na concentração sérica de glicose frente aos diferentes tratamentos observamos efeito de interação entre linhagem e tratamento, $p=0,024$. Encontramos que as linhagens diferiram significativamente entre si quando tratadas apenas com DH, onde a concentração de glicose sérica nos camundongos B6.A- $H c^{0}$ foi menor que a concentração observada nos camundongos B6. Ainda, para os camundongos B6.A-Hc ${ }^{0}$ tratados com $\mathrm{DH}+\mathrm{G}$ observamos aumento significativo de glicose sérica em relação aos tratados apenas com DH, $p<0,05$. Para os camundongos B6 a concentração sérica de glicose não se alterou com os tratamentos, manteve-se constante (Figura A.24D).

Finalmente, investigamos as concentrações séricas de triglicerídeos e colesterol total. Segundo as análises aplicadas para a concentração sérica de triglicerídeos não identificamos efeito de interação entre linhagem e tratamento, $p=0,195$. Também não encontramos diferença significativa entre os tratamentos, $p=0,255$. Mas, encontramos diferença significativa entre as linhagens, $p=0,022$. Portanto, os camundongos da linhagem B6.A- $H c^{0}$ apresentaram maior concentração de triglicerídeos séricos que a linhagem B6, independentemente do tratamento (Figura A.24E). Considerando-se os níveis séricos de colesterol não identificamos qualquer efeito de interação entre linhagem e tratamento, $p=0,637$. Mas, encontramos diferença significativa entre os tratamentos, $p=0,023$, onde os camundongos tratados com DH apresentaram significativamente menor concentração sérica 
de colesterol que aqueles tratados com $\mathrm{DH}+\mathrm{M}, p<0,05$. Também encontramos diferença significativa entre as linhagens, $p<0,001$. Os camundongos da linhagem B6.A-Hc apresentaram maior concentração de colesterol sérica que os camundongos da linhagem B6, independentemente do tratamento (Figura A.24F).

Figura A.24 - Avaliação da função hepática e de parâmetros fisiológicos gerais dos camundongos da linhagem B6 e da linhagem congênica B6.A-Hc ${ }^{0}$ (C5 deficientes) após 10 semanas de tratamento com diferentes dietas hiperlipídicas.
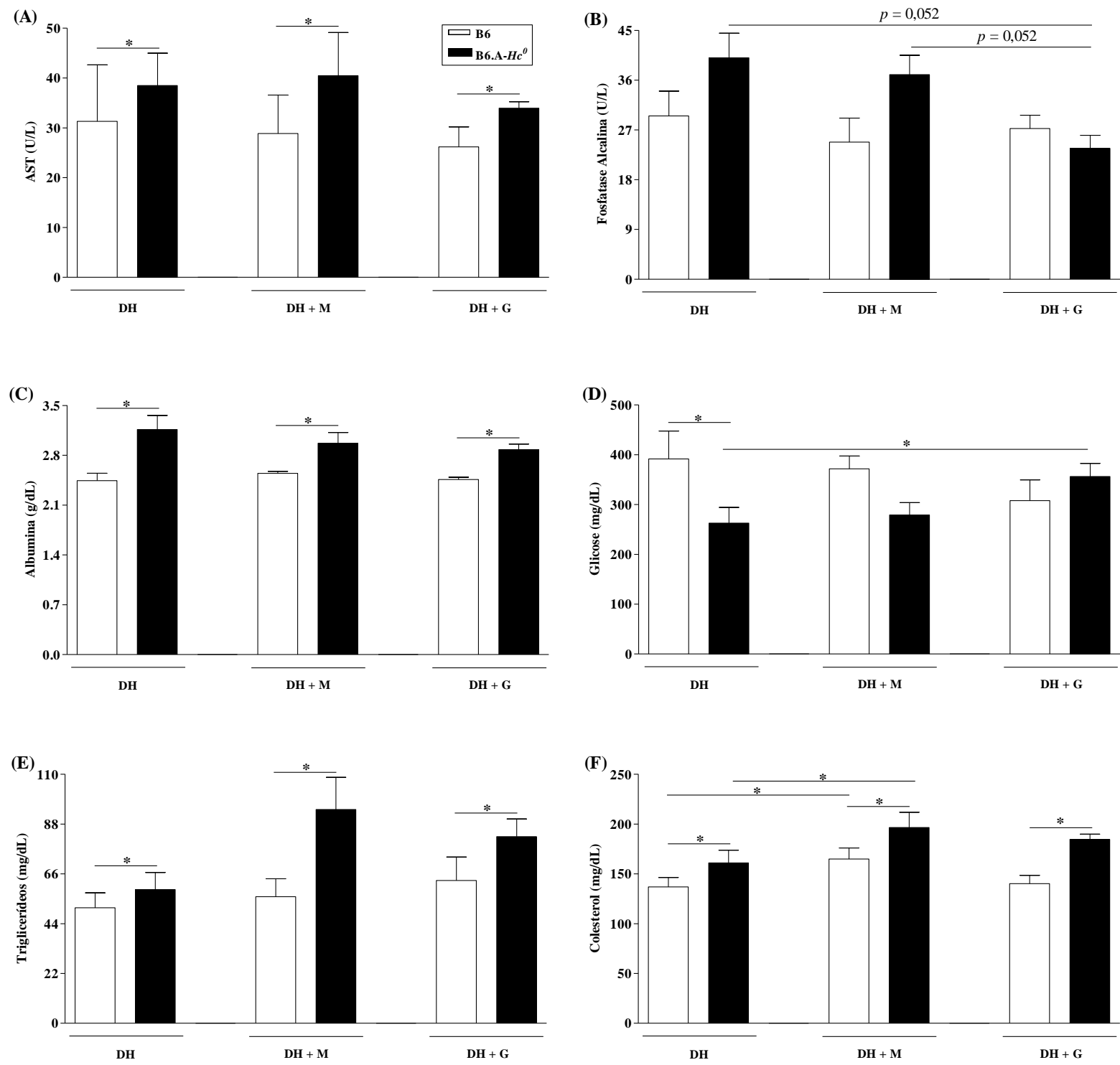

Os resultados estão representados como média e erro padrão. Empregamos pelo menos $\mathrm{n} \geq 6$ camundongos de cada linhagem e consideramos como $* p<0,05$. As siglas presentes na figura: dieta hiperlipídica (DH); dieta hiperlipídica contendo maltodextrina $(\mathrm{DH}+\mathrm{M})$; dieta hiperlipídica contendo glicose $(\mathrm{DH}+\mathrm{G})$. 
Dentre os parâmetros bioquímicos associados ao metabolismo de glicose e lipídeos encontramos que os camundongos da linhagem B6.A-Hc ${ }^{0}$ apresentaram aumento da concentração sérica de glicose após o tratamento com $\mathrm{DH}+\mathrm{G}$, sugerindo que a ausência de C5 frente ao tratamento com $\mathrm{DH}+\mathrm{G}$ permitiu o aumento sérico de glicose, uma vez que nos camundongos B6 os níveis séricos de glicose mantiveram-se constantes para os três tratamentos (Figura A.24D). Com relação aos lipídeos circulantes observamos que a ausência de C5 promoveu um aumento da circulação de triglicerídeos e colesterol independentemente do tratamento (Figura A.24E e A.24F).

Avaliando o número de leucócitos totais do sangue periférico não detectamos efeito de interação entre linhagem e tratamento, $p=0,092$. Não encontramos diferença significativa entre os tratamentos, $p=0,361$. Mas, encontramos diferença significativa entre as linhagens, $p<0,001$. A linhagem B6.A- $H c^{0}$ apresentou maior número de leucócitos circulantes em relação à linhagem B6 independentemente do tratamento, possivelmente sendo esta uma característica da linhagem. (Figura A.25).

Figura A.25 - Contagem absoluta dos leucócitos circulantes no sangue periférico dos camundongos B6 e B6.A-Hc (C5 deficientes) após 10 semanas de tratamento com as diferentes dietas hiperlipídicas.

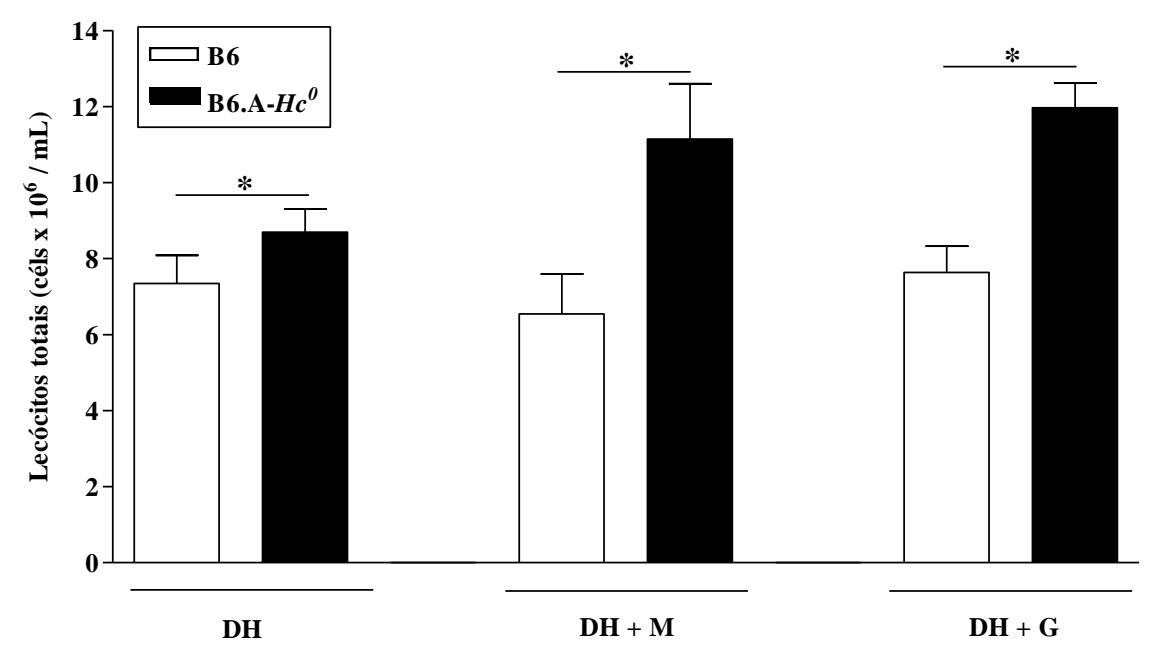

Os resultados estão representados como média e erro padrão. Empregamos pelo menos $\mathrm{n} \geq 6$ camundongos de cada linhagem e consideramos como $* p<0,05$. As siglas presentes na figura: dieta hiperlipídica (DH); dieta hiperlipídica contendo maltodextrina $(\mathrm{DH}+\mathrm{M})$; dieta hiperlipídica contendo glicose $(\mathrm{DH}+\mathrm{G})$.

Conclusão da secão 3.2.2: Identificamos que independentemente dos tratamentos os camundongos congênicos B6.A-Hc ${ }^{0}$ (C5 deficientes) apresentaram as concentrações 
séricas de: AST, albumina, triglicerídeos, colesterol total e o número de leucócitos significativamente maiores que os camundongos B6 (C5 normais). Possivelmente estas características refletem as alterações metabólicas associadas à ausência da proteína C5 no fundo genético B6. Apenas a concentração sérica da glicose aumentou nos camundongos B6.A-Hc ${ }^{0}$ após o tratamento com a $\mathrm{DH}+G$, já nos camundongos B6 não encontramos alterações para a concentração sérica de glicose.

\section{$\underline{\text { 3.2.3 Avaliação da resposta inflamatória no micro-ambiente hepático }}$}

A partir do homogenato hepático, quantificamos as seguintes citocinas próinflamatórias: TNF- $\alpha$, IL-1ß, IL-6, IL-17, IFN- $\gamma$, IL-12p(70) (Figura A.26A-F) e a citocina anti-inflamatória: IL-10 (Figura A.27A). Além disso, também determinamos indiretamente a síntese de NO no ambiente hepático (Figura A.27B). Todas as dosagens foram normalizadas pela concentração de proteínas totais presentes no homogenato.

Estudos anteriores mostraram que a citocina $\mathrm{TNF}-\alpha$ possui uma participação importante na indução de lesão tecidual e manutenção do micro-ambiente pró-inflamatório no tecido hepático em condições de DHNA (NAGATA; SUZUKI; SAKAGUCHI, 2008). Devido a isso avaliamos a concentração da citocina pró-inflamatória TNF- $\alpha$ nos camundongos B6 e B6.A- $H c^{0}$. Quanto à concentração da citocina TNF- $\alpha$ não detectamos efeito de interação entre linhagem e tratamento, $p=0,551$. E também não encontramos diferença significativa entre as linhagens, $p=0,611$. Entretanto, encontramos diferença significativa entre os tratamentos, $p=0,012$. Independentemente da linhagem, os camundongos tratados com $\mathrm{DH}+\mathrm{G}$ apresentaram aumento significativo na concentração de TNF- $\alpha$ no tecido hepático em relação aos camundongos tratados apenas com DH (Figura A.26A).

A citocina IL-1ß é o principal produto da ativação do inflamassoma (CSAK et al., 2011) e nossos dados da padronização do modelo de DHNA mostraram que nos camundongos $\mathrm{A} / \mathrm{J}$ tratados com $\mathrm{DH}+\mathrm{G}$ esta citocina esteve aumentada em todos os tempos de tratamento em relação aos controles (Figura A.14B), portanto julgamos pertinente dosá-la nos camundongos congênicos submetidos às mesmas dietas. Avaliando concentração da citocina IL-1ß no homogenato hepático não detectamos efeito de interação entre linhagem e tratamento, $p=0,666$, nem encontramos diferença significativa entre os tratamentos, $p=0,839$. Mas, encontramos diferença significativa entre as linhagens, $p=0,007$. Independentemente do 
tratamento os camundongos B6.A- $H c^{0}$ apresentaram menor concentração de IL-1ß hepática que os camundongos B6 (Figura A.26B).

A citocina IL-6 além de funções pro-inflamatória também exerce um importante papel hepatoprotetor em condições de injúria hepática induzida por etanol (HONG et al., 2002). Além disso, os resultados obtidos durante a padronização mostraram que a citocina IL-6 teve a sua concentração reduzida ao longo das semanas de tratamento (Figura A.14C). Quanto à citocina IL-6 não identificamos efeito de interação entre linhagem e tratamento, $p=0,960$. Também não encontramos diferença significativa entre os tratamentos, $p=0,797$. Mas, encontramos diferença significativa entre as linhagens, $p=0,033$. Portanto, os camundongos da linhagem B6.A- $H c^{0}$ apresentaram menor concentração da citocina IL-6 hepática que os da linhagem B6 independentemente do tratamento (Figura A.26C).

A citocina IL-17 é sintetizada pelas células Th17 ativadas, quando infiltradas no tecido hepático e sob condições patológicas desencadeadas pela DHNA acentua a esteatose e inflamação hepática atraindo neutrófilos e outras células presentes no sangue para o fígado (TANG et al., 2011). Os resultados obtidos a partir da padronização do modelo de DHNA mostraram que a concentração desta citocina reduziu-se significativamente nos camundongos B6 tratados com DH+G em relação aos controles (Figura A.14D). Portanto investigamos a concentração da citocina IL-17 no tecido hepático dos camundongos B6 e B6.A- $H c^{0}$ após 10 semanas de tratamento com as diferentes dietas. Quanto à concentração da citocina IL-17 não identificamos efeito de interação entre linhagem e tratamento, $p=0,633$, nem encontramos diferença significativa entre os tratamentos, $p=0,563$. Entretanto, encontramos diferença significativa entre as linhagens, $p<0,001$. Independentemente do tipo de tratamento os camundongos B6.A-Hc ${ }^{0}$ apresentaram significativamente menor concentração de IL-17 no tecido hepático que os camundongos B6 (Figura A.26D).

Completando a análise das citocinas pró-inflamatórias avaliamos a concentração da citocina IFN- $\gamma$ nos tecidos hepáticos dos camundongos B6 e B6.A- $H c^{0}$ tratados com as diferentes dietas hiperlipídicas por 10 semanas. Não identificamos efeito de interação entre linhagem e tratamento para a concentração de IFN- $\gamma, p=0,460$. Também, não encontramos diferença significativa entre os tratamentos, $p=0,958$. Todavia, encontramos diferença significativa entre as linhagens, $p=0,031$, onde os camundongos da linhagem B6.A- $H c^{0}$ apresentaram significativamente menor concentração de IFN- $\gamma$ hepática em relação aos camundongos da linhagem B6 independentemente do tratamento (Figura A.26E).

Na sequência, dosamos e avaliamos as concentrações das citocinas IL-12p(40) e p(70), pois durante a DHNA as células de Kupffer quando ativadas secretam IL-8, IL-12 e INF- $\gamma$ 
(VALENTI et al., 2009). E ainda, a análise estatística da concentração de IL-12 aplicada aos resultados da padronização do modelo de DHNA mostrou que a concentração de IL-12 reduziu significativamente com o tempo de exposição dos camundongos às dietas (Figura A.14E e A.14F). Avaliamos aqui tanto a sub-unidade p(40) quanto a citocina íntegra dada pela análise da p(70), entretanto apresentaremos na Figura A.26F apenas o resultados da $\mathrm{p}(70)$, uma vez que o resultado da análise estatística foi semelhante para ambas.

Para a citocina IL-12p40 não detectamos efeito de interação entre linhagem e tratamento, $p=0,527$, nem diferença significativa entre os tratamentos, $p=0,661$. Mas, encontramos diferença significativa entre as linhagens, $p=0,030$, onde a linhagem B6.A-Hc apresentou significativamente menor concentração de IL-12p40 hepática em relação à linhagem B6 independentemente do tratamento.

$\mathrm{Na}$ sequência investigamos a concentração da citocina IL-12p70 e também não detectamos efeito de interação entre linhagem e tratamento, $p=0,213$, nem diferença significativa entre os tratamentos, $p=0,414$. Contudo, encontramos diferença significativa entre as linhagens, $p=0,003$, onde os camundongos da linhagem B6.A-Hc apresentaram significativamente menor concentração de IL-12p70 no homogento hepático em relação aos camundongos da linhagem B6 independentemente da dieta dada aos animais (Figura A.26F).

Por fim, analisamos também as citocinas anti-inflamatórias IL-10 e TGF-ß. Observamos nos resultados da padronização do modelo de DHNA que os camundongos tratados com DH+G apresentaram aumento significativo de IL-10 após 10 semanas de tratamento em relação aos controles (Figura A.14G), por tanto investigamos também se os camundongos congênicos B6.A- $H c^{0}$ (C5 deficientes) também apresentariam aumento desta citocina frente ao tratamento com $\mathrm{DH}+\mathrm{G}$ para indução da DHNA. Identificamos a presença de efeito de interação entre linhagem e tratamento apenas para a citocina IL-10, $p=0,026$. Para a citocina IL-10 as linhagens diferem significativamente entre si quando tratadas apenas com DH, $p<0,05$, onde a linhagem C5 deficiente apresentou menor concentração de IL-10 que a linhagem $\mathrm{C} 5$ normal. Mas os camundongos B6.A- $\mathrm{Hc}^{0}$ quando tratados com $\mathrm{DH}+\mathrm{G}$ ou $\mathrm{DH}+\mathrm{M}$ apresentaram aumento significativo de IL-10 quando comparados aos camundongos que receberam apenas DH (Figura A.27A). Para os camundongos B6 não identificamos variação na concentração da citocina IL-10. Para a citocina TGF- $\beta$ não encontramos diferenças significativas.

$\mathrm{Na}$ sequência quantificamos a produção de NO no tecido hepático. A análise estatística para a produção de NO mostrou que existe efeito de interação entre linhagem e tratamento, $p=0,012$. Os camundongos $\mathrm{B} 6 . \mathrm{A}-\mathrm{Hc}^{0}$ tratados com $\mathrm{DH}+\mathrm{G}$ produziram 
significativamente mais $\mathrm{NO}$ que aqueles tratados com $\mathrm{DH}+\mathrm{M}$ e $\mathrm{DH}, p<0,05$, e ainda apresentaram produção significativamente maior de NO em relação aos camundongos da linhagem B6 quando tratados com $\mathrm{DH}+\mathrm{G}, p<0,05$ (Figura A.27B).

Figura A.26- Determinação das citocinas TNF- $\alpha$, IL-1ß, IL-6, IL-17, IFN- $\gamma$, IL-12p(70) nos homogenatos de tecido hepático nos camundongos das linhagens B6 e B6.A$H c^{0}$ (C5 deficientes) após 10 semanas de tratamento com as diferentes dietas hiperlipídicas.
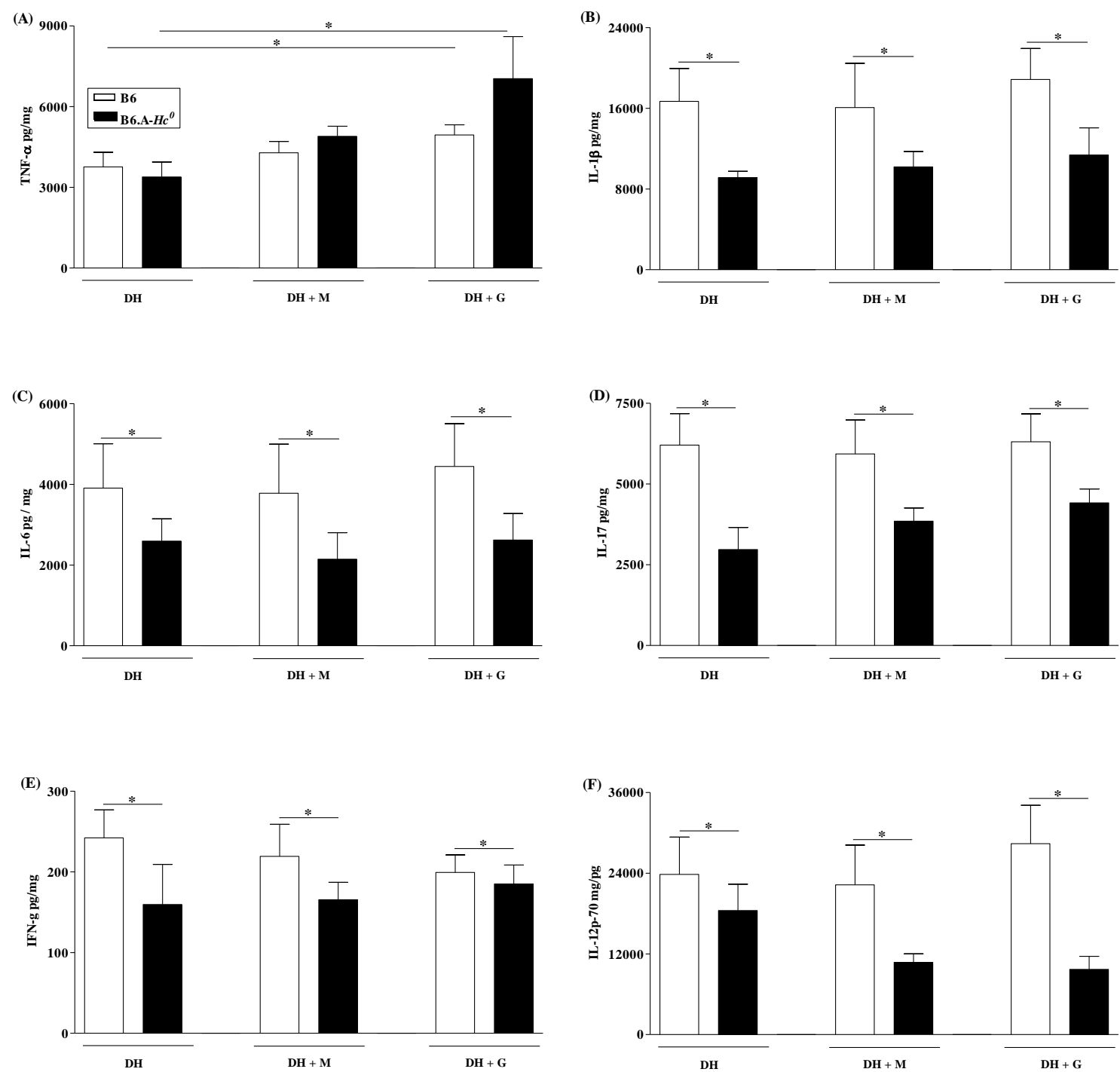

Em (A) representamos as concentrações da citocina TNF- $\alpha$, em (B) IL-1ß, em (C) IL-6, em (D) IL-17, em (E) IFN- $\gamma$ e em (F) IL-12p(70). Os resultados estão representados como média e erro padrão. Empregamos pelo menos $\mathrm{n} \geq 6$ camundongos de cada linhagem e consideramos como $* p<0,05$. As siglas presentes na figura: dieta hiperlipídica $(\mathrm{DH})$; dieta hiperlipídica contendo maltodextrina $(\mathrm{DH}+\mathrm{M})$; dieta hiperlipídica contendo glicose $(\mathrm{DH}+\mathrm{G})$. 
Figura A.27 - Determinação da concentração da citocina anti-inflamatória IL-10 e da produção de NO nos homogenatos de tecido hepático dos camundongos B6 (C5 normais) e B6.A- $\mathrm{Hc}^{0}$ (C5 deficientes) após 10 semanas de tratamento com as diferentes dietas hiperlipídicas.
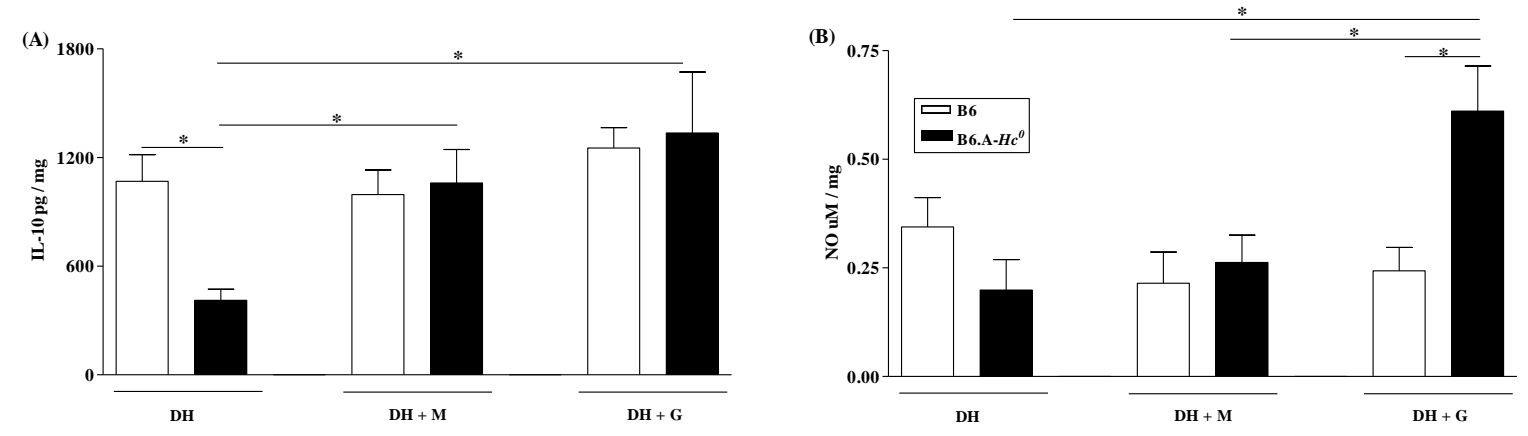

Em (A) apresentamos da determinação da concentração hepática de IL-10 e em (B) de NO. Os resultados estão representados como média e erro padrão. Empregamos pelo menos $\mathrm{n} \geq 6$ camundongos de cada linhagem e consideramos como $* p<0,05$. As siglas presentes na figura: dieta hiperlipídica (DH); dieta hiperlipídica contendo maltodextrina $(\mathrm{DH}+\mathrm{M})$; dieta hiperlipídica contendo etanol $(\mathrm{DH}+\mathrm{E})$.

Conclusão da secão 3.3.3: Ambas as linhagens apresentaram aumento significativo da concentração de TNF- $\alpha$ após o tratamento com a DH+G. Mas os camundongos congênicos B6.A-Hc ${ }^{0}$ apresentaram significativamente menor concentração das citocinas

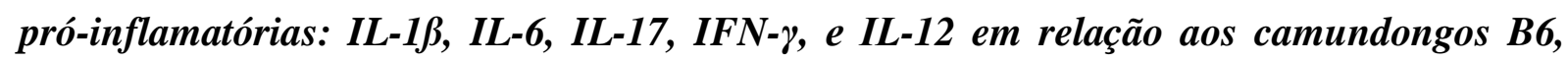
independentemente do tratamento. Ainda, os camundongos B6.A-Hc ${ }^{0}$ apresentaram aumento tanto da concentração de IL-10 quanto de $\mathrm{NO}$ após o tratamento com $\mathrm{DH}+\mathrm{G}$. $\mathrm{Ou}$ seja, a linhagem congênica B6.A-Hc desenvolveu um perfil de resposta anti-inflamatória quando tratada com $\mathrm{DH}+\mathrm{G}$.

\subsubsection{Conclusão do tópico "Aplicação da linhagem congênica B6.A- $H c^{0}$ no modelo de} DHNA"

A aplicação da linhagem congênica B6.A- $H c^{0}$ no modelo de DHNA evidenciou características aparentemente dependentes da ausência da proteína C5. Todos os parâmetros relacionados à fisiologia e bioquímica hepática são maiores na linhagem C5 deficiente, com exceção a FA que apresentou uma indicação de diferença estatística $(p=0,052)$ e reduziu após o tratamento com DH+G. Por outro lado, a ausência de C5 no fundo genético B6 promoveu um micro-ambiente hepático com menor inflamação quando comparado à linhagem B6 C5 
normal. Dentre as principais diferenças encontradas observamos à redução nas concentrações de IL-1ß, IL-6, IL-17, IFN- $\gamma$, e IL-12 em relação aos camundongos B6, independentemente do tratamento. E ainda, observamos o aumento significativo de IL-10 e NO exclusivamente observado na linhagem C5 deficiente após o tratamento com $\mathrm{DH}+\mathrm{G}$.

\subsection{Resumo dos principais resultados obtidos em cada um dos tópicos avaliados no} APÊEDICE A

Nas tabelas a seguir encontram-se resumidos os resultados mais importantes obtidos com a padronização da DHNA (Tabela A.1) e aplicação da linhagem congênica B6.A- $H c^{0}$ no modelo de DHNA (Tabela A.2). Na Tabela A.1 resumiremos os resultados obtidos a partir da padronização da DHNA onde empregamos os camundongos das linhagens isogênicas B6 e $\mathrm{A} / \mathrm{J}$, as quais foram submetidas a três tempos de tratamento (6, 8 e 10 semanas). Os resultados apresentados são referentes aos tratamentos com $\mathrm{DH}+\mathrm{G}$ em comparação aos controles $\mathrm{DH}+\mathrm{M}$ (controle equicalórico) e DH (controle real).

Tabela A.1 - Resumo dos principais resultados obtidos com a padronização da DHNA.

\begin{tabular}{|c|c|c|c|c|c|c|}
\hline Período de tratamento & \multicolumn{2}{|c|}{6 semanas } & \multicolumn{2}{|c|}{8 semanas } & \multicolumn{2}{|c|}{10 semanas } \\
\hline Parâmetro / Linhagem & B6 & $\mathbf{A} / \mathbf{J}$ & B6 & $\mathbf{A} / \mathbf{J}$ & B6 & $\mathbf{A} / \mathbf{J}$ \\
\hline Ganho de peso final & & & $\begin{array}{c}\downarrow v s . \mathrm{DH}+\mathrm{M} \\
-\end{array}$ & & $\begin{array}{c}\uparrow v s . \mathrm{DH}+\mathrm{M} \\
\uparrow v s . \mathrm{DH}\end{array}$ & $\uparrow \overline{-} \overline{\mathrm{DH}}$ \\
\hline Peso hepático / peso corporal & & $\downarrow \stackrel{-}{\downarrow}$ s. $\mathrm{DH}$ & & $\downarrow \stackrel{-}{\downarrow}$ s. $\mathrm{DH}$ & $\begin{array}{c}\uparrow v s . \mathrm{DH}+\mathrm{M} \\
-\end{array}$ & $\stackrel{-}{\downarrow v s . \mathrm{DH}}$ \\
\hline Ttriglicerídeos hepáticos & & & & & $\begin{array}{c}\uparrow v s . \mathrm{DH}+\mathrm{M} \\
\uparrow v s . \mathrm{DH}\end{array}$ & \\
\hline Leucócitos totais periféricos & & $\begin{array}{c}\downarrow v \text { vs. } \mathrm{DH}+\mathrm{M} \\
\downarrow \downarrow v s . \mathrm{DH}\end{array}$ & & & & $\begin{array}{c}\uparrow v s . \mathrm{DH}+\mathrm{M} \\
-\end{array}$ \\
\hline$T N F-\alpha$ & $\begin{array}{c}\downarrow v s . \mathrm{DH}+\mathrm{M} \\
-\end{array}$ & & & $\uparrow \overline{-}^{-}$ & & \\
\hline$I L-1 \beta$ & & $\begin{array}{c}\uparrow v s . \mathrm{DH}+\mathrm{M} \\
\uparrow v s . \mathrm{DH}\end{array}$ & & $\begin{array}{c}\uparrow v s . \mathrm{DH}+\mathrm{M} \\
\uparrow v s . \mathrm{DH}\end{array}$ & & $\begin{array}{c}\uparrow v s . \mathrm{DH}+\mathrm{M} \\
\uparrow v s . \mathrm{DH}\end{array}$ \\
\hline$I L-6$ & $\begin{array}{c}\downarrow v s . \mathrm{DH}+\mathrm{M} \\
-\end{array}$ & & $\stackrel{-}{-}$ & $\stackrel{-}{\uparrow v s . \mathrm{DH}}$ & & \\
\hline$I L-17$ & $\downarrow$ - & & $\downarrow \stackrel{-}{\downarrow v . \mathrm{DH}}$ & & $\downarrow \stackrel{-}{\downarrow}$ s. $\mathrm{DH}$ & \\
\hline$I L-10$ & & & $\stackrel{-}{\uparrow v s . \mathrm{DH}}$ & $\stackrel{-}{\uparrow v s . \mathrm{DH}}$ & & $\begin{array}{c}\uparrow v s . \mathrm{DH}+\mathrm{M} \\
\uparrow v s . \mathrm{DH}\end{array}$ \\
\hline
\end{tabular}

Camundongos das linhagens isogênicas B6 e A/J foram tratados com diferentes dietas hiperlipídicas durante 6, 8 e 10 semanas. Representamos os resultados obtidos após o tratamento com DH+G em comparação aos controles $\mathrm{DH}+\mathrm{M}(v s . \mathrm{DH}+\mathrm{M})$ ou DH (vs. DH).

Abreviaturas: vs.: versus; DH: Dieta hiperlipídica (controle real); DH+M: Dieta hiperlipídica contendo maltodextrina (controle equicalórico); DH+G: Dieta hiperlipídica contendo glicose; As setas indicam aumento e redução significativa dos parâmetros em questão 
Tabela A.2 - Resumo dos principais resultados obtidos com a aplicação dos camundongos B6 e da linhagem congênica B6.A- $H c^{0}$ no modelo de DHNA.

\begin{tabular}{|c|c|c|c|}
\hline \multirow[b]{2}{*}{ Parâmetro } & \multicolumn{2}{|c|}{$\begin{array}{c}\text { Comparação entre DH+G } \\
\text { vs. DH+M ou vs. DH }\end{array}$} & \multirow{2}{*}{$\begin{array}{c}\text { Comparação entre as } \\
\text { linhagens }\end{array}$} \\
\hline & B6 & B6.A - $H c^{0}$ & \\
\hline Ganho de peso final & $\begin{array}{c}- \\
\uparrow v s . \mathrm{DH}\end{array}$ & - $\bar{c}$ v. DH & \\
\hline Tecido adiposo / peso corporal & $\uparrow \overline{-}^{-} \mathrm{DH}$ & $\uparrow{ }^{-}$ & \\
\hline Peso hepático / peso corporal & $\downarrow$ vs. $\mathrm{DH}+\mathrm{M}$ & & В6<B6.A-Hc ${ }^{0}(D H+G)^{*}$ \\
\hline Triglicerídeos hepáticos & & & $\mathrm{B} 6<\mathrm{B} 6 . \mathrm{A}-H c^{0}$ \\
\hline Colesterol hepático & & & B6 $<$ B6.A-Hc ${ }^{0}(D H)^{*}$ \\
\hline AST e albumina séricas & & & B6 $<$ B6.A-Hc ${ }^{0}$ \\
\hline FA sérica & & $\begin{array}{c}\downarrow v s . \mathrm{DH}+\mathrm{M} \\
\downarrow v s . \mathrm{DH}\end{array}$ & Indicação ${ }^{\dagger}$ \\
\hline Glicose sérica & & $\uparrow \stackrel{-}{\imath s . \mathrm{DH}}$ & B6>B6.A-Hc ${ }^{0}(\mathrm{DH})^{*}$ \\
\hline Triglicerídeos e colesterol séricos & & & B6 $<\mathrm{B} 6 . \mathrm{A}-H c^{0}$ \\
\hline Leucócitos totais periféricos & & & B6 $<$ B6.A-Hc ${ }^{0}$ \\
\hline TNF- $\alpha$ hepático & $\uparrow{ }^{-}$ & $\uparrow{ }^{-}$ & \\
\hline IL-1ß hepático & & & B6>B6.A-Hc \\
\hline IL-6 hepático & & & $\mathrm{B} 6>\mathrm{B} 6 . \mathrm{A}-\mathrm{Hc} \boldsymbol{c}^{0}$ \\
\hline IL-17 hepático & & & B6>B6.A-Hc \\
\hline IFN-y hepático & & & $\mathrm{B} 6>\mathrm{B} 6 . \mathrm{A}-\mathrm{Hc}^{0}$ \\
\hline IL-12p70 hepático & & & B6>B6.A-Hc \\
\hline IL-10 hepático & & $\stackrel{-}{\uparrow v s . \mathrm{DH}}$ & B6>B6.A-Hc ${ }^{0}(D H)^{*}$ \\
\hline NO hepático & & $\begin{array}{c}\uparrow v s . \mathrm{DH}+\mathrm{M} \\
\uparrow v s . \mathrm{DH} \\
\end{array}$ & B6 $<$ B6.A-Hc ${ }^{0}(D H+G) *$ \\
\hline
\end{tabular}

Os camundongos das linhagens B6 e B6.A-Hc0 (C5 deficientes) foram tratados por 10 semanas com $\mathrm{DH}+\mathrm{G}$ e comparados aos controles $\mathrm{DH}+\mathrm{M}(v s$. $\mathrm{DH}+\mathrm{M})$ ou $\mathrm{DH}(v s$. $\mathrm{DH})$, onde as setas indicam aumento e redução significativa dos parâmetros em questão.

Abreviaturas: vs.: versus ou em relação a; DH: Dieta hiperlipídica (controle real); DH+M: Dieta hiperlipídica contendo maltodextrina (controle equicalórico); DH+G: Dieta hiperlipídica contendo glicose; (DH+G): diferença entre as linhagens apenas com o tratamento $\mathrm{DH}+\mathrm{G}$; $(\mathrm{DH})$ : diferença entre as linhagens apenas com o tratamento $\mathrm{DH}$; * Presença de efeito de interação entre linhagem e tratamento $(p<0,050) ;{ }^{\dagger}$ Indicação de efeito de interação $(p=0,052)$.

Realces coloridos: Azul: divergências entre as linhagens B6 e B6.A-Hc ${ }^{0}$ associados ao tratamento DH+G; Verde: diferenças entre as linhagens B6 e B6. $\mathrm{A}-\mathrm{Hc}^{0}$ não associadas ao tratamento; Vermelho: parâmetro comum às linhagens A/J (referente à Tabela A.1) e B6.A-Hc . 


\section{Discussão do APÊNDICE A}

A DHNA é considerada uma manifestação hepática da síndrome metabólica e é caracterizada pelo acúmulo excessivo de triglicerídeos hepáticos e pela presença de infiltrados celulares e necrose tecidual, os quais são resultados da progressão da DHNA para a ENA, que ainda podem avançar para a fibrose e futuramente tornar-se irreversível, chegando à cirrose. A patogênese da DHNA envolve a perpetuação da esteatose hepática acompanhada de aumento da adiposidade visceral, resistência à insulina e aumento da circulação de ácidos graxos livres. Outros eventos que também estão envolvidos com a manutenção da doença incluem o aumento: do estresse oxidativo, da peroxidação lipídica, da disfunção mitocondrial, do acúmulo de ferro, das adipocinas derivadas do TA, do micro-ambiente pró-inflamatório hepático, assim como de derivados microbianos do lúmem intestinal (KRAWCZYK et al., 2010).

Por se tratar de uma doença silenciosa e por existirem poucos modelos murinos abordando a etiopatogenia da doença (BURRAGE et al., 2010) nos propusemos a padronizar um modelo de DHNA tratando camundongos B6 e A/J com uma dieta hiperlipídica adicionando glicose. Tratamos os camundongos de ambas as linhagens por 6, 8 e 10 semanas, com o objetivo de acompanhar as alterações inflamatórias no micro-ambiente hepático, assim como o depósito de triglicerídeos (esteatose) ao longo das semanas.

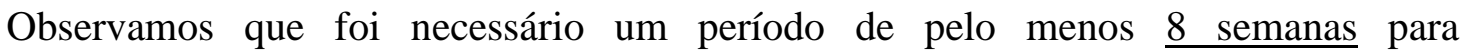
identificarmos as primeiras vesículas de depósito lipídico no tecido hepático dos camundongos da linhagem B6 tratados com DH+G (Figura A.6). Esta alteração inicial além de caracterizar um dos primeiros sintomas da DHNA veio acompanhada do aumento da concentração hepática da citocina IL-6 (Figura A.14C), da redução da concentração de IL-17 (Figura A.14D) e ainda do aumento da concentração da citocina anti-inflamatória IL-10 (Figura A.14G) em relação aos camundongos B6 tratados com DH. Surpreendentemente, após 10 semanas de tratamento dos camundongos $\mathrm{B} 6$ com $\mathrm{DH}+\mathrm{G}$, cerca de $90 \%$ do tecido hepático apresentava esteatose macro e micro-vesicular (Figura A.6). Além disso, observamos que estes animais ganharam significativamente mais peso (Figura A.3A), além de apresentarem hepatomegalia (Figura A.4A) e alto depósito de triglicerídeos em relação aos camundongos B6 controles que foram tratados com DH+M e DH (Figura A.5A). Curiosamente, estas características vieram acompanhadas apenas da redução significativa da concentração hepática da citocina IL-17 em comparação aos tratados com DH (Figura A.14D). Complementando esta análise comparativa entre os tratamentos $(\mathrm{DH}+\mathrm{G}, \mathrm{DH}+\mathrm{M}$ e 
DH) realizamos também a análise cinética dos parâmetros corporais e inflamatórios, ou seja, avaliamos como o tratamento dos camundongos com $\mathrm{DH}+\mathrm{G}$ influenciou os parâmetros avaliados ao longo de 6,8 e 10 semanas. Interessantemente observamos que nos camundongos da linhagem B6 que receberam $\mathrm{DH}+\mathrm{G}$ por 10 semanas o ganho de peso final (Figura A.3A), a razão do peso do fígado / peso corporal (Figura A.4A), e os triglicerídeos hepáticos aumentaram significativamente em relação a 6 e 8 semanas de tratamento (Figura A.5A). Caracterizando, portanto, a progressão temporal da doença e a reprodução nos camundongos da linhagem B6 alguns dos principais parâmetros observados em pacientes com DHNA. Inflamatoriamente, encontramos que a concentração hepática da citocina IL-6 aumentou de 6 para 8 semanas (Figura A.14C), acompanhando os primeiros depósitos de gordura no tecido hepático. Mas, após 10 semanas a concentração de IL-6 reduziu em relação às semanas anteriores. Quanto à concentração da citocina $\mathrm{IL}-17$, esta esteve reduzida em todos os tempos para os camundongos $\mathrm{B} 6$ tratados com $\mathrm{DH}+\mathrm{G}$, mas avaliando sua variação semanalmente identificamos que de 6 para 8 semanas de tratamento houve redução da concentração de IL-17 mas com 10 semanas houve aumento da concentração de IL-17 em relação à concentração obtida com 8 semanas (Figura A.14D). Por fim, a concentração da citocina IL-10 aumentou com 8 semanas de tratamento e manteve se inalterada até 10 semanas (Figura A.14G).

Aparentemente, o desenvolvimento e manutenção da DHNA para os camundongos da linhagem B6 exigiram um ambiente levemente pró-inflamatório, pois bastaram sutis variações inflamatórias ao longo de 10 semanas sob tratamento com uma dieta hiperlipídica contendo glicose para induzir a patologia nos camundongos B6. Em resumo, houve aumento da concentração IL-17, redução de IL-6 e manutenção na concentração de IL-10 de 8 para 10 semanas, o período crítico para a evolução da doença.

A citocina IL-17, assim como a presença de células Th17 no tecido hepático sob um contexto de dieta hiperlipídica estão associadas com esteatose e resposta inflamatória na DHNA. E ainda contribuem fortemente para a transição de uma simples esteatose para a esteatohepatite (TANG et al., 2011). Ou seja, os resultados obtidos com os camundongos B6 tratados com $\mathrm{DH}+\mathrm{G}$ por 10 semanas corroboram os com resultados descritos por Tang e colaboradores (2011), onde a citocina IL-17 exacerbou a esteatose e inflamação hepática na DHNA. Em conjunto a IL-17, o balanço entre as concentrações das citocinas IL-6 e IL-10 dirigiu a progressão da esteatose ou proteção hepática durante a DHNA. Sabe-se também que estas duas citocinas atuam sinergicamente como fatores hepato-protetores via sinalização por STAT3 (MILLER et al., 2011). Nossos resultados mostraram que com 8 semanas houve 
aumento da secreção de IL-6 e IL-10 hepática ao mesmo tempo em que apareceram os primeiros sinais de esteatose, mas após 10 semanas a concentração de IL-6 reduziu e a de IL10 manteve-se constante nos camundongos B6 tratados com DH+G. Ou seja, IL-6 contribuiu para a progressão da esteatose e a concentração IL-10 aparentemente não foi suficiente para conte-la.

Complementando a padronização da DHNA empregamos camundongos da linhagem $\mathrm{A} / \mathrm{J}$, que são conhecidos por serem geneticamente resistentes ao desenvolvimento de obesidade (BURRAGE et al., 2010). Corroborando com os dados presentes na literatura nossos camundongos $\mathrm{A} / \mathrm{J}$ tratados com as diferentes dietas não tiveram comportamento diferente do esperado. Por meio das análises histopatológicas observamos que os camundongos $\mathrm{A} / \mathrm{J}$ tratados com $\mathrm{DH}+\mathrm{G}$ não desenvolveram esteatose tão pronunciada quanto os camundongos B6 ao final de 10 semanas de tratamento (Figura A.7). Este perfil veio acompanhado do aumento da concentração hepática de IL-1ß (Figura A.14B) e de IL-10 (Figura A.14G). Surpreendentemente, após 10 semanas de tratamento dos camundongos da linhagem $\mathrm{A} / \mathrm{J}$ com $\mathrm{DH}+\mathrm{G}$ o tecido hepático estava protegido de esteatose mas estava repleto de infiltrado celular inflamatório, o que corrobora com aumento de leucócitos totais presentes na circulação sanguínea (Figura A.7). Além disso, observamos que apenas após 10 semanas estes animais ganharam significativamente mais peso em relação aos camundongos A/J tratados com DH (Figura A.3B), mas os camundongos $\mathrm{A} / \mathrm{J}$ tratados com $\mathrm{DH}+\mathrm{G}$ não apresentarem hepatomegalia (Figura A.4A). Contribuindo com a análise comparativa entre os tratamentos $(\mathrm{DH}+\mathrm{G}, \mathrm{DH}+\mathrm{M}$ e $\mathrm{DH})$ realizamos uma análise cinética de todos os parâmetros até então descritos, para isso avaliamos como o tratamento com $\mathrm{DH}+\mathrm{G}$ influenciou os parâmetros corporais e inflamatórios ao longo de 6, 8 e 10 semanas nos camundongos da linhagem A/J. Como esperado, observamos que ao longo das 10 semanas de tratamento o ganho de peso final (Figura A.3B), a razão peso hepático / peso corporal (Figura A.4B) e a concentração hepática de triglicerídeos (Figura A.5B) mantiveram-se constantes. Caracterizando e confirmando a resistência em acumular peso e a desenvolver obesidade já citada a respeito desta linhagem. Quanto ao comportamento cinético das citocinas inflamatórias no micro-ambiente hepático, encontramos que a concentração da citocina TNF$\alpha$ aumentou de 6 para 8 mas reduziu de 8 para 10 semanas, a concentração hepática de IL-1ß nos camundongos $\mathrm{A} / \mathrm{J}$ tratados com $\mathrm{DH}+\mathrm{G}$ esteve maior que os controles para todas as semanas, entretanto encontramos que a concentração hepática de IL-1ß é muito parecida com 6 e 8 semanas mas reduz com 10 semanas. Com relação à concentração da citocina IL-6 houve aumento com 8 e redução com 10 semanas (Figura A.14C). Por fim, a concentração 
hepática da citocina anti-inflamatória IL-10 aumentou com 8 semanas de tratamento mas aumentou ainda mais com 10 semanas (Figura A.14G). Este aumento veio acompanhado de um aumento na produção de NO no tecido hepático que foi significativo apenas após 10 semanas em relação à 6 e 8 semanas.

Provavelmente, os fatores que contribuíram para conter a progressão da DHNA nos camundongos da linhagem $\mathrm{A} / \mathrm{J}$ quando tratados com $\mathrm{DH}+\mathrm{G}$ foi o aumento da concentração da citocina IL-10 de 8 para 10 semanas e a redução de todas as citocina avaliadas, com exceção da IL-1ß. O aumento da concentração hepática de IL-10 foi concomitante ao notável acúmulo de infiltrados celulares, possivelmente sendo esta uma fonte extra de IL-10, a qual contribuiu para o aumento da sua concentração observada de 8 para 10 semanas. E também, possivelmente a citocina IL-1ß contribuiu sutilmente para a manutenção, mesmo que baixa, de um micro-ambiente levemente inflamatório.

Como esperado a citocina IL-10 exerceu sua função hepatoprotetora para os camundongos da linhagem A/J quando tratados com $\mathrm{DH}+\mathrm{G}$. Mas, surpreendentemente, esta linhagem mostrou aumento na concentração de IL-1ß hepática na ausência de esteatose mas na presença de infiltrado celular. Segundo Csak e colaboradores (2011) a concentração hepática de IL-1ß aumenta durante a DHNA e ENA devido à ativação do inflamassoma, que recebe o duplo estímulo via LPS oriundo do translocação do lúmem intestinal para a corrente sanguínea e pelo influxo de ácidos graxos liberados a partir da lipólise ocorrente no tecido adiposo e no tecido muscular.

Em resumo os camundongos da linhagem B6 quando tratados com $\mathrm{DH}+\mathrm{G}$ por 10 semanas desenvolveram esteatose, a qual foi acompanhada do aumento da concentração hepática de IL-17 e manutenção da concentração de IL-10. Já os camundongos da linhagem A/J são protegidos de desenvolveram esteatose e apresentaram aumento da concentração de IL-1ß e IL-10 hepática. Portanto, devido ao conjunto de resultados divergentes obtidos com as linhagens B6 e A/J, investigamos de forma mais profunda como os camundongos congênicos B6.A-Hc ${ }^{0}$ (C5 deficientes) se comportariam frente a uma DH+G durante 10 semanas de tratamento em relação aos camundongos B6. Observamos que as linhagens B6 e B6.A-Hc ${ }^{0}$ apresentaram parâmetros corporais bastante semelhantes durante o tratamento com a $\mathrm{DH}+\mathrm{G}$, onde podemos citar que o peso acumulado semanalmente (Figura A.15), o ganho de peso ao final do tratamento (Figura A.16) e a razão do peso do tecido adiposo / peso corporal (Figura A.17) foram praticamente os mesmos. Para este parâmetro o componente C5 pareceu não interferir. Surpreendentemente, encontramos resultados bastante divergentes entre as linhagens iniciando pela redução da razão do peso hepático pelo peso corporal nos 
camundongos da linhagem B6 tratados com DH+G em relação os tratados com DH (Figura A.19). Observamos também que para os camundongos B6.A- $H c^{0}$ quando tratados com $\mathrm{DH}+\mathrm{G}$ apresentaram redução da FA e aumento da glicose séricas (Figura A.24), além do aumento na concentração hepática de IL-10 e NO em relação aos tratados com apenas DH (Figura A.27).

Os camundongos da linhagem B6.A- $\mathrm{Hc}^{0}$ quando tratados com $\mathrm{DH}+\mathrm{G}$ apresentaram aumento na concentração de glicose sérica (Figura A.24), isto pode ser um reflexo da resistência à insulina induzida durante a DHNA (CHIANG et al, 2011). Possivelmente o componente C5 pode estar envolvido com a conservação da concentração sérica de glicose e uma vez ausente pode levar a um distúrbio nesta concentração sérica. A desregulação da concentração sérica de glicose conduz ao aumento da concentração de insulina circulante, e se isto ocorrer continuamente em conjunto com o aumento sérico de triglicerídeos pode desencadear a síndrome metabólica (KRAWCZYK et al., 2010). Ou simplesmente pelo fato dos camundongos terem passado por um período de jejum de 12 horas antes do sacrifício houve a quebra do glicogênio armazenado nos tecidos pela ação do glucagon e, portanto, liberação de glicose na circulação. Experimentos direcionados para o acompanhamento e detecção da glicemia nos camundongos auxiliariam potencialmente na explicação deste aumento. É possível que este aumento da glicose sérica seja realmente um reflexo da resistência à insulina, pois também encontramos nestes camundongos aumento nas concentrações séricas de triglicerídeos e colesterol total, fatores estes que estão fortemente relacionados ao desenvolvimento da DHNA, diabetes e síndrome metabólica (MATTEONI et al, 1999).

Quanto ao aumento hepático da concentração de IL-10 e de NO (Figura A.27), possivelmente as células produtoras de IL-10 foram os macrófagos (LASKIN et al., 2011). Este aumento de IL-10 foi observado nos camundongos da linhagem A/J (naturalmente C5 deficientes, WETSEL et al., 1990) também tratados com $\mathrm{DH}+\mathrm{G}$, conforme apresentado na Figura A.14. Como já foi demonstrado o caráter protetor da citocina IL-10 por Miller e colaboradores (2011), a indução de lesão hepática possivelmente desencadeou a produção de IL-10 (Figura A.27) e, consequentemente, levou a depleção da resposta inflamatória (Figura A.26)

$\mathrm{Na}$ sequência observamos que os camundongos diferiram entre si sob vários parâmetros independentemente do tratamento, onde os camundongos da linhagem B6.A- $H c^{0}$ de forma geral apresentaram em relação aos B6: aumento no depósito de triglicerídeos hepático (Figura A.20), aumento das concentrações séricas de AST, albumina, triglicerídeos e colesterol (Figura A.24). E ainda redução nas concentrações hepáticas de IL-1ß, IL-6, IL- 
17, IFN- $\gamma$ e IL-12 (Figura A.26). De acordo com esta redução das citocinas inflamatórias identificamos também menor escore de inflamação lobular para os camundongos C5 deficientes (Figura A.21D). Confirmando que o produto de clivagem de C5, o fragmento C5a, é importante no desempenho de poderosas funções biológicas que levam às respostas inflamatórias. C5a é um forte quimioatraente envolvido no recrutamento de células inflamatórias como neutrófilos, eosinófilos, monócitos, linfócitos, além da ativação de fagócitos, liberação de grânulos e geração de oxidantes, contribuindo para a efetividade da imunidade inata ou dano tecidual (GUO; WARD 2005). Portanto, a ausência de C5 em nosso modelo de DHNA teve um caráter anti-inflamatório e possivelmente induziu menos danos teciduais. Para pacientes com DHNA foi identificado no plasma aumento das citocinas próinflamatórias TNF- $\alpha$ e IL-6, redução de IL-4 e quanto a IL-10 não houve alteração. E também foi identificado aumento de TGF- $\beta$ correlacionado ao sobrepeso, deslipidemia, resistência à insulina (DAS; BALAKRISHNAN, 2011), mostrando que a resposta inflamatória sistêmica está associada com a progressão da doença.

Nos estágios iniciais da DHNA existe pouca inflamação hepática, pois há apenas depósito lipídico (VALENTI et al., 2009). Mas, é importante lembrar que as citocinas próinflamatórias TNF- $\alpha$, IL-1 $\beta$ e IL-6 também podem ser sintetizadas por macrófagos infiltrados no tecido adiposo visceral e que estas citocinas também podem contribuir para a manutenção da inflamação crônica sistêmica observada nos modelos de DHNA (SHOELSON et al., 2007, VALENTI et al., 2009). Iniciamos nossas análises pela citocina TNF- $\alpha$, fortemente correlacionada ao desenvolvimento das características observadas na DHNA (SHOELSON et al., 2007). É sugerido que o aumento de TNF- $\alpha$ reduz a sensibilidade do hepatócito à insulina, e com isso contribui para a perpetuação da resistência à insulina e posterior esteatose hepática (KRAWCZYK et al., 2010). Como esperado para o modelo, identificamos aumento significativo de TNF- $\alpha$ após tratamento dos animais com $\mathrm{DH}+\mathrm{G}$ em relação à $\mathrm{DH}$ para ambas as linhagens (Figura A.26A). Entretanto, apenas para a linhagem B6.A-Hc houve aumento significativo de IL-10 quando tratadas com $\mathrm{DH}+\mathrm{G}$ e $\mathrm{DH}+\mathrm{M}$ em relação à $\mathrm{DH}$ (Figura A.27A). Estes resultados sugerem que C5 não pareceu influenciar na concentração hepática de TNF- $\alpha$. Por outro lado, sua ausência promoveu o aumento da citocina anti-inflamatória IL10.

A DHNA também é caracterizada pela presença de estresse oxidativo no tecido hepático (KRAWCZYK et al., 2010). Portanto, analisando a produção de NO no tecido hepático observamos que o tratamento dos camundongos da linhagem B6.A-Hc ${ }^{0}$ com $\mathrm{DH}+\mathrm{G}$ promoveu o aumento significativo de $\mathrm{NO}$ em comparação aos tratamentos $\mathrm{DH}+\mathrm{M}$ e $\mathrm{DH}$ 
(Figura A.27B). Ou seja, a ausência de C5 gerou o aumento da produção de NO no tecido hepático. Isto pode estar relacionado à presença de macrófagos teciduais e a um possível contexto anti-inflamatório gerado pela ausência de C5.

Nossa proposta com o desenvolvimento deste modelo foi identificar uma relação entre a presença ou não da proteína C5 sobre o contexto inflamatório que contribuiu para o desencadeamento da DHNA. E ainda correlacionar estes parâmetros à histopatologia hepática. Interessantemente, temos aqui um comportamento controverso entre as linhagens, de um lado observamos que os camundongos B6.A- $H c^{0}$ possuem menor inflamação hepática confirmada pelas dosagens das citocinas (Figuras A.26 e A.27) e histopatologia (Figuras A.21 e A.22) mas por outro apresentaram maior circulação sérica de componentes associados à perturbação da homeostase hepática (Figura A.24). E mesmo perante a uma condição anti-inflamatória (aumento de IL-10) estes animais não foram protegidos do desenvolvimento de esteatose. Observamos que as linhagens diferem entre si, mas estas diferenças não levam a proteção ou a piora da DHNA. Podemos concluir, que mesmo na ausência do componente C5 e num contexto de baixa resposta inflamatória houve o desenvolvimento da DHNA e ENA, uma vez que o índice de atividade para DHNA esteve em média entre 3 e 4 para os camundongos de ambas as linhagens (Figura A.21F).

Possivelmente, a ausência da proteína C5 alterou fisiologicamente a função e atividade hepática (Figura A.24) tornando o fígado mais susceptível às lesões induzidas por uma dieta hiperlipídica apresentando meio acúmulo de gordura hepática (Figura A.20), entretanto devido à baixa resposta inflamatória gerada nos camundongos $\mathrm{B} 6 . \mathrm{A}-\mathrm{Hc}^{0}$ não houve a piora e progressão do quadro de DHNA.

Como perspectiva de futuros experimentos seria pertinente tratar os camundongos B6 e os congênicos B6.A- $\mathrm{Hc}^{0}$ com as dietas hiperlipídicas por mais tempo (12 a 14 semanas) para ver se é possível que a ausência de C5 protegeria os animais em numa fase mais tardia da doença, por exemplo, estes congênicos poderiam desenvolver menos fibrose hepática. 


\section{Conclusões do APÊNDICE A}

5.1 Conclusões sobre a padronização do modelo de DHNA empregando as linhagem B6 e A/J

* Padronizamos um modelo de DHNA para camundongos que induziu as principais patologias observadas nos pacientes com DHNA e nos modelos animais presentes na literatura, dentre elas foram observadas nos camundongos B6: ganho de peso, aumento da razão do peso hepático pelo peso corporal, acúmulo de gordura no tecido hepático, presença inflamação e de infiltrado celular no tecido hepático.

* A linhagem A/J apresentou aumento significativo do número de leucócitos circulantes após 10 semanas de tratamento com $\mathrm{DH}+\mathrm{G}$;

* O acúmulo de triglicerídeos hepáticos foi significativamente maior para os animais tratados com $\mathrm{DH}+\mathrm{G}$ apenas para a linhagem B6;

* A concentração da citocina hepática IL-6 decresceu significativamente no decorrer das semanas de tratamento com $\mathrm{DH}+\mathrm{G}$, tanto para a linhagem B6 quanto para a A/J;

* A concentração da citocina hepática IL-10 aumentou significativamente no decorrer das semanas de tratamento com $\mathrm{DH}+\mathrm{G}$, tanto para a linhagem B6 quanto para a A/J; Mas em maior proporção na linhagem A/J;

* A concentração da citocina hepática IL-1 $\beta$ aumentou significativamente em todos os tempos de tratamento com $\mathrm{DH}+\mathrm{G}$ para a linhagem $\mathrm{A} / \mathrm{J}$;

* A concentração da citocina hepática IL-12 decresceu significativamente no decorrer das semanas de tratamento com $\mathrm{DH}+\mathrm{G}$, tanto para a linhagem B6 quanto para a A/J;

* A produção de NO no tecido hepático aumentou significativamente no decorrer das semanas de tratamento com $\mathrm{DH}+\mathrm{G}$ apenas para a linhagem A/J;

* A histopatologia hepática mostrou elevado depósito de lipídeo hepático na linhagem B6 tratadas com $\mathrm{DH}+\mathrm{G}$ a partir da $8^{\mathrm{a}}$ semana, esse depósito tornou-se exacerbado após 10 
semanas de tratamento. A linhagem A/J apresentou-se resistente ao acúmulo de gordura hepática.

* Dentre os tempos testados para o modelo de DHNA identificamos que 10 semanas foi o período ótimo para induzir alterações inflamatórias entre os camundongos das linhagens B6 e A/J tratadas cronicamente com glicose. Ainda identificamos que os camundongos da linhagem $\mathrm{A} / \mathrm{J}$ foram protegidos do desenvolvimento de esteatose pois apresentaram um perfil anti-inflamatório protetor em relação aos camundongos da linhagem B6 tratados com $\mathrm{DH}+\mathrm{G}$. Este comportamento também pode ser uma característica fisiológica pertencente ao fundo genético da linhagem.

5.2 Conclusões sobre a aplicação da linhagem congênica B6.A-Hc e B6 no modelo de DHNA

$\underline{\text { 5.2.1 Independentemente do tratamento a linhagem B6.A- } H c^{0} \text { apresentou em relação à }}$ linhagem B6

* Encontramos nos camundongos B6.A- $\mathrm{Hc}^{0}$ aumento no número de leucócitos e na concentração sérica de AST, albumina, triglicerídeos, e ainda aumento do depósito de triglicerídeos e colesterol hepáticos em relação aos camundongos B6;

* Encontramos nos camundongos B6.A- $H c^{0}$ redução da concentração hepática das citocinas IL-6, IL-1 $\beta$, IL-12 p40 e p70, IL-17, IFN- $\gamma$ em relação aos B6. Possivelmente essa redução dos parâmetros inflamatórios é uma consequência da ausência de C5;

* Escore para inflamação apresentou efeito de interação significativo entre linhagem e inflamação (dependente da linhagem). Os camundongos congênicos B6.A-Hc apresentaram menos inflamação que os B6.

\section{$\underline{\text { 5.2.2 Independentemente da linhagem o tratamento com } \mathrm{DH}+\mathrm{G} \text { por } 10 \text { semanas promoveu }}$}

* O aumento da concentração de TNF-a e aumento do depósito de triglicerídeos hepáticos; 
* Escores para balonização e esteatose apresentam efeito de interação significativo entre tratamento e balonização e entre tratamento e esteatose;

* Porcentagem de esteatose e índice de atividade da DHNA apresentaram diferenças entre os tratamentos $(\mathrm{DH}+\mathrm{G}$ e $\mathrm{DH}+\mathrm{M}$ em relação à $\mathrm{DH})$.

\section{$\underline{\text { 5.2.3 Diferenças entre as linhagens quando tratadas com } \mathrm{DH}+\mathrm{G}}$}

* Houve aumento da razão peso hepático / peso corporal na linhagem B6 e redução da razão peso hepático / peso corporal na B6.A- $\mathrm{Hc}^{0}$;

* Apenas os camundongos B6.A-Hc apresentaram aumento sérica de glicose, dependentemente do tratamento com $\mathrm{DH}+\mathrm{G}$ em relação à apenas $\mathrm{DH}$;

* Apenas os camundongos B6.A- $H c^{0}$ apresentaram tiveram aumento da concentração hepática de IL-10 após tratamento com $\mathrm{DH}+\mathrm{G}$;

* Apenas os camundongos B6.A- $H c^{0}$ apresentaram tiveram aumento da produção hepática de $\mathrm{NO}$ após tratamento com $\mathrm{DH}+\mathrm{G}$;

* O modelo de DHNA durante o período de 10 semanas de tratamento induziu nos camundongos da linhagem B6 e nos camundongos congênicos B6.A- $H c^{0}$ as alterações corporais clássicas para a DHNA: facilidade de ganho de peso, aumento da razão do peso hepático pelo peso corporal (para os camundongos B6), acúmulo de gordura no tecido hepático, presença de infiltrado celular no tecido hepático (em maior proporção para os camundongos B6), aumento da concentração hepática de TNF- $\alpha$ (para os camundongos B6 e B6.A- $H c^{0}$ ), da concentração hepática de IL-10 e da produção de NO por macrófagos presentes no fígado (para os camundongos B6.A- $H c^{0}$ ). Os camundongos congênicos B6.A-Hc ${ }^{0}$ apresentaram um perfil anti-inflamatório como a linhagem $\mathrm{A} / \mathrm{J}$, mas não foi suficiente para proteger completamente os camundongos B6.A-Hc de desenvolver esteatose. 


\section{APÊNDICE B - Análise da composição da Dieta Hiperlipídica LABTRON.}

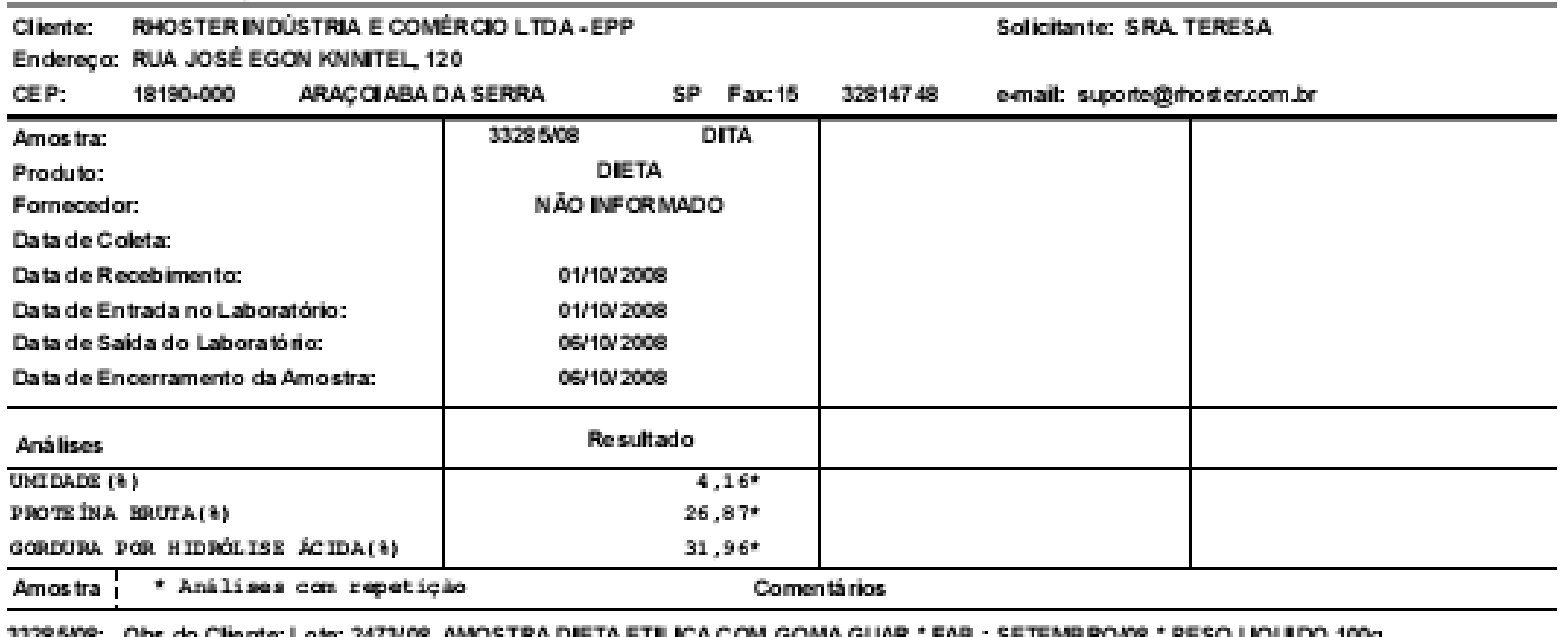

3328 6108: Obs do Cliente: Lote: 2473/68. AMOSTRA DIETA ETLICA COM GOMA GUAR * FAB.: SETEMBRON68 * PESO UQUDO 1009. Obs do Lab:

Os resultados destas análises têm significado restrito e se aplicam tão somente às amostras recebidas no laboratório.

TTAPRA, 7 de outubro de 2008

TAIS ROSTIROLLA 


\section{APÊNDICE C - Ganho de peso acumulado semanalmente e dosagem da enzima ALT dos camundongos B6 e A/J durante as 10 semanas de tratamento no modelo de DHA}

Avaliando o ganho de peso acumulado semanalmente entre os camundongos da linhagem B6 para cada tratamento individual, observamos no grupo tratado com DH+E um ganho de peso acumulado significativo até a quinta semana de tratamento, $p<0,05$, a partir da qual não houve mais ganho de peso significativo. No grupo tratado com $\mathrm{DH}+\mathrm{M}$ observamos ganho de peso significativo a partir da sétima semana de tratamento, mantendo-se constante até a décima semana, $p<0,05$. No grupo tratado com $\mathrm{DH}$ não foi observado ganho significativo de peso acumulado semanalmente.

Considerando os camundongos da linhagem B6 e comparando os tratamentos entre si, observamos que o grupo tratado com $\mathrm{DH}+\mathrm{E}$ difere significativamente do grupo tratado com $\mathrm{DH}$ a partir da quarta semana de tratamento, $p<0,05$. O grupo tratado com $\mathrm{DH}+\mathrm{M}$ apresenta diferença significativa quanto ao tratado com $\mathrm{DH}$ a partir da oitava semana, $p<0,05$. Entre os grupos tratados com $\mathrm{DH}+\mathrm{E}$ e $\mathrm{DH}+\mathrm{M}$ observamos diferença significativa entre a quinta e sétima semana de tratamento, $p<0,05$ (Figura C.1A).

Avaliando o ganho de peso acumulado semanalmente entre os camundongos A/J para cada tratamento individualmente observamos que no grupo tratado com $\mathrm{DH}+\mathrm{E}$ houve ganho de peso significativo a partir da sétima semana de tratamento, mantendo-se constante até a décima semana, $p<0,05$. No grupo tratado com $\mathrm{DH}+\mathrm{M}$ observamos que houve ganho de peso acumulado significativo a partir da primeira semana de tratamento, o qual se manteve significativo até a quinta semana, $p<0,05$. A partir da sexta semana até o final do tratamento, não houve ganho de peso significativo. No grupo tratado com DH não foi observado ganho de peso acumulado semanalmente significativo.

Comparando os tratamentos observamos que os camundongos $\mathrm{A} / \mathrm{J}$ tratados com $\mathrm{DH}+\mathrm{E}$ diferiram significativamente do grupo tratado apenas com DH a partir da sétima semana de tratamento, $p<0,05$. O grupo tratado com $\mathrm{DH}+\mathrm{M}$ apresenta diferença significativa do grupo DH a partir da terceira semana. O grupo tratado com $\mathrm{DH}+\mathrm{E}$ apresentou significativamente menor ganho de peso quando comparado ao grupo $\mathrm{DH}+\mathrm{M}$ a partir da quarta semana de tratamento, $p<0,05$ (Figura C.1B). 
Figura C.1 - Ganho de peso acumulado semanalmente dos camundongos B6 e A/J durante 10 semanas de tratamento com as diferentes dietas hiperlipídicas.
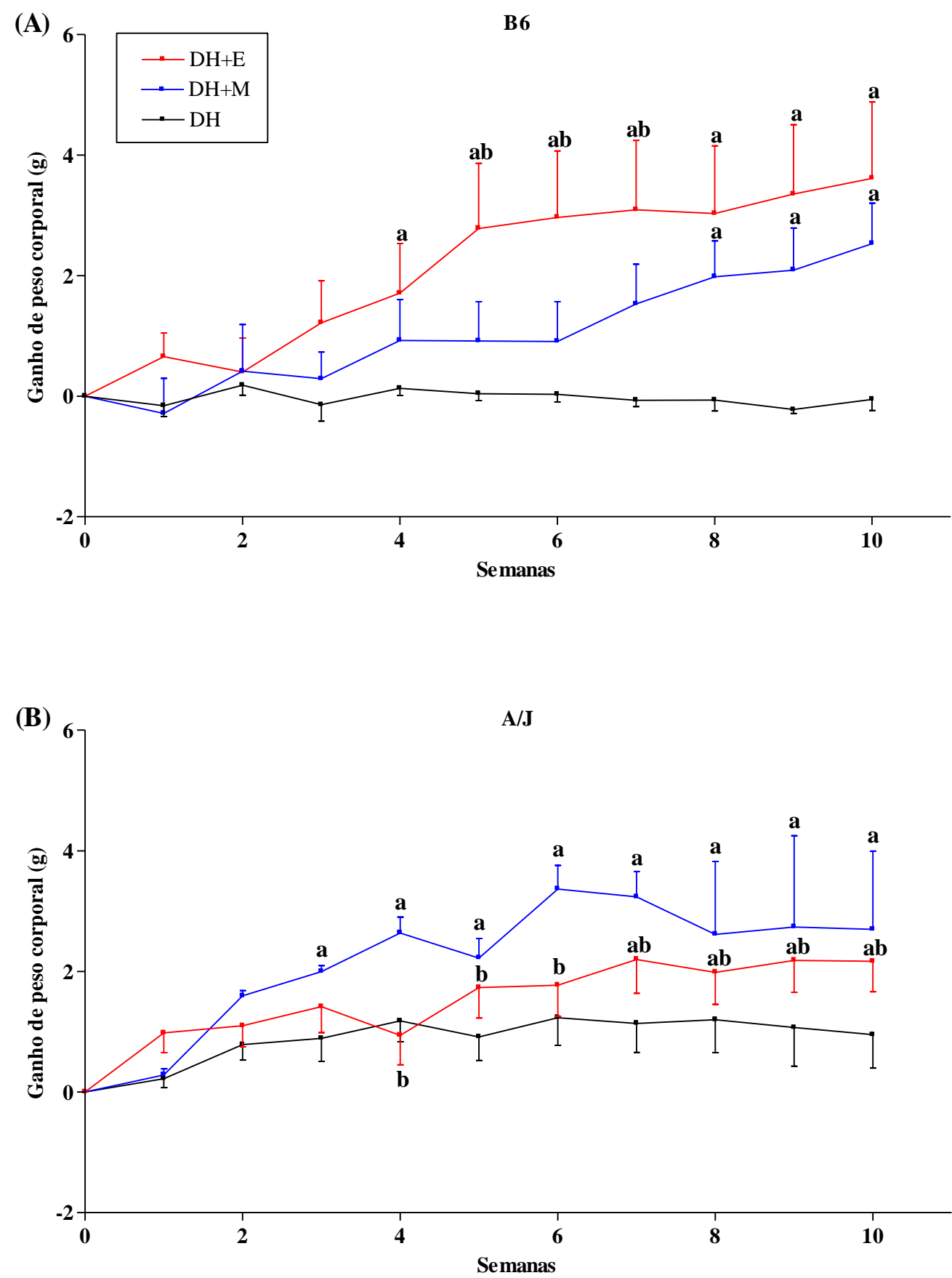

Representaremos nos gráficos de ganho de peso acumulado apenas as comparações entre os tratamentos. Os resultados estão representados como média e erro padrão, $\mathrm{n} \geq 5$. As comparações correspondem: $\mathbf{a} v s$. DH e $\mathbf{b} v s$. $\mathrm{DH}+\mathrm{M}, p<0,05$. Em (A) apresentamos o ganho de peso acumulado para os camundongos da linhagem B6 e em (B) da linhagem A/J tratados com as diferentes dietas hiperlipidicas tratados durante 10 semanas.

Siglas: DH - Dieta hiperlipídica; DH+M - Dieta hiperlipídica contendo maltodextrina; DH+E - Dieta hiperlipídica contendo etanol. 
Avaliando a concentração plasmática de ALT em camundongos da linhagem B6 identificamos a presença de efeito de interação entre tratamento e semana, $p=0,008$. Os camundongos B6 tratados com $\mathrm{DH}+\mathrm{M}$ apresentaram queda significativa da concentração plasmática de ALT de 8 para 10 semanas $p<0,05$. Já os camundongos tratados com DH apresentaram aumento significativo de 6 para 8 semanas e também apresentaram queda significativa da concentração de ALT de 8 para 10 semanas $p<0,05$. Comparando os tratamentos observamos indicação de diferença estatística entre as dietas DH+E e DH após 6 semanas de tratamento, $0,05<p<0,10$ (Figura C.2).

Com relação aos camundongos da linhagem A/J, não detectamos efeito de interação entre tratamento e semana, $p=0,07$. Também não detectamos diferença significativa entre os tratamentos e entre as semanas, $p=0,351$ e $p=0,144$ respectivamente (Figura C.2).

A presença desta enzima no plasma é uma importante ferramenta para inferir sobre a integridade da função hepática frente a um agente hepatotóxico, pois se houver injúria neste órgão e consequentemente rompimento dos hepatócitos, espera-se aumento da concentração plasmática de ALT, a qual pode ser monitorada e mensurada (BOONE et al., 2005). Entretanto, o aumento da concentração de ALT no plasma é geralmente observado em condições de injúria hepática aguda (NEFF et al., 2003). Portanto, a análise da concentração da ALT é informativa apenas nos primeiros estágios do modelo de alcoolismo crônico (PRITCHARD et al., 2007). 
Figura C.2 - Determinação da concentração de ALT plasmática nas linhagens B6 e A/J após tratamento com as diferentes dietas hiperlipídicas durante 6,8 e 10 semanas.

(A)

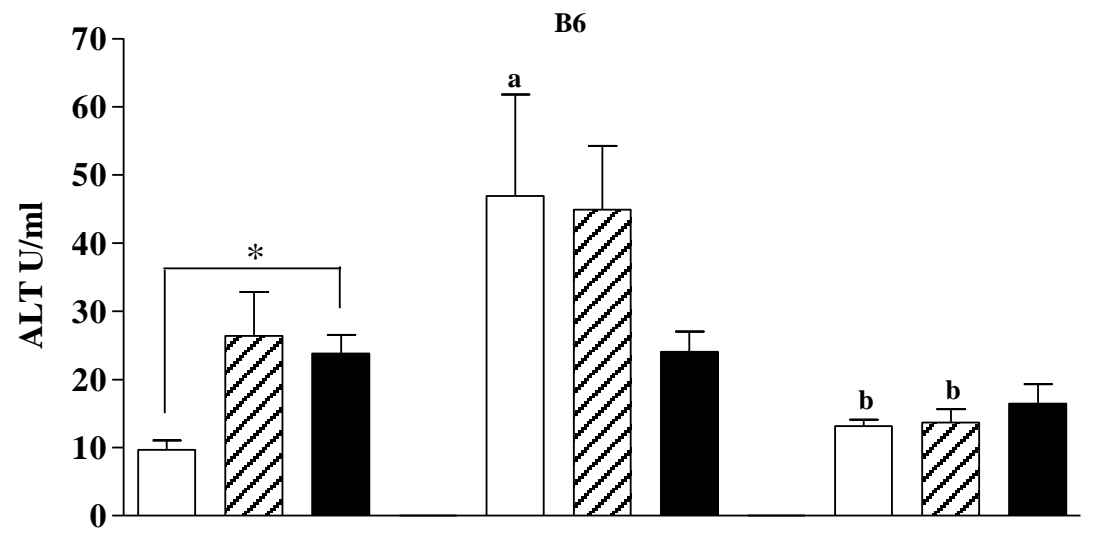

(B)

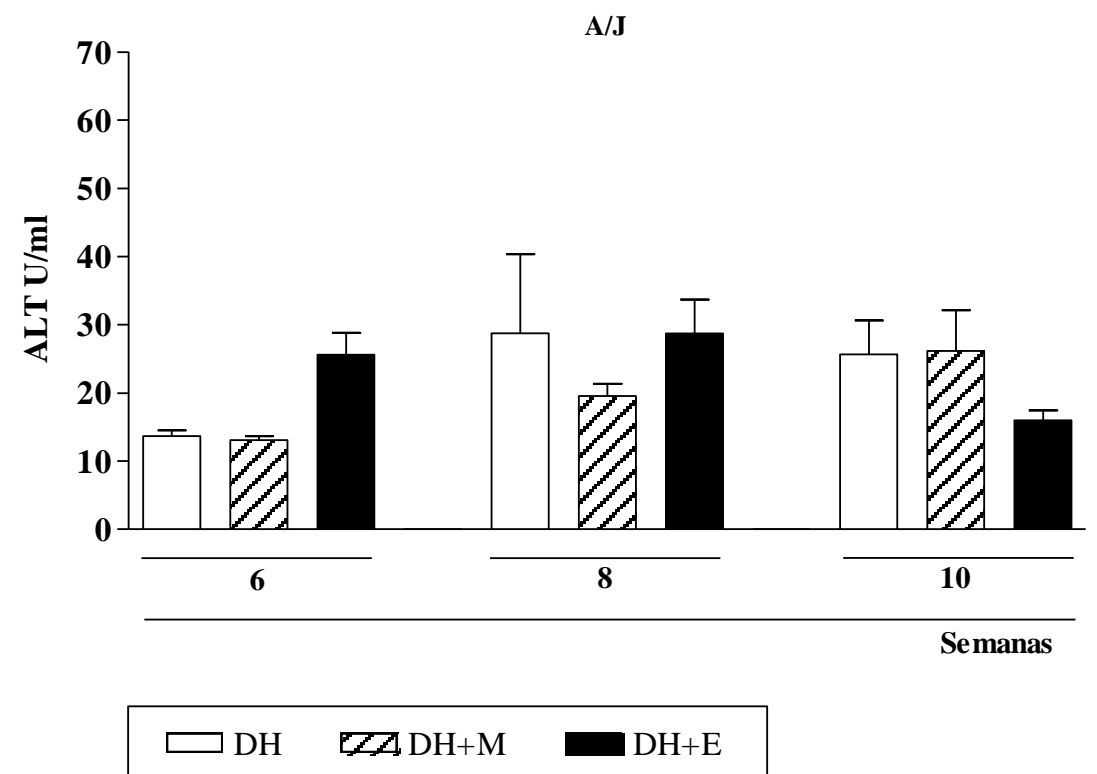

(A) e A/J (B) após tratamento com as diferentes dietas hiperlipídicas durante 6, 8 e 10 semanas. Os resultados estão representados como média e erro padrão, $\mathrm{n} \geq 5$. As comparações correspondem: a vs. 6 semanas; b vs. 8 semanas, $p<0,05$; * indicação de diferença estatística (onde $0,05<p<0,10$ ). Siglas: DH - Dieta hiperlipídica; $\mathrm{DH}+\mathrm{M}$ - Dieta hiperlipídica contendo maltodextrina; DH+E - Dieta hiperlipídica contendo etanol. 


\section{APÊNDICE D - Peso dos órgãos referentes às padronizações dos modelos de DHA e DHNA}

Além do ganho de peso ao longo dos tratamentos, analisamos após o sacrifício dos camundongos o peso de alguns órgãos como: fígado, rins, baço, estômago, coração, em relação ao peso corporal do animal coletado no final de cada tratamento.

Nas tabelas a seguir estão representados o valor médio e desvio padrão obtido com cada órgão após os três diferentes tempos de tratamentos com dieta hiperlipídica (DH), dieta hiperlipídica contendo maltodextrina $(\mathrm{DH}+\mathrm{M})$, dieta hiperlipídica contendo glicose $(\mathrm{DH}+\mathrm{G})$ e dieta hiperlipídica contendo etanol $(\mathrm{DH}+\mathrm{E})$. Da mesma forma, também apresentamos a razão referente ao peso do órgão pelo peso corporal final obtida com cada tratamento. A razão está representada apenas como a média do grupo. Na Tabela D.1 apresentamos os resultados obtidos com a pesagem dos órgãos da linhagem B6 e A/J respectivo aos diferentes tratamentos após o tempo de 6 semanas, na Tabela D.2 apresentamos os pesos dos órgãos após 8 semanas de tratamento e por fim na Tabela D.3 apresentamos os pesos dos órgãos após 10 semanas.

Tabela D.1 - Média e desvio padrão do peso dos órgãos e razão do peso do órgão pelo peso corporal final dos camundongos B6 e A/J após 6 semanas de tratamento com as diferentes dietas hiperlipídicas.

\begin{tabular}{|c|c|c|c|c|c|c|c|c|}
\hline \multirow{2}{*}{$\begin{array}{c}\text { Linhagem / } \\
\text { Órgãos }\end{array}$} & \multicolumn{2}{|l|}{ DH } & \multicolumn{2}{|l|}{ DH+M } & \multicolumn{2}{|l|}{$\mathbf{D H}+\mathrm{G}$} & \multicolumn{2}{|l|}{$\mathbf{D H}+\mathbf{E}$} \\
\hline & Peso médio (g) & Razão & Peso médio (g) & Razão & Peso médio (g) & Razão & Peso médio (g) & Razão \\
\hline \multicolumn{9}{|l|}{ B6 } \\
\hline Fígado & $0.75 \pm 0.097$ & 0.047 & $0.7 \pm 0.065$ & 0.042 & $0.758 \pm 0.137$ & 0.045 & $1.01 \pm 0.108$ & 0.060 \\
\hline $\operatorname{Rim} \mathbf{E}$ & $0.104 \pm 0.017$ & 0.006 & $0.097 \pm 0.012$ & 0.006 & $0.11 \pm 0.021$ & 0.006 & $0.112 \pm 0.011$ & 0.007 \\
\hline Rim D & $0.106 \pm 0.019$ & 0.007 & $0.102 \pm 0.008$ & 0.006 & $0.1 \pm 0.016$ & 0.006 & $0.102 \pm 0.018$ & 0.006 \\
\hline Estômago & $0.164 \pm 0.074$ & 0.010 & $0.172 \pm 0.025$ & 0.010 & $0.158 \pm 0.063$ & 0.009 & $0.258 \pm 0.055$ & 0.015 \\
\hline Baço & $0.086 \pm 0.061$ & 0.005 & $0.048 \pm 0.008$ & 0.003 & $0.052 \pm 0.011$ & 0.003 & $0.046 \pm 0.009$ & 0.003 \\
\hline Coração & \multicolumn{2}{|c|}{ Não coletado } & \multicolumn{2}{|c|}{ Não coletado } & \multicolumn{2}{|c|}{ Não coletado } & \multicolumn{2}{|c|}{ Não coletado } \\
\hline \multicolumn{9}{|l|}{$A / J$} \\
\hline Fígado & $0.653 \pm 0.056$ & 0.042 & $0.65 \pm 0.097$ & 0.039 & $0.612 \pm 0.077$ & 0.038 & $0.61 \pm 0.08$ & 0.048 \\
\hline $\operatorname{Rim} \mathbf{E}$ & \multicolumn{2}{|c|}{ Não coletado } & \multicolumn{2}{|c|}{ Não coletado } & $0.1 \pm 0.007$ & 0.006 & $0.088 \pm 0.011$ & 0.006 \\
\hline Rim D & \multicolumn{2}{|c|}{ Não coletado } & \multicolumn{2}{|c|}{ Não coletado } & $0.102 \pm 0.010$ & 0.006 & $0.091 \pm 0.132$ & 0.007 \\
\hline Estômago & \multicolumn{2}{|c|}{ Não coletado } & \multicolumn{2}{|c|}{ Não coletado } & $0.144 \pm 0.032$ & 0.008 & $0.195 \pm 0.044$ & 0.015 \\
\hline Baço & \multicolumn{2}{|c|}{ Não coletado } & \multicolumn{2}{|c|}{ Não coletado } & $0.048 \pm 0.008$ & 0.002 & $0.03 \pm 0.008$ & 0.002 \\
\hline Coração & \multicolumn{2}{|c|}{ Não coletado } & \multicolumn{2}{|c|}{ Não coletado } & \multicolumn{2}{|c|}{ Não coletado } & \multicolumn{2}{|c|}{ Não coletado } \\
\hline
\end{tabular}

Abreviaturas: DH: Dieta hiperlipídica (controle real); DH+M: Dieta hiperlipídica contendo maltodextrina (controle equicalórico); DH+G: Dieta hiperlipídica contando glicose; DH+E: Dieta hiperlipídica contendo etanol $(5,3 \%)$; D: Direito; E: Esquerdo. 
Tabela D.2 - Média e desvio padrão do peso dos órgãos e razão do peso do órgão pelo peso corporal final dos camundongos B6 e A/J após 8 semanas de tratamento com as diferentes dietas hiperlipídicas.

\begin{tabular}{|c|c|c|c|c|c|c|c|c|}
\hline \multirow{2}{*}{$\begin{array}{c}\text { Linhagem / } \\
\text { Órgãos }\end{array}$} & \multicolumn{2}{|l|}{ DH } & \multicolumn{2}{|l|}{ DH+M } & \multicolumn{2}{|c|}{ DH+G } & \multicolumn{2}{|l|}{$\mathbf{D H}+\mathbf{E}$} \\
\hline & Peso médio (g) & Razão & Peso médio (g) & Razão & Peso médio (g) & Razão & Peso médio (g) & Razão \\
\hline \multicolumn{9}{|l|}{ B6 } \\
\hline Fígado & $0.854 \pm 0.112$ & 0.049 & $0.801 \pm 0.056$ & 0.043 & $0.761 \pm 0.077$ & 0.044 & $0.885 \pm 0.132$ & 0.051 \\
\hline $\operatorname{Rim} \mathbf{E}$ & $0.111 \pm 0.025$ & 0.006 & $0.089 \pm 0.011$ & 0.005 & $0.105 \pm 0.008$ & 0.006 & $0.101 \pm 0.011$ & 0.006 \\
\hline $\operatorname{Rim} D$ & $0.107 \pm 0.014$ & 0.006 & $0.091 \pm 0.007$ & 0.005 & $0.103 \pm 0.010$ & 0.005 & $0.108 \pm 0.009$ & 0.006 \\
\hline Estômago & $0.195 \pm 0.090$ & 0.011 & $0.311 \pm 0.170$ & 0.017 & $0.188 \pm 0.047$ & 0.01 & $0.276 \pm 0.076$ & 0.016 \\
\hline Baço & $0.039 \pm 0.012$ & 0.002 & $0.044 \pm 0.010$ & 0.002 & $0.043 \pm 0.005$ & 0.002 & $0.046 \pm 0.007$ & 0.003 \\
\hline Coração & \multicolumn{2}{|c|}{ Não coletado } & \multicolumn{2}{|c|}{ Não coletado } & \multicolumn{2}{|c|}{ Não coletado } & \multicolumn{2}{|c|}{ Não coletado } \\
\hline \multicolumn{9}{|l|}{$A / J$} \\
\hline Fígado & $0.626 \pm 0.038$ & 0.041 & $0.640 \pm 0.055$ & 0.041 & $0.563 \pm 0.059$ & 0.035 & $0.624 \pm 0.079$ & 0.045 \\
\hline $\operatorname{Rim} \mathbf{E}$ & $0.099 \pm 0.012$ & 0.006 & $0.096 \pm 0.011$ & 0.006 & $0.101 \pm 0.004$ & 0.006 & $0.095 \pm 0.014$ & 0.007 \\
\hline $\operatorname{Rim} D$ & $0.099 \pm 0.013$ & 0.006 & $0.095 \pm 0.009$ & 0.006 & $0.106 \pm 0.008$ & 0.006 & $0.093 \pm 0.013$ & 0.007 \\
\hline Estômago & $0.163 \pm 0.021$ & 0.011 & $0.174 \pm 0.056$ & 0.011 & $0.19 \pm 0.064$ & 0.011 & $0.256 \pm 0.123$ & 0.019 \\
\hline Baço & $0.054 \pm 0.005$ & 0.004 & $0.051 \pm 0.004$ & 0.003 & $0.043 \pm 0.005$ & 0.002 & $0.036 \pm 0.011$ & 0.003 \\
\hline Coração & $0.080 \pm 0.006$ & 0.005 & $0.075 \pm 0.008$ & 0.004 & $0.073 \pm 0.012$ & 0.004 & $0.066 \pm 0.019$ & 0.004 \\
\hline
\end{tabular}

Abreviaturas: DH: Dieta hiperlipídica (controle real); DH+M: Dieta hiperlipídica contendo maltodextrina (controle equicalórico); DH+G: Dieta hiperlipídica contando glicose; DH+E: Dieta hiperlipídica contendo etanol (5,3\%); D: Direito; E: Esquerdo.

Empregando a relação peso do órgão/ peso corporal, identificamos o fígado como o principal órgão atingido pela dieta como podemos ver destacado em vermelho nas Tabelas D.1 - D.3. Alguns dados infelizmente não foram coletados, entretanto o peso hepático foi coletado em todos os tempos e a análise estatística sobre a relação hepática pode ser observada também nas Figura 16 e Figura 28 que abordam o modelo de DHA e nas Figuras A.4 e A.19 que abordam o modelo de DHNA descritas na seção de Resultados no CAPÍTULO 2 e APÊNDICE A, respectivamente. 
Tabela D.3 - Média e desvio padrão do peso dos órgãos e razão do peso do órgão pelo peso corporal final dos camundongos B6 e A/J após 10 semanas de tratamento com as diferentes dietas hiperlipídicas.

\begin{tabular}{|c|c|c|c|c|c|c|c|c|}
\hline \multirow{2}{*}{$\begin{array}{c}\text { Linhagens / } \\
\text { Órgãos }\end{array}$} & \multicolumn{2}{|l|}{ DH } & \multicolumn{2}{|l|}{ DH+M } & \multicolumn{2}{|l|}{$\mathbf{D H}+\mathrm{G}$} & \multicolumn{2}{|l|}{$\mathbf{D H}+\mathbf{E}$} \\
\hline & Peso médio (g) & Razão & Peso médio (g) & Razão & Peso médio (g) & Razão & Peso médio (g) & Razão \\
\hline \multicolumn{9}{|l|}{ B6 } \\
\hline Fígado & $0.708 \pm 0.136$ & 0.047 & $0.708 \pm 0.043$ & 0.041 & $1.214 \pm 0.228$ & 0.05 & $1.024 \pm 0.167$ & 0.055 \\
\hline $\operatorname{Rim} \mathbf{E}$ & $0.163 \pm 0.09$ & 0.011 & $0.103 \pm 0.005$ & 0.006 & \multicolumn{2}{|c|}{ Não coletado } & \multicolumn{2}{|c|}{ Não coletado } \\
\hline Rim D & $0.141 \pm 0.039$ & 0.009 & $0.105 \pm 0.008$ & 0.006 & \multicolumn{2}{|c|}{ Não coletado } & \multicolumn{2}{|c|}{ Não coletado } \\
\hline Estômago & $0.196 \pm 0.037$ & 0.013 & $0.168 \pm 0.033$ & 0.010 & \multicolumn{2}{|c|}{ Não coletado } & \multicolumn{2}{|c|}{ Não coletado } \\
\hline Baço & $0.055 \pm 0.013$ & 0.003 & $0.045 \pm 0.005$ & 0.003 & \multicolumn{2}{|c|}{ Não coletado } & \multicolumn{2}{|c|}{ Não coletado } \\
\hline Coração & $0.095 \pm 0.021$ & 0.006 & $0.095 \pm 0.01$ & 0.006 & \multicolumn{2}{|c|}{ Não coletado } & \multicolumn{2}{|c|}{ Não coletado } \\
\hline \multicolumn{9}{|l|}{$A / J$} \\
\hline Fígado & $0.578 \pm 0.083$ & 0.039 & $0.656 \pm 0.059$ & 0.034 & $0.063 \pm 0.198$ & 0.044 & $0.071 \pm 0.07$ & 0.048 \\
\hline $\operatorname{Rim} \mathbf{E}$ & $0.1 \pm 0.009$ & 0.007 & $0.11 \pm 0.01$ & 0.006 & \multicolumn{2}{|c|}{ Não coletado } & \multicolumn{2}{|c|}{ Não coletado } \\
\hline Rim D & $0.098 \pm 0.012$ & 0.007 & $0.116 \pm 0.005$ & 0.006 & \multicolumn{2}{|c|}{ Não coletado } & \multicolumn{2}{|c|}{ Não coletado } \\
\hline Estômago & $0.153 \pm 0.02$ & 0.010 & $0.138 \pm 0.015$ & 0.007 & \multicolumn{2}{|c|}{ Não coletado } & \multicolumn{2}{|c|}{ Não coletado } \\
\hline Baço & $0.043 \pm 0.012$ & 0.003 & $0.058 \pm 0.008$ & 0.003 & \multicolumn{2}{|c|}{ Não coletado } & \multicolumn{2}{|c|}{ Não coletado } \\
\hline Coração & $0.082 \pm 0.01$ & 0.005 & $0.084 \pm 0.009$ & 0.005 & \multicolumn{2}{|c|}{ Não coletado } & \multicolumn{2}{|c|}{ Não coletado } \\
\hline
\end{tabular}

Abreviaturas: DH: Dieta hiperlipídica (controle real); DH+M: Dieta hiperlipídica contendo maltodextrina (controle equicalórico); DH+G: Dieta hiperlipídica contendo glicose; DH+E: Dieta hiperlipídica contendo etanol (5,3\%); D: Direito; E: Esquerdo. 


\section{APÊNDICE E - Consumo semanal das dietas pelos camundongos B6 e B6.A-Hc durante as 10 semanas de tratamento com as diferentes dietas hiperlipídicas}

Acompanhamos o consumo das diferentes dietas semanalmente para cada linhagem de camundongos. Não submetemos estes dados à análise estatística, pois se tratam de dados aproximados, uma vez que mantivemos caixas contendo de 2 a 3 animais e não trabalhamos com a média de consumo individual. Para efetuar uma análise mais sólida sobre este parâmetro a condição ideal de tratamento seria manter um animal por caixa, mas considerando o número de animais totais que utilizamos e o tempo de tratamento (10 semanas) seria espacialmente complicado para o Biotério de Isogênicos atender tantas caixas de animais. Inserimos em todos os gráficos da Figura E.1 uma linha pontilhada na cor vermelha na marca de $15 \mathrm{~g}$ para evidenciar as diferenças entre os tratamentos.

É possível observar que para o modelo de DHA as linhagens B6 e B6.A-Hc ${ }^{0}$ apresentam comportamentos semelhantes, onde a média semanal para os camundongos da linhagem B6 tratados com DH+E foi 13,9 g (Figura E.1 - G), para aqueles tratados com DH+M a média foi 16,3 g (Figura E.1 - C) e por fim os que receberam DH consumiram cerca 18,1 g (Figura E.1 - D). Para a linhagem B6.A- $H c^{0}$ os resultados foram semelhantes aos da linhagem B6, aqueles tratados com DH+E consumiram em média 13,1 g (Figura E.1 H), os que receberam DH+M consumiram 16,6 g (Figura E.1 - D) e os camundongos tratados com DH consumiram 16,5 g por dia durante cada semana (Figura E.1 - B).

E para o modelo de DHNA as linhagens B6 e B6.A- $\mathrm{Hc}^{0}$ apresentam comportamentos semelhantes, onde a média semanal para os camundongos da linhagem B6 tratados com $\mathrm{DH}+\mathrm{G}$ foi 14,2 g (Figura E.1 - E), para aqueles tratados com DH+M a média foi 16,3 g (Figura E.1 - C) e finalmente os que receberam DH consumiram 18,1 g (Figura E.1 - D). Para a linhagem B6.A- $\mathrm{Hc}^{0}$ os resultados foram semelhantes, aqueles tratados com $\mathrm{DH}+\mathrm{E}$ consumiram em média 14,5 g (Figura E.1 - F), os que receberam DH+M consumiram 16,6 g (Figura E.1 - D) e os camundongos tratados com DH consumiram 16,5 g (Figura E.1 - B). 
Figura E.1 - Controle do consumo semanal das diferentes dietas hiperlipídicas pelos camundongos $\mathrm{B} 6$ e B6. $\mathrm{A}-H c^{0}$ durante as 10 semanas de tratamento.
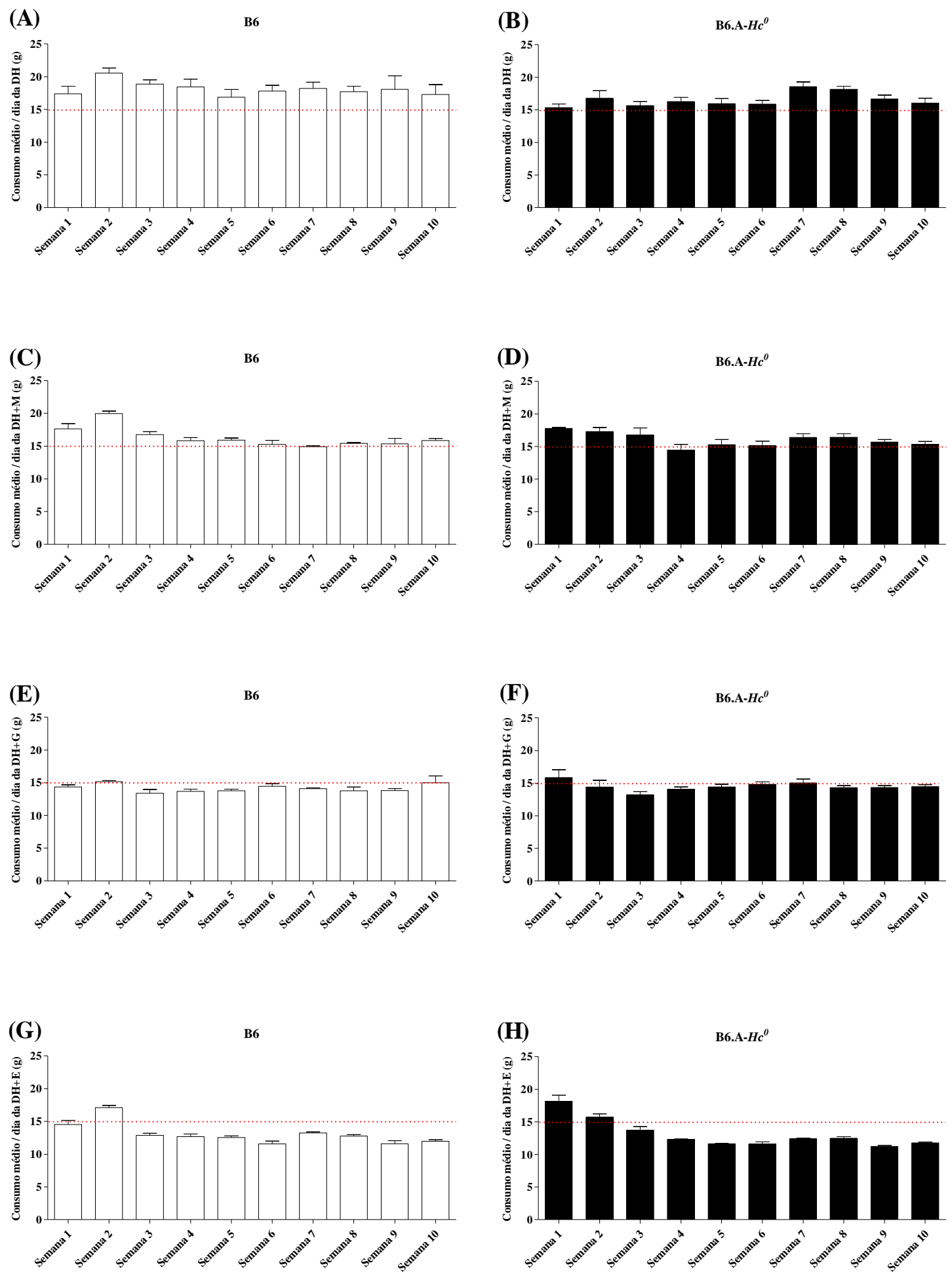

Em (A-B) representamos as médias semanais do consumo da dieta hiperlipídica (DH), em (C-D) consumo da dieta hiperlipídica contendo maltodextrina $(\mathrm{DH}+\mathrm{M})$, em $(\mathbf{E}-\mathbf{F})$ consumo da dieta hiperlipídica contendo glicose $(\mathrm{DH}+\mathrm{G})$ e em (G-H) consumo da dieta hiperlipídica contendo etanol (DH+E). 


\section{APÊNDICE F - Peso dos órgãos referentes à aplicação dos camundongos B6 e B6.A-Hc ${ }^{0}$ nos modelos de DHA e DHNA}

Analisamos após o sacrifício dos camundongos o peso de alguns órgãos como: fígado, tecido adiposo, rins, baço, estômago em relação ao peso corporal do animal.

Na Tabela F.1 estão descritos o valor médio e desvio padrão obtido com o peso de cada órgão após 10 semanas de tratamento com $\mathrm{DH}, \mathrm{DH}+\mathrm{M}, \mathrm{DH}+\mathrm{G}$ e $\mathrm{DH}+\mathrm{E}$. Da mesma forma, também apresentamos a razão encontrada dividindo-se o peso do órgão pelo peso corporal final obtido com cada tratamento. A razão está representada apenas como a média. Na Tabela F.1 apresentamos os resultados obtidos com a pesagem dos órgãos da linhagem B6 e A/J referentes aos diferentes tratamentos após o tempo de 10 semanas. Evidenciamos em vermelho o aumento da razão peso do fígado / peso corporal, um importante parâmetro no modelo de DHA, já em azul ressaltamos o aumento da razão da razão do peso do tecido adiposo / peso final um parâmetro considerável para o modelo de DHNA.

Tabela F.1 - Média e desvio padrão do peso final dos órgãos e razão do peso final do órgão pelo peso corporal final dos camundongos B6 e B6.A-Hc após 10 semanas de tratamento com as diferentes dietas hiperlipídicas.

\begin{tabular}{|c|c|c|c|c|c|c|c|c|}
\hline \multirow{2}{*}{$\begin{array}{c}\text { Linhagem / } \\
\text { Órgãos }\end{array}$} & \multicolumn{2}{|l|}{ DH } & \multicolumn{2}{|l|}{ DH+M } & \multicolumn{2}{|l|}{ DH+G } & \multicolumn{2}{|l|}{ DH+E } \\
\hline & Peso médio (g) & Razão & Peso médio (g) & Razão & Peso médio (g) & Razão & Peso médio (g) & Razão \\
\hline \multicolumn{9}{|l|}{ B6 } \\
\hline Fígado & $1.310 \pm 0.192$ & 0.043 & $1.503 \pm 0.207$ & 0.044 & $1.305 \pm 0.113$ & 0.040 & $1.377 \pm 0.145$ & 0.047 \\
\hline TA & $0.697 \pm 0.336$ & 0.023 & $1.105 \pm 0.330$ & 0.032 & $1.100 \pm 0.416$ & 0.034 & $0.734 \pm 0.231$ & 0.025 \\
\hline Rim D & $0.260 \pm 0.188$ & 0.009 & $0.191 \pm 0.012$ & 0.006 & $0.175 \pm 0.014$ & 0.005 & $0.171 \pm 0.020$ & 0.006 \\
\hline $\operatorname{Rim} \mathbf{E}$ & $0.187 \pm 0.030$ & 0.006 & $0.19 \pm 0.015$ & 0.006 & $0.173 \pm 0.010$ & 0.005 & $0.169 \pm 0.023$ & 0.006 \\
\hline Baço & $0.087 \pm 0.100$ & 0.003 & $0.103 \pm 0.007$ & 0.003 & $0.090 \pm 0.015$ & 0.003 & $0.086 \pm 0.019$ & 0.003 \\
\hline Estômago & $0.373 \pm 0.035$ & 0.012 & $0.373 \pm 0.093$ & 0.011 & $0.330 \pm 0.068$ & 0.010 & $0.303 \pm 0.055$ & 0.010 \\
\hline \multicolumn{9}{|l|}{$B 6 . A-H c^{0}$} \\
\hline Fígado & $1.133 \pm 0.136$ & 0.041 & $1.504 \pm 0.228$ & 0.043 & $1.468 \pm 0,214$ & 0.043 & $1.304 \pm 0.101$ & 0.047 \\
\hline TA & $0.668 \pm 0.227$ & 0.024 & $1.218 \pm 0.478$ & 0.034 & $1.177 \pm 0.312$ & 0.034 & $0.651 \pm 0.138$ & 0.023 \\
\hline Rim D & $0.178 \pm 0.017$ & 0.006 & $0.191 \pm 0.023$ & 0.006 & $0.182 \pm 0.023$ & 0.005 & $0.165 \pm 0.013$ & 0.005 \\
\hline $\operatorname{Rim} \mathbf{E}$ & $0.178 \pm 0.017$ & 0.006 & $0.193 \pm 0.020$ & 0.006 & $0.177 \pm 0.017$ & 0.005 & $0.164 \pm 0.012$ & 0.005 \\
\hline Baço & $0.093 \pm 0.018$ & 0.003 & $0.109 \pm 0.015$ & 0.003 & $0.105 \pm 0.019$ & 0.003 & $0.091 \pm 0.010$ & 0.003 \\
\hline Estômago & $0.365 \pm 0.077$ & 0.013 & $0.496 \pm 0.146$ & 0.014 & $0.402 \pm 0.079$ & 0.012 & $0.351 \pm 0.039$ & 0.011 \\
\hline
\end{tabular}

Abreviaturas: DH: Dieta hiperlipídica (controle real); DH+M: Dieta hiperlipídica contendo maltodextrina (controle equicalórico); DH+E: Dieta hiperlipídica contendo etanol (5,3\%); B6: C57B1/6 e B6.A - Hc ${ }^{0}$ : camundongos congênicos C57B1/6 C5 deficiente; D: Direito; E: Esquerdo; TA: Tecido adiposo. 


\section{APENDICE G - Artigos}

TEIXEIRA, A. G.; SILVA, A. S.; LIN, F. L.; VELLETRI, R.; BAVIA, L.; BELFORT, R. JR.; ISAAC, L. Association of complement factor H Y402H polymorphism and age-related macular degeneration in Brazilian patients. Acta Ophthalmol. v. 88, n. 5, p. e165-169, 2010.

SILVA, A. S.; TEIXEIRA, A. G.; BAVIA, L.; LIN, F.; VELLETRI, R.; BELFORT, R. JR; ISAAC, L. Plasma levels of complement proteins from the alternative pathway in patients with age-related macular degeneration are independent of Complement Factor $\mathrm{H} \mathrm{Tyr}{ }^{402} \mathrm{His}$ polymorphism. Mol Vis. v. 18, p. 2288-2299, 2012. 